\title{
PHILO OF ALEXANDRIA
}




\section{SUPPLEMENTS TO}

\section{VIGILIAE GHRISTIANAE}

Formerly Philosophia Patrum

TEXTS AND STUDIES OF EARLY CHRISTIAN LIFE

AND LANGUAGE

\section{EDITORS}

J. DEN BOEFT - R. VAN DEN BROEK - W.L. PETERSEN

D.T. RUNIA - J.C.M. VAN WINDEN

\section{VOLUME LVII}

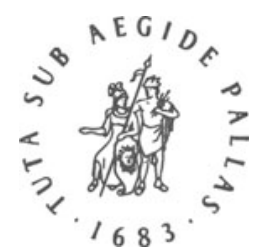




\section{PHILO OF ALEXANDRIA}

AN ANNOTATED BIBLIOGRAPHY 1987-1996

BY

DAVID T. RUNIA

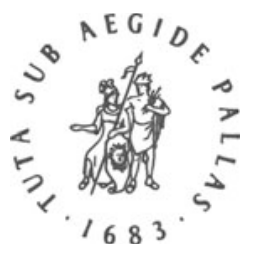

BRILL

LEIDEN $\cdot$ BOSTON $\cdot$ KÖLN

2001 
This is an open access title distributed under the terms of the CC BY-NCND 4.0 license, which permits any non-commercial use, distribution, and reproduction in any medium, provided no alterations are made and the original author(s) and source are credited. Further information and the complete license text can be found at https://creativecommons.org/ licenses/by-nc-nd/4.0/

The terms of the cc license apply only to the original material. The use of material from other sources (indicated by a reference) such as diagrams, illustrations, photos and text samples may require further permission from the respective copyright holder.

This book is printed on acid-free paper.

\section{Die Deutsche Bibliothek - CIP-Einheitsaufnahme}

\section{Runia, David T.:}

Philo of Alexandria : an annotated bibliography ; 1987 - 1996 ; with addenda for 1937 - 1986 / by David T. Runia. With the assistance of $\mathrm{H}$. M. Keizer. And in collab. with The International Philo Bibliography Project. - Leiden ; Boston ; Köln : Brill, 2000

(Supplements to Vigiliae Christianae ; Vol. 57)

ISBN 90-04-11682-6

\section{Library of Congress Cataloging-in-Publication Data}

Library of Congress Cataloging-in-Publication Data is also available

$$
\text { ISSN 0920-623X }
$$

ISBN 9004116826

\section{(C) Copyright 2001 by David T. Runia}

All rights reserved. No part of this publication may be reproduced, translated, stored in a retrieval system, or transmitted in any form or by any means, electronic, mechanical, photocopying, recording or otherwise, without prior written permission from the publisher.

$$
\begin{gathered}
\text { Authorization to photocopy items for internal or personal } \\
\text { use is granted by Brill provided that } \\
\text { the appropriate fees are paid directly to The Copyright } \\
\text { Clearance Center, } 222 \text { Rosewood Drive, Suite } 910 \\
\text { Danvers MA 01923, USA. } \\
\text { Fees are subject to change. }
\end{gathered}
$$

PRINTED IN THE NETHERLANDS 


\section{TABLE OF CONTENTS}

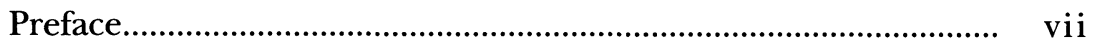

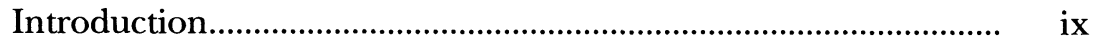

List of contributors .........................................................................

List of abbrevations .................................................................... xvii

\section{PART One}

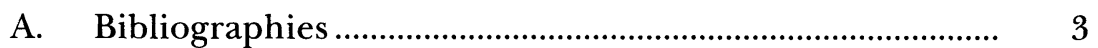

B. Critical editions.................................................................. 9

C. Translations into modern languages.................................... 11

D. Anthologies ..................................................................... 17

E. Commentaries................................................................... 19

F. Indices and lexicographical works ..................................... 20

G. Journal …….......................................................................... 22

H. Internet sites................................................................... 23

Part Two

Critical studies 1987-1996 _...........................................................

\section{Part Three}

A . Additional items 1937-1986 .................................................. 299

B. Additional reviews 1937-1986 .............................................. 347

C. Corrigenda Annotated bibliography 1937-1986................. 352

\section{INDICES}

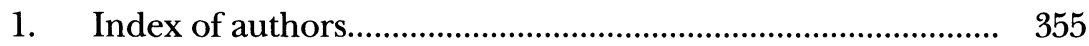

2. Index of reviewers .......................................................... 365

3. Index of biblical passages ................................................... 368

4. Index of Philonic passages................................................... 371

5. Index of subjects............................................................... 376

6. Index of Greek terms............................................................. 408

$7 \quad$ Index of contributors............................................................ 410 
Douwe (David) Runia - 978-90-04-31323-1 Downloaded from Brill.com๑4/26/2023 05:35:25AM via free access 


\section{PREFACE}

The daunting task of completing this bibliography would never have been achieved without the splendid collaboration of a large group of dedicated scholars. In thanking them all, I wish to give pride of place to Roberto Radice. Unlike in the case of the previous bibliography, he has not taken upon himself the role of editor. Due to other priorities in his research, he has had to increasingly limit his participation in the bibliography project, and it was agreed that this volume would be edited by only one of the two former editors. But nothing can change the fact that he remains the auctor intellectualis of the entire venture.

Next I would like to express my warm thanks to all the members of the International Philo Bibliography Project, who have contributed to the collection and summarizing of the bibliographical items during the past decade. Beside Roberto Radice, the current members are Albert Kees Geljon, Heleen Keizer, Jose Pablo Martín, Jean Riaud, Karl-Gustav Sandelin, David Satran and Dieter Zeller. Past members who are no longer active are Bert van den Berg and Paul Cathey. In the task of maintaining the database on which the bibliography is based, I have been greatly assisted by M. R. J. Hofstede of the Leiden University library, who used his extensive knowledge of electronic information services to locate many items that otherwise would have escaped the notice of the team members. The assistance of the Library in giving access to many of these and other items has also been quite invaluable. Other scholars too have provided the project with material, among whom I would especially like to mention my colleagues Pieter van der Horst (Utrecht) and Henk Jan de Jonge (Leiden). In recent years there has been a splendid cooperation with Lorenzo Perrone (Pisa), editor of Adamantius, the Journal devoted to the study of Origen and the Alexandrian tradition.

In 1998 the Netherlands Organization for Scientific Research (N.W.O.) generously granted a subsidy which allowed me to appoint a research assistant for the period of a year. This position was filled by Heleen Keizer. Her task was to check and process the material that had been collected over the past decade, and she was 
also primarily responsible for the location and summarizing of the additional items, as well as for the onerous job of compiling the indices. I wish to thank her most cordially for the exemplary dedication and efficiency that she displayed in carrying out these duties. Without her assistance it would have been quite impossible for me to bring the work to completion in addition to all my other commitments. The Faculty of Philosophy at the University of Leiden should also be thanked for offering her the facilities that she needed for her work.

In preparing the final version of the bibliography it soon became apparent that in a few specialized areas the project would need additional assistance. Three scholars promptly responded to my requests: Ellen Birnbaum for some difficult American items, Naomi Cohen (also a contributor to the previous bibliography) for additional items written in Hebrew, and Anna Pawlaczyk for some Polish material. All three are warmly thanked, as are other scholars who helped us gain access to obscure material, notably Wendy Helleman (Moscow) and Katerina Ierodiakonou (Oxford/ Athens).

I am also grateful to Shaye Cohen (Providence), general editor of Brown Judaic Studies, for his loyal support of The Studia Philonica Annual, in which the bibliographies that form the basis of this work first appeared, and more specifically for his agreement that I could use these bibliographies as the basis for a separate monograph.

At the publishing house of Brill here in Leiden both Theo Joppe and his successor Julie Plokker were enthusiastic and supportive when I suggested publishing a new volume of Philonic bibliography. I thank them, and also the chief editors of the series Supplements to Vigiliae Christianae, Prof. dr. J. C. M. van Winden and Prof. dr. J. den Boeft, for making publication of this specialized work possible. Last, but certainly not least, I wish to thank my wife, Gonni Runia-Deenick (Philomatheis, Leiden), for giving yet another demonstration of her desktop publishing skills in preparing a complex manuscript for the press.

David Runia

Leiden

31st August 2000 


\section{INTRODUCTION}

1. History of the Project and the present volume

2. Aim of the present work

3. Method of the present work

(a) basic method

(b) scope of the bibliography

(c) uniformity and variation

(d) additional material in Part Three

(e) indices

(f) numbering

(g) abbreviations

(h) electronic publications

4. Continuation of the present bibliography

5. Abbreviation to be used for the present bibliography

6. Some final statistics

\section{History of the Project and the present volume}

The present bibliography of Philonic studies is a continuation of Philo of Alexandria: an Annotated Bibliography 1937-1986, prepared by Roberto Radice and David Runia and published in 1988 (second edition 1992). ${ }^{1}$ It is primarily based on yearly bibliographies prepared by the International Philo Bibliography Project and published in The Studia Philonica Annual. ${ }^{2}$ The Project has been directed by David Runia, who is in charge of the database that lies at the heart of the Project. Composition of the Project team has fluctuated during the years. At the present moment its members are: A. C. Geljon, H. M. Keizer, J. P. Martín, R. Radice, J. Riaud, K.-G. Sandelin, D. Satran and D. Zeller. Other scholars who have been members are P. A. Cathey and R. M. van den Berg. Specialized assistance in the area of electronic database searching has been given each year since 1994 by M. R. J. Hofstede, a member of the University Library staff in Leiden.

For the compilation and preparation of the present volume the editor has been aided by his research assistant H. M. Keizer, who

1 See in this volume no. 1201, 1205.

2 See in this volume no. 1202-1204, 1206-1210, and subsequent bibliographies in SPhA 9 (1997) 332-355, 10 (1998) 135-164, 11 (1999) 121-147. 
reorganized the material already published in a provisional form, added the additional items present in the database and drew up the indices. Scholars who are not members of the yearly Project team but contributed items to the bibliography are E. Birnbaum, N. G. Cohen and A. Pawlaczyk.

\section{Aim of the present work}

The aim of the present bibliography is two-fold:

(1) To list and give a brief summary of all items of scholarly literature published from 1987 to 1996 dealing directly with the thought and writings of Philo of Alexandria.

(2) To add additional items which were omitted from the previous bibliography for the years 1937 to 1986, together with extra book reviews which appeared in the meantime, and to correct mistakes in the earlier volume.

\section{Method of the present work}

(a) basic method

In all essential respects but one the present bibliography continues the method of its predecessor. The chief features of this method are: ${ }^{3}$

(1) Accurate listing of items based where possible on autopsy of the original document; 4

(2) Division of the bibliography into two parts:

Part One: Bibliographies Editions Fragments Translations Anthologies Commentaries Indices Lexica Journal Internet sites

Part Two: Critical studies, presented chronologically by year and alphabetically by author;

(3) Brief summary of the contents of each bibliographical item, indicating its main thesis and the various subjects discussed;

3 For further details see Introduction to R-R, pp. xi-xxii. See esp. p. xix on the problems of listing and summarizing items written in Hebrew.

4 Exceptions have been made for dissertations (where the summaries are based on published abstracts) and occasional items for which abstracts have been supplied by the author or which proved very difficult to locate. Occasional use has also been made of abstracts provided by L'année philologique. 
(4) Listing of reviews of monographs specially devoted to Philo; 5

(5) Minimal length of contribution on Philo three pages, unless it concerns a shorter item of exceptional interest; ${ }^{6}$

(6) Full indices allowing fast and accurate access to the contents of the bibliography.

(b) scope of the bibliography

The one aspect of the method that has been changed has to do with the scope of the bibliography. For practical reasons the previous bibliography only listed works written in English, French, German, Italian, Spanish, Dutch and Hebrew. In the present volume all linguistic restrictions have been dropped. This has meant the inclusion of scholarly works written in Scandinavian, Central and Eastern European and some other languages, when this material has reached out attention. It should be recognized, however, that coverage of certain European languages (esp. Greek and Russian) and all non-European languages (e.g. Arabic, Chinese and Japanese) is very incomplete. ${ }^{7}$

(c) uniformity and variation

The preparation of the present bibliography is much more a collaborative work than its predecessor. In deciding which items should be included in the various language areas and in preparing the summaries, individual collaborators have been given considerable latitude within the guidelines listed above. This has inevitably resulted in a certain amount of variation in terms of method and content, including details of spelling and orthography. ${ }^{8}$

5 It should be emphasized that the location of reviews scattered through hundreds of journals is an extremely difficult task, and our collection is likely to be very incomplete.

6 Because - as was explained in R-R p. xiii - the study of Philo is relevant to so many areas of scholarship, it is futile to aim at a complete coverage, e.g. of monographs on other subjects which contain a number of pages or even a chapter on Philo. We have tried to be complete at least in our coverage of items with Philo in their titles. It should be noted that items relating directly to the Ps.Philonic Biblical Antiquities are once again excluded from the bibliography, but that this is not the case for items relating to the Ps.Philonic De Jona and De Sampsone.

7 Inclusion is dependent on the coverage of the standard repertories (esp. L'année philologique) and the personal contacts of the editor.

8 E.g. halachic and halakhic, programme and program etc. The editor decided not to impose a strict uniformity in this area. Note also that occasionally in the case of dissertations doublets have been allowed to remain when two differing summaries furnish complementary information, e.g. at 8841 
(d) additional material in Part Three

Part Three of the present bibliography contains additions to the previous one. In listing the additional items for 1937 to 1986 which were omitted from the earlier work, we have taken into account the broadening of the scope of the coverage, but for pragmatic reasons we have not attempted the huge task of adding missing items in all the different languages. ${ }^{9}$ The approximately 160 items in this list are still for the most part written in the languages to which the previous bibliography was limited. ${ }^{10}$ The listing of additional items also includes a few items which have been reprinted in a different work. For these items the summary has not been repeated. A separate section lists reviews of books published in the period up to 1986 (mainly from 1980 onwards) which were not yet included in the previous bibliography. Finally we include a section of corrigenda of and addenda to earlier work, part of which is taken over from the Preface to the second edition published in 1992.

\section{(e) indices}

The method of the indices is the same as that used in the previous volume, except that a separate section has been added in which the distribution of the summaries among the various collaborators has been indicated. In the case of the most important of the indices, the Index of Subjects, we remind the user that items specifically focusing on Philo's treatises are listed under the heading Corpus Philonicum and that general discussions of the man and his work are listed under the heading Philo. The practice of using bold type to indicate particularly important items, which was used in the previous work, has been discontinued.

(f) numbering

For the numbering of the items we have for the most part continued the practice of the previous bibliography, but have made the following further adaptations:

and 9651,9156 and 9449 .

9 The best coverage of Philonic scholarship outside the seven languages included in R-R for the earlier period is found in E. Hilgert's 'Bibliographia Philoniana 1935-1981', = R-R 1019. See also note 4 above.

10 On a number of occasions we have able to exploit summaries written in English or another major language of scholarship. 
(i) The numbers in Part One simply follow on from the previous work, except in the first section on bibliographies; because of a different division of the material, we have started the three subsections with new numbers beginning with 1201, 1301 and 1401 respectively.

(ii) The numbers in Part Two begin with the last two numbers of the year, e.g. 8701 etc. for 1987. This exceptionally fertile year included more than 100 items and so necessitated the inclusion of five figure numbers, i.e. 87100 etc.

(iii) Additional items for the years 1937 to 1986 listed in Part Three are given the next available number prefixed with an a, e.g. a3718 (the previous bibliography had 17 items for 1937).

(iv) Items from the earlier bibliography which are listed with additional book reviews in Part Three have been cited in the Index of reviewers under their previous number prefixed by R-R.

(v) Occasionally extra numbers have had to be created by means of the suffix $a$ in order to preserve the alphabetical listing, e.g. 8917a, or numbers have had to be dropped because of last-minute corrections in the lists, e.g. there is no item 9010.

It should be noted that in the index the references to additional items are placed after the items for 1987 to 1996, even though they are chronologically prior.

(g) abbreviations

The abbreviations used in the work are listed in the section following the Introduction. In the bibliographical references themselves series titles are abbreviated, but journal titles are not. The latter are abbreviated in the lists of reviews. In choosing the abbreviations we have tried to be consistent with those used by the Journal of Biblical Literature, The Studia Philonica Annual and L'année philologique, but it has not been possible to avoid some discrepancies.

(h) electronic publications

The present revolution in the distribution of electronic data via Internet was only in its infancy in 1996, when the period represented by the bibliography ends. Only a handful of Internet sites and electronic documents (exclusively reviews) have been listed. 


\section{Continuation of the present bibliography}

The Philo bibliography Project is being continued in the pages of The Studia Philonica Annual. See the details on the Internet site listed at 3402. Scholars who wish their writings to be included are invited to send the relevant information to the Director of the Project. ${ }^{11}$

It would be highly desirable to produce the bibliography (together with its predecessor, and, if feasible, G-G) on a CD-ROM. This would allow a much more thorough search of its contents. The practicality of this proposal is being investigated. The problem lies in the availability and suitability of public domain software.

\section{Abbreviation to be used for the present bibliography}

The choice of a suitable abbreviation for the present work, as a continuation of G-G and R-R, has proved difficult, primarily on account of the change of editorship. ${ }^{12}$ We have opted for RRS, in recognition of the fact that it is a Supplementary volume to R-R. It is to be hoped that RRS2 can follow in the not too distant future.

\section{Some final statistics}

The previous bibliography contained 1666 items for the years 1937 to 1986 , to which may be added 160 additional items included in this work, making a total of 1826 items for 50 years of scholarship. The present bibliography contains a total of 953 items for the decade 1987 to 1996. It is also instructive to compare the previous decade 1977 to 1986 , which resulted in 657 items. ${ }^{13}$ It may be concluded that scholarly output on Philo and related subjects is still on the increase, but that it shows signs of stabilizing at an average of about 100 items a year.

11 Current postal address: Rijnsburgerweg 116, 2333 AE Leiden, The Netherlands; email runia@rullet.leidenuniv.nl.

12 Thus making the abbreviation R-R2 inappropriate.

13 When comparing statistics, one should note that the scope of the present bibliography is slightly wider than the previous one, because all language restrictions have been dropped. 


\section{LIST OF CONTRIBUTORS}

Robbert M. VAN DEN BERG is about to take up the position of Postdoctoral Fellow at Trinity College, Dublin, IRELAND.

Ellen Birnbaum is a Mellon Postdoctoral Fellow at Brandeis University, Boston, U.S.A.

P. A. CAthey was formerly research assistant at the Institutum Judaicum Delitzschianum in Münster, Germany.

Naomi G. Cohen has taught Jewish Philosophy and Thought for many years at Tel-Aviv and Haifa Universities, IsRAEL.

Albert C. GeLjon teaches classical languages at the Christelijke Scholengemeenschap Oude Hoven, Gorinchem, The NetherLANDS.

M. R. J. Hofstede is Electronic database searcher at the University Library, Leiden, The NetherLands.

Heleen M. Keizer was until recently Research Assistant in the Faculty of Philosophy, University of Leiden, The NetherLANDS.

Jose Pablo Martín is Director of Studies at the Universidad Nacional de General Sarmiento, San Miguel, Argentina, and Senior Research fellow of the Argentinian Research Organization (CONICET).

Anna Pawlaczy is a doctoral student at the Institute of Classical Philology, Adam Mickiewicz University of Poznan, Poland.

Roberto RADICE is Lecturer in Ancient Philosophy at the Università Cattolica del Sacro Cuore, Milan, Italy.

Jean RIAUd is Professor in the Institut de Lettres et Histoire, Université Catholique de l'Ouest, Angers, France.

David T. Runia is Professor of Ancient and Medieval Philosophy at the University of Leiden, THE NetherLands. 
xvi LIST OF CONTRIBUTORS

Karl-Gustav Sandelin is Professor of New Testament Exegetics, Åbo Akademi University, Finland.

David Satran is Senior Lecturer in the Department of Comparative Religion, Hebrew University, Jerusalem, IsRAEL.

Dieter Zeller is Professor für Religionswissenschaft des Hellenismus at the Johannes-Gutenberg University of Mainz, Germany. 


\section{ABBREVIATIONS}

\section{Philonic treatises}

\begin{tabular}{|c|c|}
\hline$A b r$ & De Abrahamo \\
\hline Aet. & De aeternitate mundi \\
\hline Agr. & De agricultura \\
\hline Anim. & De animalibus \\
\hline Cher. & De Cherubim \\
\hline Contempl. & De vita contemplativa \\
\hline Conf. & De confusione linguarum \\
\hline Congr. & De congressu eruditionis gratia \\
\hline Decal. & De Decalogo \\
\hline Deo & De $D e o$ \\
\hline Det. & Quod deterius potiori insidiari soleat \\
\hline Deus & Quod Deus sit immutabilis \\
\hline$E b r$. & De ebrietate \\
\hline Flacc. & In Flaccum \\
\hline Fug. & De fuga et inventione \\
\hline Gig. & De gigantibus \\
\hline Her. & Quis rerum divinarum heres sit \\
\hline Hypoth. & Hypothetica \\
\hline Ios. & De Iosepho \\
\hline Leg. 1-3 & Legum allegoriae I, II, III \\
\hline Legat. & Legatio ad Gaium \\
\hline$L A B$ & Liber Antiquitatum Biblicarum (Pseudo-Philo) \\
\hline Migr. & De migratione Abrahami \\
\hline Mos. 1-2 & De vita Moysis I, II \\
\hline Mut. & De mutatione nominum \\
\hline Opif. & De opificio mundi \\
\hline Plant. & De plantatione \\
\hline Post. & De posteritate Caini \\
\hline Praem. & De praemiis et poenis, De exsecrationibus \\
\hline Prob. & Quod omnis probus liber sit \\
\hline Prov. 1-2 & De Providentia I, II \\
\hline$Q E 1-2$ & Quaestiones et solutiones in Exodum I, II \\
\hline$Q G 1-4$ & Quaestiones et solutiones in Genesim I, II, III, IV \\
\hline Sacr. & De sacrificiis Abelis et Caini \\
\hline Sobr. & De sobrietate \\
\hline Somn. 1-2 & De somniis I, II \\
\hline Spec. $1-4$ & De specialibus legibus I, II, III, IV \\
\hline Virt. & De virtutibus \\
\hline
\end{tabular}




\section{Philonic editions, translations}

\begin{tabular}{|c|c|}
\hline Aucher & $\begin{array}{l}\text { Philonis Judaei sermones tres hactenus inediti (1822), Philonis } \\
\text { Judaei paralipomena (1826) }\end{array}$ \\
\hline $\mathrm{C}-\mathrm{W}$ & $\begin{array}{l}\text { Philonis Alexandrini opera quae supersunt, ediderunt L. CoHN, } \\
\text { P. WENDLAND, S. REITER (1896-1915) }\end{array}$ \\
\hline G-G & $\begin{array}{l}\text { H. L. GoodhaRT and E. R. Goodenough, 'A General } \\
\text { Bibliography of Philo Judaeus', in E. R. Goodenough, The } \\
\text { Politics of Philo Judaeus: Practice and Theory (New Haven 1938, } \\
\text { reprinted Hildesheim } 1967^{2} \text { ) 125-321 }\end{array}$ \\
\hline Loeb & $\begin{array}{l}\text { Philo in ten volumes (and two supplementary volumes), English } \\
\text { translation by F. H. Colson, G. H. WHITAKER (and R. } \\
\text { MARCUS), Loeb Classical Library (London 1929-62) }\end{array}$ \\
\hline PAPM & $\begin{array}{l}\text { Les auvres de Philon d'Alexandrie, French translation under } \\
\text { the general editorship of R. ArnALdEz, C. MondÉSERT, J. } \\
\text { PouIlloux (Paris 1961-1992) }\end{array}$ \\
\hline R-R & $\begin{array}{l}\text { R. Radice and D. T. Runia, Philo of Alexandria: an Annotated } \\
\text { Bibliography 1937-1986, VCSup } 8 \text { (Leiden etc. 1988) }\end{array}$ \\
\hline RRS & $\begin{array}{l}\text { D. T. Runia, Philo of Alexandria: an Annotated Bibliography } \\
\text { 1987-1996, VCSup (Leiden etc. 2000) }\end{array}$ \\
\hline
\end{tabular}

\section{Journals and series}

$\begin{array}{ll}\text { AAAbo.H } & \text { Acta Academiae Aboensis, Ser. A. Humaniora } \\ \text { AAHG } & \text { Anzeiger für die Altertumswissenschaft } \\ \text { A B } & \text { Analecta Bollandiana } \\ \text { Abr-N } & \text { Abr-Nahrain (Melbourne) } \\ \text { AC } & \text { L'Antiquité Classique } \\ \text { Adamant } & \text { Adamantius } \\ \text { AGJU } & \text { Arbeiten zur Geschichte des antiken Judentums und des } \\ & \text { Urchristentums } \\ \text { AJSR } & \text { Association for Jewish Studies Review } \\ \text { AKG } & \text { Arbeiten zur Kirchengeschichte } \\ \text { ALGHJ } & \text { Arbeiten zur Literatur und Geschichte des hellenistischen } \\ & \text { Judentums } \\ \text { ALW } & \text { Archiv für Liturgiewissenschaft } \\ \text { AncPhil } & \text { Ancient Philosophy } \\ \text { Ang } & \text { Angelicum } \\ \text { ANRW } & \text { Aufstieg und Niedergang der römischen Welt } \\ \text { Ant } & \text { Antonianum } \\ \text { APh } & \text { L'Année Philologique (founded by Marouzeau) } \\ \text { ArPh } & \text { Archives de Philosophie } \\ \text { ASNU } & \text { Acta Seminarii Neotestamentici Upsaliensis } \\ \text { Ath } & \text { Athenaeum } \\ \text { AUSS } & \text { Andrews University Seminary Studies }\end{array}$


BBB

BEThL

BEvTh

BibbiaOr

Bijdr

BiOr

BJGS

BJS

BLE

BMCR

BZ

CBQ

CBQ.MS

CCARJ

$\mathrm{ChH}$

CPhRev

CR

CRAI

CRINT

CrRBR

CurrThM

D A

Dial

DOS

Elen

EphL

EPRO

EstE

EstFil

ET

EtCl

EThL

ETR

EvQ

FRLANT

Gr

Herma

HeyJ

Interpr

ISPh

IThS

JAAR

JAOS
Bonner Biblische Beiträge

Bibliotheca Ephemeridum Theologicarum Lovaniensium

Beiträge zur evangelischen Theologie

Bibbia e Oriente (Bornato)

Bijdragen

Bibliotheca Orientalis

Bulletin of Judaeo-Greek Studies

Brown Judaic Studies

Bulletin de Littérature Ecclésiastique

Bryn Mawr Classical Review

Biblische Zeitschrift

The Catholic Biblical Quarterly

The Catholic Biblical Quarterly Monograph Series

Central Conference of American Rabbis Journal

Church History

Canadian Philosophical Review

The Classical Review

Comptes Rendus de l'Académie des Inscriptions et BellesLettres

Compendia Rerum Iudaicarum ad Novum Testamentum

Critical Review of Books in Religion

Currents in Theology and Mission

Dissertation Abstracts

Dialogue. Canadian Philosophical Review

Dumbarton Oaks Studies

Elenchos

Ephemerides Liturgicae

Études préliminaires aux religions orientales dans

l'Empire romain

Estudios Eclesiásticos

Estudios Filosóficos

The Expository Times

Les Études Classiques

Ephemerides Theologicae Lovanienses

Études Théologiques et Religieuses

Evangelical Quarterly

Forschungen zur Religion und Literatur des Alten und

Neuen Testaments

Gregorianum

Hermathena

Heythrop Journal

Interpretation. A Journal of Bible and Theology

International Studies in Philosophy

Innsbrucher Theologische Studien

Journal of the American Academy of Religion

Journal of the American Oriental Society 
JbAC

JbAC.E

JBL

JFRS

JJS

JQR

JR

JSJ

JSNT.MS

JSNT.S

JSOT.S

JSP

JSP.S

JThS

Jud

Lat

LCL

LeDiv

LThPh

Meth

Mnem

MSR

Muséon

NT

NT.S

NTA

NTOA

NTT

OLZ

OrChr

OrChrP

Orph

Paid

Pens

PhilAnt

Phron

POC

PrOrth

RassLettIt

RB
Jahrbuch für Antike und Christentum

Jahrbuch für Antike und Christentum Erganzungsband

Journal of Biblical Literature

The Journal of the Faculty of Religious Studies. Montreal

The Journal of Jewish Studies

The Jewish Quarterly Review

The Journal of Religion

Journal for the Study of Judaism (in the Persian,

Hellenistic and Roman Period)

Journal for the Study of the New Testament. Monograph Series

Journal for the Study of the New Testament. Supplementary Series

Journal for the Study of the Old Testament. Supplementary Series

Journal for the Study of the Pseudepigrapha

Journal for the Study of the Pseudepigrapha. Supplement

Series

The Journal of Theological Studies

Judaica

Latomus

Loeb Classical Library

Lectio Divina

Laval Théologique et Philosophique

Methexis. Rivista argentina de filosofía antigua

Mnemosyne

Mélanges de Science Religieuse

Le Muséon

Novum Testamentum

Supplements to Novum Testamentum

Neutestamentliche Abhandlungen

Novum Testamentum et Orbis Antiquus

Nederlands Theologisch Tijdschrift

Orientalistische Literaturzeitung

Oriens Christianus

Orientalia Christiana Periodica

Orpheus

Paideia

Pensamiento. Revista de investigacion e informacion

filosofica

Philosophia Antiqua

Phronesis. A Journal for Ancient Philosophy

Proche Orient Chrétien

Présence Orthodoxe

Rassegna della Letteratura Italiana

Revue Biblique 
RBL

RBPh

REA

REArm

REAug

REByz

RecSR

REG

REJ

RelSt

RelStR

RevBib

RFN

RHPhR

RHR

$\mathrm{RPh}$

RPhilos

RPhL

RSPhTh

RSR

RThAM.S

RThL

RThPh

SAfrJPh

Sales

Salm

SBL.DS

SBLSPS

SC

SCent

ScEs

Script

ScrTh

SNTSMS

$\mathrm{SPh}$

SPhA

Spec

SR

SwJT

ThBtr

ThLZ

ThRv

ThS

TLS

TTh
Review of Biblical Literature

Revue Belge de Philologie et d'Histoire

Revue des Études Anciennes

Revue des Études Arméniennes

Revue des Études Augustiniennes

Revue des Études Byzantines

Recherches de Science Religieuse

Revue des Études Grecques

Revue des Études Juives

Religious Studies

Religious Studies Review

Revista Biblica (Argentina)

Rivista de Filosofia Neoscolastica

Revue d'Histoire et de Philosophie Religieuses

Revue d'Histoire des Religions

Revue de Philologie

Revue Philosophique de la France et de l'Étranger

Revue Philosophique de Louvain

Revue des Sciences Philosophiques et Theologiques

Revue des Sciences Religieuses

Recherches de Théologie Ancienne et Médiévale.

Supplementa

Revue Théologique de Louvain

Revue de Théologie et de Philosophie

South African Journal of Philosophy

Salesianum

Salmanticensis

Society of Biblical Literature. Dissertation Series

Society of Biblical Literature. Seminar Papers Series

Sources Chrétiennes

Second Century. A Journal of Early Christian Studies

Science et Esprit

Scriptorium

Scripta Theologica

Society for New Testament Studies, Monograph Series

Studia Philonica (1971-80)

The Studia Philonica Annual (1989- )

Speculum

Studies in Religion

Southwestern Journal of Theology

Theologische Beiträge (Wuppertal)

Theologische Literaturzeitung

Theologische Revue

Theological Studies

The Times Literary Supplement

Tijdschrift voor Theologie 
xxii

TU

VChr

VChr.S

Vich

VoxP

VT

WMANT

WUNT

WW

ZAW

ZKG

ZKTh

\section{ABBREVIATIONS}

Texte und Untersuchungen zur Geschichte der altchristlichen Literatur

Vigilae Christianae

Supplements to Vigiliae Christianae

Vichiana

Vox Patrum (Lublin)

Vetus Testamentum

Wissenschaftlichen Monographien zum Alten und Neuen

Testament

Wissenschaftliche Untersuchungen zum Neuen Testament

Wissenschaft und Weisheit. Franziskanische Studien zu

Theologie, Philosophie und Geschichte

Zeitschrift für die alttestamentliche Wissenschaft

Zeitschrift für Kirchengeschichte

Zeitschrift für Katholische Theologie

5. Scholars responsible for summaries

$\begin{array}{ll}\text { ACG } & \text { A. C. Geljon } \\ \text { AP } & \text { A. Pawlaczyk } \\ \text { DS } & \text { D. Satran } \\ \text { DTR } & \text { D. T. Runia } \\ \text { DZ } & \text { D. Zeller } \\ \text { EB } & \text { E. Birnbaum } \\ \text { HMK } & \text { H. M. Keizer } \\ \text { JPM } & \text { J. P. Martín } \\ \text { JR } & \text { J. Riaud } \\ \text { KGS } & \text { K.-G. Sandelin } \\ \text { NGC } & \text { N. G. Cohen } \\ \text { PAC } & \text { P. A. Cathey } \\ \text { RMB } & \text { R. M. van den Berg } \\ \text { RR } & \text { R. Radice }\end{array}$




\title{
PART ONE
}

\author{
BIBLIOGRAPHIES \\ EDITIONS Fragments \\ Translations Anthologies \\ Commentaries \\ INDICES LEXICA JOURNAL \\ INTERNET SiteS
}


Douwe (David) Runia - 978-90-04-31323-1 Downloaded from Brill.com๑4/26/2023 05:35:25AM via free access 


\section{A. BIBLIOGRAPHIES}

\section{Philo bibliography project}

1201. R. RAdice and D. T. Runia, in collaboration with R. A. Bitter, N. G. Cohen, M. Mach, A. P. Runia, D. Satran, D. R. Schwartz, Philo of Alexandria: an Annotated Bibliography 1937-1986, VChr.S 8 (Leiden 1988).

Predecessor of the present volume. It is an annotated bibliography of all studies on Philo from 1937 to 1986 comprising 1666 items in all. The basis of the work is supplied by Radice's Italian bibliography (= R-R 1113), which has been supplemented by studies published up to 1986. The collection aims at completeness for studies in English, French, German, Italian, Spanish, Dutch and Hebrew. For further details see SPhA 1 (1989) 74-81, 2 (1990) 141. Reviews: A. Hilhorst, JSJ 20 (1989) 254-256; P. Nautin, REG 102 (1989) 616-617; G. Vermes, JJS 40 (1989) 244-245; P. W. van der Horst, NTT 44 (1990) 262-264; R. Williamson, JThS 41 (1990) 642-643; H. Crouzel, BLE 92 (1991) 149; J. den Boeft, VChr 44 (1990) 85-86; A. Paul, RecSR 78 (1990) 459-460; M. Petit, REJ 150 (1991) 481-482; D. Winston, JQR 81 (1991) 494-495; E. Hilgert \& J. Royse, SPhA 4 (1992) 125-128; R. Williamson, NT 35 (1993) 294-295. (DTR)

1202. D. T. Runia, R. Radice and D. Satran, 'A Bibliography of Philonic Studies 1981-1986', The Studia Philonica Annual 1 (1989) 95-124.

The bibliography is a sequel to the annual bibliographies published in Studia Philonica from 1971-1980 by Earle Hilgert. It is without annotation, and is for the most part derived from R-R, with some additional items marked with an asterisk. (DTR)

1203. D. T. Runia, R. Radice and D. Satran, 'Philo of Alexandria: an Annotated Bibliography 1986-87', The Studia Philonica Annual 2 (1990) 141-175.

The first continuation of the Philo bibliography according to the method of R-R after its publication in 1988. From this year onwards each volume of The Studia Philonica Annual contains an annotated bibliography of Philonic studies for the year three years prior to the year of the Annual: in this case 1987 (92 items). 24 additional items from 1986 are also included, as well as a provisional bibliography for the years 1988-1990. On pp. 141-142 the principles of the continuation, which are rather strictly based on the method of R-R are outlined. (DTR) 
1204. D. T. Runia, R. Radice and P. A. Cathey, 'Philo of Alexandria: an Annotated Bibliography 1987-88', in D. T. Runia, D. M. HAY and D. Winston (edd.), Heirs of the Septuagint. Philo, Hellenistic Judaism and Early Christianity: Festschrift for Earle Hilgert, BJS 230 [= The Studia Philonica Annual 3 (1991)] (Atlanta 1991) 347-374.

Bibliography of Philonic studies for the year 1988 (68 items), with addenda for 1987 (9 items). The introductory section pays tribute to the labours of Earle Hilgert as Philonic bibliographer: (p. 347): 'what, we may ask, would be a more suitable way to conclude a Festschrift for Earle Hilgert than with a bibliography of Philonic studies?' (DTR)

1205. R. RAdice AND D. T. RUNiA, in collaboration with R. A. Bitter, N. G. Cohen, M. Mach, A. P. Runia, D. Satran, D. R. Schwartz, Philo of Alexandria: an Annotated Bibliography 1937-1986, VChr.S 8 (Leiden 1992²).

The second edition of R-R only differs from the first (Leiden 1988) in that a second Preface consisting of two pages has been added. It briefly states how the work is being continued in the annual bibliographies and lists a number of corrigenda. It is also announced that these bibliographies will eventually be collected together to form a supplementary volume (i.e. the current bibliography). (DTR)

1206. D. T. Runia, R. Radice and D. Satran, 'Philo of Alexandria: an Annotated Bibliography 1988-89', The Studia Philonica Annual 4 (1992) 97-124.

Bibliography of Philonic studies for the year 1989 (72 items), with addenda for 1987 (1 item) and 1988 (8 items). (DTR)

1207. D. T. Runia and R. RAdice, 'Philo of Alexandria: an Annotated Bibliography 1990', The Studia Philonica Annual 5 (1993) 180-208.

Bibliography of Philonic studies for the year 1990 (60 items), with addenda for the years 1986-89 (8 items). It is noted for the first time in the footnote on p. 180 that all language restrictions have been abandoned. (DTR)

1208. D. T. Runia, R. M. van den Berg, R. Radice, K.-G. Sandelin, D. Satran, 'Philo of Alexandria: an Annotated Bibliography 1991', The Studia Philonica Annual 6 (1994) 122-159.

Bibliography of Philonic studies for the year 1991 (95 items), with addenda for the years 1989-90 (21 items). From this year onwards the team preparing the volume was considerably expanded, reaching full strength in 
1997 (eight participants). These scholars together form the International Philo Bibliography Project under the directorship of David Runia (Leiden) (DTR)

1209. D. T. Runia, R. M. van den Berg, J. P. Martín, R. Radice, K.-G. SANdelin, 'Philo of Alexandria: an Annotated Bibliography 1992', The Studia Philonica Annual 7 (1995) 186-222.

Bibliography of Philonic studies primarily for the year 1992 (90 items), with addenda for the years 1989-91 (9 items). (DTR)

1210. D. T. Runia, A. C. Geljon, J. P. Martín, R. Radice, K.-G. Sandelin, D. Satran, D. Zeller, 'Philo of Alexandria: an Annotated Bibliography 1993', The Studia Philonica Annual 8 (1996) $122-54$.

Bibliography of Philonic studies for the year 1993 (74 items), with addenda for the years 1990-92 (6 items). (DTR)

\section{Other Bibliographies}

1301. M. Altenburger and F. Mann, Bibliographie zu Gregor von Nyssa: Editionen - Übersetzungen - Literatur (Leiden 1988).

Gives a brief listing of studies which examine the relation between Philo and Gregory of Nyssa; see the list on p.340 (with cross-references). (DTR)

1302. L. E. Navia, Pythagoras: an Annotated Bibliography (New York-London 1990).

Five references to Philo are taken up in this comprehensive bibliography on Pythagoras and Pythagoreanism in the ancient world; see index on p. 378. (DTR)

1303. P. De Rynck and A. Welkenhuysen, De Oudheid in het Nederlands: Repertorium en bibliografische gids voor vertalingen van Griekse en Latijnse auteurs en geschriften (Baarn 1992), esp. 291-292.

Repertory and bibliography of Dutch translations of Greek and Latin authors and works. The book honours as its predecessor (and recurring point of reference), the Lijst of printed Dutch translations published in 1924 by A. Geerebaert. This, however, does not prevent it from listing translations from before 1924. The section on Philo is very brief: there were no more than nine Dutch translations to be listed, ranging from 1583 to 1985 , among which only the Legatio ad Gaium (twice) and the In Flaccum figure as works translated in full (and these too have not been translated from the original Greek). (HMK) 
1304. C. Dogniez, Bibliography of the Septuagint / Bibliographie de la Septante (1970-1993) (Leiden etc. 1993), esp. 82-83.

Section no. 19 in this bibliography lists 21 studies concerning Philo's use of the LXX in general and concerning particular words found in both the LXX and Philo. These studies are covered also by R-R and RRS. Review: D. T. Runia, SPhA 8 (1996) 172-174. (HMK)

1305. A. Terian, 'The Armenian Translations of Philo', in C. Zugkerman and M. E. Stone, A Repertory of Published Armenian Translations of Classical Texts (Jerusalem 1995) 36-44.

The repertory was compiled for an Italian research programme on the 'Recovery of Classical Works in Oriental Translations'. Due to circumstances publication was badly delayed (it still has not appeared in the projected form), so it was published in a restricted edition. Though Philo is not a classical author stricto sensu (p. 1), Terian was asked to give an overview of editions, translations and scholarship on the Armenian translations of Philonic works, i.e. the Quaestiones, the philosophical treatises, various fragmenta armeniaca, and ps. Philonic treatises on Jonah and Samson. (DTR)

1306. R. W. Thomson, A Bibliography of Classical Armenian Literature to $1500 A D$, Corpus Christianorum (Turnhout 1995), esp. 75-76.

Gives a list - without annotation - of editions, translations and secondary literature on the writings of Philo in Armenian. (DTR)

\section{Surveys of research}

1401. E. Hilgert, 'A Survey of Previous Scholarship on Philo's De Somniis 1-2', in K. H. RichaRds (ed.), Society of Biblical Literature 1987 Seminar Papers, SBLSPS 26 (Atlanta 1987) 394-402.

The survey examines research carried out on the manuscripts of the two books of De Somniis, editions and translations (on the German translation made by H. Leisegang see now D. R. Schwarz, 8961, p. 70), and studies on special issues. Both works, but especially the second, have received relatively little attention. (DTR)

1402. J. P. MarTín, 'Filón y las ideas christianas del siglo II: estado de la cuestion', Revista Biblica 50 (1988) 263-294.

Martín sets himself two objectives in this article: a state-of-the-art report and critical assessment of the scholarly literature on Philo's influence in the 2nd century; and a methodological proposal for future research. The problem of Philo's historical influence can be divided into six points: (1) the New 
Testament (Paul, John, Hebrews); (2) the apostolic period; (3) the Greek apologists of the 2nd century; (4) the Gnostics; (5) popular and non-canonic pseudo-epigraphical literature; (6) the Alexandrian catechetical school. For all points (particularly 3-5) the various critical positions are assessed, both generally (pp. 267-278) and specifically (with regard to the following contexts: the Letters of Clement, Papias and Ariston of Pella, the Letter of Barnabas, Justin Martyr, Athenagoras, Theophilus of Antioch, the Gnostics, etc.). The article winds up with some observations on method showing three recurrent errors in Philonic studies: (a) excessive methodological fragmentation; (b) doctrinal prejudices which often stand in the way of an objective valuation; (c) the weakness of the historical-literary method, which gives contradictory results. (RR)

1403. D. T. Runia, 'Some Statistical Observations on Fifty Years of Philonic Scholarship', The Studia Philonica Annual 1 (1989) 74-81.

Summarizes and repeats some interesting conclusions on Philonic research based on R-R (also found there on p. xxiii-xxix). The statistics concern the number of studies, the languages in which they have been published, and the various fields of scholarship in which studies on Philo have appeared. Tables and diagrams allow various diachronic shifts to be observed. (DTR)

1404. F. Siegert, 'Der armenische Philon: Textbestand, Editionen, Forschungsgeschichte', Zeitschrift für Kirchengeschichte 100 (1989) 353-369.

This article contains the contents of a lecture held in 1988 during the fourth conference of the Association Internationale des Études Arméniennes in Freiburg, Switzerland. Because of the interest of the Armenian people in 'higher' theology and their love of books, more than a quarter of Philo's work has been preserved in the Armenian language. Part of what has come down to us in the Armenian version is also available in the original Greek, but another part is unparalleled and therefore the only source of those texts which it translates. The critical edition of Cohn-Wendland (1.lii-lvi) had already taken the Armenian parallels into account, but only in a very partial manner. Siegert summarizes the contents of the Armenian Philonic corpus and offers a valuable table of the correspondences (pp. 366-367). The comparison - where possible - of the Greek text and the Armenian version enables him to draw important conclusions on the value of the tradition. (RR)

1405. A. Uña JuArez, 'Antiqua et Mediaevalia. Sobre el significado teorico del platonismo en la historia del pensamiento', La Ciudad de Dios 203 (1990) 143-187.

Primarily a bibliographical notice. In section IV entitled 'Middle Platonism and the Platonism of Philo of Alexandria' (176-178) the author gives a rapid survey of recent scholarship covered by this title, concentrating particularly on $A N R W$ II 36.1 (1989, dedicated to Middle Platonism), II 21.1 (1984, 
dedicated to Alexandrian Judaism), and the work of D. T. Runia, Philo of Alexandria and the Timaeus of Plato (Leiden $1986^{2}=\mathrm{R}-\mathrm{R}$ 8656), which is deemed to be a work of 'high quality' (p. 185). (RR)

1406. E. Hilgert, 'A Review of Previous Research on Philo's De Virtutibus', in E. H. Lovering (ed.), Society of Biblical Literature 1991 Seminar Papers, SBLSPS 30 (Atlanta 1991) 103-115.

Gives a survey of scholarship specifically devoted to the treatise De virtutibus. Hilgert first discusses the question of its structure and contents, then lists the mss. in which the treatise is found, followed by an account of printed editions and translations. He concludes with brief references to discussions on the relation between the treatise and Classical thought and New Testament studies. It would seem that much study has been devoted to Philo's teaching on the virtues, but little to his specific treatise $O n$ the Virtues. The article concludes with the challenging words: 'The door of opportunity stands open.' (DTR)

1407. G. Boccaccini, Portraits of Middle Judaism in Scholarship and Arts: a Multimedia Catalog from Flavius Josephus to 1991, Quaderni di Henoch 6 (Turin 1992).

We include this work even though in it Philo is conspicuous by his absence (and the author does not indicate why he falls outside its scope). But since this valuable instrument of research collects all the general presentations of Judaism as it was in the period of $300 \mathrm{BCE}$ to $200 \mathrm{CE}$ (cf. by the same author 9107), necessarily many of these works will be of value for Philonic research. The individual entries, however, are not annotated, so the user is only given a first orientation. (DTR)

1408. B. Schaller, 'Philon, Josephus und das sonstige griechisch-sprachige Judentum in ANRW und weitere neueren Veröffentlichungen', Theologische Rundschau 59 (1994) 186-214.

A review article on vol. $20.1 \& 2$ (1987, on Hellenistic Judaism) and $21.1 \&$ 2 (1984, on Philo and Josephus) of the collective work Aufstieg und Niedergang der römischen Welt. From vol. 20 Schaller marks out especially the history of Hellenistic-Jewish literature by $\mathrm{N}$. Walter. From contributions bearing on Philo he mentions positively those of G. Lease $(8755)$, D. M. Hay (8749) and J. Riaud (8778). In vol. 21.1 he praises the Philo bibliography of E. Hilgert (R-R $1019)$ and the survey on Philonic research of P. Borgen (1114). New paths for Philo exegesis are indicated by J. Cazeaux (8415) and B. L. Mack (8431). Schaller remains sceptical about the chronological theories of A. Terian (8458), but shows some appreciation for the attempt of R. Barraclough (8405). For Philo's embedding in Greco-hellenistic philosophy he refers to the monographs of A. Méasson (8638) and D. T. Runia (8656), the latter receiving high praise. (DZ) 
1409. E. Hilgert, 'Philo Judaeus et Alexandrinus: The State of the Problem', in J. P. Kenney (ed.), The School of Moses: Studies in Philo and Hellenistic Religion in Memory of Horst R. Moehring, BJS 304 (= Studia Philonica Monographs 1) (Atlanta 1995) 1-15.

The theme of the article is set by a quotation by Louis Ginzberg: 'Was he [Philo] a Jewish thinker with a Greek education, or a Greek philosopher with Jewish learning'. Hilgert gives a valuable bibliographical survey of scholarly opinion on this issue (ending in about the mid-eighties), divided into four sections. First he discusses scholars who have stressed the importance of Hellenism and above all Greek philosophy for his thought. Then he records the views of another group who focus on the Jewish elements in his thought, esp. in relation to the Halakha. The third section focuses on his methods in his exegesis, which have been related to both Greek and Jewish backgrounds. Finally he looks at those scholars who emphasize Philo's Sitz im Leben in Roman Alexandria. Hilgert ends the article with some suggestions for further investigation. (DTR)

\section{B. CRITICAL EDITIONS}

\section{Greek texts -}

\section{Latin texts -}

\section{Armenian texts -}

\section{Greek fragments}

1823. J. R. Royse, The Spurious Texts of Philo of Alexandria: a Study of Textual Transmission and Corruption with Indexes to the Major Collections of Greek Fragments, ALGHJ 22 (Leiden 1991).

This important monograph has been produced as part of the preparations for an edition of the Fragments of Philo. Royse sifts out all those fragmentary texts that have been erroneously attributed to Philo in modern scholarship. At the same time he furnishes much valuable information about the transmission of less well-known parts of the Philonic corpus. In an Appendix tables are given for all the major collections of Greek fragments so far published. This was later complemented by a reverse index, see 3214. Reviews: E. Manning, Script 46 (1992) 148*; D. T. Runia, SPhA 4 (1992) 78-86 = 9270, and $V C h r 46$ (1992) 296-299; D. A. Bertrand, RHPhR 73 (1993) 203; R. Radice, Elen 14 (1993) 199-200; G. E. Sterling, RelStR 19 (1993) 274; J. A. Strauss, AC 62 (1993) 293-294; R. Williamson, NT 35 (1993) 294-295; P. H. Poirier, LThPh 51 (1995) 423-424. (DTR) 
1824. J. Hammerstaedt, 'Zu einigen Philonfragmenten bei Euseb', Jahrbuch für Antike und Christentum 35 (1992) 12-18.

Complementary to a review (ibid. p. 203f) of a new edition of Eusebius' Praeparatio Evangelica the author re-examines the text, the construction and the significance of three Philonic fragments. The main infinitives in 8.6.1 are explained as a summary of a larger passage in Philo done by Eusebius in the same way as in 8.6.8f; in 8.6.1-4 the qualities of Moses are extolled in order to demonstrate the magnitude of his people as a whole; in 8.7.7 one should read $\delta \circ \lambda \circ \hat{v} v$ instead of $\delta \circ v \lambda \circ \hat{v} v$ and translate as 'falsify through cross-breeding'. (DZ)

1825. W. Brashear, 'Literary and Sub-Literary Papyri from Berlin', in A. Bülow-Jacobsen, (ed.), Proceedings of the 20th International Congress of Papyrologists, Copenhagen, 23-29 August, 1992 (Copenhagen 1994) 284-291, esp. 290 and Plate 21.

This article publishes a tiny snippet of papyrus $(12 \times 6.3 \mathrm{~cm})$ that forms part of the Berlin collection of papyri. It is of unknown provenance and is numbered $P$. Berol. 21342. The text has been identified by R. Daniel as Philo, Deus 151, 154-155. The papyrus itself can be viewed on Plate 21. It contains writing on both sides, so must have come from a codex. It also contains a nomen sacrum, so must have a Christian origin. The papyrus is dated to the 6th7 th century CE for unspecified reasons. (DTR)

1826. M. Olivieri, 'Note critico-testuali al De Providentia di Filone Alessandrino alla luce della traduzione armena', Eikasmos 7 (1996) 167-178.

The author compares the Greek fragments $2.15,2.16,2.22,2.25,2.26,2.31 .2$, 2.39 of De providentia, transmitted by Eusebius, with the Armenian translation of the entire treatise dated to the fifth or sixth century and published in 1822 by J. B. Aucher. This comparison brings him to propose various emendations of the Greek text. (HMK)

\section{J. R. Royse, 'Yonge's Collection of Fragments of Philo',} The Studia Philonica Annual 8 (1996) 107-21.

The single volume translation of Philo's complete works published in 1993 (2113) contains an extensive collection of fragments based on the second Appendix to Mangey's great edition of 1742. Most of the references are wholly out of date, and it will be difficult for modern readers to determine where these fragments come from. Royse considers it a pity to consign this material to oblivion, and therefore presents an index of both the Eusebian extracts translated and the fragments included in the appendix. Most of them are identical to passages in the Philonic corpus, but a considerable number remain to be identified, while a minority are definitely to be regarded as spurious. (DTR) 
5. Armenian fragments -

\section{TRANSLATIONS INTO MODERN LANGUAGES}

\section{German translations}

b. Translation of single works

2052. F. Siegert, Philon von Alexandrien Über die Gottebezeichnung "wohltätig verzehrendes Feuer" (De Deo): Rückübersetzung des Fragments aus dem Armenischen, deutsche Übersetzung und Kommentar, WUNT 46 (Tübingen 1988).

See below, 3103 .

\section{English translations}

\section{a. Comprehensive translation}

2113. C. D. Yonge, The Works of Philo Complete and Unabridged, with a Foreword by D. M. Scholer (Peabody Mass. 1993).

The publication of this first single-volume translation of Philo into a modern language is undeniably an important event in Philonic studies. It should be noted, however, that the translation dates to 1854-55 and could be published at an attractive price because it is in the public domain. The editor and his collaborators have added some missing sections and - most importantly - brought the divisions of the text up to date, taking the Loeb edition as their example. This makes the translation much more suitable for contemporary use. Despite its title, however, there are, a number of Philonic works not included ( $Q G \mathrm{IV}, Q E$, the Armenian Prov., Anim., Deo). Reviews: S. E. Porter, JSNT 56 (1994) 128; D. T. Runia, SPhA 6 (1994) 171-182 (= 9462); J. C. VanderKam, JSP 13 (1995) 944; J. Murphy-O'Connor, RB 102 (1995) 303-304; D. T. Runia, VChr 49 (1995) 194-198; M. Veloso, AUSS 33 (1995) 157-158; J. Murphy-O'Connor, RB 103 (1996) 132. (DTR)

b. Translation of single works

2155. G. Paterson Corrington, 'Philo On the Contemplative Life: or, On the Suppliants (The Fourth Book on the Virtues)', in V. L. Wimbush (ed.), Ascetic Behavior in Greco-Roman Antiquity: a Sourcebook, Studies in Antiquity and Christianity (Minneapolis 1990) 131-155. 
As part of a source book for the study of asceticism in the ancient world, a new translation of De vita contemplativa has been produced. It is prefaced by a brief introduction, accompanied by brief notes. The chapter ends with a brief list of suggested further literature. Both translation and accompanying material are unfortunately marred by frequent errors. ReviEw: D. T. Runia, SPhA 4 (1992) 133-136. (DTR)

2156. [H. Lewy], 'Philo of Alexandria: 'On the Life of the Therapeutae [Ancient Contemplative Jewish Sect; Excerpt from $O n$ the Contemplative Life] ", Parabola 17 (1992) 57-60.

Translation of the description of the life of the Therapeutae in Contempl., reprinted from Hans Lewy, Philo: Philosophical Writings (see R-R 3002, 3009), without any comment or discussion as part of a special issue of Parabola dedicated to 'Solitude and Community'. (RMB)

2157. W. W. Fortenbaugh, P. M. Huby, R. W. Sharples and D. Gutas, Theophrastus of Eresus: Sources for his Life, Writings, Thought, and Influence, 2 vols., Philosophia Antiqua 54 (Leiden 1992), esp. 1.342-355.

The first collection of Theophrastus' fragments since Wimmer (1854-62) and a landmark in Theophrastean studies, it includes a text and translation of Aet. 117-149 as Fr. 184. R. Sharples' commentary on this text has been published in 1998. (DTR)

\section{French translations}

a. Comprehensive translation

2235. A. TERIAN, Alexander vel De ratione quam habere etiam bruta animalia (De animalibus) e versione armeniaca: introduction, traduction et notes, Les CEuvres de Philon d'Alexandrie 36 (Paris 1988).

A French translation and adaptation within the format of the PAPM series of Terian's earlier translation and commentary of the De animalibus ( $R-R$ 1704). Intervening scholarly developments are taken into consideration only to a very limited extent. Reviews: P. Tenant, POC 38 (1988) 412-413; X. Jacques, NRTh 111 (1989) 438f.; J. Dillon, Gnomon 62 (1990) 552-554; S. Imhoof, RThPh 122 (1990) 552; G. Pelland, ScEs 42 (1990) 113-114; D. T. Runia, SPhA 2 (1990) 184-186; J. Schamp, RBPh 69 (1991) 202-203; P. H. Poirier, LThPh 48 (1992) 452-453; J. C. M. van Winden, VChr 46 (1992) 194-195. (DTR)

2236. A. Terian, Quaestiones et Solutiones in Exodum I et II e versione armeniaca et fragmenta graeca, Les CEuvres de Philon d'Alexandrie 34c (Paris 1992). 
As we read in a brief Avant-Propos by Jean Pouilloux, this is the thirtysixth and final volume of the Lyon French translation project, which commenced in 1961 under the leadership of R. Arnaldez, C. Mondésert and Pouilloux himself (cf. R-R 2201-2234, and RRS 2235). Terian presents a French translation directly from the Armenian, with Aucher's Latin translation on the left page opposite. The introduction consists of three parts: (1) various comments on the treatise and its tradition, with special reference to the place of the surviving chapters in the original six books; (2) a longer discussion on the place of the work in the Philonic corpus as a whole, arguing that it is probably the oldest of Philo's bible commentaries; (3) a short resumé of the contents of the work and an even shorter indication of the riches of symbolism contained in its exegesis. The work is concluded with the Greek text of 2.62-68 (not included in Petit's collection of fragments (=vol. 33) published in 1978 because strictly speaking it is not a fragment) and various complementary notes and indices. Reviews: J. Pouilloux, CRAI 78 (1992) 544; D. A. Bertrand, RHPhR 73 (1993) 204; H. Crouzel, BLE 94 (1993) 150; V. Roisel, NRTh 115 (1993) 265-266; P. Tenant, POC 43 (1993) 201-202; W. Wiefel, ThLZ 118 (1993) 624; F.-X. Druet, EtCl 62 (1994) 398-399; W. Gessel, OrChr 78 (1994) 256; P.-H. Poirier, ScEs 46 (1994) 117-119; D. T. Runia, JThS 45 (1994) 287-290; J. C. M. van Winden, VChr 48 (1994) 187-189; B. O. Degorski, Ang 72 (1995) 95-96; J. Schamp, RBPh 73 (1995) 187-189; J. R. Royse, SPhA 10 (1998) 176-183. (DTR)

\section{b. Translation of single works}

2254. J.-Y. Leloup, Prendre soin de l'Être: Philon et les thérapeutes d'Alexandrie, Spiritualités (Paris 1993).

The author presents a new translation of De vita contemplativa, inspired by the preceding translations of Geoltrain (Paris 1960, = R-R 2253) and Miquel (PAPM vol. 29, Paris 1963, = R-R 2210), but nevertheless novel because differing in intention. The aim of the work, in both translation and notes and also in the brief introduction (pp. 9-26) is to make the Philonic text more accessible by bringing it up to date or modernizing it, above all in relation to the centrality of the interpretation of scripture in the life of faith. Cf. also 2453 and 2851. Review: J. Riaud, SPhA 7 (1995) 226-227. (RR)

\section{Spanish translations -}

\section{Italian translations}

\section{a. Comprehensive translation}

2405. Filone di Alessandria. La filosofia Mosaica. La creazione del mondo secondo Mosè: traduzione di C. Kraus Reggiani. Le allegorie delle Leggi: traduzione di R. RADICE. Prefazioni, apparati e commentari di R. RAdice. Monografia introduttiva di G. ReAle e R. Radice, I Classici del Pensiero (Milan 1987). 
Contains, besides the translation of Opif. and Leg., an introductory monograph (see 8776), commentaries on both works (see below, 3102), prefaces to and reading schemes of the single works, as well as an extensive bibliography and indices of persons and biblical quotations. Reviews: W. Gessel, OrChr 72 (1988) 235; G. Pelland, Gr 69 (1988) 790ff.; E. des Places, RPh 62 (1988) 152; X. Jacques, NRTh 111 (1989) 439-441; P. Nautin, REG 102 (1989) 617; D. T. Runia, VChr 43 (1989) 191ff.; J. Dillon, SPhA 2 (1990) 177-182; J. M. Igartua, Pens 46 (1990) 121-122; J. P. Martín, Meth 3 (1990) 149-150; M. Hadas-Lebel, REJ 150 (1991) 186; W. Horbury, VT 42 (1992) 135-136. (RR)

2406. R. RAdicE, Filone di Alessandria, La migrazione verso l'eterno: L'agricoltura, La piantagione di Noè, L'ebrietà, La sobrietà, La confusione delle lingue, La migrazione di Abramo, Saggio introduttivo, note e apparati di R. Radice. Presentazione di G. Reale, I Classici del Pensiero, Sezione di filosofia classica e tardo-antica (Milano 1988).

In the introductory essay (pp. 31-92) entitled 'Il concetto di migrazione in Filone di Alessandria', Radice explains the complex meanings which the allegorical figure of migration assumes from various points of view and in the context of the biblical passages for which it is used as explanation. These meanings are the following: migration in an intellectual sense (p. 39ff.), in a moral sense (p. 44ff.), in a pedagogical-scientific sense (p. 48ff.), and in a physical and metaphysical sense (p. 52ff.). Since the most profound meaning of $\dot{\alpha} \pi 01 \kappa i \alpha$ is for Philo the transcendence of the sensible world, one can postulate an extended meaning of migration in which the same concept of transcendence is expressed by other metaphors, and so becomes a truly universal theme. This essay prefaces translations - with copious annotations - of the treatises Agr., Plant., Ebr., Sobr., Conf., Migr., thus completing the translation of the Allegorical Commentary (including Opif.) into Italian. Review: J. P. Martín, Meth 3 (1990) 149f. (RR)

2407. R. RAdice, in collaboration with G. ReAle, C. KRAUS Reggiani and C. Mazzarelli, Filone di Alessandria: Tutti $i$ trattati del Commentario Allegorico alla Bibbia, I Classici del Pensiero: sezione I Filosofia classica e tardo-antica (Milan 1994).

This splendid volume collects together the five individual volumes of translations of Philo's Allegorical Commentary (R-R 2402-2406) and fully equipped with introduction, summaries, glossary and indices. Review: D. T. Runia, SPhA 7 (1995) 223-225. (DTR)

b. Translation of single works

2452. P. Graffigna, Filone di Alessandria La vita contemplativa, Opuscula 47 (Genoa 1992). 
The study comprises an extensive bibliography relevant to this treatise, a brief introduction - in which the two main problems of the work are presented, the dating and the identity of the Therapeutae - , an Italian translation with the Greek text opposite (with an apparatus criticus allowing comparison of the more important modern critical editions), a detailed commentary (pp. 93-164) and a series of appendices gathered together under the title of Prospectives, devoted to a number of major themes of Contempl:: the

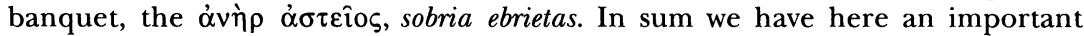
and comprehensive contribution, valuable especially for the translation - the first into modern Italian - and for the accurate and well-documented commentary. Reviews: J. Riaud, SPhA 7 (1995) 226-229; A. Grilli, Paid 51 (1996) 102-109; E. Jucci, BibbiaOr 38 (1996) 269-270. (RR)

2453. J.-Y. Leloup, Aver cura dell'essere. Filone e $i$ terapeuti d'Alessandria, translated from the French by S. PALAmidessi (Rome 1994).

An Italian translation of the French work described above at 2254. (DTR, non vidimus)

2454. G. Reale and R. Radice, Filone di Alessandria: L'erede delle cose divine, Testi a fronte (Milan 1994).

Reprint of the 1981 publication (R-R 2402), with the addition of the Greek text (edited by Wendland, PCW vol. 3) facing the translation. The introduction is by Reale, the translation, notes, synopsis and indices by Radice. Review: D. T. Runia, SPhA 7 (1995) 223-225. (RR)

\section{Dutch translations -}

\section{Hebrew translations}

a. Comprehensive translation

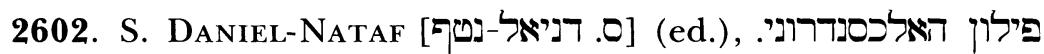
[Philo of Alexandria: Writings]: vol. 2, Exposition of the Law, Part One, Bialik Institute and Israel Academy of Sciences and Humanities (Jerusalem 1991).

This is the second in a projected five-volume presentation of the (Greek) Philonic corpus in modern Hebrew translation. The volume before us in no way departs from the high standard set by its predecessor in the series (R-R 2601). In accord with the guidelines set forward clearly in the introduction to the series (vol. 1, xxii-xxiii), this volume presents the Hebrew reader with the initial portion of the general Exposition of the Law: De opificio mundi, De Abrahamo, De Iosepho, De Decalogo, and De specialibus legibus 1. This volume is the handiwork of the general editor of the series in conjunction with C. 
Schur, who contributed the translations of $A b r$. and Spec. 1. Reviews: D. Satran, SPhA 7 (1995) 225-226; M. Hadas-Lebel, REJ 157 (1998) 255-256. (DS)

b. Translation of single works

2656. Selected Portions from Philo's Questions and Answers and from his other writings, translated into Hebrew from the Armenian and Greek

See 8904 and 9220.

\section{Polish translations}

a. Comprehensive translation

a2701. Filon Aleksandryjski, Pisma, Tom 1. O stworzeniu świata, Alegorie praw, $O$ dekalogu, $O$ cnotach. Przełożył, wstępem i komentarzem opatrzył Leon JoAchimowicz, Instytut Wydawniczy Pax (Warszawa 1986).

This volume was planned as the first part of Philo's complete translation in the Polish language. Unfortunately, the project has not been completed so far. The first volume contains four treatises translated: De opificio mundi, Legum Allegoriae, De decalogo, De virtutibus. The brief but learned preface is divided into the following thematic sections: (1-6) the background of Philo's thought; (7) a list of Philo's writings; (8) Allegorical method; (9) God; (10) Logos; (11) Brief characteristics of Philo. (AP)

b. Translation of single works

2751. Filon Aleksandryjski, Pisma. Tom 2. O gigantach, O niezmienności Boga, $O$ rolnictwie, $O$ uprawie roślin, O pijaństwie, $O$ trzeźwości. Z języka greckiego przeło żył i przypisami opatrzył STANISLAW Kalınkowski, Wydawnictwo WAM - Księża Jezuici (Kraków 1994).

Translation into Polish, without any introduction, of six allegorical treatises: De gigantibus, Quod Deus sit immutabilis, De agricultura, De plantatione, De ebrietate, De sobrietate. (AP)

\section{Portugese translations}

b. Translation of single works

2851. J.-Y. Leloup, Cuidar do ser (Petropolis, Brazil 1996). 
Portugese translation of the study first published in French in 1993 (2254). The study focuses on the treatise De vita contemplativa in the perspective of continuity between the Jewish and Christian thought in Alexandria. The Therapeutae are presented as being dedicated to 'the care of being' in all its senses, that is to say, of man in his relationship with God and with the revealed divine text, with the cosmos and with language. In short, the Therapeutae take 'care of being' in a triple dimension: body, soul and spirit. The author highlights the continuity of these teachings in the Christian monasticism and their utility for the contemporary situation of humankind. (JPM)

\section{ANTHOLOGIES}

a3014. The Life of Moses; Philo of Alexandria, in D. R. CARTLIDGE and D. L. Dungan (edd.), Documents for the Study of the Gospels (Philadelphia 1980) 253-292.

Translates extracts from Mos. I and II with an introduction, some comments and summaries of the omitted parts. The work is a revision of R-R 3011 first published in 1973. (HMK)

a3015. F. G. Downing, Strangely Familiar: An Introductory Reader to the First Century - to the Life and Loves, the Hopes and Fears, the Doubts and Certainties of Pagans, Jews and Christians (Manchester 1985).

This remarkable anthology of sources on the first century CE was privately published because no publisher was prepared to take it on. Its subtitle indicates the aim of the work. It consists of 16 chapters, covering the chief themes of social and cultural life and the thought world of this era: The family, The neighbourhood, Leisure, Education and learning, Thou shalt not, Them and us, Political and social theorising, Approaches to Deity, The cult, The code, Forgive?, What God does, What God is, What is man?, The good end to evil, Reflection and appraisal. For each chapter Downing has arranged his material in eight columns: (1) Views of Romans and Greeks, (2) Philo as representative of Jews in Egypt, (3) Jewish thinking in Palestine, (4) The New Testament, (5) Josephus, (6) Further Greek sources at the turn of the century, (7) views from Christian writers of this later period, (8) Rabbinic material. The Philonic extracts in the second column, cited in the Loeb translation, amount to 429 in total, covering all the works of Philo preserved in Greek. These are listed in the Index. (DTR)

3016. A. A. Long and D. N. Sedley, The Hellenistic Philosophers, vol.1 Translations of the Principal Sources with Philosophical Commentary; vol. 2 Greek and Latin Texts with Notes and Bibliography (Cambridge 1987) passim. 
Evidence from Philo is used on 10 occasions in this magnificent sourcebook for Hellenistic philosophy. See the listing at 1.497 . Volume 1 contains an English translation, volume 2 the Greek text with short comments. (DTR)

3017. G. Vermes and M. D. Goodman, The Essenes according to the Classical Sources, Oxford Centre Textbooks 1 (Sheffield 1989). esp. 19-31, 75-99.

The first of a new series of student textbooks modelled on the Kleine Texte and LCL. Vermes contributes the introduction, in which he compares the classical descriptions of the Essenes with the Dead Sea scrolls and concludes that they refer to the same group, while the Therapeutae were an 'Egyptian offshoot'. The greater part of the book consists of fifteen texts from the first three centuries of our era, translated and briefly annotated by Goodman (except the Appendix which is an adaptation of Conybeare's 1895 version of Contempl.). The other Philonic texts are Prob. 75-91, Hypoth ap. Eus. PE 8.11.118. Review: G. E. Sterling, SPhA 5 (1993) 227-229. (DTR)

3018. R. Williamson, Jews in the Hellenistic World: Philo, Cambridge Commentaries on the Writings of the Jewish and Christian World 200 B.C. to A.D. 200, vol. I.ii (Cambridge 1989).

A solid introduction to Philo's thought that follows a quite different procedure than the well-known works of Goodenough and Sandmel. After an initial chapter in which Philo's life and work is presented (with most emphasis on his situation in Alexandria and his hopes for the future of his community), Williamson divides his subject into four main areas. In each case a lengthy systematically presented exposition is followed by a translation and commentary on selected passages illustrating the theme. The subjects and texts examined are: (1) Philo's doctrine of God, illustrated by Deus 51-68, Mut. 7-30; Philo's Logos doctrine, illustrated by Her. 205-206, Somn. 1.227-230, Conf. 145-146, Opif. 16-25, Fug. 106-112; Philo's allegorical exegesis of scripture, illustrated by Post. 1-32; the ethical teachings of Philo, illustrated by Virt. 51101, 175-186, Decal. 121-178, Spec. 3.8-63. The method used is largely conceptual and descriptive, with only limited attention paid to areas outside the immediate context of Philo's works. The study is not annotated and is remarkable in that it declines to make any reference to secondary literature whatsoever. It is an introduction to the main strands of Philo's thought, and not to the scholarly interpretation of that thought. Reviews: M. Barker, JThS 41 (1990) 809-810; P. Ellingworth, EvQ 62 (1990) 279-280; D. Hay, SPhA 2 (1990) 186-87; P. W. van der Horst, NTT 44 (1990) 262-264; C. Kraus-Reggiani, Henoch 12 (1990) 242-245; A. Paul, RSR 78 (1990) 458; M. Barker, HeyJ 32 (1991) 599; J. A. Loader, BiOr 48 (1991) 977-979; D. Winston, JR 71 (1991) 295-296; W. M. Reedijk, Bijdr 54 (1993) 332-333. (DTR)

3019. L. H. Feldman and M. Reinhold (edd.), Jewish Life and Thought among Greeks and Romans: Primary Readings (Minneapolis 1996). 
Numerous passages of Philo are included in this comprehensive anthology on Judaism in the Greco-Roman world. See the list on p. 419 (but it is a pity that there is no complete index locorum). (DTR)

\section{E. COMMENTARIES}

3102. Filone di Alessandria. La filosofia Mosaica. La creazione del mondo secondo Mosè: traduzione di C. Kraus Reggiani. Le allegorie delle Leggi: traduzione di R. RADICE. Prefazioni, apparati e commentari di R. Radice. Monografia introduttiva di G. REAle e R. Radice, I Classici del Pensiero (Milan 1987).

Radice's commentary on Opif. is the first since Müller's published in 1841. His commentary on the three books of Leg. is the first ever devoted to this work. The four treatises are divided into parts corresponding to semantic or allegorical units. Each part is in turn subdivided into several sections in which its main themes are elaborated. Each section is introduced by a series of references relating the sections to one another in terms of their subject matter. In this way the commentary constitutes both an analysis and a series of separate contributions discussing general and fundamental themes. For reviews of this work see above, 2405 . (RR)

3103. F. Siegert, Philon von Alexandrien Über die Gottesbezeichnung „wohltätig verzehrendes Feuer" (De Deo): Rückübersetzung des Fragments aus dem Armenischen, deutsche Übersetzung und Kommentar, WUNT 46 (Tübingen 1988).

In his earlier translation of $D e$ Deo (R-R 2051) Siegert was sceptical about the Philonic authorship of the work. He is now certain that it is Philonic and devotes an important volume to this brief work. After a brief introduction in which he outlines his methodology he first prints Aucher's text and then offers a retroversion of the Armenian translation back into Greek, followed by a German translation. He then undertakes an elaborate analytical commentary (pp. 39-139) which examines virtually every single expression of the text. The chief importance of the text is that it offers a summary of Philo's cosmo-theology, in which the author is not afraid to use an unusually large number of Stoic themes. Ten excursuses to the commentary examine further points in detail. On the method used for the retroversion see further the extensive reviews listed below by D. T. Runia and J. R. Royse. The translation and abbreviated versions of the commentary have subsequently been published in 1998 in both French and English; see SPhA 10 (1998) 1-33. Reviews: D. T. Runia, VChr 43 (1989) 398-405 (reprinted as study XIII in 9059); E. Hilgert, $C B Q 52$ (1990) 569-570; M. E. Stone, JSJ 21 (1990) 136-138; R. Williamson, JThS 41 (1990) 169-171; B. Coulie, Muséon 104 (1991) 212-213; J. Royse, SPhA 5 (1993) 209-219. (DTR) 
3104. A. L. Kilaniotis, Philo of Alexandria, De Agricultura: an Analytical Commentary (unpublished dissertation Trinity College, Dublin 1989).

A brief introductory section on the general structure and argument of the treatise prefaces a detailed commentary following the same method as the commentary of Winston and Dillon on Gig.-Deus. The main emphasis is on Philo's relation to his Hellenic context, with much emphasis on linguistic and lexical aspects. (DTR)

3105. P. Graffigna, Filone di Alessandria La vita contemplativa, Opuscula 47 (Genoa 1992).

As noted in our earlier entry of the same work (above, 2452), this translation of Contempl. also contains a detailed commentary on the work on pp. 93-164. For reviews see at 2452. (RR)

3106. G. E. Sterling, 'Announcement: Philo of Alexandria Commentary Series', The Studia Philonica Annual 7 (1995) 161-168.

As the result of a meeting of Philo scholars held at University of Notre Dame in November 1994 it was decided to launch a series of commentaries on selected Philonic works. The scholar elected as general editor here outlines the intended purpose, projected audience and format of the series. So far none of these commentaries have been published. (DTR)

\section{F. INDICES AND LEXICOGRAPHICAL WORKS}

3211. D. T. Runia, 'An Index locorum Philonicorum to Völker', The Studia Philonica Annual 1 (1989) 82-94.

Völker's magisterial study, which appeared in 1938 (= R-R 3817), was published without any kind of index, and so is difficult to consult on issues of detail. The problem is remedied by this Index locorum for Philonic passages, which, given Völker's exhaustive documentation, can also be adapted for thematic purposes. (DTR)

3212. D. T. Runia, 'How to Search Philo', The Studia Philonica Annual 2 (1990) 106-139.

See 9060.

3213. D. T. Runia, 'An Index to Cohn-Wendland's Apparatus Testimoniorum', The Studia Philonica Annual 4 (1992) 87-96; reprinted in 9570. 
An index of references to later usage of Philo's writings given in the apparatus testimoniorum of Cohn-Wendland's great critical edition of Philo. These are confined to Josephus and the Patristic tradition. References to the Catenae and Florilegia are not included. An index of this kind is missing in Leisegang's indices that form volume 7 of the edition (1926-1930). (DTR)

3214. J. R. Royse, 'Reverse Indexes to Philonic texts in the Printed Florilegia and Collections of Fragments', The Studia Philonica Annual 5 (1993) 156-179.

In his monograph on the spurious texts of Philo of Alexandria (above, 1823) Royse provided lists of Philonic texts found in the printed Florilegia and in collections of fragments. This is now supplemented by a revised index which allows one to see which Philonic texts are found in these documents. The texts are sub-divided into four categories: (1) identified Philonic texts presented in the conventional order Opif. Leg. etc.; (2) fragmenta spuria; (3) other non-Philonic texts, e.g. glosses; (4) unidentified texts. The texts in the last three categories are indicated by the opening and final words. (DTR)

3215. D. T. Runia, 'References to Philo from Josephus until 1000 AD', The Studia Philonica Annual 6 (1994) 111-121; reprinted in 9570.

A list - aiming at completeness - of references to Philo in Josephus and Patristic literature up to $1000 \mathrm{AD}$, giving the location of the text and a short description of its contents. 133 texts are listed, of which about $20 \%$ are anonymous. The list amplified and corrects the one given in the author's monograph Philo in Early Christian Literature (Assen 1993) 348-356 (= 9373). An innovation of this list is that it notes whether the text in question was previously included in the lists of testimonia found in the editions of Turnebus, the Vulgata, Mangey and volume 1 of Cohn-Wendland. The full Greek or Latin text of these references can now be found in the Appendix to the Italian translation of Runia's monograph, Filone di Alessandria nella prima letteratura cristiana: Uno studio d'insieme, a cura di $R$. Radice, Pubbicazioni del Centro di Richerche di Metafysica: Collana Platonismo e filosofia patristica; Studi e testi 14 (Milan 1999) 365-445. (DTR)

3216. A. C. GelJon and D. T. Runia, 'An Index locorum to Billings', The Studia Philonica Annual 7 (1995) 169-185.

As a contribution to the Instrumenta section of the Annual the authors present a complete index locorum of Philonic passages and of Platonic passages to Billings' monograph on the Platonism of Philo published in 1919. It is preceded by a brief section outlining the details of Billings' life and some brief comments on the work itself. (DTR) 


\section{G. JOURNAL}

3307. D. T. Runia (ed.), The Studia Philonica Annual, Volume 1 (1989), Brown Judaic Studies 185 (Atlanta 1989).

A continuation under a slightly different name of the journal Studia Philonica, which appeared from 1971 to 1980 (R-R 3301-3306). In his introductory words to the first volume the co-editor of the earlier publication, Burton Mack, speaks of 'an uncommon Phoenix (1).' The journal contains specialized articles, review articles, proceedings of symposia, instruments of research, annual bibliographies (see above, 1202-1210), review articles and book reviews, and news and notes on current developments in Philonic studies. The articles and review articles are listed and summarized under the names of the individual authors elsewhere in this bibliography. (DTR)

3308. D. T. Runia (ed.), The Studia Philonica Annual, Volume 2 (1990), Brown Judaic Studies 226 (Atlanta 1990).

Reviews: J. C. M. van Winden, VChr 45 (1991) 407-409; G. E. Sterling, RelStR 18 (1992) 343.

3309. D. T. Runia (ed.), The Studia Philonica Annual, Volume 3 (1991), Brown Judaic Studies 230 (Atlanta 1991).

This volume was simultaneously a Festschrift in honour of Earle Hilgert, one of the founding editors of Studia Philonica (R-R 3001-3006). See also 9101 and 17 more titels under 1991. Reviews: J. C. M. van Winden, VChr 45 (1991) 407-409; G. E. Sterling, RelStR 18 (1992) 343.

3310. D. T. Runia (ed.), The Studia Philonica Annual, Volume 4 (1992), Brown Judaic Studies 264 (Atlanta 1992).

REVIEW: S. Silverman, IOUDAIOS 3 (1993) nr. 20.

3311. D. T. Runia (ed.), The Studia Philonica Annual, Volume 5 (1993), Brown Judaic Studies 287 (Atlanta 1993).

Reviews: S. Silverman, IOUDAIOS 4 (1994) nr. 15; J. C. M. van Winden, VChr 48 (1994) 311-312.

3312. D. T. Runia (ed.), The Studia Philonica Annual, Volume 6 (1994), Brown Judaic Studies 299 (Atlanta 1994). 
Reviews: G. J. Brooke, JSS 41 (1996) 382-383; L. H. Feldman, REJ 154 (1995) 490-492; M. J. Martin, Abr-N 33 (1995) 120-121. Volumes 1-6 (1989-1994) were reviewed by M. Hadas-Lebel, REJ 157 (1998) 256-257.

3313. D. T. Runia (ed.), The Studia Philonica Annual, Volume 7 (1995), Brown Judaic Studies 305 (Atlanta 1995).

3314. D. T. Runia (ed.), The Studia Philonica Annual, Volume 8 (1996), Brown Judaic Studies 309 (Atlanta 1996).

Reviews: G. J. Brooke, JSS 42 (1997) 461; M. J. Martin, Abr-N 34 (1996-1997) 122-124; A. Moore, SR 27 (1998) 361-362.

For current information about the Journal consult the internet site listed at 3402.

\section{H. INTERNET SITES}

The following current Internet sites offer information on Philonic scholarship, some of which goes back to 1996 and earlier.

3401. Philo home page, located on the Internet at:

http://www.hivolda.no/asf/kkf/philopag.html

This Internet site was established in 1996 by the Norwegian scholar Torrey Seland (Volda College). Its purpose is to present scholarly material on the web which is of relevance to the study of Philo of Alexandria. It contains lists of electronically available resources for the study of Philo and several electronically published articles and reviews. See further the notice at SPhA 8 (1996) 217. (DTR)

3402. Home page The Studia Philonica Annual, located on the Internet at:

$$
\text { http://www.leidenuniv.nl/philosophy/studia_philonica/ }
$$

The home page provides information on the Journal specially devoted to Philonic studies (see above 3307-3314) and related projects, including: mission and history of the Annual; details on the Annual's organization and structure; instructions to contributors; instructions to subscribers; order forms for ordering copies of the Annual; information on The Studia Philonica Monograph Series, The International Philo Bibliography Project, and the Philo of Alexandria Commentary Series; various indices. (DTR) 
Douwe (David) Runia - 978-90-04-31323-1 Downloaded from Brill.com๑4/26/2023 05:35:25AM via free access 


\section{PART TWO}

Critical Studies

$1987-1996$ 
Douwe (David) Runia - 978-90-04-31323-1 Downloaded from Brill.com๑4/26/2023 05:35:25AM via free access 


\section{7}

8701. P. Allen, 'Plato, Aristotle, and the Concept of Woman in Early Jewish Philosophy', Florilegium 9 (1987) 89-111, esp. 93-97.

Although there is no evidence that Philo was influenced by Aristotle's writings on the subject, his espousal of 'sex polarity' in the four categories of opposites, generation, wisdom and virtue are exactly parallel to Aristotle's theory. The polarity is indicated in a table on p. 97. The article is rather unclear on the extent to which Philo may have influenced later Jewish thinkers. Confusion occurs because Leone Ebreo (Judah Abrabanel, 1460-1523) introduces a character called Philo in his Dialoghi d'Amore, and the unsuspecting reader might think that the Jewish philosopher is meant. (DTR)

8702. Y. Amir, 'Der jüdische Eingottglaube als Stein des Anstosses in der hellenistischen-römischen Welt,' in I. BALDERMAN $e t$ al. (edd.), Der eine Gott der beiden Testamente, Jahrbuch für biblische Theologie 2 (Neukirchen-Vluyn 1987) 58-75, esp. 58-62.

For both Philo and Josephus Israel represents in its religion and way of life an ideal which the other nations would do well to take over. The resistance and hatred which the Jewish people arouse is thus a source of

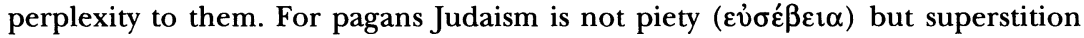
$\left(\delta \varepsilon \imath \sigma \imath \delta \alpha \imath \nu_{0} i^{\alpha} \alpha\right)$, i.e. an exaggerated form of religion, precisely on account of its exclusively monotheistic character. (DTR)

8703. Y. Amir, 'Die "Mitte der Schrift" aus der Sicht des hellenistischen Judentums'. in M. KLOPFERSTEIN et al. (edd.), Mitte der Schrift? ein jüdisch-christliches Gespräch: Texte der Berner Symposions von 6.-12. Januar 1985, Judaica et Christiana 11 (Bern-Frankfurt 1987) 217-236.

The assembled Jewish and Christian 'theologians' were asked to respond to the question: what is the centre-point of Scripture? Amir gives a response for Hellenistic Judaism in a lucid paper. The Philonic viewpoint occupies most of the article, but Amir emphasizes that it is not typical of Hellenistic Judaism as a whole, for which certainly the Law and its Halacha are central. This is not the case for Philo and his circle, however, because his thought is dominated by the Platonic division between the intelligible and the senseperceptible worlds. The commands of the Law are certainly an absolute norm, but only in the world of earthly existence. In order to reach the intelligible core of scripture the allegorical method is indispensable. What it discerns are three main themes focussing on the life of the soul: migration (Auszug), refuge (Zuflucht), nearness to God (Gottesnähe). The centre-point of 
scripture is the articulation of this path to God (p. 234). This path is illustrated by the allegory of the cities of refuge (Fug. 53-118). Primacy is ultimately given to love of God above fear of God. That this is expressed not in terms of a 'doing out of love' but in an ecstatic kind of mystical experience Amir, as a Jew, finds disturbing. (DTR)

8704. G. J. M. Bartelink, 'Die Beeinflussung Augustins durch die griechischen Patres', in J. DEN BOEFT and J. vaN OORT (edd.), Augustiniana Traiectina: communications présentées au Colloque International d'Utrecht 13-14 novembre 1986 (Paris 1987) 9-24, esp. 13-14.

Concise but valuable discussion on the possible acquaintance of Augustine with the works of Philo. (DTR)

8705. J. A. BAzeley, The Correlation of Salvation and Creation according to Philo of Alexandria (M.A. thesis University of Melbourne, 1987).

'At the basis of all of Philo's discussions is the providential concern of God for His creation and of His constant bestowal of good things. To reach the sublime height of His company, as did Moses, the soul witnesses the same quality of giving since it is given 'the divine Light identical with knowledge' (Migr. 39) by which to receive the vision itself. In reaching its goal, the very source of its being, the cause of its salvation, the soul rejoices to find its end in its beginning. This, to me, is the unique contribution of Philo to mankind (p. 146).' In support of this conclusion the author places Philo's conception of salvation against the background of the differing attitudes towards salvation found in the development of Israelite and Jewish thought up to Philo's time. (DTR)

8706. J. Becker, 'Zum Problem der Homosexualität in der Bibel', Zeitschrift für Evangelische Ethik 31 (1987) 36-59, esp. 44-46, 53.

Some Philonic passages (Abr. 135f., Spec. 2.36-43), compared with parallel texts in Paul, exemplify the position of Hellenistic Judaism on homosexuality. Philo's attitude is particularly negative, since in his thought both the biblical and Platonic condemnation of this sexual practice flow together. (RR)

8707. C. BEgG, 'The Birds in Genesis 15, 9-10', Biblische Notizen 36 (1987) 7-11.

The offering of the two birds described in Gen. 15:9-10 can be taken in two senses: both from a 'sacrificial' point of view, i.e. as an application of the levitic prescriptions with regard to offerings, and from an allegorical point of view. The latter kind of exegesis was put forward for the first time by Philo and was subsequently followed by various interpreters. (RR) 
8708. B. Belletti, 'Idea e creazionismo in Filone di Alessandria', Sapienza 40 (1987) 277-304.

The term 'idea' has a cosmological meaning, which Belletti explains with reference to the seven general ideas of heaven, earth, air, void, water, life, and light. But the term also covers many other meanings in Philo, which ought to be considered before drawing metaphysical conclusions about this concept. In particular the author examines the following different 'typologies': the ideas of intelligence and sensation, man, virtue, virginity, passion, number (idea-numbers), repentance, tabernacle. He draws the following conclusions. (1) The ideas are above all paradigms of the creation. God is the prime paradigm and the ideas are secondary paradigms as images of God. (2) The ideas are moreover the thoughts of God and (3) have a

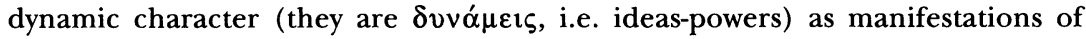
the divine activity. Especially this last aspect, according to Belletti, is new and significant. It deserves, despite some obscure points, to be valued in terms of its theological consequences. (RR)

8709. B. Belletti, 'La creazione delle idee e dell'uomo nel trattato De opificio mundi di Filone Alessandrino', Humanitas (B) 42 (1987) 273-279.

A systematic interpretation of the creation of the six days in De opificio. Belletti emphases two essential points: (a) the caesura which, from an allegorical point of view, exists between 'day one' and the other days of creation; (b) the metaphysics of the image, by which Philo explains the affinity between Creator and created, both on cosmological and anthropological levels. (RR)

8710. R. M. Berchmann, 'Arcana Mundi: Magic and Divination in the De Somniis of Philo of Alexandria', in K. H. Richards (ed.), Society of Biblical Literature 1987 Seminar Papers, SBLSPS 26 (Atlanta 1987) 403-428.

Philo's treatise Somn. displays a sound knowledge of Hellenistic dream theory. Berchmann first presents a long discussion of the role of dreams and

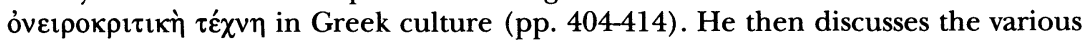
kinds of dreams presented in Somn. and their relation to the state of the soul (pp. 414-428). It is argued that oneirocritic topoi are extensively applied to Pentateuchal material. Philo is keen to show that dreams are god-sent and prophetic, that they have a logos character, and that they are divinatory rather than magic (see conclusions at 428). (DTR)

8711. G. Boccacini, 'Prospettive universalistiche nel tardo giudaismo', Parola, Spirito e Vita 16 (1987) 81-97, esp. 82-86.

The universalism of late Judaism is not at odds with its anti-paganism, for although the Jews persistently opposed polytheism and its cult, it is also true that they accepted pagan converts as Jews pleno iure, without showing prejudice 
on account of their non-Jewish background. This principle is clearly affirmed by both Philo and Flavius Josephus, as well the author of the Romance of Joseph and Aseneth. (RR)

8712. G. Bolognesi, 'Leopardi filologo e i testi armeni', Il Veltro. Rivista della civiltà italiana 31 (1987) 657-674; reprinted in IDEM, Leopardi e l'armeno (Milan 1998) 35-62.

Resumes and develops earlier research by the author (cf. R-R 7009 and RRS a8673). (RR)

8713. A. Bonato, 'L'idea del sacerdozio in S. Ambrogio', Augustinianum 27 (1987) 423-464, esp. 423-436.

Ambrose depends on Philo for his method of expounding the Old Testament (and in particular his etymological method), and also owes certain themes to Philo. Analyzing the meaning of the figure of the Levite in Ambrose and Philo, the author brings out some striking analogies (p. 436), which can be summed up in five points. (1) Both thinkers attribute to the Levites the function of redeeming the foolish, (2) a function which is also extended to the wise man (p. 429). (3) Moreover, the Levite is seen by both as a symbol of priesthood, (4) of the perfect offering (that of the first fruits), and (5) of the spiritual life (God's legacy). (RR)

8714. P. Borgen, Philo, John and Paul: New Perspectives on Judaism and Early Christianity, BJS 131 (Atlanta 1987) passim.

A collection of essays which take as their starting point the author's conviction that no sharp demarcation can be made between Palestinian and Hellenistic Judaism. None of the material on Philo is entirely new, but some chapters have been rewritten to some degree. We give references to the listing in R-R (note that the list of acknowledgements on p. 324 breaks off, no doubt due to a printing error): Chapters 1-2, cf. 8411; Ch. 3, cf. 8007; Ch. 4, cf. reply to criticism noted at 6507 ; Ch. 13, cf. 8007 again; Ch. 15, cf. 8316. Reviews: E. E. Ellis, SwJT 32 (1989) 53; L. T. Johnson, JQR 79 (1989) 386-387; M. J. Pierre, RB 97 (1990) 296; K. G. Sandelin, SPhA 2 (1990) 217-220; D. M. Smith, RelStR 16 (1990) 75; M. Hadas-Lebel, REJ 150 (1991) 183-184. (DTR)

8715. G. Bostock, 'The Sources of Origen's Doctrine of Preexistence', in L. LiEs (ed.), Origeniana Quarta: die Referate des 4. Internationalen Origeneskongresses (Innsbruck, 2. - 6. September 1985), IThS 19 (Innsbruck-Vienna 1987) 259-264.

Origen's doctrine of the pre-existence of the soul has its origins in Philo rather than Plato. In particular Origen takes from Philo the distinction between the heavenly and terrestrial bodies (cf. Somn. 1.138-140) and the conception of the soul's fall into the body. (RR) 
8716. F. F. BRUCE, 'To the Hebrews: a Document of Roman Christianity?', in W. HAASE (ed.), Aufstieg und Niedergang der römischen Welt II 25.4 (Berlin-New York 1987) 3496-3521, esp. 3506ff., $3516 f$.

Brief report on findings of various scholars on the subject of Philo and Hebrews. The author finds the importance of parallels between the two easily exaggerated. It is likely that the origo of the document was Rome, most likely in the early 60's. The Alexandrian affinities of the epistle can be accounted for if the author himself hailed from Alexandria. (DTR)

8717. G. L. Bruns, 'Midrash and Allegory', in R. Alter and F. Kermode (edd.), The Literary Guide to the Bible (Cambridge Mass. 1987) 625-646, esp. 637-642.

A defence of the allegorical method against the background of midrashic interpretation of scripture and with reference to modern hermeneutical theorists such as Gadamer, Quine, Davidson. Allegory is 'radical interpretation', i.e. the interpretation of a text or corpus that has been resituated within an alien conceptual framework. Application of the 'principle of charity' is thus essential. 'We must imagine Philo's allegorization of the Law not as a reading out or a reading in but as a laying open of a common ground between law and philosophy, or between Moses and Plato. Our task is to see that there is nothing strange in this, but that, on the contrary, it is what occurs in all understanding (p. 642).' (DTR)

8718. J. Cazeaux, 'Le voyage inutile, ou la création chez Philon', in L. Derousseaux and F. Blanquart (edd.), La création dans l'Orient ancien: congrès de l'ACFEB, LeDiv 127 (Paris 1987) 345-408.

Cazeaux's article can be divided into two parts, one 'theoretical' (p. 360ff.), focusing on the analysis of Aet., and one which sets out to give the authentically Philonic account of creation. In the first place Cazeaux regards the problem of the interpretation of Aet. as a pseudo-problem, since Philo's aim in this treatise is not to defend a specific philosophical point of view, but to disqualify as self-contradictory the purely intellectualistic positions of the philosophers. The second part of the article introduces an original dynamic conception of creation, according to which the primal creation (described in Genesis 1 and 2) is no more than the first act of a process which leads from ontogenesis to deontogenesis (p. 402). This process mainly finds its expression in the allegory of the name-changes and particularly applies to the figure of the sage. The sage, in fact, fulfils his essence in the moment of recognizing that he is nothing and therefore recognizing the essence of the Cause. Thus there are two moments in the process of creation: one which leads from chaos to the first creation, and one which leads to nullity in the deontological sense. (RR) 
8719. J. Cazeaux, 'Mystique et sagesse: le repas des trois anges et d'Abraham à Mambré vu par Philon d'Alexandrie', in Prière, mystique et Judaïsme: actes du Colloque de Strasbourg, 12-17 Septembre 1984 (Paris 1987) 21-41.

Cazeaux's interpretation of $A b r$. 107-132 is of special importance because it seizes on one of the mystic moments in Philo's thought, where by 'mystic' the author means the almost visual grasp 'of the focal point of human existence' (p. 21). The complexity of the allegorical interpretation developed here (the author shows that there are no less than three different interpretations - literal, pre-allegorical, allegorical - of the same biblical text) can be explained on the basis of a single structure, consisting of 'a fixed framework within which Philo varies, following a certain rule, subtle and simple at the same time, the concepts of unanimity and exchange' (21). (RR)

8720. G. CeAușescu, 'Augustus der «Hellenisator» der Welt (Kommentar zu Philo, Legatio ad Gaium 143-147)', Klio 69 (1987) 4657.

It is remarkable that the anonymous author, whose encomium on Augustus Philo cites, affirms that the emperor hellenized the barbarian world $(\S 147)$. This is comprehensible if understood from the Greek viewpoint, which regarded the Romans as successors to the Greeks, and thus Hellenes both in terms of their origins and their culture. At the same time the Greeks saw Europe as being in continual conflict with the oriental world. (RR; based on $A P h 58$ (1987) nr. 3226)

8721. M.-A. Chevallier, 'Sur un silence du Nouveau Testament: l'Esprit de Dieu à l'œuvre dans le cosmos et l'humanité', New Testament Studies 33 (1987) 344-369.

The theme of the Divine spirit penetrating through the cosmos and at work in man is absent in the OT, but becomes prominent in the Wisdom of Solomon and Philo, especially in exegesis of Gen. 1:2, 2:7. It is entirely absent in the NT, however, reappearing first in the Christian literature of the 2nd-3rd centuries. Universalism in the NT is not cosmic, but rather Christological and evangelical. Metaphysical and anthropological themes return to Christian thought when the first strong eschatological impulses wane. (DTR)

8722. N. G. Cohen, 'The Jewish Dimension of Philo's Judaism: an Elucidation of de Spec. Leg. IV 132-150', The Journal of Jewish Studies 38 (1987) 165-186.

The author wishes, without ignoring Philo's philosophical preoccupations, to investigate the nature of his Jewish roots. Her chief methodological premiss is that Philo 'was consciously wont to use Greek terms at one and the same time intheir philosophic Greek sense, and in their Jewish connotation' (p. 169). An analysis of Spec. 4.132-150 shows that Philo, through his 
description of the Shema' and other general commandments concerning the Torah, is advocating adherence to the Law in terms wholly consonant with the most central facets of Jewish thought and practice. Indeed a discussion of

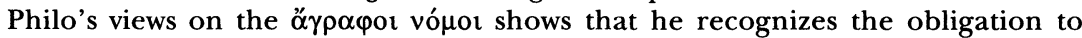
observe what would later be formalized as the 'oral law'. That Philo should wish to subsume these general injunctions of the Torah under the category justice $(\delta 1 \kappa \alpha \imath \sigma v ́ v \eta)$ only makes sense when understood in a 'HellenisticJewish' rather than a solely 'Hellenistic' frame of reference. (DTR)

8723. T. M. Conley, Philo's Rhetoric: Studies in Style, Composition and Exegesis, Center for Hermeneutical Studies Monograph 1 (Berkeley 1987).

A brief monograph on the subject of Philo's rhetoric, consisting of four chapters. The first chapter discusses grammatical and stylistic features, ending with an analysis of their application in Cher. (this part is substantially a reprint of R-R 8418). The second chapter looks at Philo's method of composition as seen in his periodic structure and use of topoi and analogy. In the third chapter macro-structural aspects of Philo's allegorical treatises are examined, including discussion of the role of division, Cazeaux's structuralist views, and emphasis on the need to look at the interaction between writer and listener. In the final chapter Conley examines the issues in relation to how Philo uses his rhetorical skills. The chief role of rhetoric is found in exegetical debate, as is illustrated by a long list of passages in which exegetical controversy takes place (pp. 71-87; note extensive parallels with the Palestinian Targumim). Philo's activity must be seen in the Alexandrian Jewish context. It is primarily practical rather than scholarly. Hence the urgency of his rhetoric. Reviews: S. Isser, CrRBR 1 (1989) 367-368; D. T. Runia, SPhA 2 (1990) 209-211. (DTR)

8724. M. G. Crepaldi, 'Ai confini del linguaggio: il discorso teologico in Filone di Alessandria', in I linguaggi della comunicazione, Centro di studi filosofici di Gallarate (Padua 1987) 157-167.

Crepaldi addresses the problem of the relationship between the transcendent principle and its linguistic expression. For Philo the expressibility of an object depends on its knowability. And so, since God cannot be known by man on account of his transcendent nature, he cannot be expressed in words either. This simple line of reasoning underlies all of Philo's reflections on the existence and essence of God, the principles of negative theology, and the expressive value of silence. (RR)

8725. P. M. Daubercies, 'Les avatars de la vertu', Mélanges de Science Religieuse 44 (1987) 89-107, esp. 98-102.

An analysis, without any reference to secondary literature, of Philo's use of the concept of virtue as part of a synoptic view of its use in philosophical and religious thought. For the Christian doctrine of the virtues the usage of Philo 
is arguably more important than the few references in scripture. One can speak of a 'panaretism' in Philo's thought, so frequent and diverse is his application of the concept. It is noted, too, that Philo is the first to speak of the virtues of hope and faith. (DTR)

8726. G. Deiana, 'Il giorno del Kippûr in Filone di Alessandria', in F. VAttioni (ed.), Sangue e antropologia, riti e culto: Atti della V settimana, Roma, 26 novembre-1 dicembre 1984, 3 vols. (Rome 1987) 2.891905.

The author translates and analyses Philo's discussion of the Yom Kippûr in Spec. 1.186-188, Spec. 2.193-196, Leg. 3.174 and Legat. 306-307. He concludes that for Philo the feast is all about fasting: the element of bringing sacrifices is almost neglected. In Philo's view, expressed elsewhere in his writings, the bringing of material sacrifices has a psychological aim and a spiritual meaning. Instead of day of atonement (kippurr) Philo speaks of day of fasting (tsom) - this in contrast to the rabbinic tradition as found in the Mishna. Day of fasting is the name of the feast as reported by Josephus, Acts 27:9, the Letter of Barnabas, and Plutarch (Quaest. conviv. IV 6,2). After comparison of Lev. 23:2728 with Num. 29:7, and Num. 29:8-10 with 29:2-6, the author concludes that Num. 29:7 (where there is no reference to sacrifices) describes the original core of the feast: penitential fasting and absolute resting (installed during the exile when there was no possibility of sacrificing). Philo takes up this penitential aspect and considers it the most important element of the feast, in line with his spiritualizing approach to the cult. (HMK)

8727. M. Del Verme, 'La "prima decima” nel Guidaismo del Secondo Tempio', Henoch 9 (1987) 5-38, esp. 24-27.

Philo fails to provide useful information on the custom of the 'first tithe', but the author quotes and briefly interprets two Philonic passages (Spec. 1.131155 and Virt. 95) reporting on priestly offerings in general. (RR)

8728. G. Delling, 'Die Begegnung zwischen Hellenismus und Judentum', in W. HAASE (ed.), Aufstieg und Niedergang der römischen Welt II 20.2 (Berlin 1987) 3-39.

According to the author one cannot clearly distinguish between the worlds of Palestinian and Hellenistic Judaism. In its own manner, Palestinian Judaism was 'Hellenistic' too, though not in the same way as Alexandrian Judaism. Philo's work is not specifically dealt with, but is frequently cited to demonstrate and illustrate this theory. Review: see 1408. (DTR)

8729. G. Delling, Die Bewältigung der Diasporasituation durch das hellenistische Judentum (Berlin-New York 1987) passim.

Diaspora Judaism has its 'foundation in Israel's faith in God, seen as the only God, Creator and Lord of history' (p. 91). It was also this faith, together 
with their faith in the Torah, which united the Jews of the Diaspora. Indeed, according to Delling, if 'the isolation of Judaism from the surrounding world constitutes the exterior aspect of this bond, the relationship of Israel with God constitutes its interior aspect' (p. 93). This claim, which the author tests from various points of view (historical, political, religious, cultural, and theological), is largely based on Philonic evidence, which is used as a primary source throughout the book. (RR)

8730. C. Deutsch, Hidden Wisdom and the Easy Yoke: Wisdom, Torah and Discipleship in Matthew 11.25-30, JSNT.S 18 (Sheffield 1987), esp. 81-90, 121-125.

In order to illuminate the Synoptic lemma the author discusses Philo's views on thanksgiving and wisdom through revelation, with special attention paid to the thanksgiving prayer for revelation in Spec. 3.6. The information that Philo can provide for the themes 'come to me [as teacher]' and wisdom as yoke is less helpful. The figure of a teacher is quite undeveloped in Philo's thought. (DTR)

8731. H. DörRIE, Die geschichtlichen Wurzeln des Platonismus, Der Platonismus in der Antike 1 (Stuttgart 1987).

The first volume of a projected multi-volumed series in which the complete evidence for our knowledge of Middle Platonism will be presented in a sequence of about 300 'Bausteine' (the project is being continued by $\mathrm{M}$. Baltes after H. Dörrie's death). Philonic material is included because he was 'ein gründlicher Kenner des damaligen Platonismus', even if his own aim was to present a Mosaic philosophy (63-64). In this volume, which deals with the period up to Cicero and thus before the actual commencement of Middle Platonism, Philonic texts are found at Baustein 9.4-5 (Spec. 1.88, Her. 153) and 28.4 (Opif. 54). (DTR)

8732. J. H. Ellens, 'Philo Judaeus and the Ancient Library of Alexandria', in K. H. Richards (ed.), Society of Biblical Literature 1987 Seminar Papers, SBLSPS 26 (Atlanta 1987) 439-442.

Some reflections on the possible influence of the Alexandrian library and its intellectual community on the method and thought of Philo. (DTR)

8733. G. Eloy Ponferrada, 'Filón de Alejandría: Filosofía y Biblia', Revista Biblica 49 (1987) 99-115.

This article aims at a general presentation of Philo's thought. Philo is the first thinker to distinguish philosophy and biblical theology, and at the same time he establishes a basis for the harmonization of both. Several passages of Philo are adduced, although without direct quotation. The author considers that Philo has a concept of philosophy of an Aristotelian stamp. The object of 
Philonic philosophy is, in the first place, man, and in the second place, the world. To answer the fundamental questions of philosophy, Philo believes that biblical revelation is necessary. In conclusion that author states that in Philo we have the first attempt to reconcile revelation and philosophy, and that his work can be considered the beginning of the kind of thought that would be developed in medieval philosophy. The author thus comes closer to Wolfson's thesis, although the bibliography on the question is not treated in depth. (JPM)

8734. H. FELD, 'Der Hebräerbrief: literarische Form, religionsgeschichtlicher Hintergrund, theologische Fragen', in W. HAase (ed.), Aufstieg und Niedergang der römischen Welt II 25.4 (Berlin-New York 1987) 3522-3601, esp. 3548ff.

Feld underscores some striking analogies between the author of Hebrews and Philo. Nevertheless he sees insufficient grounds for inferring a direct contact between the two thinkers. More probably, the analogies are due to a common background in Alexandrian culture. (RR)

8735. S. M. FinN, 'The Jewish Hellenist and the Medieval Jewish Philosopher: a Comparison of Philo of Alexandria and Saadia ben Joseph', Koers (Bulletin for Christian Scholarship, Potchefstroom, South Afrika) 52 (1987) 115-134.

A relatively superficial point-for-point comparison of the two Jewish philosophers, largely based on secondary sources. Subjects discussed are: the doctrine of God and his attributes, the Logos, creation, man's duality, modes of knowledge, revelation, prophecy, allegorical exegesis, reward and punishment, immortality. Although living in totally different intellectual spheres, the two philosophers are similar in their attempt to reconcile human knowledge and divine revelation. (DTR)

8736. L. H. Feldman, 'Philo's Views on Music', Journal of Jewish Music $\mathcal{E}^{2}$ Literature 100 (1986-87) 36-52; reprinted in 9634.

There is a great deal of evidence on the subject of music in Philo, but it has never as yet been studied. Feldman presents a competent analysis under the headings of (1) the importance of music to Philo, (2) Philo's knowledge of music, (3) music and mathematics in Philo, (4) Philo on vocal and instrumental music. He concludes that Philo's knowledge of music, especially on the theoretical side, was considerable. He is considerably indebted to the Pythagorean tradition and Plato, but goes even further than the latter in using analogies from music in his writings. But on the role of music in the Judaism of his time he is almost completely silent. Only the information on the Therapeutae's services is of interest. As far as music is concerned, the Greek attitudes in his mental make-up are more deep-seated than the Jewish. (DTR) 
8737. L. H. Feldman, 'Torah and Secular Culture: Challenge and Response in the Hellenistic Period', Tradition (A Journal of Orthodox Thought) 23.2 (1987) 1-15, esp. 5ff.; reprinted in 9634.

A sharp attack on Philo's approach to biblical thought from the perspective of orthodox rabbinical Judaism. 'We may ask... why the works of Philo and of other Hellenistic Jews were not mentioned by the Rabbis and were not even translated in Hebrew until the sixteenth century, whereas the attempted syntheses of Jewish and secular studies in medieval Babylonia and Spain did become part of the mainstream of Jewish literature... The answer would seem to be that Hellenized Jews such as Philo examined the Torah through the prism of the Greek language and culture, whereas a Maimonides viewed the Greek philosophers through the prism of the Torah and the Talmud (p. 12).' (DTR)

8738. G. FERGUSON, Backgrounds of Early Christianity (Grand Rapids 1987, 19892), esp. 380-385.

A brief introduction to Philo in the context of the New Testament and Early Christianity. (DTR)

8739. J. Fossum, 'The Magharians: a Pre-Christian Jewish Sect and its Significance for the Study of Judaism and Christianity', Henoch 9 (1987) 303-344, esp. 316-321.

The article examines - and is sympathetic towards - the view of Harkavy that the Magharians were a branch of the sect of the Essenes and the view of Poznanski that the Magharian writer called 'the Alexandrian' was Philo. The Karaites had some knowledge both of Essenian doctrines and of Philo. How could this have happened? Probably through the earlier 'Dead sea scroll find' which is recorded to have taken place in about 800 . So a branch of the wider Essene movement may have included a book of Philo in their library. (DTR)

8740. H. Frohnhofen, Apatheia tou theou: über die Affektlosigkeit Gottes in der griechischen Antike und bei den griechischsprachigen Kirchenvätern bis zu Gregorios Thaumaturgos, Europäische Hochschulschriften Series XXIII Theologie 318 (Frankfurt 1987), esp. 108-115.

The author briefly cites most of the philosophical epithets which Philo attributes to God. These are directly or indirectly reduced to one principle, the identity of acting and being in God. A conspicuous epithet is that of immutability, on which God's apatheia depends. The latter concept, however, would seem to have primarily a moral rather than ontological value indicating not that God has no feelings, but only that he has no morally inferior feelings. (RR) 
8741. G. C. Gianoulis, The Sonship of Christians in Galations 3 and 4 (diss. Lutheran School of Theology, Chicago 1987).

As background to an analysis of the theme of sonship to God and to Abraham in Galatians 3 and 4, these themes are pursued in the Intertestamental literature, the writings of Philo and in the Rabbinic literature. (DTR; based on DA 48-1796)

8742. W. L. Goмвосz, 'Anfänge einer Übertheologie: Transzendentalisierung des ersten Gottes im kaiserzeitlichen philosophischen Denken', in N. BRox et al., Anfänge der Theologie: XARISTEION Johannes B. Bauer zum Jänner 1987 (Graz 1987) 273-293, esp. 279-284.

Philo is succintly placed in the context of theological developments in Middle Platonism, as prelude to the efforts of the Apologists to relate biblical to Greek philosophical thought. Philo himself may have been responsible for the innovations in negative theology which his works disclose when compared with the earlier Eudorus. Gombocz also argues for a Philonic theory of a double creation similar to the revision of Plato found in Eudorus. (DTR)

8743. R. Goulet, La philosophie de Mö̈se: essai de reconstruction d'un commentaire philosophique préphilonien du Pentateuque, Histoire des doctrines de l'Antiquité classique 11 (Paris 1987).

An ambitious book with a radical thesis which, if accepted, would mean a revolution in Philonic studies. Goulet argues that in his allegorical commentaries Philo has thoroughly reworked an existing written commentary on the Pentateuch produced one or two generations prior to him. In this commentary a 'secular' philosophical reading of the Pentateuch was presented in terms of a coherent allegorical system. This reading had a moral-ethical

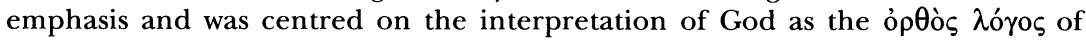
philosophy. It was not interested in the concept of creation (or of physical allegory), and probably gave an allegorical interpretation of the creation account. Philo, on the other hand, is strongly opposed to some of the tenets of the radical allegorizers, e.g. the refusal to accept any literal exegesis and the lack of interest in a creation doctrine. Philo in fact is above all preoccupied with the religious question of man's relation to God, centred on the notion of man's nothingness. Though compelled to base his exegesis on the allegorical system already constructed by his predecessors, he actually fights a continual battle against many of its presuppositions, and it is this conflict that is largely responsible for his numerous inconsistencies. It is only by means of close analysis of these conceptual layers in Philo's work that the earlier commentary can be reconstructed, for all further evidence is lacking. The bulk of the book (pp. 94-507) consists of an analysis of those Philonic exegeses of the entire Pentateuch which Goulet thinks reveal traces of the original commentary. At 58-62 there are some valuable pages on the subject of the Hebrew etymologies in Philo, which Goulet considers to have been inadequately 
studied so far. An appendix (pp. 569-578) provides an excursus on the (Peripatetic) doctrine of the three kinds of goods which is thought to provide a valuable clue in the task of separating Philo from his main source. Reviews: M. Messier, MSR 44 (1987) 197-199; G. M. de Durand, RSPhTh 72 (1988) 605607; G. M. de Durand, SR 18 (1989) 92-93; D. T. Runia, JThS 40 (1989) 590-602; Y. Verniere, $R E G 102$ (1989) 487-489; M.-J. Pierre, $R B 97$ (1990) 296-301; D. A. Bertrand, RHPhR 72 (1992) 213-214; B. Dupuy, Istina 37 (1992) 323-324; J. Dillon, Dial 33 (1994) 749-750. (DTR)

8744. J. G. Griffiths, 'Egypt and the Rise of the Synagogue', The Journal of Theological Studies 38 (1987) 1-15, esp. 4, 6, $12 \mathrm{ff}$.

Philonic evidence is invoked to support the argument that the synagogue had its origins in Ptolemaic Egypt. Egyptian influence may be seen in the combination of worship and instruction missing in Greek culture. Passing remarks are made on possible Egyptian influences on Philo's thought. (DTR)

8745. P.-M. Guillaume, Art. 'Rachel et Lia', Dictionnaire de Spiritualité, Ascétique et Mystique, Doctrine et Histoire 13 (1987) 25-30, esp. $26 f$.

Referring to the main Philonic texts, the author briefly discusses the allegorical meaning of Rachel and Leah, showing how the latter is superior to the former. (RR)

8745a. F.-P. HAGER, Gott und das Böse im antiken Platonismus, Elementa 43 (Würzburg-Amsterdam 1987), esp. 112-115.

A brief discussion of Philo's thoughts on the origin of evil in the context of an examination of this problem in the Platonic tradition. Although allowance should be made for Neopythagorean and Stoic ideas in Philo's metaphysics, the prime source, apart from the Jewish monotheistic background, is Platonic. It appears that Philo did not clearly decide whether matter was a principle beside God, or whether God brought that matter into existence. All the same it is wrong to see matter as an evil counter-principle to God. Philo does not consistently base the presence of evil in the bodily realm (both in the cosmos and man) on ontological or metaphysical principles. (DTR)

8746. A. G. Hamman, L'homme image de Dieu: essai d'une anthropologie chrétienne dans l'Église des cinq premiers siècles, Relais-Études 2 (Paris 1987), esp. 106-113.

A brief reconstruction of the creation of man according to Opif. and Leg. (creation of 'man as image' p. 107ff., of 'moulded man' p. 109ff., typology of earthly and heavenly man p. 112ff.) leads the author to conclude that Philo was much closer to Plato than to the Bible in his devaluation of the body in 
favour of the spirit. It was precisely to this aspect of his thought that the Church Fathers turned, notably Gregory of Nyssa, who displays this form of dualism even more clearly. (RR)

8747. M. HAdAs-LeBel, 'L'évolution de l'image de Rome auprès des Juifs en deux siècles de relations judéo-romaines -164 à +70 ', in W. HAase (ed.), Aufstieg und Niedergang der römischen Welt II 20.2 (Berlin 1987) 715-856, esp. 784-812.

The attitude of Philo and Josephus to Roman rule in general and as in response to particular incidents is examined together, with more emphasis on Josephus than Philo. Both are very well aware of Rome's concentration of power, and in the final analysis they see this as having both advantages and disadvantageous for their nation. Review: see 1408. (DTR)

8748. D. M. HAy, 'Politics and Exegesis in Philo's Treatise on Dreams', in K. H. Richards (ed.), Society of Biblical Literature 1987 Seminar Papers, SBLSPS 26 (Atlanta 1987) 429-438.

The question at issue is how exegetical method and compositional technique is related to political content in the De somniis. Hay concludes that Goodenough was right in claiming that part of Philo's purpose is to give answers to practical political problems facing Jews. Political allegory is placed beside or concealed within the allegory of the soul. There is, however, no evidence of specifically anti-Roman or Messianic sentiments. (DTR)

8749. D. M. HAY, 'The Psychology of Faith in Hellenistic Judaism', in W. HAASE (ed.), Aufstieg und Niedergang der römischen Welt II 20.2 (Berlin 1987) 881-925.

The term 'psychology of faith' is taken to mean 'consideration of the subjective elements and dynamic processes involved in religious belief (881)'. The article examines key areas of this subject in the recent study of hellenized writings, by which is meant especially Philo, Wisdom, 4 Maccabees. Subjects dealt with are (1) the relation between psychology of religion and literary structures; (2) the interior structures of human personality; (3) man's internal war, not only in terms of the conflict between reason and passion, but also between conflicting ideas or patterns of thought; (4) stages of spiritual consciousness as seen in the migration of the soul; (5) parallels in the literature of primitive Christianity; (6) the evidence of art (mainly DuraEuropos). Hay concludes this highly instructive paper with some general conclusions. Hellenistic Jewish psychology was relatively optimistic about man. Philo's psychology is built on a theology which takes divine transcendence for its cornerstone. Not even his most exalted religious experiences erode his sense of the difference between God and man. REviEw: see 1408. (DTR) 
8750. R. D. Hecht, 'Philo and Messiah', in J. Neusner, W. S. GreEN and E. S. Frerichs (edd.), Judaisms and their Messiahs at the Turn of the Christian era (Cambridge 1987) 139-168.

Thought-provoking presentation of both Philo's ideas on messianism (i.e. political eschatology) and secondary scholarship on the subject. Hecht begins with discussion of the opposed views of Wolfson and Goodenough, both of whom over-simplify the subject. He then proceeds to give a survey of the messianic texts in the Philonic corpus. These suggest that Philo had two different, but not irreconcilable interpretations of the messianic figure and era, the one transforming them into allegory, the other as a specific component of Philo's exposition of the Law. But even in the second interpretation the messianic era is thoroughly dehistoricized and spiritualized. In the final section of the paper the author attempts to relate Philo's messianism to his historical situation, arguing that Philo is effective in his neutralization of political messianism, especially as that was expressed at a more popular level. (DTR)

8751. A. VAN DEN HoEk, 'Mistress and Servant: an Allegorical Theme in Philo, Clement and Origen', in L. Lies (ed.), Origeniana Quarta: die Referate des 4. Internationalen Origeneskongresses (Innsbruck, 2.-6. September 1985), IThS 19 (Innsbruck-Vienna 1987) 344-348.

The relationship between mistress and maidservant in Philo characterizes the allegorical meaning of many pairs of women in the Bible, for instance Sarah-Hagar, Keturah-Hagar, and Rachel-Leah. This symbolism probably goes back to allegorical interpretations of Homer and Stoic allegorizing. Philo's originality consists in the way he applies it to the Bible. (RR)

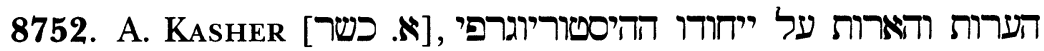
(Notes and Illuminations concerning Philo's Historiographical Uniqueness'], in J. SALmon, M. STERN and M. ZimmerMAN (edd.), עיונים בהיסטוריוגרפיה [Studies in Historiography] (Jerusalem 1987) 9-40.

Philo's historical writings are reviewed in the light of the book of 2 Maccabees and the 'rhetorical-pathetic' style of Hellenistic historiography. While Philo can be shown to have had a clear interest in such literary or stylistic techniques, the author argues, these concerns neither compromise nor endanger his status as a prime source of reliable historical knowledge for the events which he narrates. (DS)

8753. D. E. Keeney, Paul's Opponents in Acts in Light of Gentile Descriptions of Jews (diss. Southern Baptist Theological Seminary 1987), esp. chap. 3. 
The aim of the dissertation is to reach an understanding of the distinctiveness of Luke's depiction of Paul's opponents in Acts in the light of Gentile descriptions of Jews. A chapter is devoted to Philo and Josephus because these authors furnish the most information about Jews in the early empire and their perspective has shaped the perspective of many scholars who interpret the role of Jews in the early empire. Although Philo and Josephus argue that the Jews have had special privileges because of the nature of their religion, in fact they present the case that Jews have privileges at the discretion of Rome. It is particularly the religious aspects of these privileges on which Philo and Josephus focus their attention. (DTR; based on DA 49-279).

8754. J. L. KinneAvy, Greek Rhetorical Origins of Christian Faith: an Enquiry (Oxford-New York 1987), esp. 92-94.

Argues that major aspects of the Christian concept of faith ( $\pi$ ír $1 \varsigma$ ) have their origins in classical Greek rhetoric. Philo's views on faith are affirmed to be closer to the NT than the OT, as especially the similarities with the Epistle to the Hebrews show. (DTR)

8755. G. Lease, 'Jewish Mystery Cults since Goodenough', in W. HaAse (ed.), Aufstieg und Niedergang der römischen Welt II 20.2 (Berlin 1987) 858-880.

There is a deep difference between a Judaism nurtured by historical traditions and the major Hellenistic mystery cults. The author examines the debate as to whether Jewish mystery cults ever existed. First he discusses authors who developed this idea before Goodenough (including Reitzenstein, Leisegang, Leipoldt, Pascher), then Goodenough and the reactions to his theory. Lease sides with Nock and U. Früchtel: Philo, like other sophisticated authors, presents a Schreibtischmysterium. Review: see 1408. (DTR)

8756. S. Lilla, 'La teologia negativa dal pensiero greco classico a quello patristica e bizantino (prima parte)', Helikon 22-27 (1982-87) 211-279, esp. 229-242.

This survey of the main representatives of negative theology starts off with a long list of (negative) attributes of God or the first principle (e.g. 'ungenerated', 'immutable', 'outside time, space, and eternity', and 'superior to virtue'), numbered from 1 to 32 . Referring each time by number to these various attributes, Lilla gives a full schematic description of the views of the Presocratics, Plato and the Old Academy, Aristotle, Philo and later thinkers. Much space is devoted to Philo: extensive enumerations of passages (including also quotations), criticism of Wolfson's views, and continual comparison with other thinkers (both prior and subsequent to Philo, in the latter case often influenced by him). (HMK) 
8758. W. E. MANN, 'Immutability and Predication: What Aristotle taught Philo and Augustine', International Journal for Philosophy of Religion 22 (1987) 21-39.

Philo holds that immutability is a property (proprium, i $\delta$ iov) of God, thus referring to a technical term in Aristotelian logic according to which i $i \delta 10 v$ is a quality that is exclusively possessed by a given being and does not belong to its essence. As applied in Philonic theology, this results in the following views: (a) God is necessarily immutable; (b) only God is immutable; (c) immutability does not express Gods essence, which in any case remains unknowable to man. (RR)

8759. J. P. Martín, 'La concepcion del hombre en el Judaismo helenista', Oriente-Occidente 8 (1987) 43-59.

Jewish-Hellenistic anthropology is largely Philonic anthropology. In Martín's view Philo gives an ambiguous definition of man: on the one hand dualistic-Platonic and pessimistic - man is a soul imprisoned in the body and on the other hand Stoic-synthetic and optimistic - the supremacy of reason is fully realized in man's existence. This conception provides the foundation of ethics, seen as a road of progress and ascent inspired by the Delphic maxim 'know thyself'. This maxim itself is synthetic in Philo's interpretation: to know oneself is neither purely positive (as in Plato: we must know ourselves as parts of the divine intelligible) nor purely negative (as in the tragedies: we must know our own limitations), but a combination of both aspects: we must recognize ourselves as non-being through which shines the true being of the Cause. (RR)

8760. L. H. Martin, Hellenistic Religions: an Introduction (New York-Oxford 1987), esp. 104-111.

Some pages on Judaism through the eyes of Josephus and Philo in the context of Hellenistic religions, with emphasis on how a strong feminine element (Sophia) came to enter the patriarchal formulations of traditional Judaism. (DTR)

8761. A. M. Mazzanti, 'La creazione dell'uomo in Filone di Alessandria', Studi e Materiali di Storia delle Religioni 53 (1987) 165183.

The lynchpin of Philo's anthropology is the conception of man as $\mu \varepsilon \theta$ ópros (intermediate) between the sensible and the supra-sensible worlds. In its details, however, this conception can be seen to involve various levels and multiple meanings. It involves more than one level because Philo deals with man's intermediate nature from ontological, anthropological, and moral perspectives; and it implies multiple levels because it implies at least two other philosophical concepts: dualism (man is composite by nature) and ontological continuity. According to the latter concept, man is characterized - 
also in his spiritual part - by a lapse of his being from the one and the monad toward more complex and less pure forms. Mazzanti develops these topics by focusing on three Philonic contexts: (1) Opif.; (2) Leg.; (3) other treatises (Det., Plant., Fug.) in which the subject is covered in general terms. (RR)

\section{J. MÉnARd, La gnose de Philon d'Alexandrie, Gnostica (Paris 1987).}

Ménard's book has a circular structure which corresponds to the structure of the Philonic thought which it wishes to elucidate, and is expressed in three related themes: man who is close to God in the creation, man in the cosmos itself, and man who returns to God. Within this general framework the author sets out the main points of Philo's philosophy, with ample references to the texts and an insistence on their relevance to the present day. Under the heading 'Creation of man' the fundamental subjects of theology are ranged: the nature of God, creation, the concept of Logos, man as image, moulded man, etc. The second part ('Man in the world') highlights man's intermediate nature from ontological and moral points of view, while the third part ('The return to God') primarily discusses the way of progress and man's telos in its mystic-religious dimension. In general Ménard attempts to bring out the topical value of Philo's anthropology, starting from the concepts of conscience and freedom (p. 67), and the relevance of his ethics, starting from the recognition of man's inner struggle with the absolute. It is above all here that Philo's importance lies. He succeeds in anticipating and resolving - in mystic and religious terms - the anguish of modern man (181). Reviews: W. Gessel, OrChr 72 (1988) 236; D. Ellul, ETR 64 (1989) 437; G. Pelland, Gr 69 (1988) 792-793; H.-J. Klauck, BZ 33 (1989) 155; R. Williamson, $J T h S 40$ (1989) 602-604; M.J. Pierre, $R B 97$ (1990) 296-301; M. Wüsteney, ThRv 87 (1991) 111-112; J. Riaud, SPhA 7 (1995) 229-230. (RR)

8763. A. Michel, 'La métanoia chez Philon d'Alexandrie: de Platon au judéo-christianisme en passant par Cicéron', Augustinus 32 (1987) 105-120.

The concept of conversion assumes many meanings in classical thought philosophical, ethical, and religious - and it is above all Philo who is able to fuse them into a significant whole. Analyzing De virtutibus, Michel stresses that conversion in Philo is at once intellectual and moral (where it takes the form of repentance) and is incorporated in the framework of an allegorical synthesis of philosophy and religion. In this way the various meanings of the term can all be considered present in the Philonic concept of $\mu \varepsilon \tau \alpha$ vor $\alpha$. But the importance of the philosophical component is also due to the fact that Philo was strongly influenced here by Academic eclecticism, even if the latter has in turn been profoundly rethought. (RR)

8764. L. A. Montes-Peral, Akataleptos theos: der unfaßbare Gott, ALGHJ 16 (Leiden 1987). 
Philo's theology is based on two opposite principles, the transcendence and the immanence of God. It therefore develops in two different directions: one vertical, emphasizing the distance between God and the world, and one horizontal, concerned with the mediation between God and creation (p. 164). The first part of this book (pp. 1-163) is devoted to the former, and analyzes the 'modes' of God's transcendence, viewed mainly in ontological terms and distinguished by the following characteristics: 'only God is true Being', 'only Being is fundamental', 'only Being is the true and one God', 'only Being is eternal, immutable, and perfect'. The following conclusions are reached. God is transcendent not only with regard to creation, but also with regard to man, the superior spiritual realities (e.g. the angels), and his own Powers. In this sense he is the 'wholly other' (cf. p. 3). At this point Montes-Peral raises a fundamental problem: how can Philo proclaim the absolute alterity of God, and yet continually use God as a term of comparison in relation to human nature? The origin of this contradiction is said to lie in Holy Scripture, which presents God as 'a God for man'. But, the author observes, 'Philo is a philosopher and a thinker; on the one hand he therefore views God in his absoluteness, and on the other he views God as "a God for man"' (p. $39 \mathrm{ff}$.). In this way the pure theological unity of the Bible is ruptured, and this also explains the ambivalence of Philo's theological conception. The second part of the work addresses the same problem in different terms: how can the transcendent aspect and the immanent aspect of God be reconciled? The author's answer is that a distinction must be made between God's nature and God's activity (and to the latter must be related the concepts of Logos, Powers, cosmos, and man, which Montes-Peral proceeds to analyze). Only the first is wholly transcendent; the second, on the other hand, is immanent, as is demonstrated first and foremost by the biblical story of creation (p. $204 \mathrm{ff}$.). The monograph is based on a theological dissertation submitted to the University of Munich in 1979. Review: D. Zeller, SPhA 2 (1990) 201-204. (RR)

8765. J. Montserrat i Torrents dels Prats, Las transformaciones del Platonismo, Enrahonar Monografies (Barcelona 1987), esp. $37-51$.

Philo's theological conceptions are primarily interpreted in the light of Platonist theology. He is thus introduced as part of a group of philosophers (Plutarch, Albinus, Numenius etc.) in whom 'the first transcendent principle fades away and only two intelligible principles remain (p. 37)'. The author is in fact convinced that 'the God of Philo corresponds to the intellect of Platonism (p. 44)', while the Logos comes to coincide with the World-soul (p. 47). Nevertheless, Montserrat argues, this affinity with Platonist thought does not carry Philo outside the limits of Jewish orthodoxy (p. 39). (RR)

8766. J. Morris, 'Philo the Jewish Philosopher', in E. Schürer, The History of the Jewish People in the Age of Jesus Christ (175 B.C. A.D. 135), a new English version revised and edited by G. VERMES et al., vol. 3 part 2 (Edinburgh 1987) 809-889. 
From the formal viewpoint this superb contribution is a revision of the extensive account of Philo's life, work and thought first published by Schürer in 1874 and subsequently revised until reaching final shape in 1909 (cf. G-G 593). Morris begins, after a few pages of bibliography, with a brief account of Philo's life and milieu (pp. 813-819). The most valuable section is the lengthy account of Philo's works (pp. 819-870). The transmission of the corpus is discussed, followed by a detailed account of the individual works, first those in the three great series, then the separate treatises, and finally the lost and spurious writings. In each case attention is primarily given to formal and contextual features. This account is an invaluable treasure-house of information. The final section is a briefer and more general presentation of Philo's thought, with emphasis on its theological and philosophical aspects. (DTR)

\section{K.-W. Níbuhr, Gesetz und Paränese: Katechismusartige Weisungsreihen in der frühjüdischen Literatur, WUNT 2.28 (Tübingen 1987), esp. 31-72.}

The author investigates what he calls 'catechism-like summaries of the Law' in Philo's Hypothetica and Josephus' Contra Apionem, and compares these with the maxims of Pseudo-Phocylides in an attempt to give a more precise picture of the generally acknowledged view that these three texts have made independent use of a 'common fund of early Jewish apologetic materials'. Both Philo and Josephus expressly make their 'law epitomes' summaries of the Jewish Law, yet also include ethical material not explicitly named in the Torah. Examining first the Jewish/biblical content in the texts, he concludes that both Philo and Josephus (and similarly Ps.-Phocylides): (1) include central commandments (sexual behavior, parents) as well as peripheral commandments (animal protection); (2) emphasize the 'holiness laws' in their Pentateuch parallels; (3) formulate their version of Torah commandments freely; (4) employ precepts which affect the daily life of the individual, esp. sexual ethics (chiefly from Lev. 18-20); (5) emphasize protection precepts; (6) leave out certain important commandments (circumcision, Sabbath-keeping). The Greek content is included not for the purpose of questioning Mosaic authority but to show agreements between Moses and pagan ethical conceptions. The tendency to combine Torah commandments with generally valid admonitions from pagan-Hellenistic popular philosophy and ethics is already traditional and taken over as such by all three authors. The tendency and Sitz im Leben of the 'Law summaries' in Philo and Josephus are 'to provide help and direction for Jewish behavior in daily life within a non-Jewish environment (p. 70).' (PAG)

8768. J. L. North, 'Lyricarum poetarum optimus: Pindar in Philo of Alexandria', in B. P. Thомpson (ed.), Scripture, Meaning and Method: Essays presented to Anthony Tyrell Hanson for his Seventieth Birthday (Hull 1987) 218-228.

Examines the five certain allusions to Pindar in Philo and also a number of less certain allusions suggested by scholars. 'The extant texts suggest that it 
was an ancient science that could be developed into religious philosophy and a pagan morality that could be prudently deployed against a pagan emperor that Philo found in Pindar.' (DTR)

8769. E. F. Osborn, 'Philo and Clement', Prudentia 19 (1987) 3449.

A provocative and tightly argued article, which attempts to develop further the position of Mondésert and Chadwick that Clement's borrowings from Philo are copious, but generally boring and not of central importance. The achievement of Philo and his predecessors is to create the new language of biblical Hellenism, which Clement gratefully takes over. The chief difference is that Clement engages in philosophical argument, whereas Philo is more like a theosophist who accepts doctrines on authority. Clement wants to offer a logical defence of truth, a quest in which Philo is not interested. (DTR)

8770. J. PÉPIN, Art. 'Logos', in The Encyclopedia of Religion (London-New York 1987) 9.9-15.

Splendid presentation of the doctrine of the Logos at a fairly popular level, of course with frequent reference to Philo and his ideas in the context of Greek philosophy, Hellenistic Judaism and Patristic thought. (DTR)

8771. J. PÉpIN, 'Terminologie exégétique dans les milieux du paganisme grec et du judaisme hellénistique', in AA. vv., $L a$ terminologia esegetica nell'antichità, Quaderni di Vetera Christianorum 20 (Bari 1987) 9-24, esp. 13-17 and 21.

In a discussion of Greek terms (used in the period roughly from Plato to Origen) relevant to the practice and various modes of exegesis, Pépin repeatedly refers to Philo. Formula's which are used where literal and figurative

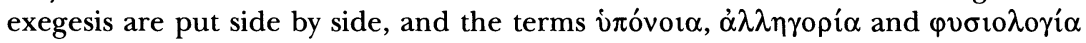
are illustrated by passages from Philo. (HMK)

8772. J. PépIn, La tradition de l'allégorie de Philon d'Alexandrie à Dante: études historiques, Études Augustiniennes 20 (Paris 1987), esp. $7-40$.

Philo was not the inventor of the allegorical method as applied to the Bible, but it was he who brought it to perfection on the basis of an already existing tradition. In his exposition of the basic character of Philonic allegory, Pépin especially draws attention to the benefits that this method offers and on the nature of the relation between literal and allegorical interpretation. With regard to the first point he affirms that allegory enables biblical exegesis to resemble initiation in the mysteries in that it discloses the essential meaning hidden beneath the surface. With regard to the second point three 
signs are indicated which force the exegete to abandon literal interpretation: (1) the presence of terms which demand etymological interpretation; (2) the necessity to resolve certain incongruities in the text; (3) the necessity to penetrate beyond the anthropomorphic language used to describe God in scripture. Reviews: R. Gigliucci, RassLettIt 96 (1992) 208-209; J. Jolivet, RPhilos 117 (1992) 72-73;J. Whitman, Spec 68 (1993) 236-239; A. Solignac, ArPh 58 (1995) 267. (RR)

8773. F. Pérez Ruiz, 'Las “ideas" en San Agustin', Pensiamento 43 (1987) 129-150, esp. 133-136.

The oldest precedent for Augustine's theory of the Ideas as thoughts of God is not found in Plotinus but in Philo's De opificio mundi and Seneca's Ep. 65. But according to the author no direct link can be established between the three philosophers. It is more reasonable to allow that the doctrine originated in the thought of Antiochus of Ascalon. (RR)

8774. M. Petit, 'Exploitations non bibliques des thèmes de Tamar et de Genèse 38: Philon d'Alexandrie; textes et traditions juives jusqu'aux Talmudim', in A $\Lambda \mathrm{E} \Xi \mathrm{AN} \Delta \mathrm{PINA}$ : hellénisme, judaïsme et christianisme à Alexandrie; mélanges offerts au P. Claude Mondésert (Paris 1987) 77-115.

Philo discusses chapter 38 of Genesis and the figure of Tamar in no less than seven works (Leg. 3, Deus, Congr., Fug., Mut., Somn. 2, Virt.). Petit analyses these at length in order to determine the overall interpretation of this figure. She then goes on to compare Philo's exegesis with that of other Jewish authors and reaches the following conclusions. (a) The Jewish exegetical tradition allows considerable freedom in the interpretation of the sacred texts, each commentator choosing aspects and episodes from the biblical story to suit his purposes. (b) Unlike the other Jewish exegetes, Philo uses the tool of etymology to justify his interpretations and (c) radically idealizes Tamar's personage. (d) Philo shows remarkable independence and originality with regard to the Jewish tradition. (RR)

8775. M. Philonenko, 'De l'habitation des deux esprits en Nous', Comptes Rendus de l'Académie des Inscriptions et Belles-lettres 1987, 388-400, esp. 390-393.

A passage in the Hermetic treatise Poimandres mentions a double spirit -

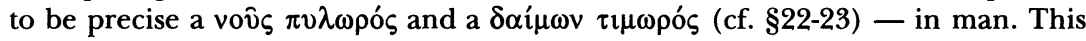
characterization is already found in Philo, as numerous passages testify. Since a direct connection between the two philosophers is to be excluded, it is necessary to consider the existence of an independent common source. (RR)

8776. G. Reale and R. Radice, 'La genesi e la natura della "filosofia mosaica": Struttura, metodo e fondamenti del pensiero 
filosofico e teologico di Filone di Alessandria. Monografia introduttiva ai diciannove trattati del Commentario allegorico alla Bibbia', in C. Kraus Reggiani, R. Radice. and G. Reale, La filosofia mosaica (see 2405) (Milan 1987) vii-cxli.

An introductory monograph that aims to present Philo as he emerges from the works of the Allegorical commentary. Chapter 1 offers a brief status quaestionis of Philonic research. Chapter 2 introduces the subject of allegory with the aid of various illustrative diagrams. Chapters 3, 4, and 5 introduce the doctrines of God and his relation to the world, which together form the keystone of Philonic thought. The subjects dealt with here are: creation, the nature and activity of God, the Powers, and the structure of the divine. The final chapter discusses Philo's anthropology and the foundations of his ethics. Review: J. P. Martín, RFN 82 (1990) 146-165. (RR)

8778. J. Riaud, 'Les Thérapeutes d'Alexandrie dans la tradition et dans la recherche critique jusqu'aux découvertes de Qumran', in W. HaAse (ed.), Aufstieg und Niedergang der römischen Welt II 20.2 (Berlin 1987) 1189-1295.

The author discusses the problem of the cultural and religious identity of the Therapeutae, both by directly analyzing Philo's $D e$ vita contemplativa and by considering the vast body of critical literature on the subject. This literature is dealt with in four chapters, each in relation to a different hermeneutical theory: (a) the Therapeutae as embodying an ascetic ideal; (b) as forming one of the first Christian communities, or (c) a sect strictly connected with the Essenes, or (d) a sect of Israelites in Egypt. In each of these chapters Riaud collects, orders, and critically assesses a large quantity of important bibliographical material. Review: see 1408. (DTR)

8779. C. Riedweg, Mysterienterminologie bei Platon, Philon und Klemens von Alexandrien, UALG 26 (Berlin-New York 1987), esp. 70115.

Riedweg carefully analyzes Philonic passages in which the terminology of the mysteries occurs (esp. Cher. 40-50, Gig. 54-57, Somn. 1.164-165, Spec. 1.319323, Leg. 3.100), briefly digresses (pp. 92-96) on Pascher's and Goodenough's well-known views on the subject, and offers a critical lexical analysis which specifically looks at Philo's use of the two terms $\mu v \sigma \tau \eta \dot{p} \rho$ เov and $\tau \varepsilon \lambda \varepsilon \tau \eta$ and their derivatives (pp. 108-115). The following conclusions are finally reached. (a) There are two uses of the terminology in Philo: one strictly esoteric, which Philo attacks, and another profane-metaphorical, open to the noninitiated. (b) Between these two poles there are two other levels, not always clearly defined, of which the first goes back to the terminology of Platonic mysteries and the other refers directly to the Bible, even if in an essentially non-Jewish allegorical form. (c) It is impossible to demonstrate from these premises that Hellenistic mysteries genuinely existed; rather it seems that Philo put the phraseology to rhetorical purposes, in order to infuse solemnity 
and profundity into his language. Reviews: O. Kaiser, ZAW 99 (1987) 471472; H.-J. Klauck, WW 50 (1987) 217-218; B. Amata, Sales 50 (1988) 585-586; H. Chadwick, CR 38 (1988) 164; B. Sesbo; RSR 76 (1988) 584-585; B. Chiesa, Ath 77 (1989) 340-341; J. Frickel, JbAC 32 (1989) 188-190; J. Kerschensteiner, AAHG 42 (1989) 159-162; E. des Places, RBPh 6 (1989) 190; D. Zeller, SPhA 2 (1990) 214 217; D. Wyrwa, ZKG 103 (1992) 112-116; R. Bodeus, EtCl 61 (1993) 77. (RR)

8780. M.-J. Rondeau, 'Pragmatologeîn: pour éclairer Philon, Fug. 54, Somn I, 230', in A $\Lambda \mathrm{E} \Xi \mathrm{AN} \Delta \mathrm{PINA}$ : hellénisme, judaïsme et christianisme à Alexandrie; mélanges offerts au P. Claude Mondésert (Paris 1987) 117-150.

The rare Greek verb $\pi \rho \alpha \gamma \mu \alpha \tau o \lambda \circ \gamma \varepsilon \hat{v} v$ derives from the technical vocabulary of rhetoric and in particular legal rhetoric, where it refers to that part of a trial in which the real facts of a case were expounded. Philo transfers this connotation of objectivity to Scripture, which is opposed not only to rhetoric (since the latter lacks a formal purpose), but even more to sophistry, on account of the latter's ambiguous and relativizing characterization of language. The overall meaning of the term thus remains connected with its original use, but now with reference to the profound meaning of Revelation. (RR)

8781. D. T. Runia, 'Further Observations on the Structure of Philo's Allegorical treatises', Vigiliae Christianae 41 (1987) 105-138; reprinted as study $\mathrm{V}$ in $\mathbf{9 0 5 9}$.

The article is a continuation of research on the structure of Philo's allegorical treatises started in $R-R$ 8447. Starting point this time is a status quaestionis, discussing the contibutions of Nikiprowetzky, Borgen \& Skarsten, Hamerton-Kelly, Cazeaux, Mack, and Radice. This leads to the summary of various points of agreement and disagreement. A comparison is then made with structures found in the Anonymous Theaetetus Commentary, Porphyry's De antro nympharum and Palestinian Midrash. These illuminate but do not explain Philo's method. Finally two further questions are discussed, primarily with reference to the double treatise Gig.-Deus: (1) the extent to which Philo uses fixed structural procedures in his composition; (2) the extent to which he attempts to impose a unity or coherence on his literary compositions. It is concluded that Philo's treatises generally have a main directive idea (Radice's term), but that they possess at most a loose kind of unity. (DTR)

8782. K.-G. SANDELIN, 'The Johannine writings within the Setting of their Cultural History', in L. Hartmann and B. Olsson (edd.), Aspects on the Johannine Literature, Coniectanea Biblica: New Testament Series 18 (Uppsala 1987) 9-26.

Observations on the theme of Wisdom as nourisher show that Diaspora Judaism, including Philo, was an active element in the historical setting of the Gospel of John. The argument is more fully developed in Sandelin's 1986 monograph. (DTR) 
8783. G. Scarpat, 'La morte seconda e la duplice morte dalla Sapientia a S. Francesco', Paideia 42 (1987) 55-62, esp. 57-60.

Philo, perhaps developing Posidonian motifs, refers more than once to the notion of the twofold death, physical and moral. Scarpat believes that this is an originally secular motif (Stoic) and notes the following difference from the corresponding Jewish conceptions (cf. Rev. 2:10-11): for late Judaism, true death strikes the sinner only at the Last Judgement, whereas for Philo it already strikes the sinner in this world, when he still appears to be alive. (RR)

8784. J. Schamps, Photios historien des lettres: la Bibliothèque et ses notices biographiques, Bibliothèque de la Faculté de Philosophie et Lettres de l'Université de Liège 248 (Paris 1987), esp. 460-469.

Analysis of the notice on Philo in Photius' Bibliotheca cod. 103-105, in which it is compared with the earlier notices of Sophronius (based on Jerome) and the Epitome of Hesychius (found in the Souda). Photius is not directly dependent on the prior notices, but has taken over material from an editor who had adapted them for the specific purpose of introducing Flacc. and Leg. (DTR)

8785. T. E. Schmidt, Hostility to Wealth in the Synoptic Gospels, JSNT.S 15 (Sheffield 1987), esp. 76-84, 191-195.

A well-documented presentation of Philo's attitude to wealth, reiterating and responding to earlier discussions (cf. R-R 7833, 8365, 8518, 8518). Philo is the example par excellence of hostility towards wealth which is caused by an aristocratic background. He in fact shows very little sympathy for the underprivileged position of many members of the Jewish community of Alexandria. (DTR)

8786. R. Schmitt, 'Ist Philo, Vita Moysis (Mos) II 251 ein Peristasenkatalog?’, Novum Testamentum 29 (1987) 177-182.

A stylistic analysis of Mos. 2.251, which is compared with similar passages in Philo and Paul. The author's aim is to define the stylistic formula of the 'peristasis catalogue' (catalogue of adversities). This type of catalogue is said to be an 'enumeration of almost exclusively negative decrees of fate, dangers, sufferings, difficulties, and also physical obstacles' with which certain persons find themselves confronted (p. $181 \mathrm{f}$.). (RR)

8787. E. Schürer, The History of the Jewish People in the Age of Jesus Christ (175 B.C. - A.D. 135), a new English version revised and edited by G. Vermes et al., vol. 3 part 2 (Edinburgh 1987) 809-889.

See above under J. Morris: 8766. Review (vols. 1-3): J. R. Royse, SPhA 4 (1992) 137-140. 
8788. O. SchwankL, Die Sadduzäerfrage (Mk 12, 18-27 parr): eine exegetisch-theologische Studie zur Auferstehungserwartung, BBB 66 (Frankfurt 1987), esp. 268-271.

Schwankl holds that there is no room in Philo's thought for the concept of resurrection. The reason for this lies in his philosophical conception of human nature and death, a conception strongly influenced by Greek thought. In his kind of dualistic anthropology a rebirth of the body would have a negative rather than positive significance. (RR)

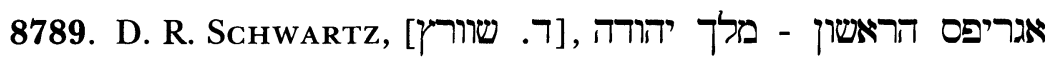
האחרון [Agrippa I - The Last King of Judaa] (Jerusalem 1987), esp. 85100, 111-119, 209-214.

In the first comprehensive study of this historical figure, the author devotes detailed attention to Philo's reliability as an historian of contemporary events. In opposition to recent studies (Smallwood, Kasher), Schwartz questions whether an author 'generally devoted to questions of philosophic truth, and whose principal approach to Scripture is one of allegory, will be a trustworthy source for history "as it was" or rather for history "as it should have been"' (p. 86, n.37). (DS)

8790. A. F. SEGAL, The Other Judaisms of Antiquity, BJS 127 (Atlanta 1987).

Contains an essay entitled 'Dualism in Judaism, Christianity, and Gnosticism: a definitive issue', which summarizes the main theses of R-R 7741 (Philo treated at 8-11), and reprints other articles (including R-R 8451 at 131146). (DTR)

8791. B. Septimus, 'Biblical Religion and Political Rationality in Simone Luzzatto, Maimonides and Spinoza', in I. Twersky and B. Septimus (edd.), Jewish Thought in the Seventeenth Century (Cambridge Mass. 1987) 399-433, esp. 419-421

Isolated but interesting remarks on the 17th century Venetian Jew Simon Luzzatto's attitude to Philo. If only Philo had educated contemporary Jews instead of writing for the Greeks, rationality would not have been such a problem for Judaism. (DTR)

8792. P. J. Sijpestein, K. A. Worp, ' $\Delta \alpha \sigma \varphi \varepsilon \tau \varepsilon p i \zeta{ }^{\prime} \mu \alpha \mathrm{l}$ ', Mnemosyne 40 (1987) 413.

The papyrus $\mathrm{P}$. Lond. inv. 2222 sheds light on a disputed reading in Mos. 1.313. (DTR) 
8793. M. Simon, 'Philons Philosophie als Modellfall für das mittelalterliche Problem des Verhältnisses von Glauben und Wissen', in G. WENDEL (ed.), Beiträge zu Wissenschaftsgeschichte: Wissenschaft in Mittelalter und Renaissance (Berlin 1987) 79-93.

The title of this paper, written at a high level of generality and without any annotation, does not cover its contents very well, because only a small part of the article actually concerns Philo, and his relation to Medieval philosophy is only superfically explored. Philo is important because he, in the situation of Hellenistic Judaism, first raises the problem of the relation between faith and knowledge in an acute form. His problem is passed on to both Arabic and Jewish philosophers through the intermediation of Neoplatonism. (DTR)

8794. O. Skarsaune, The Proof from Prophecy: a Study in Justin Martyr's Proof-text Tradition; Text-type, Provenance, Theological Profile, NT.S 56 (Leiden 1987) passim.

The aim of this massive and painstaking study is to investigate the background of Justin's use of OT texts. Philonic material that illuminates exegetical themes is invoked at regular intervals (cf. p. 46, 311, 324, 339, 341, $353,369)$. There is relatively little overlap between the two authors, however, except in the important subject of the OT theophanies, which the author discusses at some length. His conclusion is (423): 'If there is any influence from Philo on Justin's treatment of the theophanies, it is at best distant, and mainly operative in some general modes of argument rather than in concrete exegesis of texts. In the latter respect, Justin exhibits a marked independence of Philo, often directly contradicting or ignoring Philonic exegesis.' On the other hand, in his general conclusion Skarsaune underlines the importance of Jewish apologetic for an understanding of Justin, making the following (somewhat surprising) claim in relation to Goodenough's famous study, The Theology of Justin Martyr (Jena 1923) (433): 'The present study has made me believe that Goodenough was basically right: Justin is heir of much of the apologetic tradition of Hellenistic Judaism, except that Goodenough unduly took Hellenistic Judaism to mean Philo.' (DTR)

8795. R. SkARsten, Forfatterproblemet ved De aeternitate mundi $i$ Corpus Philonicum [In Norwegian: The Problem concerning the Authorship of De Aeternitate Mundi in Corpus Philonicum] (diss. Bergen 1987).

This dissertation has three main chapters discussing (I) the scholarly debate concerning De Aeternitate mundi, (II) its language and style and (III) the relationship between the treatise and other texts written by Philo and other Hellenistic authors. Different solutions of the problem announced in the title are investigated. The author concludes that the book is not written by Philo. A specific stylistic trait, a pattern of word-order called interlacing, is typical of the tractate Aet. as a whole. This excludes Philonic authorship but it 
also shows that the book is a unity and not a compilation from different sources. The numerous references to and citations of well-known philosophers in antiquity is a literary device used by the author to promote his own message. In his interpretation of Gen 1:1f. Philo in Opif. projects the creation of the Platonic world of ideas into the Biblical text, whereas such an interpretation is not to be found in Aet., in which a pantheistic worldview is dominant. The epistemological environment of the author of Aet. is demonstrated through a comparison with Pseudo-Okellos and Pseudo-Aristotle. The author of Aet. is localized to Cilicia in Asia Minor. (KGS; based upon the author's summary)

8796. E. M. Smallwood, 'Philo and Josephus as Historians of the Same Events', in L. H. Feldman and G. Hata (edd.), Josephus, Judaism, and Christianity (Detroit 1987) 114-129.

The main event allowing comparison is Gaius' attack on the temple described by both Philo and Josephus. It is clear that Josephus had no knowledge of Philo's account. On the basis of her comparison the author concludes (p. 127): 'Philo's narratives have a greater sense of immediacy than those of Josephus, but in the critical comparison attempted here of the two authors' versions of the only story given by both in full it has been argued that Philo emerges as the writer with the greater historical credibility. If that conclusion is correct, we can accept his evidence on matters for which Josephus provides no parallel with a fair degree of confidence.' (DTR)

8797. C. SpIcQ, 'L'Épître aux Hébreux et Philon: un cas d'insertion de la littérature dans la culture profane du Ier siècle (Hebr. V,11 - VI,20 et le "De sacrificiis Abelis et Caini" de Philon', in W. HAASE (ed.), Aufstieg und Niedergang der römischen Welt II 25.4 (Berlin-New York 1987) 3602-18.

The analysis concentrates on the similarities between Hebr. 5:11-6:20 and Sacr. These show not so much a direct relationship between Philo and the author of Hebrews as 'the unity of Hellenistic civilization and more exactly the similarity between the scale of values of the secular culture and of the new religious world' (p. 3618). (RR)

8798. E. Starobinski-Safran, 'La communauté juive d'Alexandrie à l'époque de Philon', in A $\Lambda$ E $\Xi A N \triangle P I N A$ : hellénisme, judaïsme et christianisme à Alexandrie; mélanges offerts au P. Claude Mondésert (Paris 1987) 45-75.

Starobinski-Safran reconstructs here the features of Alexandria's Jewish community, seen mainly from a legal, political and social perspective. Flacc. and Legat., two of her sources, provide important information on the number and distribution of the Jews in Alexandria (at least two of the town's five quarters were largely populated by Jews), on their social status (some 
families, like Philo's, were particularly influential), and on their economic activities (Philo mentions at least five social categories among the Jews in Alexandria: bankers, ship-owners, merchants, artisans, farmers). (RR)

8799. C. Thомаs, Jesus the New Moses: a Christological Understanding of the Fourth Gospel (diss. Lutheran School of Theology, Chicago 1987).

The author argues that the Fourth evangelist uses Jewish, Hellenistic and Samaritan understandings of Moses in order to interpret the person of Jesus. The concept of Moses is traced through the writings of Palestinian and Hellenistic Judaism, including Philo, as a prelude to exegesis of relevant passages in the Fourth gospel. Jesus is thus seen as the fulfilment of Jewish, Hellenistic and Samaritan Mosaic expectation. (DTR; based on DA 48-1232).

87100. H. DE VRIES, 'Philosophia ancilla theologiae bij Philo: over de verhouding tussen de cyclus van propedeutische disci-

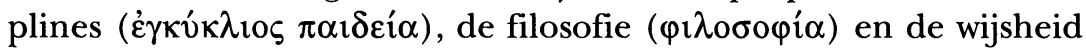
( $\left.\sigma \circ \varphi i^{\prime} \alpha\right)$ in Philo's traktaat De congressu eruditionis gratia', Stoicheia (Amsterdam) 2.3 (1987) 27-52.

A competent analysis of the contents of Philo's treatise, preceded by some general remarks on the relation between propaedeutic studies, philosophy and wisdom and on the scholarly differences of opinion on the way Philo

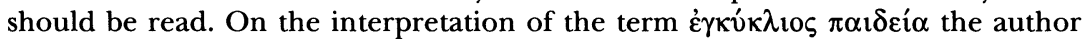
follows the theory of De Rijk (cf. R-R 6523). The articles ends with some general conclusions. In spite of wavering terminology it is possible to find a consistent point of view in Philo's allegories. In Philo we do not find a gradual intellectual progression of the mind, but rather a mystical-religious elevation of the soul. Although allegory cannot be considered a legitimate method of exegesis, from the viewpoint of theological hermeneutics it can retain some value. As Gadamer saw, allegory and symbol have in common that they indicate what happens in religious utterance, namely that existing language is used to say something about that which is on yonder side of earthly existence. (DTR)

87101. A. J. M. Wedderburn, Baptism and Resurrection: Studies in Pauline Theology against its Graeco-Roman Background, WUNT 44 (Tübingen 1987), esp. 153ff., 281ff. and passim.

The author's aim is to examine the question, raised by Romans 6 in conjunction with 1 Cor. 15, of whether Paul's language of 'dying and rising with Christ' needs to be read against the background of Hellenistic mystery religions. Philo supplies valuable evidence on the language of mysteries ( $p$. 153ff.) and the connection between Wisdom and the divine spirit (p. 281ff.). It is striking, the author claims, that the early Christians did not, like Philo, present their faith as a counter-mystery. (DTR) 
87102. J. Whitman, Allegory: the Dynamics of an Ancient and Medieval Technique (Oxford 1987), esp. 61f.

One would not think it possible that a general study could be written on the subject of allegory with so little reference to the Philonic contribution. (DTR)

87103. R. D. Williams, Arius: Heresy and Tradition (London 1987), esp. 117-124 and passim.

A compact but powerful presentation of the Philonic contribution to the background of the thought of Arius. What Wolfson thought to be their common ground - the doctrine of the double transcendent Logos - is argued to be their main point of difference, i.e. for Philo the Logos is not individually subsistent as in Arius. Williams concludes that 'Philo mapped out the ground for the Alexandrian theological tradition to build on, and that Arius' theological problematic is firmly within that tradition (123).' (DTR)

87104. R. McL. Wilson, Hebrews, The New Century Bible Commentary (Grand Rapids-Basingstoke 1987).

In a section on Philo (pp. 22-24), part of the introduction to the commentary, Wilson reviews the positions taken by various scholars (Williamson, Spicq, Sowers and others) with regard to Philonic influence on the Epistle to the Hebrews. His conclusion is that 'we may be stuck by the similarities, and even misled into thinking the relationship closer than it actually was. When we take note also of the differences, and bring other factors into the reckoning, other documents which use the same ideas but in different ways, the picture becomes very different; more complicated perhaps, but probably nearer to the truth' (27). The similarities and differences between Philo and Hebrews are amply discussed in the commentary. (HMK)

87105. D. Winston, Art. 'Philo', in The Encyclopedia of Religion (London-New York 1987) 11.287-290.

A general presentation of Philo's life and thought, with some reference to secondary literature. (DTR)

87106. D. Zeller, 'Das Verhältnis der alexandrinischen Juden zu Ägypten', in M. Pye and R. STEgerhoff (edd.), Religion in fremder Kultur: Religion als Minderheit in Europa und Asien, Schriften zur internationalen Kultur und Geisteswelt 2 (Saarbrücken 1987) 77-85.

Philo's attitude to Egyptian civilization is ambivalent, moving from one extreme to the other. In Spec. 1.2 the Egyptians and their culture are held in high esteem, but usually they are described in negative terms, even if it is conceded that they may redeem themselves in the future. (RR) 


\section{8}

8801. Manuel Alexandre JR., 'Un caso típico de encomio como técnica de amplificação em Fílon de Alexandria', Euphrosyne 16 (1988) 281-288.

The impassioned eulogy of toil in Sacr. 35-41 is a typical illustration of the encomium as an exercise in epideictic oratory: a rhetorical structure including essentally four main topics, besides proemium and epilogue, in accordance with the literary conventions of the day. Formal structures such as this, inculcated by the educational system in the formative stages of Philo's literary experience, are freely and creatively used as a generally accepted norm for coordinating the argumentative logic of amplifying digressions and for composing literary units, such as the one studied here. (RR; based on author's own English summary)

8802. Monique Alexandre, Le commencement du livre Genèse I-V: la version grecque de la Septante et sa réception, Christianisme Antique 3 (Paris 1988) passim.

In giving a commentary on Gen. 1-5, Alexandre analyses the linguistic and historical aspects of the Septuagint text in comparison to the Masoretic text and other Greek translations, as well as the various traditions of exegesis that have been developed in response to this seminal text. Among these various interpretations she pays particular attention to that of Alexandrian Judaism, being the source closest to the original and a major influence on the Christian tradition (cf. p. 9). Philo is thus frequently referred to, but these references are not so easy to locate, since regrettably the indexing of the book is minimal. ( $R R$ )

8803. Y. Amir, 'Authority and Interpretation of Scripture in the Writings of Philo', in M. J. Mulder and H. Sysling (edd.), Mikra: Text, Translation, Reading, and Interpretation of the Hebrew Bible in Ancient Judaism and Early Christianity, CRINT II.1 (Assen 1988) 421-454.

A thoroughly competent introduction to the manner in which Philo regards and interprets Scripture. The main concentration of the article is on four points. (1) The differing kinds of interpretation given by Philo in his various kinds of works. (2) The authority of Mikra, i.e. Scripture. Here the authority that Philo invests in Moses as receiver of the divine oracles seems strange to those versed in the writings of the Rabbis. 'Divine inspiration stands behind human thought, but does not replace it (p. 438).' (3) The authority of the Greek text. Amir emphasizes that Philo is the only interpreter in the 2000 year history of Jewish exegesis whose hermeneutics were not based on the Hebrew (i.e. Masoretic) text, and this makes him a problematic figure. (4) Philo's battle on two fronts, i.e. the defence of his conviction that 
the Bible should be interpreted at both the literal and allegorical level. But, Amir concludes, even in exalted moments when the interpreter is 'godpossessed' (Cher. 27), 'Philo feels his allegorical interpretation to be bound by a strict discipline which leaves no room for what is merely arbitrary and subjective (p. 425).' (DTR)

8804. R. T. BескWIтH, 'The Vegetarianism of the Therapeutae, and the Motives for Vegetarianism in Early Jewish and Christian Circles', Revue de Qumran 13 (1988) 407-410.

Although the eating of flesh has always been normal practice among Jews and Christians, vegetarianism has been practised by particular groups, including the Therapeutae. The author suggests five situations in which vegetarianism was practised: (1) Precaution in an idolatrous environment. (2) Asceticism: the abstention by the Therapeutae (Contempl. 37, 73-74) from meat and wine may be connected with a rejection of the Temple cult and its sacred meals. If this is so, it may also be the beginning of a complete spiritualization of the sacrificial law. (3) Non-violence: Philo's suggestion that temperance and self-control are best attained by abstaining from meat (Prov. 2.69-70) may be non-Jewish in origin. (4) Mourning for the Destruction of the Temple. (5) As a sign of hostility to the Temple cult (Ebionites). (PAC)

8805. H. BeIKIRCHER, 'Beiträge aus der Thesaurus-Arbeit XXIV: participium /participatio (zu Philo Quaest. in Gen. 4,195,6 p. 68)', Museum Helveticum 45 (1988) 121-124.

The Deacon Rusticus, revising the early translation of the Acts of the Council of Ephesus, substituted the phrase sine participatione for sine participio. Beikircher notes that the same term participium (in the sense of participation) appears in a variant of the Latin translation of $Q G$ and rules out the possibility of a corrector's intervention. (RR)

8806. P. J. BEKKen, 'Apropos jødedommens mangfold i det fønste ærkunre: observasjoner til debatten om jødisk kultus hos Filo, i Acta og Johannisevangelis' [in Norwegian = 'On the Variety of Judaism in the First Century: Observations on the Debate on Jewish Cult in Philo, Acts and the Gospel of John'/'La diversité du judaïsme au premier siècle: observations sur le débat sur le culte juif chez Philon, dans les Actes et dans l'Évangile de Jean'], Tidsskrift for Teologi og Kirke 59 (1988) 161-173.

The Judaism in the first century CE was diverse. The topic of this essay is an analysis of various practices and views on temple and sabbath which existed in the Alexandrian Jewish community reflected in Philo's writings. Moreover, an examination of the debate and conflicts on temple and sabbath among Jews in Alexandria may throw light upon similar debates and conflicts reflected in Acts and the Gospel of John. Accordingly, this essay 
illustrates how debate and conflicts reflected in Philo's writings can throw light upon aspects of the New Testament, just as the New Testament can illuminate aspects of Philo's writings. (KGS, based on author's abstract)

8807. E. BEN ZwI, 'The Authority of 1-2 Chronicles in the Late Second Temple Period', Journal for the Study of the Pseudepigrapha 3 (1988) 59-88, esp. 71-72.

The author compares the authoritativeness of 1-2 Chron. by examining its use in the literature of the Late Second Temple Period. Philo quotes the biblical account of the monarchic period very infrequently, and there is no solid evidence that he does so from 1-2 Chron., implying that he paid little attention to it. (PAC)

8808. R. M. Berchmann, 'Arcana Mundi: Prophecy and Divination in the Vita Mosis of Philo of Alexandria', in D. J. LuLL (ed.), Society of Biblical Literature 1988 Seminar Papers, SBLSPS 27 (Atlanta 1988) 385-423.

This wide-ranging and learned article falls into two parts. In the first the author examines the classical and hellenistic background to ideas on prophecy and divination in Philo. Not only philosophical, but also literary and medical sources are taken into account. In the second part the views on prophecy and divination that Philo puts forward in his De vita Moysis are examined. Berchmann concludes that Philo is largely indebted to Stoic and Platonic ideas, which lead him explicitly to reject the association of prophecy with irrationality or with psychic or somatic pathology. Moreover such ideas are exploited in order to prove the divine origin and noetic character of specifically Jewish prophecy, which is in his view demonstrably superior to Greek and barbarian varieties of the same. (DTR)

8809. O. Betz, 'Die Bileamtradition und die biblische Lehre von der Inspiration', in M. Görg (ed.), Religion im Erbe Ägyptens. Beiträge zur spätantiken Religionsgeschichte zu Ehren von Alexander Böhlig, Ägypten und Altes Testament. Studien zu Geschichte, Kultur und Religion Ägyptens und des Alten Testaments 14 (Wiesbaden 1988) 18-53, esp. 26-31.

Starting from the views of $\mathrm{H}$. Windisch, Betz examines the parallels between the second letter of Peter (2 Pet. 1:19-21, 2:15f.) and Philo (esp. Mos. 1.263-300) with regard to the figure of Balaam. Balaam poses difficult problems of interpretation from an allegorical point of view inasmuch as the Bible presents him as being gifted with prophetic powers, whereas Philo (taking his cue from other scriptural evidence on Balaam) describes him in morally negative terms and as an enemy of Israel. Since all prophets are for Philo divine and therefore holy men (Moses being the prototype of these), the figure of Balaam assumes a contradictory significance. However, it would 
seem that Philo succeeds in resolving this problem by demonstrating in the case of Balaam the difference between true prophecy inspired by God and the pagan practice of divination and magic of which Balaam is ultimately the model (RR)

\section{E. J. Bickerman, The Jews in the Greek Age (Cambridge Mass.-London 1988).}

Copious use of Philo as evidence for Jewish history, mainly for the period 333 to 175 BCE. Though immensely learned, the posthumously published book is regrettably without annotation. (DTR)

\section{H. BURKHARDT, Die Inspiration heiliger Schriften bei Philo von Alexandrien (Giessen-Basel 1988).}

As the author notes in the conclusion of his book (p. 221), the church tradition's concept of inspiration is to a large degree based on that of Philo. The consensus of Philonic research in the last two centuries (cf. pp. 1-49) is that Philo was strongly influenced in this regard by the religion of the Greek mysteries and by various philosophical conceptions (mainly Platonic and Middle Stoic; cf. p. 218ff.). Thus Philo, like the Greeks, is thought to regard inspiration as a complete annulment of the personality of the prophet, reduced to a pure vehicle of God's word and a pure instrument of his will. Burkhardt, however, following up leads in other interpreters, holds that this is an inadequate view for a number of reasons. (1) It is based on a few isolated passages that can be set against a large number of other passages in which the inspired author is said to be engaged in an 'effective collaboration' with God. (2) The passages which seem to refer to a cancellation of human reason should rather be interpreted as expressing the effort of transcending human reason. In this sense Philo can be regarded as anticipating what would later be called the concept of personal inspiration. (3) For Philo the essence of inspiration is the divine gift of wisdom (cf. p. 211ff.), which allows the Bible to be interpreted correctly and which requires the prophet to be totally and consciously open to the biblical revelation. This is not to say, Burkhardt concludes, that Philo's own conception of biblical inspiration leads to a better understanding of the biblical record, for his customary philosophicalallegorical interpretation completely ignores the Bible's historical dimension. Reviews: H. C. Schmitt, ZAW 101 (1989) 311; M. Wüstemey, ThBtr 20 (1989) 208-210; W. Horbury, VT 40 (1990) 503-504; J. Maier, ThRv 86 (1990) 197f.; H. M. Schenke, ThLZ 115 (1990) 444-445; F. Siegert, SPhA 2 (1990) 204 208; K. Limburg, ScrTh 24 (1992) 338; G. E. Sterling, RelStR 21 (1995) 342. (RR)

8812. P. R. Callaway, The History of the Qumran Community: an Investigation, JSOT.S 3 (Sheffield 1988) esp. 65-76, 201-202.

Philo's information on the Essenes is generally consistent with that of Josephus, but he is of no direct assistance in answering specific questions about Qumran or Essene history, his interest being primarily philosophical. (DTR) 
8813. J. Calleja, Gn 1,26s. nelle Omilie di Origene e nel Commentario in Genesim di Didimo il Cieco, Melita Theologica 39 (1988) 91-102.

It is clear that, with regard to the creation of man in God's image in Gen. 1:26f., Origen in his Homiliae in Genesim and Didymus the Blind in his Genesis Commentary borrowed from Philo (above all from the De opificio mundi) 'words, attitudes, and a view of life and truth' (p. 102). In this sense, concludes Calleja, after highlighting the main parallels between the three philosophers, Philo can truly be said to have mapped out a route for the Christian tradition. (RR)

8814. P. Carny, 'Philo's Uniqueness and Particularity', in B. UfFenheimer and H. Graf Reventlow (edd.), Creative Biblical Exegesis: Christian and Jewish Hermeneutics through the Centuries, JSOT.S 59 (Sheffield 1988) 31-38.

According to the author three major trends have emerged in Philonic studies during the last hundred years: the attempts to find connections between (1) Philo's exegesis and Greek-Hellenistic allegory of myths, (2) Philo and Palestinian Midrash, (3) Philo's allegory and patristic hermeneutics. These approaches have led to Philo being regarded as either Greek, Rabbinic, or even proto-Christian. Against this, Philo's real uniqueness can be seen in three areas: (1) Philo's attitude toward the literal meaning of scripture: Torah is not 'Revelation' but an absolute standard written in mythological language by Moses, a divinely inspired human author and the greatest of all philosophers. (2) Philo's conception of the Ideas: they are ontological creatures, paradigms of earthly creatures, existing with God in the intelligible world. (3) Philonic typology (as opposed to Christian typology), which is hierarchical and static: God, Logos, and the concrete world exist in descending order of excellence, with each term as the type of what precedes it and the archetype of what follows it. (PAC)

8815. J. Cazeaux, 'Etre juif et parler grec: l'allegorie de Philon', in E. DUPUY et al. (edd.), Juifs et chrétiens: un vis-à-vis permanent, Publications des Facultés Universitaires Saint-Louis 42 (Brussels 1988) 67-109; reprinted as 9624.

Originally a lecture, the article is to be read as a brief introduction to Philonism, or rather to the rigorous and symmetrical structure which Cazeaux sees reflected in Philo's allegorical interpretation. This structure, according to the author (p. 70), originally has two poles: the letter, i.e. the means of expression, and the aims of the text, that is to say its soul. Cazeaux also illustrates other elements (encoding, postulates, systems of transformation on various levels) of the allegorical interpretation, using significant examples to show these principles in action. (RR) 
8816. J. Cazeaux, Art. 'Sagesse II: La sagesse selon Philon d'Alexandrie', Dictionnaire de Spiritualité Ascetique et Mystique, Doctrine et Histoire 14 (1988) 81-91.

Reviews the principal meanings of the term 'wisdom' in Philo as well as the many allegorical metaphors used to express it. These meanings can be summed up under two headings: (a) wisdom understood as knowledge which God shares with man (p. 82f.) and Wisdom considered from a theological and religious perspective as the expression of a transcendent and divine reality (p. 83ff.). The same concept of wisdom is also regarded as the goal of Abraham's spiritual migration (p. 87ff.), i.e. as the crown of philosophy. (RR)

8817. A. Ceresa-Gastaldo (ed. and trans.), Gerolamo Gli Uomini Illustri, Biblioteca Patristica 12 (Florence 1988), esp. 98-99, 257-259.

Chapter 11 of the De viris illustribus is devoted to Philo. Jerome regarded Philo, through his De vita contemplativa, as a reliable source on the life of the early churches (cf. also 8.4, 13.2). Pp. 257-259 contain comments on salient points of Jerome's account. (RR)

8818. B. D. Chilton, 'Commentary on the Old Testament (with particular reference to the pasharim, Philo, and the Mekilta)', in D. A. Carson and H. G. M. Williamson (edd.), It is Written: Scripture citing Scripture; Essays in Honour of Barnabas Lindars (Cambridge 1988) 122-140, esp. 127-133.

Chilton's assignment in the Festschrift is a description of the use of Scripture in three 'genres' of biblical (OT) interpretation, namely pesher (chiefly $1 \mathrm{QpHab}$ ), Philo's allegory and Mekilta (midrash). He concludes that although 'superficially disparate' there are similarities between these three 'genres': (1) 'explicit recourse to Scripture' as the 'structural point of departure'; (2) 'a positive correlation between... the principles of exegesis, the purposes of exegesis, and the programme of collecting and arranging exegeses' (citing Neusner). The difference among the 'genres' for Chilton 'is less a matter of precise method of approach than of what Scripture is essentially taken to be. Scripture is the ciphered account of the end in the pesharim; it is the soul's map toward union with God for Philo; it is Israel's covenant of survival in the Mekilta (p. 138).' (PAC)

8818a. E. Dassmann et al. (edd.), Reallexikon für Antike und Christentum, Band XIV (Stuttgart 1988).

The principles on which our report of this work is based are set out at R-R 5016. W. Beierwaltes, art. 'Hen (๕̌v)', 445-472, esp. 460-1 (the One, unity); E. Dassmann, art. 'Hesechiel', 1132-91, esp. 1145; A. Dihle, art. 'Heilig', 1-63, esp. 33-35 (holy); R. Klein, art. 'Hellenen', 375-445, esp. 417-8 (Greeks); J. Ṕ́PIN, art. 'Hermeneutik' 722-71, esp. 728-9 (Hermeneutics); U. Wilckens, 
art. 'Heuchelei', 1205-31, esp. 1214-5 (hypocrisy); J. C. M. van Winden, art. 'Hexaemeron', 1250-69, esp. 1256-8 (six days of creation). (DTR)

8819. G. Dautzenberg, 'Mt 5,43c und die antike Tradition von der jüdischen Misanthropie', in L. Schenke (ed.), Studien zum Matthaüsevangelium: Festschrift für Wilhelm Pesch (Stuttgart 1988) 4777, esp. 68-77.

Matt. 5:43, "You have heard that it was said, "You shall love your neighbour and hate your enemy"' provides an example of the misanthropy with which Jews were often charged in antiquity. Among the various Jewish authors who attempted to defend the Jews against this accusation, Philo occupies a prominent position. Virt. 51-168, his main defence, is accurately analyzed by Dautzenberg and compared with an analogous apology in Josephus (C. Ap. 2.206-214; cf. pp. 74ff.). (RR)

8820. J. D. Dawson, Ancient Alexandrian Interpretation of Scripture (diss. Yale University 1988).

'Using philological, historical and literary critical methods, this study describes and analyses various modes of interpreting scripture in ancient Alexandria', focussing on Aristeas, Aristobulus, Philo (chapters 4-6), Clement and Valentinus. The task of allegory for Philo is to redefine classical wisdom, and it enables him to offer a reinterpretation of his social and political world. In his conclusion the author suggests that the various Alexandrian modes of allegorical reading of scripture 'may be understood as diverse attempts to reinterpret the world through the reading of scripture'. Cf. 9222. (DTR; based on DA 50/05-A p.1333)

8821. F. Dionisio, 'A Qumran con gli Esseni (parte I)', Bibbia e Oriente 30 (1988) 3-34, esp. 7-10.

Philo, and especially his treatise Prob., are used a source of information for reconstructing the nature of the Essene community and its historical development, with particular reference to social, cultural and educational aspects. (RR)

8822. J. D. G. DunN, Romans, 2 vols. World Bible Commentary 38A-B (Dallas, Texas 1988) passim.

Not another commentary on Romans, was the author's reaction when asked to write it. But he saw room for a contribution in 'penetrating more fully into the historical context within which the letter was written and to which the letter was addressed'. This objective has led to a vast number of references to Philo, which it will be worthwhile for the Philonist to pursue. These are listed on p. 971-972. (DTR) 
8823. L. Feldman, 'Josephus' Portrait of Noah and its Parallels in Philo, Pseudo-Philo Biblical Antiquities, and Rabbinic Midrashim', Proceedings of the American Academy for Jewish Research 55 (1988) 31-57.

A passage by passage analysis of Josephus' account of Noah, concluded as follows (p. 56): 'The special flavor of Josephus' version may be especially appreciated when it is compared with that of Philo, Pseudo-Philo's Biblical Antiquities, and the rabbis, particularly in the midrashic tradition. In general, Philo is more philosophical and more attuned to allegory, and Pseudo-Philo is eager to remain closer to the Biblical text, while the rabbis take greater liberties, but with no primary intention toward apologetics, whereas Josephus' chief goal is precisely to defend his people against the canards that were circulating so widely in his day. On the whole, he avoids the theological discussions of which Philo is so fond, since his main goal is to write factual history...' (DTR)

8824. L. Feldman, 'Use, Authority and Exegesis of Mikra in the Writings of Josephus', in M. J. Mulder and H. Sysling (edd.), Mikra: Text, Translation, Reading, and Interpretation of the Hebrew Bible in Ancient Judaism and Early Christianity, CRINT II.1 (Assen 1988), 455-518, esp. 473ff., 516ff.

According to Feldman 'there is good reason to believe that Josephus drew upon the work of Philo (p. 473)', and the subject of the relation between the two authors recurs at regular intervals in the article (cf. p. 461, 473ff., 480, 487, $508,511,514,516)$. (DTR)

8825. G. Firpo, 'Il tentativo di Caligola di profanare il tempio di Gerusalemme e la datazione di IV Maccabei', Quaderni dell'Istituto di Archeologia e Storia antica 4 (1988) 1-23.

Jewish non-violent opposition to the provocations of Pilate, Flaccus, and Caligula was not fortuitous, but is consistent with a long-standing tradition based on the observation of biblical norms. The Philonic evidence in Legat. forms part of the basis for this conclusion. (RR)

8826. S. D. FraAdE, 'Ascetical Aspects of Ancient Judaism', in A. Green (ed.), Jewish Spirituality: From the Bible through the Middle Ages, World Spirituality: An Encyclopedic History of the Religious Quest 13 (New York 1988) 253-288, esp. 263-266.

Brief discussion of Philo's asceticism in the context of a well-thought out presentation of the subject in ancient Judaism as a whole (on this volume see also 8872). Though specifically influenced by currents of Greek philosophical thought, Philo nevertheless gives an excellent illustration of the 'ascetic tension' that the author argues was present in Judaism. Philo's denial of 
value to the body and material and social life is not as absolute as his philosophical ideals might suggest. (DTR)

8827. D. GeorgI, 'Frau Weisheit oder das Recht auf Freiheit als schöpferische Kraft', in L. SiEgele-Wenschkewitz (ed.), Verdrängte Vergangenheit, die uns bedrängt: feministische Theologie in der Verantwortung für die Geschichte (Munich 1988) 243-276, esp. 248-259.

The female nature of biblical Sophia is discussed in depth by Philo in Fug. His idea is that Sophia cannot be related to the female gender, not even in the religious image of 'daughter of God', because as a celestial reality it transcends the distinction between the sexes. An analogous solution is put forward by Philo in his exegesis of the figure of Sarah, who is often related to Sophia. From Sarah, too, the female characteristics are abstracted, so that she can represent celestial realities. In general, according to Georgi, Philo's positions point to the existence of an extensive debate on these subjects in Jewish circles, showing that no normative Judaism existed in Philo's time, not even in Palestine (p. 257). (RR)

8828. E. R. Goodenough, Jewish Symbols in the Greco-Roman Period. Abridged Edition, edited with a Foreword by J. Neusner, Bollingen Series (Princeton 1988) passim.

This abridged version of Goodenough's celebrated magnum opus naturally contains extensive references to Philo, on whom the author drew extensively for his interpretations of Jewish symbolism. See the index entry on p.272. Review: D. M. Hay, SPhA 1 (1989) 128-134. (DTR)

8829. L. GRAB B E, Etymology in Early Jewish Interpretation: the Hebrew Names in Philo, BJS 115 (Atlanta 1988).

This exhaustive study of Philo's use of etymology in his exegesis of the Old Testament was prepared as part of the Claremont Philo Project, and completely replaces all previous studies dedicated to the subject (except the monograph of Goulet (1987) which it could not take into account). About half of the book (pp. 123-222) is dedicated to an exhaustive list of all Philo's etymologies of Old Testament names, amounting to 166 in all. For all cases the Hebrew name, the Greek name, the references in Philo and an explanation of etymology and symbolism is given. Grabbe prefaces this list with studies on how Philo uses etymologies, the traditions that influenced him in his procedure, and the possible sources of the Hebrew etymologies. He argues that the chief influence on Philo's use of etymology in his exegesis is derived from the Hellenistic sphere and from Jewish traditions heavily imprinted with the dominant Greek culture (p. 87). The actual etymologies themselves are most likely derived from some kind of onomasticon, since Philo himself did not have a working knowledge of Hebrew (p. 119f.). In an Appendix Grabbe attempts to reconstruct the list that Philo could have had in front of him. Other appendices give a translation from the Hebrew of a brief article of $\mathrm{Y}$. 
Amir (= R-R 6201), a list of Greek etymologies, and the text of two onomastica found among the papyri. We note too a brief discussion of the later history of Philo's etymologies (109-111). Reviews: R. Goulet, SPhA 2 (1990) 187-194; A. Mendelson, JBL 109 (1990) 527-528; M. Petit, REJ 149 (1990) 203-204; A. Kamesar, JAOS 111 (1991) 816-817; J. C. Vanderkam, JSP 9 (1991) 124-125; D. Winston, JQR 84 (1993-1994) 386-387. (DTR)

8830. R. M. Grant, Greek Apologists of the Second Century (Philadelphia 1988), esp. 12-14, 157-159.

Philo is an important predecessor of the early Christian apologists on account of his interpretation of the Greek Old Testament and Jewish traditions in the light of Middle Platonism (p. 12). Frequent references to Philo are scattered throughout the book. Note especially the comparison of Theophilus' exegesis of Genesis with Philo's $Q G$ at p. 157ff. (DTR)

8831. A. T. Hanson, 'Hebrews', in D. A. Carson and H. G. M. Williamson (edd.), It is Written: Scripture citing Scripture; Essays in Honour of Barmabas Lindars (Cambridge 1988) 292-305, esp. 292-295.

In order to compare the use of Scripture by the author of Hebrews with that of his contemporaries, Philo and Qumran, the author examines how the same OT texts are used in the three sources. He concludes that Philo and Hebrews have very little in common. The affinity between Hebrews and Qumran is much stronger because of the common eschatological emphasis, an aspect 'not at all central in Philo's thought'. (PAC)

8832. M. HaRl, G. Dorival, O. Munnich, La Bible grecque des Septante: Du Judaïsme hellénistique au christianisme ancien, Initiations au christianisme ancien (Paris 1988) passim.

Philo is briefly discussed on two occasions in this highly competent handbook to the Septuagint: in chapter 2 in a section devoted to the origins of the Septuagint (pp. 46-47), with reference to Mos. 2.25-44, and in chapter 7 on the relations between the Septuagint and emergent Christianity, with reference to the allegorical exegesis of the Bible (p. 272f.). As may be expected, Philo is further briefly referred to at regular intervals in the book. (RR)

8833. P. Harlé and D. Pralon, La Bible d'Alexandrie, vol. 3 Le Levitique, (Paris 1988) passim.

Philo's works figure prominently in the annotations to this translation of Leviticus (see esp. the references on pp. 88-93, 99-105, 108-114, 122-125, 130-132, 135-139, mostly drawn from the four books of the De specialibus legibus). (RR) 
8834. A. van Den Hoek, Clement of Alexandria and his Use of Philo in the Stromateis: an Early Christian Reshaping of a Jewish Model, VChr.S 3 (diss. Nijmegen, Leiden 1988).

This competent and thorough study is the first monograph to be devoted to the question of the use that Clement of Alexandria makes of the writings and thought of Philo, as found in his Stromateis (the remainder of Clement's auvre falls outside its scope). Starting point is the collection of identifications made by $\mathrm{O}$. Stählin in his GCS edition and considerably extended by L. Früchtel in his subsequent revision. Aim is 'to recreate Clement's working methods: as it were, to look at him at his desk' (p. 20). The borrowing and adaptations made by Clement are divided into four groups: A certain dependence; B probable dependence; $\mathrm{C}$ unprovable dependence; $\mathrm{D}$ non-dependence. Van den Hoek identifies and analyses at some length four main blocks in which Philo is used at great and continuous length, four shorter sequences and then a large number of isolated references. In her analysis she is careful to examine what Clement takes over and the motivations for his selectivity and the frequent changes of emphasis that he introduces. The final chapter brings together some conclusions on Clement's method and also on the shifts of biblical interpretation and theological concern that have taken place between the Jew Philo and the Christian Clement. Philo's thought is predominantly theocentric and cosmocentric; Clement adds a strong soteriological impulse. Moreover the role of the Law is very different in the two authors. The closing words of the study are (p. 230): 'Many of the twisting threads of Clement's theological thinking are taken from Philo but they are woven into a very different tapestry'. Reviews: E. Osborn, JThS 41 (1990) 653-659; A. Méasson, SPhA 2 (1990) 211-214; L. Lothar, ZKTh 115 (1993) 203. (DTR)

8835. M. J. Horowitz, 'La philosophie judéo-hellénistique de Philon d'Alexandrie', Nouvelle Revue Théologique 110 (1988) 220-244.

The author emphasizes the specifically apologetic character of Philo's work, which was above all a passionate defence of Judaism from a universalist perspective. Various elements come together in Philo's philosophy: the Alexandrian-Jewish exegetical tradition (above all Aristobulus), the Septuagint, the Book of Wisdom, as well as, of course, the profound influence of Greek philosophy. As a result, Philo addresses themes intimately related to Christian concerns (charity, the Messianic vision, a pronounced aversion to religious formalism, the idea of mystic union), which ensured that his thought was widely disseminated among the Church Fathers. (RR)

8836. K. HüLSER, Die Fragmente zur Dialektik der Stoiker: neue Sammlung der Texte mit deutscher Übersetzung und Kommentaren, 4 vols. (Stuttgart-Bad Cannstatt 1987-88) passim.

38 Philonic texts are quoted, translated and very briefly commented on and a further 19 are cited - as part of this exhaustive collection of texts recording the Stoic doctrines on Dialectic in the broad sense of the term 
(including epistemological, logical and grammatical aspects). See the index of references at 4.1864. In the introduction (lxvii) the texts Congr. 79 and 140f. are used to illustrate Fragments in Group E, i.e. texts that do not refer to the Stoics specifically, but do contribute to the reconstruction of their doctrine. (DTR)

8837. L. W. Hurtado, One God, One Lord: Early Christian Devotion and Ancient Jewish Monotheism, (Philadelphia 1988) passim.

Philo furnishes extremely valuable evidence on the occurrence of divine agent figures in Jewish tradition, whether in the form of personified divine attributes (the Logos, cf. pp. 44-48) or of exalted patriarchs (e.g. Moses, cf. pp. 59-63). Early Christian reflection on the risen Jesus was influenced by this Jewish notion of divine agency, the crucial difference being that the Christians came to worship their mediator. (DTR)

8838. M. IDEL, Kabbalah: New Perspectives (New Haven and London 1988), esp. 131-134, 190.

Discussing the Kabbalistic interpretation of the cherubim as representing the masculine and the feminine attributes of God, Idel (following the lead of Goodenough) quotes Philo's interpretation of the cherubim in $Q E$ 2.66. Idel sees this interpretation reflected in one of the first Kabbalistic texts, and states that there seems to be extant evidence for the existence of Hebrew traditions that may have mediated between Philo's views, or other ancient Jewish traditions parallel to Philo, and the emergent Kabbalah. Another example of a Kabbalistic concept evidenced by Philo is the view that the commandments had forms (for which see Philo, Legat. 210-211). (HMK)

8839. U. Jaitner-Hahner, 'Zur Besitzgeschichte einer Handschrift. Cgrm 459 (Abb. 44 und 45)', in J. Autenrieth (ed.), Renaissance- und Humanistenhandschriften, Schriften des Historischen Kollegs. Kolloquien 13 (Munich 1988) 105-108.

Recounting the history of the owners of the ms. Cgrm. 459 [= G-G 35], which contains 38 Philonic works, the author sketches a brief portrait of, among others, the Umbrian humanist Lilio Egidio Libelli. (RR)

8840. R. S. Kraemer, Maenads Martyrs Matrons Monastics: a Sourcebook on Women's Religions in the Greco-Roman World (Philadelphia 1988), esp. 27-30, 403-404.

Two Philonic texts - Contempl. 12, 32-33, 68-69, 83-88, Spec. 3.169-175 are selected for inclusion in an extensive collection of texts on women's observances, rituals and festivals in the ancient world. (DTR) 
8841. G. Kweta, Sprache, Erkennen und Schweigen in der Gedankenwelt des Philo von Alexandrien, 2 vols. (inaug. diss. München 1988).

This doctoral thesis represents the most extensive work ever devoted to Philo's views on language, thought and knowledge. Starting-point for the research is the role that Philo may have played in the development of the theme of silence in the later mystical tradition. Although this theme is scarcely touched, the entire work is designed to show how Philo's views on positive and negative aspects of language may have contributed to the concept of silence resulting from the transcendence of language. The study is written from the viewpoint of German academic philosophy and attempts a systematic account, with discussion of texts embedded in a thematic presentation. In the first chapter a comprehensive examination is presented of the role of the

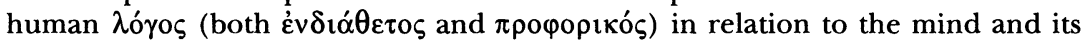
powers of thought. Chapter 2 surveys those aspects of Philo's cosmology and anthropology that are relevant for his views on language. The origins and task of language (with special attention paid to the role of Adam) is the subject of the next and longest chapter. Language is seen to possess an element of ambivalence in that it can be used for truth and falsehood, wisdom and sophistry. The epistemological aspects relevant to the evaluation of language are exhaustively studied in chapter 4. Philo's thought is dominated by a dualistic view of reality. Pure thought relates to intelligible reality and is basically monadic, whereas the spoken word is necessarily dyadic, and must therefore always retain a negative element. A similar situation is met in the case of the theory of knowledge discussed in the next chapter: language is connected to $\tau \dot{\varepsilon} \chi \vee \eta$, the lower kind of knowledge, whereas $\dot{\varepsilon} \pi \sigma \tau \dot{\eta} \mu \eta$ involves intuitive knowledge that can bypass language and the spoken word. Chapter 6 adds a discussion on the dominant role of light in Philo's views on cognition and knowledge. In the next chapter the role of language in the context of theology is examined, with particular emphasis on the description of God as tò óv and its consequences for the view that God is essentially nameless. Finally the author summarizes the results she has reached and attempts to place Philo in the context of the development of the philosophy of language from Heraclitus and Parmenides to modern times. In a sense Philo reverts back to the position abandoned by Plato that there is a correspondence between a phoneme and the reality it represents. He is able to do this by means of his theory of God's mediated presence in created reality. In the main text and above all in the notes there are numerous discussions of the contributions of previous Philonic scholars, with heavy emphasis on works in the German language (and an extensive discussion with the study of Otte (1968) on the same theme). But almost no literature later than 1970 is given consideration. See further 9651. (DTR)

8842. J. LAPORTe, 'Models from Philo in Origen's teaching on original sin', Laval Théologique et Philosophique 44 (1988) 191-203.

The author compares eight themes and their relation to original sin in the writings of Philo and Origen: (1) pre-existence (2) the Devil (3) the ages of life (4) the flesh (5) Adam (6) the seed of Abraham (7) defilement (8) 
baptism. There are important similarities between Origen and Philo in the idea of original sin. Origen's Christian faith is also responsible for important differences; his development of original sin is dependent on both Paul and Philo. (PAC)

8843. J. LAPORTE, 'Sacrifice in Origen in the Light of Philonic Models', in C. Kannengiesser and W. Petersen (edd.), Origen of Alexandria: his World and his Legacy, Christianity and Judaism in Antiquity 1 (Notre Dame 1988) 250-276.

The author summarizes recent literature on sacrifice in Philo and Origen and sees an incorrect tendency in scholarship generally to perceive Philo and Origen as trying to teach Greek philosophy under the guise of Scripture. Apart from the NT, Philo is the chief source of Origen's teaching on sacrifice (and other themes as well). Philo also provides Origen's basis for the doctrines of the Eucharist and forgiveness. The three principle forms of sacrifice found in Leviticus (whole burnt-offerings, sacrifices of salvation, sin sacrifices) are the models for Philo's allegory adopted by Origen. He also co-opts Philo's terminology in making his own Christian allegorical applications. (PAC)

8844. J. R. Levison, Portraits of Adam in Early Judaism from Sirach to 2 Baruch, JSP.MS 1 (Sheffield 1988), esp. 63-88.

Chapter four is dedicated to Philo's understanding of Gen. 1-3 in general and his portrayal of Adam in particular. The relevant texts are found in all three categories of Philo's works. We note particularly Opif. 24-25, 64-88, 13450, 151-69; Leg. 1.31-42, 2.4; Mos. 2.59-65; Virt. 199-205; $Q G$ 1.32, 51, 81. These important texts clearly show the 'Tendenz' of Philo's anthropology, namely to emphasize 'the borderline or composite character of the human race' (86). (PAC)

8845. B. LÉvy, Le logos et la lettre: Philon d'Alexandrie en regard des pharisiens (Lagrasse [Aude] 1988).

Philo of Alexandria - whose curious destiny it was to be 'the source of Christian exegesis, which nevertheless did not recognize him as its father, and to be untraceable in the chain of commentaries which constitute the tradition of his forefathers' (p. 9) - historically created the gap which exists between the Logos (reason, 'les philosophèmes') and the letter ('les sémanthèmes'; cf. 8), or, if one likes, between the Greeks and the Alexandrians on the one hand and the Pharisees on the other. But underlying this problem is another, even more radical one: 'from the point of view of existence, what does the transcendence of the One signify?' (p. 20). This problem, which emerges for the first time in Philo, also appears in the Neoplatonist philosophers (particularly in Proclus; cf. esp. p. 59ff.), but with a difference: whereas the Neoplatonists can afford to disregard the meaning of the letter (being 
merely a myth which assigns a body to the ineffable; cf. p. 61), the biblical exegete cannot do so and is obliged to explain its contradictions and absurdities whenever they occur. Lévy supports these claims through a varied and personal analysis of some metaphors and allegories typical of Philo, often comparing them with the exegesis of the Hebrew source in the Bible. (RR)

8846. J.-P. MAHÉ, 'Générations antédiluviennes et chute des Éons dans l'Hermétisme et dans la Gnose', in R. van DEN BroEK, T. BAARDA and J. MANSFELD (edd.), Knowledge of God in the GraecoRoman World, EPRO 112 (Leiden 1988) 160-177.

There is no direct dependence of the Hermetica on Philo, but Philo supplies valuable parallel information on the double creation of man in Gen. 1-2 and the depiction of Noah as representing a second creation of mankind. (DTR)

8847. J. Mansfeld, 'Philosophy in the Service of Scripture: Philo's Exegetical Strategies', in J. M. Dillon and A. A. Long (edd.), The Question of "Eclecticism": Studies in Later Greek Philosophy, Hellenistic Culture and Society 3 (Berkeley 1988) 70-102.

This rich and learned article takes its starting point from the notion of eclecticism, which was the subject of the workshop where the paper was first presented. Philo belongs to two worlds and espouses two traditions, which he seeks to interpret in terms of each other. This strategy is perhaps better called Rezeption (i.e. assimilation) rather than eclecticism. Mansfeld illustrates how Philo's use of Greek philosophy works, emphasizing that exegesis at the literal and at the allegorical level may involve the use of quite different philosophical traditions, and paying particular attention to the five philosophical treatises. For all his piety and indebtedness to exegetical themes, Greek philosophy really dominates his thought. In fact Moses is virtually converted into a Greek philosopher. Indeed Greek philosophy itself can be seen as essentially reinterpretation, because Moses came first and the philosophical tradition is indebted to him. In the second half of the article Mansfeld investigates how Philo - particularly in the texts Her. 246-248 and Ebr. 199 - exploits the sceptic notion of the $\delta 1 \alpha \varphi \omega v i \alpha$ in which the theories of philosophers are arranged in polar opposites. Yet Philo does not stay in sceptical waters, because the wise man, i.e. primarily Moses, is able to adjudicate between the warring doxai. The crucial role that Moses plays explains the way that his education is presented in the De vita Moysis, although there 'one cannot help feeling that Philo somewhat overplays his hand (p. 96)'. On the basis of the Mosaic oracles, therefore, the interpreter has access to the truth, and so can 'lord it over the Greek philosophers' (p. 102). Inevitably this strategy may give an eclectic impression, but Philo's eclecticism is free from the taint of syncretism. (DTR) 
8848. A. M. Mazzanti, 'Antropologia e radici del male in Filone di Alessandria: due possibili opzioni', Augustinianum 28 (1988) [ = XVI incontro di studiosi dell'antichità cristiana. Cristianesimo e Giudaismo: eredità e confronti. Roma, 7-9 Maggio 1987] 187-201.

Philo presents the genesis of evil in two different ways. On the one hand, it is the implicit result of the act of creation conceived of as a vertical continuum' (p. 188), that is, as a homogeneous process of derivation of things by God. On the other hand, evil is seen as a sudden introduction of an 'essential deformity' (p. 187) into the creation of man, owing to the fact that man was not created by a direct act of God. In any case, according to Mazzanti, evil for Philo does not implicate man totally, nor does it wholly define him (p. 201). (RR)

8849. A. M. Mazzanti, 'L'uomo $\mu \varepsilon \theta$ ópios da Filone all'Asclepio', Studi e Materiali di Storia delle Religioni 12 (1988) 61-69.

Man's intermediate position between the sensible and suprasensible spheres is an element common to both Asclepius and Philo, the more so in that both express this position on an ontological level (man as a union of body and spirit) as well as on an ethical level (man suspended between vice and virtue). According to Mazzanti (p. 66), the view of Asclepius is perhaps more optimistic than Philo's, since it implies that the negativity of the body can be largely overcome by a moral choice oriented to the good. (RR)

8850. R. K. McIver, "Cosmology' as a Key to the Thought of Philo of Alexandria', Andrews University Seminary Studies 25 (1988) 267-279.

After exploring 'Philo's cosmological concepts' (God creates the cosmos in two stages and is himself far removed from it, communicating with it only through a series of intermediaries) and his 'philosophic goal' ('to reunite the soul with God, to restore it to its proper place in the heavens') the author arrives at the negative conclusion that while cosmology encompasses 'a whole range of Philo's thought', and is important in understanding him, it is 'not the sole key to his thought-world'. If it were 'the unifying factor' it would be more developed than it is. Philo devotes even more attention to the areas of ethics and anthropology which cosmology does not encompass. Nevertheless Philo's cosmology is very important for understanding the intellectual milieu in which early Christianity emerged, since he can be considered representative for a larger group of contemporary thinkers. (PAC)

\section{A. Mendelson, Philo's Jewish Identity, BJS 161 (Atlanta 1988).}

The aim of this compact monograph is 'to come to terms with the foundation of Philo's faith by asking how Philo conceived of his Jewish identity' (p. 1), an issue which, according to the author, lies at the very heart of his 
religious sensibilities. Two aspects need to be investigated: (1) how did Philo regard himself as a Jew among other nations? (2) how did Philo regard himself as a Jew among other Jews? It emerges that in his situation in Alexandria Philo attemps to reconcile fidelity to the customs of his ancestors with adaptability to the social and religious realities of his environment. Crucial to his Jewish identity are orthodoxy and orthopraxy, to each of which a chapter is devoted. Philo's conception of orthodoxy is chiefly derived from the 'creed' at Opif. 170-172. His orthopraxy is harder to pin down because it is not addressed in a systematic fashion. It emerges that the observance of certain prohibitions and commands constitute an essential part of what it is to be a Jew. Next a chapter is devoted to Philo's Apologetic, i.e. how he presents his Judaism in the context of Roman Alexandria. It is stressed that this occurs in a reciprocal situation: Jews react to the way pagans see them, and vice versa. The final chapter, entitled 'Drawing the line', commences with a startling text, Spec. 4.179, in which Philo gives expression to 'a strong sense of Jewish isolation' (p. 115). Mendelson examines his attitudes to Egyptians and Greeks. Because the Torah is regarded as the standard of all things, pagan customs are found wanting. Mendelson concludes (p. 138): 'In the end... Philo perceives himself to be in an alien environment. He retreats from it into his own community - an act which further confirms the pagan's view that the Jews are misanthropic. A vicious circle thus is established. Philo's sense of spiritual superiority may have helped to preserve the Alexandrian Jews' religious identity. But, as in other times and places, the Jews of Alexandria paid a heavy price for this sense of themselves.' The book concludes with a brief epilogue by Ben F. Meyer, which makes some comments on issues raised in it. Reviews: L. H. Feldman, JQR 81 (1991) 449452; E. Osborn, Abr-N 29 (1991) 138-139; G. Sterling, CrRBR (1991) 371-372; S. Tanenzapf, SR 21 (1992) 102-103; N. G. Cohen, SPhA 4 (1992) 164-168. (DTR)

8852. M. J. J. Menken, 'The Provenance and Meaning of the Old Testament Quotation in John 6:31', Novum Testamentum 30 (1988) 39-57, esp. 49ff.

After considering the four possible sources for the OT quotation in John 6:31 (Ex. 16:4; 16:15; Ps. 78:24; 2 Esd. 19:15 [MT Neh. 9:15]), the author concludes that the most likely was the LXX version of Ps. 78:24. He then examines its meaning in the Johannine context: that the crowd has made Moses (instead of God) the subject of the quotation in 6:31 (cf. 6:32) accords with the Fourth Gospel's tendency in general 'against a kind of Judaism in whose piety Moses had a central position'. Among other diverse sources (Ezekiel the Tragedian, rabbinic texts, Samaritan sources) this Mosescentered piety is clearly discernible in Philo's writings (Sacr. 8-9, Post. 28, Gig. 49, Somn. 2.189, Mos. 1.155-58, 201-202, 2.267, QE 2.29, 40). (PAC)

8853. A. Michel, 'Judaïsme et Académie: Ciceron et Philon d'Alexandrie', Augustinianum, 28 (1988) [XVI incontro di studiosi dell'antichità cristiana. Cristianesimo e Giudaismo: eredità e confronti. Roma, 7-9 Maggio 1987] 219-236. 
The aim of this article is to demonstrate that Philo's main source is the philosophy of the Academy. Since Cicero is usually a reliable exponent of Academic thought, and he cannot have known Philo's work, a comparison of the two philosophers who show such important similarities may be able to prove the initial hypothesis. In fact, Michel goes beyond these aims and also advances ideas for a new interpretation of Cicero's theology, based mainly on Platonic principles. (RR)

8854. J. Murphy-O'Connor, 'Philo and 2 Cor. 6:14-7:1', Revue Biblique 95 (1988) 55-69.

The Jewish parallels to the (genuinely Pauline) passage derive from Philonism and not, as traditionally thought, from Essenism. The central ideas and language of the passage are firmly at home in Hellenistic Judaism, and more completely available in Philo than elsewhere. Paul's opponents, the pneumatikoi, were influenced by Philo's wisdom speculations through Apollos. Paul applies the term apistos to them, not as 'unbeliever', but in its Philonic sense, 'not trusting in God alone' (Her. 93; Abr. 269, 275). In using Philonic language against them, Paul is employing his ministerial principle ('all things to all men'), and could himself have learned of Philonic philosophy in consultation with Apollos in Ephesus. (PAC)

\section{M. NeAry, 'Philo of Alexandria: Alexandrian Judaism', Irish Theological Quarterly 54 (1988) 41-49.}

This introductory article provides a brief summary and analysis of Philo's works (giving much space to his dependence on Plato), and comments on their interpretation and reception under four sub-headings: (1) Alexandrian Judaism (2) Philo, a protean figure (3) the creation of the world in Philonic thought (4) the creation of man. The author concludes, 'Philo must be interpreted with reference to three areas, loyalty to the words of Moses, love of Greek philosophy, and an apologetic concern for his fellow Jews in Alexandria... [He] endeavours to produce a synthesis between Judaism and Hellenistic culture and... did this out of a personal need (p. 48).' (PAC)

\section{J. A. Overman, 'The God-fearers: Some Neglected Features', Journal for the Study of the New Testament 32 (1988) 17-26.}

Overman's purpose is 'to question some of A. T. Kraabel's conclusions concerning the God-fearers', i.e., that, based on the absence of the term $\varphi \circ \beta o v ́ \mu \varepsilon v o 1 / \sigma \varepsilon \beta o v ́ \mu \varepsilon v o r$ iòv $\theta \varepsilon o ́ v$ from the inscriptions of six Diaspora synagogues plus literary evidence in Acts, there is no convincing proof in the Roman Diaspora for the existence of such a class of Gentiles, and that the term is employed merely as a literary tool in Acts. The author argues that $\pi \rho 0 \sigma \eta ́ \lambda v \tau o \varsigma$ as employed by the LXX, Philo (Virt. 102-103, QE 2.2) and Luke, as well as a review of the evidence for phoboumenoi clearly support the conclusion that there existed 'just such a class of people'. (PAC) 
8857. F. Parente, 'The Third Book of Maccabees as Ideological Document and Historical Source', Henoch 10 (1988) 143-182, esp. $170 \mathrm{ff}$.

It is preferable to date the final version of 3 Maccabees to 20-15 BCE rather than 40-45 CE. Nevertheless in understanding the historical and social background 'Philo remains an extremely significant figure' (p. 180), because his principles illustrate the attitude of the leading circles in the Jewish $\pi \circ \lambda i \tau \varepsilon v \mu \alpha$ of a century before, i.e. a conciliatory position towards non-Jewish authority and culture. Anti-government propaganda from Palestine, however, was gaining the upper hand. (DTR)

8858. S. Pricoco, 'La scala di Giacobbe: L'interpretazione ascetica di Gen. 28,12 da Filone a San Benedetto', in B. Jaspert (ed.), Regulae Benedicti Studia: Annuarium Internationale 14/15 (St. Ottilien 1988) 41-58, esp. 43-45.

The author succinctly describes Philo's allegorical interpretation of Jacob and the latter's dream of the ladder (Somn. 1.134-156). He subsequently sketches the interpretation of the same theme in the tradition of Greek Fathers (such as Clement of Alexandria, Origen, Gregory of Nyssa), as well as in the Latin tradition (notably Jerome). His conclusion is that the treatment of the theme in the Benedictine Regula Magistra and the Regula Benedicti falls back on the older (and richer) Greek (Philonic) interpretation. (HMK)

8859. R. A. Pritz, Nazarene Jewish Christianity: from the End of the New Testament Period until its Disappearance in the Fourth Century, Studia Post-Biblica 37 (Jerusalem-Leiden 1988), esp. 39-42.

A brief discussion of Epiphanius' account of the Essaioi, evidence on which he derives from Philo. Epiphanius' account is certainly confused, but the conclusion that the information is derived from a mistaken coalescence of Philo's Therapeutae and Essenes would seem to be too simple a solution. (DTR)

8860. G. E. Robertson, Paul and Abrahamic Tradition: the Background of Abraham and the Law in Galatians 3-4 and Romans 4 (diss. Southwestern Baptist Theological Seminary 1988).

Philonic evidence is used in order to date the development of the Abrahamic tradition. The analysis of this tradition focuses on the use of nomistic and non-nomistic paradigms. (DTR; based on DA 50-01A p.176)

8861. J. J. Rose, The Concept of 'Arete' in Plutarch's Parallel Lives (diss. Rutgers University 1988).

'The final chapter is a brief comparison of Plutarch's concept of virtue with that of Philo Judaeus in his biography of Abraham, in order to show how a 
writer steeped in contemporary Jewish Hellenistic thought and tradition perceived virtue. This research was undertaken in order to better understand the first century CE pagan view on what being a man of virtue, one worthy of emulation, encompassed.' (DTR; taken from DA 49-10A, p.3018)

8862. D. T. Runia, 'God and Man in Philo of Alexandria', The Journal of Theological Studies 39 (1988) 48-75; reprinted as study XI in 9059.

Starting point of the article is Moses' dream in the Exagoge of Ezechiel Tragicus. If Philo saw the play, would he have approved of the presentation that Moses takes God's place on the throne and has the stars bowing down to him? Analysis of various texts, including Mos. 1.148-162, Mut. 11-26, Det. 161162 (in all of which exegesis of Ex. 7:1 is prominent), lead to the conclusion that he would not have approved. Moses can be called 'god', for thus Scripture calls him, but only as a god in relation to other men, not in relation to other divine beings, let alone to God himself. Yet a further aspect of the problem emerges when we recognize that Moses as $\theta$ cós in Ex. 7:1 can also be allegorized as the rational vov̧ (cf. esp. Opif. 69). Against the background of Philo a depiction of the human mind as $\theta$ cós is quite comprehensible. Yet it has important consequences for his doctrine of man. Man is a composite being consisting of body and rational soul (or mind), but only in respect of the latter is he related to God. The author summarizes his conclusions by distinguishing between a theological and a philosophical approach to the problem. In the case of the former it is easy to indicate the divide that separates man from God; in the case of the latter it is much more difficult for Philo to give a clear indication of where God's true divinity ends and man's derived divinity starts. These difficulties become clear in the doctrine of the divine Logos. (DTR)

8863. D. T. Runia, 'Naming and Knowing: Themes in Philonic Theology with Special Reference to the De mutatione nominum', in R. VAN DEN BRoEK, T. BAARDA and J. MANSFELD (edd.), Knowledge of God in the Graeco-Roman World, EPRO 112 (Leiden 1988). 69-91; reprinted as study XII in $\mathbf{9 0 5 9}$.

As the title indicates, the article undertakes to examine certain themes in Philonic theology through a close reading of the treatise De mutatione nominum (esp. §1-33, 175-187, 218-232). It is shown how the biblical text at Gen. 17:1 raises various aporiae, which Philo sets out to resolve. If God appears to Abraham and says 'I am your God', what does this mean for the way that God can be named and known? Interpretation of the texts Ex. 3:14 and 6:3 is crucial for Philo's interpretation. Because God is ò ळैv, this means he cannot be legitimately and properly named. This conclusion encourages the author to concentrate on a hitherto neglected theme in Philonic theology, namely the theological application of the Greek rhetorical and philosophical notion of $\kappa \alpha \tau \alpha \dot{\alpha} \rho \eta \sigma \imath \varsigma$, 'deliberate misuse of language'. The specific use of the idea in a theological context may well have been an original step on the part of Philo, 
and was hardly noticed by later Patristic writers who knew his work. It points to an unavoidable element of tension in Philo's thought, as he attempts to reconcile Jewish monotheism and ideas drawn from Greek philosophical theology. (DTR)

8864. F. Schmidt, 'Entre Juifs et Grecs: le modèle indien', in L'Inde et l'imaginaire, Études réunies par C. WeInBERger-Thomas, Collection Purusartha 11 (Paris 1988) 33-46.

In Hellenistic and Roman times, the Jews knew India and the Indians mainly through the intermediary of Greek historians. What they above all concentrate on are stories about the first encounters between the Greeks and the Indians. In the process of being recounted by the Jews, these Greek traditions have undergone certain changes. Although appearing to illustrate Alexander's famous encounter with the Indian sages, the Jewish texts among which Philonic passages are prominent - in fact dealt with the relationship between Hellenism and Judaism and raised a basic issue for the Judaic world: how to retain one's own identity despite foreign domination. (RR; based on author's summary, with slight modifications)

8865. J. M. Scholer, Proleptic Priests: an Investigation of the Priesthood in the Epistle to the Hebrews (diss. Union Theological Seminary Virginia 1988).

Philo is among the extra-NT sources consulted in an examination of the role and function of priests, preliminary to an investigation of the topic in Hebrews. For the published edition see 9175. (DTR, based on DA 49-09A p.1490)

8866. E. SchWeizer, 'Slaves of the Elements and Worshipers of angels: Gal 4:3, 9 and Col 2:8, 18, 20', Journal of Biblical Literature 107 (1988) 455-468.

Philological evidence from sources up to the second century CE (Empedocles, Cicero, Alexander Polyhistor, Ovid, Philo, Josephus, Plutarch, Hippo-

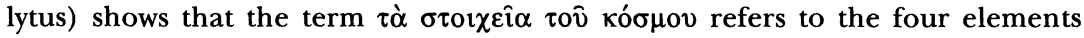
earth, water, air and fire, and not personal demonic beings or 'elemental spirits'. The sources reveal a widespread agreement that the four elements, originally in equilibrium, continually threatened the world's existence through their 'mighty strife'. This ancient belief in Cosmos as a real power is the basis for understanding 'the elements of the world' in Colossians. Philo (Her. 280-83; Somn. 1.137-41) and Josephus (BJ 6.47) give possible clues to what is meant by 'worship of angels'. (PAC)

8867. P. Sigal, Judaism: the Evolution of a Faith (Grand Rapids 1988), esp. 49-51. 
A distillation of the author's three-volume The Emergence of Contemporary Judaism, with the original section on Philo (cf. R-R 8039) correspondingly abbreviated. (PAC)

8868. S. Тімм, Der heilige Mose bei den Christen in Ägypten: eine Skizze zur Nachgeschichte alttestamentlicher Texte, in $\mathbf{M}$. GöRG (ed.), Religion im Erbe Ägyptens. Beiträge zur spätantiken Religionsgeschichte zu Ehren von Alexander Böhlig, Ägypten und Altes Testament. Studien zu Geschichte, Kultur und Religion Ägyptens und des Alten Testaments 14 (Wiesbaden 1988) 197-220, esp. 205ff.

The image of Moses in the tradition of early Christianity did not derive directly from the Old and the New Testament, but from Philo, and in particular from the treatise De vita Moysis, which is compared here on a number of points with parallel passages in Clement of Alexandria. (RR)

8869. K. L. VANDERGRIFF, The Messianic Significance of the "Seed of Abraham" Concept in Pre-Christian Judaism (diss. Southwestern Baptist Theological Seminary 1988).

A thorough review of Jewish literature, including Philo, reveals that Abraham and David or Abraham and the Messiah are occasionally mentioned together in the same context, but not that the traditions were merged, as in the New Testament. (DTR, based on DA 49-10A p. 3064)

8870. J. Weinberg, 'The Quest for Philo in Sixteenth-Century Jewish Historiography', in A. Rapoport-Albert and S. J. ZipperSTEIN (edd.), Jewish History: Essays in Honour of Chimen Abramsky (London 1988) 163-187.

The last decades of the sixteenth century saw Protestants criticising Catholics heavily for relying on Patristic authority without historical evidence. The ensuing interest in historical investigation included the work of Philo. Weinberg suggests that the Jewish scholar Azariah de'Rossi's 'Me'or Enayim' (Light of the Eyes), published in 1573, was 'the first comprehensive assessment of Philo to be undertaken by Jew or Christian'. De'Rossi's purpose was to determine whether Philo could be claimed by Jews as a representative of his people. His view towards Philo is ambivalent throughout, dividing his critique between prosecution and defence. He considers Philo a BoethusianEssene (i.e., a sectarian Jew of the second Temple period writing about the schismatic group to which he himself belonged) in contrast to the ancient reports that christianize him, which he ignores (although he was certainly aware of them). He attempts to correct Christian assumptions about Philo without explicitly refuting them. De'Rossi's main criticisms of Philo are 'ignorance of Hebrew and Aramaic, belief in the eternity of matter, allegorization of the biblical stories and ignorance of the Oral Law', the last of which he considers the most serious. Weinberg points out that certain questions 
which De'Rossi raised about Philo have still not been solved by modern scholarship. After De'Rossi Philo could no longer be ignored by the Jews, but two centuries elapsed before another Jewish scholar took up the 'ancient enigma'. (PAC)

8871. M. J. Wilkins, The Concept of Disciple in Matthew's Gospel: as Reflected in the Use of the Term $\mu \alpha \theta \eta \tau$ 'ns, NT.S 59 (Leiden 1988), esp. 100-104.

Philo's usage of the term $\mu \alpha \theta \eta \tau \eta \dot{\zeta}$ is varied enough to offer interesting background material for a study of the term in the first Gospel. (DTR)

8872. D. Winston, 'Philo and the Contemplative Life', in A. Green (ed.), Jewish Spirituality: From the Bible through the Middle Ages, World Spirituality: An Encyclopedic History of the Religious Quest 13 (New York 1988) 198-231.

This rich study of Philo's 'spirituality' is part of an equally rich volume (cf. also 8826) in an encyclopedic series on spirituality worldwide. The project of the series is described in the general preface as exploring the discovery and development of the 'spirit' as the deepest center of the person: the spiritual core, where the person is open to the transcendent dimension and experiences ultimate reality. Winston's article opens with a general introduction (including an extensive bibliography) to Philo and 'the nature of the Philonic enterprise as a whole'. He then embarks on an exposition of Philo's Logos conception within its Greek and Jewish context, since without knowledge of this conception Philo's special brand of spirituality cannot be fully appreciated. The Logos or Divine Mind is God immanent, a vivid and living hypostatization of an essential aspect of deity, the face of the utterly transcendent God turned toward creation. Winston then describes how Philo's great biblical commentary develops the allegory of psychic ascent. From Philo's platonist perspective the soul is entombed in the body; for Philo the biographies of the biblical patriarchs represent the gradual removal of the psyche from the sensible realm and its ascent to a life of perfection in God. Under the heading of Divine Worship, Philo's views on sacrifice (the fullness of moral nobility) are expounded, his preference for prayers of thanksgiving over petitionary ones, his view on contemplative prayer as the highest prayer form, and his divided sentiments regarding the practical and the contemplative types of life (since virtue is both theoretical and practical). The final section, on Philo's mysticism (a much-debated question), concludes 'that Philo was certainly a 'mystical theorist' (if not practising mystic) to his very core and that his philosophical writings cannot be adequately understood if this signal fact is in any way obscured' (226). (HMK)

8873. D. Winston, 'Two Types of Mosaic Prophecy according to Philo', in D. J. Lull (ed.), Society of Biblical Literature 1988 Seminar Papers, SBLSPS 27 (Atlanta 1988) 442-455; reprinted in Jourmal for the Study of the Pseudepigrapha 4 (1989) 49-67. 
Analysis of the three categories of divine oracles delivered by Moses as outlined by Philo at Mos. 2.188ff. yields two types of prophecy, ecstatic and hermeneutical (or noetic). In the former the prophet's mind is possessed by the divine Spirit, so that he becomes a passive 'medium'. This conception is largely derived from Philo's Hellenic background rather than the OT, and comes closer to the radical view of ecstatic prophecy found in Plato than the milder form found in Plutarch (in which there is no actual displacement of the human mind, only its tranquillization). The other kind of prophecy differs markedly in that its recipient is not rendered passive, but rather his mind is extraordinarily sharpened and quickened, so that in the case of Moses it can even take the initiative in its interaction with God. Here too philosophical influence is perceptible; one may compare Plutarch's explanation of Socrates' daimonion. Moses' prophetic revelation should thus be viewed as 'an intuitive grasp of the higher realities, the fundamental principles of being and the natural laws which constitute its structure' (p. 451). The article closes with an examination of the relation of these two types of prophecy and the mystic vision. Clearly ecstatic prophecy differs from the mystic vision because in the former the initiative lies with the Deity, in the latter with man. The noetic prophecy practised by Moses, however, is presented as the apogee of human ascension to God, and is thus superior to the mystic vision granted to other sages. See also 8974. (DTR)

8874. B. W. Winter, Philo and Paul among the Sophists: a Hellenistic-Jewish and a Christian Response (diss. Macquarie University, Sydney 1988), esp. chapters 3 to 5 .

This study explores the place of Philo among the Alexandrian Sophists as witnessed by P.Oxy. 2090 and the Alexandrian oration of Dio Chrysostom. It is shown that Philo interacted with these sophists, drawing heavily on the arguments against them outlined by Plato. Philo is especially important because he is the only source in the East for about 50 years that supplies information on the sophists and sophistic tradition. The conclusion of the dissertation gives a comparison of the responses of Paul and Philo to the sophists and their tradition. A revised edition of the dissertation was published in 1997. (DTR; based on notes supplied by the author)

8875. D. ZeLLER, Jesus als vollmächtiger Lehrer (Mt 5-7) und der hellenistische Gesetzgeber, in L. Schenke (ed.), Studien zum Matthaüsevangelium. Festschrift für Wilhelm Pesch (Stuttgart 1988) 299317, esp. 307-309.

The figure of Jesus as the founder of a new moral law contains elements deriving from the Alexandrian tradition, and especially from Philo. An important model for this figure is Philo's Moses, in whom divine nature, royal authority, and the power to establish laws are conjoined. (RR) 


\section{9}

8901. H. Attridge, The Epistle to the Hebrews: a Commentary, Hermeneia: a Critical and Historical Commentary on the Bible (Philadelphia 1989), esp. 28f. and passim.

Only brief remarks are made on the relation of Hebrews to Philo in the introduction, but in the commentary the references are copious (indexed at pp. 426-427). Thus Attridge concludes that there are 'undeniable parallels that suggest that Philo and our author are indebted to similar traditions of Greek-speaking and -thinking Judaism (29).' (DTR)

8902. A. A. BARrett, Caligula: the Corruption of Power (London 1989), esp. 73-80, 214-216 and passim.

This 'first major reassessment of Caligula's reign and violent death for over fifty years' (dustjacket) cannot fail to refer frequently to the Philonic evidence. (DTR)

8903. H. BAYER, 'Abälard-Heloise-Briefwechsel und Conte du Graal in ihrer Zeit: ein Beitrag zur Funktion der Literatur in den Glaubenskämpfen des Hochmittelalters', Zeitschrift für Kirchengeschichte 100 (1989) 3-32, esp. 8-15.

The Letters of Abelard and Heloise and the Grail Legend were in varying measure subject to Philonic influences. The author of the Letters quotes a Pythagorean Philo, from whom he adopts a large number of religious motifs, for instance that of salvation through asceticism (also held by the French Cathars, pp. 8-9), that of Essenian Wisdom, and that of the profound and full spirituality of the Therapeutae (12). Other Philonic influences can be found in the Tristan romance, but above all in the Grail Legend, in which Bayer identifies precise parallels with Philo's theology (particularly with Somn. 1.213-214, 228-230), regarded as a praeparatio evangelica. In short Bayer attempts to demonstrate through accumulated references the diffuse influence of Philo's mysticism on the literature of the High Middle Ages. (RR)

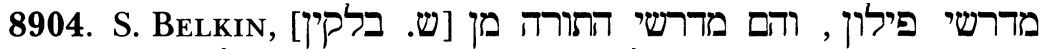

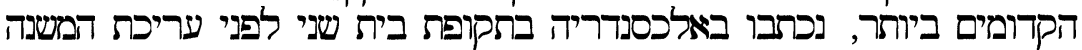

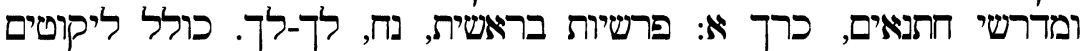

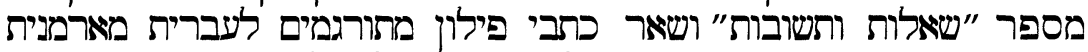

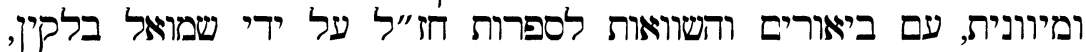
(ע) The Midrash of Philo: the Oldest Recorded Midrash Written in Alexandria by Philo (c. 20 BCE - 45 CE) before the Formulation of Tannaitic Literature. Vol. 1 Genesis II-XVII; Selected
} 
Portions from Philo's Questions and Answers and from his other writings, translated into Hebrew from the Armenian and Greek with a commentary. Based upon Parallels from Rabbinic Literature], edited by E. HuRvitz (New York 1989) [Hebrew].

For details of this work see the review of N. G. Cohen separately listed below (9220). Other Review: D. Winston, RelStR 17 (1991) 82.

8905. R. M. Berchman, 'Arcana Mundi between Balaam and Hecate: Prophecy, Divination, and Magic in Later Platonism', in D. J. Lull (ed.), Society of Biblical Literature 1989 Seminar Papers, SBLSPS 28 (Atlanta 1989) 107-185, esp. 112-117, 122-124, 128-130.

Starting point for this long contribution is the hypothesis that philosophical and religious knowledge should not be studied in isolation from its social and institutional context. The themes of prophecy, divination and magic are examined from this perspective first in Middle Platonism, then in Hellenic Neoplatonism, but for the former category Berchman studies above all the figures in the Judaeo-Christian platonizing tradition, Philo, Clement and Origen. Prophecy is for Philo the agency of divine help for mankind, involving the reification of certain types of sensible knowledge (p. 117). For Philo the figure of Balaam as magician and sorcerer is the antithesis of Moses. In this opposition we can see how prophecy serves as a function of both social relations and of personal situation. 'Moses and Balaam serve as visible gestures either of divine patronage and protection or divine displeasure and enmity (p. 130).' (DTR)

8906. F. Blanchetierre, 'Au cœur de la cité: le chrétien philosophe selon l' «A Diognète 5-6"', Revue des Sciences Religieuses 63 (1989) 183-194, esp. 188-190.

The place of the Christian in the world is paradoxical: he is in the world, but not of the world. His attitude is always 'against the stream', and for this reason he is often persecuted. This theme is already found in Philo, and is described in the significant metaphor 'resident alien', or, in a more general sense, in the motif of migration. (RR)

8907. M. N. A. Bocкmuenl, Revelation and Mystery in Ancient Judaism and Pauline Christianity, WUNT 2.36 (Tübingen 1989), esp. 69-81.

A chapter is devoted to Philo in this 'theological study of ancient Jewish and Pauline views of the revelation of heavenly mysteries (1).' Philo offers a model of what revelation might mean in a Hellenistic setting. The conclusion reached is that 'Philo's middle Platonism substantively dictates an understanding of revelation in terms of a philosophical-mystical knowledge of God as Being. This knowledge, also called "prophecy", is prompted by the 
allegorical interpretation of the Torah, a practice to which the term "mysteries" here applies as a metaphor from Hellenistic philosophy and religion (p. 81).' (DTR)

8908 A. Bonato, 'Il ruolo universale del sacerdozio di Cristo nell'allegoria delle città-rifugio (Fug. Saec. 2,5-13, 3,14-16): una rilettura dell'esegesi filoniana da parte di Ambrogio', Studia Patavina 36 (1989) 57-87.

Ambrose's De fuga saeculi is a classic example of how the Church father reads Philo's exegesis and adapts it to his own purposes. The article focuses in particular on the exegesis of the episode of the Cities of Refuge in Numbers 35. These are reinterpreted in the light of various NT passages, the main aim of which is to demonstrate the universal priesthood of Christ. (DTR, based on author's abstract)

8909. L. Brottier, 'L'episode des fleaux d'Egypte (Ex 7-11) lu par Philon d'Alexandrie et les Pères Grecs', Recherches Augustiniennes 24 (1989) 39-64.

The author analyses the episode of the plagues of Egypt in Ex. 7-11 (also with reference to Ps. 78) as it is found in the exegesis of Philo and the Fathers (esp. Origen and Gregory of Nyssa). The aspects that receive particular emphasis are: (a) the order of the plagues, which in Philo is rather different to the scriptural description; (b) the number, and (c) the agents of the various plagues. As far as the number is concerned, it needs to be said that the number 10 (just like 7, as in the Psalm) has a particular allegorical significance. The progression of the agents - the first three are attributed by Philo to Aaron, the second three to Moses, the seventh to Moses and Aaron together, the last three to God himself - clearly reveals a pedagogical intent: human power is limited, and needs the assistance of God. (RR)

8910. A. E. CAIrus, Protection and Reward: the Significance of Ancient Midrashic Expositions on Genesis 15:1-6 (dissertation Andrews University. 1989), esp. chap. 1.

Philo is one of the 'midrashic' sources analysed by the author in order to identify their theological and exegetical concerns as these progress over time. The more ancient sources emphasize the covenantal aspect of the passage, the later documents stress Abraham's eschatological reward. (DTR; based on DA 50/07-A p. 2093)

8911. J. Cazeaux, 'La parabole attire la parabole, ou le problème des sequences de paraboles (Philon et Matthieu ch 13)', in J. Delorme (ed.), Les paraboles evangeliques: Perspectives nouvelles, XII Congrès de l'ACFEB, (Lyon 1987), Lectio divina 135 (Paris 1989) 403439, esp. 403-406. 
For Cazeaux there is a formal law which causes one image to be linked to another, so that allegories are arranged in a sequence. On this basis he sets out to inquire into the reasons which 'compel or at least invite Philo to order interrelated allegorical variations under a single theme and Matthew to put together seven parables in a 'chapter' ... which is an organism where each member has a function of its own, but is ordered as part of the whole' (p. 404). To demonstrate this symmetry, Cazeaux discusses Fug. 117-201 and briefly illustrates its allegorical structure. (RR)

8912. J. Cazeaux, La trame et la chaîne: II le cycle de Noë dans Philon d'Alexandrie, ALGHJ 20 (Leiden 1989).

In this work, which is a sequel to a previous book with the same title (cf. R-R 8320), Cazeaux gives a structural interpretation (cf. 8) of the Noah cycle consisting of Gig., Deus, Agr., Plant., Ebr., and Sobr. The analysis of the first two treatises fills the first part, that of the last four the second part. Cazeaux's interpretative strategy is a special one: he regards the single works as 'chapters' of a larger structure, which in this case comprises the entire Noah cycle. In this way, according to Cazeaux, 'each local exegesis agrees with the specific angle of the work. It is as if the constellation of the texts and the notions is framed by one of its points, which has become the point of view for the occasion, with the distortions this involves, since on every page the exegete has a complete but distorted panorama of the whole system.' Thus the latent and significant structure of Gig. involves a cycle of transformations which goes from the angels to the giants, but which on another level of interpretation involves the transition from microcosm to macrocosm and to a different division of heaven (cf. the diagram on p. 58). Moreover, the largest chapter, formed by Gig. and Deus, implies a stratification of transformations in which a prominent position is occupied by the exegetical chains formed by the figures of Abraham, Hannah, Tamar and by Onan-Balaam (142). Even more complex, though subordinate to the overall cyclical structure, is the structure of Sobr., articulated in three phases: one conceived of as an (apparently) linear exegesis, another as a philosophical exegesis, the third as a dialectical exegesis. The meaning of these analyses - only a few examples have been mentioned here - is to demonstrate that 'the coherence of Philo's works is to be sought in the movement by which they follow the inspired text in its presumed continuity'. But precisely because of his unitary interpretation, which leads him to construct larger and larger agglomerates, Cazeaux is obliged to engage in a polemic with Nikiprowetzky (cf. R-R 7731), who postulates a close relationship between the Quaestiones and the treatises, and thus moves in an opposite direction in that he adopts an 'atomizing' approach (p. 273). Reviews: R. M. Berchmann, RelStR 16 (1990) 83-84; G. E. Sterling, CrRBR (1991) 351-355; M. Alexandre jr., SPhA 4 (1992) 153-156; J. Dillon, VChr 46 (1992) 83-87. (RR)

8913. J. Cohen, "Be Fertile and Increase, Fill the Earth and Master It": the Ancient and Medieval Career of a Biblical Text (Ithaca-London 1989), esp. 72-76. 
Philo is touched upon in the course of this fascinating account of the interpretation of a crucial biblical text from its time of writing until the end of the medieval period. Like other Hellenistic writers Philo shows more interest in the dominion of the first humans over nature than in their reproductive fertility, and hardly makes any direct reference to Gen. 1:28. (DTR)

8914. M. G. Crepaldi, 'Meraviglia filosofica e meraviglia teologica nel pensiero antico: Aristotele e Filone di Alessandria', in Annuario 1963-1988 del Ginnasio-Liceo “C. Bocchi” di Adria (Adria 1989) 53-60, esp. 56-59.

Wonder as the essence of philosophical knowledge (since it is enquiry into causes and especially into the First Cause) is a concept dear to Philo's heart. At the same time he seems to distinguish in his work between two types of wonder: a philosophical kind, typical of those who reach the Creator solely through the creation, and a superior theological kind, typical of those who discover God through direct revelation. (RR)

8915. L. A. Darrach, Coleridge's Logocentric Universe: the Translucent Word and the Consubstantial Symbol (dissertation University of Toronto, 1989).

This thesis argues that Coleridge places his theory of the symbol in the context of the Logos tradition that evolved from Heraclitus through Philo Judaeus to John the Evangelist and the early Church Fathers. (DTR; based on DA 50/09-A p. 2905)

8916. B. Decharneux, 'Anges, démons et Logos dans l'œuvre de Philon d'Alexandrie', in J. Ries and H. Limet (edd.), Anges et démons: Actes du Colloque de Liège et de Louvain-la-Neuve 25-26 Novembre 1987, Homo Religiosus 14 (Louvain-la-Neuve 1989) 147-175.

Arguing that Philo's angelology is based on the concept of the Logos as 'focus' of the various functions of the angels - and in this the author sees a prevalence of the Greek over the Jewish component - , Decharneux recognizes two religious and two philosophical aspects in this doctrine. From a philosophical point of view, the angels inhabit the intelligible world and are linked to the Platonic theme of the migration of the soul. From a religious point of view, the existence of a double hierarchy is supposed: that of the angels involved in the battle against evil and that of the guardian angels of the righteous and of Israel. Decharneux's conclusion is that here, too, 'Philo constructed a bridge which will enable Christian thought to be formed on the basis of Greek philosophy' (p. 170). Review: J. C. Reeves, $C B Q$ 58 (1996) 704-705. (RR) 
8917. B. A. G. M. Dehandschutter, 'Martyrium und Agon: über die Wurzeln der Vorstellung vom АГ $\Omega \mathrm{N}$ im Vierten Makkabäerbuch', in J. W. van Henten (ed.), Die Entstehung der jüdischen Martyrologie, Studia Post-Biblica 38 (Leiden 1989) 215-219.

This brief contribution asks the question why the author of 4 Maccabees so explicitly makes use of the image of the contest ( $\dot{\alpha} \gamma \omega \dot{v})$ for the Jewish martyrs whose death he describes. Philo's Prob. (esp. 21-30) shows that the theme of the struggle for virtue which may involve an honourable death was a widespread theme in anterior hellenistic literature. (DTR)

8917a. A. J. Dewey, 'Acoustics of the Spirit: a Hearing of Romans 10 (Deut 30:11-14)', in T. Callan (ed.), Proceedings of the Eastern Great Lakes and Midwest Bible Society vol. 9 (1989) 212-230.

As the title is meant to indicate, the article concentrates on the oral aspect of Paul's address to the Romans, in which an utopian perspective is presented. The quotation of scripture in the form of Deut. 30:11-14 is an act of power, to which the congregation has access through the oral experience of reading aloud. Philo is then introduced for comparative purposes, with special attention paid to his use of the same Pentateuchal text. Philo uses the best available technologies and tries to promote utopian possibilities in a gradual and irenic manner, whereas Paul may well represent a counter-cultural position. (DTR)

8918. J. Dillon, 'Logos and Trinity: Patterns of Platonist Influence on Early Christianity', in G. VESEY (ed.), The Philosophy in Christianity (Cambridge 1989) 1-13; reprinted as study VIII in 9015.

A useful contribution written at a fairly general level on those Platonist theories and discussions that exerted some influence on the early development of the Christian doctrines of the Logos and the Trinity. Though not a Middle Platonist, Philo does give insights into Platonist Logos theology. Indeed the language he uses of the Logos 'is pregnant with promise and problems for Christian theologians of the second and third centuries (p. 4).' For the doctrine of the Trinity it is above all Neoplatonism in its Porphyrian form that provided a stimulus. (DTR)

8919. J. M. Dillon, 'The Theory of Three Classes of Men in Plotinus and Philo', in R. Link-Salinger (ed.), Of Scholars, Savants, and their Texts: Studies in Philosophy and Religious Thought; Essays in Honor of Arthur Hyman (New York-Bern 1989) 69-76; reprinted as study XX in $\mathbf{9 0 1 5}$.

Dillon observes a parallelism between a tripartition of men at Plotinus Enn. 5.9.1 and Philo Gig. 60-61 and asks how this can be, since he does not 
believe in direct influence. The Pythagorean schema of the three types of life

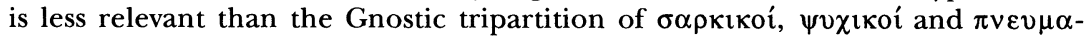

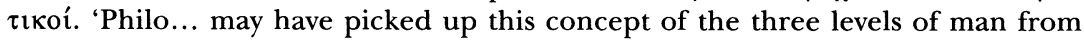
his contacts with the Essenes or Therapeutae, and Plotinus from a later stage in the Gnostic tradition (p. 75).' (DTR)

8920. A. J. Droge, Homer or Moses? Early Christian Interpretations of the History of Culture, Hermeneutische Untersuchungen zur Theologie 26 (Tübingen 1989), esp. 47-48.

Disappointingly brief remarks on Philo at the end of a long chapter on the Jewish historiographical antecedents to Christian apologetic literature. Philo differs from writers such as Eupolemus, Artapanus, and Josephus in that 'he shows relatively little interest in the problem of the history of culture (47). (DTR)

8921. M. FANDER, Die Stellung der Frau im Markusevangelium: unter besondere Berücksichtigung kultur- und religionsgeschichtlicher Hintergründe, Münsteraner Theologische Abhandlungen 8 (Altenberge 1989), esp. 277-279.

Philo's conception of marriage and sexuality, as developed above all in Ios., was profoundly influenced by Stoic morality, to which it particularly owes its strongly negative valuation of femininity. There can be no doubt that Philo identifies woman with pleasure and the senses, and man with reason, which should rule over his senses. (RR)

8922. R. A. Foster, The Role of Feminine Language and Imagery for God in the Development of a New Testament View of God (dissertation South-Western Baptist Theological Seminary, 1989), esp. part I, chap. 3.

The thesis argues that God in his complexity transcends sexuality. In part one the conceptual developments in divine imagery up to the Christian era are outlined, with Philo given a place in chapter 3, together with Jewish apocryphal writings, the Hellenistic sophia concept and worship of the mother goddess in the mystery religions. (DTR; based on DA 52/01A, p. 307)

8923. J. T. Greene, 'Balaam: Prophet, Diviner, and Priest in Selected Ancient Israelite and Hellenistic Jewish Sources', in D. J. LuLL (ed.), Society of Biblical Literature 1989 Seminar Papers, SBLSPS 28 (Atlanta 1989) 57-106, esp. 101ff.

Philo's interpretation of Balaam is not explored as such in this long survey of the Balaam tradition, but is rather the goal towards which it moves. The final pages thus set out a programme research, in which Philo's views - 
and the complex hellenistic exegetical tradition which they record - can be used to fill in the lacuna between Israelite and Islamic mantological exegesis of the Balaam theme. Cf. further 9025 and 9238 . (DTR)

8924. J.-N. Guinot, 'Sur le vêtement du grand prêtre: le $\delta \hat{\eta} \lambda$ os était-il une pierre divinatoire?’, Vetera Christianorum 26 (1989) 23-48, esp. 29-30, 39ff.

In Cyril of Alexandria a text is found which explains the urim on the High Priest's breastplate in terms of a divinatory stone. The author examines the anterior Jewish and Christian tradition, including Philo, in order to discover the provenance of this view. In Philo both a cosmological and a moral interpretation is given, but not what is found in Cyril. (DTR)

8925. J. HanegraAf, Met de Torah is het begonnen, vol. 2 De voortgang van het Jodendom in Tenach en Septuagint (Nijkerk 1989), esp. 107-128.

Just like it is said that Luther made Paul speak German, so Philo lets Moses speak Greek. This is the conclusion reached by the author on the basis of a brief synoptic presentation of Philonic thought, and especially the role of the Logos therein. (DTR)

8926. D. M. HAY, 'Pistis as "Ground for Faith" in Hellenized Judaism and Paul', Journal of Biblical Literature 108 (1989) 461-476, esp. $463-468$.

The term $\pi i$ i $\tau \iota \varsigma$ by no means always signifies subjective belief not based on evidence or objective grounds. The author presents evidence to show that in Jewish and Christian writings from the period of Christian origins the term is often used precisely in the sense of 'pledge' or 'evidence' on which subjective confidence of belief may be based. The 156 occurrences of $\pi$ í $\sigma \imath \varsigma$ in Philo are analysed into the semantic fields of pledge (11), evidence (82), loyalty (10), trust (15), belief (20), and other (18). The frequency of the meaning 'evidence' is striking indeed. Hay concludes on the basis of his discussion that 'some of his [Philo's] uses of pistis shed special light on his view of the interrelationship between human faith and its objective foundations. Philo thinks of humans as requiring revelatory signs from God on which to ground their religious convictions: evidence in the natural order, in biblical statements and events, and in certain unique or customary happenings of his own day... Faith is no arbitrary leap into the darkness (p. 468). (DTR)

8927. R. HAYWARD, 'The Date of Targum Pseudo-Jonathan: some Comments', The Journal of Jewish Studies 40 (1989) 7-30.

The author is struck by the affinity of Ps.Jonathan's exegesis of Gen. 27 with Philonic material, which argues for a potentially pre-Christian origin for some of the exegetical material in the Targum (29). (DTR) 
8928. A. Hilhorst, "Servir Dieu' dans la terminologie du judaisme hellénistique et des premières générations chrétiennes de langue grecque', in A. A. R. Bastiaensen, A. Hilhorst and C. H. KNEEPKens (edd.), Fructus centesimus: mélanges offerts à Gerard J. M. Bartelink à l'occasion de son soixante-cinquième anniveraire, Instrumenta Patristica 19 (Steenbrugge-Dordrecht 1989) 177-192.

Analyses a group of verbs which refer to the concept of 'fear of God' and

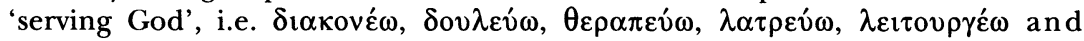
$\dot{v} \pi \rho \varepsilon \tau \varepsilon \dot{\varepsilon} \omega$. Philo's writings are mainly used to define the meaning of $\theta \varepsilon \rho \alpha \pi \varepsilon v ́ \omega$ (a frequent term in Philo) and, to a lesser extent, of $\lambda \alpha \tau \rho \varepsilon v ́ \omega$ and

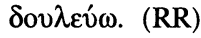

8929. A. VAN DEN HoEK, 'The concept of $\sigma \hat{\omega} \mu \alpha \tau \hat{\omega} v \gamma \rho \alpha \varphi \hat{\omega} v$ in Alexandrian Theology', in E. A. Livingstone (ed.), Studia Patristica vol. XIX: Papers presented to the Tenth International Conference on Patristic Studies held in Oxford 1987 (Leuven 1989) 250-254.

Where does the application of the image of body and soul to scripture body as the letter, soul as the underlying meaning - found in Origen come from? The earliest occurrence is in Philo, Contempl. 78 and Migr. 93. From Philo it passed to Clement and Origen, and from there it came to play an important role in the hermeneutic tradition. (DTR)

8930. D. N. Jastram, Philo's Concept of Generic Virtue (dissertation University of Wisconsin at Madison, 1989).

In Philo's use of allegory to integrate Greek philosophy with the Jewish Pentateuch he uses certain technical terms in his ethical theory in order to expand a simple distinction between genus and species into numerous levels including generic virtue, specific virtues, and particular acts of specific virtues. In addition to this vertical classificatory dimension he incorporates another horizontal dimension in which he distinguishes the imperishable archetype (i.e. the 'genus') from the perishable copy (i.e. 'species'); the former he equates in many respects with Platonic forms. The dissertation examines the way in which Philo uses these schemata, with a particular concentration on the notion of generic virtue. Generic virtue itself is on a level relatively close to God who is its cause and essence; like God it becomes less describable the more generic it is. Methods of attaining generic virtue are represented by the three patriarchs, and on a higher level, by Moses. Philo also often refers to spiritual escape as a means for attaining generic virtue, ultimately by death or physical assumption. Nevertheless it is also to some degree attainable during life through deeds of virtue. See further the author's presentation of his main thesis in 9136. (DTR; based on DA 50/09-A p. 2905) 
8931. H.J. Klauck, 'Die heilige Stadt: Jerusalem bei Philo und Lukas', in IDEM, Gemeinde-Amt-Sakrament: neutestamentliche Perspektiven (Würzburg 1989) 101-129.

Reprint of the essay listed under R-R 8627, with a brief Literaturnachtrag containing items published in 1987-88. (DTR)

8932. C. R. Koester, The Dwelling of God: the Tabernacle in the Old Testament, Intertestamental Jewish Literature, and the New Testament, CBQ.MS 22 (Washington 1989), esp. 58-67.

As part of his comprehensive analysis of interpretative traditions concerning the tabernacle the author devotes a brief section to Philo, in conjunction with the Wisdom of Solomon and Josephus. A useful table is given on p. 60 outlining the similarities and differences between Philo and Josephus in their cosmological interpretation. Both allegorical and 'literal' interpretations are discussed in a rather superficial manner. (DTR)

8933. R. S. Kraemer, 'Monastic Jewish Women in GrecoRoman Egypt: Philo Judaeus on the Therapeutrides', Signs: Journal of Women in Culture and Society (Chicago) 14 (1988-89) 342-370.

Because there are virtually no accounts of communities of Jewish women in antiquity, Philo's presentation of the Therapeutrides (female Therapeutae) is particularly significant. Four aspects in his description deserve attention: they are virgins, advanced in age, have sought Wisdom as spouse, and have no children. Kraemer discusses these features at length, paying attention to the assumptions on the nature and role of women held by Philo and the community of Alexandrian Judaism. Philo's evidence shows that it is erroneous to make a contrast between the role of women and female communities in Judaism and in Early Christianity. (DTR)

8934. P. KuHN, Offenbarungstimmen im Antiken Judentum: Untersuchungen zur Bat Qol und verwandten Phänomenen, TSAJ 20 (Tübingen 1989), esp. 153-175.

In connection with the subject of the divine voice of revelation Kuhn discusses four passages in particular: Decal. 32-35 (156-167) and 46-49 (167168), Migr. 47-52 (169-172), and $Q E 2.68$ (172-174). He draws the following conclusions from the analysis of these texts. (1) Philo occupies a special position in ancient Jewish literature in that he reflects profoundly on the nature and origin of the $\theta \varepsilon i ́ \alpha \varphi v \eta$ on the basis of theologico-philosophical concepts of Greek origin. (2) There are parallels between Philo and the Rabbinic tradition both from a formal point of view - the Pentateuch being conceived of as absolutely normative - , and in terms of content - the acceptance of innumerable intermediate realities between God and the world-, though this does not necessarily imply a reciprocal influence. (3) Philo takes an 
eminently spiritual view of how the revelation is received. (4) God is increasingly alienated from the world and the privileged relationship with his people is largely lost. (5) Philo's work should be considered in relation to the writings of other Jewish-Hellenistic writers, in particular Aristobulus, Artapanus, and Josephus. (RR)

8935. E. LAMIRANDE, 'Le masculin et le feminin dans la tradition alexandrine: le commentaire de Didyme l'Aveugle sur la 'Genèse', Science et Esprit 41 (1989) 137-165.

A valuable contribution in which Didymus' debts to the Alexandrian tradition are examined in his views on the relation between man and woman. Among the themes discussed are the double creation of man, the superiority of man and inferiority of woman, the role of pleasure in man's fall, attitude to marriage and procreation, the role of asceticism. The influence of Philo on Didymus' thought is very strong, as the author can show through numerous references to Opif. and the allegorical treatises. Through the discovery of Didymus' exegetical works fifty years ago, we now have proof that the teachings of Philo (and Clement and Origen) remained alive and influential in the Alexandria of the fourth century. (DTR)

8936. J. Laporte, 'Sacrifice and Forgiveness in Philo of Alexandria', The Studia Philonica Annual 1 (1989) 34-42.

Taking his point of departure in the article of $\mathrm{V}$. Nikiprowetzky on the spiritualization of sacrifices in Philo, Laporte examines what is for Philo the obvious and common meaning of ritual purification, for sin and Yom Kippur, and secondly what is their symbolic interpretation. Comparisons are also made with parallel treatments in early Judaism. The ritual of sacrifice is given because man cannot acquire forgiveness on his own. It is for God to forgive, and forgiveness by means of expiation is the perfect process. (DTR)

8937. A. Le Boulluec and P. Sandevoir, La Bible d'Alexandrie, vol. 2 L'Exode (Paris 1989) passim.

In their introduction the authors affirm that Philo inscribes his name in the truly religious tradition of Israel, that which is expressed in Siracides and the Wisdom of Solomon. In him one finds earlier themes brought to their fullest conclusion: Moses the legislator; Moses the sage par excellence; moreover, one notes the central role attributed to Moses as inspired prophet (p. 30).' They further conclude that Philo's treatises 'are nourished by the thought of Exodus', and this is confirmed by the annotations to the text of Exodus, where Philo's works are copiously cited. (RR)

8938. J. Mansfeld, Studies in Later Greek Philosophy and Gnosticism, Variorum Collected Studies Series (London 1989). 
Reprints four studies which are wholly or in part devoted to Philo: I 'Providence and the Destruction of the Universe in Early Stoic Thought' = R-R 7924; VII 'Heraclitus, Empedocles and Others in a Middle Platonist Cento in Philo of Alexandria' = R-R 8430; $X$ 'Philosophy in the Service of Scripture: Philo's Exegetical Strategies' = 8847; XIV 'Bad World and Demiurge: a 'Gnostic' Motif from Parmenides and Empedocles to Lucretius and Philo' = R-R 8114. (DTR)

8939. J. P. Martín, 'La antropología de Filón y la de Teófilo de Antioquia: sus lecturas de Genesis 2-5’, Salmaticensis 36 (1989) 23-71.

Theophilus avoids every kind of cosmic and anthropological dualism, as well as the christological implications of the subject of paradise and the first Adam. He takes over something from Paul and something from Philo in order to reject completely the Gnostics and Marcionites who have deepened the duality of ontological levels and the duality of history. $\mathrm{He}$ is one of the first Christian thinkers to work out the view of the resurrection of the flesh. The resurrection is presented as a continuation of the work of creation. Exegetical continuities between Philo and Theophilus constrain us to assert a dependence of the latter on the former. (RR; based on the author's summary at the end of the article)

8940. J. P. Martín, 'Traducciones de filosofos juios en la bibliografie argentina', Pensamiento 45 (1989) 207-222, esp. 208-211.

Discusses the Argentinian translations of Philo by J. M. Triviño (all the Greek works, = R-R 2301-2305) and F. de P. Samaranch (Prob. only, = R-R 3251). The former is based on the original Greek, the latter only on the English translation of Colson. Martín offers some criticism of Triviño's method of dealing with technical philosophical terms, but considers the work as a whole a valuable contribution. (DTR)

8941. S. McKnight, 'De Vita Mosis 1.147: Lion Proselytes in Philo?', The Studia Philonica Annual 1 (1989) 58-62.

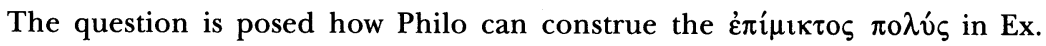
12:38 at Mos. 1.147 in such a clearly demarcated three-fold division of Gentile proselytes. This view is too close to targumic and rabbinic understandings to be accidental. McKnight suggests that Philo's text uncovers views on proselytes that have hitherto been documented only for the 2nd century CE. The interpretation is given further support by another passage, Virt. 102-108 (DTR)

8942. J. M. Murdoch JR., Teleological Perfection in the Thought of Clement and Origen, (M. A. thesis Miami University, 1989).

Relevant themes from Philo are discussed as background to an examination of teleological ideals in 2nd and 3rd century Alexandria, as found above 
all in the writings of Clement and Origen. (DTR; based on Masters Abstracts 28/02 p. 212)

8943. J. Murphy-O'Connor, 'Philo and 2 Cor 6:14-7:1', in L. DE Lorenzi (ed.), The Diakonia of the Spirit (2 Cor 4:7-7:4), Monograph Series of «Benedictina», Biblical-Ecumenical Section 10 (Rome 1989) 133-160.

The same article as $\mathbf{8 8 5 6}$, here published together with the contributions, on pp. 146-160, of 24 scholars (including the author) to the discussion which followed the lecture when it was originally held in 1987 in Rome. (HMK)

8944. V. Nikiprowetzky, 'Le thème du désert chez Philon d'Alexandrie', in Y. Christie, M. Sartre, B. Urio, I. Urio (edd.), Le désert: image et réalité; actes du colloque de Cartigny 1983, Les cahiers de CEPOA 3 (Leuven 1989) 99-113; reprinted in 9659.

This study, written just before the author's death in 1983, aims not only to discuss Philo's interpretation of the Jews' wanderings in the desert after the Exodus, but also to ascertain the meaning of the desert to Philo's contemporaries, esp. the Therapeutae and Essenes. To Philo the desert is partly a horrific place, full with hardships and dangers and therefore a fitting place for the rebellious Jews of the Exodus to be punished by God. On the other hand the desert is also a most excellent place for the Jews to be initiated in the divine philosophy. It is where they receive the divine Laws that enable them to live well. The Exodus into the desert means a breaking away from the civilised, luxurious life that distracts the human mind from God and thus offers the Jewish community the possibility to approach God, a mystical experience both for the community as a whole and for the individual. This also applies to the Therapeutae and Essenes of Philo's own time. For them the desert is no longer a solitary and horrible place, but a place of joy because it removes all opportunities for self-love that may intervene between man and God. (RMB)

8945. V. Nikiprowetzky, 'Thèmes et traditions de la lumière chez Philon d'Alexandrie', The Studia Philonica Annual 1 (1989) 6-33.

Published posthumously - the author passed away at the age of 64 in 1983 - , this article is the unannotated and unrevised typescript of the address given at the conference on Exegetical traditions in Philo of Alexandria held at Claremont on 20-22 October 1977. Though merely an outline, the article is important for two reasons: (1) it illustrates what Nikiprowetzky regarded as the correct methodology for approaching a thematic study on Philo; (2) it offers valuable insights into a central theme in Philo's project for interpreting the Pentateuch. After some preliminary methodological remarks, the author outlines the various themes and traditions associated with light in Philo's writings, beginning with light in the divine domain (cf. esp. Opif.), 
light in the created domain ( $\varphi v \sigma \imath \lambda o \gamma i \alpha)$, light in anthropological perspective (man's fall, cf. esp. Legum Allegoriae), light in man's intellectual and mystical ascent. The article ends with a brief survey of what Nikiprowetzky regarded as the central thrust of Philo's allegorization of the Pentateuch. The central themes are those of migration and freedom: the mind is freed from the body and enters into virtue after the mystical experience of Sinai. Against this background further important themes are those of the wise man, the festivals, the temple. On the collective level these themes are developed into an Heilsgeschichte of Israel, and are concretely manifested in the community of the Therapeutae. A valuable bibliography on the theme of light in Philo and Greek Philosophy is appended. (DTR)

8946. M. Petit, 'L'homme politique: interprète de rêves selon Philon d'Alexandrie (De Iosepho 125: ó $\pi \mathrm{o} \lambda$ ıкı

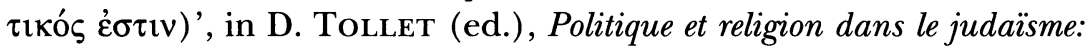
Interventions au Colloque des 8 et 9 décembre 1987 organisé par le Centre d'Études Juives de l'Université Paris-IV Sorbonne (Paris 1989) 41-54.

The relation between the man of politics and the interpreter of dreams, as presented above all in Ios. 125, has two aspects: (1) Joseph has become the $\pi 0 \lambda \imath \tau \imath$ kó $\varsigma$ precisely because he has interpreted Pharaoh's dreams; (2) the world in which we live is nothing but empty appearance, and so is similar to a dream, i.e. the man of politics holds sway in the domain of dreams. Petit attempts to advance beyond this interpretation. Pointing out the predominantly literal character of the first exegesis and allegorical character of the second, she concludes that Philo, when he wishes to speak in general about the nature of the $\pi 0 \lambda \imath \tau 1 \kappa o ́ s$, customarily follows the second type of exegesis, but when he wishes to refer to a specific historical personage, he makes use of the literal interpretation (p. 48). (RR)

8947. B. Pouderon, Athénagore d'Athènes philosophe chrétien, Théologie historique 82 (Paris 1989), esp. 270-274.

The author turns to Philo in order to illuminate Athenagoras' doctrine of angels. In his writings Philo expressed an original theory of angels and demons, without positing substantial differences between the two entities (indeed, he seems to have used the two terms synonymously). For Philo angels and demons are part of a hierarchical structure of psychic beings, functioning as intermediaries between God and man. (RR)

8948. R. RADICE, Platonismo e creazionismo in Filone di Alessandria, Introduzione di G. Reale, Metafysica del Platonismo nel suo sviluppo storico e nella filosofia patristica: Studi e testi 7 (Milan 1989).

In this book the author attempts to give a convincing demonstration of the following thesis: Philo was indebted to Greek philosophy, but he also gave much in return, since he not only took many themes and ideas from Platonism, but also made fundamental contributions to Platonism - mainly 
in the area of theology - which influenced its development. The first among these is the concept of the ideas as the thoughts of God, which modifies Plato's entire metaphysical structure by ontological priority to God rather than the Ideas. Naturally enough, this concept - which is shown to be Philonic or at least of Jewish-Alexandrian origin (cf. pp. 229-319) - directly affects the concept of creation, which is the author's main subject. He distinguishes and describes three types of creation in Philo: 'diaeretic', 'phyturgic', and 'protological' creation, which he then reduces to a common foundation, what he calls the 'biblical theorem' or the attribution of a creative power to the thought and word of God. It is on this foundation that Philo's theory of creation is based, and it is this exclusively Jewish theme which gives rise to the new philosophical theory of creation which Philo introduces into the Greek tradition. The Philonic theory of creation, maintaining as it does an intermediate position between creation ex nihilo and demiurgic creation (Plato), can be called 'foundational' (378ff.) inasmuch as it regards God as the creator ex nihilo of 'positive reality' but not of its negative aspects. In his 'General Conclusions' the author suggests that Philonic morality, too, is based on a 'foundational' theory of creation, in which God is not only creator of the physical cosmos but also of the ethical cosmos, as seen in its positive values and in its ideal virtues (p. 383ff.). See further 9161, which is a summary of the main points of the author's thesis. Reviews: H. Crouzel, BLE 91 (1990) 74f.; J. P. Martín, Meth 3 (1990) 119-127 and RFN 82 (1990) 146-165; G. Pelland, Gr 71 (1990) 604; G. L. Martinez, Pens 47 (1991) 251-252; L. Rizzerio, RPhL 90 (1992) 96-99; D. Winston, SPhA 4 (1992) 159-164. (RR)

8949. W. Richardson, 'The Philonic Patriarchs, Buddha, and Clement of Alexandria's True Gnostic', in E. A. Lrvingstone (ed.), Studia Patristica XXI: Papers presented to the 10th International Conference on Patristic Studies held in Oxford 1987 (Leuven 1989) 325-332.

Clement knew about Buddha and this posed a problem for him. If Buddha was such a remarkable parallel for Jesus Christ, how could Clement defend the unique claims of Christianity? For his solution he turns to the Philonic

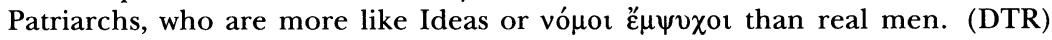

8950. L. Rosso Ubigli, 'L'immagine di Israele in Filone di Alessandria', Ricerche Storico-Bibliche, 1 (1989) 81-97.

This study deals with Philo's historical and religious conception of 'Israel', as can be found in particular in Flacc., Legat., and Spec. Philo's thought is seen against the background of the Judaism of his time, i.e., against the historical reality of the diaspora (both in Alexandria and in the rest of the Mediterranean world) which created a broadening of the concept of 'Israel' to the effect that this concept lost its characteristics of ethos (connected to a certain territory) and genos (connected to consanguinity). The synthesis brought about by Philo between universalism and particularism has theological and religious foundations which could provide Israel with a new role of 'mediator' between other nations. (RR) 
8951. J. R. Royse, 'Cain's Expulsion from Paradise: the Text of Philo's Congr 171', The Jewish Quarterly Review 79 (1989) 219-225.

According to the mss. of Philo of Alexandria's Congr. 171, God expelled both Adam and Cain from Paradise. Believing that Philo could not have thought that Cain had ever been in Paradise, Mangey and Colson wished to emend 'Cain' to 'Eve'. However, a tradition found in bSanh 38b and elsewhere places the birth of the first two (unnamed) children before the first sin and the subsequent expulsion from Paradise. Hence, consistently with such a tradition, Philo could well have thought that God literally expelled these first two children from Eden. In related texts, Philo show that he thought that these children were Cain and Abel, and that they were twins. There is thus no reason to reject the reading of the manuscripts in Congr. 171. (DTR; based on author's abstract)

8952. D. T. Runia, 'The Image of the King and the Architect in Philo's De opificio mundi', in E. A. Livingstone (ed.), Studia Patristica XVIII: Papers of the 1983 Oxford Patristics Conference (KalamazooLeuven 1989) 2.133-136.

Brief examination of Philo's image at Opif. 17-18; cf. also 8955, below.

8953. D. T. RuniA, 'Philo, Jood en Alexandrijn', Lampas 22 (1989) 205-218.

A synoptic general presentation of Philo, with emphasis on his attitude to the problems of acculturation in the predominantly Hellenic cultural environment of Alexandria. An English translation, published under the title 'Philo, Alexandrian and Jew', is published as study I in 9059. (DTR)

8954. D. T. Runia, 'Philo van Alexandrië: een jood als kerkvader honoris causa', Beweging 53 (1989) 66-70.

A brief account written at a popular level of how Philo's Jewish thought came to be influential in the early Christian church. Eusebius was factually wrong to identify the Therapeutae with the first Christians in Alexandria. Yet in some respects there was more continuity between this 'proto-monastic' community and the Church fathers than there was between the Therapeutae and the Rabbinic Jews of Eusebius' own time. (DTR)

8955. D. T. Runia, 'Polis and Megalopolis: Philo and the Founding of Alexandria', Mnemosyne 42 (1989) 398-412.

Argues that Philo's celebrated image of the founding of a city at Opif. 17-18 is inspired by accounts of the founding of Alexandria by Alexander the Great, as demonstrated on the basis of a number of literary parallels. The recognition of this background has some interesting repercussions for the interpretation of the passage. The article ends with some brief remarks on the use of a 
similar image by Rabbi Hosha'ia recorded in Genesis Rabbah, which is almost certainly derived from Philo, but contains some instructive modifications. (DTR)

8956. C. Salvaterra, 'Considerazioni sul Progetto di Caligula di visitare Alessandria', in L. Criscuolo and G. Geraci (ed.), Egitto $e$ storia antica dall'Ellenismo all'età araba: bilancio di un confronto; Atti del colloquio Internazionale, Bologna 31 agosto-2 settembre 1987 (Bologna 1989) 631-656.

The projected voyage to Alexandria by Caligula is discussed in three sources: Suetonius, Josephus, and Philo in his Legatio ad Gaium. The motivation for the voyage given by Philo - which has been regarded as probable by almost all historians - is that the emperor wished to bring to completion the process of self-divinization in this city (Legat. 338). Salvaterra suggests and supplies solid arguments for another hypothesis, that the emperor's mission was tied to the political situation in the city at this time, and in particular to the unrest in $38 \mathrm{CE}$. In order to demonstrate his thesis Salvaterra makes extensive use of the Philonic treatises Flacc. and Legat. (RR)

8957. K. G. SANDELIN, 'Dragning till hednisk kult bland judar under hellenistisk tid och tidig kejsartid [in Swedish = Attraction towards Pagan Cults among Jews during the Hellenistic and Early Imperial Era]', Scandinavian Jewish Studies [Nordisk Judaistik] 10 (1989) 11-26.

There exists evidence that some Jews did participate in pagan cults during the time of the Greek and the Roman hegemonies in the eastern Mediterranean area. Examples may be shown of clear deviations from the basic Jewish principle not to mingle with heathen devotional activities both inside the Jewish realm (Maccabees) and outside it (papyri and inscriptions). In some instances Jews were forced to join pagan cults, in other cases they did it without external pressure. In Wisdom and in Philo we find a polemical attitude towards such behaviour. Jews were also in a more indirect way brought under pagan influence by athletic contests and theatre, education in the gymnasia and adjustment to architectural and artistic endeavours. (KGS)

8958. W. R. Schoedel, 'Apologetic Literature and Ambassadorial Activities', Harvard Theological Review 82 (1989) 55-78, esp. $63-69$.

The author examines Philo's Legatio in order to illuminate Christian apologies such as those of Athenagoras and Justin. Information that it contains on documents presented to the Emperor indicate that these took the form of a petition rather than an apology. As for the work itself, it is an example of epideictic literature, or more specifically, of invective. This explains

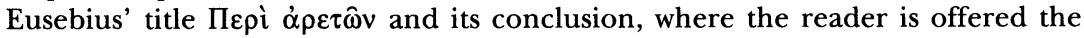
prospect of a 'palinode'. (DTR) 
8959. W. Schrage, 'Zum Verhältnis von Ethik und Vernunft', in H. MerkLein (ed.), Neues Testament und Ethik: für Rodolf Schackenburg (Freiburg 1989). 482-506, esp. 488-491.

A brief discussion of the role of vov̂s and rationality in Philonic ethics. Although Philo's synthesis of revelation and rationality is in many ways impressive, the debet side is a world-denying spiritualization. Note that in the table of contents the article is given the title 'Komparitive Ethik im Neuen Testament'. (DTR)

8960. W. L. Schutter, 'Philo's Psychology of Prophetic Inspiration and Romans 10:20', in D. J. LuLL (ed.), Society of Biblical Literature 1989 Seminar Papers, SBLSPS 28 (Atlanta 1989) 624-633.

In order to gain insight into Paul's use of the verb $\dot{\alpha} \pi \circ \tau \circ \lambda \mu \alpha \dot{\omega}$ at Romans 10:20 to introduce a quotation from the prophet Isaiah, Schutter turns to Philo's use of the verb, all the instances of which are carefully examined. Especially the parallel at Prob. 43 concerning Moses encourages him to conclude that Paul is emphasizing the divine compulsion under which Isaiah delivered his oracle. (DTR)

8961. D. R. Schwartz, 'Philonic Anonyms of the Roman and Nazi Periods: Two Suggestions', The Studia Philonica Annual 1 (1989) 63-73.

The article consists of two parts which only have in common that they concern a person whose name we do not know. In the first it is argued that various clues point to the identification of the Egyptian 'governor' who attempted to force the Jews to refrain from Sabbath observance (Somn. 2.123132) with Philo's nephew Tiberius Julius Alexander. Secondly Schwartz notes that two of the translators of vol. 5 of the German translation of Philo, published in 1938, are anonymous. It was suggested to him by M. Mach that this might indicate that they were non-Jews. The translator of Somn. was Hans Leisegang, as Schwartz can easily prove. The translator of Fug. remains more elusive, but there are good grounds for believing that it was Max Pohlenz. The article ends with some brief notes on the careers of the scholars involved in this volume. (DTR)

8962. D. R. Schwartz, 'On Drama and Authenticity in Philo and Josephus', Scripta Classica Israelica 10 (1989-90) 113-129.

'Philo's histories [in Flacc. and Legat.] are frequently quite enjoyably read or heard read, but this enjoyment sometimes results from a willingness to depart from the facts in order to make the story more dramatic. This, apparently, did not bother Philo, because he was out to write enjoyable and didactic historical novels (p. 119).' Apologetic aims too frequently interfere with Philo's historiography. (DTR) 
8963. A. B. Scotт, Origen and Astral Souls (Plato, Socrates) (dissertation Yale University, 1989).

Chapter two considers Origen's immediate intellectual predecessors in his view that the stars are ensouled. Confusions about how to talk about the stars are evident in Philo, whose theories about the heavens had a great impact on Origen. The dissertation was published in 1991; see 9177. (DTR; based on DA 50/11A p.3626)

8964. R. Sgarbi, 'Analisi linguistico-filologica della interpretazione armena della trattazione greca filoniana Intorno all'altare', Memorie dell'Istituto Lombardo: Accademia di Scienze e Lettere 39 (Milan 1989) 97-228.

This study analyzes from a linguistic-philological point of view the section

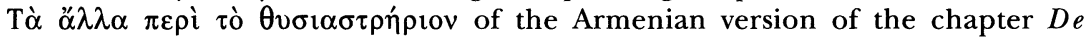
sacrificantibus which concludes the first book of Spec. $(=1.285-345)$. By comparing the Armenian text published by the Mekhitarist Fathers of San Lazzaro in Venice in 1892 and the corresponding Greek text of Cohn's critical edition, it is possible to make interesting discoveries concerning the translation technique of the 'Hellenistic School' to which the Armenian version belongs, and also to verify conjectural readings of Cohn or earlier scholars concerned with the Greek Philonic text. Review: M. Morani, Orph 12 (1991) 578-584; A. Terian, SPhA 8 (1996) 204-205. (RR)

8965. R. W. Sharples, 'The Criterion of Truth in Philo Judaeus, Alcinous, and Alexander of Aphrodisias', in P. HuBy and G. NEAL (edd.), The Criterion of Truth: Essays written in Honour of George Kerferd together with a Text and Translation (with Annotations) of Ptolemy's On the Kriterion and Hegemonikon (Liverpool 1989) 231-256, esp. 234f.

Philo's epistemology cannot be regarded as primarily Stoic, as argued by Dillon, because of its distinction between two types of reason, one on the basis of sense-perception, one dealing with things that are not sense-perceptible at all, as indicated clearly in $Q G 3.3$. (DTR)

8966. G. W. A. Thorne, 'The Structure of Philo's Commentary on the Pentateuch', Dionysius 13 (1989) 17-50.

A remarkable contribution, which claims to identify the basic structure and argument of Philo's commentary on scripture, taken to include all three series of exegetical treatises. Earlier scholars such as Nikiprowetzky, Mack and Cazeaux have recognized the central role of exegesis in Philo's work, but have not realized that there is a radical identity of the Word of God with philosophical truth (p. 22). This allows Philo to present an integrated corpus of exegesis with a rigorously symmetrical structure. The key to this structure is furnished by the De opificio mundi, and especially its opening, which asserts 
the intimate relation between cosmos and law (\$1-3) and the accessibility of the beauty of the ideas of creation through the prophet Moses (\$4-6). In this opening work the descent is outlined from the intelligible world created in the first six days to man in his corporeal fallen form who descends into the sensible realm. At this point allegorical discourse is introduced $(\$ 157)$. The integrity of the corpus follows from Opif. in that it will show how the fallen individual soul can achieve salvation (30). The role of the Exposition is to describe how the individual can be related to a transcendent God through the participation in the various levels of reality. The patriarchs as 'living laws' mediate between intelligible and sensible reality in the ethical realm. The treatise on the Special laws shows how individual laws are related to the intelligible world at several removes. Thorne claims that only in his interpretation can sense be made of the section on justice at the end of Spec. IV. Virt. describes the final descent of the soul in the ethical realm, while Praem. sums up the argument of the Exposition and forms a transition to the Allegory. On the Allegorical Commentary Thorne is very brief, defending its symmetries and structures, but arguing that there cannot be a logical progressive argument in this part because it is dealing with the sensible realm and has its limitations because it moves from the sensible and discrete to the intelligible (p. 36). The longest section of the article concentrates on the Quaestiones, which complete the commentary. $Q G$ 's task is to examine the intelligible order as it occurs within the soul, showing how the inner life of the individual progresses and locates its grounding in the intelligible. It brings the argument of the Philonic corpus to completion. $Q E$ is presented in the form of a recapitulation, 1.1-2.52 taking up the introductory section in Opif. 1-3, while 2.51-123 refers back to Opif. 4-6. Thorne concludes by repeating his claim that it is only when scholarship recognizes the overall structure of Philo's commentary that it can make proper analyses of individual treatises. (DTR)

8967. C. Touatı, 'Judaïsme talmudique et rabbinique: la découverte par le judaïsme de la Renaissance de Flavius Josèphe et de Philon le Juif', Ecole Pratique des Hautes Etudes, Section des Sciences Religieuses: Annuaire 97 (1988-89) 210-217, esp. 214-217.

The article briefly looks at the œuvre of Azariah dei Rossi, the Renaissance scholar who in 1573 rediscovered and introduced to the Jews of Italy, after years of oblivion, the figure of Philo. Azariah's chief concern was to confront the Talmudic tradition with that of Alexandrian Judaism. (RR)

8968. P. R. Trebilco, 'Paul and Silas - 'Servants of the Most High God' (Acts 16, 16-18)', Journal for the Study of the New Testament 36 (1989) 51-73, esp. 53ff.

As background to the use of the epithet $\ddot{\psi}$ i $\sigma \tau \sigma_{\circ}$ for God in Acts 16:17b the author examines Philo's usage and notes that he is 'generally cautious about the use of the term and is anxious to avoid misunderstanding (54).' (DTR) 
8969. A. Uña Juarez, 'Hermeneutica de las Ideas: de Platon a Ockham, pasando por Filón y San Agustin', La Ciudad de Dios 202 (1989) 173-230, esp. 201-209.

In order to understand the Augustinian conception of the Ideas it is necessary to study the analogous conception of Philo, which Una Juarez calls 'creationistic transformations of the ideas'. This development was historically possible through the meeting of the concept the idea with the non-hellenic cultural tradition in the figure of Philo. Philo, although strongly influenced by Platonism, always remained faithful to Judaism (p. 203ff.). The resultant fusion of culture leads on the one hand to a rigorously monotheistic and transcendent conception of God, and on the other hand to a revolution in the conception of the Ideas, which are no longer considered independent with respect to God, but rather internal to him, in the figure of the Logos (p. 208). The concept of the Logos is thus the key to interpreting the philosophical novelty of Philo. But, the author warns, it is a concept that is not entirely clear and is burdened with meanings that are not always mutually compatible. (RR)

8970. G. Veltri, 'Canone, scrittura e contesto immanente in alcuni testi del I secolo dopo Cristo (Philo Vit. Cont. 25, Lc 24, 44; Jos., Cont. Ap. I, cap. 8)', Laurentianum 30 (1989) 3-24, esp. 3-12.

Today there are two schools of thought on the canonization of the Scriptures. One, which could be called 'methodology of development according to a synthetic model', holds that there was a canon of Old Testament books from the very beginning and that it became defined more precisely in the course of time. The other, which could be called 'methodology of development at a selective level', postulates a initial moment of profuse literary production which was non-selective for lack of an official orthodoxy (5) and a successive moment of transmission in which the scribe 'updates' the received tradition and enriches it with new beliefs which are presented as ancient. At a certain point in this final hermeneutical phase, perhaps because of a political or cultural predominance, one particular exegesis gets the upper hand and establishes itself to the exclusion of the others. To support the latter solution, the author also quotes Philo, Contempl. 25, showing that the Philonic text cannot be taken as a reference to the three-part canon of the Jews, in view of the total non-specificity of the terms which it uses (12). (RR)

8971. G. M. VIAN, 'Interpretazioni giudaiche e cristiane antiche del sogno di Giacobbe (Genesi 28, 10-22)', XVII Incontro di studiosi dell'antichità cristiana. Sogni, visioni e profezie nell'antico Cristianesimo. Roma, 5-7 Maggio 1988, Augustinianum 29 (1989) 307-332, esp. 307-311.

The dream of Jacob described in Somn. 1.2-188 is classified here according to the familiar Philonic tripartition of dreams (cf. p. 308) and interpreted 
allegorically on a cosmological and anthropological level. This interpretation had an important influence on Christian exegesis, where one finds two different approaches to the dream: one which give preference to a mystic reading of the biblical passage and another, more decidedly christological, which identifies Jacob with Christ. The author illustrates both traditions with a wide variety of references - to Hippolytus, Tertullian, Origen, John Chrysostom, Clement of Alexandria, Justin Martyr, Augustine -, linking the Philonic treatment to the first tradition with ample documentation. (RR)

8972. H. D. Weiss, 'A Schema of 'The Road' in Philo and Lucan’, The Studia Philonica Annual 1 (1989) 43-57.

In the Hellenistic period the image of the journey with stages along the road became a schema for the moral life. Weiss compares two applications of this schema, Philo on Abraham in Migr. and Lucan on Pompey in De bello civili. Both works use historical events to argue a moral point, both regard progress as tied to mastery over passions. But there are also important differences. In Lucan the emphasis is on human achievement, and Pompey is very concerned with his mortality; in Philo the soul is orientated towards God, and death is not an issue. In Lucan we have an ethic of virtue, whereas Philo presents an ethic of obedience whose purpose is to live according to God. (DTR)

8973. N. Willert, Pilatusbilledet $i$ den antike jødedom og kristendom [in Danish = The Image of Pilate in Ancient Judaism and Christianity] (Aarhus 1989), esp. 25-60.

The book contains a series of detailed analyses of texts from Antiquity describing the figure of Pontius Pilate. The basic authors analyzed are Philo, Josephus and the writers of the Gospels of the New Testament. The Philonic text given special attention is Legat. 298-305. Like in the case of the writings of Josephus, Willert here detects political as well as religous tendencies. In his book, probably meant for Emperor Claudius, Philo wants to denounce the political order of having a Roman prefect stationed in Palestine. According to Willert neither Tiberius nor Pilate were anti-Semitic or anti-Jewish by principle. In some of their actions disapproved of by the Jews we may see examples of a nascent Emperor-cult instead. (KGS)

8974. D. Winston, 'Two Types of Mosaic Prophecy According to Philo', Jourmal for the Study of the Pseudepigrapha 4 (1989) 49-67.

See above $\mathbf{8 8 7 3}$. 


\section{0}

9001. Manuel Alexandre JR., Argumentação Retórica em Fílon de Alexandria, Bibliotheca Euphrosyne 4 (Lisbon 1990).

A comprehensive study on Philo's rhetorical argumentation and the role that rhetoric plays in the composition of his treatises. In the first part Alexandre gives a full account of the background of rhetorical theory and practice in the Greco-Roman world and of Philo's own theory of rhetorical argumentation. In the second part he focusses on how these theories are put into practice in Philo's own writings, organizing his examples under three headings: (a) formal structure of a discourse; (b) structures of a complete argument; (c) rhythmic and periodic structures (for this section see also 9101). An English summary of the main theses is provided at pp. 339-346. An English translation has now been published: Rhetorical Argumentation in Philo of Alexandria, BJS 322; Studia Philonica Monographs 2 (Atlanta 1999). Review: J. P. Martín, SPhA 4 (1992) 156-157. (DTR)

9002. Manuel Alexandre JR., 'Periodic Style in Philo of Alexandria', Euphrosyne 18 (1990) 39-52.

An earlier version of the article published by the author in the Earle Hilgert Festschrift. See below 9101. (DTR)

9003. Y. Amir, 'The Decalogue according to Philo', in B. Z. Segal and G. Levi (edd.), The Ten Commandments in History and Tradition, Publications of the Perry Foundation for Biblical Research: The Hebrew University of Jerusalem (Jerusalem 1990) 121-160.

English translation of the article earlier published in German and Hebrew; see R-R 8307, 8604. (DTR)

9004. K. Aspegren, The Male Woman: A Feminine Ideal in the Early Church (edited by R. Kieffer), Acta Universitatis Upsaliensis: Uppsala Women's Studies, A: Women in Religion 4 (Stockholm 1990), esp. 79-98.

This study deals with the view of the role and duties of women in both non-Christian and Christian environments, illustrated by a selection of authors from about $400 \mathrm{BCE}$ (Plato) to about $300 \mathrm{CE}$. A chapter on Philo sketches his method of interpretation in general, and his views on the creation, the fall, male and female, spiritual growth, salvation and marriage in particular. The way to salvation is in Philo expressed in terms of male and female. Man must overcome his female, i.e., weak, side in order to be male, i.e., strong and godlike. Philo sees in the female character as such the cause 
of the transgression of mankind against God. In his allegorical interpreta-

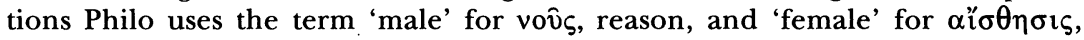
sense-perception: the two can be complementary to each other, but more often they are treated by Philo as contrasts. Woman must become manly in order to be perfect, and man must develop his manliness as far as possible. Another pattern in Philo is that man must become female in relation to God, i.e., passive and self-effacing. This does not mean, however, that Philo values here woman as such, but only womanly submissiveness. (HMK)

9005. B. Bellettr, 'Il logos come immagine di Dio in Filone di Alessandria', Sapienza 43 (1990) 311-320.

This article discusses one of the most important and central themes in Philo's thought, the relation between God and Logos. Indeed, this theme determines the general nature of Philo's metaphysics, which can be characterized as exemplaristic and imaginistic. Belletti analyses the various relations between Logos, God, and 'Man in God's image', and reaches the following conclusions. 'Man in God's image' signifies both the Logos and the ideal man. The prevailing hierarchy in Philo's writings is that of God-LogosIntellect. It follows that 'Man in God's image' is man's reason and that there is a clear difference between the ideal man and sensible man (p. 319). By 'man's reason' Belletti means 'the reason which is in each of us and which constitutes the 'model' and guide for our lives, containing the imprint of the divine' (p. 320). (RR)

9006. G. Carras, 'Philo's Hypothetica, Josephus' Contra Apionem and the Question of Sources', in D. J. LuLL (ed.), Society of Biblical Literature 1990 Seminar Papers, SBLSPS 29 (Atlanta 1990) 431-450.

An earlier version of 9314. (DTR)

9007. N. G. Cohen, 'Agrippa I and De Specialibus Legibus IV 151159', The Studia Philonica Annual 2 (1990) 72-85.

The author argues that Philo's intention in composing the passage headed 'On the appointment of rulers' was not so much to recapitulate the relevant halakha from an academic point of view, but rather to express his views on a burning political issue of his day, namely the suitability of Agrippa I to be king of Judea from the viewpoint of kashruth. By means of his 'homiletic hermeneutic' Philo contends that Agrippa's appointment by the Roman authorities is legitimate. The article concludes with some remarks on the relation between scriptural commentary and topical political comment. (DTR)

9008. N. G. Cohen, “'Contemporary” Political Overtones of Philo's Specialibus Legibus IV 151-159', in D. AssaF (ed.), Proceedings of the 10th World Congress of Jewish Studies, Division A: The Bible and its World (Jerusalem 1990) 253-260.

A shortened presentation of $\mathbf{9 0 0 7}$. (DTR) 
9009. C. Colpe, 'Von der Logoslehre des Philo zu der des Clemens von Alexandrien', in Das Siegel der Propheten: historische Beziehungen zwischen Judentum, Judenchristentum, Heidentum und frühem Islam, Arbeiten zur neutestamentliche Zeitgeschichte 3 (Berlin 1990) 141-164.

Reprint of article first published in 1979 (= R-R 7907). (DTR)

9010. B. Decharneux, 'Mantique et oracles dans l'œuvre de Philon d'Alexandrie', in A. Мотте (ed.), Oracles et mantique en Grèce ancienne: Actes du colloque de Liège (Mars 1989) = Kernos (Revue internationale et pluridisciplinaire de religion grecque antique) 3 (Liège 1990) 123-133.

Philo's views on divination are especially important because he is the first to interpret divination in a monotheistic context, whereas the usual context of soothsaying is polytheism. Decharneux underlines two aspects: (1) Philo rejects technical divination by means of his allegorical exegesis of Balaam. (2) He accepts and approves of divination which works via the interpretation of dreams (p. 124). The underlying position is that Philo accepts forms of divination in which the initiative is left to God or the word of God and rejects forms which rely on human devices. These lead to false knowledge and ultimately to impiety. The same position allows Philo to establish a hierarchy of inspired forms of divination, in which dreams are more significant the more they come from God, and the interpreter is more faithful the closer he is to the mystic state. In the latter case 'the philosopher is transformed into a kind of anti-philosopher, alogos ... totally dedicated to God', to being the mouthpiece of his word (p. 132). (RR)

9011. B. Decharneux, 'Interdits sexuels dans l'œuvre de Philon d'Alexandrie dit «le Juif»', in J. MARX (ed.), Religion et tabou sexuel, Université Libre de Bruxelles Institut d'étude des religions et de la laïcité: Problèmes d'Histoire des Religions 1 (Brussels 1990) 17-31.

The basic thesis of the author is that the sexual prohibitions of the Bible are transformed in Philo, by means of the allegorical process of interpretation, into philosophical concepts. 'Les austères interdits sexuels de la Bible se trouvaient ainsi transposés dans le champ infini, de Dieu, du Monde, de l'âme et du philosophe. A l'interdit l'effort de rationalisation de l'Alexandrin voulait substituer la philosophie (p. 27).' Within this framework a number of themes are analysed: the practice of circumcision (including the relation to the doctrine of the Logos tomeus and its metaphysical foundations), the episode of Abraham and Sarah, that of Joseph and Potiphar's wife, and also the praise of virginity which is expressed in arithmological terms, with reference to the hebdomad. (RR) 
9012. V. Desprez, 'Jewish Ascetical Groups at the Time of Christ: Qumran and the Therapeuts', American Benedictine Review 41 (1990) 291-311.

As part of a series of articles outlining Jewish roots of Christian monasticism the author discusses the communities of Qumran and the Therapeutae. The method is largely descriptive, but some evaluative comments are given by way of conclusion. The piety of both groups is authentically biblical, but in both cases there are also problems. At Qumran it is the tendency towards excessive particularism, while in Alexandria it is the 'excessive idealism, due in great part to the bias of our historian, Philo. The Therapeuts seem like intellectuals lost in allegory, living on air (p. 311).' This is in marked contrast to later Egyptian Christian monks who had their feet firmly on the ground. (DTR)

9013. A. J. Dewey, 'A Re-hearing of Romans 10:1-15', in D. J. Lull (ed.), Society of. Biblical Literature 1990 Seminar Papers, SBLSPS 29 (Atlanta 1990) 273-282.

Slightly condensed version of $\mathbf{8 9 1 7 a}$.

9014. J. Dillon, The Golden Chain: Studies in the Development of Platonism and Christianity, Variorum Collected Studies Series (London 1990).

Five of the 28 studies reprinted in this volume refer to Philo in the title: IX (The Transcendence of God in Philo: Some Possible Sources, = R-R 7513); $\mathrm{X}$ (Philo and the Stoic Doctrine of Eupatheiai, written in collaboration with A. Terian, = R-R 7713; XI Ganymede as the Logos: Traces of a Forgotten Allegorisation in Philo? = R-R 8011); XVIII Plotinus, Philo and Origen on the Grades of Virtue = R-R 8328); XX (The Theory of Three Classes of Men in Plotinus and in Philo $=\mathbf{8 9 1 9}$ ). Philo is also mentioned in some other studies; see index p. 3 at the end of the volume. (DTR)

9015. H. Dörrie and M. Baltes, Der hellenistische Rahmen des kaiserzeitlichen Platonismus, Der Platonismus in der Antike 2 (Stuttgart 1990).

In Baustein 41, entitled 'Other manifestations of criticism of Plato', the first text which is translated and discussed is Contempl. 57, 59-63, Philo's wellknown diatribe against homosexual love. On this important multi-volumed work see above 8731. (DTR)

9016. T. L. Donaldson, 'Proselytes or 'Righteous Gentiles'? The Status of Gentiles in Eschatological Pilgrimage. Patterns of Thought', Journal for the Study of Pseudepigrapha 7 (1990) 3-27, esp. 116. 
Eschatological pilgrimage in the terminology of this study has to do with the view that on the day of judgment those scattered in exile will return to Zion. The study deals in particular with the question whether the gentiles that turn to the God of Israel in the end times are fully regarded as proselytes or rather as 'righteous gentiles'. Two texts by Philo, Praem. 164-172 and Mos. 2.43-44 are discussed and it is concluded that it is unlikely that Philo's text provides any solid evidence for a proselyte view of eschatological pilgrimage on the part of gentiles. 'Language apparently 'proselyte' in form is used to describe something closer to 'righteous gentiles' in substance. (p. 16)' (RMB)

9017. F. G. Downing, 'Ontological Asymmetry in Philo and Christological Realism in Paul, Hebrews and John', The Journal of Theological Studies 41 (1990) 423-440.

Starting-point of this rich and challenging contribution on Philo's theological thought is the monograph of J. D. G. Dunn, Christology in the Making (London 1980) (= RRS a8048), in which it is argued that for Philo the Logos bridges the gulf that exists between God and creation. But, according to Downing, Philo never speaks of such a 'gulf'. God as transcendent Being exists in a way that man can acknowledge but not apprehend. This constitutes what Downing describes as an 'asymmetry of knowing', asymmetrical precisely because God knows man, but man is not in a position to know God. Moreover one can also argue that there is an 'asymmetry in being', as seen in the statement in Legat. 118 that it would easier for God to become human than for a human to become God. The article concludes with reflections on the status of the Logos. 'The Logos is real, because it/he is less distinct from God than any other reality of which we can conceive (p. 439).' This Philonic background implies that some intellectuals at least were much more ready for the notion of a 'pre-existent' Christ than Dunn allows. (DTR)

9018. H. Eilberg-Schwarz, The Savage in Judaism (Bloomington 1990), esp. 154-155, 175.

In providing his controversial interpretation of early Judaism from the viewpoint of cultural anthropology, the author is struck by Philo's recognition of the centrality of procreation in God's covenant with Abraham. (DTR)

9019. C. Elsas, 'Argumente zur Ablehnung des Herrscherkults in jüdischer und gnostischer Tradition', in C. ElsAS and H. G. KIPPENBERG (edd.), Loyalitätskonflikte in der Religionsgeschichte: Festschrift für Carsten Colpe (Würzburg 1990) 269-281, esp. 279-281.

Argues that the positive attitude towards monarchic imperial rule (conditional upon there being no threat to monotheism) represented by Philo and Hellenistic Judaism may have contributed to the Gnostic revolt against both earthly rulers and the God of Judaism. (DTR) 
9020. J. Ferguson, 'Epicureanism under the Roman Empire', in W. HaAse (ed.), Aufstieg und Niedergang der römischen Welt II 36.4 (Berlin-New York 1990) 2257-2327, esp. 2273-74.

Brief and regrettably superficial treatment of Philo's knowledge of Epicureanism, which is described as 'accurate and detailed'. (DTR)

\section{E. Fleischer [ע. עליישר], לקדמוניות תפילות החובה בישראל} [= 'On the Beginnings of Obligatory Jewish Prayer'] Tarbiz 59 (1990) 397-441, esp. 410-411.

In the course of a wide-ranging argument against the existence of communal, fixed prayer prior to age of the Rabbis, the author surveys a range of ancient authors, including Philo, in order to demonstrate that during the period of the Second Temple the synagogue served not as a place of prayer but as a forum for public gathering and for the study of Law. (DS)

9022. P. Gilabert i BarberÀ, ' " «... Però la dona ho esguerrà tot»: el De opificio mundi de Filó d'Alexandria (LIII-LXI) o els fonaments grecs d'una fita en la història da la misogínia occidental', Anuari de Filologia: Studia Graeca et Latina (Barcelona) 13 (1990) 55-84.

Gilabert i Barberà analyzes the main passages of Opif. relating to the theme of woman and the creation. A translation is given of $\$ \S 136-138,140$ 142, and 151-166, together with the crucial Greek terms and comments on the attitude to women which emerges from these passages. In the author's view Philo is strongly influenced by Platonism on this point. Indeed, the role of woman in the creation is of fundamental allegorical significance in explaining man's fall from the perfect condition in the World of ideas (corresponding to the biblical paradise) to the world of becoming (cf. p. 57, 67). Perhaps Philo has also been unconsciously influenced by the myth of the ages of the world (cf. Hesiod, Works and Days, 106-201; cf. 62ff.), but the closest reference for Philo is most certainly Plato's ontological and moral dualism. In any case Philo's text expresses the patently misogynous view (p. 76) that man's 'progressive degradation' goes hand in hand with the 'increasing sexualization of the story of the fall' (p. 73, 79). The connections with Greek culture (lyric poetry, tragedy, philosophy) show that Philo, too, takes a negative view of the love of women, which is seen as sensual (p. 76) and as conflicting with the love of God (p. 59). These ideas were widely used by the Church Fathers, who in the end took a saner view of these 'obsessions'. (RR)

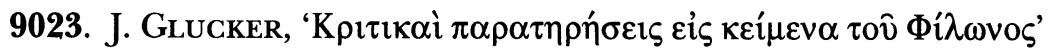
[= Critical Observations on texts of Philo], Platon 42 (1990) 128-135.

Critical notes on Sacr. 102, Sacr. 123, Det. 135, Det. 138, QG 1.79, Agr. 25, Agr. 97. A list in English of the proposed emendations is given on p. 135. (DTR) 
9024. P. J. Grabe, Dunamis in the Sense of Power in the Main Pauline Letters (diss. University of Pretoria 1990)

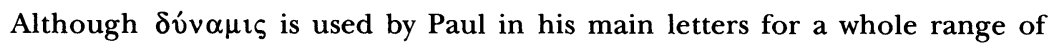
meanings, this investigation deals with $\delta \dot{v} \alpha \mu \iota \varsigma$ in the sense of power. Section A has been devoted to a lexico- and conceptual-historical survey of $\delta v v_{\alpha \mu \iota \varsigma}$ in which the Hellenistic (profane Greek) use of $\delta v v^{\prime} \alpha \mu \varsigma$, the Old Testament basis for Paul's use of $\delta v ́ v \alpha \mu t \varsigma$, as well as concepts of power in early Judaism, Philo and Qumran are discussed. It is concluded that Hellenistic

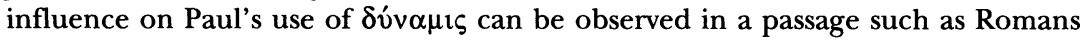
$1: 20$, which is only to be understood against the background of a Hellenistically influenced Jewish apocalyptic tradition. By and large, however, the lexico- and conceptual-historical background of Paul's use of $\delta$ v́v $\alpha \mu \mathrm{s} \varsigma$ is to be found in the Old Testament. (DTR, based on DA 52-04A, p.1388)

9025. J. T. Greene, 'Balaam as Figure and Type in Ancient Semitic Literature to the First Century BCE, with a Survey of Selected Post-Philo Applications of the Balaam Figure and Type', in D. J. Lull (ed.), Society of Biblical Literature 1990 Seminar Papers, SBLSPS 29 (Atlanta 1990) 82-147.

Continuing the research initiated in 1989 (8923), this study aims to present - in a fairly exhaustive manner - preliminary materials for an interpretation of Balaam in Philo. Thirteen pre-Philonic and six postPhilonic interpretations are set before the reader, allowing him or her 'to not have to study Philo's consideration of Balaam within a hermeneutical vacuum (p. 143)'. But no discussion is actually given of Philo's contribution. See now also the monograph on the same subject published in 1992 (9238). (DTR)

9026. C. W. Griggs, Early Egyptian Christianity from its Origins to 451 CE, Coptic Studies 2 (Leiden 1990, 19912), esp. 19-20.

The use of Philonic evidence in the discussion of the origins of the Alexandrian church is disappointingly limited. (DTR)

9027. A. J. Guerra, 'The One God Topos in Spec. Leg. 1.52', in D. J. Lull (ed.), Society of Biblical Literature 1990 Seminar Papers, SBLSPS 29 (Atlanta 1990) 148-157.

The affirmation that 'there is One God' is a prominent feature of Jewish, and later Christian, exclusivism, and plays an important role in the relation of both groups to the Hellenistic gentile world. As used in literary works, this theme can be described as a topos. The author first briefly examines some uses of the topos in the Sybilline Oracles and Josephus, which are useful for comparative purposes when he turns to Philo. In the text examined in detail, Spec. 1.52, it emerges that Philo is above all concerned to promote the acceptance and even privileged treatment of proselytes. A contrast is drawn between 'Hellenistic Judaism and ... Hellenistic philosophy at large', in which 
'the primary concern was the pursuit of a theoretical basis of unity', and Philo, who 'was far more concerned to articulate the social implications for unity which the shared acceptance of One God afforded' (p. 157). (DTR)

9028. M. Hadas-Lebel, Jerusalem contre Rome, Patrimoines Judaïsme (Paris 1990), esp. 61-64, 344-347.

There is an undoubted tendency to idealize Rome and its Empire in both Philo and Josephus, even if they give accurate denunciations of abuses that take place (61ff.). This appreciation is due to the realization that Rome's military and political power, together with its judicial organization, was in a position to guarantee freedom of worship, which in the time of Philo was more important to Jews than political freedom. (RR)

9029. R. A. HARrisville III, In the Footsteps of Abraham: the Figure of Abraham in the Epistles of Saint Paul (diss. Union Theological Seminary in Virginia 1990)

A chapter on Abraham in Philo is included as part of an investigation on Paul's use of the patriarch Abraham. (DTR, based on DA 51/12A, p. 4162)

9030. W. E. Helleman, 'Philo of Alexandria on Deification and Assimilation to God', The Studia Philonica Annual 2 (1990) 51-71.

Philo's views on man's deification and assimilation to God form an important background to the Patristic view of salvation as 'deification' of man. The author concentrates above all on Philo's use of the Platonic motif of

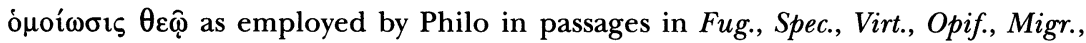
and $Q E$. On the basis of this material the following aspects are further analysed: (a) assimilation as a process of transition; (b) the 'god' to whom man is assimilated, namely the divine Logos; (c) the kinship between God and man, as indicated above all by Gen. 1:26; (d) the divine nature of the human mind; (e) the special status of Moses as a 'god', but only in a derivative sense. Helleman concludes that Philo on the one hand recognizes assimilation to god as a legitimate and proper goal of human life, involving a choice based on knowledge and reason, but that on the other hand man cannot become God nor gain a true vision of who God is. The contradictory nature of these two positions can only be resolved if we take into account the flexibility with which he uses the word $\theta \varepsilon$ ós. Against this Philonic background it should come as no surprise that the Church Fathers assigned to Christ the Logos the pivotal role in the process of salvation as deification. The patristic view of sharing in the divine nature, however, finds no support in Philo. (DTR)

9031. A. VAN DEN HoEk, 'How Alexandrian was Clement of Alexandria? Reflections on Clement and his Alexandrian Background', Heythrop Journal 31 (1990) 179-194. 
The author concludes that Clement must have had a good Christian library at his disposal, in which a prominent place was given to Philo. 'The multitude of sources that reached him - whether in the form of extracts or complete works - proves how richly endowed his immediate environment was. His borrowings are often literal, and he often mentions his source by name. Philo remains strangely unacknowledged, but this omission is an exception rather than the rule. (p. 190)' (DTR)

9032. P. W. van DER Horst, 'Nimrod in the Jewish Haggada', in A. Kuyt, E. G. L. Schrijver and N. A. van Uchelen (edd.), Variety of Forms: Dutch Studies in Midrash (Amsterdam 1990) 59-75, esp. 61-63; reprinted in a Dutch version in IDEM, Studies over het Joden in de Oudheid (Kampen 1992) 108-126.

A shorter version of the article published together with $\mathrm{K}$. van der Toorn. See below 9071. (DTR)

9033. L. D. Hurst, The Epistle to the Hebrews: its Background of Thought, SNTSMS 65 (Cambridge 1990), esp. 7-42.

During the last century a number of differing backgrounds have been exploited in order to explain the Sitz im Leben of the Letter of the Hebrews. To a remarkable degree each seems convincing when considered in isolation from the rest. The study's aim is to examine these various backgrounds in order to determine their strengths and weaknesses. The first chapter gives an excellent analytic survey of various attempts to privilege the Philonic, Alexandrian and Platonist background. The author concludes that the various aspects of Platonist dualism, both in motifs and vocabulary, have been exaggerated, and that apocalyptic themes are more important. We quote the chapter's final words (p. 42): 'Enough indications exist to point to a reasonable conclusion that Auctor [i.e. the anonymous author] developed certain OT ideas within the Jewish apocalyptic framework, while Philo developed the same themes within a Platonic framework. Both writers ... probably go back independently to a common OT background. The Platonic/Philonic background for Hebrews is therefore "not proven", and as such it must give way to an examination of other possible backgrounds.' (DTR)

9034. S. Isser, 'Two Traditions: the Law of Exodus 21:22-23 Revisited', The Catholic Biblical Quarterly 52 (1990) 30-45, esp. 37-38.

The article examines the two different traditions of the law on injury done to a pregnant woman and the child she carries represented by the MT and the LXX respectively. Philo's exegesis is evidence for the understanding of the Septuagint version. (DTR) 


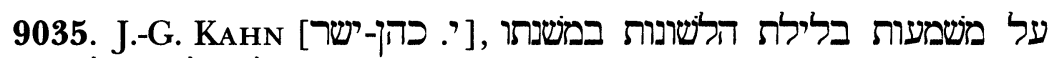
שיל בילון האלכסנדרוני according to Philo of Alexandria'], Proceedings of the Tenth World Congress of Jewish Studies (Jerusalem 1990) A.127-134.

The author examines briefly Philo's attitude toward language and concludes that he saw human language by its very nature as an obstacle to thought and the multiplicity of languages as yet a further encumbrance. Despite the title of the article, very little space is devoted to the story of Babel and its exegesis. (DS)

9036. M. Kerkhoff, 'Kairos kainos: la double kairosophie de Philon d'Alexandrie, crise de la rationalité greque', in J. F. MatTEI (ed.), La naissance de la raison en Grèce. Actes du congrès de Nice (Mai 1987) (Paris 1990) 257-264.

Kerkhoff examines the twofold notion of kairos as constructed by Philo from two different traditions, that of the rational kairos and that of the irrational kairos. Philo distinguishes between a real atemporal kairos that accompanies or is identified with God and a temporal kairos which is portrayed as an anti-God. The first kairos is related to the well-being of the soul, the second kairos to worldly luck. In the last section of this paper the author argues that Philo is guilty of a 'vrai scandale herméneutique' by interpreting the same kairos at one time as God and at another time as anti-God. (RMB)

9037. R. A. Kraft, 'Tiberius Julius Alexander and the Crisis in Alexandria according to Josephus', in H. W. Attridge, J. J. Collins and T. H. ToBin S.J. (edd.), Of Scribes and Scrolls: Studies on the Hebrew Bible, Intertestamental Judaism, and Christian Origins presented to John Strugnell on the occasion of his Sixtieth Birthday, College Theology Society Resources in Religion 5 (Lanham 1990) 175-184.

Independently of Schwartz 8961 the author looks at the career of Philo's nephew as described by Josephus and poses the question whether a connection can be made between Philo's account of the 'Sabbath crisis' in Somn. 2.123-132 and Josephus' story of the Alexandrian confrontation with Tiberius Julius Alexander in $66 \mathrm{CE}$. There are chronological difficulties involved (Philo would have to be in his 70's or even 80 's), but in the author's view 'it is an attempt worth considering' (p. 184). See also his article in the FS Koester, 9137. (DTR)

9038. C. Kraus Reggiani, 'Tradizione e innovazione nel giudaismo ellenistico', in La tradizione: forme e modi: XVIII Incontro di studiosi dell'antichità cristiana (Roma 7-9 maggio 1989), Studia Ephemeridis Augustinanum 31 (Rome 1990) 93-117. 
The author approaches the subject of tradition and innovation in Hellenistic Judaism by looking at those passages of Wisdom and IV Maccabees which show substantial innovations with regard to the Old Testament tradition of eschatological themes, such as the doctrine of retribution and the immortality of the soul. Reggiani's third and most important example is Philo, all of whose philosophical elaborations are innovative in relation to traditional Hebrew thought. Yet man's journey to God, which Philo deals with in a masterly manner, does not provide an eschatological conclusion, but fully adheres to the Jewish conception of perfect happiness which can be achieved in this world by the wise and virtuous, who gain it as a reward for the spiritual union which they have achieved with God, together with the Jewish conception of retribution in this life for the wicked, whose punishment is to have a soul dead to virtue and knowledge. Consequently, Philo shows little interest in the eschatological problem. Nevertheless, on the few occasions when he does touch on the subject, it is clear that - like the author of Wisdom and IV Maccabees - he does not regard immortality as an ontological fact, but as the fruit of a personal achievement reserved for a few elected souls. (RR)

9039. S. R. G. Lilla, 'Die Lehre von den Ideen als Gedanken Gottes im griechischen patristischen Denken', in H. EISENBERGER (ed.), EPMHNEYMATA: Festschrift für Hadwig Hörner zum sechzigsten Geburtstag, Bibliothek des klassischen Altertumswissenschaften 2.79 (Heidelberg 1990) 27-50, esp. 29-32.

Philo's thoughts on the Ideas as God's thoughts need to be included in this survey of the theme in the Greek Church Fathers, the author argues, because he so clearly influenced later developments. A short presentation of Philonic texts is given, with the chief emphasis on Opif. With regard to the sources of Philo's usage, Lilla sees a coalescence of Platonic and Stoic elements which go back to both Antiochus and Posidonius. (DTR)

9040. S. R. C. Lilla, 'Le fonti di una sezione dell'omelia De Fide di S. Basilio Magno', Augustinianum 30 (1990) 5-19, esp. 11-12, 17-19.

In Basil's account of the heavenly ascent of the soul in contemplation before attaining to God in the first chapter of $D e$ fide, there are not only Plotinian, but also Platonic, Philonic and Hermetic echoes. Particular attention is paid to Basil's use of philosophical attributes to describe the divine nature. (DTR)

9041. J. A. LoAder, A Tale of Two Cities: Sodom and Gomorrah in the Old Testament: Early Jewish and Early Christian Traditions, Contributions to Biblical Theology and Exegesis 1 (Kampen 1990), esp. 8696.

Philo's evidence furnishes important material for the Wirkungsgeschichte of the exegesis of Genesis 18-19 in Jewish and Early Christian traditions, but 
because it is so copious the discussion has to be abridged and reduced to 'some basic tenets'. These are summarized at the end of the discussion as: (1) Philo's treatment is determined by the scriptural background; (2) he is acquainted with the familiar motifs of wickedness, wealth, punishment, with special concentration on the ideas of barrenness and blindness; (3) these motifs determine his allegorical treatment; (4) this treatment has an anti-hedonistic focus and breathes the spirit of a stern Stoicizing ethic; (5) the story symbolizes the destruction of what is bodily as opposed to what is spiritual; (6) the story is used not only to extol Abraham, but also to expound theological views. (DTR)

9042. J. MAIER, Zwischen den Testamenten: Geschichte und Religion in der Zeit des zweiten Tempels (Würzburg 1990), esp. 83-88, 128-130.

Two sections deal with Philo in this book. On pp. 82-88 Maier discusses the written sources of Jewish literature in the period of the Second Temple and briefly presents Philo's works (list of writings and summary of contents) and fundamental bibliographical aids (editions, translations, lexicons, bibliographies, critical literature). On pp. 128-130 he succinctly describes the relation between the Jewish Halakah and Philo's allegorical method and highlights the analogies that can be detected in them. (RR)

9043. F. MAnns, Le Midrash, approche et commentaire de l'Ecriture (Jerusalem 1990), esp. 60-69.

A modest contribution designed to introduce students to an aspect of the world behind the New Testament. The author emphasizes the balance in Philo's exegesis between literal and allegorical interpretation, and also his use of midrashic techniques. (DTR)

9044. J. Mansfeld, 'Doxography and Dialectic: the Sitz im Leben of the 'Placita', in W. HAASE (ed.), Aufstieg und Niedergang der römischen Welt II 36.4 (Berlin-New York 1990) 3056-3229, esp. 311722.

Philo's passage in Somn. 1.21-32 about the unknowability of the heavens and the intellect is an extremely important document in the history of ancient doxography, as already demonstrated by Wendland in his neglected 1897 article. Mansfeld analyses the part of the text dealing with the mind and soul, as part of a comprehensive examination of the doxographical tradition on these subjects. It emerges that Philo used either an academic source or a source of the Placita older than the Vetusta Placita postulated by Diels. Further references to Philo are listed in the index at 3225. (DTR)

9045. J. P. Martín, 'Filon Hebreo y Teofilo Cristiano: la continuidad de una teologia natural', Salmanticensis 37 (1990) 302-317. 
Theophilus of Antioch at Ad Autolycum 3.9 follows the five points of Philo's teaching at Opif. 170-172 very exactly in order to develop a natural theology based on a biblical and stoicizing perspective. On the other hand he systematically criticizes the Platonic concepts of Philo's exegesis of Genesis to the extent that they contain either cosmological or anthropological dualism. Antecedents of the Antiochean school of biblical exegesis are thus to be found in both dependence and criticism of Philo. (RR; based on author's abstract)

9046. J. P. Martín, 'Filon y la historia del platonismo: un dialogo con R. Radice', Methexis 3 (1990) 119-127.

Martín emphasizes the important points of agreement between his work Filón de Alejandría y la génesis de la cultura occidental (1986, R-R 8636) and R. Radice's Platonismo e creazionismo in Filone di Alessandria $(1989,8948)$. Briefly, these are: (1) the way of reading Philo's text; (2) the interpretations of its content; (3) the attempt to determine Philo's place in the history of philosophy. The article discusses these subjects and also dwells on the problem of creatio ex nihilo (pp. 122-124), which is dealt with at length in Radice's book. (RR)

9047. J. P. Martín, 'Ontologia e creazione in Filone Alessandrino: dialogo con Giovanni Reale e Roberto Radice', Rivista de Filosofia Neoscolastico 82 (1990) 146-165.

Starting from the generally similar positions of Reale and Radice on the way in which Philo's thought should be interpreted, Martín sets himself two aims in this article. First, he wants to show that there are no grounds for assuming that Philo is philosophically inferior to the Greek tradition. This assumption prevents us from properly understanding the philosophy of the first centuries (p. 148ff.). To show this he follows a different route from that of Reale and Radice, concentrating on the relations between Theophilus of Antioch and Philo. His second aim is to find the core of Philo's thinking. This core has been located in four different areas by Philonic scholars (p. 151ff.): (a) in the theory of Ideas (Wolfson); (b) in the theory of creation, particularly in that of the Ideas as thoughts of God (Reale-Radice); (c) in the concept of migration (Nikiprowetzky); (d) in the polarity self-love-love of God (Harl). Martín agrees with the second view, but extends it in such a way as to incorporate the others (p. 165) and to include his own view of the "centrality of the ontological exegesis of Ex. 3:14'. Like Reale and Radice, he concludes that in the light of the new interpretation of Philo 'we need to rewrite the history of Middle Platonism and the precursors of Neoplatonism' (p. 165). (RR)

9048. A. M. Mazzanti, L'uomo nella cultura religiosa del tardoantico: tra etica $e$ ontologia, Cristianesimo antico e medievale 3 (Bologna 1990), esp. 3-52.

The theme chosen for extended study by Mazzanti is that of man as $\mu \varepsilon \theta$ ópros ('border-dweller'). It is developed in accordance with the various stages of Philonic thought in the following sequence. (1) The term $\mu \varepsilon \theta$ óptos 
has in the first place an ontological sphere of reference (p. 9ff.), describing man as partly earthly substance and partly divine spirit. This structure is dependent on the moment of creation in which the foundations of his ethically mediate position are laid, i.e. the fact that he can turn to good and to evil. Mazzanti then examines the concept of creation in Opif. (p. 19ff.), in Leg. (p. 27ff.), and in other Philonic works (p. 31ff.). In this analysis a prominent role is played by the helpers of God in the act of creation, i.e. the divine powers (p. 35ff.). From the anthropological viewpoint a consequence of the interrelation of ontology and ethics in the creative act is found in the negative interpretation of sexual duality which the author interprets (in chap. 4, p. 39ff.) in all its various aspects: anthropological, ethical, eschatological, physiological, institutional (i.e. in marriage). In the second part of the book (p. 53ff.) the thematics of Philonic anthropology are developed in a piece of comparative historical research, which examines in turn Plutarch (pp. 5760 ), Origen (pp. 61-66), the Asclepius (67), and is concluded with a general evaluation of the term $\mu \varepsilon \theta$ óptos as found in all the authors examined. (RR)

\section{M. Mills, Human Agents of Cosmic Power in Hellenistic Juda- ism and the Synoptic Tradition, JSOT.S 41 (Sheffield 1990), esp. 42-46.}

The starting point of this study on human agents of cosmic power is Jesus the exorcist. Various literary traditions on wonder-workers are examined, including Moses. The two documents used for the Moses tradition are the magical text The Sword of Moses and Philo's De vita Moysis. The similarity in both texts is that Moses is 'regarded as an extremely significant human being because he is able to channel divine energy to human situations' (p. 46). (DTR)

9050. H. W. Neudorfer, 'Das Diasporajudentum und der Kanon', in G. MAIER, Der Kanon der Bibel (Giessen-Basel-Wuppertal 1990) 83-101, esp. 89-92.

Although Philo does not possess the concept of the Canon as a technical term with reference to Scripture, there can be no doubt that he regards the Pentateuch as being of superior status to the rest of the Hebrew Bible, as is evidenced by the fact that of the 1161 citations of the Bible in Philo only 41 do not deal with the Pentateuch. Tied to this is Philo's mechanical conception of prophetic inspiration, in which the personality of the prophet is reduced to zero and he is regarded as nothing but the instrument of God. (RR)

9051. B. A. Pearson, Gnosticism, Judaism, and Egyptian Christianity, Studies in Antiquity and Christianity 5 (Minneapolis 1990).

Reprints a important selection of articles with themes covered by the title, published in various journals and collections of essays during the past two decades. Specifically devoted to Philo are 'Friedländer Revisited: Alexandrian Judaism and Gnostic Origins' (1973, = R-R 7333), and 'Philo, Gnosis, and the New Testament' $(1983$, = R-R 8359). See further the REviEw of G. E. 
Sterling in SPhA 4 (1992) 175-178, which lists all the references to Philo and also gives an Index locorum Philoneorum. (DTR)

9052. S. Pétrement, A Separate God: the Christian Origins of Gnosticism (San Francisco-London 1990) passim.

English translation of earlier voluminous French study (Le Dieu séparé: les origines du gnosticisme, Paris 1984), in which the author argues a Christian origin for the Gnostic movement. Extensive use is made of Philonic material (see index, p. 540), even if it is argued that (p. 41): 'But, heretic or not, Philo is still very far from being a Gnostic.' The translation was prepared by Carol Harrison. (DTR)

9053. P. Pilhofer, Presbyteron kreitton: Der Altersbeweis der jüdischen und christlichen Apologeten und seine Vorgeschichte, WUNT 2.39 (Tübingen 1990), esp. 173-192

By 'Altersbeweis' the author means the apologetic argument or proof founded on the axiom that 'what is old is good', which is then extended to the view that 'what is older is better' (the title of the book is derived from a concise formulation of this position in Timaeus Locrus 7). The study of the theme is divided into four parts: Greek literature, Roman literature, Hellenistic-Jewish literature, and the Christian apologetic literature of the 2nd century (excluding Clement). In the third part an extensive chapter is devoted to Philo. In $1880 \mathrm{M}$. Joel, attacking the authenticity of the Aristobulan fragments, had claimed that few statements claiming the greater antiquity of Judaism were to be found in Philo. Pilhofer argues that he could not have read the complete Philo when making this claim, and sets out to present the evidence as thoroughly as possible. To be sure, Philo's attitude towards the relation between old and new is complex, and cannot be reduced to a single formula (his emphasis on the validity of the new in a theological context in the case of God nothing is old, but rather timeless - is quite unusual). Pilhofer then proceeds to enumerate and discuss all the texts in which Philo asserts the antiquity of the Judaism compared with Greek culture. These are quite copious, but it remains true that on a number of occasions Philo does not use the argument when we might expect it, e.g. in the De vita Moysis. In many aspects, it is concluded, Philo's approach shows similarity with that of Cicero, the former as apologist pro Ioudaeis, the latter pro Romanis. But Philo has the easier task: Moses was after all of venerable antiquity... (DTR)

9054. M. Pucci Ben Zeev, 'New Perspectives on the JewishGreek Hostilities in Alexandria during the Reign of Emperor Caligula', Journal for the Study of Judaism 21 (1990) 227-235.

Some interesting critical comments provoked by two articles published about a decade earlier. Polaček's description of the Alexandrian pogrom in 38 $\mathrm{CE}$ as a 'holocaust' (see a8139) is misleading and methodologically unsound. Cracco-Ruggini's interpretation of the same event in terms of a 'class struggle' (see a8046) raises interesting issues. The assumption that the Jewish 
population represented a homogenous group that can be described as a 'politically evolved social stratum of petty bourgeois' is questioned. It would seem that socio-economic differences within the Jewish community were extensive and profound. A task for future research is to unravel the political, social and religious factors at work in Alexandria in the first century of our era. (DTR)

9055. P. J. Rask, The Lists of the Twelve Tribes of Israel (diss. The Catholic University of America 1990).

In investigating the differences between the lists of of the sons of Jacob/tribes of Israel in the OT, the author also pays attention to other, extrabiblical, sources containing such lists, among which Philo is included. (RMB, based on DA 51-05A p.1663)

9056. G. REAlE, A History of Ancient Philosophy, edited and translated by J. R. CATAN, vol. 4 The Schools of the Imperial Age (Albany, N.Y. 1990) 169-204.

Reale's chapter entitled 'Philo of Alexandria and Mosaic Philosophy' in his general history of Greek philosophy (cf. R-R 7839), the longest to be presented in a work of that kind, is now available in English translation. (DTR)

9057. A. Rescigno, 'Nota a Filone, De praemiis et poenis, 1,1', in I. Gallo (ed.), Contributi di filolofia greca, Università degli Studi di Salerno: Quaderni de Dipartimento di Scienze dell'Antichità 6 (Naples 1990) 127-136.

The article concentrates on the final part of the text under discussion: $\tau \grave{\alpha}$

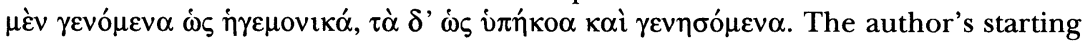
point is the emendation of the text suggested by Cohn and the defence of the traditional text by Colson, with which she agrees. Philo's text is then interpreted in the light of his general doctrine of creation, and particularly his view of matter, which sometimes seems to have been created, but at other times pre-exists the same creation process. (RR)

9058. H. Graf Reventlow, Epochen der Bibelauslegung I: von Alten Testament bis Origenes (München 1990), esp. 44-49.

Brief general presentation of Philo's allegorical method as part of an account of biblical interpretation 'zwischen den Testamenten'. (DTR)

9059. D. T. Runia, Exegesis and Philosophy: Studies on Philo of Alexandria, Variorum Collected Studies Series (London 1990).

This volume collects together 11 articles and 2 reviews on Philo published between 1981 and 1989. In sequence of presentation they are: 8953 (in an 
English translation), R-R 8658, 8955, R-R 8447, 8781, R-R 8659, review of 8743, R-R 8126, R-R 8657, R-R 8446, 8863, 8862, review of 3103. The pagination of the original publications is retained. Some brief addenda and a short index (restricted by the format of the series) conclude the volume. Reviews: M. J. Edwards, CR 41 (1991) 476-477; M. Schofield, Phron 36 (1991) 238-239; R. M. Berchman, SPhA 4 (1992) 146-153; A. Viciano, ScrTh 24 (1992) 681; R. A. Bitter, Mnem 46 (1993) 251-252. (DTR)

9060. D. T. Runia, 'How to Search Philo', The Studia Philonica Annual 2 (1990) 106-139.

Since the writings of Philo are by any standard voluminous, it will be useful for the Philonist to develop techniques that enable him or her to carry out searches. This article outlines and illustrates five different techniques for searching Philo: Leisegang's Indices, Mayer's Index Philoneus, Borgen and Skarsten's KWIC concordance, and using the TLG database on the IBYCUS and Macintosh personal computers. In each case an example is used, namely

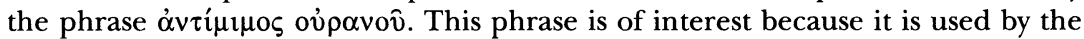
4th century writer Heliodorus in a passage that must be dependent on Philo Mos. 2.195. Some research shows that the parallel was probably first discovered by the great Frisian classical scholar Tiberius Hemsterhuys. The article concludes that computer searches should be a supplement of, not a substitute for, wide reading (134). (DTR)

9061. E. P. SANDERS, Jewish Law from Jesus to the Mishnah (London-Philadelphia 1990), esp. part IV, 255-308.

Extensive use of Philonic evidence in an penetrating examination of the extent to which Diaspora Judaism was dependent for its practice in the area of purity, food and offerings on rules formulated in Jerusalem. Philo yields important information on Diaspora practice. (DTR)

9062. D. A. SAPP, An Introduction to Adam Christology in Paul: a History of Interpretation, the Jewish Background, and an Exegesis of Romans 5:12-21 (diss. Southwestern Baptist Theological Seminary 1990).

Argues that approaches to Paul's Adam Christology in terms of Gnostic or Philonic thought are inadequate. (RMB, based on DA 51-07A, p. 2427)

9063. S. Schwartz, Josephus and Judaean Politics, Columbia Studies in the Classical Tradition 18 (Leiden 1990), esp. 40-43, 5154, 209-210.

Schwartz concedes that Josephus may have been indebted to Philo for some details of biblical exegesis (p. 54), but for the most part strongly downplays any influence that Philo may have exerted. Josephus was 'not profoundly interested in or well-informed about the Hellenistic-Jewish intellectual tradition' (p. 209). (DTR) 
9064. A. F. Segal, Paul the Convert: the Apostolate and Apostasy of Saul the Pharisee (New Haven-London 1990), esp. 43-45 and passim.

Evidence from Philo is used to furnish background for Paul's 'mysticism'. (DTR)

9065. P. Shuler, 'Philo's Moses and Matthew's Jesus: A Comparative Study in Ancient Literature', The Studia Philonica Annual 2 (1990) 86-103.

Not persuaded by the frequently stated view that the Gospels do not share any affinities with genres of Greco-Roman literature, the author believes that they can be illuminated by looking at features of the encomiastic biography which they take over. For this purpose he compares Matthew's Gospel with Philo's Life of Moses. Both choose the genre of encomiastic biography, and this choice gives them the freedom to construct their portraits in such a way as to fulfil their purposes. In their desire to communicate they direct their message to both Jewish and Gentile readers. Moreover the two accounts share a similar topical arrangement. In both cases emulation of the portrayed hero is required. The various similarities discovered can only be explained if one takes into account the type of narrative used, i.e. encomiastic biography. (DTR)

\section{D. SLY, Philo's Perception of Women, BJS 209 (Atlanta 1990).}

This revised doctoral dissertation prepared at McMaster University under the supervision of Alan Mendelson is the first monograph specifically to address the question of Philo's perception of women and the place they occupy in both his social world and his thought as expressed primarily in his biblical exegesis (in many respects therefore the study is a continuation at a more specific level of Baer's study on the relation between male and female, R-R 7005). Chapters one and two introduce Philo and place his views on women against the background of Jewish Alexandrian society (Sly thinks that Philo himself was probably married, but had no children). Chapter three examines the small amount of scholarship on the subject. Chapter four examines Philo's use of language with regard to the sexes, concluding that women are not inclusively designated in the terms $\alpha$ $v \theta \rho \omega \pi \circ \varsigma$ and $\alpha v \eta^{\prime} \rho$. In chapter five a crucial distinction is made in Philo's perception between women and virgins (based on remnants of blood taboo). This distinction is used to structure the following five chapters on Philo's presentation of biblical material involving the female sex. Biblical women are presented in chapters six (Eve) and seven (others); biblical virgins in chapters eight (general allegorical considerations), nine (Sarah and Rebecca) and ten (others). In chapter 11 the focus moves to women in Philo's own world (a direct connection is postulated with how he presents women in his exegesis). Here the main distinction seems to be between women under male control (good women) and women eluding male control (harlots). There is a discrepancy between Philo's ideals and the real social situation of women in his society, for most of whom virginity could not possibly be an option. Chapter twelve 
gives a summary and draws some conclusions. Philo's conviction that women need to be controlled stands in strong contrast to the spiritual freedom that he offered man in the Odyssey of the spirit. Reviews: R. S. Kraemer, SPhA 4 (1992) 168-173; C. A. Brown, RelStR 19 (1993) 176; J. Dillon, ISPh 26 (1994) 136-137. (DTR)

9067. J. Z. Smith, Drudgery Divine: on the Comparison of Early Christianities and the Religions of Late Antiquity (Chicago 1990), esp. 7-13.

Those intrigued as to how the proverb about Plato and Philo comes to be mentioned in correspondence between two early Presidents of the United States may wish to consult this astonishingly learned exposé entitled 'On the Origins of Origins'. (DTR)

9068. G. Sterling, 'Philo and the Logic of Apologetics: an Analysis of the Hypothetica', in D. J. Lull (ed.), Society of Biblical Literature 1990 Seminar Papers, SBLSPS 29 (Atlanta 1990) 412-430.

The aim of the paper is to offer a basic reconstruction of this fragmentary and little studied work of Philo and to attempt to locate it within the context of Jewish-Egyptian relations. Sterling examines in turn the content, form and function of the work. Especially the title has been a source of much controversy. After rejecting other interpretations Sterling notes that $\dot{\pi} \pi 0 \theta \varepsilon \tau 1 \kappa \alpha ́$ is a terminus technicus in Stoic logic and explores the possibility that Philo may have meant by the title something like 'Hypothetical propositions', i.e. logically valid statements which will be apologetically effective. Thus Philo's apologetics in this case appeal to the authority of reason rather than of scripture. The choice of such a method is bound up with the work's purpose and historical context: it was written as a response to insinuations made against the Jews and Jewish culture by Greco-Egyptian intellectuals such as Lysimachus, Apion and Chaeremon. It is perhaps no coincidence that the latter two had ties with Stoicism. (DTR)

9069. Т. H. Товіn, 'The Prologue of John and Hellenistic Jewish Speculation', The Catholic Biblical Quarterly 52 (1990) 252-269.

Distinguishing an original Logos hymn from the rest of the Prologue to John's Gospel, the author seeks to determine its relation to Hellenistic Jewish wisdom speculation. Three themes are examined in turn: (1) the reality and functions of the Logos; (2) the contrast between light and darkness; (3) the Logos and Heavenly Man. Philo is the main point of comparison, which leads to the following conclusion (p. 268): 'On the basis of the parallels between the hymn of the Prologue and some of the biblical interpretations of Philo of Alexandria, one is led to the conclusion that the hymn in the Prologue, like Philo of Alexandria, was part of the larger world of Hellenistic Jewish speculative interpretations of biblical texts... The argument is not that the author of the hymn had read Philo of Alexandria; the parallels are not close enough to maintain that kind of position. But the parallels do show that 
both the author of the hymn and Philo of Alexandria were part of the larger tradition of Hellenistic Jewish biblical interpretation and speculation. Both were making use of similar structures of thought and were expressing those structures through the use of similar vocabulary, even though the results were very different.' (DTR)

9070. P. J. Tomson, Paul and the Jewish Law: Halakha in the Letters of the Apostle to the Gentiles, CRINT 3.1 (Assen 1990), esp. 36-47.

In investigating Paul's relation to the halakha, the author notes that it is accepted that halakha occupied a central place in 'hebraizing Palestinian Judaism', but that its function in diaspora Judaism is far less clear. For this reason he turns to Philo and gives a critical survey of the literature on the subject from Ritter (1879) to N. Cohen (1987). After dealing at some length with Migr. 86-93 he concludes that 'the image we gain from Philo is that of enlightened piety, freely enriched with numerous elements from Hellenistic intellectual tradition, but organized along the lines of Jewish life' (p. 45). Philo's evidence thus shows that the halakha was no less vital an element in diaspora Judaism, and therefore that it must have been a central factor for Paul, unless it can be shown that he effectively departed from the ways of Judaism. (DTR)

9071. K. VAN DER TOORN and P. W. VAN DER Horst, 'Nimrod before and after the Bible', Harvard Theological Review 83 (1990) 1-29, esp. 17-19.

Philo is the first post-biblical writer to mention Nimrod explicitly. In the two passages in which he is discussed, $Q G$ 2.81-82 and Gig. 65-66 a number of haggadic elements occur which return frequently in later haggadic developments. Moreover the interpretation that Nimrod was 'against' rather than 'before' the Lord recurs explicitly in Augustine $D C D$ 16.4. This section was written by $\mathrm{P}$. W. van der Horst (see also above under his name). (DTR)

9072. R. Williamson, Art. 'Philo', in R. J. Coggins and J. L. Houlden (edd.), A Dictionary of Biblical Interpretation (LondonPhiladelphia 1990) 542-544.

More than 5 columns devoted to Philo is rather generous in this single volume dictionary. Both the survey and the bibliographical information are idiosyncratic, but charmingly so. (DTR)

9073. D. Winston, 'Judaism and Hellenism: Hidden Tensions in Philo's Thought', The Studia Philonica Annual 2 (1990) 1-19.

Originally presented as a keynote address to the North American Patristic Society in 1989, the article takes as its starting point the assertion that it is in the nature of so vast an enterprise of conceptual adaptation [as undertaken by 
Philo], that inner tensions must inevitably work their way ever so subtly to the surface, thus creating elements of stress that only an exposition employing systematic ambiguity could contain' (p. 3). Winston then proceeds to discuss several fundamental themes that illustrate such ambiguity as it emerges in Philo's commentary on Scripture. These themes are: repentance, the divine nature, Moses as sage, Moses as prophet, ecstatic and noetic prophecy and mystic vision. On the basis of these discussions Winston concludes that although Philo 'allows the Jewish side of his thought the dominant place in his presentation, he invariably tones it down by introducing some philosophical twist and by allowing the perceptive reader a glimpse of his true position... The philosophical portrait of Philo that thus emerges is that of a mind fully committed to a mystical form of Platonism. At the same time, it is the mind of a Jew who has remained loyal to his native religious tradition. (p. 18)' (DTR)

9074. D. Winston, 'The Sage as Mystic in the Wisdom of Solomon', in J. G. Gammie and L. G. Purdue (edd.), The Sage in Israel and the Ancient Near East (Winona Lake 1990) 383-397, esp. 386-388.

Attention is devoted to similarities and differences between the author of the Wisdom of Solomon and Philo on the theme of the sage as mystic. (DTR)

9075. B. P. Wolfe, The Place and Use of Scripture in the Pastoral Epistles (diss. Aberdeen 1990).

The author claims among other things that the traditions of II Peter and Philo on the doctrine of Scripture are not as different from Paul as is often supposed. (RMB, based on DA 53-03A, p. 846)

\section{D. Zeller, Charis bei Philon und Paulus, Stuttgarter} Bibelstudien 142 (Stuttgart 1990).

Zeller's first concern in this book is to show that Philo and Paul operated in a similar context: they were contemporaries, both were familiar with the Judaism of the Diaspora, and both championed the monotheism of their faith against pagan polytheism. Whereas this position is all-important to Philo, for Paul it merely serves as a 'prelude' to his more important campaign on behalf of Christ (p. 10). The two thinkers also express themselves in different ways: Philo mainly wrote allegorical, philosophically oriented treatises and is strictly an interpreter of Scripture. Paul, by contrast, is essentially a missionary (and a theologian) who writes letters, and though he is no stranger to philosophy, he is not conditioned by it to the same extent as Philo. On the basis of these similarities and differences Zeller compares Philo and Paul on the theological conception of grace. Though neither depends on the other, they do have common roots in the historical tradition. Zeller starts with a general lexical analysis of the term $\chi \alpha$ ós, and then looks at the meaning of 
the word in Greek antiquity, in the Septuagint, and in Hellenistic Judaism (pp. 13-32). The second part of the book analyzes the concept in Philo, with special reference to the relationship between grace and creation (pp. 33-48) - the main relationship in Philo - , that between grace and sin, and that between grace and moral perfection (pp. 49-103). In this ethical context the ultimate objective appears to be knowledge of God, which is identical to moral and spiritual perfection. Philo goes beyond Plato (and the Stoics) here in that man's understanding of God is not due to human virtue or merit but comes about by the initiative, i.e. in self-revelation, of God in the moment of ecstasy (pp. 103-105) and so, in the final analysis, by grace. Chapter 3 deals with $\chi \alpha$ or $\varsigma$ in the New Testament and in the period immediately prior to Paul, while chapter 4 is devoted to $\chi \alpha$ ó conviction that man cannot save himself. Like every pious Jew, Philo bases the possibility of man's salvation on the Bible and the Patriarchs. In his view, true faith culminates in the recognition of the Creator and the gratuitousness of his acts, in man's total dependence on God, and in the gift of grace, which extends not only to man but to all creation. The 'place' where grace is experienced is the created cosmos, and also the people of Israel, where the ecstatic knowledge of God is possible. For Paul, on the other hand, the principle of grace is Christ and his sacrifice for man, and this makes for a fundamental distinction between grace and human action, and between grace and law. For Philo, too, grace and moral perfection are gifts from God, but they are awarded only to those who lead a deserving life. In this way the gratuitousness of grace is given much less emphasis in Philo than in Paul, for whom the difference between the time before Christ (the era of sin) and the new dispensation brought by Christ constitutes a clean break, not only historically, but also in terms of individual salvation (this passage from sin to a state of grace is much more gradual in Philo). Zeller concludes: 'Even though the starting-points of Philo and Paul are so different, nevertheless we have been able to fix similar tendencies and consequences. The recognition - in the case of Paul, the demonstration - of $\chi \alpha$ óp $1 \varsigma$ brings man's pride to silence and leads him to thanksgiving' (p. 199). Reviews: D. M. Hay, SPhA 4 (1992) 174-175; F. Siegert, JSJ 23 (1992) 302-305; D. Winston, JBL 111 (1992) 548-550; R. Radice, SPhA 5 (1993) 195; P. Fiedler, ALW 35-36 (1993-1994) 238; K.-G. Sandelin, ThRv 91 (1995) 314-315. (RR)

\footnotetext{
9077. A. Zoumpos, 'Avó $\lambda \varepsilon \kappa \tau \alpha '$ [= 'Readings'], Platon 42 (1990) 85-92.
}

25 textual notes, of which two are on Philo. (DTR, based on APh 62 (1991) no. 14635) 
9101. M. Alexandre JR., 'The Art of Periodic Composition in Philo of Alexandria', in D. T. RuniA, D. M. HAY and D. Winston (edd.), Heirs of the Septuagint. Philo, Hellenistic Judaism and Early Christianity: Festschrift for Earle Hilgert, BJS 230 [= The Studia Philonica Annual 3 (1991)] (Atlanta 1991) 135-150.

Rhetoric for Philo is not merely the art of speaking well or a technique of persuasion. It has a crucial role in the interpretation of wisdom. Philo's method of writing lengthy and complex periods should be seen in the context of ancient rhetoric. Alexandre thus first briefly outlines the theory of the period in Greco-Roman rhetoric. He then proceeds to analyse a number of examples of Philonic periods, dividing them into cola and demonstrating Philo's love for various rhetorical techniques such as the use of isocolic phrases, gradatio and amplificatio. The examples given are Legat. 53-56, Mos. 2.253-255, Flacc. 123-124, Ebr. 157-159. In Philo's rhetoric structure is the key to meaning, but that meaning is placed in the service of the interpretation of scripture. For an earlier version of this article see 9002. (DTR)

9102. M. Alexandre JR., 'Some Reflections on Philo's Concept and Use of Rhetoric', Euphrosyne 19 (1991) 281-290.

This brief article gives a synoptic view of Philo's attitude to and use of rhetoric. It is for Philo much more than the simple art of speaking well or of persuasion. It has a vital role in interpreting and giving expression to divine wisdom. A central text on this issue is Det. 38-40, which explains the role of Aaron beside Moses. Philo's works also reveal his complete familiarity with the technical aspects of rhetoric as a $\tau \dot{\varepsilon} \chi \vee \eta$. Alexandre illustrates this with a brief analysis of Post. 110-111. (DTR)

9103. J. N. Bailey, 'Metanoia in the Writings of Philo Judaeus', in E. H. Lovering (ed.), Society of Biblical Literature 1991 Seminar Papers, SBLSPS 30 (Atlanta 1991) 135-141.

This study examines the use of $\mu \varepsilon \tau \alpha$ ovor $\alpha$ and cognate terms in the writings of Philo, especially in the tractate On Repentance, a part of the work On the virtues. Philo is almost the only author of Greek philosophy who endorses $\mu \varepsilon \tau \alpha$ ́not $\alpha$ as a virtue. It is concluded that the aims of this treatise were: (1) to show that repentance as part of Jewish religion is rational and virtuous, in an attempt to enhance adherence to the Law among an educated Hellenistic audience and to respond to philosophers who denigrated it; (2) to encourage proselytes to recognise the importance of their conversion, while at the same time urging ethnic Jews to fully accept them. (RMB) 
9104. M. BARKer, 'Temple Imagery in Philo: An Indication of the Origin of the Logos?', in W. Horbury (ed.), Templum amicitiae. Essays on the Second Temple presented to Ernst Bammel, JSNT.S 48 (Sheffield 1991) 70-102.

The author argues that there existed in ancient Israel the belief that God, called Yahweh, was in fact an archangel, the chief of the sons of El. He was the second deity, and was believed to have been the human figure in the Hebrew Bible. This Great Angel, it is claimed, became Philo's Logos. Philo linked the Angel/Logos of his Judaism to the Reason/Logos of the philosophers. The Logos is also the High Priest, and most of Philo's description of the Logos is based on the imagery of the temple cult in Jerusalem. (ACG)

9105. L. L. Belleville, Reflections of Glory: Paul's Polemical Use of the Moses-doxa Tradition in 2 Corinthians 3:1-18, JSNT.S 52 (Sheffield 1991), esp. 31-35.

The author examines the Jewish and Hellenistic Moses-doxa tradition in order to explain the differences that occur between 2 Cor. 3:7, 12-18 and Exod. 34:28-35, paying some attention to Philo, and especially to his De Vita Moses. As various parallels show, Philo and Paul both made use of the same Mosesdoxa tradition concerning the prophet's changed appearance after he had descended from Mt. Sinai. (RMB)

9106. B. L. Blackburn, Theios Anêr and the Markan Miracle Traditions, WUNT 2.36 (Tübingen 1991), esp. 64-69.

In his survey of divine miracle workers of the pre-Christian period the author examines the treatment of Moses by Philo. He refutes the claim that for Philo Moses was a deity, although he admits that Philo saw him as a divine man on more intimate terms with God than the Moses that occurs in Exodus. (RMB)

9107. G. BoccaCcini, Middle Judaism: Jewish Thought 300 BCE 200 CE (Minneapolis 1991), esp. 189-212.

To demonstrate the methods of Philo's exegesis of the Torah, the author discusses his treatment of two themes, memory and virginity. Philo follows the Aristotelian distinction between memory and recollection, but where Aristotle uses these terms for indicating functions of the mind only, Philo extends them to religious concepts used in describing the mind's path to the mystical encounter with God. In his reflection on virginity Philo accepts the negative perception of sexuality prevalent in Middle Judaism. New, however, is that he sees in virginity, as a part of continence, a way to regain the felicity of Eden. Review: D. Winston, SPhA 5 (1993) 233-237. (RMB) 
9108. P. Borgen, 'The Sabbath Controversy in John 5:1-18 and Analogous Controversy Reflected in Philo's Writings', in D. T. Runia, D. M. HAY and D. Winston (edd.), Heirs of the Septuagint. Philo, Hellenistic Judaism and Early Christianity: Festschrift for Earle Hilgert, BJS 230 [= The Studia Philonica Annual 3 (1991)] (Atlanta 1991) 209-221.

Comparisons between Philo and John show that John 5:1-18 is a specifically christianized version of a conflict on the sabbath that was also present in the Jewish community in Alexandria. In both Philo and John exegesis of Gen. 2:2-3 plays a central role. (DTR)

9109. A. P. Bos, In de greep van de Titanen: Inleiding tot een hoofdstroming van de Griekse filosofie, Verantwoording 5 (Amsterdam 1991), esp. 89-96.

In this book, which concentrates on the views of the origin and destination of man as given in Greek pre-philosophical and philosophical thought, a chapter is devoted to Philo. After Philo, his Jewish background and his allegorical mode of interpretation have been introduced, attention is paid to his doctrine of the double creation of both the universe and man and to the destination of man, viz. his return to his divine origin. In order to illustrate the doctrine of the soul's journey, allegorical interpretations of various Pentateuchal passages are listed and briefly discussed. (RMB)

9110. S. B. Bowman, Art. 'Philo', in A. P. Kazdhan (ed.), Oxford Dictionary of Byzantium, 3 vols. (New York-Oxford 1991) 3.1655.

Disappointingly brief and superficial notice on the fate of Philo in the Byzantine period. (DTR)

9111. H. Burkhardt, 'Inspiration der Schrift durch weisheitliche Personalinspiration: zur Inspirationslehre Philos von Alexandrien', Theologische Zeitschrift 47 (1991) 214-225.

A modern theological orientation regards inspiration as a veritable dictation by God of the contents of revelation, so that the prophet can be considered as a kind of secretary or as God's quill. This brings inspiration close to mantic, and in a certain sense this association is present in Philo, for it is true that there are a considerable number of passages, e.g. Spec. 1.65 and 4.49, - almost certainly inspired by Plato - , which express the notion of inspiration with concepts and terms derived from the terminology of mantic. Nevertheless this analogy does not go beyond the level of terminology, and is used exclusively to demonstrate the divine origin of Mosaic wisdom. In this sense, the author concludes, Philo cannot be regarded as the spiritual father of the doctrine of the mechanical inspiration of scripture, as he is often regarded. (RR) 
9112. C. CARLIER, La $\mu \eta \tau \rho o ́ \pi 0 \lambda 1 \varsigma$ chez Philon d'Alexandrie: le concept de colonisation appliqué à la Diaspora juive (Mémoire pour l'Académie des Inscriptions et Belles-Lettres, Ecole Biblique et Archéologique Française, Jerusalem 1991).

Taking Legat. 281 as starting point, the author presents a detailed study of Philo's use of the terms $\mu \eta \tau \rho o ́ \pi \circ \lambda_{1 \varsigma}$ and $\dot{\alpha} \pi \circ \imath \kappa i \alpha$, also comparing them with what is found in the LXX. Behind Philo's seemingly Greek use of the term $\mu \eta \tau \rho o ́ \pi 0 \lambda_{1 \varsigma}$ lies a resurgence of the problem of the relation between the centre (Jerusalem) and the periphery (Jewish communities in the Diaspora, described as $\dot{\alpha} \pi$ oเkí $\alpha$ l). On the other hand Philo uses the term $\pi \dot{\alpha} \tau \rho \iota \varsigma$ to describe the city where the Jews live in the Diaspora. This usage must be seen as being in opposition to the role of the $\mu \eta \tau \rho o ́ \pi 0 \lambda$ เs. (DTR)

9113. A. Chester, 'Jewish Messianic Expectations and Mediatorial Figures', in M. Hengel and U. Heckel (edd.), Paulus und das antike Judentum, WUNT 58 (Tübingen 1991), esp. 48-50.

Sketching the main features and significance of mediatorial figures from the second century BCE to the first century CE, the author turns to Philo's mediatorial concepts. The most important of these is the Logos which, as a figure separate from God, represents God's activity towards and relation with the world. (RMB)

9114. A. D. DE Conick and J. Fossum, 'Stripped before God: a New Interpretation of Logion 37 in the Gospel of Thomas', Vigilae Christianae (1991) 123-150.

The authors reject the widely accepted interpretation of Logion 37 in the Gospel of Thomas as baptismal. In their view the message of the Logion is that encratitism was a requirement for salvation and the return to the prelapsarian condition of paradise. To support their alternative interpretation the authors make use of relevant passages in Philo. (RMB)

\section{J. D. Crossan, The Historical Jesus: The Life of a Mediter- ranean Jewish Peasant (San Francisco 1991).}

In his assessment of the evidence for the historical Jesus, Crossan draws on Philonic material in three contexts. First, he weighs the evidence from Josephus and Philo (Legat.) for the aniconic shields and Caligula's statue (pp. 129-32), preferring the Josephan version where they differ. Second, he uses Philo as a representative of a sapiential understanding of the kingdom of God (pp. 288-89). Third, he draws on the Carabas episode and a governor's attitude toward a criminal condemned to crucifixion during feasts in Flacc. in his treatment of the passion narrative (pp. 380-81, 390-91). (DTR; based on summary supplied by G. Sterling) 
9116. E. Dassmann et al. (edd.), Reallexikon für Antike und Christentum, Band XV (Stuttgart 1991).

Articles with special sections on Philo are: G. O'Daly, Art. 'Hierarchie', 41-73, esp. 50-51 (hierarchy); A. Lumpe-H. Bietenhard, Art. 'Himmel', 173212, esp. 196-197 (heaven); J. Engemann, Art. 'Hirt', 577-607, esp. 589 (shepherd); J. Procopé, Art. 'Hochmut', 795-858, esp. 824-825 (pride, arrogance); F. K. Mayr, Art. 'Hören', 1023-1111, esp. 1071-1074 (hearing); A. Dihle-B. Studer-F. Rickert, Art. 'Hoffnung', 1159-1250, esp. 1177-1178 (hope). (DTR)

9117. B. Decharneux, 'Apparitions et miracles des anges et démons chez Philon d'Alexandrie et Plutarque', in A. Dierkens, (ed.) Apparitions et miracles, Problèmes d'histoire des religions 2 (Brussels 1991) 61-68, esp. 62-64.

Lists and analyses those Philonic texts in which the appearance of angels is connected with miraculous events. The miracles fall into two categories: those that contravene the laws of nature and those that reveal to selected souls the course of future events. The link between the two is the role of the Logos. The remainder of the article discusses parallel texts in Plutarch. (DTR)

9118. B. Decharneux, 'Le temps et l'espace dans la double création philonienne du monde', in L'espace et le temps: Actes du XXII e congrès de l'Association des Sociétés de Philosophie de Langue Française (Dijon, 29-31 aô̂t) (Dijon-Paris 1991) 142-144.

The conception of time appears to be a common element between Aet. and Opif., even if in the two texts the same definition is used in order to reach opposed conclusions (in the one case the eternity of the cosmos, in the other its origin in creation). For Decharneux the difference is to be explained through the differing contexts, abstract and theoretical in Aet., mythical in Opif. (RR)

9119. L. H. Feldman, 'Nodet's New Edition of Josephus' Antiquities', Journal for the Study of Judaism 22 (1991) 88-113, esp. 90f.

In his extensive review of Nodet's new edition of the first three books of Josephus' Antiquitates, Feldman argues against the editor that there is more than a coincidental resemblance between the works by Philo and Josephus, listing a large number of parallel passages. (RMB)

9120. F. Fendler, Studien zum Markusevangelium: zur Gattung, Chronologie, Messiasgeheimnistheorie und Überlieferung des zweiten Evangeliums, Göttinger theologische Arbeiten 49 (Göttingen 1991), esp. 62-68. 
Even if we do not posses sufficient material to define the chronology of the Philonic writings in a precise manner, it can be maintained that the De vita Moysis is a late work. Fendler reaches this conclusion on the basis of a brief but articulated analysis of the treatise from diverse perspectives - linguistic, stylistic, compositional (confirming the division into two books), thematic, and finally from the viewpoint of its origin and the purpose for which it was written. The final part of the discussion (pp. 66-68) is devoted to an examination of the relations between Mos. and Mark's Gospel. (RR)

9121. S. D. FraAde, From Tradition to Commentary: Torah and its Interpretation in the Midrash Sifre to Deuteronomy (Albany 1991), esp. $7-13$.

In his introductory chapter the author compares the Dead Sea scroll pesarim, the commentary of the Sifre on Deuteronomy and Philo's commentaries with each other. Three structural features of Philo's commentaries, shared with the Sifre, distinguish them from the pesarim: (1) their dialectical style; (2) the enchaining of interpretations; (3) multiple interpretations. An important difference between the multiple interpretation of the Sifre and Philo's commentaries, however, is that the first lacks a standard hierarchical plan, in contrast to Philo, for whom the allegorical interpretation is the more important one in comparison with the literal one. (RMB)

9122. Y. Frankel [י. ברנקל] [= דרכי האגדה ודמדרש [= The Methods of the Aggadah and the Midrash] (Jerusalem 1991), esp. 2.473-475.

In the course of this comprehensive investigation of rabbinic literature, the author briefly discusses possible connections with Philo's method. He relies on the study of Heinemann (R-R 5006) and concludes that 'even if in the general perception of Torah and its exegesis there are qualitative differences between the Jewish-Hellenistic philosopher and the Rabbis, there exists, nevertheless, a proximity in the sort of interpretative questions which they address to the biblical text' (p. 473). (DS)

9123. G. Gilbert, "The making of a Jew: "God-fearer" or convert in the Story of Izates [Josephus' JA 20.34-38]', Union Seminary Quarterly Review 44 (1991) 299-313, esp. 303-305.

In arguing that Izates was a Jew and not a 'God-fearer', the author adduces Philo as evidence of a Judaism in which there were Jews who were not circumcised. Passages discussed are Migr. 89-93, QE 2.2. (DTR)

9124. I. Goвry, 'La ténèbre ( $\gamma$ vópos): l'héritage alexandrin de Saint Grégoire de Nysse', Diotima: Revue de Recherche Philosophique 19 (1991) 79-89, esp. 79-81. 
A passage in Book II of the De vita Moysis of Gregory of Nyssa (p. 162ff.), in which it is stated that in order to obtain the visio Dei Moses had to enter into the darkness, certainly has Philonic precedents (Post. 13-16). This would explain the predominantly metaphysical character of the passage. Gregory, however, probably did not receive it directly from Philo, but made use of Clement of Alexandria as intermediary. (RR)

9125. L. L. Grabbe, 'Philo and Aggada: a Response to B. J. Bamberger', in D. T. Runia, D. M. HAY and D. Winston (edd.), Heirs of the Septuagint. Philo, Hellenistic Judaism and Early Christianity: Festschrift for Earle Hilgert, BJS 230 [= The Studia Philonica Annual 3 (1991)] (Atlanta 1991) 153-166.

Grabbe notes that the question of the relation between Philo and the Agga$\mathrm{da}$ is important, but has never received an adequate treatment. He commends the study of Bamberger (= R-R 7703) for its methodological awareness, as distilled in six cautionary rules. But an analysis of the 41 examples of parallels that Bamberger collected between Philo and the Aggada reveals that he very often transgressed his own rules. Indeed only 6 of the original 41 examples remain as possibly valid, and even these are not compelling. Grabbe concludes the article by adding 4 more rules to Bamberger's list and briefly making some suggestions for a 'proper study'. (DTR)

9126. P. Graffigna, 'Un hapax di Filone d'Alessandria:

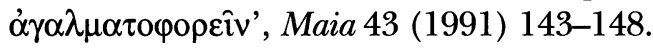

This study undertakes a semantic analysis of the term $\alpha \gamma \alpha \lambda \mu \alpha \tau \circ \varphi \circ \rho \varepsilon \dot{c} \omega$. The term is an original Philonic creation, and it plays an important in his theory of the image. The essay examines the passage where Philo uses this verb, and compares this usage with several other similar terms and phrases in sources close to Philo. On the basis of this examination it is concluded that Philo coined the term to signify that an idea 'bears form' in the divine and human intellect. In Philo the specific term ö $\gamma \alpha \lambda \mu \alpha$ denotes an idea that

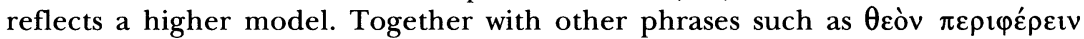

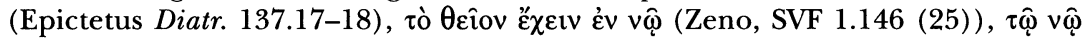

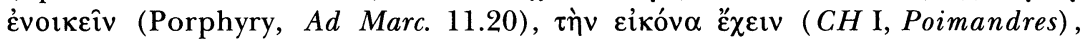
$\dot{\alpha} \gamma \alpha \lambda \mu \alpha \tau о \varphi о \rho \varepsilon \dot{\varepsilon} \omega$ constitutes a semantic 'paratactic' field, where the terms

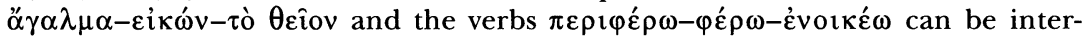
changed. $\dot{\alpha} \gamma \alpha \lambda \mu \alpha \tau о \varphi о \rho \dot{\varepsilon} \omega$ represents a synthesis of that field, unifying the various elements in it. (RR)

9127. J. Grondin, Einführung in die philosophische Hermeneutik (Darmstadt 1991), esp. 33-36.

In the context of the history of philosophical hermeneutics attention is drawn to Philo's allegorical model of interpretation. (RMB) 
9128. J. M. Hallman, The Descent of God: Divine Suffering in History and Theology (Minneapolis 1991), esp. 23-29.

Philo's views on the immutability or mutability of God are examined as part of an investigation into the viability of an incarnational Christology. The author argues that Philo's adherence to a doctrine of divine immutability (esp. in Deus) must be carefully analysed. It is suggestive, for example, that he never uses the concept of apatheia of God. It is concluded that Philo does not completely absorb the Greek notion of divine immutability and impassibility. The scriptural portrait of God remains dominant. (DTR)

9129. R. G. Hamerton-Kelly, 'Allegory, Typology and Sacred Violence: Sacrificial Representation and the Unity of the Bible in Paul and Philo', in D. T. Runia, D. M. HAY and D. Winston (edd.), Heirs of the Septuagint. Philo, Hellenistic Judaism and Early Christianity: Festschrift for Earle Hilgert, BJS 230 [= The Studia Philonica Annual 3 (1991)] (Atlanta 1991) 53-70.

This article approaches Philo's thought from a broad theological perspective, honouring him for interpreting the Bible for his time, just as we must do for ours. First four methods of biblical interpretation are outlined: allegory, typology, Bultmannian theology, Biblical theology of Sacred History (Heilsgeschichte). In opposition to these theologies the author presents the hermeneutic of Sacred Violence as proposed by R. Girard, which is then related to the Pauline theology of the cross. Hamerton-Kelly concludes that Philo was right to seek the universal meaning of the biblical text, but "was wrong to find that meaning in a form of Platonism rather than in the Gospel of the Cross' (p. 70). (DTR)

9130. D. M. HAy (ed.), Both Literal and Allegorical: Studies in Philo of Alexandria's Questions and Answers on Genesis and Exodus, BJS 232 (Atlanta 1991).

First collective study devoted to the subject of Philo's Quaestiones, based in part on a seminar held in Anaheim in 1985. Individual contributions are summarized under the names of the authors. The volume concludes with a bibliography and four indices. Reviews: S.-K. Wan, SPhA 5 (1993) 222-227; D. Winston, RelStR 19 (1993) 175. (DTR)

9131. D. M. HAY, 'References to Other Exegetes', in IDEM (ed.), Both Literal and Allegorical: Studies in Philo of Alexandria's Questions and Answers on Genesis and Exodus, BJS 232 (Atlanta 1991) 81-97.

Collects, analyses, and reflects on those passages in the Quaestiones in which Philo refers to other exegetes. Of the 47 references 9 may be purely hypothetical, while another 9 have parallels in other Philonic writings. Some of these are so close that Hay suggests there may not have been a great 
time gap between the Quaestiones and other exegetical works. The last part of the article makes interesting observations on the purpose of the treatises. The actual questions posed may well in many cases have come from previous or contemporary exegetes. Philo does not name them in order to lend his own work greater authority. The very form of the Quaestiones, Hay concludes, suggests that Philo saw himself as belonging to a community and succession of exegetes. (DTR)

9132. D. M. HAY, 'Philo's View of Himself as an Exegete: Inspired, but not Authoritative', in D. T. RUNIA, D. M. HAY and D. Winston (edd.), Heirs of the Septuagint. Philo, Hellenistic Judaism and Early Christianity: Festschrift for Earle Hilgert, BJS 230 [= The Studia Philonica Annual 3 (1991)] (Atlanta 1991) 41-53.

The evidence on which Hay's discussion is based on is the collection of all those passages in Philo in which he uses the pronoun ż $\gamma \omega$ and/or the first person singular to describe his own exegetical activity. This yields interesting observations on Philo's perception of the inspiration he received as exegete and on the potential audience he may have had in mind. Philo may have avoided being specific on the nature of his audience because he expected (or at least hoped) that he would have a wide and continuing audience. (DTR)

9133. E. Hilgert, 'The Quaestiones: Texts and Translations', in D. M. HAY (ed.), Both Literal and Allegorical: Studies in Philo of Alexandria's Questions and Answers on Genesis and Exodus, BJS 232 (Atlanta 1991) 1-15.

Gives a thorough survey of the various traditons of the Quaestiones. The fragmentary Greek tradition is very complex, and we may be certain that not all fragments have yet been located. The Latin translation has been well edited by F. Petit. In the case of the Armenian translation the lack of a critical edition is keenly felt. Substantial work remains to be done on this tradition, but at least we have good translations. (DTR)

9134. D. W. Hurley, A Historical and Historiographical Commentary on Suetonius' 'Life of C. Caligula' (diss. Columbia University 1991).

This commentary is a close reading of Suetonius' Life of Caligula, which is compared to accounts in other authors, including Philo. (RMB, based on DA 52-08A, p. 2912)

9135. N. Janowitz, 'The Rhetoric of Translation: Three Early Perspectives on Translating Torah', Harvard Theological Review 84 (1991) 129-140. 
The article argues that the reports given by Aristobulus, Aristeas and Philo on the translation of the Torah into Greek differ because the authors adapted the story to their personal situation. Philo's version, in which it is stated that the translators were under inspiration and that each word was translated literally, has to be understood against the background of his exegetical model. His exegesis was based on the premiss that each word of the Torah was inspired by God, and this had to be case for the Greek translation as well. (RMB)

9136. D. N. Jastram, 'Philo's Concept of Generic Virtue', in E. H. Lovering (ed.), Society of Biblical Literature 1991 Seminar Papers, SBLSPS 30 (Atlanta 1991) 323-347.

Based on research carried out by the author for his Wisconsin Ph.D. (8930), this article tackles the complex but important use that Philo makes of

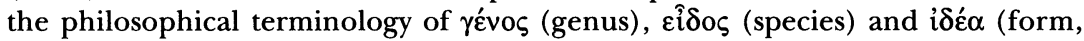
idea) in his ethical theory in order to describe various aspects of virtue. Two patterns are followed: (1) a simple contrast between generic and specific virtue; (2) a tripartite framework comprising generic virtue, specific virtues, and particular concrete acts of instances of specific virtues. Two key allegorical examples are used for these distinctions, the rivers in Paradise and the Ten Commandments. In two other key passages the genus-species hierarchy is fused with the Platonic forms: the double creation of man, and the change of name from Sarai (perishable virtue) to Sarah (imperishable virtue). Philo regards imperishable virtue (generic and specific) as the archetype of perishable virtue (also generic and specific), thus equating the former in many respects with Platonic forms. This means that the terms 'generic' and 'specific' receive a double sense: (1) what is more or less general in the classificatory hierarchy of genus, species, particular; (2) what is imperishable or perishable. This duality lies behind Philo's use of homonymous ethical terms (e.g. prudence can be imperishable or perishable ) and the structure of his allegories. (DTR)

9137. R. A. Kraft, 'Philo and the Sabbath Crisis: Alexandrian Jewish Politics and the Dating of Philo's Works', in B. A. PEarson et al. (edd.), The Future of Early Christianity: Essays in Honour of Helmut Koester (Minneapolis 1991) 131-141.

This essay is described by the author as a report on work in progress concentrating on chronological clues in Philo's writings. It is argued that the anonymous authority who tried to destroy the sabbatical tradition mentioned at Somn. 2.123-132 is likely to have been Philo's nephew Tiberius Julius Alexander. This is an economical hypothesis in two respects. (1) It helps to count for the negative treatment of the figure of Joseph in Somn. contrary to the positive depiction of him in other works such as Ios. Initially Philo treated Joseph sympathetically, but after the Sabbath crises he made him into a prototype of Alexander. (2) Since the negative Joseph is especially found in the allegorical treatises and since Alexander was prefect of Egypt in the late 
sixties, it may be suggested that these treatises were written considerably later than is generally thought, i.e. when Philo was in his seventies or eighties. This is chronologically not impossible. (RMB)

9138. J. Laporte, 'The High Priest in Philo of Alexandria', in D. T. Runia, D. M. HAY and D. Winston (edd.), Heirs of the Septuagint. Philo, Hellenistic Judaism and Early Christianity: Festschrift for Earle Hilgert, BJS 230 [= The Studia Philonica Annual 3 (1991)] (Atlanta 1991) 71-82.

Examines the role of the high priest in the thought of Philo both from the literal and the allegorical perspective. Though idealized, the high priest is not deprived of his human reality. His most important task is the liturgical act of propitiation on Yom-Kippur. But in Philo's view the priesthood of the high priest is also combined with the priesthood of the faithful in a movement of interiorization made possible through the doctrine of the logos as human reason related to the divine Logos. The Sage is thus the chief symbol of healing. But this does not mean that the practice of ritual forgiveness as practised by the human high priest becomes spiritually meaningless. (DTR)

9139. M. LatTKE, Hymnus: Materialien zu einer Geschichte der antiken Hymnologie, Novum Testamentum et Orbis Antiquus 19 (FreiburgGöttingen 1991), esp. 129-132.

Detailed terminological observations on Philo's references to hymns and

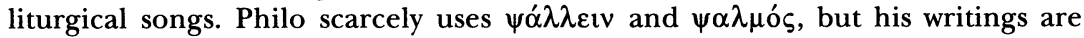
rich in references to $\dot{v} \mu v \varepsilon \hat{v} v$, $u \mu v o \varsigma$ and related terms. Special attention is paid to the description of the liturgy of the Therapeutae in Contempl. (DTR)

9140. S. Levarie, 'Philo on Music', Journal of Musicology 9 (1991) 124-130.

Philo makes many references to music throughout his voluminous writings, but these have hitherto received little attention. Though not a professional musician, Philo is well acquainted with the basic facts of music theory and practice. After dealing with examples of musical metaphor, analogy and actual praxis in Philo (the most important is found at Contempl. 64ff.), the author concludes that Philo, unlike later generations, still recognised music as a spiritual force. (RMB)

9141. B. LÖFSTEDT, ' $\mathrm{Zu}$ den lateinischen Übersetzungen von (Ps.)Philons Schriften', Eranos 89 (1991) 101-106.

Brief introductory remarks on the Latin translations of Contempl., $Q G$ IV and Ps. Philo $L A B$ and on modern editions of these texts, followed by comments on the syntax of various passages and on the translator's unusual vocabulary. (DTR) 
9142. D. LührmanN, 'The Godlessness of Germans Living by the Sea according to Philo of Alexandria', in B. A. Pearson et al. (edd.), The Future of Early Christianity: Essays in Honour of Helmut Koester (Minneapolis 1991) 57-63.

Reflections on the curious account given by Philo at Somn. 2.120-121 about Germans living by the sea and trying to keep back the incoming tides with their swords. Philo calls this an action of 'godlessness' $(\dot{\alpha} \sigma \varepsilon \dot{\varepsilon} \varepsilon \iota \alpha)$. The accusation may in fact have a political rather than a religious background, i.e. these German tribes were godless because they did not accept the Roman order of peace. Philo might have known better if he had read the account of the Germans in Strabo, as derived from Posidonius. (DTR)

9143. B. L. MACK, 'Wisdom and Apocalyptic in Philo', in D. T. Runia, D. M. Hay and D. Winston (edd.), Heirs of the Septuagint. Philo, Hellenistic Judaism and Early Christianity: Festschrift for Earle Hilgert, BJS 230 [= The Studia Philonica Annual 3 (1991)] (Atlanta 1991) 21-39.

Examines the theme of the relation between wisdom and apocalyptic eschatology in Philo's thought, arguing against the position of P. Borgen in his article "There Shall Come Forth a Man": Reflections on Messianic Ideas in Philo' (9211). The final words of the article summarize Mack's thesis trenchantly (39): 'Philo was a child of wisdom and the diaspora synagogue. He was hardly a strong candidate for an apocalyptic persuasion. Because he was not, the turn he took with its language in De praemiis et poenis is singularly unconvincing. Wisdom in Philo? Yes. Apocalyptic? No.' (DTR)

9144. S. MacKnight, A Light among the Nations: Jewish Missionary Activity in the Second Temple Period (Minneapolis 1991), esp. 68-70.

Dealing with Jewish missionary activity in the Second Temple period, the author pays attention to the propaganda techniques used by Philo, of which his depiction of Moses is perhaps the best example. Notwithstanding Philo's skill in apologetics, polemics and propaganda, the author concludes that Philo was not so much interested in proselytizing gentiles as in bolstering Jewish self-identification. This is shown by the lack of direct speech to gentiles in Philo's auvre. (RMB)

9145. J. A. Martens, A Second Best Voyage: Judaism and Jesus on Oaths and Vows (diss. McMaster University, Hamilton 1991).

The carelessness in swearing oaths and taking vows leading to swift regret at the end of the Second temple period confronted the leaders within Judaism with two problems: (1) which formulae of oaths and vows are binding? (2) how can one gain release from an oath or a vow? The dissertation proposes and defends the independent integrity of the stands on oaths and 
vows by Philo, Qumran, and the Pharisees. Their positions are compared to that of Jesus. (RMB, based on DA 54-02A, p. 561)

9146. J. W. Martens, The Superfluity of the Law in Philo and Paul: a Study in the History of Religions (diss. McMaster University, Hamilton 1991).

Martens investigates how Graeco-Roman discussions of 'higher' law - viz. the law of nature (nomos physeos), the unwritten law (agraphos nomos), and the living law (nomos empsychos) - influenced or might have influenced Philo and Paul in their attempts to understand the Mosaic law in a Hellenistic environment. Each of these forms of Graeco-Roman law, it is argued, implied a depreciation of the written or civil law. Did Philo, who adopted each of these forms of law, imply such a depreciation of the Mosaic law? The author concludes that for Philo this was not the case. Contrary to Paul, he upheld the Mosaic law. (RMB, based on DA 54-02A, p. 562)

9147. J. W. Martens, 'Philo and the Higher Law', in E. H. Lovering (ed.), Society of Biblical Literature 1991 Seminar Papers, SBLSPS 30 (Atlanta 1991) 309-322.

In facing the problem of the relation between the written law of Moses and the 'higher' law, i.e. non-arbitrary law as demanded by Greek philosophy, Philo was confronted by a dilemma. If he accepted the existence of a kind of 'higher' law he was in danger of rendering the law of Moses superfluous; if he did not accept its existence the law of Moses would be arbitrary. In an attempt to find a way out, Philo linked together all forms of higher law (the law of nature, the unwritten law, the nomos empsychos) so that they almost became one. The law of Moses is then conceived as a 'true copy' of this higher law. It helps to guide the weak and the ordinary people who are not by themselves in a position to be an unwritten law or a nomos empsychos. In this way the law of Moses is clearly linked with the higher law without becoming superfluous or only of secondary importance. It is a vision of law unique in the ancient world. (RMB)

9148. E. Martin Morales, 'De Fuga et Inventione: Filón de Alejandría', Notizario Centro di Studi sul Guidaismo Ellenistico $2^{\text {bis }}$ (1991) 1-7.

An occasional paper presented in the context of the research centre for Hellenistic-Jewish studies in Rome. De fuga is one of Philo's most systematic treatises because it has a clearly defined didactic-methodological goal. Its function becomes clear if it is read in conjunction with Congr. and Mut. in a sequence which is not only determined by the continuity of the biblical text (Gen. 16:1-6 in Congr., Gen. 16:6-14 in Fug., Gen. 17:1-11 in Mut.), but also by the complementarity of themes dealt with, which are presented as stages in the same formative-educative process, i.e. propaedeutics represented by Abraham, ascesis represented by Jacob, contemplation represented by Isaac. The 
author emphasizes the great influence that Fug. had in Christian thought, and mentions as concrete example the De doctrina christiana of Augustine. (RR)

9149. J. P. Martín, 'El Sofista de Platón y el platonismo de Filón de Alejandría', Methexis 4 (1991) 81-99.

The analysis carried out in this article focuses especially on the history of Platonism and Philo's place therein. Martín holds that the relation between Plato and Philo should be evaluated from at least four points of view: topological (i.e. the citations of Plato found in Philo), epistemological, comparative/ historical, and systematic or properly philosophical. In the case of the fourth area, which is particulary broad in its connotations, he intends not to furnish definitive results, but rather simply to indicate some lines of research. His basic thesis is that, "just as the Timaeus is central for the theme of creation and the Phaedrus for the doctrine of man, so the Sophist has this place for ontology and dialectic' (p. 83). A detailed analysis of the Platonic text and the corresponding passages in Philo leads to the conclusion that Philo's synthesis of the Timaeus and Genesis is systematically incompatible with Plato's Sophist. This is so because in the latter the Absolute is constituted through a movement of relations between supreme genera, whereas in the former relations are constituted through the action of an Absolute which is transcendent and inscrutable. (RR)

9150. J. P. Martín, 'Philo and Augustine, De civitate Dei XIV 28 and XV: Some Preliminary Observations', in D. T. Runia, D. M. Hay and D. Winston (edd.), Heirs of the Septuagint. Philo, Hellenistic Judaism and Early Christianity: Festschrift for Earle Hilgert, BJS 230 [= The Studia Philonica Annual 3 (1991)] (Atlanta 1991) 283-294.

Argues on the basis on an examination of 14 conceptual pairs of themes that the nucleus of Augustine's idea of the two cities goes back to Philo. Biblical pairs such as Abel and Cain, Sarah and Hagar etc. are not only related to themselves, but also to the themes of two citizenships and two moral paths in history. Both in Augustine and in Philo there is a tendency to confuse two schemes, that of evil versus good and nature versus grace. Martín declines to answer the question whether there was a direct dependence of Augustine on Philo, but does assert that so far scholarship has not asked the right questions on this issue. (DTR)

9151. B. C. McGing, 'Pontius Pilate and the Sources', The Catholic Biblical Quarterly 53 (1991) 416-438.

It is generally agreed that there is a divergence between Philo and Josephus on the one hand and the Gospel authors on the other in their portrayal of Pontius Pilate. In the view of the author, however, there is no flagrant contradiction between our three sources. Although not specially incompetent and not a monster, Pilate was unable and unwilling to avoid situations of serious friction with the Jews. (RMB) 
9152. B. McGinn, The Presence of God: a History of Christian Mysticism, vol. 1 The Foundations of Mysticism (New York-London 1991), esp. 35-41.

A section is devoted to Philo as part of a comprehensive account of the foundations of Western, i.e. Christian, mysticism. Philo is regarded as one of 'central philosophers whose thought is both representative of the time and also directly relevant to Latin Christian mysticism (p. 35)' (the others are Plotinus and Proclus). (DTR)

9153. A. Méasson and J. Cazeaux, 'From Grammar to Discourse: a Study of the Questiones in Genesim in Relation to the Treatises', in D. M. HAY (ed.), Both Literal and Allegorical: Studies in Philo of Alexandria's Questions and Answers on Genesis and Exodus, BJS 232 (Atlanta 1991) 125-225.

The title of this long and important analysis of the relation between the Quaestiones and the Treatises (i.e. primarily the Allegorical Commentary) is explained through the authors' conviction that the Treatises have a fully developed dynamic quality which gives them force and movement, whereas the Quaestiones are static and fragmented, like 'note-cards'. The difference is compared to that between grammar and the style of a masterpiece. Chronological considerations are of secondary importance. It is the literary genre that differentiates them. The authors illustrate their thesis with extensive analyses of Philonic texts which can be subdivided as follows: (a) a profile of $Q G 1$ (including a list of parallel of passages); (b) reflections on the structure of Leg., allowing comparison between the two works; (c) comparison of Leg. 3.75-104 with $Q G$ 1.47-48; (d) comparison of $Q G$ 1.57-99 with Gig.-Deus; (e) analyses of $Q G$ 2-3; (f) extensive analyses of $Q G 4$ (note esp. long passages on $\S 1,2,8)$, including extensive comparison with parallel passages in other Philonic works; (g) brief remarks on $Q G$ 5-6 (i.e. 4.71-245 Aucher). The article is concluded with a final analogy. The Quaestiones are not to be viewed as notes containing preliminary materials for a treatise. They are to be compared with a catechism, solid and elementary, allowing the meaning to be preserved and Faith to be guarded. The Treatises in contrast form a theology, more ambitious and more suited for infusing the truth of Reason into the human mind, but at the same time making maximum demands on the reader. The two series are unequal in value, for "Philo" is himself only in the Treatises (p. 225).' (DTR)

9154. J. Mélèze Modrzejewski, Les Juifs d'Egypte de Ramses II à Hadrien, Collection des Nereides (Paris 1991), esp. 135-144 and passim.

A study on Jews in Egypt from the time of Joseph until the 2nd century CE can hardly avoid making frequent reference to Philo, even if in the foreword the author declares that he will place the emphasis on documents less well 
known than the LXX and Philo. From p. 131 onwards the story of the Jews under Roman rule is told, with interesting information on Philo's family at 150-151. (DTR)

9155. A. Mendelson, 'Two glimpses of Philo in Modern English Literature: Works by Charles Kingsley and Francis Warner', in D. T. Runia, D. M. HAY and D. Winston (edd.), Heirs of the Septuagint. Philo, Hellenistic Judaism and Early Christianity: Festschrift for Earle Hilgert, BJS 230 [= The Studia Philonica Annual 3 (1991)] (Atlanta 1991) 328-343.

Philo appears on the stage in at least two works of modern English literature, in Charles Kingsley's novel Hypatia (1853), and Francis Warner's play Light Shadows (1979). Mendelson examines the role that Philo plays in both works and draws some conclusions on his role as a Jew. Kingsley uses systematic stereotyping, in which social and theological views coincide. In Warner social stereotyping has disappeared, but Philo and his co-religionists are still regarded as theologically immature. (DTR)

9156. K. A. Morland, The Galatian Choice. Galatians 1:6-12 and 3:8-14 in the Light of Jewish Curse-Texts and Antique Rhetoric (diss. Oslo-Trondheim 1991), esp. Part I.

In this book the Philonic references with a few exceptions are confined to Part I: Curse and anathema - the Jewish horizon. After a semantic field analysis of the Pauline passages studied, the author looks for Jewish parallel material which he finds also in Philo's writings. Lists of the Philonic texts pertaining to the concept of 'curse' are given on pp. 347-348, 352-357, 361-62 and 369-70. Praem. 79-172 is analyzed on pp. 49-52. According to the author the paraenetic feature of Deut. 27-30 commented upon in this passage has been sharpened. The aim of the treatise seems to be to exhort the fellow Jews to follow the law in order to prepare for the turning of the ages, with the curse and blessing motif as an important element' (p. 52). Leg. 3 is basically an exposition of the curses in Gen. 3. 'By relating the curse to pleasure, senseperception and actions, Philo manages to establish the curses... as exhortations toward covenantal obedience' (p. 87). Several texts are found in Philo where curse and blessing form antitheses (p. 96-97). Philo also refers to texts (e.g. Gen. 12:3) containing promises to the Gentiles (e.g. Migr. 118-126, p. 107). When Philo in Spec. 1.315-318 refers to Deut. 13:1-11 demanding the putting to death of the prophet who propagates apostasy, this killing 'seems to take the form of lynching' (p. 135). See further 9449 for the published version of this thesis. (KGS)

9157. J. H. C. NeEB, Genesis 28:12: The Function of a Biblical Text in Early Jewish and Christian Communities (Origen) (diss. St. Michael's College, Toronto 1991). 
Chapter 4 situates Origen within his Greek philosophical context (Plato, Philo). In chapter 5 Origen's dependence on Philo's De Somniis is also discussed. (RMB, based on DA 53-08A, p. 2856)

9158. J. van OoRT, Jerusalem and Babylon: a Study into Augustine's City of God and the Sources of his Doctrine of the Two Cities, VChr.S 14 (Leiden 1991), esp. 234-254.

In his exhaustive study on the sources of Augustine's doctrine of the two cities Van Oort examines the claim that Augustinus had been influenced in this respect by (Neo)-Platonism, esp. Philo and Plotinus. It is concluded that there is some superficial resemblance between (Neo)-platonic thought and Augustine. But no parallels are found for the most characteristic elements of Augustine's doctrine, namely (1) that the two societies are absolutely antithetical, and (2) that they have an origin and a progress in time. Augustine must have derived these elements from another source. (RMB)

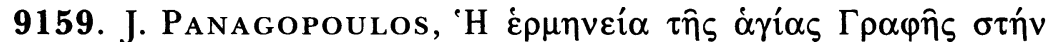

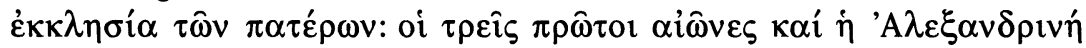

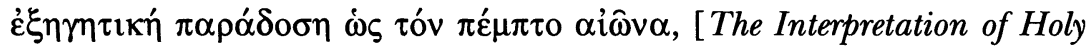
Scripture in the Patristic Church: the First Three Centuries and the Alexandrian Exegetical Tradition up to the Fifth Century] vol. 1 (Athens 1991), esp. 79-85.

A section is devoted to Philo as part of a comprehensive account of biblical exegesis during the first three centuries of the Church and of Alexandrian exegesis up to the fifth century. (DTR)

9160. R. J. Quinones, The Changes of Cain: Violence and the Lost Brother in Cain and Abel Literature (Princeton 1991), esp. 23-29.

Philo plays an extremely important role in the history of the Cain-Abel theme, because through his exegetical commentaries the biblical brothers are transformed into universal rival and contending principles. This approach is followed by Ambrose and Augustine. (DTR)

9161. R. RADICE, 'Observations on the Theory of the Ideas as the Thoughts of God in Philo of Alexandria', in D. T. Runia, D. M. Hay and D. Winston (edd.), Heirs of the Septuagint. Philo, Hellenistic Judaism and Early Christianity: Festschrift for Earle Hilgert, BJS 230 [= The Studia Philonica Annual 3 (1991)] (Atlanta 1991) 126-134.

Radice offers arguments against the conventional view that Philo cannot possibly have played a role in the development of the Middle Platonist doctrine of the ideas as thoughts of God, even though he is the first to record it. He postulates a double Platonist tradition, one purely Greek, the other Jewish- 
Alexandrian. Philo developed the notion of the ideas as thoughts of God as the result of his exposition of Mosaic thought. His location in Alexandria at the cross-roads of various philosophical tendencies meant that Greek philosophers must have been acquainted with his works, and so he was able to act as a catalyst in the development of Middle Platonist thought. Radice refers for further details to his 1989 monograph (8948). (DTR)

9162. J. Riaud, Art. 'Thérapeutes', Dictionnaire de Spiritualité, Ascétique et Mystique, Doctrine et Histoire 15 (1990) 562-570.

Discusses the controversial topic of the historical identity of the community which established itself on the mountains above Lake Mareotis and which Philo describes in Contempl. Philo uses two names to designate these monks: 'Therapeutae' and 'Suppliants'. The first term indicates that they 'regarded themselves as priests and worshippers of the one true God and as moralists and philosophers who healed the body by curing the soul. The name 'Suppliants', on the other hand, suggests a connection with the Levites and the great allegorical theme of the migration from the dominion of the body and from the 'Egypt' of the passions (p. 565). Riaud describes the characteristics of the Therapeutae (average age, social origin, way of life, etc.), their relations with the priesthood of Jerusalem (p. 568), their use of allegory (p. $565 \mathrm{ff}$.), and their links with Christian monasticism (p. 568 ff.). The article ends with a useful bibliography. (RR)

9163. J. Riaud, 'Quelques réflexions sur les Thérapeutes d'Alexandrie à la lumière de De vita Mosis II, 67', in D. T. Runia, D. M. Hay and D. Winston (edd.), Heirs of the Septuagint. Philo, Hellenistic Judaism and Early Christianity: Festschrift for Earle Hilgert, BJS 230 [= The Studia Philonica Annual 3 (1991)] (Atlanta 1991) 184-191.

Various reflections on the portrait of the theoretic or contemplative life of the Therapeutae such as it is presented in Contempl. According to Riaud their perfect way of life represents the goal of philosophy such as Philo conceived it. (DTR)

9164. S. D. Robertson, The Account of the Ancient Israelite Tabernacle and First Priesthood in The 'Jewish Antiquities' of Flavius Josephus (diss. Annenberg Research Institute, Philadelphia 1991), esp. chap. 2.

In chapter 2 the author compares the description of the Tabernacle court and superstructure by Flavius Josephus to, among others, Philo. It is concluded that Josephus shows close acquaintance with Philo's Life of Moses. (RMB, based on DA 53-07A, p. 2504) 
9165. J. R. Royse, 'Philo's Quaestiones in Exodum 1.6', in D. M. HAY (ed.), Both Literal and Allegorical: Studies in Philo of Alexandria's Questions and Answers on Genesis and Exodus, BJS 232 (Atlanta 1991) 17-27.

Taking his cue from L. Früchtel, Royse shows that the original Greek text of the passage can be almost entirely reconstructed on the basis of two quotations in the Sacra Parallela. On the basis of this text he makes comments on the Armenian translation and argues against Petit that, when Philo

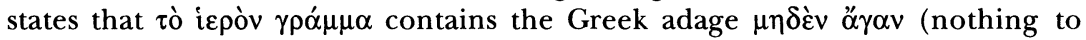
excess), he is referring to Mosaic scripture. (DTR)

9166. J. R. Royse, 'Philo, Kúpros, and the Tetragrammaton', in D. T. Runia, D. M. HaY and D. Winston (edd.), Heirs of the Septuagint. Philo, Hellenistic Judaism and Early Christianity: Festschrift for Earle Hilgert, BJS 230 [= The Studia Philonica Annual 3 (1991)] (Atlanta 1991) 167-183.

Printed editions of the LXX, based primarily on Christian mss., render

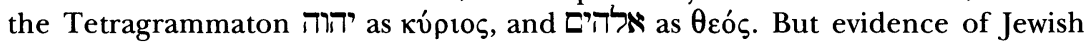
practice accumulated during the last century indicates that there was considerable variety in the way the Tetragrammaton was dealt with in written form. Royse examines the evidence allowing us to determine what Philo read in his mss. and what he himself wrote, and comes to the following conclusions: (1) in the biblical texts which he read the Tetragrammaton was written in palaeo-Hebrew or Aramaic letters and not translated by кúpios; (2) his own written use of kv́pı̧ is consistent with having read such texts and having pronounced the Tetragrammaton as кúpıos; (3) his remarks at Mos. 2.114 and 2.132 can be explained if we suppose that he saw the Tetragrammaton untranslated in the text he had before him. (DTR)

9167. C. Ruiz-Montero, 'Aspects of the Vocabulary of Chariton of Aphrodisias', The Classical Quarterly 41 (1991) 484-489.

Compares vocabulary of the novelist with, inter alia, Philo. Finds that it coincides more with Plutarch, Josephus and Philo than with Diodorus of Sicily and Dio of Prusa, the other authors used. This leads to a dating c. 100 CE. (DTR)

9168. D. T. Runia, 'Secondary Texts in Philo's Quaestiones', in D. M. HAy (ed.), Both Literal and Allegorical: Studies in Philo of Alexandria's Questions and Answers on Genesis and Exodus, BJS 232 (Atlanta 1991) 47-79.

Philo's Quaestiones answer exegetical questions posed on Genesis and Exodus taken in the sequence of the biblical text. The paper addresses the 
question to what extent other biblical texts are referred to in the course of the exegesis (a practice that is fundamental to Philo's method in the Allegorical Commentary). In total 100 examples of such 'secondary texts' are found. These are analysed from various points of view. It is concluded that the use of such texts in the Quaestiones is strictly limited. They are used primarily to illustrate or confirm interpretations that Philo puts forward. For only about two-thirds of the examples can parallels be found elsewhere in the Philonic corpus. This shows that the Quaestiones have an independent position among Philo's writings, and do not have a merely preparatory character. (DTR)

9169. D. T. Runia, 'Philo of Alexandria in Five Letters of Isidore of Pelusium', in D. T. Runia, D. M. HAY and D. Winston (edd.), Heirs of the Septuagint. Philo, Hellenistic Judaism and Early Christianity: Festschrift for Earle Hilgert, BJS 230 [= The Studia Philonica Annual 3 (1991)] (Atlanta 1991) 295-319.

Gives text and translation, together with detailed commentary, of the four letters of the desert father Isidore of Pelusium (370-435) in which Philo is explicitly named (Ep. 2.143, 270, 3.19, 3.81), and also of a fifth letter (4.176), the contents of which are clearly based on Mos. It emerges that Isidore possessed a more than superficial acquaintance with Philo's thought and writings. In two letters Philo's status as a Jew is emphasized. Isidore uses him as an effective weapon in his contest with contemporary Judaism. (DTR)

9170. D. T. Runia, 'Witness or Participant? Philo and the Neoplatonic Tradition', in A. VAnderJagt and D. PÄtzold (edd.), The Neoplatonic Tradition: Jewish, Christian and Islamic Themes, Dialectica Minora 3 (Köln 1991) 36-56.

As everyone knows, Philo gives much valuable information as a witness on the beginnings of Middle Platonism. But did he participate in and contribute to that tradition himself? The paper makes a start on examining the extent to which Philo may have played a role in the development of Neoplatonism. In the first part a status quaestionis is given, particularly on the relation between Philo and Plotinus. In the second part a survey is given on the survival of Philo's writings. The third part concentrates on a specific example, namely the theme of God as ó $\dot{\varepsilon} \sigma \tau \omega^{\prime}$ ('the standing one'). It is argued that Plotinus' use of the concept goes back to Philo, probably via Numenius. In conclusion it is asserted that the entire question is very difficult, but that the burden of proof in this question must lie with those who argue that Philo had no influence on the Neoplatonic tradition whatsoever. (DTR)

9171. D. T. Runia, 'Underneath Cohn and Colson: the Text of Philo's De Virtutibus', in E. H. Lovering (ed.), Society of Biblical Literature 1991 Seminar Papers, SBLSPS 30 (Atlanta 1991) 116-134. 
How reliable are the texts of Cohn-Wendland and Colson which almost all Philonists use? This question is posed in the case of De virtutibus. This treatise has a complex textual history. The paper examines the evidence of the direct and indirect tradition, and also looks at the problems surrounding the title and the structure of the work (i.e. which parts did it originally consist of). It is concluded that Philonists may consider themselves fortunate that the job of editing has been competently done, but that there are no grounds for complacency. Serious research cannot just be based on translations, but must take text and critical apparatus into account. (DTR)

9172. D. T. Runia, D. M. HAY and D. Winston (edd.), Heirs of the Septuagint. Philo, Hellenistic Judaism and Early Christianity: Festschrift for Earle Hilgert, BJS 230 [= The Studia Philonica Annual 3 (1991)] (Atlanta 1991).

The third volume of The Studia Philonica Annual deviates from earlier volumes in that it almost entirely consists of articles written by scholars in honour of Earle Hilgert, former editor of Studia Philonica, who retired in 1991 from his professorship at McCormick Theological Seminary. A photo of the honorand is placed opposite the title page. All but two of the articles focus on Philo, and thus are summarized under the names of their authors in this bibliography. (DTR)

\section{K. G. SANDELin, 'The Danger of Idolatry According to} Philo of Alexandria', Temenos 27 (1991) 109-150.

Pagan religion exerted an attractive force on many Jews in the Hellenistic and Imperial era. Philo wrestles with the question in several texts. This shows that it was a real problem among Jews in Alexandria. For Philo idolatry is a deification of created things and it is also closely connected with the passions. It is dangerous because those who have invented the pagan myths had the intention of consigning the God who really exists to oblivion. Jews in Alexandria confronted idolatry in several contexts: gymnasia, sporting contests and the theatre. Philo presents topical applications of various Biblical passages, giving him the opportunity to take a warning stand against idolatry in its diverse forms. (KGS)

9174. G. Scarpat, 'La Torre di Babele in Filone e nella Sapienze (Sap. 10, 5)', Rivista Biblica 39 (1991) 167-173.

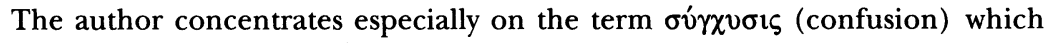
Philo deals with in Conf. 187 in relation to the bibical episode of the construction of the tower of Babel. The term in question shows a semantic affinity

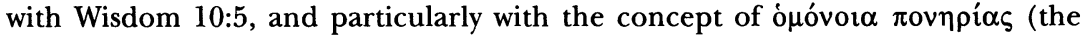

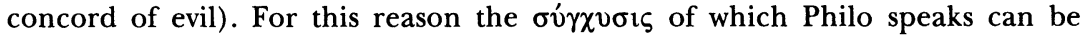
interpreted as the confusion which God arouses in the planning of evil by malevolent men. Such confusion is necessary so that the good will triumph. (RR) 
9175. J. M. Scholer, Proleptic Priests: Priesthood in the Epistle to the Hebrews JSNT.S 49 (Sheffield 1991), esp. 63-71.

In the chapter on priesthood in the literature outside the New Testament a section is devoted to Philo's views on priesthood. A distinction is made between Philo's description of actual priesthood and his symbolic interpretation of it. In his description Philo does not diverge significantly from the Old Testament tradition. In his symbolic interpretation the high priest represents the Logos that is the mediator between God and man. The universal priesthood of the people of Israel during the Passover is interpreted as a portrayal of the soul's progress towards God. This spiritual priesthood requires a spiritual sacrifice in the form of prayer. Although Philo does not discard animal sacrifice, he values prayer as the superior form of sacrifice. (RMB)

\section{C. Schur מדרשי-השמות העבריים בפרשנות האליגורית, [ח. שירי]} [Etymologies of Hebrew Names in Philo's Allegorical Exegesis] (diss. Tel Aviv University 1991).

This dissertation surveys and assesses the 162 instances where Philo presents the readers of his allegorical treatises with an explicit etymological treatment of proper names in the scriptural narrative. While roughly a third of these passages are based on biblical paronomasia, the great majority reflect, according to the author, Philo's own interpretative and philological acumen. Though conscious of the weight of scholarly opinion which regards Philo as derivative of and dependent on earlier etymological tradition, Schur argues throughout for Philo's knowledge of the Hebrew language and his unmediated access to the Hebrew biblical text. Perhaps most central to the thesis advanced here, beyond the author's detailed investigation of each instance, is the conviction that the etymologies must be examined within the context of the broader lines of Philonic interpretation: these treatments are never an etymological exercise in its own right; rather, their 'raison d'être is the contribution of symbolical ideas to the allegorical exegesis' (p. 216). (DS; based on English Summary, vol. 2, *1-*15)

\section{A. B. Scotт, Origen and the Life of the Stars, Oxford Early} Christian Studies (Oxford 1991), esp. 63-75.

As part of the background to Origen's views on the life and nature of the stars a short chapter is included on Philo. Scott lists and briefly discusses the more important Philonic passages on his subject. Philo does much to accommodate himself to the prevailing philosophical climate, and so comes close to regarding the stars as divine. 'He follows the conventions of his day in honouring the stars, but he is both too good a Jew and too good a Platonist to take this to its logical consequences (p. 74).' Differently than Origen, however, Philo does not recognize the possibility of evil in heaven. (DTR) 
9178. J. P. Scullion, A Traditio-Historical Study of the Day of Atonement (Yom Kippur, Purification) (diss. Catholic University of America 1991), esp. chap. 2.

In aiming to further an understanding of the soteriological significance of the Christ event through a traditio-historical study of Yom Kippur, chapter 2 examines the understanding of Yom Kippur in various Second Temple authors, including Philo. (DTR; based on DA 52-02A p. 569)

9179. T. Seland, Jewish Vigilantism in the First Century CE: a Study of Selected Texts in Philo and Luke on Jewish Vigilante Reactions against Nonconformers to the Torah (diss. Trondheim 1991).

See the summary of the published version at $\mathbf{9 5 7 4}$.

9180. R. Skarsten, 'Some Applications of Computers to the Study of Ancient Greek Texts: a Progress Report', Symbolae Osloenses 66 (1991) 203-220.

A brief introduction to the possibilities that computers offer for studying ancient Greek texts, written at a non-specialist level. For Philonists two aspects are particularly interesting: Skarsten furnishes further information on the KWIC-concordance to Philo's works being produced in Norway (see further Runia, 9060); various examples are given to support his conviction that the work $D e$ aeternitate mundi is pseudo-Philonic. The author refers to the unpublished version of his doctoral thesis, for which see 8795. (DTR)

9181. D. I. SLY, ' 1 Peter 3:6b in the Light of Philo and Josephus', Journal of Biblical Literature 110 (1991) 126-129.

This short article attempts to explain the inconsistency between the depiction of Sarah's relation to her husband Abraham in Genesis and in 1 Pet $3: 6 \mathrm{~b}$ by the fact that the author, shocked by the behaviour of Sarah, tried to turn her into an ideal Hellenistic wife. The treatment of Sarah by Philo and Josephus is discussed in order to show that this ambiguity of feelings towards Sarah was shared by contemporaries. (RMB)

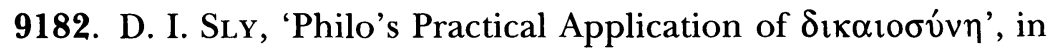
E. H. Lovering (ed.), Society of Biblical Literature 1991 Seminar Papers, SBLSPS 30 (Atlanta 1991) 298-308.

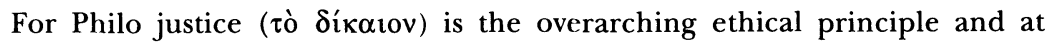
the same time identical with God's covenant. Given the hierarchical view of

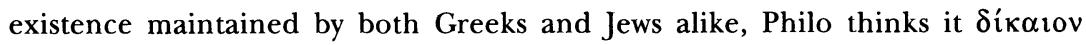
when the better rules and the worse is ruled. This principle of justice determines the relations of man to God, man to man and man to nature. The 
appropriate form of $\delta 1 \kappa \alpha 10 \sigma u ́ v \eta$ for a man in his relation to inferior beings is

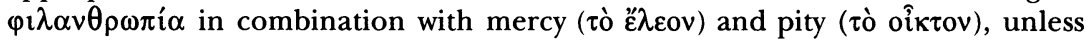
one has broken the law. Such an action means that one has acted deliberately against the best interest of Israel as God's covenant people. This helps us to understand Philo's attitude to women, which seems rather inconsistent at first sight. Women, lacking reason, are inferior to men. As long as they allow to be ruled by men and do not break the law, men should show philanthropy, mercy and pity to them. As soon as women start to be assertive or immodest however, not accepting their inferior role, they should be punished most severely, because they threaten the greater good. (RMB)

9183. D. I. SLY, 'Changes in the Perception of the Offence in Numbers 25:1', Proceedings of the Eastern Great Lakes $\mathcal{E}$ Midwest Biblical Society 11 (1991) 200-209, esp. 204-206.

Philo's perception is included in this survey of references and allusions to the Phineas story, which concentrates on the implications concerning the nature of the offence which triggered Phineas' heroic reaction. For Philo Phineas and the Midianite women represent moral paradigms of universal significance, i.e. good versus evil. (DTR)

9184. G. E. STERling, 'Philo's Quaestiones: Prolegomena or Afterthought?', in D. M. HAY (ed.), Both Literal and Allegorical: Studies in Philo of Alexandria's Questions and Answers on Genesis and Exodus, BJS 232 (Atlanta 1991) 99-123.

The author argues that if we are to understand the raison d'être of the Quaestiones, we have to determine their place within the Philonic corpus and especially their relation to the Allegorical Commentary. Sterling bases his verdict on a detailed examination of the first book of $Q G$, which is compared with the corresponding sections of the Allegorical Commentary. He concludes that the undoubted difference in emphasis between the two is to be explained through the fact that in the Quaestiones Philo wanted to present all the options, where in the Allegorical Commentary he wrote from a definite perspective. This means that the Quaestiones can be regarded as the prolegomena to the Allegoriae, and that they should therefore be intensively used in interpreting the latter. (DTR)

9185. L. Telesca, 'Filone e Ambrogio: due testi a confronto', Notizario Centro di Studi sul Guidaismo Ellenistico 2 (1991) 1-13.

Telesca examines the text of Fug. 157-160 and the parallel passage of Ambrose, Ep. III (67) 3-7 in order to demonstrate by means of the method of 'schematic' analysis the structural analogy that exists between them. On the basis of this confrontation, which takes into account various levels of significance, i.e. biblical/exegetical, symbolic, and theological, it is concluded that Philo, despite appearances to the contrary, was able to express his own 
doctrinal contributions in a much more ordered way than Ambrose. The same comparison also reveals the remarkable ability of the allegorical method to express new kinds of meaning - in Ambrose's case in the area of christology - even though it makes use of the same symbolic elements. (RR)

9186. A. Terian, 'The Priority of the Quaestiones among Philo's Exegetical Commentaries', in D. M. HAY (ed.), Both Literal and Allegorical: Studies in Philo of Alexandria's Questions and Answers on Genesis and Exodus, BJS 232 (Atlanta 1991) 29-46.

In order to determine the chronology of the Quaestiones within the Philonic corpus it is necessary to make a careful examination of the internal crossreferences given by Philo himself. Terian examines such passages, many of which had been adduced by earlier scholars, and concludes that 'textual arguments that do not allow the Quaestiones to stand at the beginning of Philo's exegetical commentaries can no longer be maintained. Except for references to the $\Pi \varepsilon \rho i \alpha^{\alpha} \rho \theta \theta \omega \hat{v}$, Philo is altogether silent in the Quaestiones about his other works. These should thus be regarded as the earliest of his exegetical commentaries (46).' (DTR)

9187. A. Terian, 'Strange Interpolations in the Text of Philo: the Case of the the Quaestiones in Exodum', in D. T. Runia, D. M. HaY and D. Winston (edd.), Heirs of the Septuagint. Philo, Hellenistic Judaism and Early Christianity: Festschrift for Earle Hilgert, BJS 230 [= The Studia Philonica Annual 3 (1991)] (Atlanta 1991) 320-327.

Eight interpolations in the Armenian text of the Quaestiones in Exodum are identified and analysed. Five of these were already present in the Greek text translated by the Armenian translator. Terian argues that these betray the same hand as three interpolations in the text of De animalibus. This scribe seems to have become frustrated by the extremes of Philo's allegorical practice, and so from time to time could resist undermining the text he was copying out. (DTR)

9188. T. H. Tobin, 'Romans 10:4: Christ the Goal of the Law', in D. T. Runia, D. M. HAY and D. Winston (edd.), Heirs of the Septuagint. Philo, Hellenistic Judaism and Early Christianity: Festschrift for Earle Hilgert, BJS 230 [= The Studia Philonica Annual 3 (1991)] (Atlanta 1991) 272-280, esp. 277ff.

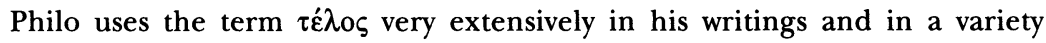
of contexts. Two of these can be adduced to illuminate Paul's usage in Rom. 10:4: (1) the context of metaphors of seeking or striving toward a goal; (2) the context that speaks more specifically about the goal of the Law. (DTR) 
9189. N. Uмемото, 'Die Königsherrschaft Gottes bei Philon', in M. Hengel and A. M. Schwemer (edd.), Königsherrschaft Gottes und himmlischer Kult im Judentum, Urchristentum und in der hellenistischen Welt, WUNT 55 (Tübingen 1991) 207-256.

Even though the possibility that man has to know, and therefore also to speak, about God is limited in absolute terms, he is at least able to recognize God's unicity and, in consequence thereof, also his sovereignty. In this description philosophical principles of Platonic and Stoic doctrine are expressed: from Platonism the affirmation that God is cause of good alone; from Stoicism the conception of God as king of the cosmic megalopolis. It is possible to derive from these two philosophical orientations respectively the transcendent role of God-king and the immanent aspects of his sovereignty. The meeting point of these two tendencies is the Jewish conception of the monarch who shows justice, mercy and sollicitude for his subjects. From the theological viewpoint the view is translated into the doctrine of the two powers, one beneficent/creative, the other royal/ sovereign (pp. 226ff.). Philo holds that the royalty of God stands at the basis of every form of human monarchy, including the empire of Rome (cf. 241ff.), and also, in particular, the superiority of the wise man, of whom Abraham and Moses are examples (pp. 252ff.). REview (of the whole volume): D. Zeller, SPhA 4 (1992) 145146. (RR)

9190. J. Romney Wegner, 'Philo's Portrayal of Women Hebraic or Hellenic?', in A.-J. Levine (ed.), “Women like this": New Perspectives on Jewish Women in the Greco-Roman World, Early Judaism and its Literature 1 (Atlanta 1991) 41-66.

The author returns to the subject she dealt with earlier at R-R 8250. Philo has no interest in women as a subject for sustained discussion, yet he expresses his opinions on 'the female' at every turn. This depiction owes far more to Greek ideas, mediated through Hellenistic culture, than to the Jewish Scripture he inherited from his ancestors. His views on mind as a male attribute and sense-perception as a female attribute can be traced back to Aristotelian science and Pythagorean dichotomies. Moreover Philo often insults women beyond the needs of the context or describes their positive traits as male rather than female, contradicting the 'Jewish' interpretations of these texts. But Philo does assign a positive value to women in his treatment of procreation, and it may be suggested that 'Philo's true attitude to women was one of ambivalence - perhaps even cognitive dissonance rather than the misogyny that seems to inform most of his theoretical statements about the female' (50-51). (DTR)

9191. H. Weiss, 'Philo on the Sabbath', in D. T. Runia, D. M. Hay and D. Winston (edd.), Heirs of the Septuagint. Philo, Hellenistic Judaism and Early Christianity: Festschrift for Earle Hilgert, BJS 230 [= The Studia Philonica Annual 3 (1991)] (Atlanta 1991) 83-105. 
The Sabbath functioned for Philo in diverse important theological, cosmological, philosophical, religious and social roles. Weiss collects all the evidence that he can muster in Philo's writings and discusses it under the headings of (a) the significance of the observance, (b) the significance of the number, and (c) the significance of the Sabbath (i.e. as a period of rest). In the final section nine conclusions are drawn, of which we mention only the last: Philo did not consider the Sabbath 'a cornerstone of Jewish practice' (Mendelson). (DTR)

9192. H. F. Weiss, Der Brief an die Hebräer, Kritisch-exegetischer Kommentar über das Neue Testament 15 (Göttingen 1991), esp. 100-103 and passim.

Further material in the on-going discussion on Philo's relation to the Epistle to the Hebrews. (DTR)

9193. E. Will, 'Philon et les prosélytes', in P. Goukowsky and C. BRIXHE (edd.), Hellènika symmikta: histoire, archéologie, épigraphie, Études d'archéologie classique 7 (Nancy 1991) 151-168.

Will attacks the view that Philo was a propagandist of Judaism, aiming at the conversion of the gentiles. It is argued that Philo thought it useless to try to convert them because their conversion is a matter of divine Providence, not of human effort. The author especially concentrates on Mos. 2.17-31, the account of the translation of the Septuagint. Ever since G. F. Moore this text is quoted as a testimony of the success of Jewish missionary activities. Will shows that this passage is in fact evidence in favour of his view. When Philo is addressing the gentiles his aim is not that of the missionary, but an apologetic one. Philo was no missionary to the gentiles; instead he had an internal mission: the salvation of those Jews who had abandoned their ancestral faith under the pressure of the Hellenistic world. All passages interpreted as aimed at a pagan public could perhaps better be read as addressing these Jewish apostates. See also 9290. (RMB)

9194. D. Winston, 'Aspects of Philo's Linguistic Theory', in D. T. Runia, D. M. HAY and D. Winston (edd.), Heirs of the Septuagint. Philo, Hellenistic Judaism and Early Christianity: Festschrift for Earle Hilgert, BJS 230 [= The Studia Philonica Annual 3 (1991)] (Atlanta 1991) 109-125.

Winston gives a synoptic account of Philo's views on the origin and status of language. Philo has a general theory of language which is derived from Greek philosophical speculation, but is nonetheless marked by various adaptations made in order to suit it to the scriptural account. Philo thus follows his philosophical master Plato in having a deep distrust of language and the written word. On the other hand his praise of the accuracy of the Septuagint translation seems informed by propagandistic motives. And when he claims 
that Mosaic names differ in no way from the external object they represent, this can only be read as an exaggerated attempt to emphasize the absolute precision of Mosaic name-making, for this statement clearly transgresses the bounds of his own epistemological principles. (DTR)

9195. D. Wyrwa, 'Über die Begegnung des biblischen Glaubens mit dem griechischen Geist', Zeitschrift für Theologie und Kirche 88 (1991) 29-67, esp. 39-47.

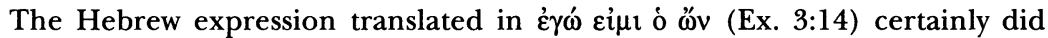
not have a philosophical content in the original biblical version, but simply expressed God's presence and his freedom. Nevertheless this expression concerning God, when combined with the other divine characteristics of unity, majesty and transcendence, was open to a metaphysical interpretation (in the sense of a spiritual Being who is pure and absolute) which is first historically realized in Philo. Philo deals with this biblical text about thirty times and builds on it a theology with a transcendent orientation. Its principal doctrines are the distinction between the existence of God and his essence, which is unknowable for man, and the theory of the Logos as creator, in which biblical, Stoic and Platonic themes flow together (p. 41ff.). Philo's contribution, broadly speaking, consisted in the translation of the foundations of the Jewish faith into the dualistic-transcendent ontology of Plato. (RR)

9196. A. Xavier, A Study of Theodidaktoi (I.Thessalonians 4,9) (diss. Pontifical Gregorian University, Vatican 1991).

This thesis is devoted to the hapax legomenon in 1 Thess. 4:9 theodidaktoi. Within this scope attention is paid to the use of autodidaktos by Philo. (RMB, based on DA 53-04C, p. 627)

9197. J. ZANDEE, The Teachings of Silvanus: a Commentary (Nag Hammadi Codex VII, 4): Text, Translation, Commentary, Egyptologische uitgaven 6 (Leiden 1991), esp. 516-522.

Frequent reference is made to Philo throughout this massive commentary on an anti-Gnostic document found at Nag Hammadi. Various threads are drawn together in the concluding section at pp. 516-522. The connections of Silvanus with Philo are paralleled in his relation to Clement and Origen, so that one may speak of an 'Alexandrian' type of theology. (DTR) 


\section{2}

9201. J. ARIETI, 'Man and God in Philo: Philo's Interpretation of Genesis 1:26', Lyceum 4 (1992) 1-18.

The interpretation of this verse has played a central role in the marriage of Hebrew thought and Greek philosophy, with Philo taking on the role of matchmaker. What is meant by the 'image'-character of man? In the Bible and in Jewish thought it may refer to man's body, but by Philo's time this was seen as philosophically naive. It had to refer to man's rational nature. Man is created as image of God 'according to the Logos', i.e. the Logos preserves the gulf between God and man. This points to a basic difference between Hebraic and Hellenic culture. Philo's explanation of the plural in Gen. 1:26 also reveals aspects of both Greek and Jewish thought. 'If Philo must fit the story of man's creation to blend with his philosophical substructure of Platonism, he also adjusts his Platonism to fit his Hebraic notion of an unknowable God. (p. 18)' (DTR)

9202. M. BARKer, The Great Angel: a Study of Israel's Second God (Westminster 1992), esp. 114-133 = Chapter 7, The evidence of Philo.

Barker's central claim in this book is that pre-Christian Judaism was not monotheistic and that the roots of Christian Trinitarian theology lie in a pre-Christian Palestinian belief about angels, a belief derived from the ancient religion of Israel in which there was a High God and several Sons of God. Yahweh was $a$ Son of God. Jesus was a manifestation of Jahweh. Philo is discussed as evidence for the not so rigid monotheistic character of preChristian Judaism. Philo's concept of Logos is interpreted as a second god. Philo's Logos is not an importation from Hellenistic philosophy into Jewish philosophy, but a translation of a Jewish concept already existing into the vocabulary of Greek philosophy. The Logos can be thus identified with Yahweh. (RMB)

9203. J. M. G. Barclay, 'Manipulating Moses: Exodus 2:10-15 in Egyptian Judaism and the New Testament', in R. Carroll (ed.), Text as Pretext: Essays in Honour of Robert Davidson, JSOT.S 138 (Sheffield 1992) 28-46, esp. 37-40.

Philo's account of Moses' education and flight from Egypt in Mos. is briefly discussed as one example of how the figure of Moses had to be manipulated so that it could be taken up as a living and relevant part of Jewish and Christian religion. (DTR) 
9204. H. BAyer, 'Philo Pythagoricus: die Gnosis Philos von Alexandrien im Spiegel der hochmittelalterlichen Literatur', Euphorion 86 (1992) 249-83.

In this extensive article Bayer distinguishes three main tendencies in the reception of Philo in the literature of the High Middle Ages, closely connected with the Gnostic and Catharist movement of the age: (1) Recognition of Philo as auctoritas of a Neoplatonic-Gnostic religious way of life (esp. in the Contempl. and Prob.) which transmits Pythagorean and Stoic wisdom. (2) Incorporation of Philonic material in Neoplatonic oriented literature of the educated, especially female, aristocracy, e.g. the conception of the world in which necessitas rules as a machina mundi and the idea that apatheia and contemplative catharsis lead to salvation of the self. (3) A counter-reaction of more orthodox authors who fulminate against this Catharist Philo-Schwärmerei, beginning with an account from William of Newburgh about the synod and inquisition of heretics in Oxford (1161-66). One of the weapons of the official church in this confrontation was Pseudo-Philo. It should be noted that the basis of this reconstruction is formed not by named references to Philo, but by various motifs shared by Philo's writings and medieval documents. Moreover it is worth noting that the author inclines to the view that the chief Philonic documents Contempl. and Prob. in fact were forged by 3rd cent. Gnostic or Manichean circles on the basis of genuine Philonic diction (p. 251). (RMB-DTR)

9205. E. Birnbaum, The Place of Judaism in Philo's Thought: Israel, Jews, and Proselytes (diss. Columbia 1992).

This dissertation was subsequently published in a revised form in 1996 . See the summary below at 9608 . (DTR)

9206. R. A. Bitter, 'De androgynie van de mens bij Philo van Alexandrië, Clemens van Alexandrië, Origenes en de Russische Orthodoxie', in G. Quispel (ed.), De Hermetische Gnosis in de loop der eeuwen (Baarn 1992) 53-95, esp. 56-79.

Though the Greek word for androgyny, arrenothêlus does not occur in Philo, he does know the myth about an original unity between male and female which is broken. This emerges from some passages on the creation of man, which the author discusses. Philo emphases the original unity of the first man (Opif. 151-152). Androgyny is also encountered in his allegorical interpretation of male as mind and female as sense-perception. Mind and perception, male and female, need each other. Philo knows a restoration of the original unity as well. In the author's opinion Philo found the myth of androgyny in his environment and borrowed ideas from it. Characteristic of Philo is that he transformed it into an allegory. (ACG) 
9207. C. BlöNnigen, Der griechische Ursprung der jüdisch-hellenistischen Allegorese und ihre Rezeption in der alexandrinischen Patristik, Europaische Hochschulschriften Reihe XV: Klassische Sprachen und Literaturen 59 (Frankfurt etc. 1992), esp. 70-137.

The task of this dissertation submitted to the Justus-Liebig University Giessen in 1991-92 is to examine the influence of the Hellenistic-Jewish method of allegory on the Alexandrian church fathers Clement and Origen. The author expresses dissatisfaction with the results of research so far, which has been theologically biased, pays too little attention to the common intellectual background of all three Alexandrians, and also is vague about the precise relation between Clement and Origen. Blonnigen argues that the agreements between Hellenistic allegorical aims and methods and the procedures of the Alexandrians is much greater than has so far been recognized, as is indicated by their common apologetic motivation and the prominence of ethical aims. The originally separate traditions of ethical allegory and typological biblical interpretation are brought together for the first time by Clement, who profoundly christianizes what he takes over from Philo, but is unable to free himself from specific Philonic examples. But he does make the way free for Origen to take over the allegorical method without slavishly following Philo in its application to biblical interpretation. This understanding of Philo's influence via the intermediation of Clement can explain why Origen uses the same method, but seldom shows a direct debt to his Jewish predecessor. In his long chapter on Philo (pp. 70-137) the author first presents an outline of his thought, then turns to his views on myth and biblical hermeneutics. Philo's allegorical method is hierarchical, culminating in ethical allegory, as developed above all in his interpretation of the Patriarchs. In the equally long chapters on Clement and Origen constant reference is made to the Philonic background. The book has only a index of ancient names and a limited subject index. (DTR)

9208. D. J. Boorstin, The Creators: A History of Heroes of the Imagination (New York 1992), esp. 46-55.

The Jewish motif of the creation by God ex nihilo is an important landmark in the history of the imagination, the subject of this study. Philo's important contribution is to combine this Jewish belief in a creating God with Greek philosophy (esp. Plato) that had hitherto rejected the idea of a creation ex nihilo. He thus founded a new discipline, theology, and stimulated Christianity to play a leading role in the discovery of man's creative power. (RMB)

9209. P. Borgen, 'Filo fra Aleksandria: Jødisk filosof og Jesu samtidige' [In Norwegian: = Philo from Alexandria: Jewish philosopher and contemporary with Jesus], Midtøsten Forum. Tidskrift om Midtøsten og Nord-Afrika. [= Journal for the Middle East and North Africa] 7 (1992) 40-46. 
A general presentation of Philo in his historical context, which sees him as the peak of the Alexandrian Jewish literary development. Philo represents a Judaism, which had an interest in infiltrating and conquering its nonJewish environment, but which itself stood on the verge of being vanquished by the ideas and values of this environment. After a short account of the importance of Philo for NT studies, the article ends with a list of Philo's works. (KGS)

9210. P. Borgen, 'Art. 'Philo', in D. Freedman (ed.), Anchor Bible Dictionary (New York 1992) 5.333-342.

An informative encyclopedia presentation of Philo under the following headings: A. The Man and his Family; B. Philo's writings (with some criticisms of the conventional division); C. Philo and the Jewish Community of Alexandria; D. Philo as Biblical Exegete; E. Central Ideas and Perspective; F. The significance of Philo. A bibliography of almost two columns completes the entry. We note also the entry by the same scholar, 'Judaism in Egypt, vol. 3, 1061-1072, in which Philo is the chief source for the Roman period (10681072). (DTR)

9211. P. Borgen, “"There Shall Come Forth a Man”: Reflections on Messianic Ideas in Philo', in J. H. Charlesworth (ed.), The Messiah (Minneapolis 1992) 341-361.

The article focuses on eschatological statements in the works on Philo (cf. 9143). In Mos. 1.289-291 the prophecy of Balaam in Num 24:1-9 is paraphrased by Philo in a way which shows that he sees in the Biblical words a prophecy which is going to be fulfilled much later than in the times of Moses. In his reflections on future events Philo develops an eschatology which entails 'the realization of the universal aspect of Moses' kingship and the universal role of the Hebrew nation' (p. 342). The universal realization of Moses' kingship will be accomplished in the future by 'a man' who will be emperor of many nations, and will continue Moses' work and bring it to its complete fulfilment. In Praem. 95 the 'man' is also seen as the commanderin-chief in the eschatological war. In substance this figure for Philo is the Messiah, although he does not use the term. Texts analysed closely in the article are Mos. 1.289-91, Praem. 79, 93-97, 163-72. (KGS)

9212. P. Borgen, 'Philo and the Jews in Alexandria', in $P$. Bilde, T. Engberg-Pedersen, L. Hannestad and J. Zahle (edd.), Ethnicity in Hellenistic Egypt, Studies in Hellenistic Civilization 3 (Aarhus 1992) 122-138.

Having sketched the historical perspective, Borgen first delineates relations between Jews and non-Jews, pointing out various sources of tension. Then he explores the interaction that took place between the two groups. Philo is capable of both sharp criticism of certain practices and generous acknowledgements of debts he has incurred. In his works Philo also reveals 
tensions within the Jewish community. Finally Borgen briefly notes eschatological views in the community, and argues that these aspirations led to disastrous destruction of Egyptian and Alexandrian Jewry in 117 CE. (DTR)

9213. D. Boyarin, 'This we know to be the Carnal Israel', Critical Inquiry 18 (1992) 474-505, esp. 474-480.

The author opposes the tradition of literal interpretation of the Scripture by the Rabbis to that of allegorical interpretation by Philo, Paul and the Fathers. It is argued that for both parties the theory of language and that of the body coincide. The allegorical reading practice is founded on a binary opposition in which the meaning as a disembodied substance exists prior to its incarnation in language, just as in the anthropology of Philo, Paul and their Christian intellectual descendants spirit precedes and is primary over the body (this is illustrated by a discussion of Philo's interpretation of the anthropogony at pp. 477-480). The rabbinical tradition on the other hand resists this Platonic dualism in which body/language is subordinate to spirit/meaning. In this view body and spirit, language and meaning are inseparably bound together. (RMB)

9214. D. Boyarin, "Behold Israel According to the Flesh": On Anthropology and Sexuality in Late Antique Judaisms', Yale Journal of Criticism 5 (1992) 27-57, esp. 33-37.

Companion piece to the preceding study, the focus now being less on hermeneutical questions and more on the differences in evaluating the body and its sexuality between the Philonic-Pauline-Christian and the Rabbinic traditions (note that the dividing-line is not Jewish-Christian). Boyarin again uses the creation of man and woman as his chief example. Philo and the Fathers interpret the first creation in Gen. 1 in terms of a spiritual androgyne, whereas the Rabbis interpret it in terms of a corporeal androgyne. (DTR)

9215. F. E. Brenk, 'Darkly beyond the Glass: Middle Platonism and the Vision of the Soul', in S. Gersh and C. Kannengiesser (edd.), Platonism in Late Antiquity, Christianity and Judaism in Antiquity 8 (Notre Dame 1992) 39-60, esp. 46-51.

Philo's statement on man's knowledge of God frequently leave us baffled: is he speaking about this world or the next, and does he mean complete knowledge of God, or just an intellectual vision? He shares these ambiguities with (near)-contemporary Middle Platonists. (DTR)

9216. D. I. BREWER, Techniques and Assumptions in Jewish Exegesis before 70 CE, TSAJ 30 (Tübingen 1992), esp. 198-213. 
The aim of the study is to describe and evaluate the methods of biblical exegesis practised before the fall of Jerusalem. Philo is examined in part II as belonging to the group of contemporaries of the scribes (others are the various biblical texts, the Dorshe Reshumot and Dorshe Hamurot, Josephus, Qumran). Philo is taken as representative of exegetical techniques practised in Alexandria. Brewer gives a brief treatment of the various issues related to Philo's exegesis: his use of allegory, the nature of the allegorical rules, the origin of his exegetical techniques, his knowledge of Hebrew, his acquaintance with Palestinian halachic traditions. The source of his allegorical method is Greek, but his methods of minute examination of the text has Jewish (but possibly also Greek) roots. The main assumption underlying Philo's exegesis is that the whole of Scripture is inspired prophecy, and that its interpretation and translation must also be equally inspired (p. 208). This 'inspirational' assumption is shared with the other contemporaries of scribes mentioned above. It is to be contrasted with the 'Nomological' approach practised by the scribes. After $70 \mathrm{CE}$ the distinction between these two approaches to scripture starts to become blurred. Review: F. Calabi, SPhA 8 (1996) 185-187. (DTR)

9217. S. P. Brock, 'To Revise or not to Revise: Attitudes to Jewish Biblical Translation', in G. Brooke and B. Lindars S.S.F. (edd.), Septuagint, Scrolls and Cognate Writings: Papers Presented to the International Symposium on the Septuagint and its Relations to the Dead Sea Scrolls and Other Writings (Manchester, 1990), Society of Biblical Literature Septuagint and Cognate Studies Series 33 (Atlanta 1992) 301338, esp. 304-305 and passim.

In Philo and in the Greek XII Prophets fragments there is evidence of two completely different and conflicting attitudes to biblical translation, the point at issue being: 'do the original Greek translations require revision or not?' (DTR)

9218. G. L. Bruns, Hermeneutics Ancient and Modern (New HavenLondon 1992), esp. 83-103.

The author's general aim is not so much to give a conceptual history of hermeneutics for its own sake, but one from which literary criticism may benefit. Within this scope Philo's allegorical mode of interpretation is discussed in terms of 'radical interpretation', a concept based on Quine's 'radical translation', meaning the redescription in one's own language of sentences from an alien system of concepts and beliefs. The lesson that we may learn from Philo is that hermeneutics is never less than the living of the contemplative life to its proper end. (RMB)

9219. R. and C. Clark Kroeger, I Suffer not a Woman: Rethinking 1 Timothy 2:11-15 in Light of Ancient Evidence (Grand Rapids 1992), esp. 146-148. 
Brief (and limited) discussion of Philo's interpretation of the role of women, emphasizing his relation to Gnostic thought. It is furnished as background to an exegesis of the text in 1 Timothy which is used more than any other to disbar women from proclaiming the Gospel (p. 11). (DTR)

9220. N. G. Cohen, 'Review of S. Belkin, The Midrash of Philo vol. 1', Journal for the Study of Judaism 23 (1992) 100-105.

Contrary to our usual practice we list this review separately because for the scholar unable to read modern Hebrew it is the best introduction to an extensive body of work on Philo in relation to his Jewish background. The review actually concerns volume 1 of a projected six-volume work presenting the material left unpublished by the distinguished Philonist and Rabbinic scholar Samuel Belkin on his death and prepared for publication with great devotion by E. Hurvitz. For the full title see at 8904. It aims to reintroduce Philo to the traditional halakhic and midrashic corpus and thus enable a more positive evaluation of Philo in orthodox Judaism. Belkin does not argue for direct contact between Philo and Rabbinic midrash, but rather that they both drew from a common Palestinian tradition. In the first volume now published Belkin arranges Philonic midrash in the form of a commentary to selected passages from the Quaestiones. The reviewer argues that what we are presented with is more of a presentation of 'raw material' than any kind of scholarly comparison, but that it is nonetheless a valuable contribution, particularly on account of the relevance of Philo to modern religiously committed Jews. She ends by emphasizing the limited accessibility of the work. Not only is it published in Hebrew, but it also makes use of a number of conventions that only make sense to scholars versed in the Rabbinic tradition. (DTR)

9221. I. P. Couliano, The Tree of Gnosis: Gnostic Mythology from Early Christianity to Modern Nihilism (San Francisco 1992), esp. 121124.

The author endeavours to show that the ideas of the different directions of dualistic Gnosis (from Gnosticism to the Cathars to Romantic poets and 20th century philosophers and biologists) hold together by virtue of belonging to the same system: they are what a structuralist calls 'synchronic' ideas. The perennial and frustrating quest for establishing the 'origins' of gnostic myth is redundant: what is necessary is a radical shift of emphasis from the 'origins' of Western dualism to the system of Gnosis in itself. In a chapter entitled 'Gnostic Myth 2: The Ignorant Demiurge', Couliano discusses the Philonic Logos and Sophia (in a section entitled 'Second God, Second Goddess'). Since Philo's influence on early Christian Logos theories was overwhelming, the question arises whether he influenced gnostic mythology as well. 'From our perspective, the question as formulated is not relevant. What should be emphasized is that Philonic exegesis is a transformation of the myth of Genesis according to a set of rules deriving from Platonism. ... Gnostic exegesis of Genesis admits a definition strikingly similar to Philonic exegesis. (p. 123)' (HMK) 
9222. D. Dawson, Allegorical Readers and Cultural Revision in Ancient Alexandria (Berkeley 1992), esp. 73-126.

This important study on the tradition of ancient allegorical interpretation, began as a Yale dissertation (8820). The study consists of an Introduction and four chapters. In the introduction Dawson makes clear that he wishes to interpret the practice of allegory from a broad perspective, looking not only at its theoretical aspects, but also at the way it functions in a social and cultural context. In the first chapter the Hellenistic background is investigated. The three remaining chapters focus on Philo, Valentinus and Clement respectively. These three figures are seen as representing three different ways of using allegory. Philo uses allegory to rewrite the Mosaic text, claiming that the divinely inspired text represents the totality of authentic wisdom. In Valentinus the Gnostic myth is allegorized so that it becomes the interior vision of the interpreter. Clement is closer to Philo, but locates in the text above all the divine Voice identified with Christ the Logos. The chapter on Philo covers a broad range of hermeneutical issues, concentrating especially on the view of language presupposed by his readings of scripture and how scripture forms the lens through which the whole of Philo's social and cultural reality is viewed and interpreted (a process which Dawson labels 'reinscription'). Reviews: A. Dugdale, JFRS 21 (1993) 89-90; B. N. Fisk, JECS 2 (1994) 344-346; D. T. Runia, SPhA 6 (1994) 199-203. (DTR)

9223. F. Dexinger, 'Jüdisch-Christliche Nachgeschichte von Gen 6,1-4', in S. KREUzer and K. LÜTHI (edd.), Zur Aktualität des Alten Testaments: Festschrift für Georg Sauer zum 65. Geburtstag (Frankfurt am Main etc. 1992) 155-175, esp. 164-166.

Under the heading of pre-christian Jewish interpretation of Gen. 6:1-4 the author first discusses Ethiopian Henoch and the Septuagint and then turns to Philo's treatment of the passage in Gig. His conclusion is that Philo rejects the connection of the Genesis passage with the Giants of Greek mythology-a connection apparently presupposed in the Septuagint and accepted in hellenistic Judaism-and that he gives the 'angels' an allegorical interpretation in terms of spirits or souls, which in Jewish as well as Christian context after initial acceptance was later rejected. (HMK)

9224. M. Diego SAnchez, Historia de la espiritualidad patristia (Madrid 1992), passim.

The study considers some aspects of Philo's influence on early Christian spirituality, especially in relation to the themes of virginity, monasticism and ascetic behaviour. (JPM)

9225. C. Dogniez and M. HARL, La Bible d'Alexandrie: Le Deuteronome (Paris 1992), esp. 69-70 and passim. 
This volume follows the same formula as the three earlier volumes published in the series (cf. R-R 8620, 8832 and 8937). Philo's interpretations of the LXX translation of Deuteronomy are cited on numerous occasions in the notes. In the Introduction the authors note that Philo's manner of reading the book is quite striking, particularly because he gives a privileged status to selected texts, which are cited in the course of interpreting other biblical lemmata. (DTR)

9226. C. A. Evans, Non-canonical Writings and New Testament Interpretation (Peabody 1992), esp. 80-86.

Some introductory remarks on Philo and his value for New Testament studies. (DTR)

9227. L. H. Feldman, 'Was Judaism a Missionary Religion in Ancient Times?', in M. Mor (ed.), Jewish Assimilation, Acculturation and Accommodation: Past Traditions, Current Issues and Future Prospects (Lanham 1992) 24-37.

Philonic evidence is frequently appealed to in defence of the view that Judaism in the Hellenistic-Roman period (323 BCE to $133 \mathrm{CE}$ ) actively attempted to recruit adherents. Indeed the text at Spec. 2.62 suggest that synagogues will have attracted large numbers of members of the non-Jewish population. (DTR)

9228. R. Feldmeier, Die Christen als Fremde: die Metapher der Fremde in der antiken Welt, im Urchristentum und im 1. Petrusbrief, WUNT 64 (Tübingen 1992), esp. 60-74.

A positive evaluation of the OT concept of 'stranger' is found in two Jewish groups who live outside their land, whether in the sense that they had abandoned their original theological culture, or because they became different on account of religious and geographical factors. One of these groups can be recognized in the radical Judaism of the community of Qumran. The other group is located in Diaspora Judaism and has as its most important representative Philo. This group has in common that it existed in an hostile and alien environment and that it found its own existential situation represented in the category of the 'stranger'. In Philo's case the metaphor is expressed in three different forms. (1) Being a stranger occurs in confrontation with the world though being a fellow-citizen of God. This is the status of the sage, finding its foundation from a theological point of view in the absolute autonomy and independence of God. (2) Being a stranger indicates the sojourn in the encyclopedic studies, as preparation for the ascent to the vision of God. (3) A final interpretation of 'stranger' has as its basis a dualistic cosmological vision (heaven/earth) and attributes to the wise man an affinity to the heavens and an alienation towards the earthly region. (RR) 
9229. D. N. Freedman (ed.), The Anchor Bible Dictionary, 6 vols. (New York 1992).

For the contributions on Philo and Judaism in Egypt see above under the name of their author, P. Borgen (9210). Some other contributions dwell on the role of Philo, notably the article 'Logos' by T. H. Tobin (4.350-351). But the tendency to divide subjects into sections on OT and NT respectively means that coverage of Hellenistic Judaism is rather spotty. (DTR)

9230. Y. D. Gilat, 'The Sabbath and its Laws in the World of Philo', in R. Link-SAlinger (ed.), Torah and Wisdom. Studies in Jewish Philosophy, Kabbalah, and Halacha: Essays in Honor of Arthur Hyman (New York 1992) 61-73.

Philo attributes a universal significance to the observance of the Sabbath as a day of rest, study and thanksgiving. In the many passages in his work that provide information on how the day should be and was observed, Philo does not distinguish between scriptural precepts, halachic tradition and ancient customs. Gilat suggests that where his views contradict the Halacha, they may go back to an ancient halachic tradition. Historic sources confirm some of the prohibitions that Philo records, e.g. appearing in court on the Sabbath. (DTR)

9231. G. H. Gilbert, Pagans in a Jewish world: Pagan Involvement in Jewish Religious and Social Life in the First Four Centuries CE (diss. Colombia 1992).

The thesis analyses the involvement of non-Jews (the so-called 'Godfearers') in ancient Jewish communities. All the relevant evidence is examined (including Philo), and each text is regarded as an independent witness to the phenomenon. (DTR; based on summary in DA 54-01A, p. 210).

\section{J. Glucker, 'Critolaus' Scale and Philo', Classical Quarterly} 42 (1992) 142-146.

Critolaus used the metaphor of a balance to argue that the goods of excellence outweighs external and bodily goods (cf. Cicero Tusc. 5.51, Fin. 5.92). Two passages in Philo, Her. 45-46 and Fug. 151, use the same metaphor in a similar context. Can the passages be explained through Philo's own idiosyncratic use of metaphor, or is there a debt to Critolaus? Glucker opts for the latter alternative, and uses the Philonic text to make some observations on what may have been Critolaus' original Greek terminology. (DTR)

9233. M. Goodman, 'Jewish Proselytizing in the First Century', in J. Lieu, J. North and T. Rajak (edd.), The Jews among Pagans and Christians in the Roman Empire (London 1992) 53-78. 
Philo is a key witness in the argument that first-century Jews, in contrast to the early church, did not engage in active proselytizing or missionary activities. (DTR)

9234. K. Goudriaan, 'Ethnical Strategies in Graeco-Roman Egypt', in P. Bilde, T. Engberg-Pedersen, L. Hannestad and J. ZaHle (edd.), Ethnicity in Hellenistic Egypt, Studies in Hellenistic Civilization 3 (Aarhus 1992) 74-99, esp. 79-94.

In spite of the risks involved (his date is late, i.e. post-Ptolemaic, and his works are mainly exegetical) Philo's writings can offer us a valuable example of a firm and subtle ethnical strategy as it emerges in his dealings with Jews, Greeks, and Egyptians. Goudriaan first examines the various ethnic categories used by Philo to name and describe these groups. He then asks how Philo puts them to use. The opposition between Jews and other people is pervasive throughout all his works, even though he lacks the equivalent of the Hebrew distinction âm-goyim. Philo avoids making a direct opposition between Jews and Greeks, no doubt on account of his high respect for Hellenic culture. On the other hand, he is highly negative towards the Egyptians. So it may be concluded that universalism and ethnocentrism exist side by side. The remainder of the article discusses how this ethnical strategy should be considered against the background of the events of $38 \mathrm{CE}$. Differing strategies may have led to ethnic friction. Philo no doubt regarded the anti-Semites as Egyptians, whereas they saw themselves as Hellenes. This friction, however, is not enough to explain the violence that took place. Goudriaan suggests that a process of 'ethnic incorporation' had taken place, i.e. the society is divided along ethnic lines, between Jews and non-Jews, 'us' and 'them'. (DTR)

9235. L. Grabbe, Judaism from Cyrus to Hadrian: Sources, History, Synthesis, 2 vols. (Minneapolis 1992).

This two volume work is meant as a handbook for students of the history and religion of the Judaism during the Second Temple period and for scholars working in a adjoining disciplines. Philo is mainly treated as a major original source. See especially pp. 372-374 (a short introduction on life and work of Philo), pp. 395-397 (Philo on the gilded shields episode under the reign of Pilate), pp. 399-409 (Philo as a source for the contemporary troubles of the Alexandrian community), pp. 492-499 (Philo on the Essene community and the Therapeutae). Review: C. R. Holladay, SPhA 7 (1995) 231-236. (RMB)

\section{G. Gresholt, 'Philo of Alexandria: Some Typical Traits of his Jewish Identity', Classica et Mediaevalia 43 (1992) 97-110.}

Græsholt sets out to draw a picture of what Jewish identity was like in Alexandria on the base of Philo's writings. The Jews tended to be exclusive because of their particular customs (monotheism, circumcision, Sabbath, festivals and temple-worship, dietary laws and marriage). On the other hand Philo undertakes the task of universalising the message of the Torah. But this 
universalism has its limits when we examine his attitude towards other peoples. The way he portrays Egyptians is so negative that it may be described as 'racist' (p. 110). (RMB)

9237. P. Graffigna, 'Osservazioni sull'uso del termine $\varphi \alpha v \tau \alpha-$ oí $\alpha$ in Filone d'Alessandria', Koinonia (Naples) 16 (1992) 5-19.

The author does not analyse all the passages in the Philonic corpus in which the term $\varphi \alpha v \tau \alpha \sigma i \alpha$ appears, but only those passages in which it reveals new elements of significance in comparison with customary usage. On the basis of this analysis she concludes that $\varphi \alpha v \tau \alpha \sigma i \alpha$ always indicates functions related to appearance (dreams, visions etc.) and that, in this perspective, a

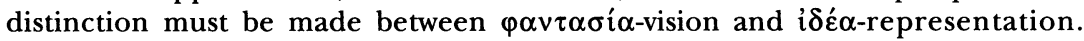
(RR)

9238. A. Green, Seek my Face, Speak my Name: a Contemporary Jewish Theology (Northvale N.J.-London 1992), esp. 128.

Though the discussion on Philo, which focuses on the relation between Torah and natural law, is confined to but a single page, we include it in our bibliography because Green is a leading exponent of modern Jewish theology and the fact that he draws attention to Philo's contribution to Judaism is significant. See further the article of David Winston, 9593, esp. pp. 141-142. (DTR)

9239. J. T. GReEne, Balaam and His Interpreters: a Hermeneutical History of the Balaam Traditions, BJS 244 (Atlanta 1992), esp. 145-147.

For Philo Balaam symbolizes the base, negative traits of religion. He was not a prophet, only a wizard. Cf. 8923 and 9025 . (RMB)

9241. D. M. Hay, 'Things Philo Said and Did not Say about the Therapeutae', in E. H. Lovering, JR. (ed.), Society of Biblical Literature 1992 Seminar Papers, SBLSPS 31 (Atlanta 1992) 673-684.

The aim of the article is to draw attention to problematic aspects of Philo's account of the Therapeutae. Clearly it is meant to be an account of an ideal community, but its ideals are only partly shared by Philo himself. For example both its asceticism and the equal status accorded to women are foreign to Philo's own thought. But since his purpose is apologetic, he is not at all interested in criticizing them, or even in evaluating their particular form of Judaism. At the same time he is very reticent about describing their doctrines. It is possible that they had eschatological ideas, perhaps of the 'realized' sort with which Philo would not at all have been in agreement. Hay ends his article with two brief sentences that neatly summarize his provocative thesis: 'He writes in praise of their way of life. He does not encourage investigation of their ideas (p. 683).' (DTR) 
9242. A. Hilhorst, 'Was Philo Read by Pagans? the Statement on Heliodorus in Socrates Hist. Eccl. 5.22', The Studia Philonica Annual 4 (1992) 75-77.

A brief article in response to the claim by David Runia in 9060 pp. 135-136 that the novelist Heliodorus was the only pagan of whom we can say beyond all doubt that he had read Philo. The report of the church historian Socrates that Heliodorus wrote his erotic novel during his youth and later became a bishop should not be interpreted to mean that he was first a pagan and then converted to Christianity. Parallels with other writers show that he could easily have been a Christian all along. (DTR)

9243. P. Hofrichter, 'Logoslehre und Gottesbild bei Apologeten, Modalisten und Gnostikern: Johanneische Christologie im Lichte ihrer frühesten Rezeption', in H.-J. KlaUcK (ed.), Monotheismus und Christologie: zur Gottesfrage im hellenistischen Judentum und im Urchristentum, Quaestiones Disputatae 138 (Freiburg 1992) 186217, esp. 187-193.

Justin Martyr, especially in his Dialogue with Trypho, often makes use of the concept of the divine Logos (identified with Christ) in an almost certainly Philonic sense. The author reaches this conclusion on the basis of a number of clear indications: (1) The analogous interpretation by both exegetes of the passage in Genesis 18, to be found in Dial. 56-59 and in Abr. 110ff.; (2) the plurality of names attributed to the Logos; (3) the assimilation of the Logos to Sophia; (3) the conception of the Logos as 'second god'; (4) the method of argumentation. (RR)

9244. L. P. Hogan, Healing in the Second Temple Period, NTOA 21 (Freiburg-Göttingen 1992), esp. 168-207.

When Philo touches on the subject of healing, he is primarily concerned with healing of the soul. He shows himself indebted to his Greek philosophical background when he portrays the way to full spiritual health as the overcoming of the passions and the acquisition of virtue. At the same time he also preserves both the central teaching of the Hebrew Bible that God alone is the healer of the sicknesses of soul and body. Philo's world view has no room for evil spirits as the cause of illness. Illness that cannot be explained by sin is part of God's plan for perfecting man or the world. Finally, because God's providence is frequently expressed through mediators, Philo has no difficulty in seeing medical remedies and physicians as ways in which God ministers healing. (RMB)

9245. P. W. VAN DER Horst, “'Gij zult van goden geen kwaad spreken": de Septuaginta-vertaling van Exodus 22:27 (28), haar achtergrond en invloed', Nederlands Theologisch Tijdschrift 46 (1992) 
192-198; reprinted in Studies over het Jodendom in de Oudheid (Kampen 1992) 142-151.

Why does the LXX translate the words of the Hebrew Bible in Ex. 22:27 'you shall not revile God' as 'you shall not revile the gods'? Philo is the first author who explicitly interprets the verse in $Q E$ 2.5. If the Jews refrain from negative language about pagan gods, this may have the positive consequence that pagans may come to praise the only true God. A similar interpretation is found in Josephus, but is not taken over in the early Christian tradition. For an English version of this article see 9345. (DTR)

9246. S. Katz, 'Utterance and Ineffability in Jewish Neoplatonism', in L. E. Goodman (ed.), Neoplatonism and Jewish Thought, Studies in Neoplatonism Ancient and Modern 7 (Albany 1992) 279-298, esp. 285-288.

In examination of the Neoplatonic doctrine of the ineffability of God (apophasis) the author distinguishes between two traditions, the Philonic and the Plotinian. Philo's ineffability is rather elastic, since he has to conceal the Platonic and Jewish supreme entity. This results in an important difference between the creating activity of his God and that of Plotinus. Whereas the Plotinian, impersonal One creates out of spontaneous necessity, the Philonic personal God wills to create. (RMB)

9247. H.-J. Klauck (ed.), Monotheismus und Christologie: zur Gottesfrage im hellenistischen Judentum und im Urchristentum, Quaestiones Disputatae 138 (Freiburg 1992).

This volume publishes the papers presented at a conference of Germanspeaking Catholic New Testament scholars held on 18-22 March 1991. It brings together a number of contributions that focus on early Christian theology, and in particular on the problem of the relation between theology and christology and the influence of Jewish monotheistic theology on this question. For the contributions of Hofrichter, Sellin and Theobald see 9243, 9279 and 9284 resp. Review: D. Zeller, SPhA 5 (1993) 242-245. (RR)

9248. R. S. Kraemer, Her Share of the Blessings: Women's Religions among Pagans, Jews, and Christians in the Greco-Roman World (Oxford 1992), esp. 113-117, 126-127.

Philo's account of the Theapeutrides allows a more substantial glimpse into the religious lives of a handful of women. They form a select group because they are literate. Their childlessness was central to their choice of the contemplative life, and may have gone against social norms and expectations. Kraemer ends her brief discussion by citing Goodenough's interpretation of $Q G 4.145$ in terms of a union with the eternally virginal universal spirit. (DTR) 
9249. P. V. Legarth, Guds tempel. Tempelsymbolisme og kristologi hos Ignatius af Antiokia [In Danish = God's Temple: Temple Symbolism and Christology in Ignatius of Antioch] (Århus 1992), esp. 38-43.

Under the rubric Philo and Josephus (I 5) the author points out that the temple cult and the priesthood play important roles in the writings of Philo. The priesthood is either idealized or it is spiritualized like the idea of the temple. Man's mind can be seen as the temple of God. Philo never reflects on the new temple nor does he see the Messiah as a temple-builder although he may refer to Zach. 6:12 (cf. Conf. 62f.). (KGS)

9250. C. Lévy, Cicero Academicus: recherches sur les Académiques et sur la philosophie cicéronienne, Collection de l'École Française de Rome 162 (Rome 1992).

In the course of this massive French thèse d'état, which has as its main subject Cicero's relation to the sceptical movement (avant la lettre) of the New Academy, the author frequently refers to Philo and, especially in the last two sections on Ethics and Physics, makes a number of extended comparisons between Philo and the Roman statesman. See the lists of references on p. 676 \& 681. Review: D. T. Runia, SPhA 7 (1995) 241-242. (DTR)

9251. C. LÉvy, 'Le concept de doxa des Stoïciens à Philon d'Alexandrie: essai d'étude diachronique', in J. BRUnSCHWIG and M. Nuss baum (edd.), Passions and Perceptions: Proceedings of the Fifth Symposium Hellenisticum (Cambridge 1992) 250-284, esp. 250251, 274-284.

About a third of this wide-ranging article concentrates on Philo. Somewhat defensively the author argues that Philo's complex thought can offer illumination in the area of history of philosophy. The main theme is the psychology (and not the epistemology) of opinion (doxa). The Stoics depart from earlier tradition (esp. Plato) in arguing that in a rational world nothing need impede the sage from reaching full knowledge and thus leaving the world of doxa behind altogether. In this perspective it can be argued that the New Academy in their psychology make a partial return to Plato. Not that they have a positive psychology, but they do make a link between the world and the soul. The world is full of darkness, and as such is the object of the soul's doxa. Arcesilaus and his followers thus banish light from the world. It is Middle Platonism's achievement to bring the light back and rescue the Platonist tradition from the cave. Here Philo becomes a witness. Lévy first discusses the way Philo appropriates Stoic psychology, but reworks it into a dualism quite foreign to Stoic ideas. Is it possible to offer a Philonic psychology which is not just a collection of topoi chosen in order to correspond to this or that aspect of scripture? It is argued that Philo's pronouncements make more sense if they are seen as a development of the New Academy in the light of a new transcendental perspective, which allows a certain rehabilitation of doxa. Of this the complex figure of Joseph is a symbol. Lévy especially 
concentrates on the text at Somn. 2.15, in which Joseph is presented as the 'image of a heterogeneous and mixed opinion'. The four categories that the allegorical explanation reveals are related to the division of the Stoic soul, but they are transformed in a way that is interesting for the psychology of Middle Platonism. Joseph symbolizes the 'mixed soul', a concept that reappears in Albinus and Apuleius. (DTR)

9252. H. A. McKay, 'From Evidence to Edifice: Four Fallacies about the Sabbath', in R. CARroll (ed.), Text as Pretext: Essays in Honour of Robert Davidson, JSOT.S 138 (Sheffield 1992) 179-199, esp. 185, 190-193.

Philonic evidence, particularly about the practices of the Therapeutae, is used to cast doubt on widely-held scholarly assumptions about biblical and Jewish sabbath observance. (DTR)

9254. J. MANSFEld, Heresiography in Context: Hippolytus' Elenchos as a Source for Greek Philosophy, Philosophia Antiqua 56 (Leiden 1992), esp. 312-315.

Repeats the main thesis of the author's earlier article (= R-R 8530) on a Middle Platonist cento of themes from Pythagoras, Plato, Empedocles and Heraclitus, which forms a crucial component of Philo's doctrine of the soul. The church father Hippolytus uses similar material in his attack on nonorthodox Christian thinkers, whom he accuses of being dependent on Greek philosophers for their heretical ideas. (DTR)

9255. C. MARKSGHIES, Valentinus Gnosticus? Untersuchungen zur valentinianischen Gnosis mit einem Kommentar zu den Fragmenten, WUNT 65 (Tübingen 1992) passim.

In the commentary on the fragments of Valentinus many references to Philonic writings are given - esp. to Opif. These serve to clarify the text, but are not the specific object of discussion. (DTR)

9256. J. Martens, 'Unwritten Law in Philo: a Response to Naomi G. Cohen', The Journal of Jewish Studies 43 (1992) 38-46.

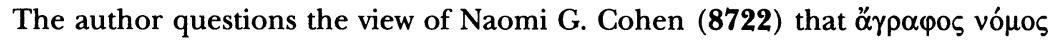
has a Jewish connotation and that Philo intended anything other than the general, Greek sense of the term. He concludes that the terms o' $\gamma \rho \alpha \varphi \circ \varsigma$ vó $\mu \circ \varsigma$ and $\alpha \gamma \rho \alpha \varphi$ o $\ddot{\varepsilon} \theta$ o were used in three ways; (1) unwritten law as eternal law, (2) unwritten law as custom, (3) unwritten custom as Jewish custom. The last category should not be viewed as halakhot. The term $\varepsilon^{\prime} \theta \eta$ does not have the force of oral law, but rather the binding force of tradition. (RMB) 
9257. J. P. Martín, 'El platonismo medio y Filón según un estudio de David Runia', Methexis 5 (1992) 135-144.

This article examines in five sections D. T. Runia's monograph Philo of Alexandria and the Timaeus of Plato (cf. R-R 8656). After a brief presentation (a) of book's content, the author notes its significance (b) for the history of Platonism in its turn from Academic to dogmatic philosophy in the first two centuries of our era. Three observations on Runia's thesis follow. Philo's predecessor Aristobulus (c), who testifies to an early comparison of Genesis with Plato, was insufficiently considered. It is also argued (d) that there is a problem in the use of authors from the 2nd century CE, in that the Middle Platonist philosophers are used as witnesses for the antecedents of Philo, whereas the Christian authors of the same period are regarded as dependent on him. Finally (e) the article suggests that Numenius, Celsus, Galen and perhaps other pagan philosophers of the 2 nd century may be more greatly indebted to Philo for than the book allows for. (JPM)

9258. J. P. MARTín, 'La sagezza creatrice secondo Teofilo d'Antiochia ed i suoi silenzi cristologici', Augustinianum 32 (1992) 223-235, esp. 229-235.

The author cites various Philonic passages to show a Jewish-Hellenistic tradition reflected by Theophilus of Antioch. This tradition illuminates the Ad Autolycum christology, in the sense that Logos and Sophia do not refer to Christ, even though the texts of 1 Cor. 1:24 and John 1:1-14 are cited and commented on. The author's intentions reflect a sapiential triadic theology, closest to the Philonic tradition. (JPM)

9259. J. P. MARTíN, 'El lenguaje lógico-matemático como modelo semiótico en el siglo I', Signos Universitarios. Revista de la Universidad del Salvador 11 (1992) 49-58.

Comments on Mos. 2.39, where Philo uses geometry as the perfect language pattern, because each thing belongs to one sign and each sign to one thing, as is recommended by proposition 3.325 of Wittgenstein's Tractatus. God is to be regarded as the perfect geometer, because he produced at the same time signs, meanings and things. Moses is then the real philosopher. The Bible and the World are perfect orders, produced by God. Both of them can be decoded by rules. In human activity the geometer represents divine semiotic perfection, as is also found in Adam and Moses. (JPM)

9260. P. A. MeIJer, Plotinus On the Good or the One (Enneads VI,9), Amsterdam Classical Monographs 1 (Amsterdam 1992), esp. 326328.

In his examination of the historical background of Plotinus' teachings on the unification of the mystic's self with the One, Meijer argues that there are 
not only differences, but also 'astonishing similarities' with Philo. Attention is drawn especially to two aspects of Philonic ecstasy: the arrival of the divine light that inspires the soul to prophecies and the mystic's ascent to God. But in Philo there is no complete union. Meijer argues for a common background, but we cannot prove historical connections. It is possible that Numenius could have formed a link between the two. (RMB)

9261. R. Mortley, 'The Name of the Father is the Son (Gospel of Truth 38)', in R. Wallis and J. BREgmaN (edd.), Neoplatonism and Gnosticism, Studies in Neoplatonism Ancient and Modern 6 (Albany 1992) 239-252.

A paper presented at the Sixth International Conference of the International Society of Neoplatonic Studies held in 1984, but only now published. Mortley attempts to account for the enigmatic statement in the Gospel of Truth by invoking Philo and esp. the passage at Conf. 145 where the Logos is called the Name of God. He also argues that the version of the treatise found at Nag Hammadi contains a response to Arianism, i.e. that it was revised, and that the revisor made use of Philonic ideas. In an afterword M. Tardieu expresses agreement that the passage represents a Gnostic response to the Arian debate. (DTR)

9262. R. NASH, The Gospel and the Greeks: Did the New Testament Borrow from Pagan Thought? (Richardson TX 1992).

Nash contends that the essential beliefs and practices mentioned in the New Testament are unique and not borrowed from contemporary Hellenistic culture. Focusing upon three alleged sources of early Christian notions Hellenistic philosophy, mystery religions, and Gnosticism - he argues that parallels between NT concepts and these three cultural domains do not signify dependence of the NT upon these areas. Philo is discussed in the philosophy section (Chapters Five and Six, pp. 81-112) in relation to the Logos concept of the Fourth Gospel and particularly of the Book of Hebrews, where the concept is implicit. In neither case can the Christian Logos be considered dependent upon the Philonic notion. In fact, according to Nash, a major purpose of the author of Hebrews is to show that Jesus is superior to other mediator figures. (EB)

\section{M. Nienoff, The Figure of Joseph in Post-Biblical Jewish Literature, AGJU 16 (Leiden 1992), esp. 54-83.}

Philo is the first and indeed only complete treatment of the Joseph story. For the biographical moulding of the story Philo was inspired by his Greek background. The biblical figure is reshaped in accordance with Philo's concepts of both 'allegorical' and 'political' biography. Those passages which Philo himself introduces as allegorical incorporate diverse philosophical material on the role of the politician. Here the biblical story tends to recede into the background. Philo presents an idealised image of Joseph and 
accommodates the biblical material to his preconceived ideals of political personalities. He also presents him as an ideal Hebrew in Egypt, i.e. topical and exegetical aspects are blended, and Philo's ambivalence to Egypt comes to the fore. (RMB)

\section{F. Petit, La Chaîne sur la Genèse: Édition intégrale chapitres 1 à 3, Traditio Exegetica Graeca 1 (Louvain 1992).}

Basing her thesis on years of concentrated research, Petit argues that the Catena in Genesim is not a collaborative and cumulative work, but basically the compilation of a single redactor. She has now commenced to produce the first edition that integrates the various manuscript traditions. The first three chapters contain four Philonic texts. Cf. further 9363 and 9563. Review: D. T. Runia, SPhA 5 (1993) 229-232. (DTR)

9265. M. Petit, 'Les Esséens de Philon d'Alexandrie et les Esséniens', in D. Dimant and U. Rappaport (edd.), The Dead Sea Scrolls (Leiden-Jerusalem 1992) 139-155.

Where did Philo derive his knowledge of the sect of the Essenes from? Certainly he may have been indebted to his older contemporary Nicholas of Damascus. Another possibility is that he may have been dependent on oral traditions from Palestine, as is suggested by comparison of his material with what we find in both Talmudic texts and the Dead Sea scrolls themselves. This material points to an identification of the Essenes with the inhabitants of Qumran. Philo may also have put together his account on the basis of what he heard about important Essene personages. At the end of the article Petit raises the question of personal contact. The suggestion of a prolonged contact with the sect is considered unlikely, though the possibility that Philo paid a short visit to the sect during his pilgrimage to Jerusalem is considered a possibility. This would explain the fact that the picture of the Essenes in the Hypoth., a work edited at the end of his life, includes extra details not found in Prob., a work of Philo's youth. (RMB)

9266. S. M. Pogoloff, Logos and Sophia: the Rhetorical Situation of 1 Corinthians, SBL.DS 134 (Atlanta 1992), esp. 180-187.

The author interprets 1 Cor. 1-4 in terms of its rhetorical features. The fact that Apollos, who is named in 1 Cor., was a rhetor from Alexandria, induces the author to give a brief discussion of Philo as rhetor and the context of Alexandrian rhetoric. (ACG)

9267. A. Reinhartz, 'Philo on Infanticide', The Studia Philonica Annual 4 (1992) 42-58.

Even though Philo expresses outrage and condemnation at the practices of exposure of infants and infanticide, his discussions on them may imply that they took place in his community. From these passages it may be concluded 
that (a) many people did consider exposure of infants to be a lesser evil than infanticide, and (b) Philo's intended audience of his writings were men. (RMB)

9268. C. J. Roetzel, 'Oikoumene and the Limits of Pluralism in Alexandrian Judaism', in J. A. Overman and R. S. MacLennan (edd.), Diaspora Jews and Judaism: Essays in Honor of, and in Dialogue with, A. Thomas Kraabel, University of Florida: Studies in the History of Judaism 41 (Atlanta 1992) 163-182, esp. 174-179.

By studying the ways in which the Diaspora community appropriated the Hellenistic vision of the oikoumene in order to lay claim to their status as God's elect, the author hopes to come to a better understanding of how a Diaspora Jew like Paul could combine a universalistic gentile mission with an appeal to a rather narrow slice of Jewish tradition. Philo is one of the members of the Diaspora community to whom attention is given. It is argued that he neither wanted to forsake his Jewishness, nor did he want to withdraw in a cultural ghetto and thus remove himself from the oikoumene. This explains his criticism of both rigorous interpreters of the Scripture and those who neglected the letter of the law. (RMB)

9269. J. L. Rubenstein, The History of Sukkot during the Second Temple and Rabbinic Periods: Studies in the Continuity and Change of a Festival (diss. Columbia, New York 1992).

Since all sources for the observance of Sukkot in this period are studied, this means that Philo too is included. See further 9567. (DTR)

9270. D. T. Runia, 'Confronting the Augean stables: Royse's Fragmenta Spuria Philonica', The Studia Philonica Annual 4 (1992) 78-86.

A review article on Royse's important study 1823. Before outlining the contribution made by this study, the article first examines the question of how much has survived of what we know Philo to have written. It is concluded that only about half remains in the original Greek. Of the half that is lost about a third remains in the Armenian tradition. (DTR)

9271. D. T. Runia, 'The Language of Excellence in Plato's Timaeus and Later Platonism', in S. Gersh and C. KAnNengiesser (edd.), Platonism in Late Antiquity, Christianity and Judaism in Antiquity 8 (Notre Dame 1992) 11-37.

The starting-point of the article is a Philonic passage, Plant. 127-131, in which Philo exploits the characteristic phraseology used in Plato's Timaeus to describe the excellence of the cosmos. Similar adaptation is found in Plutarch 
and Plotinus. The article goes on to analyse this phraseology in Plato himself, concentrating especially on his use of the superlative. The key to Plato's language of excellence is his rationalist conviction that the cosmos cannot be better than it is. At the end of the article a brief return is made to the passages in Philo, Plutarch and Plotinus with which it started. Philo's approach is very different from that of Plato. For him God is no philosophical abstraction, but rather the supreme Being whom man must worship in love or in fear. (DTR)

9272. D. T. Runia, 'A Note on Philo and Christian Heresy', The Studia Philonica Annual 4 (1992) 65-74.

The article examines those passages in the church fathers in which Philo is associated with Christian heresy. Gregory of Nyssa in two texts accuses the Neo-Arian Eunomius of filching material from Philo. In two passages in Ambrose we can see that he is wary of taking over expressions from Philo that might be understood as favouring heresy. There is, however, no evidence connecting Philo with the 'archheretic' Arius himself. (DTR)

9273. D. T. Runia, 'Philo and Origen: a Preliminary Survey', in R. J. DALY (ed.), Origeniana Quinta: Papers of the 5th International Origen Congress Boston College 14-18 August 1989, BEThL 105 (Leuven 1992) 333-339.

Status quaestionis on the relationship between Philo and Origen. A full list of sixteen passages is given in which Origen refers to Philo, either explicitly by name or by implication in anonymous references. Much detailed work remains to be done on the extent to which Origen was indebted to his reading of Philo and the way he adapted exegetical and theological themes of his predecessor. It is apparent that Origen regards him as a honoured member in a long line of inspired exegetes. For this reason he gave him an place in his library, which ultimately resulted in the preservation of the corpus Philonicum. (DTR)

9274. D. T. Runia, Platonisme, Philonisme en het begin van het christelijk denken, Quaestiones Infinitae 2 (inaugural lecture, Utrecht 1992).

The main question addressed in the inaugural lecture is whether it can be said that Philo played a significant or even a decisive role in the development of Christian thought. It begins with an exegesis by Augustine of Ex. 3:14-15, in which a distinction is made between the two divine pronouncements 'I am he who is' (v. 14) and 'I am the God of Abraham, Isaac and Jacob' (v. 15). The only other example of this distinction is to be found in a number of Philonic texts. Was Augustine indebted to Philo? A difficulty in answering the main question posed in the lecture is the tension between a historical and a systematic approach. Moreover Philo is only the most important representative of a wider Hellenistic-Jewish tradition. It is suggested 
that we should speak of Philonism rather than just Philonic thought. Four important sources of influence are then outlined in order of increasing importance: the origin of dogmatism, the origin of the allegorical method, the choice of the Platonist paradigm for the interpretation of Moses, the localization of insights from the Greek philosophical tradition in the authoritative words of scripture. The choice fell on Platonism because it was best able to give systematic expression to the conviction of God's faithfulness and his transcendence. The lecture concludes with a discussion of related passages in Basil and Gregory of Nyssa, before returning to Augustine. The precise relation between Philo's and Augustine's use of the theme is difficult to pin down, but the common element does illustrate the importance of Philonism for Christian thought. See further 9568, which is for the most part based on this inaugural lecture, and 9570, which presents an English translation. (DTR)

9275. D. T. Runia, "Where, tell me, is the Jew...?': Basil, Philo and Isidore of Pelusium', Vigiliae Christianae 46 (1992) 172-189.

At the end of his homilies on the Hexaemeron Basil briefly examines the text describing the creation of man (Gen. 1:26) and immediately launches into a polemic against a Jewish thinker who asserts that God uses a plural verb because he was conversing with himself. It has been thought that Basil has Philo in mind here, but it is shown that this cannot be the case. The Jew is a collective figure, representing Jewish exegetes opposed to Christian interpretations which read the presence of the Logos or the Trinity into the Mosaic creation account. In the final part of the article it is shown that Basil's account was familiar to Isidore of Pelusium. But this church father adopts a different attitude, defending Philo from attack. The reasons for this move are strategic. Philo can be used as ammunition in discussions with contemporary Jews. (DTR)

9276. D. T. RuniA, 'Verba Philonica, 'АГА $\Lambda$ MАТОФОРEIN, and the Authenticity of the De Resurrectione Attributed to Athenagoras', Vigiliae Christianae 46 (1992) 313-327.

The chief purpose of the paper is to draw attention to a special form of vocabulary that passes via Philo into Patristic texts. It concerns compound words taken over or even coined by Philo in order to express particular aspects of his exegetical and apologetic activity. A list of such words is given, followed by a detailed analysis of one example, the rare term $\dot{\alpha} \gamma \alpha \lambda \mu \alpha \tau$ o image-bearer'. The term occurs in some 10 patristic texts. The most interesting occurrence is perhaps in the treatise On the Resurrection attributed to the apologist Athenagoras, but of disputed authenticity. It is argued that the presence of the term in this work supports the view that the work is later than the 2nd century, and thus not by Athenagoras. (DTR)

9277. E. P. SANDers, Judaism: Practice and Belief, 63 BCE - $66 C E$ (London-Philadelphia 1992). 
Extensive use is made of Philonic evidence for the reconstruction of what the author calls 'common Judaism', and esp. for the role of diaspora Judaism therein. Review: A. Mendelson, SPhA 6 (1994) 160-170 (see 9447). (DTR)

9278. D. R. Schwartz, Studies in the Jewish Background of Christianity, WUNT 60 (Tübingen 1992), esp. 16-18, 214-217.

In this volume of collected essays which focuses inter alia on the development of Judaism in the second Temple period, we note: (1) in the introductory chapter 'On the Jewish Background of Christianity' a discussion of Philo and esp. Migr. 89-93 under the heading 'undermining the Law: in the Hellenistic Diaspora'; (2) an English version of the article earlier published in Hebrew on 'Pilate's Suspension from Office' (see R-R 8245), in which it is argued that Josephus made use of Philo's Legatio ad Gaium. (DTR)

9279. G. SEllin, 'Gotteserkenntnis und Gotteserfahrung bei Philo von Alexandria', in H.-J. Klauck (ed.), Monotheismus und Christologie: zur Gottesfrage im hellenistischen Judentum und im Urchristentum, Quaestiones Disputatae 138 (Freiburg 1992) 17-41.

In many respects Philo is a paradigm figure, because he was the first to put forward with lucidity the dilemma that is implicit in every discourse on God, namely the necessity of speaking about that which is in the category of ineffable substance (p. 17). From this are derived consequences of considerable theological importance, such as negative theology, the symbolic use of divine names, analogical thought, metaphorical (but not mythical) language, and so on. But consequences of philosophical and exegetical importance also make their presence felt (which turn Philo's thought into a bridge between the Old Testament and Stoic and Middle Platonist philosophy), as well as those of a mystical-religious character (connected with the theology of the Logos). Sellin distinguishes two methods of approaching Philo's evidence: one is to regard the Alexandrian as a quarry of information; the other takes the form of a lectio continua that concentrates on the writer and his work in synchronic unity. In this perspective the substantial diversity in Philo's theology comes to the fore, the result of the exegetical and non-systematic nature of his treatises. There is, however, a third approach which leads to a 'deeper level of the text' less confused than what appears on the surface, namely the existentially determined level of Philonic piety. The analysis of this deep level leads the author to embark on the first part of his article (pp. 19-26), entitled 'the God of the philosophers', followed by the second on the existential roots of Philo's thought (pp. 26-28), 'the God of the Old Testament'. To these are added a third section dedicated to the ö $v \theta \rho \omega \pi \circ \theta_{\zeta} \theta \varepsilon \hat{v}$ (man of God) as Logos (pp. 29-34) and a fourth which draws consequences of Philo's theology and Logos doctrine for the Christology of the New Testament (34-40). (RR) 
9280. R. Sgarbi, 'Problemi linguistici e di critica del testo nel "De vita contemplativa" di Filone alla luce della versione armena', Memorie dell'Istituto Lombardo, Accademia di Scienze e Lettere, Classe di Lettere, Scienze morali e storische 40.1 (1992) 5-48.

The study examines difficult passages of the Philonic treatise and discusses the reconstruction of the text on the part of modern editors (Conybeare, Cohn-Reiter, Colson, and finally the French edition of the CERF). Making extensive use of the Armenian version, which is particularly faithful to the original Greek (as is characteristic of many other similar products of the socalled Hellenistic school of Armenian translators), the author not only demonstrates that textual corruptions penetrated into the manuscript tradition very early in its transmission, but also contributes to their removal. The study takes great care to demonstrate the various degrees of fidelity to the Greek text shown by the Armenian translation. It increases our knowledge of technical aspects of this process by making precise remarks and providing copious discussions of an inter-linguistic nature. Review: A. Terian, SPhA 8 (1996) 204-205. (RR)

9281. F. Siegert, Drei hellenistisch-jüdische Predigten: Ps.-Philon, 'Über Jona', 'Über Jona' (Fragment), 'Über Simson'. II. Kommentar nebst Beobachtungen zur hellenistische Vorgeschichte der Bibelhermeneutik, WUNT 61 (Tübingen 1992).

This study is the sequel to the translation of the same Ps.Philonic texts presented in volume I (= R-R 2051). Siegert gives a full commentary, preceded by two introductory chapters which place them in their Jewish and Hellenistic settings (pp. 1-91) and followed by a final chapter containing a theological appreciation (pp. 293-319). The importance of these texts for our knowledge of Hellenistic Judaism cannot be overestimated, because they are the only surviving examples of what might be called Hellenistic-Jewish homilies or, more accurately, logoi, no doubt pronounced in the Alexandrian synagogue. Siegert argues that their literary origin is to be sought in the Greek educational system and its focus on the exegesis of Homer. They are to be dated to the first century CE. The study also contains numerous excursuses and discussions of detailed questions relating to Philo and his intellectual milieu. Reviews: A. G. Holder, RelStR 19 (1993) 364-365; P. W. van der Horst, SPhA 5 (1993) 219-222; M. Nobile, Ant 68 (1993) 399-401; P. Devos, AB 112 (1994) 453; C. Thoma, Jud 50 (1994) 50-52; R. Vicent, Sales 56 (1994) 788789. (DTR)

9282. D. Sills, 'Vicious Rumours: Mosaic Narratives in First Century Alexandria', in E. H. Lovering JR. (ed.), Society of Biblical Literature 1992 Seminar Papers, SBLSPS 31 (Atlanta 1992) 684-694.

Reading Philo's De Vita Moysis within the framework of Jauss' theory of reception, the author confronts Philo's text with the anti-Jewish account of 
Moses found in Josephus' Contra Apion. It is concluded that some explicitly anti-Jewish themes in first century Alexandrian narratives represent part of the literary horizon of Philo's work. In addition, Philo's Moses narrative reinscribes, transforms, and finally provides a rationale for Scripture's decidedly hostile view of the Egyptians. (RMB)

9283. G. E. Sterling, 'Creatio Temporalis, Aeterna, vel Continua? an Analysis of the Thought of Philo of Alexandria', The Studia Philonica Annual 4 (1992) 15-41.

The article attempts to examine the question of Philo's view on the temporal or non-temporal creation of the universe in the light of a systematic reconstruction of the Middle Platonist tradition. Firstly the various positions put forward by Philo's modern interpreters (Wolfson, Baltes, Sorabji, Weiss, Winston, Runia) are outlined. The greatest difficulty encountered is the presence of discordant notes in the Philonic corpus, which have to be accounted for. Sterling then moves on to the philosophical tradition, presenting the contributions of Plato, Aristotle and Theophrastus, the Old Academy, the Middle Platonists (including Eudorus and Alcinous). Finally he returns to Philo and re-examines the texts, with particular emphasis on Opif. 7-12, Aet. 13-19, Prov. 1.7. He concludes that Philo inherits the figurative interpretation prominent in many Middle Platonist authors. The evidence of the Philonic texts points to the conclusion that he held a view of creatio aeterna. This also explains problems in our interpretation of Opif. All temporal distinctions in the biblical account of creation are meant didactically, i.e. to show that the universe is not autonomous, but dependent on a Supreme being. This is Philo's understanding of creation. (DTR)

9284. M. Theobald, 'Gott, Logos und Pneuma: Trinitarische Rede von Gott im Johannesevangelium', in H.-J. KLAuck (ed.), Monotheismus und Christologie: zur Gottesfrage im hellenistischen Judentum und im Urchristentum, Quaestiones Disputatae 138 (Freiburg 1992) 41-87, esp. 79-85.

Especially from the terminological point of view (i.e. the 'Gesprächsituation'), the Prologue to John's Gospel gains in clarity if it is considered in the light of Jewish-Alexandrian culture, and particularly with reference to the figure of the Philonic Logos, which basically has a mediating function (between God's transcendence and the world) and is directly connected with the doctrine of creation. (RR)

9285. T. H. Tobin S. J., 'Interpretations of the Creation of the World in Philo of Alexandria', in R. J. Clifford and J. J. Collins (edd.), Creation in the Biblical Traditions, CBQ.MS 24 (Washington 1992) 108-128. 
Analysing interpretations of the creation of the world given in Philo's in De Opificio Mundi (esp. in 15-35 and 129-130), Tobin reaches three tentative conclusions. (1) Philo was part of a larger tradition of Hellenistic Jewish biblical interpretation. The text was not interpreted simply by itself but within the context of a larger exegetical tradition. (2) The interpretations were not made in a cavalier fashion, but based on a close reading of the biblical text. For each detail of the interpretations a justification is given, based on noting a particular element in the biblical text. (3) These interpretations have been clearly influenced by the thought of Plato's Timaeus and its reinterpretation in Middle Platonism. The five central teachings of Moses outlined at the treatise's conclusion are certainly indebted to Plato's Timaeus. But it would be difficult to claim that they represent views that are not in harmony with the biblical account of creation. (RMB)

9286. H. Tronier, 'Spørgsmålet om hermeneutisk kongruens i Pauluseksegesen: 1. del: Hermeneutiske overvejelser omkring et Paulusseminar [In Danish $=$ The Question of hermeneutical congruity within the exegesis of Paul: 1st part: Hermeneutical reflections on the occasion of a seminar on Paul]', Dansk Teologisk Tidskrift 55 (1992) 102-122; 'Spørgsmålet om hermeneutisk kongruens i Pauluseksegesen: 2. del: Allegorisk og typologisk hermeneutik i eksegesen [In Danish $=$ The Question of hermeneutical congruity within the exegesis of Paul: 2nd part: Allegorical and typological hermeneutics within the exegesis]', Dansk Teologisk Tidskrift 55 (1992) 191-208, esp. 192-96.

The two articles form a unity. The second of them contains a passage presenting the method used by Philo as a device for interpreting scripture. The author gives a summary of his views elaborated in 9382. 'Philo's allegorical method proves to be based on a type of diairetical hermeneutics that was to a large extent applied by Hellenistic philosophy (summary in English p. 207).' (KGS)

\section{G. M. Vian, 'Le Quaestiones di Filone', Annali di Storia dell'Esegesi 9 (1992) 365-388.}

A learned general introduction to Philo's least well known work. The author gives an account of their textual tradition, literary form and exegetical method, followed by a brief survey of various exegetical themes covered in the course of the six (or eight) books. The final pages are devoted to some concluding remarks. It is argued that Philo is engaged in a constant dialectic between the literal and the allegorical meaning. Though preference is given to the literal meaning, the exegesis is consistent with his other works. The text contains important hermeneutic developments and enjoyed considerable success in the Christian world, a fact which guaranteed their (partial) survival. (DTR) 
9288. S.-K. WAN, The Quaestiones et solutiones in Genesim et in Exodum of Philo Judaeus: a Synoptic Analysis (diss. Harvard 1992).

The question that this dissertation attempts to answer is why Philo casts his Quaestiones, a work that covers substantially the same ground as his Allegorical Commentaries, in a genre that is so radically different. The thesis proposed is that the Quaestiones were composed as an independent commentary intended for a quite different audience, namely the general reading public of Alexandrian Jewry. The first half of the study examines the use of

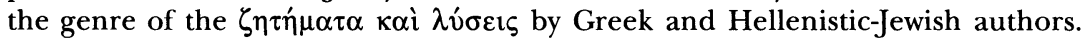
Commentaries using this genre were primarily intended for a more general public. The second half consists of two synoptic studies, comparing the parallel treatments of the creation account (Gen. 2-3) and the episode of the giants (Gen. 6) in both the Quaestiones and the Allegorical Commentary. It is shown that the former were not written as preparatory notes for the latter. They also demonstrate a greater tolerance towards myths, which may also imply a less sophisticated audience. (DTR; based on summary in DA 5405A, p. 1839)

9289. J. Whittaker, 'Catachresis and Negative Theology: Philo of Alexandria and Basilides', in S. Gersh and C. KanNengiesser (edd.), Platonism in Late Antiquity, Christianity and Judaism in Antiquity 8 (Notre Dame 1992) 61-82.

Examining Runia's hypothesis of a theological exploitation of the gram-

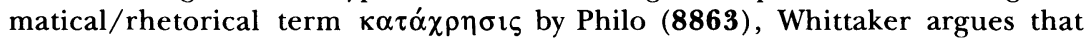
even if Philo (or others) had exploited this term theologically (which he thinks Philo did not do), Philo must soon have realized that such exploitation could be achieved only by redefining the term whenever it occurred with a meaning different from that commonly accepted. As a result the adepts of negative theology refrain from using this term in such a new, theological sense. Whittaker discusses various Philonic passages adduced by Runia in his article, and concludes the article with an analysis of some further texts in the Middle and Neoplatonist tradition which reinforce his view. (RMB)

9290. E. Will and C. OrRieux, "Prosélytisme juif"?: histoire d'une erreur, Histoire (Paris 1992), esp. 81-101

Chapter four has the title 'Philo and the proselytes' (earlier published separately; see 9193). Many commentators on Philo, including Arnaldez and Nikiprowetzky, had showed no hesitation in attributing to him the role of a missionary of the Jewish religion. This does not, however, in the view of Will correspond to the truth, not only because the texts of Philo do not support it, but also because 'missionary preaching is as foreign to Philo's thought as it is to the biblical tradition which is his point of departure (p. 99)'. Those passages which appear to have an apologetic intention are in fact not directed to pagans for the purpose of converting them, but rather to apostates in order 
to lead them back to the faith. Whereas for a Jew apostasy is a most serious sin, the conversion to Judaism of a pagan is an act of divine grace, on which man can exercise no influence. (RR)

9291. D. Winston, 'Philo's Conception of the Divine Nature', in L. E. Goodman (ed.), Neoplatonism and Jewish Thought, Studies in Neoplatonism Ancient and Modern 7 (Albany 1992) 21-42.

Philo, following Middle Platonic and Neopythagorean traditions about the transcendent character of God, held that it is impossible to know the essence of God. As a result God is, amongst other things, apathês, without irrational impulses of any kind. How then are we to account for passages in Scripture that seems to ascribe passions to God? Philo, it is argued, turns to the Stoic concept of eupatheia for a way out. His doctrine of the eupatheiai is, however, not purely Stoic. This is shown by the fact that he ascribes pity (eleos) to God, a divine attribute in the Jewish tradition, but not at all in the tradition of the Old Stoa. (RMB)

\section{C. K. Wong, 'Philo's Use of Chaldaioi', The Studia Philonica Annual 4 (1992) 1-14.}

The article examines Philo's use of the term $\mathrm{X} \alpha \lambda \delta \alpha \hat{\imath} \mathrm{ot}$. Three basic meanings are found: (1) a designation for astronomical studies and their practitioners; (2) a geographical term for inhabitants of Mesopotamia; (3) a designation for the Hebrew language or members of the Hebrew race. The author pursues the use of these three designations in the Philonic corpus and discovers that the third meaning is never found in the Allegorical Commentary. Various explanations for this phenomenon are suggested. Wong himself favours a chronological approach. As a result of his trip to Rome, Philo will have grown more sensitive to the negative associations which the name 'Chaldaioi' had for Romans, who used it as a synonym for 'astrologers' and saw astrology as a potential source of rebellion. Given the whole affair of the anti-Jewish riots in Alexandria, Philo, who had hitherto used 'Chaldaioi' as a synonym for 'Hebrews', from than on avoided calling Hebrews by this term, fearing it might suggest that the Hebrews were troublesome. (RMB) 
9301. M. Alexandre JR, 'A Rhetorical Analysis of Philo's $D e$ virtutibus', Euphrosyne 21 (1993) 9-28.

The author builds on earlier studies $(9002$ and 9101) in which he has analysed the argumentative structure of parts of Philo's treatises. This time he deals with an entire treatise. He first notes that Virt. is divided into four parts which can each be treated as complete rhetorical units. This is followed by a more detailed analysis of the contents of De humanitate (\$51-174) in which first the structural elements and then aspects of style are outlined. Philo combines technical rhetorical competence with literary and argumentative elegance. (DTR)

9302. M. E. Allison, The Motif of Parresia in Acts (diss. Southern Baptist Theological Seminary 1993).

In chapter 3 various pagan and Jewish sources, including Philo and Josephus, are examined as background to a treatment of the motif of $\pi \alpha \rho \rho \eta \sigma i \alpha$ in Acts. (DTR; based on summary in DA 54-04A, p. 1416)

9303. Y. Amir, 'Monotheistische Korrekturen heidnischer Texte', in D.-A. Koch and H. Lichtenberger (edd.), Begegnungen zwischen Christentum und Judentum in Antike und Mittelalter: Festschrift für Heinz Schreckenberg, Schriften des Institutum Judaicum Delitzschianum 1 (Göttingen 1993) 9-19.

How do Jewish authors use pagan texts referring to Greek gods? Aristobulus (in Eusebius $P E$ 12.12.6) consciously replaces the name Zeus in Aratus by the term God. Philo, Ebr. 150 corrects Hesiod's plural gods with the singular number. In Prob. 116 he quotes Euripides with the plural form, but in Prob. 19 he has God instead of Zeus in a quotation from Sophocles. This text should not be emended, but one should follow the original mss. reading and Ambrose Ep. 37.28. In Opif. 104, however, the term God is already in Solon's poem, as is shown by the parallel quotation in Anatolius. Thus, it is concluded, Hellenistic Jews felt authorized to adjust words from pagan poets in a monotheistic sense. (DZ)

9304. Y. DE ANDiA, Henosis: l'union à Dieu chez Denys l'Aréopagite (diss. Paris Sorbonne 1993), esp. Part IV Chapter I.

Some pages on Philo (and Gregory of Nyssa) are included as part of a massive thesis on the philosophical and religious theme of union with God in Dionysius the Areopagite. For the definitive publication see below 9602. (DTR) 
9305. K. Armstrong, A History of God: From Abraham to the Present, the 4000 Year Quest for God (London 1993), esp. 81-86.

In this 'biography of belief' Philo is briefly discussed as one of the first monotheists to fall in love with Greek philosophy. How can we only know of God's existence, and yet also be convinced that he speaks through the prophets? The answer for Philo involves the distinction between God's essence, which is wholly incomprehensible, and his activities in the world by means of his powers. Philo's transcendent theology is not as bleak as it sounds, but Jews have always found its contents somewhat inauthentic. (ACG)

9306. J. N. BaIley, Repentance in Luke-Acts (diss. Notre Dame 1993).

In the New Testament, the subject of repentance is most prominent in the Gospel of Luke and the Acts of the Apostles. Luke's view of repentance is unique in its religio-historical context and significant in his overall theology. This topic, however, has not been adequately investigated or explained. The author argues that Luke took over a theme that was present in Early Judaism and in Early Christianity and developed it in a way appropriate for a Christian community of Jews and Gentiles who were sensitive to literary and philosophical traditions of the Hellenistic world. Luke's treatment of the topic of repentance has important parallels in Jewish literature. For example, repentance was a characteristic feature of the community at Qumran. Even more significant parallels are found in the writings of Philo, who presented repentance in the most favourable light to an educated Hellenistic audience. (DTR; based on summary in DA 54-05A, p. 1838)

9307. M. BALDASSARRI, 'Le opere filosofiche di Filone Alessandrino', in La filosofia antica II (Como 1993) 173-202.

The author examines the Philonic writings devoted to 'pure philosophy', i.e. the philosophical writings Aet., Prov., Prob., Anim., together with Hypoth., Contempl., Flacc. and Legat., and also accompanied by a brief general discussion of the Allegorical Commentary (pp. 173-180). Baldassarri sees a philosophical continuity between Prov., Aet. and Anim., regarding the second as a development of the first in a cosmological key and the third as a development of the first in an anthropological key (the superiority of the human being in relation to other living beings, p. 189), especially in relation to the themes of rationality and freedom. On the other hand the treatise Prob. - parallel to Contempl. - concentrates on ethical themes in a Stoic perspective, because it demonstrates the real existence of the Stoic sage in the sect of the Essenes. The author concludes that Stoic philosophy is solidly and extensively present in Philo, but always remains subordinate to Platonic thought, because the latter alone is able to guarantee recognition of divine transcendence. In a more general cultural perspective the author evaluates Philonic philosophy as providing an opening into a 'new world', though of itself it is incapable of 'producing an original synthesis and making an effective advancement in the theoretical and practical domain' (p. 200). (RR) 
9308. G. H. Baudry, 'Le péché originel chez Philon d'Alexandrie', Mélanges de Science Religieuse 50 (1993) 99-115.

Philo does not have a united and coherent theory about original sin. The accounts of Genesis interest him only for their symbolic significance, i.e. the creation of Adam and Eve as an allegorical representation of human nature and their fall as a type for all sin. Reflection on the origin of sin is found rather in the context of general reflections about evil. Evil follows on from existence in the changing sublunary world; evil and human sin are linked to man through his nature, which in accordance with Platonic anthropology is mixed. This is then combined with the pessimistic Jewish theory of a dominant inclination towards evil. The origin of sin is less protological than ontological. Philo has supplied the anthropological basis for the encratistic currents of thought out of which (but nor exclusively) the Christian theory of original sin will emerge. (RR, based on author's abstract)

9309. R. Bergmeier, Die Essener-Berichte des Flavius Josephus: Quellenstudien zu den Essenertexten im Werk des jüdischen Historiographen (Kampen 1993).

In this philological and religio-historical study Bergmeier postulates four sources for Josephus' portrait of the Essenes. Beside some anecdotes on mantic Essaioi (probably from Nicolaus of Damascus) and a doxographical report on the three schools of Pharisees, Sadducees and Essenes, Josephus uses a Hellenistic-Jewish source on the Essaioi which also underlies Philo, Prob. 75-91 and Hypoth. 11.1-18. From similarities between Contempl. and Pliny 5.73 Bergmeier furthermore postulates a fourth source which represented the Essenes as Pythagoreans. Josephus drew heavily on this source, as repetitions and disagreements make clear. Philo's Therapeutae thus form an ideal picture. Finally the main sources are compared with the Qumran texts. The author warns against making inferences from literary representation to historical facts. (DZ)

9310. L. BERK, 'Logos bij Johannes en Philo', Interpretatie 1.4 (1993) 17-19, 1.6 (1993) 23-24.

According to the author it is important to notice that in the Johannine Prologue the Logos is called $a$ God, and his Father the God. He regards Philo as a predecessor of John, because Philo too calls the Logos a god, next to the God. Attention is also drawn to parallels in phraseology concerning the Logos between the two authors. (ACG)

9311. E. Birnbaum, 'The Place of Judaism in Philo's Thought: Israel, Jews, and Proselytes', in E. H. Lovering, JR. (ed.), Society of Biblical Literature 1993 Seminar Papers, SBLSPS 32 (Atlanta 1993) 5469. 
The author discusses the distinction Philo makes between 'Israel' and the 'Jews'. 'Israel' signifies a rather loosely defined entity comprising those who can see God. To this class belong all respected philosophers, or philosophically-minded people, whether they are Jewish or not. Philo calls 'Jews' those who are born as a Jew and those who have chosen to lead the Jewish way of life. They follow the Jewish laws and practices. When describing 'Israel' and the 'Jews' as collectivities, Philo uses different terms with different connotations. Moreover he speaks differently about the relationship between God and 'Israel' and that between God and the 'Jews'. It is not possible to reach firm conclusions on the question of whether Philo regards Jews and non-Jewish philosophers equally or that he regards Jews more highly. The article ends with some comments on the issue of universalism and particularism in Philo's thought. (ACG)

9312. P. Borgen, 'Heavenly Ascent in Philo: an Examination of Selected Passages', in J. H. Charlesworth and C. A. Evans (edd.), The Pseudepigrapha and Early Biblical Interpretation, JSP.S 14 (Sheffield 1993) 246-268.

In the presentation of the research situation concerning the theme of heavenly ascent in antiquity Borgen notes that Philo is often neglected or, as was the case in the research of Goodenough, given too narrow an interpretation. In order to fill this gap Borgen shows that Philo has many references to the theme which reveal his indebtedness to Jewish tradition with regard, for instance, to the figures of Enoch, Moses and Elijah. For Philo these figures serve as paradigms for others aiming at a heavenly goal. Greek ideas of Platonic, Stoic and astrological provenance too have penetrated Philonic thought in this area. Borgen also discusses Philo's thoughts on the function of angels within the process of the heavenly ascent, comments upon the Alexandrian's individual experiences of it, and shows how the theme in his writings is contrasted to invasion into the heavenly realm by sinister forces of this world, for instance emperors, sophists and materialists. (KGS)

9312a. D. Boyarin, Carnal Israel: Reading Sex in Talmudic Culture (Berkeley 1993), esp. 3-5, 78-80, 231-234.

The author argues that there is a fundamental difference between Rabbinic views on the body and sexuality and that of the earlier Judaism, influenced by Platonic modes of thinking, of which Philo is a significant representative. An account is given of Philo's interpretation of Eve. In Opif. 151-152 two ingredients are present which Boyarin claims to be endemic in Western misogyny: woman as misfortune, and the ontologically secondary status of the gendered human being identified primarily with woman. Some remarks are also devoted to Philo's espousal of universalism. (DTR)

9313. N. L. Calvert, Abraham Traditions in Middle Jewish Literature: Implications for the Interpretation of Galatians and Romans (diss. Sheffield 1993). 
For the chapter in this dissertation on Abraham traditions in Philo see below at 9406 .

9314. G. P. Carras, 'Dependence or Common Tradition in Philo Hypothetica viii 6.10 - 7.20 and Josephus Contra Apionem 2.190219', The Studia Philonica Annual 5 (1993) 24-47.

The question of the relationship between Philo's summary of the Law in his Hypothetica and the similar passage in Josephus' Contra Apionem has long been debated. Carras first makes some background remarks about Philo's treatise and the problems of interpretation that surround it. In the main body of the article he discusses the main themes of its summary of the Law, relating them to the following categories of Jewish evidence: (1) biblical law; (2) OT non-legal material; (3) Jewish material from the close of the OT prior to the time of Philo; (4) material shared by Philo with his contemporaries; (5) ideas shared by the two works; (6) material unique to the Hypoth.; (7) ideas in the Hypoth. that were common in antiquity, among Jews as well as non-Jews. On the basis of his findings he concludes that the Hypoth. reveals a varied and complex collection of traditions and sources. What then is the relationship to Josephus' work? It is concluded that Josephus did not use Philo as a direct source. The common-source theory gains some support from the evidence, but it is necessary to qualify this conclusion by emphasizing that a body of shared traditions also played a significant role. For an earlier version of this study see 9006 . (DTR)

9315. G. Casadio, 'Gnostische Wege zur Unsterblichkeit', in E. Hornung and T. Schabert (edd.), Auferstehung und Unsterblichkeit, Eranos N.F. 1 (München 1993) 203-254, esp. 214-218.

Philo's dualistic anthropology is to be counted as one of the premises of the Gnostic doctrine of immortality . For Philo the way to immortality is to get rid of the body and to surrender to the grace of a transcendent God. This God, however, is not consubstantial with the pneuma which he breathes into man (Gen. 2:7). (DZ)

9316. M. Giccarelli, 'Il rapporto sacrificio-misericordia nell'A.T., nel Giudaismo e nella letteratura rabbinica', in F. VATTIONI (ed.), Sangue e antropologia nel Medioevo: atti della VIII settimana, Roma, 25-30 novembre 1991, 2 vols. (Rome 1993) 1.305-325, esp. 316320 .

The author analyses the significance of the verb $i \lambda \alpha^{\prime} \sigma \kappa o \mu \alpha \imath$ in Philo, showing that it has a double meaning as 'rendering favourable' and 'expiate'. The theological function of the term is then examined. It relates to the merciful Power of God, one of the five chief powers (p. 318), which has an iconographic-symbolic correspondence to the cover of the Ark described in Fug. 100. The most important conclusion that is drawn from the brief discussion is that Philo brings about a profound spiritualization of sacrifice (p. 320). (RR) 
9317. J. Cohen, The Origins and Evolution of the Moses Nativity Story, Numen Book series 58 (Leiden 1993), 40-46 and passim.

In his treatment of the Moses nativity story in post-biblical sources the author includes a discussion of Philo's description in Mos. He notes that Philo reveals parallels with the haggadic and midrashic traditions. In contrast to the biblical story Philo mentions God's leading role in the events. He not only enlarges on the biblical account, but also alters its structure: the description of the enslavement is placed at the end of the nativity story. Another difference is that he does not mention the basket. These alterations serve to remove difficulties inherent in the biblical text. Review: G. E. Sterling, SPhA 8 (1996) 187-189. (ACG)

9318. N. G. Cohen, 'The Greek Virtues and the Mosaic Laws in Philo: an Elucidation of De Specialibus Legibus IV 133-135', The Studia Philonica Annual 5 (1993) 9-23.

The article shows how the 'philosophical' and the 'Jewish' components of Philo's thought are indissolubly entwined, as illustrated in a discussion of two detailed aspects of Spec. 4.133-135. Firstly, when Philo in this text speaks of the whole family of virtues, he is in fact talking about the practice of Judaism. In line with post-Platonic thought it is simply assumed that philosophy means knowledge that leads to the good life. The list of virtues that he gives

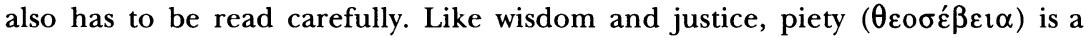
super-virtue that subsumes within it all the other virtues. Secondly, in $§ 134$ Philo alludes to the philosophical topos of the harmony of thoughts, words and actions, which he associates with the triad mouth, heart and hand in LXX Deut. 30:14. This homiletic association precedes Philo himself, as can be shown from an addition made in LXX text. Moreover vestiges of the same association are also discernible in later Rabbinic midrash, where 'philosophical' aspects are filtered out. (DTR)

9319. N. G. Cohen, 'A Response to John W. Martens', The Journal of Jewish Studies 44 (1993) 114-115.

Short comments in answer to Martens' discussion (see 9256) of Cohen's 1987 study (8722), anticipating Cohen's then forthcoming book (see 9520). Philo was a committed Jew whose writings are an integral part of the Palestinian/Diaspora haggadic/halakhic ferment. Martens' criticism is not only mistaken in conception but also misconstrued since Cohen did not write that the $" \theta \eta$ were halakha but that they were 'the forerunner of what later became formalized as the oral law' [Cohen's italics]'. (HMK)

9320. J. Dillon, 'Philo and Middle Platonism: a Response to Runia and Sterling', The Studia Philonica Annual 5 (1993) 151-155.

Brief remarks in response to the papers of Runia (9374) and Sterling (9377) as part of a session of the Philo of Alexandria seminar held in San 
Francisco (on which see SPhA 5 (1993) 95, 246) devoted to the topic of Philo and Middle Platonism. The author agrees with Runia's characterization of Philo as a Platonizing expositor of scripture with a preference for Middle Platonist doctrines. He also finds himself in agreement with Sterling, who sees Philo as a 'pluralist'. He is less content, however, with Runia's positive statements on Goulet's monograph La philosophie de Moise (8743). He doubts whether there was anything like Philo's enterprise before Philo, and thinks that Philo may well have invented the predecessors to whom he refers. (ACG)

9321. P. Ellingworth, The Epistle to the Hebrews: A Commentary on the Greek Text, New International Greek Testament Commentary (Grand Rapids 1993), esp. 45-48.

A short but judicious section is devoted to Philo as part of the discussion of the Epistle's background. 'The author is first and foremost a Christian; secondarily a Christian steeped in the OT; and no doubt in the third place a man affected by linguistic habits and intellectual traditions similar to those which contributed to Philo's development. On this basis both the similarities and the contrasts between Philo and Hebrews can be satisfactorily be explained. (p. 47)' (DTR)

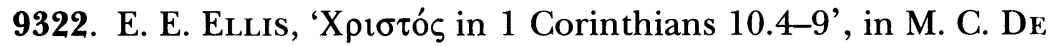
Boe R (ed.) From Jesus to John: Essays on Jesus and New Testament Christology in Honour of Marinus de Jonge, JSNT.S 84 (Sheffield 1993) 168-173.

It is argued that a wisdom Christology is present at 1 Cor. 10.4, 9, where Christ is given a predication and a function that were ascribed in the OT to Yahweh and in pre-Christian Judaism to the divine wisdom. Philo explains the rock in Deut. 8:15-16 as the wisdom of God, and Paul can identify the rock (and thus Christ) as the divine wisdom. He and Paul, though working in different hermeneutic traditions, may be drawing on a common Jewish tradition. (ACG)

9323. C. A. Evans, Word and Glory: on the Exegetical and Theological Background of John's Prologue, JSNT.S 89 (Sheffield 1993), esp. 100114.

There are many parallels between Philo's use of Logos and that in the Prologue of John. The idea of the Logos becoming a human being is not found in Philo. But his identification of the Logos with the 'heavenly man' of Gen. 1:27 may be regarded as a step towards the identification of the Logos with Jesus of Nazareth. Philo's notion of the Logos as intermediary and as angel of the Lord forms a bridge between Logos speculation and the Johannine Prologue. In short 'Philo's biblical exegesis makes explicit certain Wisdom features that constitute the important components in the bridge between Gen. 1-2 and John 1.1-18' (p. 112). (ACG) 
9324. D. Farias, Studi sul pensiero sociale di Filone di Alessandria, Pubblicazioni degli Istituti di Scienze giuridiche, economiche, politiche e sociali della facoltà di giurisprudenza della Università di Messina 180 (Milan 1993).

The fundamental theme of this book is the relationship between social ethics and creation, not so much in its theological or cosmological significance, but in its axiological value, that is to say in its value as gift (p. $11 \& 15$ ). The character of grace attributed to creation is tied to the concept of measure (creation as what is well measured, i.e. in proportion to the capacity of man to accept it) and, more concretely, to the concepts of order and number. But the gift of creation entails two fundamental ideas: the idea of the disproportion between the Giver (God) and the beneficiary (man), and the idea of the reciprocity that exists between men (p. 42). To put the matter more clearly, whereas God alone gives without receiving anything in exchange, which makes Him alone the true Giver, mankind always gives in order to receive something back. Nevertheless on this score Philo does not reduce social relations to a kind of 'illumined utilitarianism' (p. 52), but refers it back to the initial absolutely unconditional gift of creation. In short, the debt that man has incurred to God should be repaid, not to God, who is wholly without needs, but to man's neighbour, thereby giving rise to a firm sense of fellowship both in the spiritual and the material sphere. In such a way, Farias goes on to argue, a solid foundation is given not only to the relationship between creationism and social thought, but also to the typically Philonic concept of natural law. Indeed, according to the Alexandrian a direct connection exists between the physical laws of the cosmos, the embodied laws as represented by the Patriarchs, the revealed laws, and - in the most attenuated form - the enacted legislation of society. All these laws have their foundation in the creative act of God, which is free and has a moral end. This means that in not a single case, not even in the physical world, can these laws be regarded as absolutely determined. The final chapter gives a more integrated treatment of themes which have been developed earlier in the monograph, and especially the theme of brotherhood, which is also conceived in terms of grace. The author emphasizes, however, that this solidarity cannot reach the deeper level of individual responsibility over against God. (RR)

\section{L. H. Feldaman, Jew and Gentile in the Ancient World (Princeton 1993).}

There is no specific section on Philo in this massive treatment of the relation between Jew and Gentile in antiquity written from a firmly orthodox point of view, but he is continually used as an invaluable source of evidence, especially for the situation in the Diaspora and more particularly in Alexandria. See the list of references on pp. 629-30 and the index at p. 657 . REviEw: G. E. Sterling, SPhA 6 (1994) 183-185. (DTR) 
9326. L. H. Feldman, 'Palestinian and Diaspora Judaism in the First Century', in H. Shanks (ed.), Christianity and Rabbinic Judaism: a Parallel History of their Origins and Early Development (Washington 1993) 1-39, 327-336 (notes), esp. 28-39.

Philo is referred to extensively as a source for our knowledge of the religious and cultural background of the Diaspora and its success in the area of proselytism. A special box on pp. 30-31 gives specific details on Philo and cites Smallwood's view that he is a more reliable recorder of events than Josephus. (DTR)

9327. D. Fernandez-Galiano, 'Un monasterio pitagórico: los terapeutas de Alejandría', Gerión 22 (1993) 245-269.

The author argues the thesis that the Monasterion which is described by Philo's De vita contemplativa is not a Christian monastery, as Eusebius believed, nor a Jewish one, as Philo presents it, but a pagan Pythagorean monastery, as may be concluded from a comparison with passages of Porphyry and Iamblichus. The article also includes a summary in Spanish of the contents of Contempl. The article makes no reference to other Philonic works nor to the considerable bibliography on this question. (JPM)

9328. J. Fernandez Lago, La montaña en las Homilias de Origenes, Collectanea Scientifica Compostellana 7 (Santiago de Compostela 1993).

The author frequently adduces Philonic passages and concepts to explain the exegesis of mountains and others topographical termini given by Origen. Philo is considered an important antecedent for methods and contents of the Christian exegete. (JPM)

9329. S. D. FraAde, 'The Turn to Commentary in Ancient Judaism: the Case of Sifre Deuteronomy', in P. Ochs (ed.), The Return to Scripture (New York 1993) 142-171.

Reprint of introductory chapter of 9121.

9330. R. A. J. GaGNon, 'Heart of Wax and a Teaching that Stamps: $\tau \dot{\pi} \pi \circ \varsigma \delta เ \delta \alpha \chi \hat{\eta} \varsigma$ (Rom. 6:17b) once more’, Journal of Biblical Literature 112 (1993) 667-687, esp. 681-687.

The author argues that Philo's extensive use of $\tau$ v́ $\pi$ os imagery can supplement our interpretation of the difficult $\tau \dot{0} \pi \circ \varsigma \delta 1 \delta \alpha \chi \hat{\eta} \varsigma$ in Rom. 6.17b. He notes four points: (1) it is used specifically of the creation of man; (2) imprints are received on the soul when it thinks virtuous or evil thoughts; (3) teaching plays an important role in shaping the imprint and determining how 
deeply it is impressed; (4) the imprint is also affected by one's conduct. On the basis of these observations Gagnon argues that the genitive $\delta 1 \delta \alpha \chi \hat{\eta} \varsigma$ should be taken as one of source, i.e. from teaching. Paul's phrase can be read as agreeing with a core meaning of the term $\tau$ ínos. (ACG)

9331. F. GARcía BAzAn, Plotino sobre la trascendencia divina: sentido $y$ origen, Universidad Nacional de Cuyo (Mendoza 1993).

The author uses Philo frequently as a source for reconstructing the linguistic or philosophical background of Plotinus. García discusses the following themes: the terminology of mysteries (p. 21), the distinction between the nous in movement and the nous in repose (pp. 92-93), the expression $\mu$ óvo $\kappa \alpha i$

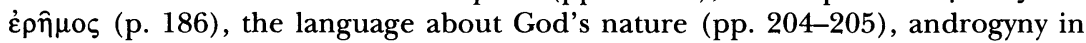

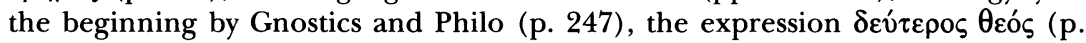
262), and others. Philonic passages are adduced generally to illustrate a biblical philosophy against which the polemic of Plotinus is directed. (JPM)

9332. M. García Cordero, 'El 'Logos' de Filon y el 'Logos' del prólogo al Cuarto evangelio', Ciencia tomista 120 (1993) 209-242, 433461 .

The first part of this study consists of an analysis of the various meanings of Logos and similar expressions in ancient thought. The second part accepts in part the thesis of Loisy about the relationship between the Logos of Philo and that of John, although qualifying it to some degree. (JPM)

9333. A. C. GeLjon, 'De goddelijke Logos bij Philo', Interpretatie 1.8 (1993) 28-29.

Response and critical remarks on the article of Berk summarized above (9310). In Philo, the Logos has the function of a bridge between God in his transcendence and the created universe, but should not be seen as an independent entity. In the author's view, Philo's role as a predecessor of John is rather questionable. (ACG)

9334. I. D. Gilat השבת והלכותיה בכתבי פילון [י. ד. ג'ילת ["The Sabbath and the Halakhah in the Writings of Philo'], Beit Mikra 38 (1993) 216-228.

The central importance of the Sabbath in Philo's writings is brought into conjunction with a range of other views from the literatures of the Second Temple and Rabbinic periods. While Philo's legal (halakhic) outlook would appear to have accorded generally with emergent attitudes in Jewish circles of the period, his perception of the Sabbath's underlying value and rationale was quite unique. In distinction to a common tendency to address the observance of the seventh day as an expression of the special relationship between God and the Jewish people, Philo described the Sabbath as an arena of 
philosophic concerns (contemplation vs. action) and, therefore, as universal in its implications. (DS)

9335. J. Glucker, 'Piety, Dogs and a Platonic Reminiscence: Philo, Quod deterius 54-56 and Plato, Euthyphro 12e-15a', Illinois Classical Studies 18 (1993) [= Studies in Honor of Miroslav Marcovich] 131-138.

Glucker begins by citing the Philonic passage and marking all the allusions to the Platonic dialogue that it contains (15 in all). It is clear that Plato has passed through a serious transformation: the aporetic dialogue is converted into positive theology. After discussing various aspects of Philo's exploitation and alteration of Platonic themes, the author notes that use of this dialogue was rare in antiquity. Did Philo have Plato's text in front of him? Various considerations make this unlikely. It is more probable that he made use of notes that he himself had earlier compiled. The article ends with some interesting personal notes on reading Philo. (DTR)

9336. G. GræSholt, 'Er Filon bare et sidespor? [In Danish, = Is Philo just a side-track?]', Dansk Teologisk Tidskrift 56 (1993) 19-34.

The article contains two parts, followed by a summary in English. Firstly the study Judaism and Antiquity (Sheffield 1990, Danish edition 1984) by B. Otzen is criticized for not taking Philo seriously as a representative of Diaspora Judaism. Secondly a picture of Alexandrian Judaism based on Philo is presented, making basically the same points as the author's article 'Philo of Alexandria: Some Typical Traits of his Jewish Identity' (9236). Less emphasis is placed, however, on 'Philo's racism'. (KGS)

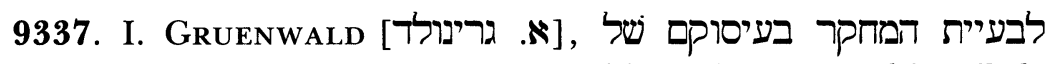
ח'Methodological Problems in Researching Rabbinic Mysticism'], in I. GafNi, A. Oppenheimer and M. STERN (edd.), Jews and Judaism in the Second Temple, Mishna and Talmud Period. Studies in Honor of Shmuel Safrai (Jerusalem 1993) 297-315.

This wide-ranging article addresses central questions in the determination of the nature and extent of early rabbinic mysticism: particularly, the complex nature of the relationship, historical and phenomenological, between mystical speculation and legal reasoning. By way of conclusion (pp. 313-314), the author distinguishes decisively between the mystical thought of Philo - whether understood in the extreme terms framed by Goodenough or according to the more controlled formulation of Winston and the 'merkabah-mysticism' current among first and second century rabbinic figures. (DS)

9338. V. Guignard, Le rapport d'Israel à l'histoire dans l'œuvre de Philon d'Alexandrie (D.E.A. d'histoire ancienne, Poitiers 1993). 
Philo's attitude towards history is tinged with scepticism, especially with regard to the prediction of the future, which explains his lack of interest in the messianic future. This means that there is no other source of earthly salvation in the immediate future than the protection of Rome. Philo's utter confidence in the particular solicitude of Providence for the Jews, as well as the certitude derived therefrom that the chosen people have a special place in history, are based on his faith and not in speculations about the future. (DTR, based on summary by author).

9339. F. Hahn, 'Die Gestalt Abrahams in der Sicht Philos', in F. Hahn, F.-L. Hossfeld, H. Jorissen and A. Neuwirth (edd.), Zion: Ort der Bewegung. Festschrift für L. Klein zur Vollendung des 65. Lebensjahres, Bonner Biblische Beiträge 90 (Bodenheim 1993) 203215.

Starting from the question how far the monotheistic oecumene of Jews, Christians and Muslims has its foundation in Abraham, Hahn concentrates on Philo's portrait of Abraham in his De Abrahamo. He summarizes its content and points out that according to Philo every person has the opportunity to acquire virtue and knowledge of God, as exemplified by Abraham, since there is no real distinction between piety of the Patriarchs and the piety of the Torah of Moses. (DZ)

9340. M. Harl, 'La Bible d'Alexandrie et les études sur la Septante: réflexions sur une première expérience', Vigiliae Christianae 47 (1993) 313-340, esp. 330-334.

Brief but important remarks about the place of Philonic exegesis in the context of the commentaries on the Septuagint published in the ambitious French research project 'La Bible d'Alexandrie'. (DTR)

9341. T. K. Heckel, Der Innere Mensch: Die paulinische Verarbeitung eines platonischen Motivs, WUNT 2. Reihe 53 (Tübingen 1993), esp. $42-76$.

2 Corinthians 4:16 speaks of the 'inner' and 'outer human being'. After a survey of the research done on the meaning and origin of this metaphor (Chap. I) the author discusses its first occurrence, viz. in Plato, Rep. IX, 588-589 (Chap. II). The third chapter, starting with a section on Middle Platonism as a historical phenomenon in general, presents an elaborate discussion of the 'inner human' in Philo (Chap. III $\S \S 2-3$ ) as well as in 4 Maccabees, the Corpus Hermeticum and the Nag Hammadi codices; the remaining three chapters of the book deal with the metaphor in 2 Cor., Romans 7 and other New Testament writings (with a brief discussion of its later history and meaning). The section on Philo (starting with a general introduction to the man and his work) explores the motive of the 'inner human being' as it occurs more than twelve times in the context of Philo's interpretations of various biblical 
passages, and exposes the similarities and differences with the Platonic usage. In an evaluation of Philo's own contribution and his dependence on traditions, Heckel draws some general conclusions. He discerns in Philo a 'half victory' of Plato over the Torah, and a 'hidden victory' of the Torah over Plato; he objects against the practice of calling Philo a Middle Platonist, but does position him in the Entstehungsbereich (area of origin) of Middle Platonism. Review: D. Zeller, SPhA 6 (1994) 203-206. (HMK)

9342. M. Himmelfarb, Ascent to Heaven in Jewish and Christian Apocalypses (Oxford 1993).

The main emphasis of this book is on Jewish and Christian apocalypses involving ascent to heaven, but it includes a number of important references to Philo, who plays an important comparative role; see pp. 43-44, 48-49, 70-71, 85. (DTR)

9343. H. W. Hollander and J. W. Holleman, 'The Relationship of Death, Sin and Law in 1 Cor. 15:56', Novum Testamentum 35 (1993) 270-291, esp. 275-278, 286.

In connecting mortality with the sin of the first man Adam, Paul shows familiarity with Jewish traditions, not only in apocalyptic authors, but also in Philo, as shown in quotations from Opif. and $Q G$ 1. (DTR)

9344. P. W. van der Horst, 'Philo van Alexandrië over de toorn Gods', in Ab DE JoNG and Aleid DE JoNG (edd.), Kleine Encyclopedie van de Toorn, Utrechtse Theologische Reeks 21 (Utrecht 1993) 77-82; reprinted in IDEM, Mozes, Plato, Jezus: Studies over de wereld van het vroege christendom (Amsterdam 2000) 59-64.

God's anger is mentioned many times in the OT. The Greek philosophers, however, following Plato, are convinced that God is without passions and feelings, and so cannot feel anger. The author considers how Philo, as both an exegete and a philosopher, deals with the texts from the OT in which the divine anger is mentioned. Philo clearly states that God is not acquainted with any form of passion. He explains these texts by means of the principle later called synkatabasis. Moses adapts his writing to the level of his readers. To speak of God as a man is not in accordance with the truth, but has a didactic aim. There are people who cannot conceive of God in any other way. This idea of synkatabasis is also found in Clement and Origen. (ACG)

9345. P. W. van DER Horst, 'Thou shalt not Revile the Gods': the LXX Translation of Ex. 22:28 (27), its Background and Influence', The Studia Philonica Annual 5 (1993) 1-8.

One of the many riddles of the LXX is the change from singular to plural in the text of Ex. 22:28. Philo is the first author where we can see the biblical 
passage at work. Three texts are discussed: Spec. 1.53, Mos. 2.203ff., $Q E$ 2.5. The general tendency of his interpretation is positive and apologetic in intent, e.g. that the commandment was given so that Jews would not revile other gods and God would not be reviled by non-Jews in return. This positive interpretation differs from later Patristic exegeses. The article is an English version of 9245. (DTR)

9346. U. JAITNER-HAHner, Humanismus im Umbrien und Rom. Lilius Tifernas, Kanzler und Gelehrter des Quattrocento, 2 vols., Saecula Spiritalia 25 (Baden-Baden 1993), esp. 332-404.

This monograph on the 15 th century humanist contains a lengthy chapter on his translations and commentaries on Philo (on these see G-G 330-334). The author describes the manuscripts that were used, Lilius' translation technique (verbum ad verbum) and discusses his prologues, which in the second volume are printed in the original Latin. These reveal the motives for Christian interest in Philo. Lilius regards him as a herald of the Divine Word and his activity in the history of salvation from the incarnation until his return. (DZ)

9347. A. Kamesar, Jerome, Greek Scholarship, and the Hebrew Bible: a Study of the Quaestiones Hebraicae in Genesim, Oxford Classical Monographs (Oxford 1993).

This book contains frequent references to Philo and especially his Quaestiones, as is only to be expected in a study concentrating on Jerome's Quaestiones Hebraicae in Genesim, even though the author affirms (p. 93) that in contrast to the works of Philo..., it is not the commentary form that has intruded in $Q H G$, but another form of exegesis, that is termed excerpta or scholia'. (DTR)

9348. P. Kingsley, 'Empedocles in Armenian', Revue des Etudes Armeniennes 24 (1993) 47-57.

The author examines three passages in Philo's account of Empedocles' philosophy at Prov. 2.60. In so doing he illustrates a number of technical translation problems that an editor or commentator needs to be aware of. $\mathrm{He}$ also emphasizes how important it is to take into account literary and stylistic aspects, not only of Philo but also of the earlier Greek writers to which he refers. It is argued that the final passage involves a 'pious corruption', for which radical emendation is required. (DTR)

9349. T. E. KNight, 'The Use of Aletheia for the 'Truth of Unreason': Plato, the Septuagint, and Philo', American Journal of Philology 114 (1993) 581-609.

The author argues that Philo's notion of truth is not a natural semantic extension of Platonic usage, but is determined culturally. For Plato, truth is a 
property of the objects of knowledge. The grasping of this property takes place in a pluralistic, dialectical, and competitive context. Philo, on the other hand, regards truth as the content of belief, which comes about by conviction, rather than persuasion, as Plato. It is no longer the result of pluralistic discourse in an open society. This understanding of the notion of truth is determined by the way it is used in the LXX. (ACG)

9350. C. Kraus Reggiani, 'L'uso della Scrittura in Filone di Alessandria', in H. Merklein, K. Müller and G. STEMBerger (edd.), Bibel in jüdischer und christlicher Tradition: Festschrift für Johann Maier zum 60. Geburtstag, Bonner Biblische Beiträge (Bonn 1993) 177-191.

In order to deal with the subject indicated in her title, Kraus Reggiani dwells on three points: (1) the nature of the Septuagint text used by Philo (p. 177ff.); (2) the choice of the Pentateuch as fundamental reference point for his thought (pp. 181ff.); the character and form of his allegorical practice (p. 183ff.). This last point is dealt with at slightly greater length and reaches the following conclusions: (a) Philo's thought is always developed with reference to the Bible; (b) his purpose is almost always exegetical in the allegorical-philosophical sense, even if (c) he does not do away with the literal meaning of the biblical text; finally (d) the philosophical results of the interpretation of the Sacred Text, which have substantially Platonic character, are of a metaphysical-ontological nature, but ultimately have an ethicalreligious purpose (p. 190f.). (RR)

\section{L. Kreitzer, '1 Corinthians 10:4 and Philo's Flinty Rock', Communio Viatorum 35 (1993) 109-126.}

In his discussion of 1 Cor. 10:4c, where Paul identifies the rock of Horeb with Christ, the author pays attention to the Philonic background. In Leg. 2.86

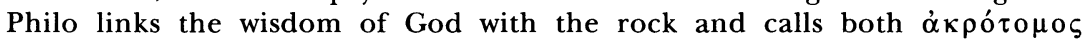
(flinty). The connection of 'rock' with 'flinty' occurs in the LXX and Philo is

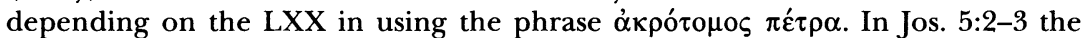
word 'flinty' is used in connection with the knives used for circumcision in a context that is a call for a New Covenant. This New Covenant context has several significant links with Paul, the Epistle to the Hebrews, and Justin Martyr. (ACG)

9352. D. B. Levine, 'Hubris in Josephus' Jewish Antiquities 1-4', Hebrew Union College Annual 64 (1993) 51-87.

Throughout this paper, Josephus' use of the term hubris ('outrageous behaviour') is compared with that of Philo (Philo being repeatedly quoted). The author concludes that both Philo and Josephus appear to be influenced directly by their classical education in their use of hubris and related words. Josephus associates hubris with illicit sexuality in much the same way as Philo does (but more frequently). It seems that both used hubris terminology in an apologetic 
way, e.g. in the context of countering charges of Jewish sexual impropriety. Philo as well as Josephus made free use of this classical Greek term in order to reach his readers more easily. (HMK)

9353. D. LindSAy, Josephus and Faith: 'Pistis' and 'Pisteuein' as Faith Terminology in the Writings of Flavius Josephus and the New Testament, ALGHJ 19 (Leiden 1993), esp. 53-73.

In spite of the title this study has an entire chapter devoted to Philo's use of the terminology of $\pi i ́ \sigma \tau \varsigma$ and $\pi \imath \sigma \tau \varepsilon v i \varepsilon v$. Lindsay follows A. Schlatter in analysing the various usages of the term $\pi i \tau^{\prime} \downarrow \varsigma$ into four categories: (a) as pledge, security, proof; (b) as faithfulness in the execution of a charge; (c) as faith, trust (here Gen. 15:6 plays a crucial role); (d) conviction, belief. The verb $\pi \imath \sigma \tau \varepsilon v \varepsilon \imath v$ is used in credal formulas, but most of all in the expression $\pi \imath \tau \tau \varepsilon v \varepsilon \varepsilon v \theta \varepsilon \hat{\omega}$. Because Philo is strongly influenced by Greek conceptuality and philosophical thought, his understanding of faith differs from that of the Bible, both in the LXX and in the NT. The author thus sees his use of faith terminology as an excellent example of his tendency to synthesize Jewish and Greek thought. At the same time it should be recognized that his expansion of the use of the two words, especially in the direction of credal faith, has opened the possibility of new developments in other directions. Review: D. M. Hay, SPhA 6 (1994) 216-219. (DTR)

9354. H. LöHR, „Umriss” und „Schatten”: Bemerkungen zur Zitierung von Ex 25,40 in Hebr 8', Zeitschrift für die neutestamentliche Wissenschaft 84 (1993) 218-232.

The addition of panta in the quotation of Ex. 25:40 in Hebr. 8:5 has an interesting parallel in Philo, Leg. 3.102. This passage (cf. its parallels in Plant. 27, Somn. 1.206) has in common with Hebrews not only the idea of an archetype and its copy, but also the contrast between a creator and an artisan of the sanctuary. This points to a connection in history of tradition, the more so since Leg. 3.103 quotes Num. 12:7 which Hebr. 3:5 uses in a similar context. (DZ)

9355. H. E. Lona, Über die Auferstehung des Fleisches: Studien zur frühchristlichen Eschatologie, Beihefte zur Zeitschrift für die neutestamentliche Wissenschaft 66 (Berlin-New York 1993), esp. 99-103.

Retracing the use of the theme of the resurrection of the flesh in Christian authors of the 2nd and 3rd cent. CE, Lona finds the philosophical background of Justin's argument on the immortality of the soul at Dial. 5.46.2 in Philo; similarities in Justin's exegesis of Gen. 2:7 and interpretation of Plato's Timaeus are pointed out. (DZ)

9356. J. P. MARTín, 'Metáfora y metonimia para nombrar a Dios. Otra lectura de Filón', Epimeleia (Buenos Aires) 2.4 (1993) 153-167. 
Allegory has been considered as an expansion of metaphor. But in many cases, Philonic allegory is in fact a reduction in the sense of metonymy, not of metaphor. From a linguistic point of view, the case of radical metonymy is the interpretation of the name of God as 'Who is'. The author concludes that the allegorical practice of Philo is a system that combines metaphorical and metonymical processes. (JPM)

9357. J. P. Martín, 'Metáfora y Alegoría', Escritos de Filosofía (Buenos Aires) 23-24 (1993) 149-167.

The author attempts to develop a connection between two themes: on the one hand, allegory has been considered generally as a type of metaphor; on the other hand, there is a large tradition that resorts to allegory as a method of knowledge. Philo is taken as a typical representative of this latter tradition. It is argued that the practice of allegory as a method of knowledge must be placed in an intermediate zone between poetics and speculative discourse, according to the distinction brought by $\mathrm{P}$. Ricoeur, and that this zone is situated in the field of rhetoric. (JPM)

9358. G. MAYer, 'Die herrscherliche Titulatur Gottes bei Philo von Alexandrien', in D.-A. Koch and H. Lichtenberger (edd.), Begegnungen zwischen Christentum und Judentum in Antike und Mittelalter: Festschrift für Heinz Schreckenberg, Schriften des Institutum Judaicum Delitzschianum 1 (Göttingen 1993) 293-302.

Since in New Testament research on God's Kingdom Philonic evidence is often disregarded, Mayer inquires into the word group $\beta \alpha \sigma \imath \lambda \varepsilon v_{\varsigma}$ and its equivalents. God's monarchy is manifested in the creation and preservation of the world. Nevertheless, in his intervention Philo distinguishes God's royal power from the preceding creative power (table 1 with the corresponding names кúpios and $\theta \varepsilon$ ćs). God descends into the soul, his palace. On the other hand, there is a 'royal way' from below to God, the King. Table 2 shows the competition between $\dot{\eta} \gamma \varepsilon \mu \omega \dot{v}$ and $\beta \alpha \sigma \imath \lambda \varepsilon v$ s. After a paragraph on the origin of these concepts, both in Hellenistic philosophy and in Jewish tradition (table 3), Mayer concludes with remarks on their symbolic meaning: in spite of God's unknowable essence, the language of his Kingship is required to confront him with man in demand and care. The result, that Philo places the emphasis on ethics, seems somewhat awkward, since the preceding proves only that his use is not eschatological. Mayer was unable to take into consideration the essay of M. Umemoto (see 9189). (DZ)

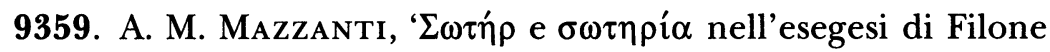
di Alessandria', Annali di Storia dell'Esegesi 10 (1993) 355-366.

Adhering faithfully to the texts, Mazzanti first considers the significance of the two terms $\sigma \omega \tau \eta \dot{\eta} \rho$ and $\sigma \omega \tau \eta \rho i \alpha$ in relation to God, then examines them in the context of the divine reality (powers, angels etc.), and finally studies them in relation to human reality (ethics and anthropology). The salvific 
intervention of the divine - also in the context of sacrificial ritual - is rather well developed and involves both the psychic sphere (liberation from evil) and the bodily sphere (preservation of life). As far as the anthropological aspect is concerned, the author emphasizes the prevalence of a dualistic conception that is not easily reconcilable with the biblical view. (RR)

9360. W. B. McNeil, Homeric Poetry in Philo of Alexandria (M.A. thesis, Miami University 1993).

We have not been able to gain access to a summary of this thesis. (DTR)

9361. W. A. MeEks, The Origins of Christian Morality (New Haven 1993), esp. 29-31.

In the context of a chapter entitled 'Turning: moral consequences of conversion', the author discusses some passages from Philo's Virt. on conversion. These provide a useful point of comparison with early Christian texts. Various analogies are observed. In both, 'conversion is described as the transformation both of a way of thinking and of a form of life, as a change of allegiance from many false gods to the one true God, as a radical resocialization' (p. 30). (ACG)

9362. R. NASH, 'Was the New Testament Influenced by Pagan Philosophy?', Christian Research Journal 16 (1993) 16-19, 35-38.

Nash argues that none of the essential beliefs in the New Testament were borrowed from pagan philosophy. He focuses upon Platonism, Stoicism, and Philo as alleged sources for NT beliefs and emphasizes the differences between these sources and ideas in the NT. Although some scholars contend that Philo's Logos concept influenced ideas in the Gospel of John and the Book of Hebrews, Nash lists several important differences, contrasting, e.g., Philo's belief in the Logos as a metaphysical abstraction and his disparagement of the body with the Christian belief in a specific, historical messiah and the doctrine of Incarnation. Further details can be found in Nash's book The Gospel and the Greeks (9262). (EB)

9363. F. Petit, La Châ̂ne sur la Genèse: Édition intégrale II, chapitres 4 à 11, Traditio Exegetica Graeca 2 (Louvain 1993) passim.

Philo's Quaestiones in Genesim are once again an important source for the Catena in Genesim, which is being reconstructed by the author. Of the 395 exegetical excerpts included in this volume, 20 can be attributed to Philo, as usefully listed on p. 248. Cf. 9264 (vol. 1) and 9563 (vol. 3). (DTR)

9364. J. Rackman, 'Philo of Alexandria', Jewish Spectator 58 (Winter 1993-94) 26-28. 
This brief profile summarizes Philo's work and life, giving examples of his allegorical interpretations and describing his participation in the delegation to Gaius. Rackman emphasizes Philo's Alexandrian and Greek background, citing the renown of the Alexandrian synagogue. He also notes with irony that while Alexandrian Jews annually celebrated the translation of the Hebrew Bible into Greek, Jews in the homeland annually celebrated Chanukah, commemorating the rebellion against Greek political and cultural domination. 'The greatest Jewish writer to adapt Greek thought', Philo was ignored by Jews for centuries because his allegorical approach was not popular, he wrote in Greek, he was unfamiliar with Rabbinic interpretations, and perhaps because he was so greatly admired by the Church. Only in the nineteenth and twentieth centuries have Jews, grappling with modernity, re-discovered Philo who had himself grappled with 'the modernity of his time'. (EB)

9365. R. Radice, 'Didaskalikos 164, 29-30 e la probabile influenze di Filone di Alessandria', Archivio di Filosofia 61 (1993) 45-63.

In the metaphysical doctrine of Plato expounded by Alcinous in the Didaskalikos it is possible to identify a contradiction between the doctrine of three principles (God, matter, Ideas) and the doctrine of the Ideas as thoughts of God. In effect if the Ideas are thought up by God, then there will not be three principles, but only two. The contradiction is resolved if the Ideas are meant not as created, but simply as placed in the mind of God. This position could be the fruit of the mediation between the current of Platonism influenced by Philo and the current which is properly Academic. (RR)

9366. J. Rebolle Barrera, La Biblia Judía y la Biblia Cristiana. Introducción a la historia de la Biblia (Madrid 1993), esp. 240-244, 495499.

Briefly adduces Philonic passages to show the reception of the Bible in the Diaspora and Philo's influence on Christian exegesis. (JPM)

9367. A. Reinhartz, 'Parents and Children: a Philonic Perspective', in S. J. D. Cohen (ed.), The Jewish Family, BJS 289 (Atlanta 1993) 61-88.

The author discusses the relationship between children and their parents as described in Philo's Exposition of the law. She deals with four aspects in particular: (1) The hierarchical structure of the parent-child relationship, which is an expression of the dualistic view of human society. (2) Parents' responsibilities towards their children, which consists of bringing children into the world and nurturing them. Moreover, parents should give their children financial support, and instruction or education. They are also obliged to exercise discipline over them. (3) Responsibilities of children towards their parents, as expressed in obedience, fear, courtesy and care for them in their old age. Here Philo bases himself mainly on the fifth 
commandment. (4) Family affection. In her conclusion the author notes three fundamental characteristics of the parent-child relationship: the presence of an indissoluble bound of love and kinship between parent and child; the inherent superiority of the parent to the child; the hierarchy of male and female. (ACG)

9368. A. Reinhartz, 'Philo's Exposition of the Law and Social History: Methodological Considerations', in E. H. Lovering, JR. (ed.), Society of Biblical Literature 1993 Seminar Papers, SBLSPS 32 (Atlanta 1993) 6-21.

Philo's Exposition of the Law contains a great deal of socio-historical material pertaining to family life. Is it possible to exploit this material for our understanding of contemporary Alexandria? Reinhartz examines the methodological problems involved in this exercise. She identifies four exegetical moves that Philo generally makes in commenting on the biblical text: (a) providing a rationale for biblical law when none is given in the Bible itself; (b) extending the laws to other analogous situations; (c) reinterpreting laws that pertain to social conditions no longer operative in his milieu; (d) providing specific instructions when biblical has only a general formulation. The author concludes that it is easier to reconstruct Philo's own Jewish family values than the actual contours of Jewish family life. But if one moves with caution it is possible to derive information on the Jewish family in Alexandria, which then needs to be corroborated or corrected by information derived from elsewhere. This result is important for topics such as adultery, death of fathers of unmarried daughters, the exposure of infants and so on. (DTR)

9369. G. P. Richardson, 'Philo and Eusebius on Monasteries and Monasticism: the Therapeutae and Kellia', in B. McLean (ed.), Origins and Method: Towards a New Understanding of Judaism and Christianity. Essays in Honour of John C. Hurd, JSNT.S 86 (Sheffield 1993) 334-359.

Eusebius' identification of the Therapeutae with first-century Christians in his Ecclesiastical History provides valuable information about the state of Christian monasticism in his own day (end of the 3rd century). There are in fact striking resemblances between Philo's description of the buildings of the Therapeutae community and the extensive remains of Christian monasteries in the Kellia, a site about $60 \mathrm{~km}$ from Alexandria and only a short distance from the Jewish site. The author demonstrates these by means of analysis of Philo's text and drawings of archaeological remains. Eusebius, who had visited Egypt, may have observed these similarities and so developed his erroneous theory. This remains uncertain, but what is clear is 'that there is an unusually close similarity between a first-century form of Jewish monasticism and a fourth-century form of Christian monasticism' (p. 357). The author also notes that Philo's description of a wall dividing the sexes in the 
meeting-house is unique in ancient evidence, and speculates about possible influence on the design of later synagogues as well as Christian monasteries. (DTR)

9370. C. RIEDWEG, Jüdisch-hellenistische Imitation eines orphischen Hieros Logos: Beobachtungen zu OF 245 und 247 (sog. Testament des Orpheus), Classica Monacensia 7 (Tübingen 1993) passim.

Riedweg first establishes an new history of tradition of the so-called 'Testament of Orpheus' with only two independent recensions (the original version accessible via Ps-Justin De monarchia, and the Jewish redaction of Aristobulus). The presentation of the corresponding texts with translation and critical notes is followed by an interpretation which settles the questions of genre, authorship, philosophical background and epic language. The Jewish redactor, probably Aristobulus himself, contributed Platonic-Aristotelian ideas on God. Relevant Philonic material is cited throughout. REview: N. Walter, SPhA 8 (1996) 177-185. (DZ)

9371. D. T. Runia, Bios eudaimoon (inaugural lecture, Leiden 1993), esp. 4-5.

The starting point of the oration is the fact that Philo ends his De opificio mundi and at least five other texts with the theme of eudaimonia (well-being). This turns out to be a characteristic of many Greek, Latin and Patristic works, going back at least as far as Plato, and has a protreptic origin. (DTR)

9372. D. T. Runia, 'God of the Philosophers, God of the Patriarchs: Exegetical Backgrounds in Philo of Alexandria', in F. J. Hoogewoud and R. Munk (edd.), Joodse Filosofie tussen Rede en Traditie: Feestbundel ter ere van de tachtigste verjaardag van Prof. $d r . H . J$. Heering (Kampen 1993) 13-23.

The antithesis between God of the philosophers and God of the patriarchs, made famous in the Mémorial of Pascal, is already found in a different form in Judah Halevi. The article shows that this theme has an anterior exegetical basis which goes all the way back to Philo. Three Philonic passages are discussed, Mos. 1.74-76, Abr. 50-52, Mut. 7-14, and some comments are given on his interpretation. In Philo's case a distinction is made based on Ex. 3:14-15, but there is no antithesis such as we find in Pascal. If there is a connection between the two authors, Augustine may have been the intermediary. (DTR)

9373. D. T. Runia, Philo in Early Christian Literature: a Survey, Compendia Rerum Iudaicarum ad Novum Testamentum III 3 (AssenMinneapolis 1993).

This monograph contains the first comprehensive examination of the reception of Philo's writings and thought in Early Christian literature. The 
cut-off point is $400 \mathrm{CE}$ (Isidore of Pelusium, Augustine), although some pointers to later developments are also given. The book is divided into four parts. The first part commences with a chapter on the legend of Philo Christianus, Philo's fate in the Jewish and pagan traditions and the fascinating story of the transmission of his writings. There follows a chapter stating the book's purpose and method and a chapter giving a status quaestionis. In the second part the Greek-speaking Christian authors are dealt with in chapters on the New Testament, the Apologists, Alexandria before Clement, Clement, Origen, the later Alexandrian tradition, Eusebius and the Cappadocians. The Latin fathers are treated in Part III, with chapters on Beginnings in the West, Ambrose, and Other Latin authors (including Jerome and Augustine). The fourth part is entitled Epilogue and reaches a number of conclusions, including suggestions for further research. In his treatment the author generally takes as his starting-point those passages in which Philo is named. This places the research on a sure footing. An appendix gives a complete list of such passages up to $1000 \mathrm{CE}$. Because of the vastness of the subject, the author makes extensive use of existing scholarship (hence the sub-title of the book), but also adds the results of his own research. See further the comments by A. Terian (9471), A. van den Hoek (9430), R. L. Wilken (9477), and D. Winston (9479). Reviews: M. J. Edwards, CR 44 (1994) 317-318; L. L. Grabbe, IOUDAIOS 4 (1994) nr. 19; A. Hilhorst, JSJ 25 (1994) 330-333; N. R. M. de Lange, BJGS 14 (1994) 17-18; P. McKechnie, Prudentia 26 (1994) 71-73; G. A. Anderson, RelStR 21 (1995) 55; H. W. Attridge, JAAR 115 (1995) 713-714; R. A. Bitter, Mnem 48 (1995) 97-101; R. M. Grant, JR 75 (1995) 274-275; A. Kerkeslager, BMCR 6 (1995) 57-61; R. Radice, Elen 16 (1995) 410-415; C. Riedweg, JThS 46 (1995) 691694; P. W. Flint, JECS 4 (1996) 587-590; D. M. Hay, Interpr 50 (1996) 208; E. Krentz, CurrThM 23 (1996) 58-59; E. Nodet, RB 103 (1996) 310-311; J. W. Trigg, ChH 65 (1996) 252-254. (DTR)

\section{D. T. Runia, 'Was Philo a Middle Platonist? a Difficult Question Revisited', The Studia Philonica Annual5 (1993) 112-140.}

This paper, part of the San Francisco seminar on Philo and Middle Platonism (see 9320), is divided into two main parts. In the first the author looks back on his dissertation on Philo and Plato's Timaeus, considers developments since then and examines a number of questions that have been raised in critiques and reviews of the book. In the second part he returns to the question of whether Philo can and should be dubbed a Middle Platonist. First a typology of six different positions on the issue is presented. Then a number of clarificatory issues are discussed: (1) the question of loyalty; (2) scripture and the status of the scriptural commentary; (3) self-definition versus historical perspective; (4) the question of eclecticism. Runia then presents two case studies, one historical (the parallel figure Chaeremon the Egyptian and Stoic), one doctrinal (the question of God's relation to the Ideas). The upshot is that the author persists in his view that Philo should not be regarded as a Middle Platonist in the strict sense, even though Platonism patently exercised a strong influence on his thought. (DTR) 
9375. M. Simonetti, 'L'allegoria in Celso, Filone e Origene', in R. Pretagostini (ed.), Tradizione e innovazione nella cultura greca da Omero all'età ellenistica: scritti in onore di Bruno Gentili, 3 vols. (Rome 1993) 1129-41.

The author discusses the evolution of the term 'allegory' in pagan philosophy and in Jewish philosophy (Philo). For the pagans, e.g. Celsus, allegorical exegesis as applied to myths and fables wholly replaces the significance of the original text. In the case of Philo, however, the text dealt with, i.e. the Old Testament, is not cancelled out, but rather its understanding is deepened in the process of allegorical interpretation. The reason for this difference is clear: the Bible is a sacred text, intrinsically worthy of faith. (RR)

9376. R. SorabJI, Animal Minds and Human Morals: the Origins of the Western Debate (Ithaca-London 1993) passim.

Frequent references to Philo's De animalibus are given in this wideranging and thought-provoking analysis of the history of philosophical debate on the status of animals. See esp. p. 161 and indices on p. 245, 262. (DTR)

9377. G. E. Sterling, 'Platonizing Moses: Philo and Middle Platonism', The Studia Philonica Annual 5 (1993) 96-111.

Paper presented in the context of the SBL Philo Seminar (see 9320). It argues that Philo's marriage of Jewish scripture and Greek philosophy through allegorical exegesis is an example of the effort to bridge East and West within the philosophical tradition. For Philo Platonism and Judaism are similar at the most essential point, namely the understanding of God. The author regards Philo's position as 'pluralistic', i.e. he is convinced of the validity of both Platonism and of Judaism. Comparable positions are taken up by Chaeremon of Alexandria, Plutarch, and Numenius, to each of whom brief discussions are devoted. The article concludes with some words on the question of Philo's Middle Platonism. 'Philo's Moses was not a Hebrew Moses; he was a Middle Platonist. It is from this perspective that I think we can speak of Philo as representative of Middle Platonism (p. 111).' (ACG)

9378. H. TARRANT, Thrasyllan Platonism, (Ithaca-London 1993), esp. 109-117.

The author argues that the epistemological passage in Porphyry Harm. 1214 Düring goes back to Thrasyllus, and that its logos doctrine shows important resemblances to that of his contemporary Philo, which in turn suggests that much of Philo's logos theory 'will have evolved directly from his secular environment' (p. 116). (DTR) 
9379. A. Terian, 'Two Unusual Uses of $a \dot{r} n$ in the Armenian Version of Philo's Quaestiones', Annual of Armenian Linguistics 14 (1993) 49-54.

An unusual derivation of a participial noun form, namely $a \dot{r} n$, is used at two places in the Armenian translation of Philo, at $Q G 1.27$ and $Q E 1.1$. According to Terian, at both places it is a derivation from arnal. In the case of the former passage the Armenian can be checked against the surviving Greek fragment. Marcus' emendation in the second passage cannot be maintained. (ACG)

9380. T. H. Товin S.J., 'Was Philo a Middle Platonist? Some Suggestions', The Studia Philonica Annual 5 (1993) 147-150.

Brief response to the papers of Sterling and Runia in the context of the SBL Philo Seminar (see above, 9320). It is important to recognize, Tobin emphasizes, that Philo comes early in the history of Middle Platonism. The question of Philo's hairesis may be elucidated by the distinction between 'emic' and 'etic' analysis. (DTR)

9381. P. J. Tomson, 'Voor één dag genoeg' (Matt 6:34): het brood, het Woord en de wetenschap, In Caritate 3 (inaugural address, Brussels 1993), esp. 11-18.

As part of general exploration of the Jewish background to the logion in the Sermon on the Mount a comparison is made between the Rabbinic Midrash and Philo. In both cases the motif of the gift of heavenly manna in Exodus is fundamental. The contrast between the spiritual realm and that of confused everyday experience is of course Platonic, but was also widespread in Jewish thought. Tomson prefers to speak of convergence between Platonism and Judaism rather than (in most cases) direct influence. He further notes important parallels between Philo and the Rabbis in relation to the theme of spiritual food and ends his section on Philo with some remarks on the translation of this theme into the ideal of scientific and philosophical knowledge, as espoused in our century by Albert Einstein. (DTR)

9382. H. Tronier, 'Virkeligheden som fortolkningsresultat: om hermeneutik hos Filon og Paulus [In Danish $=$ Reality as a result of interpretation: on hermeneutics in Philo and Paul]', in M. Müller and J. Strange (edd.), Det gamle Testamente $i$ jødedom og kristendom, Forum for Bibelsk Eksegese 4 (Copenhagen 1993) 151182, esp. 153-164.

Philo's and Paul's hermeneutical methods are compared and contrasted. Philo's allegories are based on a Platonic method consisting in a diairesis of concepts as exemplified by an analysis of De migratione Abrahami. In the 
Scriptures Philo by means of a deductive method looks for a hierarchy in which the concrete Scriptural concepts and events form manifestations of higher concepts in the transcendental sphere. The latter is not understood in spatial but in logical terms. According to Philo the rationality, i.e. real meaning of different events told in the Scriptures, is localized in those aspects which unite them as manifestations of transcendental concepts. The migration of Abraham from Haran to Canaan in reality means the migration from the body and its sense-perception to the noetic vision and thus conveys the same philosophical idea as for instance the Exodus of Israel from Egypt. The correct understanding of the rational structure of the Scriptural events corresponds to a transformation of the mind of the interpreter, who in the Scriptures will detect a reality which is familiar to him and is identical with his own noetic experience. (KGS)

9383. W. C. VAN Unnik, Das Selbstverständnis der jüdischen Diaspora in der hellenistisch-römischen Zeit, aus dem Nachlaß herausgegeben und bearbeitet von P. W. VAN DER Horst, AGJU 17 (Leiden 1993), esp. 127-137.

The text of these lectures held in 1967 in Jerusalem is supplemented by P. W. van der Horst with notes, a biography of the author and list of his publications and two appendices. Van Unnik investigates the evaluation that Jews - especially Greek speaking Jews - connected with the term 'diaspora'. He contests the wide-spread optimistic interpretation of the term and makes it clear that from the use of the noun and the verb in ancient literature, in the LXX and in Jewish writings of Hellenistic and Roman times an unfavourable meaning prevails. The 'dispersion' does not in the first place signify a geographic fact, but is the result of divine anger which brings the nation close to dissolution. Philo, discussed on pp. 127-137, dissimulates this biblical interpretation somewhat, but in Praem. 164f. he too echoes the Jewish hope for return and restoration. Like Josephus (pp. 137-147) he never uses the noun 'diaspora' to describe the situation of the Jewish people. The reason for this is apologetic. Review: F. Siegert, SPhA 6 (1994) 192-199. (DZ)

9384. S.-K. WAN, 'Philo's Quaestiones et Solutiones in Genesim: a Synoptic Approach', in E. H. Lovering, JR. (ed.), Society of Biblical Literature 1993 Seminar Papers, SBLSPS 32 (Atlanta 1993) 22-53.

The paper is divided into two halves. In the first Wan discusses the history of the zetematic genre, which is shown to have three general characteristics: it is apologetic, public, and popular or educative. Philo's Quaestiones appear to be the earliest extant example of this genre whose compositional principle was based on a continuous text. In the second half the relation of Philo's Quaestiones to his Allegorical Commentary is examined, taking the second creation of man (Gen. 2:7, Leg. 1.19-42, $Q G$ 1.1-5) as a case study. It is concluded that the Quaestiones should not be seen as a note-book or preliminary notes for the Allegories. On the other hand it cannot be denied that the consistently used question and answer technique gives a less sophisticated and 
more accessible interpretation, and so can be seen as 'preparatory' or 'preliminary' in the sense that they were intended as general introduction to the more advanced writings represented in the Allegoriae. (DTR)

\section{R. McL Wilson, 'Philo and Gnosticism', The Studia Philonica Annual 5 (1993) 84-92.}

In a general paper presented to the SNTS Philo seminar in 1992 the author summarizes the results of fifty years of research and reflection on the theme of Philo's relation to Gnosticism. It is necessary to be clear on what one understands Gnosticism to be before one can judge whether any ancient author belongs to it or has contributed to its development. In Wilson's view Philo is sometimes very close, but not so close that he can be said to have belonged, and it is also by no means certain that he contributed. What he certainly does do is provide us with evidence for the intellectual climate of the time. (DTR)

9386. D. Winston, 'Philo and Middle Platonism: Response to Runia and Sterling', The Studia Philonica Annual 5 (1993) 141-146.

In his contribution to the session on Philo and Middle Platonism (see 9320) Winston emphasizes that Philo did not regard his activity of Platonizing exegesis as subversive because he was convinced that his philosophical reading of scripture was entirely legitimate. A similar approach is shown by medieval kabbalists. Finally some comments are devoted to the parallel figures of Chaeremon and Numenius. (DTR)

9387. D. Zeller, 'Notiz zu den 'immerfließenden Quellen der göttlichen Wohltaten’, The Studia Philonica Annual 5 (1993) 93-94.

In this note, an additional footnote to his book on Charis (9076), the author continues his search for the origin of the Philonic poetic expression indicated in the title. No direct source is found, only a series of similar metaphors. The theological application, however, first occurs in Philo. (DZ) 
9401. D. C. Aune, 'Mastery of the Passions: Philo, 4 Maccabees and Earliest Christianity', in W. Helleman (ed.), Hellenization Revisited: Shaping a Christian Response within the Greco-Roman World (Lanham 1994) 125-158.

On the subject of mastery of the passions we find in Philo the Stoic definition of passion combined with the Platonic tripartite division of the soul. The rational part of the soul should rule over the irrational elements, or, what is better, the irrational parts should be radically excised. Moses did in fact achieve the state of apatheia, cutting out all passions. Not everyone, however, is able to reach this state. Philo divides humanity in three categories: the beginners, those making moral progress, and those who have reached perfection. He accepts that persons can be at different stages of growth and offers an adaptable ascetic program. In 4 Maccabees a different view is found. This author states that 'pious reasoning' can master the passions completely. Idealised accounts of Jewish heroes are presented who attain freedom from passions by obeying the Law. Contrary to Philo, the author of 4 Maccabees does not offer a program of asceticism. Aune ends his article with some comments on the theme in the early Christian writers. (ACG)

9402. G. H. BAUDRY, 'La theorie du penchant mauvais et la doctrine du péché originel', Bulletin de litterature ecclesiastique 95 (1994) 271-301, esp. 286-289.

The author attempts to determine whether there is a significant relation between the theory of the 'bad inclination' (yeser ha-ra) and the later classic doctrine of original sin. He investigates the Old Testament, Qumran writings, the OT Pseudepigrapha, and also Philo, 'the most celebrated representative of Hellenistic Judaism' (286-289). The following passages are examined: QE 1.23, Praem. 62-63, Opif. 73-75, 143-135, Fug. 69-70. These texts confirm the prevalence of the theory of the two inclinations in Hellenistic Judaism (and esp. in Alexandria). Philo adapts its characteristics within the framework of Greek philosophy. He is thus instrumental in effecting the transition from a Judaism expressed in Greek to a Christianity expressed in the same terms. (JR)

9403. A. P. Воотн, 'The Voice of the Serpent: Philo's Epicureanism', in W. Helleman (ed.), Hellenization Revisited: Shaping a Christian Response within the Greco-Roman World (Lanham 1994) 159172.

It is argued that Philo exploits his knowledge of the philosophy of Epicureanism in his treatment of evil. Evil is associated with pleasure, symbolised 
by the serpent in the garden. Philo is very hostile towards Epicureanism. What he attacks, however, is not proper Epicureanism, but a caricature of it made by its opponents. (ACG)

9404. P. Borgen, 'Jesus Christ, the Reception of the Spirit, and a Cross-National Community', in J. B. Green and M. Turner (edd.), Jesus of Nazareth: Lord and Christ. Essays on the Historical Jesus and New Testament Christology (Grand Rapids-Carlisle 1994), 220-235, esp. 226-229.

Philonic material is briefly invoked in order to show what becoming a proselyte involved, with special emphasis on the reception of the Spirit as experienced by the proto-proselyte Abraham (cf. Virt. 212-219). This furnishes important evidence for the background to Paul's argument in Galatians. (DTR)

9405. P. Borgen, "Yes," "No," "How Far?": The Participation of Jews and Christians in Pagan Cults', in T. ENGBerg-Pedersen (ed.), Paul in his Hellenistic Context (Edinburgh 1994, Minneapolis 1995), 30-59, esp. 38-41, 44-46.

In this article the focus is on the attitudes to pagan cults which emerge in encounters with the non-Jewish and non-Christian world. The attitudes among both Jews and Christians varied along a wide scale, from different forms of participation to strict isolation. The author illustrates his thesis with passages from Philo, Paul, Josephus, the Apocalypse, Rabbinic sources and archaeological material. Philo said 'no' to participation in pagan cults. But this did not prevent him from praising the pagan gymnasium, nor from watching boxing, wrestling and horse-racing. He was critical towards Jews, however, who joined non-Jewish social associations or clubs, where religious activities such as sacrificial meals were performed. But the boundary line drawn by Philo was not extremely strict. He could allow for Jewish participation in club-gatherings provided that the Jews kept their own customs and standards of behavior. (KGS)

9406. N. L. Galvert, 'Philo's Use of Jewish Traditions about Abraham', in E. H. Lovering, JR. (ed.), Society of Biblical Literature 1994 Seminar Papers, SBLSPS 33 (Atlanta 1994) 463-476.

The author presents results of her research on Philo as part of a larger project: 'Abraham traditions in Middle Jewish Literature: Implications for the Interpretation of Galatians and Romans' (Ph.D. thesis, Sheffield 1993). Taking the lead of Tobin and Hamerton-Kelly in her methodology, she presents four differing traditions that can be traced to an Alexandrian background: (a) that Abraham originally was a Chaldean astrologer; (b) that he rejected astrology; (c) that he is the prototype for the 'nation that sees God'; (d) that he was obedient to the Mosaic law in an oral form. Abraham thus 
represents for the Jews of Alexandria those things that distinguish them from their Gentile neighbours, faith in one God and obedience to the Mosaic law. His apologetic is addressed to both Jewish and Gentile readers. The existing traditions that Philo takes over are shaped into his own creation through the use of philosophical methodology. (DTR)

9407. S. Cheon, An Investigation of Pseudo-Solomon's Interpretation of the Exodus Story in The Wisdom of Solomon 11-19 (diss. Graduate Theological Union, Berkeley 1994).

In investigating the hermeneutical principles and theological tendencies of Ps.Solomon's account of the Exodus narrative, the author compares it to other interpretative texts, including Philo. The text is dated to soon after the persecutions of the Jews during the reign of Gaius (37-41 CE). (DTR; based on DA 55-12A, p. 3878)

9408. N. G. Cohen, 'Philo's "Literal Meaning" and Rabbinic Peshat', in Proceedings of the Eleventh World Congress of Jewish Studies (Jerusalem, June 22-29, 1993), Division A (Jerusalem 1994) 171-178.

This paper argues that the technical term tò ṕntóv in Philo, rather than indicating (as e.g. LSJ suggest) the 'literal' as opposed to the allegorical sense of a text, stands for the 'traditional sense', which is also the meaning of the Rabbinic term peshat. This is illustrated by a comparison of Philo QG 2.49 with a chain of rabbinic midrash, all dealing with Gen. 7:7. It is concluded that the Philonic passage is a very early example of exegetical traditions found also in the Rabbinic sources. Philo's presentation (using the term $\tau$ ò

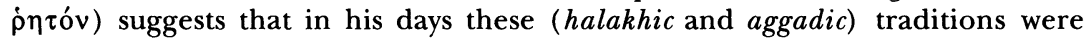
already traditional, a point argued in much greater detail in the author's monograph 9520. (HMK)

9409. J. H. Corbett, 'Muddying the Water: Metaphors for Exegesis', in W. Helleman (ed.), Hellenization Revisited: Shaping a Christian Response within the Greco-Roman World (Lanham 1994) 205221, esp. 214-215, 221.

Starting-point of the article, in which the metaphor of muddying water is discussed, is a passage of Paulinus of Périgeux on St. Martin of Tours. In order to understand the background Corbett examines Numbers 21:16-18 and two Qumran documents, the Damascus Rule and the Thanksgiving hymn. In the Jewish texts digging the well is interpreted in terms of seeking out the Torah with the stave of exegesis. The clear water of the well is mixed with mud, which denotes the process of exegesis. In the final part of the paper this interpretation is contrasted to Philo's use of the image, for whom the 'muddy springs are to be avoided as manifestations of mass unreason' (p. 215). (ACG) 
9410. K. L. Cukrowski, Pagan Polemic and Lukan Apologetic: the Function of Acts 20:17-38 (Paul) (diss. Yale University 1994), esp. chap. 2.

In order to elucidate Luke's depiction of Paul in Acts 20, the author analyses five treatments of the ideal philosopher, including Philo's portrait of Moses in De vita Moysis. (DTR; based on DA 55-06A, p. 1589)

9411. E. Dassmann et al., Reallexikon für Antike und Christentum, Band XVI (Stuttgart 1994).

F.-L. Hossfeld-G. Schöllgen, Art. 'Hohepriester' 4-58, esp. 19-23 (High priest); G. J. M. Bartelink, Art. 'Homer' 117-147, esp. 125-126 (Homer); K. Thraede, Art. 'Homonoia (Eintracht), 176-289, esp. 238-239 (concord); K. Hoheisel, Art. 'Homosexualität', 289-364, esp. 334-335 (homosexuality); J. Hammerstaedt, Art. 'Hypostasis', 986-1035, esp. 998-9 (hypostasis); K. Thraede, Art. 'Jacob und Esau', 1118-1217, esp. 1125-30 (Jacob and Esau).

9412. D. Daube, 'Human Rights: The Rabbis and Philo', unpublished paper delivered at the McGill Colloquium on Judaism and Human Rights, Montreal, Canada, 1994, 12 pages. Available only in Widener Library of Harvard University.

Noting that the category 'human rights' is found in neither Rabbinic sources nor Philo, Daube focuses on various areas in which these interpreters' positions on human rights can be discerned. The areas include biblical situations - such as the punishing of Cain, Er, and the inhabitants of Eden - in which God's actions may appear discriminatory. Both the Rabbis and Philo offer interpretations exonerating the Lord of charges of arbitrariness. When interpretations of Philo and the Rabbis coincide, Daube claims Philo is generally, though not always, dependent upon the Rabbis. Other areas discussed include rights of slaves and captives who have escaped and the right to die by suicide. (EB)

9413. B. Decharneux, L'ange, le devin et le prophète: chemins de la parole dans l'ouvre de Philon d'Alexandrie dit "le Juif", Spiritualités et pensées libres (Brussels 1994).

This work represents the first separate monograph devoted to Philo's angelology. Not surprisingly it turns out to be a complex affair, which cannot be treated in full detail without devoting considerable attention to Philo's conception of the human figures of the prophet and the diviner (hence the title). The approach is based primarily on the method of the history of religions, but the author also takes into account Philo's debt to Greek philosophy. The theme of angelology takes us into the heart of Philo's thought, it is claimed, because they mediate between the divine and the human, being both messengers and logoi. The titles of the twelve mostly brief chapters give a 
good indication of the book's scope: I Philonic definition of angels and difficulties of interpretation; II Functions of angels; III Angels as saviours of human beings; IV Angels as logoi of God; V Influences of the Phaedrus and the Epinomis; VI Chaldeanism or the limits of cosmological piety; VII The chariot of the Great King, a founding myth of angelology; VIII The ark and the Cherubim; IX Balaam, symbol of the professional diviner; X Joseph the inspired diviner; XI The figure of the Prophet and the High Priest; XII The Logos High Priest and Levitic spirituality. Reviews: L. Brottier, REAug 42 (1996) 161-162; R. Hoven, RBPh 74 (1996) 191-192; J. C. Reeves, CBQ 58 (1996) 704-705; D. T. Runia, SPhA 8 (1996) 199-201 and VChr 50 (1996) 428-429; J. Wankenn, AC 66 (1997) 414-415. (DTR)

9414. B. Decharneux, 'Philon d'Alexandrie, un philosophe témoin de la violence religieuse au premier siècle de notre ère', in Violence et coexistence humaine: Actes du IIe Congrès mondial de l'ASEVICO Montréal 1992 (Montreal 1994) 262-267.

Philo is the principle witness of the violence that was directed against the Jewish community of Alexandria in the 1st century of our era. In two treatises, Flacc. and Legat., he describes the anti-Jewish disturbances, but does not limit himself to description alone. In addition the Philonic narrative has both a philosophical and a religious purpose, to offer a defence of the Mosaic philosophy and the nation of Israel. Violence, according to the Alexandrian author, reveals the disorder which plagues the world if it is not harmonized with the laws of revelation and of the cosmos, i.e. the laws dictated by the God of Israel, for which the emperors have to be the respectful intermediaries. The account of what happened to the Jewish community of Alexandria and of the folly of the emperor Gaius demonstrates to the Gentiles that a lack of respect for the Jewish laws initiates barbarism, folly and the degeneration of civilization. (JR)

9415. A. J. Dewey, 'A Re-hearing of Romans 10:1-5', Semeia 65 (1994) 109-127.

In the author's view Romans 10 must be understood as an oral performance dealing with the problem of power and universal access to the source of power, God. The oral performance brings about an interplay between the performer of the letter and his audience. In this oral setting Paul made use of the written tradition from Deut. 30. The author compares Philo's use of the same text in Virt. 180-85, Prob. 62-73, and Spec. 4.160-69. Both Paul and Philo set the access to power question before the listener, but there are important differences between them. Philo sees the realization of this dream in establishing a sovereign self apart from the masses. He may be considered a social traditionalist. Paul, on the other hand, represents a counter-cultural position. Romans 10 is at odds with the established social order and is an attempt to bring about the utopian vision. A response to the paper is given by A. Wire on pp. 129-135. For an earlier version of the article see 8917a and 9014. (ACG) 
9416. J. Dillon, 'Philo and the Greek Tradition of Allegorical Exegesis', in E. H. Lovering, Jr. (ed.), Society of Biblical Literature 1994 Seminar Papers, SBLSPS 33 (Atlanta 1994) 69-80.

Dillon builds on and re-examines earlier work that he did on the sources of Philo's allegorical method and his relationship to the use of allegory in the Platonist tradition. It is not necessary, as he once thought, to postulate an intermediate tradition between Philo and the Stoically orientated Pergamene school, because other allegorists roughly contemporary with Philo (Heraclitus, Ps.Plutarch) too make free use of non-Stoic philosophical material. The basic allegorical method could be adapted in various directions. (DTR)

9417. G. Dorival, La bible d'Alexandrie (LXX), Tome 4 Les Nombres (Paris 1994).

Although there is no specific analysis of Philo's exegesis of Numbers, frequent references are made to it in the commentary on the LXX text. Review: A. van den Hoek, SPhA 8 (1996) 167-172. (DTR)

9418. P. Dumoulin, Entre la Manne et l'Eucharistie: Etude de Sg 16,15-17,1a, Analecta Biblica 132 (Rome 1994), passim.

The author undertakes to examine the passage on the Israelites receiving manna in the desert in the Wisdom of Solomon in relation to the biblical text, the Jewish tradition and the reception in the Patristic and Medieval period. Extensive reference is made to the writings of Philo, especially for the second task. The interpretation of the manna passages is discussed in relation to the themes of divine nourishment, creation, the source of teaching and the word, prayer and immortality. See further the index of passages at pp. 227-228. (DTR)

9419. N. A. Evans, 'Diotima, Eros, Cherubim and the Sources of Divine Knowledge', in E. H. Lovering, JR. (ed.), Society of Biblical Literature 1994 Seminar Papers, SBLSPS 33 (Atlanta 1994) 822-846, esp. $840 \mathrm{ff}$.

A comparison is made of the usage of Eleusinian mystery language by Plato in Diotima's speech in the Symposium and by Philo in De Cherubim 21-50. The language in both authors is very similar, but the cultural context differs considerably. Exploiting the insights of Mary Douglas about the relation between the social and the physical body, the author concludes that Plato's mysteries remain somehow rather abstract, whereas those of Philo are focused on Moses who stood face to face with God on Sinai and personally experienced the collapse of the boundary between human and divine. (DTR)

9420. J. J. Fernandez SAngrador, Los orígenes de la comunidad cristiana de Alejandría (Salamanca 1994), esp. 47-50. 
The author presents a well documented study about the difficult subject of the origin of the Christian community of Alexandria. He gives an exhaustive review of the different theories about its origin, and the place occupied by Philo in each one of them. A valuable bibliography on the subject is added. (JPM)

9421. P. Garnsey, 'Philo Judaeus and Slave Theory', Scripta Classica Israelica 13 (1994) 30-45.

In Prob. Philo upholds the Stoic view on slavery, namely that it is not a condition of the body, but of the soul which becomes enslaved to the passions. The wise man is free. Although Philo seems here to move away from Aristotle, in whose view some people are slaves by nature, in the Allegorical Commentary he does defend the Aristotelian position. There are two examples of enslavement in the OT: Canaan is a slave to Ham, and Esau to Jacob. From Philo's discussion on them, it appears that in his view a class of natural slaves does exist. The author concludes that there are two kinds of slavery in Philo's view. Firstly, there is bodily slavery, which is an accident and such slaves are not slaves by nature. Secondly, there is moral slavery. The reason of the morally enslaved is overwhelmed by passions. Their slavery is in their own interest and can be ordained by God. The chief example in the OT is Esau. Philo is led to his view on slavery by the biblical texts. 'It was Philo the Jewish exegete rather than Philo the Stoicising philosopher who produced a version of the natural slavery theory. (p. 44)' (ACG)

9421a. J. GLUCKER, 'The Origin of $\dot{v} \pi \alpha \dot{\rho} \chi \omega$ and $\ddot{z} \pi \alpha \rho \xi_{1 \zeta}$ as Philosophical Terms', in F. Romano and D. P. TAORmina (edd.), Hyparxis e hypostasis nel neoplatonismo, Lessico Intellettuale Europeo 64 (1994 Firenze) 1-23, esp. 19-20.

Brief but valuable discussion of Philo's use of the terms $\dot{v} \pi \alpha \rho \chi \omega$ and $\ddot{v} \pi \alpha \rho \xi_{1 \zeta}$. It is suggested that he may have invented the noun $\ddot{v} \pi \alpha \rho \xi_{1 \varsigma}$ because he patently needed a term in order to distinguish between God's existence and his essence. (DTR)

9422. M. Gonzalez Fernandez, 'Philon d'Alexandrie et Michel de Montaigne', Bulletin de la Societe des amis de Montaigne 37-38 (1994) 23-36.

The author shows that several doxographical passages of Philo could have been exploited by Montaigne in the reconstruction that he gives of Pyrrhonism in his best known essay, L'Apologie de Raimond Sebond. Montaigne possessed in his personal library a copy of the editio princeps of Philo by A. Turnebus (Paris 1552). Particularly the texts Ebr. 171-205 and Ios. 125-147 may have inspired him. (JR) 
9423. S. Goranson, 'Posidonius, Strabo and Marcus Vipsanius Agrippa as Sources on Essenes', The Journal of Jewish Studies 45 (1994) 295-298.

The author suggests that Philo and Josephus use Strabo as a source in their accounts of the Essenes. Strabo in turn depends on Posidonius. (ACG)

9424. P. Graffigna, 'Tra il doppio e l'unita: parentela ( $\sigma v \gamma \gamma \varepsilon$ $v \varepsilon i \alpha)$ tra uomo e Dio in Filone d'Alessandria', Koinonia 19 (1994) 5-15.

On the basis of a considerable number of Philonic texts the author concludes that for Philo man is, as it were, the 'double' of God and this notion is inherent in the terms he uses for the relation, in particular $\sigma v \gamma \gamma \varepsilon \dot{v} \varepsilon 1 \alpha$, $\dot{\alpha} \gamma \chi i \sigma \pi$ opos, $\dot{\alpha} v \tau^{\prime} \mu t \mu o \varsigma$. Although the divide between creator and creature can never be overcome, Philo nevertheless manages rigorously to sub-divide the gap and so overcome the duality, at least from the conceptual and linguistic point of view. He is thus a vital connecting link between the earlier and later periods of antiquity. (RR)

9425. N. V. Harrison, 'The Feminine Man in Late Antique Ascetic Piety', Union Seminary Quarterly Review 48 (1994) 49-71.

Philosophers, Jews, and Christians of late antiquity whose misogyny is well-documented nevertheless affirm both masculine and feminine qualities in the spiritual pursuit of human wholeness. Positive feminine qualities to be cultivated include 'spiritual desire, receptivity, and fruitfulness'. Through allegorization Philo and others depict the spiritual quest as a primarily human rather than gender-defined experience. Feminine qualities such as desire and receptivity are portrayed by Philo as negative when associated with the senses but positive when associated with the mind. Moreover the split in his characterization between woman and virgin can be understood symbolically to represent aspects of a universal human striving toward spiritual childbearing. Besides Philo, Plato is discussed, as are the Christian writers Origen, Methodius of Olympus, and Didymus of Alexandria, who add a Christological dimension to their symbolic portrayal of the spiritual quest. (EB)

9426. D. M. HAY, 'Defining Allegory in Philo's Exegetical World', in E. H. Lovering, JR. (ed.), Society of Biblical Literature 1994 Seminar Papers, SBLSPS 33 (Atlanta 1994) 55-68.

This article focuses on the self-consciousness of the Allegorists to whom Philo refers. After a brief sketch of the views of T. H. Tobin, R. Goulet, and D. Dawson regarding the Allegorists mentioned by Philo, the author discusses some Philonic passages describing other Allegorists. He sees no reason to conclude from these passages that the pre-Philonic allegorical commentary 
had a strong 'secular' character, as Goulet assumes. Further, he voices doubt on Dawson's view that Jewish allegory represented a bold 'victimization' of Greco-Roman culture. In his conclusion he remarks that 'at least some of these Allegorists were self-conscious about practising a distinctive, non-literal mode of interpretation; they developed or maintained theories (...) to conceptualize the connection of scripture with unseen realities'. Most Allegorists did not reject outward observance of the Jewish ritual law. (ACG)

9427. G. HeIL, Die Ablehnung der Speisegebote durch Paulus, Bonner Biblische Beiträge 96 (Weinheim 1994), esp. 74-81.

As part of a lengthy investigation on the significance of dietary laws in Judaism, this revised Bonn dissertation gives a summary of Philo's position. In spite of his figurative interpretation dietary laws were taken serious in the Diaspora. This marks a difference between Philo and Paul. (DZ)

9428. W. E. Helleman, 'Epilogue', in eadem (ed.), Hellenization Revisited: Shaping a Christian Response within the Greco-Roman World (Lanham 1994) 429-513, esp. 465-468.

In a lengthy epilogue to a collection of papers on the theme of Hellenization of Christianity, Helleman subjects the famous thesis of A. Harnack to critical scrutiny. Philo can be regarded as a test case for the synthesis of faith and philosophy, but this verdict must be explored further. In what sense is Philo a representative of synthetical thinking? Helleman sees two different judgements of historians on Philo. Some historians wish to do justice to Philo, whereas other judgements are the result of a systematic analysis of Philo's work from the perspective of later thought. We should, Helleman remarks, recognize Philo's need to make use of contemporary philosophical positions and of speaking the language of his time in order to be able to communicate clearly with his contemporaries. REview (of the whole volume): D. T. Runia, SPhA 7 (1995) 237-238; H. M. Keizer, PhilRef 62 (1997) 99-111. (ACG)

9429. R. J. V. Hiebert, 'Deuteronomy 22:28-29 and its Premishnaic Interpretations', Catholic Biblical Quarterly 56 (1994) 203220.

This article deals with the interpretation of the law concerning the violation of an unbetrothed virgin in Deut. 22:28-29. The author examines the LXX translation, comparable legislation in the Pentateuch (Ex. 22:15-16), the Qumran Temple Scroll and the writings of Philo and Josephus. Philo deals with this biblical legislation in Spec. 3.65-71, combining Deut. 22:28-29 and Ex. 22:15-16. This combination occurs also in Josephus and in the Qumran Temple Scroll. Philo adds to the biblical text that the aggressor should be brought before the judges. Furthermore, he shows concern for the virgin. (ACG) 
9430. A. van Den Hoek, 'Philo in the Alexandrian Tradition', The Studia Philonica Annual 6 (1994) 96-99.

In responding to D. T. Runia's monograph on Philo in the early Christian tradition (9373), the author draws attention to two points. Comparing two authors with each other can be a tricky business, for one can easily find what one is looking for. The best approach is to map out all the available material. Secondly, it is striking how rarely Philo is named in both Clement and Origen. In order to understand this phenomenon it will be necessarily to look at techniques of citation more thoroughly. (DTR)

9431. W. Horbury, 'The Wisdom of Solomon in the Muratorian Fragment', Journal of Theological Studies 45 (1994) 149-159.

Doubt is cast on Tregelles' famous emendation, which attributes Wisdom to Philo in the Muratorian Canon. Horbury concludes that it would not be anachronistic to date the fragment to the end of the 2nd or the beginning of the 3rd century. (DTR)

9432. P. W. VAN DER Horst, 'Silent Prayer in Antiquity', Numen 41 (1994) 1-25, esp. 13.

Only a single page is devoted to Philo, but we mention it because of the importance of its evidence. Philo is the first post-biblical Jewish author to mention silent prayer. The author states that Philo would be better placed in the section on Platonism, but that he lists him under Jewish evidence because of his strong influence on the incipient Christian tradition. (DTR)

9433. D. N. Jastram, 'The "Praeparatio Evangelica" and "Spoliatio" Motifs as Patterns of Hellenistic Judaism in Philo of Alexandria', in W. Helleman (ed.), Hellenization Revisited: Shaping a Christian Response within the Greco-Roman World (Lanham 1994), 189-204.

The question the author poses is the following: what kind of interaction takes place between Judaism and Hellenism in Philo's thought? According to Jastram Philo took a middle position, which he terms 'appropriation'. Part of this pattern of appropriation are the 'spoliatio' and the 'praeparatio evangelica' motifs in his writings, which are briefly discussed. Philo's middle position concerns the three areas of religion, ethics, and culture. Jastram concludes that Philo was not a mono-cultural antagonist, but had a transcultural perspective. (ACG)

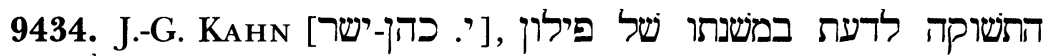
['Libido sciendi: the Lust for Knowledge according to Philo Alexandrinus'] Proceedings of the Eleventh World Congress of Jewish Studies (Jerusalem 1994) A.103-106. 
The author examines briefly Philo's use of erotic terminology as a means of expression of desire for knowledge and wisdom. Philo's positive attitude towards the Platonic development of this theme, specifically as expressed in the Symposium, must be understood as selective appropriation despite the attendant sexual ethos. (DS)

9435. A. Kamesar, 'Philo, Grammatike, and the Narrative Aggada', in J. C. ReEves and J. Kampen (edd.), Pursuing the Text: Studies in Honor of Ben Zion Wacholder on the Occasion of his Seventieth Birthday, JSOT.S 184 (Sheffield 1994) 216-242.

On Philo's relationship to haggada there is a general consensus that we do find in his works allusions to narrative haggada material, but not haggada such as is found in the rabbinic literature or in early Jewish Hellenistic texts. The author gives two reasons for this relative scarcity of haggada in Philo. One reason lies in the genre which Philo inherited, viz. scientific exegesis, earlier used by Demetrius the Chronographer. In this genre more extensive narrative embellishment of the biblical text was not tolerated. The other reason is the influence exerted on Philo by the Asclepiadean system of $\gamma \rho \alpha \mu \mu \alpha \tau \iota \kappa \dot{n}$, which led Philo to regard the narrative haggada as part of history and thus as separate from the other components of exegesis. From a moralistic and philosophical perspective on literature he wished to reduce $\tau$ ò

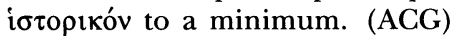

9436. H.-J. KLAUCK, 'Ein Richter im eigenen Innern: das Gewissen bei Philo von Alexandrien', in IDEM, Alter Welt und neuer Glaube: Beiträge zur Religionsgeschichte, Forschungsgeschichte und Theologie des Neuen Testaments, NTOA 29 (Freiburg-Göttingen 1994) 33-58.

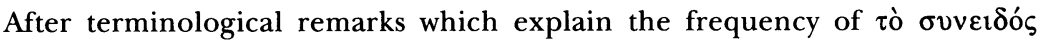
in Philo the author analyses Decal. 82-91 with its central concept है $\lambda \varepsilon \gamma \chi 0 \varsigma$. Further aspects of the conscience are gained by briefly consulting other Philonic writings: it is both immanent in the soul and sent by God; it is the Logos-priest and custodian angel, but it can only be called God analogically (Fug. 211f.). There are no sure examples for the concept of a conscientia antecedens. Klauck inquires into the origin of this concept, its earlier attestations and concludes on p. 56 that Philo combined the punishing spirits of vengeance (cf. Cicero) and the benevolent guardian angel (cf. Seneca) with the personified censure found in Jewish wisdom-literature. In an epilogue he contrasts Philo with Paul and briefly alludes to Philo's influence on Christian Fathers. Review: G. E. Sterling, SPhA 7 (1995) 230-231. (DZ)

9437. R. S. KraEmer, 'The Other as Woman: an Aspect of Polemic among Pagans, Jews, and Christians in the Greco-Roman World', in L. Silberstein et al. (edd.), The Other in Jewish Thought and History, New Perspectives on Jewish Studies (New York 1994) 121-144, esp. 133-135. 
Philo's De vita contemplativa is one of three documents discussed in which Jews represent either the Self or the Other and in which gender figures significantly in the construction of the Other. Philo's characterization of the Self, identified with the Therapeutae, and the Other, foreigners presented as feminized men, has clear gendered components and strong value judgements attached to masculinity and femininity. (DTR)

9438. M. A. KRaUs, 'Philosophical History in Philo's In Flaccum', in E. H. Lovering, JR. (ed.), Society of Biblical Literature 1994 Seminar Papers, SBLSPS 33 (Atlanta 1994) 477-495.

The author pleads for a philosophical reading of Philo's In Flaccum which has generally been classified as a historical work. He puts forwards several arguments for such a philosophical interpretation. Flacc. belongs to a larger

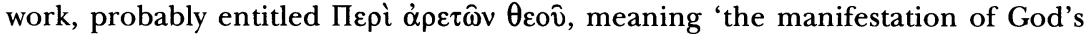
power in the defence of his people' (S. Reiter). The last sentence of the work says as a conclusion that Flaccus was a proof of God's providence for the Jewish nation. Since for Philo theology and philosophy are not separate disciplines, the title and the conclusion of the work place it in the realm of philosophy. Besides the external evidence, there are also internal pointers. Philo gives hints in the text that he sees God's $\pi$ póvor $\alpha$ in the events recounted. Furthermore, he dots the treatise with philosophical sententiae. Kraus makes some general observations on Philo's politics as well. In Philo's view, the character of a person motivates his political behaviour. Philo distinguishes between good government, which produces obedience to the law and equality, and bad government, generating disobedience. Because in Philo's view political decisions are caused by false or correct knowledge, he combines epistemology with politics. At the end of the treatise, Philo presents Flaccus as receiving a mystical vision of divine providence (Flacc. 169-171). However, his knowledge of God comes too late. The Jewish exegete thus shows that unio mystica does not guarantee divine approval. 'Providential care depends on ethical behaviour as well ... The intellectual value of contemplating the divine in no way erases past misdeeds. (p. 495)' (ACG)

9439. C. Kraus Reggiani, 'La simbologia di Abramo in Filone di Alessandria', in J. Driscoll and M. Sheridan (edd.), Spiritual Progress: Studies in the Spirituality of Late Antiquity and Early Monasticism. Papers of the Symposium of the Monastic Institute Rome, Pontificio Ateneo S. Anselmo 14-15 May 1992, Studia Anselmiana 115 (Rome 1994) 13-27.

The article opens with a brief general introduction to Philo as primarily an exegete of Holy Scripture, who has achieved a synthesis of Greek and Hebrew thought without one of the two spheres of thought prevailing at the expense of the other. According to the author, Philo's use of the allegorical method and of Greek philosophical doctrines (such as the theory of Ideas) in his exegesis of Scripture entails a radical transformation of this method and these doctrines. A central theme for Philo is the relation between God and 
man, in particular human spiritual progress, which Philo considers on the ethical and cognitive plane. Abraham is of special importance for Philo: the author elaborates Philo's spiritual interpretation of the theme of Abraham's migration, including the change of Abra(ha)m's name and the virtue and

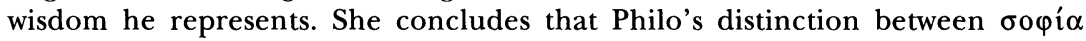

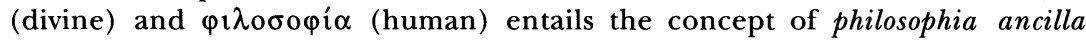
theologiae, which implies a break with the cult of human intellect. (HMK)

9440. J. LeIfer, Logos and God. Philo's Influence on Early Christian and Arian Theology (M.A. Thesis, San Francisco State University 1994).

Through an investigation of the pertinent primary and secondary sources the author examines the influence of Philo of Alexandria on Orthodox and Arian views of the nature of God and the Logos. He first considers Orthodox views as represented by the writings of Clement of Alexandria, followed by Arian views as represented by the writings of Arius and some of his opponents. It is finally shown that the source of both these views is ultimately to be found in Philo of Alexandria. (DTR, based on author's abstract)

9441. J. R. Levison, 'Two Types of Ecstatic Prophecy according to Philo', The Studia Philonica Annual 6 (1994) 83-89.

The author undertakes to corroborate and refine David Winston's thesis that there are two types of ecstatic prophecy in Philo: (1) ecstatic trances in which the prophet becomes a wholly passive, mindless medium; (2) a milder form of ecstasy in which the rational faculties are not completely displaced. Four examples in De vita Moysis 2.187-287, all pertaining to the prophet Moses, allow the second form to be further analysed. There is no need to confine this type to instances of prediction of the future, as Winston contends. Also it need not be restricted to 'vision trances'. Finally Mos. 2.265 shows that ecstatic prophetic inspiration may engage and quicken the mind. (DTR)

9442. M. Ludwig, Wort als Gesetz: Eine Untersuchung zum Verständnis von „Wort “ und „Gesetz “ in israelitisch-frühjüdischen und neutestamentlichen Schriften. Gleichzeitig ein Beitrag zur Theologie des Jakobusbriefes, Europäische Hochschulschriften 23.502 (Frankfurt etc. 1994), esp. 79-88.

This Heidelberg theological dissertation starts from the observation that in James 1:22f. and 25 'word' and 'law' are synonymous. The author looks for parallels of this 'nomistic conception' in the Hebrew and Greek Bible and in Jewish literature (especially Deuteronomy, Psalm 118, Qumran). The pages on Philo first list passages where law(s) and $\lambda$ ó $\sigma_{0}-\lambda{ }^{\prime} \gamma 1 \alpha$ are syntactically correlated or substituted for each other. Ludwig cannot recognize any special interest of Philo in the deuteronomistic tradition. She explicitly identifies word(s) and law(s) in his theory of inspiration and in his Hellenistic-Stoic 
Logos-theology. Despite some verbal resonances (esp. God as genitor of the stars at Spec. 3.189 as in James 1:17) the verses James 1:17f. and 23 are not influenced by Philonic ideas. They represent the same nomistic current, which in part III is verified in some other writings of the NT. The Jewish interpretation of James 1:18-21 ( $\lambda$ ó $\gamma \circ \varsigma$ does not mean the Gospel but the Jewish law) in part IV certainly will give rise to controversy. (DZ)

9443. J. Martens, 'Nomos Empsychos in Philo and Clement of Alexandria', in W. Helleman (ed.), Hellenization Revisited: Shaping a Christian Response within the Greco-Roman World (Lanham 1994) 323338.

In presenting Christ as the living law, Clement not only bases himself on Philo, as has been generally recognized, but also on Hellenistic Pythagorean fragments such as we find in Stobaeus. An important feature of the view of the kingship in these fragments is that the king, as living law, is contrasted with the written law. Hence, the law is either written or it is embodied in the king. This either/or character is not found in Philo. Clement, however, does take over this contrast between the 'written law' and the 'living law', that is Christ. The nomos empsychos replaces and is superior to the written law. Clement uses the concept of the nomos empsychos for his own needs as a Christian apologist. (ACG)

9444. J. P. Martín, 'La cultura romana y la Prima Clementis', Teologia. Revista de la Facultad de Teología de la pontificia Universidad Católica Argentina 21 (1994) 55-71.

The article undertakes to place 1 Clement in the cultural situation of the

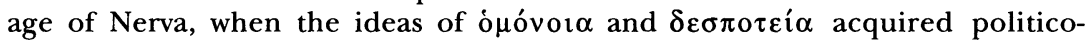
religious relevance. In that context Philo is discussed as an antecedent in the use of Christian expressions and concepts. (JPM)

9445. J. P. Martín, 'Prima Clementis: ¿estoicismo o filonismo?', Salmanticensis 41 (1994) 5-36.

The author analyses chapter 20 of 1 Clement, which scholars have considered to be the 'most stoic' chapter in the document, and compares it systematically to the Philonic corpus. Against the conventional view, the article concludes that Philo is the closest antecedent for almost all the topics that are considered Stoic. Moreover there are frequent and specific lexical similarities. It is concluded that the combination of the Stoic doctrine of the order of nature with the Biblical creationistic theology, typical of Clement, has been inherited by Christianity from Hellenistic-Jewish sources. In this context the idea of the cosmic order as liturgy rendered to God is important. (JPM) 
9446. J. P. Martín, 'Sobre Heráclito y la naturaleza que ama ocultarse', Méthexis 7 (1994) 107-111.

In a brief note the author poses the question whether the famous expression 'nature likes to hide' are the actual words of Heraclitus, or whether it is a Philonic interpretation of the early Greek philosopher; cf. $Q G 4.1$ in relation to Fuga 179 and Leg. 3.7. (JPM)

9447. A. Mendelson, 'Did Philo Say the Shema?' and Other Reflections on E. P. Sanders' Judaism: Practice and Belief', The Studia Philonica Annual 6 (1994) 160-170.

This review article undertakes to examine how Philo fares in E. P. Sanders' important work Judaism: Practice and Belief, 63 BCE - 66 CE (9277). The elitist Philo does not fit so well into the somewhat populist Common Judaism which Sanders reconstructs, as can be seen in various passages in which Sanders exploits Philonic texts. Nevertheless it is unavoidable and legitimate for the historian to select his evidence, and there is a great deal that the Philonist can learn from this book, which does so much to illuminate the Judaism of the Second temple period. (DTR)

9448. M. Merino and E. Redondo, Clemente de Alejandria. El Pedagogo. Introducción, traducción y notas, Fuentes Patrísticas 5 (Madrid 1994).

Frequent reference is made to Philo in the comments appended to this translation of Clement's Paedagogus. Indeed Philo is the most quoted author after the Bible, cited on more than 160 occasions. It emerges that Philo is the catalyst for many of Clement's Platonic ideas. The use of the Philonic corpus is, however, not complete, since the Armenian Philo is largely ignored. (JPM)

9449. K. A. Morland, The Rhetoric of Curse in Galatians: Paul Confronts another Gospel, Emory Studies in Early Christianity (Atlanta 1994).

Revised version of the author's Oslo-Trondheim dissertation; see 9156. The study seeks to explain Paul's use of the curse from two main perspectives: the rhetoric of the letter, and the conventional Jewish background regarding the curse-concept. All texts in Philo where we find curse-terminology are considered together with other Jewish curse-texts. In two appendices they are compared with the 'semantic field' of Paul's curses in Gal. 1:8-9, 3:10-13. The most suitable comparative material for Paul in Philo is found in texts such as Praem. 79-172, texts that cite curses from Deut. 27-28 (cf. Leg. 3.107-8, Post. 84), texts that cite curses from primal history (cf. Leg. 3.65-199, Agr. 20-25, Det. 96ff., Sobr. 30-51), and texts citing the Gen. 12:3 formula (cf. Migr. 109, Mos. 1.291). It is argued that Philo in these texts draws on the conventional Jewish covenantal curse-tradition, and that he is one of many representatives of this 
tradition, which Paul also draws on in his curses. (abstract supplied by author).

9450. M. Müller, Kirkens første Bibel [In Danish: The First Bible of the Church]: Hebraica sive Graeca veritas? (Copenhagen 1994), esp. $45-48$.

The author presents the Philonic version of the legend also found in the Letter of Aristeas of how the Law was translated into Greek (Mos. 2.26-44). Philo sees the translation as 'prophetic'. In other words: it is divinely inspired. Therefore it is not a 'daughter'-version, but a 'sister' on an equal footing compared to the Hebrew version. The Law has to be taken literally. Both the Hebrew and the Greek versions of the Law are fully valid expressions of the spiritual reality behind them. (KGS)

9451. R. Neudecker, 'Das 'Ehescheidungsgesetz' von Dtn 24,1-4 nach altjüdischer Auslegung. Ein Beitrag zum Verstandnis der neutestamentlichen Aussagen zur Ehescheidung', Biblica 75 (1994) 350-387, esp. 356-360.

In contrast to the Hebrew text, Deut. 24:1 in the Greek version is an autonomous casuistic law. However, Spec. 3.30f. presupposes the syntactical coherence of v. 1-4; the difference is that the case is seen from the perspective of the woman. The bulk of the study concerns the rabbinic interpretation of the passage. $(\mathrm{DZ})$

9452. G. S. Oegema, Der Gesalbte und sein Volk: Untersuchungen zum konzeptualisierungsproze $\beta$ der messianische Erwartungen von den Makkabäern bis Bar Koziba, Schriften des Institutum Judaicum Delitzschianum 2 (Göttingen 1994), esp. 115-122.

Starting from a very broad definition (28), Oegema reviews the messianic expectations in Judaism and Early Christianity. In his passage on Philo he analyses the allusions to Num 24:7 in Mos. 1.290 and Praem. 95 in their context. While the first text envisages an eschatological warrior-king like Moses, the second has in mind not an eschatological war, but a present one, carried on with ethical weapons. In the description of the end time, Praem. 163ff., it is God himself who liberates Israel. The author puts these different views in relation to Philo's political ideals and the political events around him, and suggests a self-correction from Mos. to Praem. Review: K.-W. Niebuhr, ThLZ 121 (1996) 41-45. (DZ)

9453. A. Pawlaczyk, 'Filona z Aleksandrii 'Quis rerum divinarum heres sit 45-48' - interpretacja [in Polish]', Eos 82 (1994) 213219. 
The author examines in detail the text and interpretation of two passages, Her. 45-46 and 47-48. She discusses some readings of the papyrus and shows

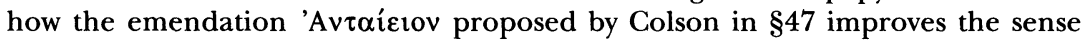
of the passage in its context. The ethical division of lives gives an extra dimension to the theme of division which is so prominent in the treatise. (DTR; based on author's summary)

9454. P.-H. PoIrier, 'Pour une histoire de la lecture pneumatologique de Gn 2, 7: quelques jalons jusqu'à Irenée de Lyon', Revue des Études Augustiniennes 40 (1994) 1-22, esp. 2-4.

After the Wisdom of Solomon it is in Philo that one encounters the first witness of a pneumatological reading of Gen. 2:7. The interpretation is placed in the framework of the reading given to the two creation accounts of man in Gen. 1 and 2. The author focuses on Opif. 134-135, Leg. 1.31-32, 37-38, 42. (JR)

9455. R. RADICE, 'Miti di origine, miti di caduta e presenza del femminino nella loro evoluzione interpretativa', in G. L. Prato (ed.), XXXII Settimana Biblica Nazionale, = Ricerche Storico-Bibliche 6 (1994) 167-177.

The interaction between the categories 'masculine' and 'feminine' cannot be reduced to an opposition, but rather to a 'polar' relation, i.e. the existence of the one entails the existence of the other. This having been said, five semantic areas can be distinguished for this pair of terms: (1) arithmological (odd and even); (2) psychological-theological (divine grace and soul); (3) psychological-anthropological and (4) psychological-ethical (intellect and sensation); (5) cosmogonic-anthropogonic (active and passive principle). We should, however, not overlook the important use of the two terms in Philo in the category 'neither masculine nor feminine', which he uses to indicate the realm of the supra-sensible (176f.). (RR)

9456. R. RAdice, La filosofia di Aristobulo e $i$ suoi nessi con il De Mundo attribuito ad Aristotele, Pubblicazioni del Centro di Ricerche di Metafisica: Collana Temi metafisici e problemi del pensiero antico, Studi e Testi 33 (Milan 1994).

Radice considers Aristobulus and Philo as the two points in the evolution of Hellenistic Judaism between which one can trace the movement's development. The detailed analysis of the fragments of Aristobulus is related above all to the allegory of migration, and particularly to the figure of the Chaldeans. Radice concludes: 'In metaphorical terms, whereas for Philo the 'Chaldean' either cannot see God at all or can see him only in a doubtful or approximative manner, ... for Aristobulus he appears to be capable of gaining knowledge of God to the extent that it is possible for man to gain access to celestial and divine realities.' (182) This entails that Philo has conceived an 
ontological level superior to the astronomical and sense-perceptible, i.e. a metaphysical and supra-sensible realm. This should be considered an event of absolute novelty in ancient thought. In order to reach this conclusion the author frequently compares Aristobulus' thought with that of Philo, with particular emphasis on the doctrine of creation (107ff.) and of dynamis (84ff.). Reviews: D. Winston, SPhA 8 (1996) 161-166; N. Walter, SPhA 8 (1996) 183185. (RR)

9457. G. J. Reydams-Schils, Stoic and Platonist Readings of Plato's Timaeus, (diss. Berkeley 1994), esp. chap. 3, 'Philo Judaeus, on a Cruise to Alexandria'.

The thesis supervised by A. A. Long depicts a journey through intellectual history, a merging of Stoic and Platonist interpretations of the Timaeus through some 800 years. The method is not so much doxographical as concentrating on the philosophical arguments used. Philo is one of the authors examined in detail. See further the next item in this bibliography. (DTR; summary based on DA 55-09A, p. 2816)

9458. G. J. Reydams-Schils, 'Stoicized Readings of Plato's Timaeus in Philo of Alexandria', in E. H. Lovering, JR. (ed.), Society of Biblical Literature 1994 Seminar Papers, SBLSPS 33 (Atlanta 1994) $450-462$.

See the summary of the revised version of this paper below at $\mathbf{9 5 6 6}$.

9459. C. Riedweg, Ps.Justin (Markell von Ankyra?) Ad Graecos de vera religione (bisher Cohortatio ad Graecos). Einleitung und Kommentar, 2 volumes, Schweizerische Beiträge zur Altertumswissenschaft 25 (Basel 1994), passim.

The Christian author of this pseudonymous apologetic work names Philo three times and cites his De vita Moysis. A brief section of Riedweg's magnificent study is devoted to a specific discussion of this usage (pp. 145-147). But elsewhere in the introduction and throughout the extensive commentary he also makes copious use of other relevant Philonic evidence, especially in relation to the author's philosophical background (see passages listed on pp. 684-685). A chance find via searches of the TLG led Riedweg to make a tentative identification of the author with the 4th century bishop Marcellus of Ancyra. If this hypothesis can be accepted, it sheds new light on the dissemination of Philo's works in the 4th century. (DTR)

9460. G. Rösel, Übersetzung als Vollendung der Auslegung: Studien zur Genesis-Septuaginta, Beihefte zur Zeitschrift für die alttestamentliche Wissenschaft 223 (Berlin-New York 1994). 
German translation of Gen 1-11 with commentary. According to the index the author makes limited use of the Philonic evidence. He detects in the Greek version the same understanding of the double creation-story as in Plato's Timaeus and in Philo. The translation itself is located in a Jewish school in Alexandria which is also attested by Philo (p. 258). (DZ)

9461. D. T. Runia, 'Philonic Nomenclature', The Studia Philonica Annual 6 (1994) 1-27.

A commonplace of modern Philonic scholarship is that Philo is known under two titles, Philo Alexandrinus (or Philo of Alexandria) and Philo Judaeus (or Philo the Jew). But what was the situation in antiquity? The article first discusses Philo's name and those other men with the same name who achieved prominence (about 15). A list is then given of all the passages in ancient literature up to the year 1000 in which Philo is described or given a title (these are, except Josephus, exclusively Christian). The references are then analysed under 9 headings: Philo a man of learning, Philo as historian, Philo the philosopher, Philo the exegete, Philo the Hebrew, Philo the Jew, Philo the Israelite, Philo the Bishop, Philo the Alexandrian. On the basis of this evidence 6 conclusions are drawn of which we mention the following: (1) the titles and descriptions used concentrate on his learning and his Jewish descent; (2) of the two titles used for his Jewish descent Hebraios is clearly dominant until the 4th century, but thereafter Ioudaios takes over; (3) his Alexandrian origin is almost never emphasized. The article ends with some comparisons between ancient and modern nomenclature used to describe Philo. (DTR)

9462. D. T. Runia, 'Philo in a Single Volume', The Studia Philonica Annual 6 (1994) 171-182.

A review article discussing the translation of Philo by C. D. Yonge in the Bohn Classical Library, first published in 1854-55 and now reprinted in a single volume (see 2113). The translation is analysed and found wanting. Moreover the volume does not contain the complete Philo. The author concludes that it should only be used for purposes of consultation, and not for the furtherance of scholarship. The article ends with some musings on what the ideal Philo in a single volume would be and whether this ideal can be achieved. (DTR)

9463. G. Schimanowski, “'Abgrenzung und Identitätsfindung”: Paulinische Paränese im 1 Thessalonicherbrief', in R. FELdmeIER and U. Heckel (edd.), Die Heiden, Juden, Christen und das Problem des Fremden, WUNT 70 (Tübingen 1994) 296-316, esp. 306-309.

In his analysis of 1 Thess. 4 the author focuses especially on v. 11f. The exhortation to 'keep quiet' is not motivated by the eschatological enthusiasm of the community; it does not urge abstinence from public affairs, as in popular philosophy, but rest on the Sabbath. This is demonstrated by Philo's use of the terms $\dot{\eta} \sigma u \chi \alpha \dot{\zeta} \varepsilon ı v, \dot{\eta} \sigma v \chi i \alpha$. (DZ) 
9464. F. Schmidt, 'Between Jewish and Greeks: the Indian Model', in H. Goodman (ed.), Between Jerusalem and Benares (Albany NY 1994) 41-53, 285-8.

The theme of this article is how India was perceived by the Jewish writers. The author discusses some passages from Prob., in which Philo speaks about Indian gymnosophists (Prob. 93-96, 73-75). In his description Philo largely relies on information supplied by Megasthenes. For both Philo and Josephus the Indian gymnosophists are comparable with the Essenes in their resistance to acculturation. Earlier published under the French title 'Entre Juifs et Grecs: Le Modèle Indien', in C. Weinberger-Thomas (ed.), Collection Purusartha II: L'Inde et l'imaginaire (Paris 1988) 9-31. (ACG)

9465. F. Siegert, 'Die Heiden in der pseudo-philonischen Predigt De Jona', in R. Feldmeier and U. Heckel (edd.), Die Heiden, Juden, Christen und das Problem des Fremden, WUNT 70 (Tübingen 1994) 52-58.

Siegert suggests as Sitz im Leben of this pseudo-Philonic sermon (on which see further 9281) the final lecture in the afternoon-office of the Day of Atonement. He reports on the author's view of gentiles and of God's friendliness towards them. Following Stoic ideas they should use the gift of thought in a kind of natural religiosity. In this way the author encourages his listeners to be open-minded towards people of other faith. (DZ)

9466. M. SimonetTi, Biblical Interpretation in the Early Church: an Historical Introduction to Patristic Exegesis (Edinburgh 1994).

English translation of the Italian edition published in 1981 and abstracted in R-R 8127. (ACG)

9467. D. Sty, 'The Plight of Woman: Philo's Blind Spot?', in W. Helleman (ed.), Hellenization Revisited: Shaping a Christian Response within the Greco-Roman World (Lanham 1994) 173-188.

The author gives a brief characterization of the way Philo depicts women. In Philo's writings the gender distinction is ubiquitous: 'masculine' is conceived as strong, virtuous and active, whereas what is weak, emotional and passive is designated as 'feminine'. Philo lays great emphasis on the status of virginity, which denotes the absence of 'feminine' passion. In general it can be said that he classifies women in three groups: the best class consists of virgins; the second best is controlled by men, while the lowest status is accorded to those women who are uncontrolled. The author concludes that Philo's view on women is wholly in accord with the presuppositions of his environment. (ACG) 
9468. H. J. Spierenburg, H. P. Blavatsky: On the Gnostics (San Diego 1994), esp. 40-50.

Part of a series of reference works on the writings of H. P. Blavatsky. It emerges that she made numerous references to the Essenes and Therapeutae in her works and also some direct references to Philo himself. See the list of passages on p. 300. (DTR)

9469. C. Stead, Philosophy in Christian Antiquity (Cambridge 1994), esp. 56-62.

A brief outline of the more important themes of Philonic thought in the context of a survey of Patristic philosophical ideas. (DTR)

9470. A. Terian, 'Had the Works of Philo been newly Discovered', The Biblical Archaeologist 57 (1994) 86-97.

In this paper the author berates the scholarly neglect of Philo's work due to the discovery of the Dead Sea Scrolls and the Nag Hammadi library. Contributing to this neglect was also the fact that a quarter of Philo's auvre survives in an Armenian translation. Terian emphasizes the value of the Armenian works and invites scholars to learn Armenian and to devote themselves to the study of the Armenian Philo. He remarks that Philonic passages can shed light on texts from the New Testament. The article ends with the prediction that the next phase of scholarly interest after Qumran and Nag Hammadi will be Philo. (ACG)

9471. A. Terian, 'Notes on the Transmission of the Philonic Corpus', The Studia Philonica Annual 6 (1994) 91-95.

In response to D. T. Runia's monograph on Philo in the early Christian tradition (9373) Terian emphasizes how broad and deep Philo's influence on the Fathers was and suggests topics for further research. (DTR)

9472. H. Tronier, 'Om engle og den sunde fornuft - angelus interpres og Logos [In Danish: On angels and common sense: the angelus interpres and the Logos]', in N. P. LEMCHE and M. MüLler (edd.), Fra dybet. [In Danish: Out of the Depths] Festskrift til John Strange, Forum for Bibelsk Exegese 5 (Copenhagen 1994) 253-273.

The article compares the epistemological contents of the Philonic idea of the Logos with the interpretative function of the angelus interpres in 1 Enoch. The Logos in Philo is the principle of creation and thus has an objective function. The universe is structured like a pyramid of ontological levels, which correspond to different conceptual levels. The most comprehensive of all concepts, the Logos, has divided all concepts into sub-concepts 
(diairesis). But the Logos also has a subjective function in revealing the transcendent conceptual structure of the empirical world to the rational mind through noetic vision, resulting in a transformation of human knowledge. Thus the objective and the subjective functions of the Logos are identical. The transformation of human knowledge results in a transformation of the evaluation of the world. Having been experienced as hostile and unfamiliar, the world will now be felt as a familiar and a good place in which to exist. The angelus interpres of 1 Enoch is understood as a mythologized version of the Logos. Both ideas have similar functions. But the authors differ in their understanding of the transcendent. For Philo transcendence is a conceptual reality which forms an aspect of the empirical world, whereas the transcendent world in 1 Enoch is understood in concrete and spatial terms. The author is of the opinion that this apocalyptic view presupposes the Hellenistic conceptual understanding of the transcendent. (KGS)

9473. H. Tronier, Transcendens og Transformation i Første Korintherbrev [In Danish: Transcendence and Transformation in the First Letter to the Corinthians], Tekst og Tolkning 10 (Copenhagen 1994), esp. 9-37.

The book investigates the relationship between the description of empirical reality and the structure of Paul's hermeneutics in 1 Cor. As a point of departure the author presents the diaeretical method used by Philo in his interpretation of the world and the scripture (cf. 9472 and 9382). The subject matter is treated under the following headings: (a) the epistemological dualism; (b) the diaeretical hermeneutics; (c) the allegorical method; (d) the concept of the transcendent; (e) the hermeneutical resonance and the transformation of values; (f) the static-paradigmatic interpretation of history; ( $g$ ) Israel (and the Jews) as an interpreting community. According to the author close affinities exist in the hermeneutical procedures of Philo and Paul, the basic difference being the understanding of the transcendent. Whereas transcendence for Philo is a conceptual aspect of the world, it is a spatial extension of the visible world for Paul (cf. apocalyptic writings like 1 Enoch). (KGS)

9474. N. Umemoтo, 'Juden, „Heiden“ und das Menschengeschlecht in der Sicht Philons von Alexandria', in R. Feldmeier and U. Heckel (edd.), Die Heiden: Juden, Christen und das Problem des Fremden, WUNT 70 (Tübingen 1994) 22-51.

In this short version of a yet unpublished research project the author starts with lexical remarks: $\tau \grave{\alpha} \varepsilon^{\prime} \theta v \eta$ in Philo is not a technical term for 'pagans'. The main part of the paper consists of a thematic collection of passages, irrespective of their biblical context and the literary genre of Philo's writings. Umemoto reports on Philo's attitude to non-Jewish peoples and the function of the Jewish people for the rest of mankind. Philo is not interested in the antagonism between Jews and gentiles, but sees Israel as representing 
the destiny of mankind, visible already in Adam. He devalues consanguinity as opposed to the relationship with God and wants to win a new universal identity for the Jews, i.e. their vicarious priestly service for the whole world. The reason for this is the love of God directed to all men. (DZ)

9475. S.-K. WAN, 'Charismatic Exegesis: Philo and Paul Compared’, The Studia Philonica Annual 6 (1994) 54-82.

Wan first introduces the concept of charismatic exegesis, which has been especially connected with Qumran, but also with the Zealots and Josephus. The definition of such exegesis as 'inspired eschatological commentary' (Aune) is, however, too narrow. Wan wishes to broaden it and examine its value in the study of Philo and Paul. The chief question he poses is how scripture functions in their personal ecstatic experiences and vice versa. First four passages in the Philonic corpus are examined in which Philo speaks of his own experience: Migr. 34-35, Spec. 3.1-6, Somn. 2.250-254, Cher. 27-28. The experience of exegetical inspiration recounted in the last-named passage is unique in the corpus, but there are reasons to suspect that it may have been more common. In the case of Paul Wan concentrates on 2 Corinthians 3:1 to 4:6, where, it is concluded, Paul argues that scripture should be read in the light of one's mystical experience. In his conclusion Wan states that for both Philo and Paul there are two different forms of appeal, the mystical and the textual, and these constitute two loci of authority. In the case of Philo there is no evidence that they are in conflict with each other; for Paul, however, the situation is radically different, because espousing both forms of authority together brings him into sharp conflict with his fellow missionaries. Ultimately the conflict between these two types of authority has to be resolved by institutional control, as takes place both in Qumran and in the later Pauline communities. (DTR)

\section{S. Weitzman, 'The Song of Abraham', Hebrew Union College Annual 65 (1994) 21-33.}

Recently the view has emerged that scriptural interpretation played an important role in the origins of Jewish apocalyptic literature. In this context the author discusses the song of Abraham in the Apocalypse of Abraham. He suggests that the presentation of Abraham having sung a song is determined by an interpretative tradition of the final words of Gen. 14 already established in the Second Temple Period. This tradition is also seen in Philo, Ebr. 105-107, where the Jewish exegete represents Abraham 'as raising the hymn of thanksgiving', associating it with Gen. 14:22. The Philonic connection of Gen. 14:22 with a song sung by Abraham is paralleled in rabbinic exegesis. This interpretation is inferred from the words ' $I$ have raised my hands'. The conception of these words as referring to singing an song rather than to swearing an oath results from an anti-oath posture. The same posture is also reflected in Philo, for instance in Leg. 3.207. (ACG) 
9477. R. L. Wilken, 'Philo in the Fourth Century', The Studia Philonica Annual 6 (1994) 100-102.

Wilken responds to D. T. Runia's monograph on Philo in the early Christian tradition (9373), concentrating his remarks on the theme of 4th century biblical interpretation. In the author's view the contrast between Alexandrian and Antiochene schools of exegesis as presented in the monograph is a chimera and gives a wrong impression of the reception of Philo in the early church. (DTR)

9478. N. G. Wilson, Photius The Bibliotheca, (London 1994), esp. 122-123.

We mention the brief discussion of Photius' chapters devoted to Philo (103-105) because of the paucity of scholarly literature devoted to them. (DTR)

9479. D. Winston, 'Philo's Nachleben in Judaism', The Studia Philonica Annual 6 (1994) 103-110.

Taking as his starting-point D. T. Runia's monograph on Philo in the early Christian tradition (9373), Winston adds valuable remarks on the fate of Philo's writings in Jewish tradition. Authors mentioned are various rabbis, Jacob Qirqisani, Saadia and Flavius Mithridates. (DTR)

9480. A. Wolters, 'Creatio ex Nihilo in Philo', in W. Helleman (ed.), Hellenization Revisited: Shaping a Christian Response within the Greco-Roman World (Lanham 1994) 107-124.

The article on the theme of creatio ex nihilo in Philo is divided into four sections. The author begins by giving a definition of creatio ex nihilo and indicating the importance of the subject. Next he describes the different positions of scholars, among whom the view of Wolfson has been very influential. In the third section Wolters scrutinises the arguments of Wolfson and Winston, who agree with each other that for Philo God created from pre-existent matter. But they disagree on the question how this pre-existent matter owes its existence to God. The author ends with some concluding observations. Because Philo wants to make a synthesis between two different views, namely the biblical view of creatio ex nihilo and the Platonic view of creation from preexistent matter, we cannot find a harmonious overall conception in his cosmology. Inconsistencies are the result of a fundamental tension between Plato and Moses. If creatio ex nihilo is defined as 'God's causing the world to exist without the benefit of an already existing material', then it is clear that it is not met with in Philo. The doctrine itself is a later formulation, forged in the polemical context of the confrontation between the Hellenic and biblical traditions. (ACG) 


\section{5}

9501. Y. Amir, 'La letteratura giudeo-ellenistica: la versione dei LXX, Filone e Giuseppe Flavio', in S. J. SIERRA (ed.), La lettura ebraica delle scritture, La Bibbia nella storia 18 (Bologna 1995, 1996 ${ }^{2}$ ) 31-58.

Philo's testimony on the translation of the LXX adds an important and discordant note in relation to the account in Pseudo-Aristeas, namely that all the translators, though operating separately, produced an identical version as the result of divine inspiration. From this statement many scholars have deduced that Philo did not know Hebrew and based his interpretation solely on the Greek version. For Philo the words of the Bible are 'the words of Moses' (p. 42), but Moses speaks under divine inspiration and in that sense he was a prophet. Moses does not confine himself, however, in his role as legislator to revealing a series of laws of universal validity, but he also indicates the deeper significance of these rules as is brought to light in allegorical exegesis, and for this reason he is also a philosopher. Amir also discusses the sources of Philo's allegorical method, which are at least partly inspired by the allegorization of Greek myth (p. 49). (RR)

9502. M. Azkoul, St. Gregory of Nyssa and the Tradition of the Fathers, Texts and Studies in Religion 63 (Lewiston 1995), esp. 103137.

In this study a chapter is devoted to the thought of Philo and Gregory of Nyssa on Logos and creation. The author rejects the view that John's Logos has a Philonic origin. Rather, the Logos in Philo and the Christian Logos are anti-types, and Gregory's exegesis of the prologue to the Gospel of John may be regarded as an attack on Philo's conception. In his exegesis Philo uses the method of allegory to uncover the truths taught by Moses. He did not use typology, which is favoured by the Church fathers. There are major differences between Philo and Gregory regarding their cosmology. In Gregory's view Adam, the first man, made in the image of God, is a type of Christ. The cause of the Fall lies in the human choice for evil. Philo places the origin of evil in the passions, rooted in the flesh. For Gregory, the paradise and the Fall are historical facts, for Philo not. In contrast to Philo, Gregory has an eschatological vision: man will return to the blessed state from which he has fallen. Philo and Gregory also have a different conception of the Logos. For Philo, although he uses terms familiar for Christians, the Logos is neither a Person, nor the Incarnated Logos, nor God's son. The author concludes that 'St Gregory of Nyssa and Philo of Alexandria believed and lived and ratiocinated in two different realities. (p. 130)' (ACG)

9503. W. R. BAKER, Personal Speech-ethics in the Epistle of James, WUNT 2.68 (Tübingen 1995), esp. 69-74, 120-121, 168-170, 214218, 271-274. 
By the term personal speech-ethics in the title of this study the author means ethics as applied to inter-personal communication. The book is divided into five parts, each of which deals with a section of the Epistle of James. In each part Philo's view on the aspect in question is shortly presented. Regarding the theme of the rudiments of speech-ethics Philo thinks that control of speech is an important aspect of self-restraint. One should be silent at the right time as well as speak at the right time. Philo despises listening to professional orators. Repeatedly he stresses the notion that one's words and deeds should be in harmony with each other. Like James he conceives of the tongue as tending towards evil. In society speech benefits both oneself and the other. One should, however, dedicate one's speech, soul, and senses to God. In the human-divine relationship an important place is occupied by the worship and praise of God. The last part of the study deals with the relationship between speech and truth. For Philo God and truth are closely intertwined: God is the true God, who is also free from falsehood. (ACG)

9504. P. J. BEKKEN, 'Paul's Use of Deut. 30:12-14 in Jewish Context', in P. Borgen and S. Giversen (edd.), The New Testament and Hellenistic Judaism (Aarhus 1995) 183-204.

In Romans 10 Paul cites Deuteronomy 30 using the method of exegetical paraphrase in which a series of (partial) quotations are altered by interpretative clauses. This same method was applied by Philo in Praem. 80 and Virt. 183. There are some formal points of agreement, for instance the use of

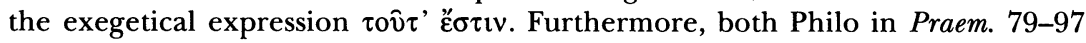
and Paul in Rom. 10 interpret Deut. 30 in an eschatological perspective within the framework of the principle of the Law. For Paul, in contrast to Philo, the Law was abolished through the coming of Christ. (ACG)

9505. R. M. Berchmann, 'Arcana Mundi: Prophecy and Divination in the Vita Mosis of Philo of Alexandria', The Ancient World 26 (1995) 150-79.

The focus of the study is on 'hyparic' prophecy and divination (i.e. by day, in a waking state). The first half of the article gives an extensive account of these phenomena in Greek culture from Homer to Plutarch. Philo sides with the tradition, represented by the Asclepiads, the Stoa and the Academy, which regard these as giving access to the divine, as opposed to the more sceptical attitude of Aristotle, Democritus and the Hippocrateans. In the second half of the article the author discusses Philo's own views as they are found in the treatise on the life of Moses. The biblical text furnishes him with much data, but he in many cases explains them with reference to Stoic and Platonic topoi. Of great significance is his linkage of prophecy with intellection, which entails a rejection of the stigma of irrationality argued for by some philosophers. Jewish prophecy is superior to Greek and barbarian varieties, and is not esoteric. 'Hellenistic prophetic and divinatory theory ... are valuable tools for Philo's intentions. Its use permits Philo to lift the Pentateuch out of the arcana mundi to which it was consigned. (p. 179)' (DTR) 
9506. R. M. Berchmann, 'The Categories of Being in Middle Platonism: Philo, Clement, and Origen of Alexandria', in J. P. Kenney (ed.), The School of Moses: Studies in Philo and Hellenistic Religion in Memory of Horst R. Moehring, BJS 304 [= Studia Philonica Monograph Series 1] (Atlanta 1995) 98-140, esp. 115-119.

In the first part of the article Berchmann gives a brief account of the history of the categories in early Middle Platonism, with emphasis on the contribution of Eudorus and the evidence in Seneca. He then analyses the theory of the categories in the Alexandrian thinkers Philo, Clement and Origen. A distinction is made between apophatic and kataphatic metaphysics in order to show how the various approaches relate to each other. Philo's category theory is typified as apophatic-kataphatic, and differs from the strict apophaticism of ps.Archytas and the rigorous kataphaticism of Antiochus of Ascalon. Berchmann concludes that the theory of the categories represents a valuable tool for interpreting a constellation of problems that dominated later Platonic metaphysics. (DTR)

9507. S. Bhattacharyya, Philo of Alexandria: his Perspectives on Human Life and Taking Human Life (M.A. thesis University of Virginia 1995).

We have not gained access to a summary of this thesis. (DTR)

9508. E. Birnbaum, 'What Does Philo Mean by 'Seeing God': some Methodological Considerations', in E. H. Lovering, JR. (ed.), Society of Biblical Literature 1995 Seminar Papers, SBLSPS 34 (Atlanta 1995) 535-552.

Before dealing with the main theme of the article, Birnbaum sets out her assumptions on the Jewish thinker. In her view Philo is first and foremost an exegete of scripture. His different exegetical series have different purposes and aims. Further, it is important to take into account Philo's intellectual background. Turning to Philo's ideas about seeing God, she first makes some general remarks, namely that God is seen by the eyes of the soul, and that this is a goal that can be attained at one's lifetime. In interpreting Israel as one that sees God, Philo follows a traditional Hebrew explanation. But Platonic influence can be discerned as well. On the basis of two passages ( $Q G 4.2$ and Her. 68-85) Birnbaum shows that it is important to bear in mind the biblical verses Philo interprets. She ends the article with a list of factors that may have influenced Philo's discussion of seeing God, among which are the exegetical context, the different pre-Philonic traditions, and the thematic context of a treatise. (ACG)

9509. G. Boccaccini, 'The Preexistence of the Torah: a Commonplace in Second Temple Judaism, or a Later Rabbinic Development?', Henoch 17 (1995) 329-350, esp. 333-338. 
Philo cannot be used as evidence for the presence of the theme of the preexistence of the Torah in Second Temple Judaism. Moreover no links can be made between his writings and Rabbinic literature, where the theme is found. (DTR)

9510. M. Bоскмuerl, 'Natural law in Second Temple Judaism', Vetus Testamentum 45 (1995) 17-44, esp. 39-42.

Both Philo and Josephus are included in a wide-ranging discussion of natural law (by which the author means prescripts for ethical behaviour that are derived from nature). Philo follows Stoic thought in his presentation of the universe as a polis constituted by the law of nature. This law of nature always remains the divine law of creation. The written laws are copies of it. But apart from the written laws, there are also unwritten laws, of which the patriarchs are embodiments. The various commandments of the Decalogue and specialized laws are included in the law of nature. The author disagrees with the thesis of $\mathrm{H}$. Koester that Philo is the inventor of the theory of natural law. One of the general conclusions of the author is that in Second Temple Judaism natural law always has its origin in God. The law of nature is in keeping with the law of God and vica versa. (ACG)

9511. P. Borgen, 'Man's Sovereignty over Animals and Nature according to Philo of Alexandria', in T. Fornberg and D. HellHolm (edd.), Texts and Contexts: Biblical Texts in their Textual and Situational Contexts: Essays in Honor of Lars Hartman (Oslo etc. 1995) 369-389.

This wide-ranging article contains the following subheadings, which give an indication of the ground it covers: 1. The problem of Method; 2. The Interpretation of Gen. 1:26-28 in Opif. 83-84; 3. The Actual Sovereignty; 4. Jewish Criteria in a 'Greek' Debate; 5. Dominion over the Created World in General; 6. Greed, Idolatry and Vices Now; 7. Conditioned Eschatological Realization; 8. Cosmos, Humanity and Israel; 9. Conclusion. Borgen argues that the interpreter of Philo's writings should take into account their organization into larger groups. This article concentrates on The Exposition of the Laws of Moses, which contains both Opif. and Praem. Within the context of a cosmic framework Philo finds room for both the protological and eschatological perspectives on the topic of man's sovereignty over animals and nature. The place of the topic of man's domination over creation in Philo's thought is thus by no means peripheral. (KGS)

9512. P. Borgen, 'Mennesket som forvalter over naturen ifølge Filon fra Aleksandria: Noen observasjoner med utgangspunkt i Filons tolkning av Gen 1:28 [In Norwegian: Man as the keeper of nature according to Philo of Alexandria: Some observations with reference to Philo's interpretation of Genesis 1:28]', in J. BLOMQUIST 
(ed.), Människan och naturen: Rapport från Platonsällskapets tolfte symposium (Lund 4-7 juni 1993) [In Swedish: Man and Nature. Report from the Twelfth Symposion of the Plato Society (Lund, 4th-7th of June, 1993)] (Lund 1995) 62-82.

An earlier Norwegian version of 9511 with an English summary.

9513. P. Borgen, 'Some Hebrew and Pagan Features in Philo's and Paul's Interpretation of Hagar and Ishmael', in P. BORGEN and S. Giversen (edd.), The New Testament and Hellenistic Judaism (Aarhus 1995) 151-164.

Borgen asks how Paul's exegesis of the story of Abraham, Sarah, Hagar, Ishmael and Isaac (Gal. 4:21-31) can serve as an argument against the Judaizers in Galatia. By means of a comparison with Philo's treatment of the Biblical characters mentioned (esp. Abr. 247-53), he sees the figures of Hagar and her offspring in Paul's text as representatives of proselytes. In Philo Hagar is a pagan woman who has become 'Hebrew by choice and by way of life', i.e. a proselyte. Borgen postulates a similar thought in Paul: the Judaizers made proselytes out of the Christian converts with the obligation to follow the laws of Moses. The difference between Philo and Paul is that whereas the former saw Hebrew life as freedom, for Paul it was slavery. (KGS)

9514. P. Borgen and S. Giversen (edd.), The New Testament and Hellenistic Judaism (Aarhus 1995); American edition: Peabody MA 1997.

Proceedings of a conference held at the University of Aarhus in 1992. Three contributions specifically deal with Philo (see 9504,9513 and 9571), while several others touch on him when discussing characteristics of Hellenistic Judaism (cf. 9589). Review: D. T. Runia, SPhA 8 (1996) 210-212. (DTR)

9515. F. Calabi, 'Il cibo dell'anima in Filone alessandrino', in O. Longo and P. ScarPI (edd.), Nel nome del pane: regimi, miti e pratiche dell'alimentazione nelle civiltà del Mediterraneo: Atti del convegno Nel nome del pane, Bolzano 3-6 giugno 1993, Homo edens 4 (Bolzano 1995) $421-430$.

The article analyses the fields of reference of the term for food in Philo,

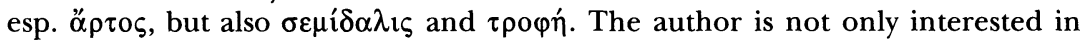
their semantic diversity, but also their transposition from the literal meaning in the biblical text into an allegorical key. Themes that arise are the relation between God and man, the proximity of material and spiritual food, and the establishment of the relation between human and divine logos. In various Philonic texts bread assumes a negative connotation, because it symbolizes sensations and passions which distance the soul from God. But the 
majority of texts are more positive. Simple food is opposed to what is superfluous, vehicle for approach to God, symbol of teaching. Because of Philo's commitment to allegory, quite a few texts are given a symbolic interpretation when a literal one would also have been quite suitable. The article ends with a brief glance at interpretations of the same passages in later Jewish interpreters such as Ibn Ezra, Rashi and Ramban. (RR)

9516. D. Carabine, The Unknown God: Negative Theology in the Platonic Tradition: Plato to Eriugena, Louvain Theological and Pastoral Monographs 19 (Leuven-Grand Rapids 1995), esp. 191-222.

In this monograph, which deals with the tradition of negative theology from Plato to Eriugena, a chapter is devoted to Philo. The author first sets out the scriptural background of Philo's thoughts. From the Old Testament a deus absconditus appears, a God who is hidden but reveals himself. Symbol of God's hidden nature is darkness, e.g. in Ps. 18:11. According to Carabine, 'an apophatic attitude is at the heart of God's self-revelation in the OT' (p. 201). In his description of God Philo relies, on the one hand, on the OT texts, but, on the other, he borrows much from the Platonist tradition. The foundational text for Philo's negative theology is Num. 23:19 'God is not as a man'. God cannot be likened to anything in the created world, and $\mathrm{He}$ is the transcendent source of all being. God is the unnameable, based on Ex. 3:14, which, in Philo's view, means: 'My nature is to be, not to be spoken'. If God is unnameable, $\mathrm{He}$ is also inconceivable and incomprehensible. The human mind can only know that God exists, but not what He is. Knowledge of God's ov $\sigma i$ í is impossible. The author concludes that Philo does not have a systematically developed theory of negative theology. His theology is a mixture of positive and negative statements on God; a mixture that is characteristic of the Middle Platonists. Yet, despite the many Platonist elements in it, his theology is firmly based on scripture. (ACG)

9517. C. M. Carmichael, 'The Marriage at Cana of Galilee', in J. Davies et al. (edd.), Words Remembered, JSOT.S 195 (Sheffield 1995) 310-320.

The author discusses the story of the wedding and the miracle at Cana in the Gospel of John in the light of the creation story of the third day. Jesus' use of water to produce wine is equivalent of the union of earth and water on day three of creation. Comparison with Philo's Opif. is an important part of the argument, because Carmichael sees significant parallels in the way both authors make use of the creation account. See also 9263. (ACG)

9518. J. Cazeaux, “Nul n'est prophète en son pays': Contribution à l'étude de Joseph d'après Philon', in J. P. Kenney (ed.), The School of Moses: Studies in Philo and Hellenistic Religion in Memory of Horst $R$. Moehring, BJS 304 (= Studia Philonica Monograph Series 1) (Atlanta 1995) 41-81. 
The three grand figures of politics in Philo are Abraham, Joseph, Moses. In a dialectical fashion they are placed around a moral axis formed by two infernal regions, Mesopotamia and Egypt. Abraham and Moses remove themselves and their families from these evil lands. In between the two heroes Joseph descends into Egypt, lives there and even plays a considerable role in government. He embodies the 'temptation of politics'. After dealing with Abraham as a 'king without a kingdom', the author presents a plan of the treatise De Iosepho, followed by an analysis, in which it emerges that it moves from politics (first part) to the essential value of 'fraternity' (second part). Philo's aim, which conforms to the intention of the original biblical story, is the spiritual reconciliation of the sons of Israel. The allegory of the first part, which discredits politics, is pessimistic. The second part, in which wisdom replaces allegory, is optimistic. The work thus begins with allegory and ends with wisdom, moving from criticism of politics to celebration of brotherhood. Cazeau also deals with specific allegorical themes. The ideal of

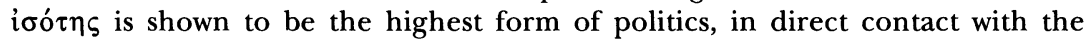
law of nature, which on earth is associated with Israel. Joseph's use of prophecy in Egypt reveals his quality as Hebrew. Ios. does not give an encomium of Joseph, but of Israel through Joseph or even despite him. In Somn. 2 the perspective is different: Joseph's dreams in the territory of Israel introduce the Egyptian tendency in Israel, whereas in Egypt he introduces the Jewish way of thinking. Hence the title of the contribution: "no one is a prophet in his own country'. This very rich article concludes with a reading of Mos. 1.150-162 and a survey of the four books of Spec. (JR)

\section{N. G. Cohen, 'Philo and Midrash', Judaism 44 (1995) 196- 207.}

A compact statement of the author's basic views on Philo and his place in the Jewish world of his day, as worked out in much more detail in the monograph summarized in the following item. It is wrong to see a sharp divide between Palestinian and Alexandrian and between Hebrew-speaking and Greek-speaking Judaism. There was considerable interaction between the two, from which Philo profited. The preferred medium of study of scripture was Midrash, which in Philo's works becomes homiletic hermeneutics and was quite compatible with his aim to translate Jewish truths in the language of Greek philosophy. In short Philo should be seen as 'a distinguished representative of the contemporary Alexandrian version of 'normative Judaism' and in spite of the language in which they are written, his works belong well within the scope of traditional midrashic study' (p. 204). (DTR)

\section{N. G. Cohen, Philo Judaeus: his Universe of Discourse, Beiträge zur Erforschung des Alten Testaments und des Antiken Judentums 24 (Frankfurt etc. 1995).}

This monograph represents the most thorough-going attempt in recent years to locate Philo's thought in a Jewish context that extends well beyond the confines of Hellenistic Judaism. She argues that Philo presents evidence of a common underlying Palestinian/Alexandrian midrashic tradition 
which is both haggadic and halachic in character. The chief focus of the book is the passage Spec. 4.133-150, which allows the author to discuss diverse aspects of Philo's Judaism and its relation to Greek thought. The following themes may be mentioned: the role of the Decalogue as a framework for Jewish Law; the relation between Jewish observance of the law and the Greek conception of virtue; the interpretation of $\delta ı \alpha \_$iovv $\eta$; the Shema in Philo; Philo's vocabulary as a synthesis of Greek and Jewish ideas; Philo's curriculum of study; Philo's conception of ancestral tradition and the relationship of the 'unwritten law' to the Greek conception of the law of nature. Cohen concludes that 'the Philonic agraphos nomos and its synonyms ... and the rabbinic 'Oral Law' ... indicate the same body of tradition, which was already clearly identifiable in Philo's day, and it was this body of tradition which was in the course of time sifted and codified by the Sages (p. 284).' This common background has been overlooked by scholars who are insufficiently rooted in traditional Jewish culture. Philo thus should be read in terms of the Septuagint and against the background of traditional Jewish mores and midrashic lore. In fact Philo's writings represent one of the earliest midrashic works. The combination of this background with Philo's herculean attempt to assign the highest Greek philosophical value to what he considered important in Judaism is what fostered his creative ability. Reviews: R. Vicent, Sales 57 (1995) 763-764; E. Birnbaum, SPhA 8 (1996) 189-196; K. S. Füglseth, JSJ 27 (1996) 338-342; D. Winston, JQR 86 (1996) 510-515; P. W. van der Horst, NTT 51 (1997) 243-244; W. S. Wurzburger, Tradition 31 (1997) 83-84. (DTR)

\section{P. Daubercies, 'La vertu chez Philon d'Alexandrie', Revue Theologique de Louvain 26 (1995) 185-210.}

After remarking that Her. 241 is the only text where Philo expatiates on the word $\dot{\alpha} \rho \varepsilon \tau \eta$ itself and after determining the relations between virtue and the movements of the soul (I), the author examines the places where virtue resides in relation to the theological order adopted by J. Daniélou (God, Powers, Logos, angels, man) (II). He then determines who shares in virtue (III), and discusses the point of view which Philo finds most important (IV), i.e. the perspective of the human soul in different situations in conformity to God. This leads him to propose the following definition: 'Virtue is everything which, from nearby to far away, is in conformity with God'. 'Everything' here includes attitude, movement of the soul, action. At the end of his investigation Daubercies lists a number of easily identifiable themes: the flight from the sense-perceptible and the body, the assimilation to the divine from Plato's Theaetetus (cf. Fug. 63, 82), the tension of the soul (cf. Det. 168, Praem. 172). But these are all reinterpreted in a context in which moral virtue receives a strictly religious significance. Its source and driving force is God or the Logos. It is the imitation of this divine model which it seeks to attain. (JR)

9522. B. Decharneux, 'De l'Israël historique au judaïsme universel: histoire religieuse de l'annexation territoriale de l'univers', in La construction religieuse du territoire (Paris 1995) 55-65. 
Of all the Alexandrian Jews Philo is the one who advances the furthest in commenting on and allegorizing the sacred geography of Israel. His allegorical views on the temple are significant for the conception of the territory of Israel held by Jews in the diaspora. But Philo also develops his allegories in relation to the tabernacle carried in the desert, bringing together not only the teachings of the Torah, but also the cosmic symbolism which it represents. It is given a universality which goes beyond its pagan rivals. But this does not lead Philo to forget the temple made of stone in Jerusalem. The author discusses those passages in Flacc. and Legat. which dwell on Caligula's attempt to place his statue in the temple. Piety and justice triumph through divine pronoia. But the nucleus of Philo's position is that the religion of Israel is combined with philosophical religion and the laws ruling the cosmos. The temple and the holy land of Israel are places where the spirit blows, but are not strictly necessary for the practice of the Jewish religion. (JR)

9523. F. DeUtSCH, Quelques approches relatives au concept de $\varphi \imath \lambda \alpha v \tau i ́ \alpha$ chez Philon d'Alexandrie (Mémoire de D.E.A., Université de Poitiers 1995).

This thesis on the concept of self-love in Philo is a straight-forward presentation of a study that has subsequently been pursued further. The subject gives rise to a large number of questions and problems. The author attempts to respond to these, first by studying the sources which Philo could have used and the influences he could have undergone. Certain clues lead to Plato and more convincingly to Aristotle. The second part of the study is devoted to the significance of the concept in Philo's thought. What are the characteristics of the man who is marked by $\varphi \imath \lambda \alpha v \tau i \alpha$ ? What is its basis, and what are the reasons that lead the soul to adopt it? These questions lead to a discussion of the relations that exist between human nature and the world of senseperceptible reality. (JR)

9524. J. Dillon, 'Reclaiming the Heritage of Moses: Philo's Confrontation with Greek Philosophy', The Studia Philonica Annual 7 (1995) 108-123.

As part of a conference held at the University of Notre Dame in November 1994, Dillon presents some general thoughts on Philo's relation to Greek philosophy. He organizes his lecture around a set of three hermeneutical axes: (1) orthodoxy and eclecticism; (2) tradition and originality; (3) coherence and incoherence. These are then illustrated in the case of three topics which interest him: the createdness of the world, the role of the Logos, and the structure of the human soul. The discussion of these topics show how Philo can manoeuvre within the framework of contemporary philosophy (except Epicureanism), in the confidence that he is reclaiming the philosophical heritage of Moses. Trying to present a picture of Philo in the context of his contemporary scene is like piecing together the sherds of an Attic vase. There are plenty of gaps in our knowledge, but these do not prevent us from reconstructing a reasonably plausible picture. Reprinted in The Great Tradition: 
Further Studies in the Development of Platonism and Early Christianity (Aldershot 1997) essay IV. (DTR)

9525. K. G. Evans, 'Alexander the Alabarch: Roman and Jew', in E. H. Lovering, JR. (ed.), Society of Biblical Literature 1995 Seminar Papers, SBLSPS 34 (Atlanta 1995) 576-594.

The article presents the first comprehensive account of what we can know about Philo's brother, the famous Alabarch of Alexandria. It shows how his dual status as a Jew and a Roman citizen were inextricably entwined and jointly defined both him and his family. First the nature of the source material on Alexander and his family is examined. Then an account is given of what we know about his life. Evans continues with a discussion on his Roman citizenship, including a discussion of his name. It is argued in this connection that the text at Anim. 2 and 72, in which Lysimachus is said to be both Tiberius Julius Alexander's uncle and his nephew, can be accepted at face value. Briefer comments are also made about Alexander's status as a Jew and what this can tell us about the status of his brother Philo. (DTR)

9526. F. ó Fearghail, 'Philo and the Fathers: the Letter and the Spirit', in T. Finan and V. Twomey (edd.), Scriptural interpretation in the Fathers: Letter and Spirit (Dublin 1995) 39-59.

At the beginning of this article some remarks are made about Philo's background and his Alexandrian predecessors who also used allegorical exegesis. Next the author proceeds to the main subject of the article: Philo's allegorical and literal interpretation of scripture. The Jewish exegete, believing in the history of the biblical account, does not reject its literal meaning, but defends the observance of the Law. More important, however, is allegorical exegesis, which reveals the deeper meaning of the text. Many circumstances require an interpretation in allegorical terms, for instance, when a contradiction appears in the text, or when human characteristics are ascribed to God. Philo also allegorizes when he conceives the literal meaning as unworthy of the writer, or as unreasonable. Fearghail ends with a discussion of Philo's influence on the Church fathers. Clement of Alexandria was the first Christian writer to use Philo extensively, and he also borrowed allegorical interpretations from Philo. Origen and Gregory of Nyssa are also indebted to Philo in their allegorical exegesis. These authors christianized their borrowings from Philo. Among the Latin writers above all Ambrose is strongly influenced by Philo, adapting the Philonic material to his own circumstances. (ACG)

9527. S. FowL, 'Texts Don't Have Ideologies', Biblical Interpretation 3 (1995) 15-34, esp. 19-22.

It is the trend in 'ideological criticism' of the Bible to say that (biblical or any other) texts have ideologies, or have meanings, which means that an ideology or meaning is considered as a property of a text. Fowl argues here 
that this way of speaking confuses a wide range of issues concerning relationships between texts and the social practices which both generated those texts and are sustained by interpretations of particular texts. He illustrates this position by examining the very different ways in which the Abraham story is used by the book of Genesis, Philo, Paul, and Justin Martyr. As regards Philo, Fowl leans heavily on David Dawson's Allegorical Readers and Cultural Revision in Ancient Alexandria (9222) in order to sketch both Philo's allegorical interpretation of Abraham and his broader allegorical strategy, which is designed (as Dawson formulates it) to subordinate Hellenistic cultural ideals to scripture. (HMK)

9528. G. I. GARGANO, 'L'itinerario dell' «homo religiosus» in Filone d'Alessandria. Il superamento delle forme verso il mistero (Lumen Gentium 48)', Theologica E $\mathcal{F}^{2}$ Historica. Annali della pontificia facoltà teologica della Sardegna 4 (1995) 137-159.

The difference between the literal meaning and the deeper significance of the text which is revealed by allegory has a tradition which proceeds from the Stoics, e.g. in their treatment of the myth of Penelope and Odysseus, and reaches Philo (with his allegory of Abraham, Hagar and Sarah) and Paul, who uses the same Philonic method of allegory to illustrate the difference between the old and new dispensation. Gargano first analyses the most important texts for his subject (Cher. 1-10, Leg. 3.236-244). He emphasizes that for Philo exegesis is not must a mental and intellectual exercise, i.e. in relation to the interpreted object, but that it also involves a religious experience on the part of the subject, i.e. the exegete (see p. 155), which proceeds along the lines of a truly spiritual itinerary with a mystical goal that it can attain. (RR)

9529. P. von Gemünden, 'La culture des passions a l'époque du Nouveau Testament: une contribution théologique et psychologique', Études Theologiques et Religieuses 70 (1995) 335-348.

The author's approach is inspired by the studies of Norbert Elias, the precursor of historical psychology, and makes use of the categories proposed by A. Nitschke, who distinguishes three kinds of dynameis which he calls 'autodynamic', 'heterodynamic' and 'dynamic of transformation', in order to discuss the theme of the 'culture of passions' in 4 Maccabees, Philo and Paul. Some Philonic texts encourage the cultivation of the passions, while others express an antagonism against the passions. This coexistence is explained in Leg. 3.128-132, where Aaron is presented as a prokoptôn and Moses as a teleios sophos. Few men, such as Isaac and Moses, attain the state of apatheia, which is a gift of God. The remainder have to struggle in order to advance. Unlike in Stoicism, where the not-yet-perfect man has to struggle in an autodynamic manner, in Philo he is aided by God when he makes his effort to reach perfection. Philo thus tends to a heterodynamic solution, which might also be called 'theodynamic'. As for apatheia, it is only a preparatory act to the ecstasy of the soul in God, which can also be described as the descent of God towards man. (JR) 
9530. K. M. Girardet, 'Naturrecht und Naturgesetz: eine gerade Linie von Cicero zu Augustinus?', Rheinisches Museum 138 (1995) 266-298, esp. 292-298.

The question posed in the article's title is denied, because for Cicero the 'eternal law' in its content is determined by the concrete positive law, whereas for Augustine the unchangeable laws are placed above the changeable positive law as their source and measure. Part of the 'eternal law' is the 'law of nature', perceived in the unwritten Golden Rule and in the written Decalogue. Unravelling the pre-history of the Augustinian conception the author points to NT passages (Rom. 2:14f; Matt. 7:12, 22:36-40) and to Philo, who concretizes the 'law of nature' through the Decalogue without, however, distinguishing - as Augustine does-between an 'eternal' and a 'natural law'. Both Philo and Cicero were indebted to Antiochus of Ascalon, but developed similar ideas independently of each other. (DZ)

9531. M. González Fernández, 'El ideario Pirrónico en el Oriente Medieval (Presencia y Divulgación)', Agora-Papales de Filosofia (Spain) 14 (1995) 55-77.

The article studies the tradition of Pyrrhonism in its development from Alexandria to Islamic and Byzantine philosophy. In this development some Philonic passages occupy an important place, especially Ebr. 170-205, Somn. 1.21-34 and Ios. 125-147. (JPM)

9532. M. Goulder, 'Colossians and Barbelo', New Testament Studies 41 (1995) 601-619, esp. 608-611.

The author compares the 'Colossian heresy' with the Apocryphon of John, a gnostic document with Jewish roots. He explains the Pauline letter as an answer to gnostic elements in the Jewish-Christian counter-mission. This mission preached a myth that is comparable to the creation myth in Apoc. The author enumerates several parallels of thought between the Apoc. and Philo's exegesis of the creation account, for instance the distinction between two levels of world, and the androgyny of the heavenly man. It is emphasized, however, that this does not mean that Philo was a gnostic. (ACG)

9533. G. GRæShOLt, 'Jødisk tradition i den hellenistisk-romerske verden: Filon [In Danish: Jewish Tradition in the HellenisticRoman World: Philo]', in P. Bilde, T. Engberg-Pedersen, L. Hannestad AND J. Zahle (edd.), Jødedommen og hellenismen [In Danish: Judaism and Hellenism], Hellenismestudier 9 (Aarhus 1995) 13-25.

(1) Philo's attitude towards the Roman Empire is traditionally Jewish: world politics cannot be substantially influenced by small nations such as the Jewish one or its individual members. Consequently, Philo does not attack 
Roman rule as such, although he is critical towards certain persons who misuse their power like Caligula and Flaccus. (2) Philo's attitude towards Hellenistic culture is characterized by openness, but also by arrogance. Although the education offered by pagan society offers many advantages, it is nevertheless in Philo's view inferior to the Law of Moses, which is identical to the Law of the universe. (3) Philo welcomed a certain adjustment to Hellenistic culture but he detested assimilation. The various commandments of the Jewish law were to be rigorously kept and mixed marriages avoided. In sum, Philo was more Jew than Greek. (KGS)

9534. G. Granata, Introduzione allo studio del De vita Mosis di Filone Alessandrino (diss. Pisa 1995).

The structure of this doctoral dissertation is: Introduction; 1. Religious and political thought in Mos.; 2. Moses in Mos.; 3. Moses in Jewish sources; 4. Moses in the Philonic corpus. In her conclusion (163-168) the author summarizes her results. She disputes that the work is strongly indebted to Hellenistic models; in fact the Jewish dimension is strong. Apologetics and polemics are not strongly represented. The 'pagan world' is just one of the facts that the Jewish diaspora have to deal with. The choice of Moses is determined more by religious than political concerns. The author is sceptical about trying to determine differing audiences for Philo's various kinds of works: 'the particular characteristics of individual works does not help to locate them in relation to an external context, but merely to characterize the various aspects of the intellectual activity of a culturally complex and original personality (p. 168).' (DTR; based on a summary in Adamantius 2 (1996) 17-18)

9535. A. J. Guerra, Romans and the Apologetic Tradition: The Purpose, Genre and Audience of Paul's Letter, SNTSMS 81 (Cambridge 1995), esp. 58-59, 62-63, 76-83, 108-110.

The chief thesis of this work is that Romans is a an apologetic writing of the protreptic kind, seeking to affirm Paul's ministry and the gospel which he preached-not a self-apology wherein Paul defends his apostleship, as others have argued. Various apologetic motifs or topoi used by Paul can be found also in Philo, notably the concept of interiorized Law, the spiritual interpretation of circumcision, the One God topos, and the testimonial use of 'great name' figures (Abraham, Moses). (HMK)

9536. V. E. F. Harrison, 'The Allegorization of Gender: Plato and Philo on Spiritual Childbearing', in V. L. Wimbush and R. Valantasis (edd.), Asceticism (New York-Oxford 1995) 520-534.

First the author discusses the following themes in Plato: (1) suggestions of androgyny, (2) masculine and feminine aspects of the tripartite soul, and (3) spiritual childbearing. Thereafter several texts of Philo are treated in which these themes occur. In Philo's exegesis of Genesis 2-3 besides androcentrism the theme of original androgyny plays an important role. In order to become 
fully human the soul should include both intellect, represented by Adam, and sense-perception, represented by Eve. In Philo a gender reversal is also found similar to what is found in Plato's Symposium. At the beginning of the spiritual journey the soul exercises masculine virtues, but at the end it functions as feminine by receiving seed, becoming pregnant and giving birth. Philo develops the theme of spiritual childbearing especially in $D e$ Cherubim. (ACG)

9537. C. T. R. Hayward, Saint Jerome's Hebrew Questions on Genesis: Translated with Introduction and Commentary, Oxford Early Christian Studies (Oxford 1995), passim.

In discussing the sources of Jerome's Hebrew Questions on Genesis the author states (18) that 'Philo's influence, although unacknowledged, can be detected in comments such as that on $25: 8$, which discusses the seemingly tautologous language of LXX as referring to Abraham's virtue.' In his commentary on the text frequent references are made to Philo's works. See the list given on p. 266. (DTR)

9538. M. HeIL, 'Baebius und der erste Konsular des Germanicus', Klio 77 (1995) 224-231.

The article comments on Alex. 27. The Baebius mentioned there (name rightly reconstructed by Terian) can be identified with a companian of Germanicus mentioned in a papyrus. The show with tamed elephants took place during the first consulate of Germanicus in $12 \mathrm{CE}$. Heil elucidates the political background. (DZ)

9539. G. C. Den Hertog, 'Philo van Alexandrië', Vrede over Israel 39.6 (1995) 6-10.

Brief article on Philo's place in Judaism and relation to early Christianity. He is neither a Jewish heretic nor a Christian church father honoris causa, but a representative of the pluriform Judaism of his time. (DTR)

9540. C. R. Holladay, Fragments from Hellenistic Jewish Authors: Volume III Aristobulus, Texts and Translations 39 Pseudepigrapha Series 13 (Atlanta 1995).

Aristobulus' relation to Philo is a recurrent theme in the history of research, as set out in detail in p. 49-66 of the Introduction. REviEw: D. Winston, SPhA 8 (1996) 155-166. (DTR)

9541. N. Hyldahl, 'Betragtninger vedrørende Filons antropologi [In Danish: Meditations on Philo's anthropology]', in P. BILdE, T. Engberg-Pedersen, L. Hannestad and J. Zahle (edd.), Jødedommen og hellenismen, Hellenismestudier 9 (Aarhus 1995) 26-42. 
Some texts are discussed in which Philo comments upon Gen. 1:26 and 2:7 with the aim of giving a background to the problems in the Pauline congregation of Corinth which resulted from the activity of the Alexandrian Apollos. The Philonic texts are basically taken from Opif. and Leg. 1-3. In the former treatise Philo has a cosmological interest and there he describes the ideal prototype of man and the creation of the first human being, Adam. In Leg. Philo's interest is more anthropological: there exist two types of empirical entities, the heavenly or pneumatic man and the earthly man. The latter is in danger of getting lost in matter, but there exist a God-given possibility for him to obtain the status of the pneumatic. (KGS)

9542. L. A. Jervis, '1 Corinthians 14:34-35: A Reconsideration of Paul's Limitation of Free Speech of Some Corinthian Women', Journal for the Study of the New Testament 58 (1995) 51-74, esp. 61-65.

In discussing 1 Cor. 14:34-35, a Pauline passage on the silence of women, the author makes some remarks on Philo's view on spiritual speech, because the Corinthians may have shared similar thoughts. In Philo's view to be silent-i.e. suppression of speech-is a requisite for listening to God and a necessary aspect of the spiritual journey. This view may be helpful to appreciate Paul's words. He thought that the speech of the women was in fact 'aspiritual', whereas they themselves regarded it as spiritual. (ACG)

9543. A. KameSAR, 'Philo and the Literary Quality of the Bible: a Theoretical Aspect of the Problem', The Journal of Jewish Studies 46 (1995) 55-68.

In discussions on the problem of the literary (lack of) quality of the Bible in the Patristic period one can distinguish between the Origenian position which excused it as being of little significance and the Augustinian view that it did possess literary merit. The same question was already an issue in Hellenistic Judaism. Kamesar argues that Philo is a precursor of the Augustinian position. Moses received divine revelation through wordless intellection, but then converts it into 'nouns and verbs', a process for which he needs literary art $(\tau \dot{\varepsilon} \chi \vee \eta)$. Philo's position on how such art is to be judged can be derived from an analysis of Det. 123-125. Drawing on Stoic theory, Philo regards the goal of literature as joy $(\chi \alpha \rho \alpha)$, which is ultimately based on usefulness $(\dot{\omega} \varphi \varepsilon ́ \lambda \varepsilon 1 \alpha)$, because literature enables the soul to attain harmony with nature. The achievement of Moses' literary goal is thus achieved not so much through prophetic power but rather through technical skill. (DTR)

9544. A. Kamesar, 'San Basilio, Filone, e la tradizione ebraica', Henoch 17 (1995) 129-140.

This article contains a discussion of St. Basil's Ep. 190.3. In this passage Basil cites and attributes to Philo of Alexandria a statement about the nature of manna. The statement, however, is not found in Philo's preserved works. In addition, Basil suggests that Philo may be drawing on oral Jewish 
tradition. The purpose of the present article is twofold: (1) to identify the actual sources on which Basil is drawing, or at least clarify the issue of sources; (2) and more importantly, to elucidate the basis and purpose of Basil's suggestion that Philo's statement may be derived from oral Jewish tradition. It is possible that Basil's source is not a missing Philonic work (e.g. the Quaestiones in Exodum), but the passage in Wisdom 16:20-21, the authorship of which he may attribute to Philo (a possibility also entertained by Jerome). But because Wisdom by this time was regarded by many as deutero-canonic, he refers to the oral Jewish tradition as a higher authority. (RR; based on author's abstract)

9545. J. P. Kenney (ed.), The School of Moses: Studies in Philo and Hellenistic Religion in Memory of Horst R. Moehring, BJS 304 (= Studia Philonica Monograph Series 1) (Atlanta 1995).

The seven essays in this memorial volume in honour of Horst Moehring, who died in 1986, all concentrate on Philo. They are listed and summarized under the name of their authors in this bibliography (for the contribution of E. Hilgert see 1409). The volume also includes a reprint of an important article on Philonic arithmology by Moehring himself. Review: S.-K. Wan, RelStR 24 (1998) 115. (DTR)

9546. K. L. KING, 'The Body and Society in Philo and the Apocryphon of John', in J. P. Kenney (ed.), The School of Moses: Studies in Philo and Hellenistic Religion in Memory of Horst R. Moehring, BJS 304 (= Studia Philonica Monograph Series 1) (Atlanta 1995) 8297.

The author discusses a few agreements between the writings of Philo and the Apocryphon of John which, however, do not in all cases have the same meaning. Both in Philo and in Apoc. man is composed of a higher immaterial part, and a lower material part, in which sense-perception and passion are located. A difference between Philo and Apoc. in this notion is that in Philo the higher part corresponds to the ruling power of the world, whereas in Apoc. the lower body corresponds to the powers of the world. Both Philo and the author of Apoc. see in the attainment of apatheia likeness to God; both discern in each man a battle between the soul and the passions. In the final section the author speculates upon the political implications of the positions of Philo and Apoc. Philo locates the power for salvation within the self, in the soul that turns toward God. In Apoc. we find a more critical and more intellectually negative stance toward the world of power and politics. (ACG)

9547. P. Kingsley, Ancient Philosophy, Mystery, and Magic: Empedocles and Pythagorean Tradition (Oxford 1995), esp. 21-23, 31-35.

Discussion of the Philonic passage on Empedoclean cosmology at Prov. 2.60. See further 9348. (DTR) 


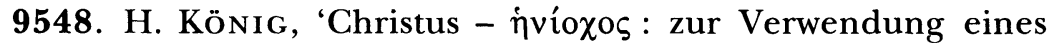
traditionellen Motivs bei Origenes', in W. GeERLINGS and H. KöNIG (edd.), Origenes vir ecclesiasticus: Symposion zu Ehren von Herrn Prof. Dr. H.J. Vogt, Hereditas 9 (Bonn 1995) 45-58.

Origen uses the image of the charioteer in the allegorical interpretation of Matt. 21:1-7: through the ministry of His disciples Christ takes possession of both Jews and pagans. To explain why He rides on them only after they are freed from sins, the authoress investigates the motif in Clement of Alexandria (esp. Protr. 12.118-121 and Str. 5.52f) and in Philo (esp. Agr. 6788). There it is applied in a more individual, moral sense, inspired by Plato's Phaedrus. The charioteer steering the irrational parts of the soul is Christ and virtous reason respectively. In both authors, the victory over the nous dedicated to the passions is described by quoting Ex. 15:1, 21. (DZ)

9549. K.-S. Krieger, 'Pontius Pilatus - ein Judenfeind? Zur Problematik einer Pilatusbiographie', Biblische Notizen 78 (1995) 6383, esp. 74-79.

This essay endeavours to sketch the biography of Pontius Pilate on the basis of a new investigation of the source texts, which according to the author have so far not been taken into account in a methodologically sound way. Krieger's investigation brings him to the conclusion that Pilate's behaviour must be assessed on the basis not of alleged qualities of character or political positions but of the juridical room and authority available to him. Krieger translates and discusses Philo, Legat. 299-306 (on Pilate) and Legat. 159-160 (on Seianus). It emerges that Philo's black picture of Pilate is part of an apolegetic argument. (HMK)

9550. R. Kushelevsky, Moses and the Angel of Death, Studies on Themes and Motifs in Literature 4 (New York 1995).

Translation from Hebrew of a revised version of the author's Bar Ilan dissertation. The theme of Moses' death is traced from the Hellenistic period to modern times. Philo is one of the sources for the first period. The method is 'thematological', exploring the dynamics of the units of the material (themes) as they develop from the writings of one author to another, and from one genre to another. (DTR; based on author's abstract)

9551. J. Laporte, Théologie liturgique de Philon d'Alexandrie et d'Origène, Liturgie 6 (Paris 1995).

A collection of seven essays on Philonic and Origenian spirituality, most of which have been previously published and are now presented in a translated and/or revised form. For chapter 1 'Modèles eucharistiques philoniens dans l'Eucharistie d'Origène' see R-R 8631. For chapter 2 'Sacrifice chez Philon d'Alexandrie et Origène' see RRS 8843. Chapter 4 'Le divorce entre l'âme et l'esprit' is a revised version of R-R 7024. For chapter 5 'Les «âges de 
la vie» chez Philon d'Alexandrie' see R-R 8630. For chapter 6 'Modèles philoniens dans la doctrine origénienne du péché originel' see RRS 8842. For chapter 7 'Le Grand Prêtre chez Philon et Origène' see RRS 9138 (the section on Origen is additional). The only part that has so far not been published is chapter 3 'Modèles philoniens de pardon dans la doctrine origénienne du pardon des péchés', p. 91-132, in which brief remarks are made on the Philonic concept of forgiveness of sins and a lengthier examination is presented of its adaptation in the writings of Clement and Origen. Reviews: H. Crouzel, BLE 96 (1995) 311; M. S. Driscoll, SPhA 8 (1996) 196-198; M. J. Edwards, JThS 47 (1996) 646-648; P.-M. Gy, RSPh 80 (1996) 451; A. Haquin, EThL 72 (1996) 266-267; M. E. Johnson, ThS 57 (1996) 565-566; M. Szram, VoxP 16 (1996) 464-467; M. Fédou, RecSR 85 (1997) 636-637; A. Ward, EphL 111 (1997) 199-200. (DTR)

9552. O. Leaman, Evil and Suffering in Jewish Philosophy, Cambridge Studies in Religious Traditions 6 (Cambridge 1995), esp. 33-47.

The chief focus of this study is the challenge of the book of Job, with which it commences and ends. But it also examines the analyses of the problem of evil given by Job's philosophical successors in Judaism, the first of whom is Philo (others are Saadya, Maimonides, Gersonides, Spinoza, Mendelssohn, H. Cohen, Buber, Fackenheim, A. Cohen). The discussion of Philo's thought is at a rather general level, with few references to specific texts and scholarly discussion, but it raises important issues. Philo is regarded as a 'highly eclectic thinker' and because he wrote so much, it is easy to find him affirming mutually inconsistent positions. The main thrust of his thought, however, is Platonist and emphasizes the distance between transcendent God and the world (and human beings). Human knowledge is necessarily limited, and cannot attain the divine perspective on evil. This recognition of the gap between divine and human perspectives on evil was to become a central theme in Jewish philosophy. Throughout the chapter the author also often refers to Philo's explicit discussion on the perceived evil in the world in De providentia, which is strongly influenced by Stoic thought. (DTR)

9553. J. R. Levison, 'Inspiration and the Divine Spirit in the Writings of Philo Judaeus', Journal for the Study of Judaism 26 (1995) 271-323.

This article deals with the theme of the divine inspiration in Philo. The author discusses Philo's references to the divine spirit in relation to three areas of concern: (A) exegesis; (B) autobiographical experience; (C) apologetics. (A) In his exegesis of the LXX Philo makes an extensive and free use of the texts on the divine spirit. (B) In the autobiographical accounts on the spirit the author distinguishes three distinct experiences of inspiration: (1) inspiration as poetic ecstasy; (2) inspiration as philosophical ascent, which renders valuable aid in the allegorical interpretation of scripture; (3) the attainment of the rational mind to truth that would otherwise be unobtainable. (C) Wishing to extol the surpassing character of Abraham and Moses, 
Philo emphasizes the uniqueness of their functioning as prophets. In his conclusion the author sets forth three key issues: (1) the inspiration of the divine spirit is necessary in the process of allegorical interpretation; (2) Philo considers the spirit the source of many forms of inspiration; (3) Philo has a unique view of inspiration by the spirit. (ACG)

9554. J. R. Levison, 'The Prophetic Spirit as an Angel according to Philo', Harvard Theological Review 88 (1995) 189-207.

The purpose of the article is to demonstrate that in several texts Philo understands the divine spirit as an angelic being (cf. 9555). In his treatment of the story of Balaam (Mos. 1.273-284) Philo attributes the seer's inspiration to the angel who can be identified with the prophetic spirit. Philo presents Moses as inspired but at the same time remaining rational in his prediction of the sabbath (Mos. 1.263). The divine spirit is the leading factor in this rational process. The same kind of inspiration can be seen in Joseph's explanation of Pharaoh's dreams, and in Philo's own allegorical interpretation of scripture. The author also discusses some parallels with the writings of Plutarch. (ACG)

9555. J. R. Levison, 'The Angelic Spirit in Early Judaism', in E. H. Lovering, JR. (ed.), Society of Biblical Literature 1995 Seminar Papers, SBLSPS 34 (Atlanta1995) 464-493, esp. 486-488.

This essay explores pre-exilic and post-exilic Israelite texts as well as early Jewish translations and texts of the Greco-Roman period for what they say on the angelic spirit (ruach or $\pi v \varepsilon \hat{\nu} \mu \alpha$ ) 'as possible foregrounds for conceptions of the divine spirit in the Fourth Gospel, the Shepherd of Hermas, and the Ascension of Isaiah'. The final section discusses Josephus and Philo where they deal with the tale of Balaam and with prophetic possession or inspiration. As regards Philo, the section presents briefly and summarily what the author has argued in substantial detail elsewhere: see 9441 and 9554. (HMK)

9556. B. L. Mack, 'Moses on the Mountaintop: A Philonic View', in J. P. Kenney (ed.), The School of Moses: Studies in Philo and Hellenistic Religion in Memory of Horst R. Moehring, BJS 304 (= Studia Philonica Monograph Series 1) (Atlanta 1995) 16-28.

This article is a stimulating general discussion of the central role that Moses plays in Philo's presentation of Judaism. Why does he present the vision of the logos as hidden in the Mosaic writings, and not as his own? Mack first gives an analysis of the exegesis of Moses on the mountain in $Q E$ 2.29-47. There are two chief metaphors for his followers: mimetic, i.e. the example of the vision which Jews should imitate, and instructive, i.e. the prophetic knowledge received by Moses as codified in his writings. Mack then turns to the presentation of the 'school of Moses'. He argues that Moses and his writings furnish a foundation mythology for Jewish life in the diaspora, cut off from the history of the temple state in Jerusalem. The model 
of the inspired scribe was insufficient, so Moses is also invested with the offices of king, priest and prophet. The third part of the article discusses the 'school of Philo', i.e. Philo's role as teacher and exegete in Alexandria. Students in his school would have had two authoritative texts, the Pentateuch and Philo's own explanations codified with use of the conventions of Greek rhetoric. The authority of scripture and of the teacher were interlocking, but it was the logos of the teacher's vision that the students were asked to see ( $p$. 26). Philo's solution differs from the model chosen in Rabbinic Judaism. (DTR)

9557. K. E. McVey, 'Biblical theology in the Patristic Period: the Logos Doctrine as a "physiological" Interpretation of Scripture', in S. Kraftchick et al. (edd.), Biblical theology (Nashville 1995) 15-27, 293-297.

The author's thesis in this article is that the Logos theology of the secondcentury Greek apologists can be understood as an aspect of a type of Stoic allegorical interpretation called 'physical' allegory. Physical allegory was applied to the sexual relation of the gods described in Hesiod. The author distinguishes two types of birth imagery: (1) intersexual intercourse, conception and birth (e.g. Zeus' union with Hera); (2) male parthenogenetic birth (e.g. Athena's birth from the head of Zeus). The influence of this type of Stoic exegesis is discernable in Philo when he refers to 'physical men'. The first type of birth imagery can be seen in Ebr. 30-31, where God is called the father of the universe, wisdom being its mother. The other is found in Fug. 50-51, where Bethuel, explained as Wisdom, is called a true-born and evervirgin daughter. (ACG)

9558. G. MASI, Lo spiritualismo ellenistico: la grande svolta del pensiero occidentale (Bologna 1995), esp. 81-183.

The second half of this monography is devoted to the subject of 'Philo between the Bible and Plato'. It is divided into the following sections: 1. Introduction, 89-92; 2. Allegory and analogy, 93-103; 3. The biblical component in Philo, 104-111; 4. The Platonic component in Philo, 112-127; 5. The Posidonian component in Philo, 127-147; 6 . The paradigm of creation in Opif. and Leg., 148-168; 7. Conclusion: Philo's creationistic spiritualism and the concept of God, 168-183. Philo's Platonism is not only based on some doctrinal convergences, but is also a question of method, namely the adoption of the analogy, or rather of uni-equivocation of the Aristotelian type, in which analogy is a unity of relation between terms which are in themselves distinct (see p. 85). Philo's allegory should be seen in this light, and also his views on the relationship between God and the world (p. 93ff.). Philo's spiritual world, however, is varied and complex. (1) Masi regards it as influenced by the personalism of Panaetius and Posidonius as well as by the heritage of Egyptian culture, which shifts it away from the centre of gravity of Greek philosophy (87). (2) This personalism gains in strength through contact with biblical revelation, furnishing the basis for a system of hypostases (powers, 
wisdom etc.), and also the concepts of creation, revelation and original sin. (3) The Platonic dimension is also important. Masi is convinced that the biblical conception of creatio ex nihilo is already philosophically founded in Plato, and that his philosophy also elucidates the relation between creation and time which is so important in Philo's exegesis. The difference between Philo and Plato is that the former substitutes the personalistic-biblical, Middle Stoic perspective for the cosmological perspective. Masi assumes a particular importance for the role of man as copula mundi (junction-point of the world), in which the three philosophical figures of the logos, wisdom and spirit meet together (144ff.). The role of pneuma allows Philo to move from Platonic dualism to a more developed form of spirituality. (RR)

9559. J. Mélèze Modrzejewski, The Jews of Egypt. From Rameses II to Emperor Hadrian (Philadelphia-Edinburgh 1995, Princeton 1997), esp. 169-173; translation of Les Juifs d'Egypte, de Ramses II à Hadrien (Paris 1992).

In this lively account of the long history of Jews in Egypt, Philo repeatedly figures as a source, notably for the events in Alexandria in $38 \mathrm{CE}$ as described in the In Flaccum. (HMK)

9560. H. Moenring, 'Arithmology as an Exegetical Tool in the Writings of Philo of Alexandria', in J. P. Kenney (ed.), The School of Moses: Studies in Philo and Hellenistic Religion in Memory of Horst R. Moehring, BJS 304 (= Studia Philonica Monograph Series 1) (Atlanta 1995) 141-176.

Reprint of Moehring's important contribution on the role of arithmology in Philo's writings (R-R 7834), including a long section on the sources of his information on the hebdomad and its role in exegesis. (DTR)

9561. A. B. Nelson, The Classroom of Didymus the Blind (diss. Univ. of Michigan 1995).

The dissertation explores the evidence of Didymus' commentaries on the Septuagint for classroom methods in 4th cent. Alexandria. Philo is discussed as one of the exegete's sources. (DTR; based on DA 56-12A, p.4758)

9562. M. R. Niehoff, 'What's in a Name? Philo's Mystical Philosophy of Language', Jewish Studies Quarterly 2 (1995) 220-252.

A wide-ranging article, in which it is claimed that Philo's theory of the divine logos entails a mystical philosophy of language. Philo consistently assumes the notion of a divine meta-language, which is also conceived as a divine emanation. On the other hand God's language is entirely different from its human counterpart, not consisting of parts of speech, but rather to be regarded as ideal in the Platonic sense. This conception of divine language 
does not appear to have had a Middle Platonist model. In order to express the relationship between language and idea, or between the name and the essence of the object which as been named, Philo consistently uses three allegorical figures: language as water, language as light, language as imprinting seal. A large part of the article consists of the analysis of Philonic passages containing these metaphors. The impetus to transform the Platonic metaphor of water into an allegory of the emanation of the divine word comes from Philo's own priestly orientation (and perhaps Ben Sira). By applying the allegory of light to language, Philo is able to combine the notions of seeing and speaking which denote respectively the basic cultural orientations of Platonism and Judaism. The metaphor of the seal refers specifically to the written word, but also plays an important role in the doctrine of creation, in which God's word is at the same time his deed. Niehoff concludes that Philo's concept of language is based on the assumption of an ideal, natural language that emanates from God, in which idea and name are identical, and that serves as an archetype for human language. On the other hand, Philo refuses to be specific about the language which God speaks and is careful not to identify it with the language of the Torah as it is handed down. Philo has thus raised language to an entirely new level, and it is only a small step to Kabbalistic theories of language. (DTR)

9563. F. Petit, La Châ̂ne sur la Genèse: Édition intégrale III, chapitres 12 à 28, Traditio Exegetica Graeca 3 (Louvain 1995).

Continuation of the integral edition of the Catena on Genesis (cf. 9264 and 9363). Of the 657 exegetical excerpts 34 can be attributed to Philo, all extracted from books III and IV of the Quaestiones in Genesim. Review: D. T. Runia, SPhA 11 (1999) 113-120. (DTR)

9564. C. Perrot, 'L'inspiration des Septante et le pouvoir scriptu-

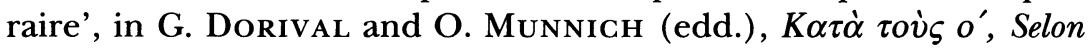
les septante. Trente études sur la Bible greque des Septante. En hommage à Marguerite Harl (Paris 1995) 169-183.

Of all the texts where Philo deals with the inspiration of the Septuagint the most important is Mos. 2.37-40 (see also Spec. 1.65, 4.49). The author raises the following points: the special status of the Septuagint, and above all of the Pentateuch; the denial of essential differences between the Hebrew and Greek; the preference given to a Greek theory of prophecy; the equal status given to the two versions of scripture, Hebrew and Greek. The Septuagint is regarded as inspired. Its text is equivalent to the original Hebrew. The two versions should be regarded as 'sisters', or-even better-as one and the same work, both in form and in content. (JR)

9565. D. Pralon, 'L'allegorie au travail. Interpretation de Lévitique X par Philon d'Alexandria', in G. Dorival and O. MunNich,

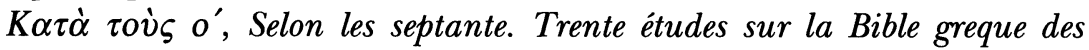
Septante. En hommage à Marguerite Harl (Paris 1995) 483-498. 
The article discusses Philo's interpretation of Leviticus 10 and the six texts in which he refers to the figures of Nadab and Abihu. Two of these texts focus primarily on the mention of them in Ex. 24:1 rather than in Leviticus 10 ( $Q E$ 2.27, Migr. 169). The other four elaborate on their surprising disappearance (Fug. 59, Somn. 2.67, Leg. 2.57-58, Her. 309). Although the text of Leviticus explicitly condemns them and all other exegetes explain their guilt in terms of sacrilege, Philo explains their disappearance allegorically in terms of sanctification, not without various nuances and distortions, which the author carefully studies in discussing each of the above-mentioned texts. (JR)

9566. G. Reydams-Schils, 'Stoicized Readings of Plato's Timaeus in Philo of Alexandria', The Studia Philonica Annual 7 (1995) 85-102.

Revised version of the paper presented to the Philo seminar in the previous year (9458). Its hypothesis is that the two influences on Philo of Plato's philosophy and the Stoics should not be artificially kept separate. 'When Philo-or his source-is looking at the Timaeus, the Stoics are reading over his shoulder (86).' After some brief remarks on Philo's predecessor, Reydams-Schils focuses on two main subjects: God and the principles of the universe (including the Logos); the doctrine of soul, especially in relation to the Stoic analogy between the cosmic and the human soul. Philo is able to exploit for his own purposes the Stoic nuances located in current interpretations of the Timaeus account. (DTR)

\section{J. L. Rubenstein, The History of Sukkot during the Second Temple and Rabbinic Periods, BJS 302 (Atlanta 1995), esp. 69-73.}

Revision of 9269, with several chapters and sections omitted and other sections added. On the basis of Philo's evidence on the Festival of Sukkot it is concluded that the Jews in Alexandria and probably elsewhere in the diaspora did build booths (sukkot). Philo conveys no hint that Sukkot was a special temple festival or included elaborate cultic rituals, probably because his context is the diaspora. It is difficult to know whether the allegorical interpretations of the sukkot which he presents were widespread or were his own individual achievement. (HMK)

9568. D. T. Runia, 'Philo of Alexandria and the Beginnings of Christian Thought', The Studia Philonica Annual 7 (1995) 143-160.

As part of a conference held at the University of Notre Dame in November 1994, the speaker gives a presentation of his evaluation of the influence of Philo's writings and thought on the development of early Christianity, based largely on his Utrecht inaugural lecture (see 9274). (DTR)

9569. D. T. Runia, 'Why does Clement of Alexandria call Philo 'the Pythagorean'?', Vigiliae Christianae 49 (1995) 1-22. 
On two of the four occasions that Clement explicitly refers to Philo, he calls him the Pythagorean (Str. 1.72.4, 2.100.3). The article attempts to explain why Clement used this surprising epithet. First the two passages and their context are examined, but these are unable to provide a clear answer. It is then recalled that Clement in a rather similar fashion calls Philo's predecessor Aristobulus a 'Peripatetic', even though he was obviously a Jewish writer. In fact such epithets can refer to two separate things, (a) membership of a philosophical hairesis, or (2) affinity to the thought of a particular hairesis. It is argued that Clement's reference to Philo belongs to the second category. What aspect of Philo's thought does it then refer to? Either the prominence of arithmology in his exegesis or more generally the dominant Platonist strain in his thought (which at this time can be subsumed under the title 'Pythagorean'). The second alternative is considered to be the more likely of the two. In the light of Clement's relatively liberal stance towards pagan culture, the epithet has a positive connotation. (DTR)

\section{D. T. Runia, Philo and the Church Fathers: a Collection of} Papers, Supplements to Vigiliae Christianae 32 (Leiden 1995).

This book brings together 12 articles and 2 lists of references that were written and compiled during the preparation of the author's study on Philo in Early Christian Literature $(9373 ;$ cf. 9430, 9471, 9477, 9479) and were published in the years 1991-1995. The first chapter is an English translation of the author's Utrecht inaugural lecture originally published in Dutch (9274). A final section entitled 'Addenda et corrigenda' (250-261) presents some corrections and gives references to further research that has been carried out since they were written. Reviews: J. C. Cavadini, SPhA 8 (1996) 201-203; M. J. Edwards, JJS 47 (1996) 164-165; P. Nautin, REG 109 (1996) 323; B. Ehrman, JBL 116 (1997) 774-775; E. Ferguson, RelStR 23 (1997) 78; B. Meunier, REA 99 (1997) 599-600; H. Burkhardt, ThLZ 123 (1998) 264-266; E. G. Estébanez, EstFil 135 (1998) 422-423. (DTR)

9571. K.-G. SAndelin, 'Does Paul argue against Sacramentalism and Over-confidence in 1 Cor 10.1-14?', in P. BorgeN and S. Grversen (edd.), The New Testament and Hellenistic Judaism (Aarhus 1995) 165-182, esp. 168-170, 172, 179.

The article adopts a critical stance towards attempts to see 1 Cor. 10:1-14 as directed towards over-confidence in God. Paul's words are better understood as a part of a traditional OT and Jewish pattern in which the apostasy of the people of Israel is contrasted with the beneficent acts of God. This pattern is also found in Philo (Mos. 2.161, 167, 270-71). The beneficent events in the desert recorded by Paul have significant Philonic parallels. The idea of 'baptism into Moses in the cloud' may be understood against the background of ideas found in Her. 203-4. There are also several Philonic texts which illuminate the idea of the spiritual rock in the desert. (KGS) 
9572. J. M. Sсотт, 'Philo and the Restoration of Israel', in E. H. Lovering, Jr. (ed.), Society of Biblical Literature 1995 Seminar Papers, SBLSPS 34 (Atlanta 1995) 553-575.

The author agrees with P. Borgen that the Jewish nation was the lifesetting for Philo's philosophical and mystical ideas. The question he wishes to examine is Philo's conception of the concrete nation (" $\varepsilon^{\prime} \theta$ vo $)$ of the Jews. In the first section he notes that in the Philonic corpus most occurrences of है $\theta$ vo $\varsigma$ refer to the Jewish nation. The second part deals with Philo's view on the Jewish diaspora. It is conceived as a colonization of the world due to the overpopulation of Jerusalem. Two important notions-Jerusalem as mothercity (metropolis) and the Jewish as a populous nation-stem from the OT. Besides this positive view Philo also sees the diaspora as a negative situation that has to be overcome. In the final part the author focuses on Philo's hope of restoration for the Jewish nation. In Praem. the Jewish exegete relates that one day the Jewish nation will repent and return to the land. God then will put all the curses described in the law on Israel's enemies. Philo also expects a messianic figure who will be the commander-in-chief of the Hebrew nation. Scott concludes that Philo fully shared the nationalistic hope of Judaism. A question remains, however, as to the urgency of his messianic expectations. (ACG)

9573. T. SEland, 'The 'Common Priesthood' of Philo and 1 Peter: a Philonic Reading of 1 Peter 2:5, 9', Journal for the Study of the New Testament 57 (1995) 87-119.

The question in this article is: how does one who is well versed in Philo's writings interpret the 'common priesthood' in 1 Peter 2:5, 9? First, Seland shortly examines Philo's view on the Temple, the high priest, and the priest. Philo characterizes the entire universe as a temple. He considers the high priest, who prays on behalf of whole human race, to be a mediator for the whole world. The entire people of Israel also act as priests. The second part deals with the main question of the article. The author suggests that the Philonic reader would regard the 'common priesthood' in 1 Peter as some-

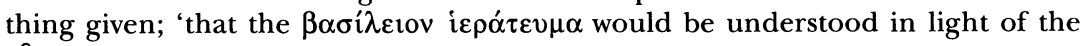
oi $k \mathrm{~s} \varsigma$ and the sacrificial terms in its context as 'temple' rather than 'household'; and that the role of the priesthood would be directed towards God, not people.' (118-9). (ACG)

9574. T. SELAND, Establishment Violence in Philo and Luke: a Study of Non-Conformity to the Torah and Jewish Vigilante Reactions, Biblical Interpretation Series 15 (Leiden 1995).

The purpose of this extensive monograph is to study Jewish self-redress against non-conformity to the Torah, as it emerges in some works of Philo and Luke-Acts. The author formulates the hypothesis that Philo advocates zealotic establishment violence against some specific deviations from the Torah. In Chapter 1 he discusses and evaluates the thesis of Goodenough that 
Philo reports on lynching Jews who transgressed certain laws by fellow Jews. In Chapter 2 some aspects of Philo's social world pertaining to establishment violence are discussed. An important observation is that in Philo there is evidence that he knew various categories of apostates. In the next chapter the author analyses three texts drawn from Spec. in which Philo deals with violence against fellow Jews. These texts (Spec. 1.54-56, 315-318, 2.252-254) treat the crime of apostasy, of false prophecy, and perjury respectively. Discussing these texts, the author focuses on five interrelated aspects: the literary context, the crimes expounded, the measures suggested, the agents supposed to inflict them, and the legitimations given or assumed. The author concludes that the contexts suggest that Philo's expositions were intended to be presentations of laws that were meant to be observed. He thus supports Goodenough's thesis that Philo does not deal with theoretical laws but with actual legal issues. The crimes can be characterized as 'ingroup' Jewish crimes. They concern the honour of God. The measure Philo prefers is punishment by death. In the description of the agents their zeal for virtue plays an important role. In Spec. 1.56-57 Philo uses the Pinehas episode of Num. 25 as an example of such zeal. The legitimation for the measures are inherent in the Pentateuch that Philo expounds. The author's concluding verdict is that Philo's expositions 'might very well be taken both then and now as evidence for an endorsing attitude to establishment violence' (181). Reviews: R. I. Pervo, SPhA 8 (1996) 208-210; H. van de Sandt, TTh 36 (1996) 191; L. H. Feldman, JAOS 117 (1997) 154-155; G. E. Sterling, JBL 116 (1997) 368-370; P. J. Tomson, JSJ 28 (1997) 349-350. (ACG)

9576. M. Sheridan, 'Jacob and Israel: a Contribution to the History of an Interpretation', in M. LöHrer et al. (edd.), Mysterium Christi. Symbolgegenwart und theologische Bedeutung: Festschrift für Basil Studer, Studia Anselmiana 116 (1995) 219-241.

The works of John Cassian (a late fourth-early fifth century Christian writer in Latin) contain several references to Jacob's change of name to Israel as a symbol of the spiritual struggle against the vices in the quest for the contemplative life. This understanding is based upon etymologies of Jacob as 'the supplanter', given in Gen. 27:36, and of Israel as 'one who sees God', derived from Gen. 32:31. These interpretations are first found in Philo, who portrays Jacob as one who gains virtue through practice by struggling against the passions and who achieves a vision of God. In Philo can be found all the important elements (detailed on pp. 222-233) that characterize depictions of the spiritual struggle in such later Christian sources as Clement of Alexandria, Origen, early Coptic monastic literature, fourth century Greek patristic writers, and some Latin writers. Perhaps because Jerome rejected the etymology linking Israel with vision, this interpretation of Israel is less prevalent in Latin writers. (EB)

\section{D. I. Sty, Philo's Alexandria (London 1995).}

The author's aim in this compact study is to collect all the material from Philo's works that can inform us about life in the Alexandria of his day. It is 
presented in eleven very readable chapters, each of which is given as its title a quote from Philo or another contemporary work. In the first Philo himself is presented. The second and third concentrate on the city itself, its history and how it would have appeared to an imaginary tourist. The fourth treats the city's rulers, the fifth a number of important women who held positions of power and influence (including Cleopatra and Berenice). In the sixth the harbour and the agora are discussed and evidence on social conditions is presented. Chapters 7 and 8 discuss pagan and Jewish religion respectively, to which is appended a further chapter on the contemplative religion of the Therapeutae. Chapter 10 moves on to 'physical culture', i.e. the role of sport and medicine in Alexandrian life. The final chapter recounts the history of the Jewish community in Philo's life-time, especially in relation to the Roman rulers. Sly concludes that after the terrible events during the reign of Gaius, Philo would have been 'not entirely displeased' with the intervention of Claudius as laid down in his letter to the Alexandrians. Reviews: Anon., TLS 4851 (1996) 32; R. Alston, CR 47 (1997) 214-215; D. T. Runia, VChr 52 (1998) 115-118 and SPhA 10 (1998) 194-197; G. E. Sterling, RelStR 24 (1998) 435; T. Kruse, Klio 81 (1999) 1-12. (DTR)

9578. R. SRIgLey, 'Albert Camus on Philo and Gnosticism', The Studia Philonica Annual 7 (1995) 103-106.

Brief remarks on the role ascribed by Camus to Philo in the evolution from Hellenism to Christianity in his first philosophical work, Métaphysique chrétienne et Néoplatonisme. Philo is portrayed as an 'outside influence' in the achievement of a Gnostic synthesis, which in turn is seen as an unsuccessful attempt to reconcile the Hellenic and the Judaic tradition. The author shows that Camus was influenced by the scholarly currents of the time, and argues that the central question involved is deserving of further study. (DTR)

9579. G. E. Sterling, 'Recluse or Representative? Philo and Greek-Speaking Judaism beyond Alexandria', in E. H. Lovering, JR. (ed.), Society of Biblical Literature 1995 Seminar Papers, SBLSPS 34 (Atlanta 1995) 595-616.

The question addressed is Philo's relation to Greek-speaking Judaism in the diaspora. To what extent can we use his auvre to reconstruct diaspora Judaism? Does he differ only in degree or is he sui generis? In order to determine his answer Sterling presents a valuable overview of surviving diaspora documents (and also some references to those now lost) and examines their relation to the Philonic corpus. The following regions and authors are treated: North Africa (Cleodemus Malchas); Cyrene and Egypt (Testaments of the Twelve Patriarchs, 2 Enoch, 3 Baruch, Egyptian Sibylline oracles); Palestine (Eupolemus, Sibylline Oracle 4, Justus of Tiberias); Syria (4 Maccabees, Hellenistic synagogue prayers); Rome (Caecilius of Calacte, Pseudo-Longinus, Josephus). Also treated are pagan Syrian writers who betray acquaintance with Philo's works. From this evidence it is concluded that Philo was not a recluse, but a thinker whose works probably received a wide distribution and offer the modern scholar a window into a much wider world. But it is also fair to say that there are certain areas where he is more representative than 
others. Most common ground is found in the areas of cosmology and anthropology. A revised version of the paper was subsequently published in SPhA 11 (1999) 1-30. (DTR)

9580. G. E. Sterling, “Thus are Israel': Jewish Self-Definition in Alexandria', The Studia Philonica Annual 7 (1995) 1-18.

In light of the paradigm shift that has led scholars to speak of Judaisms rather than Judaism, it is necessary to take the local situation and the peculiarities of each Jewish community more seriously than has been done hitherto. Sterling examines the self-identity of the Jewish community in Alexandria, basing his results on an examination of three kinds of material: Greco-Jewish literature in Alexandria, non-literary texts from or dealing with Alexandria, and accounts of Jews by non-Jewish residents of the city. Philo presents valuable evidence on the nature of the community itself and the two central issues with which it was preoccupied: the understanding of God and the observance of the Law. Sterling concludes that the right to participate in Hellenism was just as important a component of the identity of Alexandrian Judaism as the observance of the Law. Moreover it was historically of greater consequence. It looked as much to the West (Greece) as it did to the East (Palestine). The interpretatio graeca was not confined just to the elite whom Philo represents. (DTR)

9581. G. E. Sterling, "Wisdom Among the Perfect': Creation Traditions in Alexandrian Judaism and Corinthian Christianity', Novum Testamentum 37 (1995) 355-384, esp. 361-7, 371-6, 380-2.

On the basis of 1 Cor. 15:44-49, 2:6-3:4, and 11:7-12, the author reconstructs the Corinthians' understanding of the fundamental anthropological texts Gen. 2:7 and 1:26-27. He compares their views with exegetical traditions on the creation of man found in Philo. There are similarities between the Corinthians' position and Philo which enable the Corinthians' position to be better understood. Both Philo and the Corinthians derive two classes of human beings from Gen. 2:7. In the light of Philo's negative attitude towards the body, the Corinthians denial of a bodily resurrection is explicable. Their

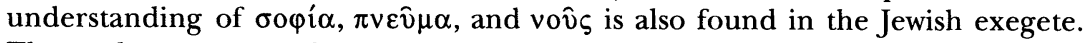
The author suggests that via Apollos the Corinthians came into contact with Jewish traditions on the creation. (ACG)

9582. A. TERIAN, 'Inspiration and Originality: Philo's Distinctive Exclamations', The Studia Philonica Annual 7 (1995) 56-84.

In two respects at least it is difficult to determine where Philo is being original. Firstly originality was not a high priority in ancient literary theory. Secondly the anterior tradition on which Philo depends is difficult to separate from his own contribution. Terian suggests a new line of approach by looking at those texts in which Philo addresses himself with the expres-

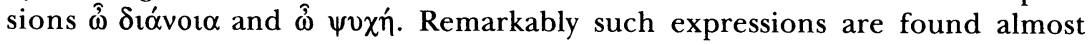


nowhere else in ancient literature. Terian's hypothesis is that Philo by means of these vocative expressions makes a claim to personal inspiration, and so conveys to us his own originality. The main body of the article examines the 39 instances of these expressions, plus four that Terian has discovered in the Quaestiones. On the basis of these analyses he is able to reach a number of conclusions. Generally speaking the use of the expressions comes at the beginning or end of an interpretation of a biblical passage, and are often centred around the contrast between mind and senses, and between virtue and vice. Their use seems more deliberate than spontaneous. They are especially significant in contexts of multiple interpretation, in which he follows up the interpretations of others (whether he agrees or disagrees with them) with another one of his own. It is concluded that 'an identifiable stratum of originality in Philo is likely to be found in those contexts which include personal pronouncements suggestive of inspiration. More specifically these include distinctively recognizable, formulaic exclamations ... hitherto unidentified as peculiarly Philonic. (p. 84)' (DTR)

\section{T. Thatcher, 'Philo on Pilate: Rhetoric or Reality?', Restoration Quarterly 37 (1995) 215-218.}

Philo's description of the 'Golden Shields' episode (Legat. 299-305) portrays Pilate as stubbornly opposing the Jews whereas in the Gospels Pilate appears weak and ready to yield to the Jews. Rather than offering an accurate account of Pilate's character or actions, however, Philo's depiction must be understood as part of a hortatory epistle, a form which uses paradigms of behavior to persuade the addressee to act or not to act in a certain way. Written by Philo but attributed by him to Agrippa I, the epistle was purportedly sent to Gaius to persuade him not to offend Jewish sensibilities by having an image of himself erected in the Temple. The whole treatise, which argues that Gaius's bad behavior led to bad consequences, was probably directed at Claudius after $41 \mathrm{CE}$ with the aim of offering instruction on how a 'virtuous ruler' should treat the Jews. (EB)

9584. S. Torrallas Tovar, El De somniis de Filón de Alejandría (diss. Madrid 1995).

Several aspects of Philo's thought are studied in this important dissertation. First an introductory synthesis is given of Philo's biography and his writings, with special attention paid to the manuscript tradition. An exposition is then given of the allegorical method in later ancient literature, in Judaism and in Philo. The subject of dreams is studied from a philological view in Greek, Semitic and biblical culture, and is supplemented by a history of the classification of dreams in ancient and medieval writers. In the final part a detailed analysis is given of the treatises De somniis of Philo. He wrote three treatises on this theme, of which the first one has been lost. What we know as Somn. I and II could have been II and III in the original work. The three treatises may have been ordered in a descending thematic order, illustrating the contemplative life, the ascetic life and the life that is still darkened by the passions. The symbols of these states are (1) Isaac, (2) Jacob 
and Abraham, and (3) Joseph. We know that the texts expounded in (2) were Gen. 28 and 31, and in (3) Gen. 37, 40-41. The thesis suggests as contents of the lost first treatise the text in Gen. 26:2-5 (see p. 295), in which God orders Isaac in a dream not to go down to Egypt. (JPM)

9585. R. Trevijano Etcheverría, Orígenes del cristianismo. El trasfondo judio del cristianismo primitivo, Plenitudo Temporis 3 (Salamanca 1995), esp. 134-146

The author dedicates a special chapter to Philo of Alexandria, describing his personality, his biography, the works that have been preserved, the allegorical method, and the influence that he had on the allegorical and typological treatment of Christian theology. Philo is also a chief witness for other themes central to the relationship between ancient Judaism and Christianity, such as the Diaspora (pp. 92-96) and the Therapeutae as forerunners of monasticism (pp. 298-299). (JPM)

9586. D. W. Ullmann, Moses'Bronze Serpent (Numbers 21:4-9) in Early Jewish and Christian Exegesis (diss. Dallas Theological Seminary 1995).

The dissertation presents a history of the interpretation of Moses' bronze serpent (Num. 21:4-9) and evaluates the validity of the interpretative methods employed. It considers Jewish literature (rabbinic, midrashic and targumic) up to the medieval period and Greek, Latin and eastern Christian literature up to Bernard of Clairvaux (1090-1153). Philo is the first author to connect the bronze serpent with the serpent in the garden of Eden. He and other Jewish authors add details to the story that are not found in Num. 21:4-9. But they never comment on why God would command Moses to fabricate a bronze serpent in order to heal the people after he had forbidden idols (Exod. 20:36). Their exegesis was consistent but embellished and incomplete. (DTR; based on summary in DA 56-05A, p. 1832)

9587. J. C. VanderKam, Enoch: A Man for All Generations, Studies on Personalities of the Old Testament (Columbia SC 1995), esp. 148-152.

This monograph provides a survey of the ancient Jewish and Christian references to Enoch and Enochic themes. Some Philonic passages which refer to Enoch are shortly discussed, namely Post. 42-43, Mut. 33-34, Abr. 1719, Praem. 16-17, $Q G$ 1.82-86. In Philo's view Enoch represents the one who repents and is hence transferred to a better life. Philo never connects Enoch with the angels who descended from heaven. (ACG)

9588. G. Veltri, 'The Humanist Sense of History and the Jewish Idea of Tradition: Azaria de' Rossi's Critique of Philo Alexandrinus', Jewish Studies Quarterly 2 (1995) 372-393. 
Azaria de' Rossi, the first Jewish writer since antiquity to give a detailed analysis of Philo's writings and thought is first presented against the contemporary background of Renaissance humanist learning. Veltri argues that his aims were those of an apologist rather than of a historian. He wishes to restore to Israel the brilliance of its ancient learning. His discussionpartners and opponents are especially Christian theologians. Others had paved the way in this pursuit, but Azaria is the first to make extensive use of non-Jewish and Hellenistic-Jewish literature. The remainder of the article concentrates on two themes. A brief discussion is given of Azaria's critique of Philo's thought and how it relates to contemporary portraits of Philo at the cross-roads of Christianity and Judaism. Secondly it is shown how Azaria distinguishes between the essence of tradition in Judaism as transmitted in the Bible and the sages, which is beyond the limits of scholarly questioning, and the milleta be-'alma (side-aspects) on which dispute and progress is possible (even if later thinkers can only be dwarfs on the shoulders of giants). Azaria believes that Philo's thought, which is not without errors and shortcomings, can only be used for the latter, and is irrelevant for the core of the tradition. This learned article provides highly valuable information on a little-known period of Philo's reception in later European thought. (DTR)

9589. N. Walter, 'Hellenistische Diaspora-Juden an der Wiege des Urchristentums', in: P. Borgen and S. Giversen (edd.), The New Testament and Hellenistic Judaism (Aarhus 1995), 37-58, esp. 4144; reprinted in IDEM, Praeparatio Evangelica, WUNT 98 (Tübingen 1997) 383-404.

Walter first distinguishes the 'Hellenists' in Jerusalem, who were Greek speaking Jews, not only in the Primitive Church, and the 'Hellenistic Diaspora-Jews', who were determined by a Hellenistic world-view. In Alexandria the latter consist of different groups, exemplified by Philo, but also by the Oracula Sibyllina, which are less friendly with regard to pagans. Like other Jewish writers (Ezekiel the Tragedian, Aristobulus, Philo the Epic Poet) they reveal a thorough hellenic formation. The conflicts mentioned in Acts 6-7 show that Jews returning from the diaspora were not uniform in their attitude to the Law or to non-Jews. Philo represents a current of opinion which wants to open the Torah for all men. This position is also assumed for the group around Stephen. There is also an additional note on the role of the LXX. (DZ)

9590. S. K. Wan, 'Abraham and the Promise of the Spirit: Galatians and the Hellenistic-Jewish Mysticism of Philo', in E. H. Lovering, Jr. (ed.), Society of Biblical Literature 1995 Seminar Papers, SBLSPS 34 (Atlanta 1995) 6-22.

Starting-point of the paper is the two-part conclusion that Paul draws in Gal. 3:14, paralleling the blessing of Abraham to the gentiles and the acceptance of the promise of the Spirit through faith. Wan argues that Philo's presentation of Abraham as a mystic who abandoned his Chaldean background 
and sought to gain knowledge of God sheds valuable light on this text. Philo uses the figure of Abraham in an apologetic context. Paul's portrait of Abraham in Galatians shows several points of contact with that of Philo. They are, however, painted on two quite different canvasses: the one is eschatological, the other based on the Hellenistic model of contemplation. What is comparable is the manner in which the figure of Abraham is appropriated. (DTR)

9591. S. K. WAN, 'Allegorical Interpretation East and West: a Methodological Enquiry into Comparative Hermeneutics', in D. Smith-Christopher (ed.), Text and Experience. Towards a Cultural Exegesis of the Bible (Sheffield 1995) 154-179.

The first part of the paper briefly deals with the allegorical method of Ps. Heraclitus, Philo, and Paul. The leading motif in Philo's allegory is the journey of the soul. Having then introduced the Confucian commentator tradition of the Shih Ching (Odes), the author compares the two types of allegorical interpretation. Regarding the method of allegory the interpretation of the Odes can be compared well to Philo. There are also differences. The Confucian allegory does not deal with the journey of the soul, but with concrete historical events and personages. (ACG)

9592. G. J. WARne, Hebrew Perspectives on the Human Person in the Hellenistic Era: Philo and Paul (Lewiston N.Y. 1995), esp. 8-20, 123156, 221-249.

In Chapter One the context of Philo of Alexandria and Paul of Tarsus is set out. The author thinks that Philo's primary concern remains theological. He wants to interpret Jewish theology in terms of Greek philosophy. To achieve the synthesis between Jewish and Greek thought he uses the method of allegory. Chapter Four is devoted to the Philonic conceptuality of the soul. In Philo's thought the Greek concept of human person as consisting of body and soul is determinative. The soul originates from God's Logos, whereas the body is created from the clay of the earth. Because the human vov̂ is stamped with God's image, it possesses a kinship with God himself. On the basis of this affinity man can get knowledge of God. Beside the basic distinction between body and soul, there is a subdivision within the soul into $\psi v \chi \grave{\eta} \lambda \lambda_{0} \gamma_{\iota} \eta^{\prime}$ (vovิs), $\theta \dot{v} \mu \circ \varsigma$, and $\dot{\varepsilon} \pi \imath v \mu \eta \tau \iota \kappa o ́ v$. The rational element should rule over the irrational parts of the soul. The final goal of the soul is to return to the source of its life and being, the Eternal Mind itself. In the final chapter the author argues that in Paul's letter to the Corinthians we find 'a confrontation between a Philonic-type of hellenized Judaism and a distinctively Christian perspective, as represented in the teaching of Paul' (p. 242). Reviews: G. J. Brooke, ET 108 (1996) 57; D. M. Hay, SPhA 8 (1996) 205-207; D. C. Aune, RelStR 23 (1997) 301. (ACG)

9593. D. Winston, 'Philo and the Hellenistic Jewish Encounter', The Studia Philonica Annual 7 (1995) 124-142. 
As part of a conference held at the University of Notre Dame in November 1994, Winston gives a general presentation of Philo's place in ancient Jewish thought and his reception in modern Judaism. Philo's cultural world is illustrated by brief discussions of Qohelet, Wisdom of Solomon, 4 Maccabees, Pseudo-Aristeas, Aristobulus. Winston then briefly outlines how Philo himself reshapes his Jewish heritage in the light of his Platonist convictions. He should be characterized as a radical Jewish thinker with strong mystical overtones. In the final part of the paper it is shown how the neglect of Philo in Jewish circles is being overcome. After brief remarks on the portrait of Philo given by Azaria de' Rossi in the 16th century and R. David Cohen in the 20th, he concludes with an account of the thought of R. Arthur Green's (cf. 9238), which he regards as an exciting and profound attempt to produce a contemporary Jewish theology from the perspective of Jewish mysticism. It is no coincidence that Green has a positive view of Philo. Winston hopes that the ground is being prepared for a revival of interest in Philo and especially in his mystical thought. (DTR)

9594. D. Winston, 'Philo's Doctrine of Repentance', in J. P. Kenney (ed.), The School of Moses: Studies in Philo and Hellenistic Religion in Memory of Horst R. Moehring, BJS 304 (= Studia Philonica Monograph Series 1) (Atlanta 1995) 29-40.

In Greek philosophy feelings of repentance or remorse were not highly regarded. There is only one positive pronouncement in the philosopher Democritus. On the other hand the doctrine of repentance had long had a central place in Judaism. Winston examines with much attention to historical detail Philo's various pronouncements on repentance and their relation to both the Jewish and philosophical tradition. He concludes that Philo has not succeeded completely in assimilating the concept of repentance to his philosophical thought (p. 39). It is given a secondary rank in the hierarchy of virtue. The doctrine is thus an excellent example of tension between his philosophical impulse and religious conceptions native to his ancestral tradition. (DTR)

9595. D. Winston, 'Sage and Super-sage in Philo of Alexandria', in D. P. Wright, D. N. Freedman and A. Hurvitz (edd.), Pomegranates and Golden Bells: Studies in Biblical, Jewish and Near Easter Ritual, Law and Literature in Honor of Jacob Milgrom (Winona Lake, Indiana 1995) 815-824.

English version of a study first published in Hebrew in 1983 (= R-R 8379). Winston first shows how Philo takes over Stoic ideas in his portrait of the wise man, though some differences are to be noted. In his portrait of Moses, however, he goes beyond the parameters of Stoic theory. Moses is an even higher type than Isaac because he is translated to the level of nous. He is thus not just a sage but a super-sage, whose mind lives in perfectly rational conjunction with his body. He resembles God in that of the rational emotions he only possesses joy, the only difference between them being that his joy cannot be eternal and without elation. The presentation of Moses as super- 
sage is another good example of Philo's 'one-upmanship' in relation to Greek philosophy. (DTR)

9596. D. Zeller, 'The Life and Death of the Soul in Philo of Alexandria: the Use and Origin of a Metaphor', The Studia Philonica Annual 7 (1995) 19-56.

Philo often illustrates the vital necessity of virtue for man by describing it as the life of the soul. If the soul loses virtue, it is said to die. Zeller first outlines the content of this metaphor, and then investigates its use in Philo's biblical exegesis which in this case seems to have a rather personal element. Favourite texts are Deut. 4:4 and 30:15, 19, 20; they define the life of the soul not only in a moral, but also in a religious sense. By using the metaphor Philo intents to buttress his value-system: with the 'death of the soul' he underlines the immediacy of punishment. In the third part the origins of Philo's conception are examined. Zeller first looks in classical philosophy (Heraclitus in his neo-Pythagorean and Neoplatonic guise; Plato, Aristotle). Since, however, in its sophisticated form it presupposes a differentiation between soul and mind, its existence cannot be fully verified prior to Philo. While the Pythagorean-Platonic tradition suggests a death of the soul in its incarnation and its paradoxical coming to life through bodily death, Philo more often applies the metaphor in a moral sense. In this tendency Zeller surmises the impact of popular philosophy, which explicitly calls those lacking education or virtue living dead people. (DZ)

9597. B. Zuber, 'Die „Geschichts“-Traditionen der alttestamentlichen „Königszeit“: - z.B. als literarischer Niederschlag einer historischen Auseinandersetzung mit der Herodes-Dynastie zu lesen?', in Landgabe: Festschrift für Jan Heller zum 70. Geburtstag (Prague 1995) 133-172, esp. 145-147 and 170-172 (appendix).

The author considers the biblical books on the period of the kings (i.e., the 'early prophets': Joshua - 2 Kings) as an ideological and programmatic confrontation of 'Israel' with a much later historical period, viz. that of 100 BCE - 135 CE (in which the Herodian dynasty played an important role). She argues for a complete reversal of the burden of proof: starting from the presumption of a late date for these books of the Bible, she states that any early dating should prove its case. Zuber sees traditional research as ascribing to these books the intention and method of modern historiography, whereas she wants to approach them as literature with its own character. Philo is one of the authors used to demonstrate her case. She observes that he quotes less than $0.5 \%$ of all biblical verses outside the Pentateuch (against $24.2 \%$ of all verses of the Pentateuch). Philo's (and rabbinic) allegorical exegesis inspires Zuber to suggest that the biblical authors themselves may well never have intended to report historical events as such. Two appendixes list the verses (in German translation) of Joshua - 2 Kings as present in the Qumran texts and in Philo's writings respectively (the latter list is taken from H. E. Ryle, Philo and the Holy Scripture or the Quotations of Philo from the Books of the Old Testament, London-New York 1895, and does not give the Philonic references). (HMK) 


\section{6}

9601. A. AdE, Sklaverei und Freiheit bei Philo von Alexandria als Hintergrund der paulinischen Aussagen zur Sklaverei (diss. Heidelberg 1996).

Since the author finds in Philo a synthesis of philosophical and biblical tradition, she first summarizes the attitude of Greek philosophy and of the Hebrew Bible to slavery. After some introductory remarks on Philo's biography and writings, she unfolds his statements on slaves to the extent that he expounds the biblical doctrine. Compared with the rabbinic halacha the difference between Hebrew and non-Jewish slaves for Philo is not so important because of his general interest in man as such. Ade investigates the special cases of permanent slavery, of prisoners of war and paid labourers, and the release of slaves on the occasion of sabbath, jubilee etc. Philo provides new motivations like human kinship, measure, philanthropy for the Old Testament laws, but sometimes he also allegorizes them. The third chapter pursues the Greek philosophical ideas of liberty and equality in Philo's work and concludes that in practice 'proportional equality' prevails over 'arithmetic equality'. The fourth chapter is mainly an analysis of Prob.; to the individual examples of liberty-in the sense of mastery of the passions-mentioned there Ade adds the biblical ones. In the fifth chapter she presents the communities of the Essenes and Therapeutae which in Philo realize the utopia of liberty-though in a paradoxical manner-and of a society without slavery. Chapter VI is dedicated to the messianic understanding of liberty in Praem. There the final supremacy of the Jewish people includes moral superiority over the pagans. The last chapter compares Philo and Paul. Both do not abolish the institution of slavery, but plead for release; in agreement with the philosophers they agree that social status is not relevant for true liberty. (DZ)

9602. Y. DE Andia, Henosis: l'union à Dieu chez Denys l'Aréopagite, Philosophia Antiqua 71 (Leiden etc. 1996), esp. 309-18, 355-373.

In chapter I 3 of the Mystical Theology, Dionysius the Areopagite presents the ascension of Moses and his entry into the darkness as the model for every mystical ascent. In order to expound this theme, the author makes a systematic comparison of the Areopagite's treatment with his predecessors Philo and Gregory of Nyssa. The Philonic material discussed is taken both from Mos. and the Allegorical Commentary. The results of the four subthemes analysed-the stages of ascent, the place of God, the darkness, the vision-are summarized in a table on pp. 371-373. (DTR)

9603. M. BALtes, Die philosophische Lehre des Platonismus: einige grundlegende Axiome/Platonische Physik (im antiken Verständnis) I, Der Platonismus in der Antike 4 (Stuttgart 1996), esp. 130-131, 409-413. 
The only Philonic text treated in detail in this volume, which assembles and comments on fundamental Platonist texts, Platonist metaphysics and physics, is Cher. 125-127. It falls under the heading Doctrine of four principles. On the series see 8731 . (DTR)

9604. J. M. G. BARclay, Jews in the Mediterranean Diaspora from Alexander to Trajan (323 BCE - $117 \mathrm{CE}$ ) (Edinburgh 1996), passim.

This wide-ranging monograph is particularly valuable on two accounts. It attempts to treat the Jewish diaspora in its entirety within its chosen timeframe, and it looks very self-consciously and illuminatingly at conceptual tools-such as Hellenization, deviation, assimilation, acculturation, accommodation-that should be used in such an analysis. The first half of the book focuses on the diaspora in Egypt. The evidence of Philo and his writings plays a prominent role. See especially Barclay's discussion of the events of 38-41 CE, with an excursus on the legal status of Jews in Alexandria (48-71), his judgment on Philo as a personage to be included in the category of Jews showing 'medium assimilation' (113-114), and his section on Philo as an example of 'cultural convergence' (158-180). According to Barclay Philo's allegories 'expressed the dual commitments of a man whose integration of Judaism in Hellenistic culture was exceptionally profound, but who ultimately turned that synthesis to the advantage and defence of the Jewish community (180).' In the final chapter of the book Philo's evidence is again extensively used in order to give a sketch of 'Jewish identity in the Diaspora' (399-444). Review: E. Birnbaum SPhA 12 (2000) 192-197. (DTR)

\section{G.-H. BAUDRY, 'Le péché des origines selon Didyme d'Alexandrie', Mélanges de Science Religieuse 53 (1996) 163-182.}

The author presents the conception of 'original sin' such as it appears in Didymus' Commentary on Genesis. He shows that this conception follows the interpretation of the Alexandrian school as found especially in Philo, but also in Origen. It is marked by the idea of a double creation of man. The first concerns the 'celestial man' who is immaterial and created according to the image of God. The second is connected with the fall of mankind and concerns the 'earthly man' with a mortal body. (JR)

9606. G. H. BAudRY, 'La responsibilité d'Ève dans la chute: analyse d'une tradition', Mélanges de Science Religieuse 53 (1996) 293320, esp. 303-305.

A very widespread tradition sees Eve as having the primary responsibility for original sin and, at the same time, as the archetype of woman. The inquiry in this article proceeds from the interpretation of Genesis by Sirach 25:24, going through the inter-testamental writings and Philo, and referring to some of the great names in Christian thought (Origen, Didymus, Tertullian, Augustine, Thomas Aquinas). The author concludes that the universally acknowledged presupposition that woman is by nature inferior to 
man has in our contemporary culture become obsolete, and that the exclusions justified by it will continue to disappear progressively. As for Philo's view, Adam before the creation of Eve was the perfect human being, i.e., androgynous. Due to its belonging to the world of becoming (and not because of an original sin as a free act), the androgynous monad was broken into a duality. Adam allegorically represents the intellect, Eve sense-perception (easily seduced by the Serpent, i.e., pleasure). Woman, according to Philo, is connected to matter, body, and sensation. Philo's misogynous ideology took its arguments primarily from Greek thought (Plato), and exerted a nefarious influence on Christian thinkers. (HMK)

9607. R. H. BeLL, 'Sin Offerings and Sinning with a High Hand', The Journal of Progressive Judaism 4 (1996) 25-59.

This article considers the meaning of Numbers 15:30-31, which says there is no sin offering for a sin committed with a 'high hand'. After concluding that these verses pertain to sins committed deliberately rather than unwittingly, Bell surveys treatments of deliberate and unwitting sins in a wide range of Jewish and Christian sources, including the Apocrypha, Pseudepigrapha, Philo, Josephus, Qumran, Rabbinic literature, Letter to the Hebrews, and Paul. Only Paul believes in atonement for the deliberate sinner, namely, through the death of Jesus. Philo distinguishes between intentional and unintentional sins several times but not always in connection to the cult. In Spec. Leg. 1.226-38, he cites this distinction in discussing the sin offering, suggesting that this offering atones only for unintentional sins. Elsewhere, he portrays the deliberate sinner as provoking God and having to reckon with the divine rather than human tribunal. (EB)

9608. E. Birnbaum, The Place of Judaism in Philo's Thought: Israel, Jews, and Proselytes, Brown Judaic Studies 290, Studia Philonica Monographs 2 (Atlanta 1996).

The question Birnbaum poses in this study is how Philo himself assesses the significance of being a Jew. From the analysis of Philo's use of the terms 'Jews' and 'Israel' it appears that for describing the actual nation Philo uses 'Jews' or 'the Hebrews', not 'Israel' (chapter 1). After the discussion of the background for Philo's etymology of 'Israel' as 'one that sees God', Birnbaum treats Philo's ideas on seeing God (chapter 2). Next she raises the question whether 'the one that can see' can be identified with a real social group, and she concludes that it is impossible to do so. The class that can see consists of all philosophers who command respect (chapter 3). Birnbaum proceeds to show that Philo transforms the biblical presentation of the relationship between God and Israel. In the Bible this relationship is based on the covenant that God established with his people. Philo, on the contrary, hardly mentions God's covenant, presenting the view that God associates with virtue and with wise and knowing people (chapter 4). In answer to the question how Philo interprets the relationship between God and the contemporary Jews Birnbaum gives five features, prime among which is that the Jews believe in the one true God. This relationship is accessible to any virtuous 
person who believes in the truly Existent (chapter 5). Finally Birnbaum discusses the relationship of proselytes with God, the Jews, and Israel, and she concludes that Philo associates proselytes with the Jews, not with Israel. Regarding the central question of the study Birnbaum concludes that for Philo 'Judaism represents one approach-indeed probably the best approachto belief in the one God' (p. 229). His commitment to being a Jew should thus be explained as resulting from his involvement with the Jewish community. Reviews: A. Reinhartz, JJS 48 (1997) 366-367; P. J. Bekken, JSJ 29 (1998) 145146; A. C. Geljon, VChr 49 (1998) 211-212; D. N. Jastram, RelStR 24 (1998) 207; F. J. Murphy, $C B Q 60$ (1998) 145-146; G. Pfeifer, OLZ 93 (1998) 340-342; G. Sterling, SPhA 10 (1998) 191-194; A. Terian, AJSR 23 (1998) 250-253; P. J. Tomson, JThS 49 (1998) 211-212; P. Borgen, JBL 118 (1999) 734-736; A. M. Mazzanti, Adamant 5 (1999) 291-294; E. Nodet, RB 106 (1999) 471-472; G. E. Sterling, JR 79 (1999) 170-172. (ACG)

9609. P. Borgen, 'Autobiographical Ascent Reports: Philo and John the Seer.', in IDEM, Early Christianity and Hellenistic Judaism (Edinburgh 1996) 309-320.

An analysis is given of Spec. 3.1-6. The text describes personal experiences of Philo, i.e. experiences of ascents to the ethereal and aerial spheres. These occurred both during a time when Philo was free from earthly troubles with leisure for philosophy and when he was involved in the cares and troubles of the Jewish politeia. The author thinks it possible, though not necessary, that these troubles consisted of the pogroms in Alexandria $38 \mathrm{CE}$ and the embassy to Gaius $41 \mathrm{CE}$. Philo may also refer to what preceded these events. The experiences of the ascent serve a hermeneutical function by enabling Philo both to allegorize the Scriptures and to unfold what is not clear in the Laws of Moses. There exist several points of contact between Philo and John the Seer. (KGS)

\section{P. Borgen, Early Christianity and Hellenistic Judaism (Edinburgh 1996).}

This volume contains twelve essays, nine of them published elsewhere in the period 1988-1994. Abstracts of the three articles first published in 1996 are given at nrs. 9609, 9613, 9614. Three earlier articles are: "Yes," "No," "How Far?": The Participation of Jews and Christians in Pagan Cults' (9405); "The Sabbath Controversy in John 5:1-18 and Analogous Controversy Reflected in Philo's Writings' (9108); 'Jesus Christ, the Reception of the Spirit, and a Cross-National Community' (9404). (KGS)

9611. P. Borgen, 'Emperor Worship and Persecution in Philo's In Flaccum and De Legatione ad Gaium and the Revelation of John', in H. Cancik, H. Lichtenberger and P. Schaefer (edd.), Geschichte Tradition - Reflexion. Festschrift für Martin Hengel zum 70. Geburtstag, 3 vols. (Tübingen 1996) 3.493-509. 
There exist several points of agreement between Philo and John the Seer on the subject of emperor worship. The Roman emperor's claim to divinity is seen as illegitimate by both authors, who describe the main elements of imperial worship in similar ways. Both maintain that the whole world took part in the worship of the emperor. The only exception were the Jews and the Christians respectively, who for this reason were persecuted and attacked by the imperial government. Both Philo and John see the punishment of the illegitimate usurpers as justified. Philo, however, has a more positive general attitude to the Roman empire than John. (KGS)

9612. P. Borgen, 'The Gospel of John and Hellenism: Some Observations', in R. A. Culpepper and C. A. Black (edd.), Exploring the Gospel of John: in Honor of D. Moody Smith (Louisville, Kentucky 1996) 98-123, esp. 101-9.

The article discusses the ideological background of the Gospel of John. The author finds it 'difficult to identify direct Hellenistic influence on John from outside of Judaism.' Philo serves as an example of a textual corpus containing Jewish ideas also cultivated by the Gospel of John. Thus Philo's works employ the idea of agency (e.g. Legat. 239) found both in later Rabbinic writings and very early documents from the Mediterranean world. In Mos. 1.158f. Philo describes the heavenly ascent and vision of God experienced by Moses at Sinai, and in the same passage the theme of equality with God also occurs. The ascent of Moses at Sinai also was a second birth ( $Q E$ 2.46). Close parallels exist between the prologue of John and Philo's ideas of the Logos, creation, God's government and communication with the world. Both Philo and John are dependent on Biblical and early Jewish wisdom teaching. (KGS)

9613. P. Borgen, 'Illegitimate Invasion and Proper Ascent: A Study of Passages in Philo's Writings and the Revelation of John', in IDEM, Early Christianity and Hellenistic Judaism (Edinburgh 1996) 293-307.

A proper ascent to the heavenly realm is understood by Philo in two ways: either a person, e.g. Moses, ascends to the presence of God in heaven, or the mind soars above the created things in order to 'see' the Uncreated. The latter ascent is a privilege for the race that 'sees God', i.e. the Jews. Although Philo occasionally evaluates the general search upwards through philosophical reasoning in a positive way, he nevertheless ties the proper ascent to the nation under the laws of Moses. There also exists an illegitimate invasion into the heavenly realm accomplished both by certain philosophers and by rulers such as Gaius Caligula. The common denominator is a denial of God's eternal cosmic government. Comparing Philo with the Revelation of John is a relevant task. (KGS)

9614. P. Borgen, 'Militant and Peaceful Proselytism and Christian Mission', in IDEM, Early Christianity and Hellenistic Judaism (Edinburgh 1996) 45-69, esp. 53, 57-59. 
The article compares Jewish proselytism of various kinds with the early Christian mission to the gentiles. A short passage deals with Philonic material under the heading 'General characterization of proselytism' (§B.3). According to Philo the conversion of gentiles has three aspects: (1) Religious conversion, the central theme of which is the change from polytheism to the worship of the True God; (2) Ethical conversion from pagan way of life to the Jewish life of virtue; (3) Social conversion, implying a breaking of earlier social bonds and becoming a member of a 'new and godly commonwealth'. These three aspects can also be detected in early Christian mission (62-64). Philo expects an increase of proselytes in the future. He does not, however, mention military force as a method for gaining proselytes. (KGS)

9615. P. Borgen, 'Moses, Jesus, and the Roman Emperor: Observations in Philo's Writings and the Revelation of John', Novum Testamentum 38 (1996) 145-159.

The article argues that since apocalyptic texts and mystical texts overlap, passages in Philo which describe heavenly ascents can be drawn into the discussion on the Revelation of John. Philo's ideas of Moses as king, his worthiness, membership in a priestly nation and his position as friend and partner of God are discussed and compared with corresponding traits in the description of Jesus in the Apocalypse. In both cases an influence can be detected from the political milieu surrounding emperors and kings. Both Moses and Jesus in the texts have an authority ranking above that of political rulers, some of whom claimed divine authority. Central to the argument is the interpretation of Mos. 1.158. (KGS)

9616. P. Borgen, 'Philanthropia in Philo's Writings: Some Observations', in L. B. Elder, D. L. BARR and E. S. MAlbon (edd.) Biblical and Human: a Festschrift for John F. Priest (Atlanta GA, 1996) 173-188.

According to Philo philanthropia characterizes God's relation to human beings. This can be seen for instance when God revealed himself to Abraham, when $\mathrm{He}$ as a king dwells in the soul as a palace-temple, and when $\mathrm{He}$ meets the needs of human beings. God's love for humanity is particularly directed towards the twelve tribes of Israel, the centre of humankind. From the people of God the influence of the divine philanthropia is to be spread to all. The Greek usage of the term can be detected in the background of Philo's thoughts. The gods show philanthropia towards men, and a Hellenistic king is expected to do likewise towards his subjects. In Philo Moses serves as a paradigm of philanthropia. In Philo's presentation of the concept apologetic, systematic and theological motifs can be detected: (1) Philo defends the Jews against charges of misanthropy, (2) he sees philanthropia as one of the virtues and (3) as a way of imitating God. (KGS)

9617. P. Borgen, 'Philo of Alexandria - a Systematic Philosopher or an Eclectic Editor?’, Symbolae Osloenses 71 (1996) 115-134. 
The treatises contained in the Exposition of the Laws of Moses are examined with a view to answering the question whether Philo was a systematic philosopher or an eclectic editor. The Exposition is a rewritten presentation of the five books of Moses paralleled by other Jewish writings. In his interpretations Philo combines both Jewish viewpoints and Greek (i.e. Platonic and Stoic) notions. The treatises in the Exposition are tied together by transitional statements. It is especially in these transitions that Philo states his own perspectives and understanding. Although he is not a systematic philosopher, he is more than just an eclectic editor. (KGS)

\section{A. P. Bos, Geboeid door Plato: het christelijk geloof bekneld door het glinsterend pantser van de Griekse filosofie (Kampen 1996).}

The subject of this study is the encounter of Judaism and the Christian faith with Greek philosophy. In this process Philo, who accepts the Greek tradition of rationality, played a pivotal role. After Philo the Christian exegetes read the Bible through the glasses of Greek philosophy. The author's attitude towards this process of Hellenization of the Christian faith is rather negative (7-19). Because of the key role played by Philo, Bos discusses his exegesis, and as an example treats Philo's interpretation of Sarah and Hagar

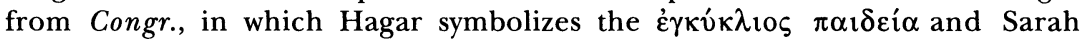
supreme virtue. His treatment consists of a translation of $\S 1-18$ and $\$ 71-89$, followed by some remarks in which he explains that Philo deprives the story of its historical meaning and replaces it by an interpretation involving abstract, philosophical themes. Bos argues that in his exegesis Philo derives two points from Greek philosophy that do not belong to the Jewish tradition: (1) the method of allegorical interpretation; (2) philosophically based interpretations. Disagreeing with Wolfson, he defends the thesis that in Philo God's word, i.e. faith, is subordinated to philosophy, which leads to the subversion of the real meaning of scripture (20-36). In the chapter devoted to the views on creation in Jewish and Christian thinkers Bos gives a translation of Opif. 1-25 with some comments (122-140). In the final chapter the author discusses his own attitude towards the process of Hellenization, contesting the view of D. T. Runia that this process was inevitable. The Christian faith was bound by the chains of Greek philosophy (and especially Plato), so that the true meaning of the Bible was mutilated (154-164). This view is encapsulated in the title of the book, which involves a play on words and can be translated as follows: Enchained/captivated by Plato: Christian faith hemmed in by the shining armour of Greek philosophy. (ACG)

9619. P. R. Bosman, The Evolution of Conscience: the History of Development of the 'sunoida' Word Group and its Use by Philo and Paul (diss. University of Pretoria 1996).

The study investigates the initial phases of the Western concept of conscience by means of an analysis of the $\sigma v v_{v o t} \alpha \alpha$ word group. First the history of development of the word in the literature before Philo is presented. After this all the occurrences of the word group in Philo and Paul are analysed. The analysis shows the fluidity of the concept. The same topoi-products of the 


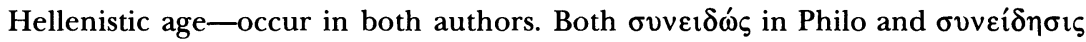
in Paul act as inner monitors. For both authors the inner entity functions on the basis of the individual's access to truth and the good. (DTR; summary based on DA 58-03A, p. 939)

9620. D. H. Bradshaw, Activity, Actuality, and Energy: 'Energeia' in Aristotle and in Later Greek Philosophy (diss. University of Texas at Austin 1996).

The dissertation traces the evolution of the concept of energeia from its origins in Aristotle to the Neoplatonists. In chapter 3 developments in Philo are discussed. (DTR; summary based on DA 57-06A p. 2515)

9621. R. VAN DEN BRoEK, Studies in Gnosticism and Alexandrian Christianity, Nag Hammadi Studies 39 (Leiden-New York-Köln 1996), esp. 117-130 and 206-234.

Collection of fifteen articles, four of which are published here for the first time while two others appeared in relatively inaccessible collections. The two studies dealing with Philo, nrs. 7 and 13, are reprints of R-R 8606 and R-R 7902 respectively. (HMK)

9622. C. Carlier, 'Sur un Titre Latin du De Vita Contemplativa', The Studia Philonica Annual 8 (1996) 58-72.

The author focuses attention on the Latin translation of De vita contemplativa published by Jean Sichard in Basel in 1527, and especially on its title and subtitle in the text proposed by Sichard: De Essaeis et Philonis Iudaei liber de statu Essaeorum, id est Monachorum qui temporibus Agrippae regis monasteria sibi fecerunt ('On the Essenes: book of Philo the Jew on the subject of the way of life of the Essenes, that is the Monks who made monasteries for themselves in the time of King Agrippa'). All the evidence that can be brought to bear on this curious title is collected together. It is impossible to determine when and by whom this title was devised, but the working method of Jean Sichard points to the conclusion that it was already found in the now lost manuscript of Lorsch. If the translator did not formulate the title himself, then it must have been added later under the strong influence of the treatment of Philo and the Therapeutae by Eusebius in his Ecclesiastical History, which was subsequently taken over by Jerome. (DTR)

9623. C. M. Carmichael, The Story of Creation: its Origin and its Interpretation in Philo and the Fourth Gospel (Ithaca 1996).

The mention of Philo in the title is deceptive. The monograph is not focused on Philo, but rather uses Philonic evidence to give support to the thesis that in the first five chapters of the Gospel of John the seemingly historical narrative of the events of Jesus' life are in fact shaped by certain ideas about the creation of the world that the evangelist has taken from the account of 
creation in Genesis 1. 'The ideas determine the history, not history the ideas (p. ix).' For each section of the narrative, equivalent to the seven days of creation, Philonic evidence is used to illustrate the manner in which a contemporary of the author read scripture. Much material is taken from Opif., but the Quaestiones and other treatises are also used. See the list of passages used on p. 132-133. Reviews: J. W. McCant, Choice 34 (1997) 1355; A. Mendelson, JJS 48 (1997) 368-369; C. H. Williams, JThS 49 (1998) 531-532; D. T. Runia RBL (1999) 299-301. (DTR)

9624. J. Cazeaux, 'Être juif et parler grec: l'allegorie de Philon', in C.-B. Amphoux and J. Margain (edd.), Les premières traditions de la Bible, Histoire du texte biblique 2 (Lausanne 1996) 165-205.

First published in 1988 (see 8815) and reprinted here, this article constitutes an excellent introduction to Philo. It includes a presentation of him as a historical figure, an account of his style, of the principles and codes of Philonic exegesis and of the characteristics of his discourse. (JR)

9625. N. G. Cohen, 'The Elucidation of Philo's Spec. Leg. 4:137-8: "Stamped too with Genuine Seals", in R. Katzoff (ed.), Classical Studies in Honor of David Sohlberg (Ramat Gan 1996) 153-166.

This article - parallel to the discussion in the author's 1995 monograph (9520) 129ff.-offers a detailed examination of Spec. 4.137f., featuring a new understanding of the passage and suggesting, consequently, that a number of proposed textual emendations are, in fact, superfluous. The heart of the argument lies in the conviction that the pericope must be read in close exegetical conjunction with the preceding section 4.55-78: a reading which allows an appreciation of the parallelism between the contents of the Sh'ma (Deut. 6:6ff; Spec. 4.137-8) and the vestments of the High Priest. 'This dual image,' concludes the author, 'must have belonged to Philo's Jewish cultural heritage as part of the joint Palestinian/Diaspora midrashic tradition' (p. 164). (DS)

9626. P. Copan, 'Is Creatio Ex Nihilo a Post-Biblical Invention? An Examination of Gerhard May's Proposal', Trinity Journal n.s. 17 (1996) 77-93.

Though Philo is only very briefly treated, we include this article because of the importance of its subject. Copan argues against Gerhard May's thesis that the doctrine of creatio ex nihilo originated with second-century Christian thinkers concerned to defend their notion of God against contrary Gnostic and Middle Platonist beliefs. Agreeing that the doctrine may have been formulated explicitly only in the 2nd century, Copan argues that the doctrine is found, even if sometimes implicitly, in several extra-Biblical Jewish and Christian writings, and indeed in the Bible itself. Philo exemplifies a Jewish thinker influenced by the Platonic belief in eternal formless matter; even Philo, however, sometimes sounds like a proponent of creatio ex nihilo. (DTR) 
9627. B. E. Daley S. J., "Bright Darkness' and Christian Transformation: Gregory of Nyssa on the Dynamics of Mystical Union', The Studia Philonica Annual 8 (1996) 83-98, esp. 85-7.

Brief aspects of mystical elements in the thought of Philo (and Origen) are presented as background for a discussion of Gregory's mysticism. In Opif. 70 many of the central themes and images of later Jewish and Christian mysticism can be detected. (DTR)

9628. E. Dassmann et al., Reallexikon für Antike und Christentum, Band XVII (Stuttgart 1996).

H. Thyen, Art. 'Ich-bin-Worte' 147-213, esp. 168-170 (I am sayings); M. Baltes, Art. 'Idee (Ideenlehre)' 213-246, esp. 235-238 (Idea, doctrine of ideas); E. Dassmann, Art. 'Jeremia' 543-626, esp. 554-555 (Jeremiah); P. Jay, Art. 'Jesaja' 764-821, esp. 778 (Isaiah); A. P. Bos, 'Art. Immanenz und Transzendenz' 1041-1092, esp. 1073-1076 (Immanence and Transcendence).

9629. M. Desjardins, The Origins and Development of the Notion of Isostheneia in Greek Scepticism: a Collection of Texts (diss. University of Ottawa 1996).

There is some evidence to suggest that Philo had knowledge of the concept of $i \sigma o \sigma \theta \dot{v} v \varepsilon i \alpha$, which was to become fundamental in imperial scepticism. (DTR; based on summary in DA 58-06A, p. 224)

9630. A. Dihle, 'Das Streben nach Vollkommenheit nach Philon und Gregor van Nyssa', in G. Schöllgen and C. Scholten (edd.), Stimuli: Exegese und ihre Hermeneutik in Antike und Christentum; Festschrift für Ernst Dassmann, JACErgbd 23 (Münster 1996) 329-335.

The allegorical interpretation of Moses' Midianitic sojourn in Gregory's and Philo's De vita Moysis is compared in order to illustrate the different exegetical approach of both authors. Their exegesis of Ex. 33 too has a different focal point: according to Philo God grants Moses a prophetic vision of the noetic world; according to Gregory man reaches perfection by never attaining the end of his striving. In this text Gregory comes closer to Plato's Phaedrus than to later Platonism. (DZ)

9631. J. Dillon, 'The Formal Structure of Philo's Allegorical Exegesis', in J. GLUCKeR and A. LAKs (edd.), Jacob Bernays: un philologue juif, Cahiers de Philologie 16 (Lille 1996) 123-131.

It is argued that the tradition of the commentary within which Philo is working and that of the Neoplatonist commentators is basically the same. The common source of this method is postulated to be the commentary form 
developed by Stoic scholars in the last two centuries BCE. This article was originally presented at a conference in Tel Aviv in 1981 (the papers of which took an unusually long time to prepare for publication). In the meantime it was also published as part of the commentary on Quod Deus edited by D. Winston and J. Dillon; see the summary at R-R 8326. (DTR)

9632. J. Dillon, The Middle Platonists: a Study of Platonism 80 B. C. to A.D. 220, Revised edition with a new afterword (London 1996).

The author adds a lengthy afterword (pp. 422-452) to the new edition of his celebrated account of Middle Platonism (first published in 1977, see R-R 7714), in which he comments on scholarly developments that have taken place in the meantime and also sometimes revises his earlier views. A review of Philonic studies is given on pp. 438-441, concluding with the following words: 'Philonic studies, then, continue to be an actively volcanic area, and no consensus has been reached on the nature of his relationship to the Platonist tradition.' (DTR)

9633. C. Dohmen and G. Stemberger, Hermeneutik der jüdischen Bibel und des Alten Testaments (Stuttgart-Berlin-Köln 1996).

This manual for students gives a presentation first of the Jewish and then of the Christian view of Israel's Bible. In the former section Stemberger describes first the understanding of the Sacred Book during the period of the second Temple. Here, the pages on Josephus (pp. 33-36) and the Septuagint (pp. 51-59) will be of interest for the Philo specialist. A longer paragraph on 'Philo and his allegorical exegesis' is presented at pp. 63-74. Stemberger shows Philo's dependence upon the interpretation of Homer and his Jewish predecessors. The importance of both the literal and the symbolical meaning is demonstrated with examples. (DZ)

9634. L. H. Feldman, Studies in Hellenistic Judaism, AGAJU 30 (Leiden 1996), esp. 490-494, 504-528.

In this collection of articles and studies written over a period of 40 years Feldman reprints two studies that deal with Philo at some length: 'Torah and secular culture: challenge and response in the Hellenistic period' (8737), p. 487-503, esp. 494-498; 'Philo's views on music' (8736), p. 504-528. There are also some interesting remarks on Josephus' use of Philo as a source (p. 12) and Philo's references to Judea (p. 563-564). (DTR)

9635. W. Fauth, 'Salutatio Solis Orientis. Zu einer Form der Heliolatrie bei Pythagoreern, Manichäern, Therapeuten und Essenern', in H. Cancik, H. Lichtenberger and P. Schaefer (edd.), Geschichte, Tradition, Reflexion. Festschrift für Martin Hengel zum 70. Geburtstag. Bd. II: Griechische und Römische Religion (Tübingen 1996) 41-54, esp. 48-51. 
This article deals with testimonia concerning sun worship in various more or less philosophical circles or communities. The author gives a brief survey of the various scholarly opinions concerning the community of the Therapeutae as pictured in Philo's De vita contemplativa. He notes that a neglected feature in the discussion is the sun worship of the Therapeutae, which according to him can be explained on the basis of (1) the Egyption environment, (2) the sun as image for both intellectual and visionary 'illumination', and (3) the community's aspiration to moral and inner purity. The attitude of the Essenes (for which see Philo, Prob. 75 and Josephus, BJ 2.128) towards the rising and setting sun must be seen against the background of the dualism between (the sons of) light and darkness as expressed in Qumran texts. (HMK)

9636. K. L. GACA, The Early Christian Adaptation of Ancient Greek Philosophical and Biblical Principles of Human Sexual Conduct (diss. University of Toronto 1996).

The dissertation presents the relationship between Greek philosophical, biblical, and Christian sexual principles of human sexual conduct, setting out the important differences between them, and explaining why it is misguided to mute the differences. After five chapters dealing with Greek philosophical views, the sixth chapter is devoted to Philo. It is argued that he achieves an innovative synthesis of Pentateuchal sexual norms, Pythagorean procreationism, and aspects of Platonic and Stoic philosophy. Philo's views exert an important influence on those of Clement of Alexandria, with which the thesis ends. See also the following item. (DTR, summary based on DA 57-08A, p. 3480)

9637. K. L. GACA, 'Philo's Principles of Sexual Conduct and their Influence on Christian Platonist Sexual Principles', The Studia Philonica Annual 8 (1996) 21-39.

Though not himself a Christian, Philo plays a major role in the development of early Christian sexual morality through his reinterpretation of LXX sexual regulations. He has two fundamental criteria by which he distinguishes between permissible and impermissible sexual activity. The first is that sexual activity should take place for the purpose of procreation only. The source of this view is Pythagorean teaching. The normative force of this principle is extended by Philo's contention that it is taught by Pentateuchal law, as seen for example in his interpretation of Lev. 18:19, 22. The second criterion is motivated by the LXX, namely that if a sex act involves sexual apostasy from God, it is absolutely forbidden and that its agents should be put to death. In his application of this principle Philo takes a harsher stand than the LXX itself. But he does not conclude that engaging in sexual activity for the sake of pleasure rather than procreation, as stipulated by the first principle, is in itself an act of sexual apostasy. He thus takes a lenient view towards love-making within marriage. In the final section of the article the author examines how Philo's views were taken over and developed by Clement of Alexandria, who does take the step of regarding non-procreationist 
sexual activity within marriage as apostasy. The stage is thus set for Christian Platonist writers to argue that the procreationist sexual principle is the inflexible mandate of God. (DTR)

9638. P. GARNSEY, Ideas of Slavery from Aristotle to Augustine (Cambridge 1996), esp. 157-172.

In Garnsey's monograph, based on the Stanford lectures presented in Dublin in 1995, a chapter is devoted to Philo. This is unusual, the author claims, but Philo's views are not only interesting in themselves, but also play an important role in linking pagan and Christian thought on the issue. Close analysis of Philo's views reveals a kind of 'intellectual schizophrenia' (p. xv). In Prob. and other writings Philo basically adopts the Stoic view that no person is a slave by nature, but that real slavery is a moral position, consisting of submission to the mastery of passions. Philo is a bit careless in his use of the phrase 'slave by nature', but there is no real contradiction. Moral slavery is ordained by God, and allows the subjection of moral slaves to institutional slavery to be sanctioned. On the other hand, in his allegorical interpretation of biblical figures such as Esau and Canaan, he does incline to the view that some persons are inherently slavish and that there is a natural class of slaves, which is the Aristotelian position on slavery. It is surprising that Philo does not describe Egyptians as natural slaves in the context of his allegories, but perhaps his local circumstances held him back. In the course of Garnsey's discussion 16 Philonic texts are cited and discussed. In a subsequent chapter on Ambrose's views of slavery it is further noted that the bishop is strongly indebted to Philo as a source. In Ep. 7 we have a kind of Christian development of Philo's Prob. (see esp. pp. 195-199). (DTR)

9639. J. Glucker and A. Laks (EDD.), Jacob Bernays: un philologue juif, Cahiers de Philologie 16 (Lille 1996).

Some brief remarks on Bernays' interest in Philo are given by E. E. Urbach (pp. 21-23, on the Breslau years) and by J. Bollack (pp. 210-211 on the alleged inauthenticity of De aeternitate mundi). See also 9631. (DTR)

9640. P. Graffigna, ‘ $\Phi Y \Sigma I K \Omega \Sigma$ 'A $\Lambda \Lambda$ HГOPEIN. Osservazioni lessicali sulla teoria allegorica filoniana', Koinonia 20 (1996) 107-113.

The article undertakes to examine the relation between $\varphi v ́ \sigma \varsigma s$ and $\dot{\alpha} \lambda \lambda \eta \gamma o-$ $\rho i \alpha$ in the writings of Philo by means of a detailed examination of the more significant passages in which they occur. On the basis of these it emerges that for Philo the Law is truly a mystical reality, the unique expression of

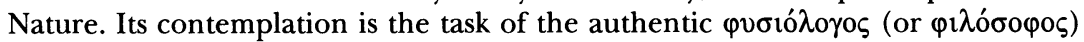
and deserves his full concentration. $\varphi v ́ \sigma \varsigma \varsigma$ assumes a particular significance for the Alexandrian, because through it a reality is expressed which exists beyond the words of the text, and thus is not subject to arbitrary interpretation.

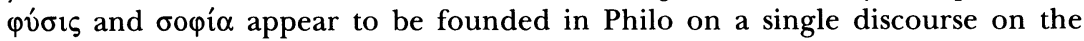
divine, a $\theta \varepsilon 0 \lambda$ orí $\alpha$ which is above all a commentary on the sacred text and anticipates both its levels, the literal and the allegorical. $\dot{\alpha} \lambda \lambda \eta \gamma$ oí $\alpha$ thus 


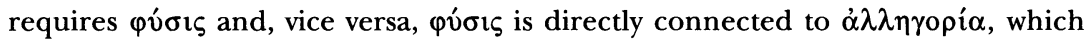

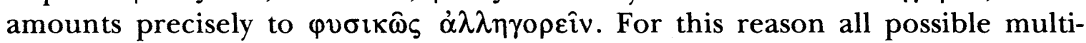
plicity $\left(\pi \circ 1 \kappa \imath \lambda i^{\prime} \alpha\right)$ is excluded from interpretation, because when the hidden

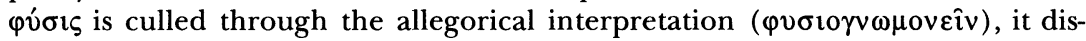
plays the hallmarks of simplicity and authenticity. (DTR, based on author's summary)

9642. G. A. P. HARvey, The True Israel: Uses of the Names Jew, Hebrew and Israel in Ancient Jewish and Early Christian Literature, AGAJU 35 (Leiden 1996).

In this study Philo's use of the names Jew, Hebrew and Israel is analysed.

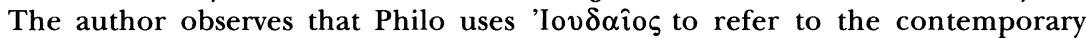
Jews, but also to the Jews of past generations. This designation does not have a philosophical meaning as is the case for the name Israel (pp. 43-46). In Philo's usage of 'Hebrew' two distinct applications can be seen. First, biblical persons are thus named; second, 'Hebrew' is used in the etymological explanation of names (pp. 121-124). In most of the cases in which Philo uses 'Israel' it means the person or group who sees God. It is primarily the name of a philosophical construct rather than a socio-political or religious group (p. 223). (ACG)

9643. B. Heininger, Paulus als Visionär. Eine religionsgeschichtliche Studie, Herder Biblische Studien 9 (Freiburg etc. 1996), esp. 146-159.

In his overview of the different forms of vision in the Old Testament, the Greco-Roman world and Judaism, Heiningen has a section entitled 'Ekstatische Schau bei Philo von Alexandrien'. In describing the visionary prophecies of Moses, Balaam and the three types of dreams outlined in Somn. 1.1, Philo orientates himself more according to Greek mantic theories than to the prophets of the Old Testament. He takes over the Platonic division of the divine possession, but with a different content and evaluation, as well as the use of the language of the mysteries to depict the heavenly ascent of the dianoia and its vision of God (at least in $Q E$ 2.39). There is, however, a measure of ambiguity about whether such a vision is actually possible. By means of the metaphorics of 'light' Philo interprets Old Testament epiphanies as inner illumination. With regard to the recipients of visions the author observes both a moralizing and democratizing tendency (the latter seen for example in the autobiographical passages). (DZ)

9644. E. Hilgert, 'The Son of Timaeus: Blindness, Sight, Ascent, Vision in Mark', in E. CAStelli et al. (edd.), Reimagining Christian Origins (Valley Forge 1996) 185-198.

This article investigates the motif of the ascent vision which, according to Hilgert, is present in Mark 8-16. This motif consists in the descent of a heavenly figure who carries out his mission on earth, returns on high, and finally sees God. Mark's stories about Jesus, for instance his healing of 
blindness and his journey to Jerusalem, fit well into this pattern. This ascent motif can be paralleled with Philo's depiction of Moses' life in De vita Moysis, and Hilgert signals common vocabulary and imagery. Both in Philo and Mark the ascent vision has a Platonic background, namely the encomium on sight in the Timaeus and the allegory of the cave in the Republic. The author ends his article with some comments on the way Mark makes use of the pattern of ascent. (ACG)

9645. H. Jacobson, A Commentary on Pseudo-Philo's Liber Antiquitatum Biblicarum with Latin Text and English Translation, 2 vols., AGAJU 31 (Leiden etc. 1996).

The history of Ps.Philo's History of Biblical Antiquities is closely related to the transmission of a part of the Philonic corpus. Jacobson makes a suggestion how $L A B$ could have become attributed to Philo (196-7) and also gives interesting details on how the two were confused in Byzantium and the Medieval West (273ff.). For references to Philo in the exhaustive commentary on the text of $L A B$ see the listing on p. 1285. (DTR)

9646. J.-G. Kahn [ישרן. בהן-'Philo Hebraicus?', in R. MARgoLIN (ed.), Jewish Studies 36 (Jerusalem 1996), 41*-58* [English Section].

A brief assessment of the initial volumes of the translation of the Philonic corpus into modern Hebrew (Daniel-Nataf $1986=\mathrm{R}-\mathrm{R}$ 2601; $1991=\mathrm{RRS}$ 2602) serves as a point of entry to a discussion of Philo's own attitude toward and knowledge of the Hebrew language. As in earlier studies, the author affirms Philo's ability to read the Hebrew Bible and even to converse with 'Hebrew speaking rabbis in Judea and the diaspora' $\left(58^{*}\right)$. Kahn concludes, nevertheless, that Philo's philosophical orientation demanded a Greek vocabulary, thus rendering the cognomen 'Philo Hebraicus' unsuitable. (DS)

9647. R. Katzoff [רוך. רופק, 'Philo and Hillel on Violation of Betrothal in Alexandria', in I. GafNi, A. Oppenheimer and D. R. Schwartz (edd.), The Jews in the Hellenistic-Roman World. Studies in Memory of Menahem Stern (Jerusalem 1996) 39*-57* [English Section].

This article offers a detailed examination of Spec. 3.72 (the seduction of a bride on the eve of her marriage) within the overall context of rabbinic halacha and Roman legislation. Following a survey of previous discussions (Goodenough, Heinemann, Gulak, Belkin) and with the aid of a recent analysis by the Dutch scholar H. Ankum, the author provides a fresh assessment of Philo's attitude toward biblical and Roman law. His conclusion dismisses earlier attempts to distinguish between the customs or practices of the Jewish communities of Alexandria and Palestine, concluding that the Philonic passage 'is theoretical speculation, and is no evidence at all for the behaviour of Alexandrian Jews' (54*). (DS) 
9648. I. G. KidD, 'Theophrastus Fr. 184 FHS\&G: Some Thoughts on his Arguments', in K. A. Algra, P. W. van Der Horst and D. T. Runia (edd.), Polyhistor: Studies in the History and Historiography of Ancient Philosophy presented to Jaap Mansfeld on his Sixtieth Birthday, Philosophia Antiqua 72 (Leiden 1996) 135-144.

The main subject of the contribution is the Theophrastean origin of Philo's arguments in Aet. 117-150. But the author reminds his readers that, as in the case of all fragments, it is important to keep distinct reporter, context and reference (135). Consistent with this methodological premiss, he makes various observations on the Philonic elements in the passage. It is also noted that the main weight of evidence in the treatise derives from sources dating back to the 2nd century BCE. (DTR)

9649. B. Kollmann, 'Das Schwurverbot Mt 5,33-37 / Jak 5,12 im Spiegel antiker Eidkritik', Biblische Zeitschrift 40 (1996) 179-193, esp. 184-188.

Since R. Hirzel's monograph on the oath in antiquity (1902), the view is generally accepted that theologically motivated rejection of swearing an oath is something genuinely Jewish (and Christian). This article argues, however, that theological (as distinct from ethical or anthropological) criticism of the oath is by no means a non-hellenic phenomenon, but was fully present (from an early time) in the Greek world, notably in Pythagoreanism, and from there entered into the Jewish and Christian tradition. The author elaborates on Philo's theory and criticism of the oath, in which he sees influence of various Greek traditions. Where Philo (as well as Josephus) describes the Essene community and ascribes to it a total prohibition of the oath, he lends it pythagorean features (Prob. 84). (HMK)

9650. J. Kügler, 'Die Windeln Jesu (Lk 2)—Nachtrag. Zum Gebrauch von $\Sigma \Pi$ ПРГАNON bei Philo von Alexandrien', Biblische Notizen 81 (1996) 8-14.

The author argues that, though Philo uses the expression 'from the nappies onwards' quite often, esp. in the context of education, in Legat. 54 it involves a reminiscence of Hellenistic royal ideology, and ultimately of the Egyptian conception of 'ruling from the nappies onwards'. (DZ)

9651. G. KwETA, Sprache, Erkennen und Schweigen in der Gedankenwelt des Philo von Alexandrien, Europaïsche Hochschulschriften 20.403 (Frankfurt-New York 1996).

The author was originally interested in the role of silence for the analysis of language. Her voluminous study (744 p.), based on a philosophical dissertation (Munich 1988, see 8841), begins with a short survey on the situation of research, and then proceeds systematically. First she describes the structure of 
the human logos within Philo's dualistic worldview, thereby correcting the 'optimistic' understanding of language in K. Otte's 1968 dissertation (see R-R 6827). Chapter 2 develops Philo's doctrine of creation through the Logos and his anthropology, esp. the dominance of the nous, both determined by the hierarchy of model and image. In outlining his theory of linguistic decadence Kweta again is in disagreement with Otte (pp. 112ff., 119ff). Chapter 3 places the origin of language and its function within this framework. Chapters 4 and 5 are dedicated to the corresponding theory of knowledge and its degrees. Only the lowest degree is bound to language. Chapter 6 treats the role of light in this concept and the precedence of intuition over hearing. The deficiency of speech is evident in the problem of naming God (chapter 7). The summarizing final chapter localizes Philo in the history of the preceding Graeco-occidental philosophy of language (pp. 418-426). In the case of Philo language is limited to the physical-physiological phenomenon of sound; it has no sign-value, but an interpretative function; it is only a medium of communication in the external sphere, ambivalent between truth and untruth. Hence the importance of non-verbal cognition. Silence-corresponding to light-forms a kind of horizon of human consciousness (p. 413f). Objectively it is identified with the Divine, accessible through the Logos. Man has to mediate between language and truth through his religious-ethical behaviour (p. 424). The path of metanastasis conducts him to a positive use of speech (p. 406). In addition the theory of silence of $O$. Casel is referred to, and further pragmatic passages on silence are collected. An appendix of more than 60 pages contains several excursuses. (DZ)

9652. J. MAIER, 'La Torah di purità nel Levitico e sua trattazione nella letteratura giudaica del periodo del Secondo Tempio e nei primi secoli cristiani', Annali di storia dell'esegesi 13 (1996) 39-66.

This article presents a collection of texts concerning the laws on purity and impurity, for which see Leviticus 11-14. Four groups are considered: texts from Qumran, the works of Philo, the works of Josephus, and Rabbinic texts. The author characterizes these sources in their approaches to the Pentateuch and to the oral law or tradition. The Appendix, constituting the largest part of the article, gives an extensive list of passages from the four groups of sources as they bear upon the successive verses of Lev. 11-14, including numerous references to the writings of Philo. (HMK)

9653. J. MAnsfeld and D. T. Runia, Aëtiana: The Method and Intellectual Context of a Doxographer, Philosophia Antiqua 73 (Leiden 1996), esp. 161-3, 317-8.

In two respects Philonic evidence is important for the study of the doxographer Aëtius: firstly the interpolation of material from ps.Plutarch in Prov. 1.22, secondly the pre-Aëtian doxographical passage at Somn. 1.21-32. Both passages are briefly discussed in the context of a comprehensive examination of the reconstruction of Aëtius' work. (DTR) 
9654. J. P. Martín, 'El motor inmóvil de Aristóteles y el Dios de Filón', Methexis 9 (1996) 84-98.

The article attempts to show lexical and conceptual continuity between book Lambda of Aristotle's Metaphysics and the writings of Philo. In lexical terms Plant. 89 may be the nearest passage. There is a common feature shared by Aristotle and Philo, namely use of the term nous to name God. However there is also a difference: Philo does not attribute to God the function of noêsis. (JPM)

9655. S. L. Mattila, 'Wisdom, Sense Perception, Nature and Philo's Gender Gradient', Harvard Theological Review 89 (1996) 103129.

This article focuses on three female personifications that are important in Philo's thought, namely Wisdom, sense-perception, and Nature. In the case of divine Wisdom Matilla argues that Philo presents her as more male than female. In her relation to God Wisdom is female, being his wife and the mother of creation, but in relation to humanity Wisdom becomes male: she is father, doing male tasks, namely sowing and begetting. Sense-perception in turn is predominantly depicted as female, having a negative connotation due to her close relationship with the material world. Philo does not, however, see sense-perception in totally negative terms: she is necessary in order to observe the marvels in the universe. Although Philo pictures a continuous struggle between mind and sense-perception, it is nevertheless his final aim to achieve a harmony between the two. In Philo's description of Nature many Stoic elements are discernible: Nature is presented as the master craftsman who shapes and generates the material world. She can be best described as semi-immanent. She is immanent, because she can be identified with the cosmos. At the same time, however, by staying in contact with the transcendent Logos, she is not totally immanent in the way that Stoic nature is. Matilla ends her article by giving a schematic overview of what she calls Philo's 'gender gradient', on which the transcendent God is placed beyond the peak of the positive or male side. Wisdom and Logos emanate from God, being mediators between God and creation. They are more male than female. Mind and Wisdom stand also on the male side. Sense perception on the other hand is placed on the negative or female side, at the end of which unformed matter is located. (ACG)

9656. E. Mazzetti, Megalopoli/ecumenopoli. La città come destino e come sfida. Dalla megalopoli di Filone all'ecumenopoli di Gottmann, Atti del Seminario interdisciplinare della Facoltà di Scienze Politiche dell'Università di Napoli Federico II, in collaborazione con l'Istituto di Urbanistica dell'Università di Roma 'La Sapienza', tenutosi a Napoli dal 9 aprile al 16 giugno 1984, Università di Napoli. Quaderni di Scienze Politiche 43 (Naples 1996). 
We include this volume because it mentions Philo in the title and as a curiosity. In fact there is only a single mention of Philo in the whole book (p. 10). It is made by the editor in his introduction and refers to the book of the Geographer Jean Gottmann, Megalopolis: the Urbanized Northeastern Seaboard of the United States (New York 1961), as a reflection on the title of his volume, inasmuch as Philo 'taught that an great city of ideas existed which predetermined and directed the material world in which we live, a city that Philo calls the megalopolis'. (RR)

\section{M. Merino Rodriguez, Clemente Alejandrino: Stromata I; Cultura y Religión, Fuentes Patrísticas 7 (Madrid 1996).}

This new edition of Stromateis I pays careful attention to the subject of Clement's sources. Philo is frequently considered as antecedent of Clement, who cites him by name on four occasions. The author highlights the narrow relationship between the treatise De vita Mosis and the development of Stromateis 1.151.1-157.4. (JPM)

9657a. G. Messadié, La fortune d'Alexandrie (Paris 1996); German translation, Alexandria (Munich 1997).

For lovers of historical novels we include this work of fiction, set in Alexandria in $38 \mathrm{CE}$. The adventures of the Alexandrian hetaira Delia bring her into contact with the 'philosopher' Philo, 'who had always dreamt of fusing Hellenism and Judaism into one'. In some explanatory notes at the back of the book the author claims that 'Philo was in the first century the most famous philosopher in the eastern part of the Mediterranean'. Other familiar figures to receive a mention are Flaccus and the Therapeutae of Lake Mareotis, who are presented a 'hemerobaptists', a group derived from the Essenes. (JR)

9658. D. A. NiELSEN, 'La Misura Divina: creazione e retribuzione nel libro della Sapienza e in Filone. Aspetti dell'incontro fra giudaismo ed ellenismo', Religioni e Società 24 (1996) 9-21.

Taking his starting-point in Wisdom 11:20 ('But you have ordered all things with measure, number and weight'), Nielsen compares Wisdom with Philo on the following points: (1) the concept of 'measure, number and weight' and its meaning in the context of the history of philosophy; (2) the role of the law and of order in creation; (3) the meaning of number symbolism in creation; (4) the role of the Logos with regard to creation; and (5) the relation between these concepts and the theme of retribution-judgmentpunishment. According to Nielsen, the points analysed bring to light that the philosophical dimension (Middle Platonist, Pythagorean, Stoic, Aristotelian, p. 12) for all its importance does not constitute the heart of Philo's thought, but must always be brought into relation to a 'Hebrew core'. More specifically, both Wisdom and the works of Philo can be understood as efforts to reinforce the Hebrew religion and culture by bringing them into rapport with the present situation (p. 19). (RR) 
9659. V. Nikiprowetzky, Études philoniennes (Paris 1996).

Published 13 years after his untimely death, this volume has been put together by its editor J. Riaud both as a homage to the man who made such a great contribution to Philonic studies and for the purpose of making it easier to consult a number of studies which are not very accessible to most scholars. The volume contains twelve studies in all, presented in chronological order of their original publication. We list the titles and give a reference to the location in our bibliography where a summary can be found: 'Les suppliants chez Philon d'Alexandrie' (= R-R 6320); 'Problèmes du "Récit de la création" chez Philon d'Alexandrie' (= R-R 6520); La spiritualisation des sacrifices et le culte sacrificiel au temple de Jérusalem chez Philon d'Alexandrie' (= R-R 6741); 'Schadenfreude chez Philon d'Alexandrie? note sur In Flaccum, 121 sq.' (= R-R 6826); 'L'exégèse de Philon d'Alexandrie' (= R-R 7332); 'Note sur l'interprétation littérale de la Loi et sur l'angélogie chez Philon d'Alexandrie' (= R-R 7530); 'Rébecca, vertu de constance et constance de vertu chez Philon d'Alexandrie' (= R-R 7635); ' $\Sigma T E I P A, ~ \Sigma T E P P A, ~ \Pi O \Lambda \Lambda H$ et l'exégèse de I Samuel 2, 5 chez Philon d'Alexandrie' (= R-R 7732); 'Le De vita contemplativa revisité' (= R-R 7931); 'Sur une lecture démonologique de Philon d'Alexandrie, De gigantibus 6-18' (= R-R 8032); 'Quelques observations sur la répudiation de l'esclavage par les thérapeutes et les esséniens d'après les notices de Philon et de Flavius Josèphe' (= R-R 8236); 'Le thème du désert chez Philon d'Alexandrie' (RRS 8944). The various indices at the end of the book amounting to 21 pages in all make it into a precious instrument of research for all Philonic scholars. See also 9671. Reviews: C. Bernas, RelStR 23 (1997) 419; C. Barry, ScEs 49 (1997) 369-370; H. Crouzel, BLE 98 (1997) 398-399; P. Luisier, OrChrP 63 (1997) 567-568; J. Lust, EThL 73 (1997) 167; D. M. Hay, SPhA 10 (1998) 189-191; J. M. Leonard, ETR 73 (1998) 270-271; G. Pelland, Greg 79 (1998) 186; F. Siegert, ThLZ 123 (1998) 379-380; J. M. Auwers, RThL 30 (1999) 104-105; S. Pearce, JJS 50 (1999) 151-152. (JR)

9660. A. Orbe, Teología de San Ireneo IV. Traducción y Comentario del Libro IV del "Adversus Haereses", Biblioteca de Autores Cristianos: Series maior 53 (Madrid 1996).

Orbe compares some texts of Philo, together with other early Christian authors, in order to illustrate the background of Irenaeus. The author points out a parallel between Adversus haereses IV 31,1 and QG 4.56: Philo is the oldest Greek testimony that tries to rescue the responsibility of the daughters of Lot completely in their relationship to their father. (JPM)

9661. J. D. Owens, Pauline Cosmological Statements in Light of Textual and Conceptual Parallels in Classical and Hellenistic Writings (diss. South-Western Baptist Seminary 1996).

Traces of Greek natural philosophy can be found in the cosmological passages of Paul's letters. In order to demonstrate this claim the author makes use of parallel material in the writings of Philo. (DTR; summary based on DA 58-05A, p. 1762) 
9662. J. C. Paget, 'Jewish Proselytism at the Time of Christian Origins: Chimera or Reality?', Journal for the Study of the New Testament 62 (1996) 65-103.

Whereas previous studies on Jewish proselytism contend that a missionary consciousness was absent from Judaism at the time of Christian origins, this paper is an attempt to show that the evidence, though not abundant, exists in sufficient measure to argue for the existence of such consciousness among some Jews. The author develops his points through a discussion of the way in which the evidence, including Philo, is used by various scholars. In response to M. Goodman's thesis that in the first century CE the term 'proselyte' was only becoming a technical one for a Gentile convert to Judaism, Paget on pp.

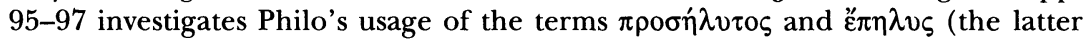
being preferred by Philo). (HMK)

9663. A. PAul, 'De l'Intertestament à la christologie. Voies et fondements du monothéisme chrétien', in A. MARCHAdour (ed.), L'Évangile exploré: Mélanges offerts à Simon Légasse, Lectio divina 166 (Paris 1996) 91-120.

It took many centuries before the biblical tradition was able to conceive monotheism in all its theological rigour. The biblical tradition includes, according to the author, the New Testament, which bears witness to the completion of divine revelation through the incarnation of the Logos or divine Word. From this event flow all the conditions required for true monotheism. The contribution of Philo in this theological development consists of his presentation of two figures, the Logos and Sophia. These must be placed in a network of divine manifestations and substitutions for which one finds functional correspondences in pre-Christian Jewish literature, including the Hebrew Bible. The author presents a dynamic organization of Philonic texts, viewed in relation to other more or less contemporary texts, in order to illuminate the genesis and structure of the Christian doctrine of the incarnation, which is considered to be the ultimate expression of revealed monotheism. (JR)

9663a. A. Pawlaczyk, 'Division as the Fundamental Idea in the Treatise of Philo of Alexandria Quis Rerum Divinarum Heres Sit', Eos 84 (1996) 75-85.

The purpose of this paper is to describe and analyse the notion of logos and division in Her. Scholars have found that the passage on the Logos-cutter

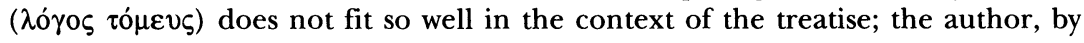
contrast, argues that the logos/division theme is the directive idea of Her. as a whole. She presents various aspects of the logos as discussed by Philo in the treatise, all of which concern the notion of division and equality/unequality. The real heir of divine things (cf. the title of the treatise) is he who knows to discern (make divisions) and to choose the right kind of life: the life of the wise. (HMK) 
9664. F. Petit, 'La chaîne grecque sur la Genèse, miroir de l'exégèse ancienne', in G. Schöllgen and C. Scholten (edd.), Stimuli. Exegese und ihre Hermeneutik in Antike und Christentum: Festschrift für Ernst Dassmann, JbAC.E 23 (Münster 1996) 243-253, esp. 245-247.

Brief remarks on Philo's place and influence in the tradition of biblical exegesis, in the context of an exposition centering on the Catena on Genesis. This anonymous commentary compiled from quotations of exegetes from the first five centuries of the Christian era and preserved in a good number of biblical manuscripts contains numerous quotations from Philo's Quaestiones et solutiones in Genesim. (HMK)

9665. A. Piñero, J. Montserrat Torrents, and F. García BAzÁn, Escritos gnósticos. Biblioteca de Nag Hammandi I: Textos filosoficos y cosmológicos (Madrid 1996).

This translation of the Nag Hammadi writings is supported by original research on the sources of Gnosticism. In this context Philo is mentioned several times, and his cultural context is considered near to Gnosticism ( $p$. 98). Two references stand out. The influence in the description of the Jewish God Yaldabaot, NHC II 100.3-4, as "the one that crosses", probably originated in the exegesis of Migr. 20 where the Hebrew man is defined peratês. Secondly, the Philonic distinction between theos and kyrios could have influenced the Letter to Eugnostos, NHC III 78.2. (JPM)

9666. A. K. Pinnick, The Birth of Moses in Jewish Literature of the Second Temple Period (diss. Harvard 1996).

Six Jewish texts which relate the story of Moses' birth are examined in order (1) to investigate how traditions concerning Moses' birth arose from the biblical text, and (2) to examine the context and setting of these exegetical developments. One of these texts is Philo's account in his Life of Moses. (DTR; based on summary in DA 57-10A, p. 4413)

9667. Z. Plese, The Apocryphon of John: Narrative, Cosmology, Composition (Gnostic, Roman Hellenistic) (diss. Yale 1996).

Most scholars have approached the remarkable syncretism of the Apocryphon of John from the perspective of the legacy of Judaism and Christianity in the text. This thesis argues that it is an artfully constructed narrative informed by a creative use of Plato's cosmogonic account in the Timaeus. Perfect congruence of course does not occur. The author also makes use of other traditions, including that of Alexandrian allegorical exegesis as this is found in Philo. Attention is also given to the methodological problem of distinguishing between the genuine influence of Plato and that of subsequent Platonist interpretations of the Timaeus. (DTR; summary based on DA 5711A, p. 4778) 
9668. B. Pouderon, 'Apologetica (Suite et fin)', Revue des Sciences Religieuses 70 (1996) 224-239, esp. 233-236.

Stimulated by the study by D. T. Runia (9276) on a prominent verbum Philonicum in the work De resurrectione, whose attribution to the apologist Athenagoras has been disputed, the author undertakes to examine instances of Philonic vocabulary in the other writing extant under his name, the Legatio. Three examples are discussed, including the image of God as pilot of the cosmos, which is frequently found in Philo. The author is encouraged by these finds to conclude that Athenagoras resided in Alexandria during the period when these two works were written. (JR)

9669. G. Quispel, 'The Original Doctrine of Valentinus the Gnostic', Vigiliae Christianae 50 (1996) 327-352, esp. 339-342.

As part of a review of 50 years of his own research on the doctrine of Valentinus, Quispel also briefly touches on the question of whether Valentinus was acquainted with the work of Philo, without being able to give a definite answer. (DTR)

9670. H. Remus, 'Moses and the Thaumaturges: Philo's De Vita Mosis as a Rescue Operation', Laval Theologique et Philosophique 52 (1996) 665-680.

In Mos. the depiction of the magician Balaam occupies a relatively large place. The author suggests that this is due to the fact that Jews had a reputation for thaumaturgy and that Moses was widely considered a magician. In Mos. Philo contrasts Balaam, portrayed as a mercenary technician, with Moses who is the true thaumaturge and mystagogue. The Jewish legislator is thus set apart from figures like Balaam who were working in contemporary Egypt. In so doing, Philo can rescue Moses from the misunderstanding of being a mere thaumaturge. In addition to this, Moses is presented not only as lawgiver and true prophet, but also as priest and king. The author argues that Philo's 'rescue operation' stands in a broader tradition of rhetoric and biography. (ACG)

9671. J. Riaud, 'Les études philoniennes de Valentin Nikiprowetzky', Impacts: Revue de l'Université Catholique de l'Ouest 4 (1996) $43-51$.

After first presenting an evocation of the life and academic career of Valentin Nikiprowetzky, the author gives an outline of the studies collected together in the volume Études philoniennes (9659) and shows how these studies can be regarded as supporting and illustratory material for the thesis of Nikiprowetzky's magnum opus, Le commentaire de l'Écriture chez Philon d'Alexandrie (Leiden 1977 = R-R 7731). (JR) 
9672. P. Richardson, 'Early Synagogues as Collegia in the Diaspora and Palestine', in J. S. KlopPenborg and S. G. Wilson (edd.), Voluntary Associations in the Graeco-Roman World (LondonNew York 1996) 90-109, esp. 93-95.

Philonic evidence is incorporated in an argument attempted to demonstrate that the first synagogues functioned and were perceived as collegia. (DTR)

9673. P. Richardson and V. Heuchan, 'Jewish Voluntary Associations in Egypt and the Roles of Women', in J. S. KLOPPENBORG and S. G. Wilson (edd.), Voluntary Associations in the GraecoRoman World (London-New York 1996) 226-52, esp. 239-46.

The authors contend that one of the features of social relations in Egypt is the more equal roles of women and men. This is illustrated by two Jewish groups in Egypt, the temple community at Leontopolis and the Therapeutae/ Therapeutrides at Lake Mareotis described by Philo. The particular social features of this latter community are outlined, leaving no doubt that most Greeks and Romans would have regarded it as a voluntary association. There are, however, no contemporary parallels for this kind of social organization. The most outstanding feature of the description, when compared with Qumran, is the careful attention paid to the role of women, the Therapeutrides. It seems that there were almost no gender-determined roles for women. In response to the question how this group developed such gender-equivalence a double answer is given. A likely source is the Egyptian cult of Isis-Osiris. But it is a Jewish group and it is also likely that inspiration was drawn from Israel's ancient history, and specifically the traditions about Moses and Miriam at the time of the Exodus. (DTR)

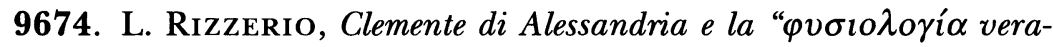
mente gnostica". Saggio sulle origini e sulle implicazioni di un'epistemologia e di un'ontologia cristiane, RThAM.S 6 (Leuven 1996), esp. 120-127.

After an introduction on Clement and Alexandrian Christianity, the study concentrates on the notion of $\varphi v \sigma i d \lambda_{0} i^{\alpha} \alpha$ in Clement, taking as its point of departure the definition in Str. IV 3.1-4, its philosophical sources (Aristotle, Epicurus, Plutarch, Philo), physiologia as part of philosophy, and finally the epistemological and ontological presuppositions of a 'truly gnostic physiologia'. This final subject deals with Clement's epistemological doctrine, the characteristics of his notion of ascent, the hierarchical structure of the universe and the doctrine of 'assimilation to God'. Paragraph 6 of the third chapter (pp. 120-127) is dedicated to Philo. Philo is an important source for Clement, because he makes an original use of the concept of physiologia as a science that is able to surpass knowledge based on the senses and obtain a vision of the divine (Her. 98), which is connected with the allegorical interpretation of scripture (cf. Prov. 2.34-41), is related to the mathematical 
disciplines and operates in the context of the strong influence of the Timaeus of Plato. (RR)

9675. D. T. Runia, 'Caesarea Maritima and the Survival of Hellenistic-Jewish Literature', in A. RABAN and K. G. Holum (edd.), Caesarea Maritima: a Retrospective after Two Millenia, Documenta et Monumenta Orientis Antiqui 21 (Leiden 1996) 476-95.

The Episcopal library of the Church of Caesarea was instrumental in ensuring the survival of most of the Hellenistic-Jewish literature that we still possess. The author traces the history of this intervention by examining a number of crucial texts: firstly the pinax of Codex Vindobonensis theologicus graecus 29, followed by the catalogue of Philonic works in Jerome's account of Philo's life and works in his On famous men. Then the evidence in Eusebius' Church History and Preparation for the Gospel is examined in detail. Finally some observations are made on Origen's library, which in all likelihood played a crucial role in the transmission of Philonic and other HellenisticJewish texts. (DTR)

9676. D. T. Runia, 'Philon von Alexandrien', in F. Ricken (ed.), Philosophen der Antike, 2 vols., Kohlhammer Urban-Taschenbücher 459 (Stuttgart-Berlin-Köln 1996) 2.128-45.

Synoptic presentation of Philo in the context of a presentation of ancient Greek philosophers. As the editor emphasizes in his foreword, the selection of philosophers included has been primarily determined by the extent to which their writings and thought concentrate on and have contributed to the attainment of the good life. Against this background it was natural to include a chapter on Philo, even though he is not generally regarded as an ancient philosopher in the strict sense. (DTR)

9677. I. Rutherford, 'Pindarus Armenicus: Paean, IX 1-10 as Transmitted in Philo, De Prov. 2.80 (97 Aucher)', Zeitschrift für Papyrologie und Epigraphik 112 (1996) 37-46.

In Prov. 2.80, transmitted only in an Armenian translation, Philo quotes a poem by Pindar, namely Paean IX, 1-10, in the context of a discussion whether the eclipses of the sun and the moon are evidence against the existence of divine providence. The author compares the Armenian translation with the Greek text which is found in Dionysius of Halicarnassus' De vita Demosthenis. The conclusion is that the Armenian rendering is based on a general misinterpretation of the Greek. The translator does not take it as 'an alarmed response to an eclipse (which is how Pindar meant it, and how Philo understood it), but rather as an encomium of the sun as a symbol of the principles of order and rationality that lie beyond mortal vision' (p. 46). (ACG) 
9678. S. SCHNEIDER, 'Glaubensmängel in Korinth: eine neue Deutung der 'Schwachen, Kranken, Schlafenden' in 1 Kor. 11, 30', Filología neotestamentaria (Córdoba) 9 (1996) 3-19.

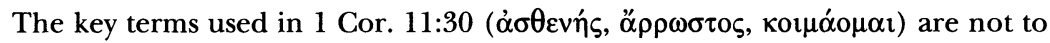
be understood in their proper sense, but in a metaphoric sense: to be weak, sick and sleeping in regard to the faith. The Philonic texts, Somn. 1.80 and 2.160, are adduced as important evidence for this use of the verb of

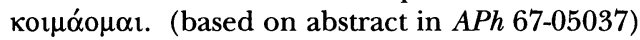

9679. A. M. Schwemer, 'Zum Verhältnis von Diatheke und Nomos in den Schriften der jüdischen Diaspora Ägyptens in hellenistisch-römischer Zeit', in F. Avemarie and H. LichtenBERGER (edd.), Bund und Tora: zur theologischen Begriffsgeschichte in alttestamentlicher, frühjüdischer und urchristlicher Tradition, WUNT 92 (Tübingen 1996) 67-109, esp. 92-101.

The close examination of the use of $\delta 1 \alpha \theta \eta \dot{\kappa} \eta$ in Jewish-Hellenistic writings and prayers shows the tendency to assimilate $\delta 1 \alpha \theta$ ' $k \eta$ with 'law', 'ordinance' (esp. in translations from Hebrew). On the other hand, the promises to the fathers $(\delta 1 \alpha \theta \hat{\eta} \kappa \alpha \iota$ or $\sigma v v \theta \hat{\eta} \kappa \alpha \imath)$ are highlighted. They are understood as royal gifts (Ezekiel Tragicus, Josephus). So in Philo, too, who takes $\delta\llcorner\alpha \theta \dot{\eta} \kappa \eta$ literally as 'last will', 'testament'. In the covenants with Noah and Abraham, he identifies $\delta\llcorner\alpha \theta \dot{\eta} \kappa \eta$ with the Logos. God communicates wisdom and virtue to all men. In relation to the Law, given by Moses, $\delta 1 \alpha \theta \dot{\eta} \kappa \eta$ means the spontaneous fulfilling of the Law. In Praem. 167 synonyms of $\delta i \alpha \theta \dot{\eta} \kappa \eta$ occur even in an eschatological context. The relative scarcity of the concept should thus not dissimulate its importance in Philo. An explanation for its absence in the apologetic writings directed to non-Jews is given on p. 73. (DZ)

9680. T. Seland, 'Philo and the Clubs and Associations of Alexandria', in J. S. KLOPPENBorg and S. G. WiLson (edd.), Voluntary Associations in the Graeco-Roman World (London-New York 1996) 110-27.

Various texts in Philo furnish evidence on the nature and role of clubs and associations in Alexandrian social and cultural life. The article examines what this evidence can tell us about the functioning of the clubs in Philo's environment. He often associates them with drunkenness and excessive behaviour (e.g. in Flacc. 176). Nevertheless there was a danger that Jewish synagogue worship would be confused with such gatherings. For this reason Philo often contrasts the sobriety of Jewish meetings with what took place in the clubs, e.g. in the description of the Therapeutae in Contempl. 40-47. Another text, Ebr. 20-26, discusses the payment of dues. Despite the allegorical context, this text provides evidence on social life. From it we may deduce that Philo did not wholly forbid participation, but was nevertheless cautious about membership, because it could easily lead to apostasy. (DTR) 
9681. G. Sellin, 'Die religionsgeschichtliche Hintergründe der platonischen 'Christusmystik', Theologische Quartalschrift 176 (1996) 7-27.

The author first reviews the history of interpreting Paul in mystical categories since A. Deissmann, which as time went on were replaced by the model of the gnostic 'Urmensch'. After some preliminary remarks on the role of tradition in Philo and Paul, and on the relation of mystical expressions to the doctrine of justification, to baptism etc., Sellin ventures to derive the following complexes from Jewish-Hellenistic thought as represented by Philo. (1) The replacement of the human nous in the pneumatic person through the pneuma, wisdom, the Logos or Christ. Here, the Platonic concept of ecstatic possession looms in the background. (2) Presupposing a basic local meaning of 'in Christ' Sellin appeals to the Philonic conception of the Logos as place (topos), not only of the ideas, but also as refuge for the sage. The Logos is compared to the head of the whole body, which recalls the idea of the body of Christ in Colossians and Ephesians. (3) The unity in Christ corresponds to the coherence of the Israelites in their father Jacob, identified with the Logos. (DZ)

9682. F. SiEgerT, 'Early Jewish Interpretation in a Hellenistic Style', in M. SAEB $\varnothing$ (ed.), Hebrew Bible/Old Testament. The History of Its Interpretation (Göttingen 1996) 130-198, esp. 162-189.

As part of a lengthy contribution on the hermeneutical practice of Hellenistic Judaism, Siegert gives a detailed presentation of Philo's exegetical method and writings, with copious references to secondary literature. Philo is not an innovator. His works are the rich harvest of two centuries of exegetical work in the Alexandrian context. His impact on early Christian exegesis is 'immense' (p. 188). Separate sub-sections are devoted to Philo's life and background, the classification of his writings, the theological basis for the interpretation of scripture (including remarks on his theory of inspiration), the extent of his Bible (the question of a canon is foreign to him), the four major groups of writings, his rules of literal and allegorical interpretation, and the reception of his works. Of special value is the section on Philo's hermeneutics (pp. 182-187), which contains a list of biblical persons in whom the basic concepts of Mosaic wisdom and legislation are incorporated. Philo creates a universe of interpretation in which things or persons who have something in common are seen as related or referring to each other. Modern readers who wish to understand Philo are exhorted to 'free themselves from the monopoly of causal thinking' that has been undisputed since the scientific revolution (p. 187). Review: G. E. Sterling, SPhA 12 (2000) 197199. (DTR)

9683. U. Sim, Das himmlische Jerusalem in Apk 21,1-22,5 im Kontext biblisch-jüdischer Tradition und antiken Städtebaus, Bochumer Altertumswissenschaftliches Colloquium 25 (Trier 1996), esp. 59-61. 
This study compares the description of the heavenly Jerusalem in the book of Revelation with descriptions in ancient texts of real (Babylonian, Greek, Roman, Israelite) as well as ideal cities. Its conclusion is that the author of Revelation for his presentation of the new Jerusalem made use not only of Old Testament and Jewish traditions, but also of motives of ancient city planning. As sources on the ideal city, Sim discusses Plato, Aristotle, Hippodamus of Milete, Vitruvius, Lucianus of Samosata, Philo, and texts from Qumran. The three pages devoted to Philo (plus two pages of notes providing the text references) present Philo's remarks on city building and organisation (democracy the best form of constitution), his views on the kosmos as God's polis, and his interpretation of the life of the wise (soul) as a journey to the real home in heaven. (HMK)

9684. D. I. Sty, 'Reflections on Philo, Plotinus and The Great Chain of Being', in A. Sharma (ed.), The Sum of Our Choices: Essays in Honour of Eric J. Sharpe, McGill Studies in Religion 4 (Atlanta 1996) 120-145.

The author explores Philo's and Plotinus' placement of humans on the Great Chain of Being (cf. the work of A. Lovejoy under that title, which expounds the Platonic conception of the universe as an infinite number of links ranging in hierarchical order from the tiniest up to the highest kind of being). She gives a sketch of the Alexandrian society in Philo's days (pp. 120-124), of Philo's own education (125-126), and of his views on male and female, free and slave, society, and education, all in relation to the Great Chain of Being (126-131). After describing Plotinus' views on the same topics, Sly concludes that Philo and Plotinus differ sharply only in respect to women: unlike Plotinus, Philo places them under the 'intellectual' line which separates humans operating on the level of the body from those operating on the level of mind. Without ceasing to admire them, she concludes, one must recognize that the truth for Philo and Plotinus was in a significant way determined by who they were: two men of privilege in a society where the vast majority were forced to experience life quite differently. (HMK)

9685. Th. Söding, " "Gott ist Liebe“: 1 Joh 4,8.16 als Spitzensatz Biblischer Theologie', in Th. SöDING (ed.), Der lebendige Gott. Studien zur Theologie des Neuen Testaments: Festschrift für Wilhelm Thüsing zum 75. Geburtstag, Neutestamentliche Abhandlungen NF 31 (Münster 1996) 306-357, esp. 327-330.

The author collects and evaluates the passages in the Bible and early Judaism which mention God's love. Philo, who prefers the terms $\varphi \imath \lambda \alpha v \theta \rho \omega \pi i \alpha$ and $\theta \varepsilon \circ \varphi \imath \lambda \dot{\eta} \varsigma$ to $\alpha \gamma \alpha \dot{\alpha} \eta$, continues the tendency of late biblical texts to differentiate and individualize. In the convergence of $\theta \varepsilon \circ \varphi \imath \lambda_{i} \alpha$ and $\varphi \imath \lambda_{\circ} \theta \varepsilon i \alpha$ the cosmological and anthropological harmony is realized which has its foundation in God's creation and is continually stabilized by his philanthropic action. (DZ) 
9686. F. Strickert, 'Philo on the Cherubim', The Studia Philonica Annual 8 (1996) 40-57.

At several places in his work Philo allegorises the two Cherubim as the creative and the kingly power of God, held together by the Logos (Cher. 27, Fug. 100-101, Her. 166, Mos. 2.97-100, QE 2.62-68). The author of the article

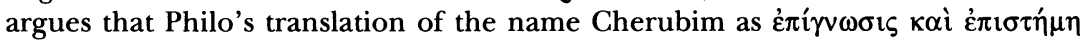
$\pi \circ \lambda \lambda \dot{\eta}$ is based on two traditions. The first tradition, in which the name was

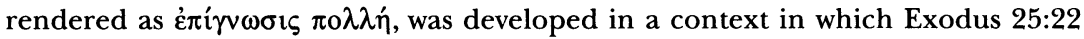
and Habakuk 3:2 in the LXX reading were studied together. In both verses the verb $\gamma \imath \gamma \vee \omega \sigma \kappa \omega$ is used in association with the Cherubim. The second

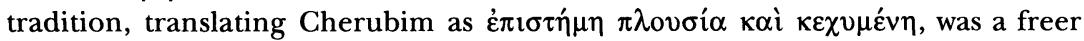
explanation based on the Eden story. Philo combines these two traditions, wishing to pay attention to the duality of the Cherubim. He also offers two physical allegories of the Cherubim. In the first, one of the Cherubim is a symbol of the sphere of the fixed stars, while the second represents the sphere of the planets (Cher. 23-24). This interpretation, in which Philo clearly makes use of Plato's Timaeus, is invented by Philo himself. The second physical allegory, in which the two Cherubim stand for the two hemispheres, is based on a pre-Philonic tradition. Philo's 'higher' interpretation of the Cherubim as God's powers may have as background Habakuk 3:2-3 in the LXX and the Barberini version. In this passage exactly the same image is presented as in Philo's Cher., namely Yahweh together with his Logos guiding the winged Cherubim under his feet. (ACG)

9687. H. Tronier, 'Hellenistic Hermeneutics and Paul's Idea of the Spirit in First Corinthians', in G. A. Jónsson, E. SIGURBJörnsson and P. PÉtursson (edd.), The New Testament in its Hellenistic Context: Proceedings of a Nordic Conference of New Testament Scholars, held in Skálholt, Studia Theologica Islandica 10 (Reykjavík 1996) 37-55, esp. 37-47.

The article presents the author's interpretation of Philo's diaeretical method in order to show that Paul's mythological understanding of the Spirit and the Christian community is moulded in the categories of Hellenistic hermeneutics. For a more detailed account of Tronier's understanding of Philo's diaeretical method see 9473. (KGS)

9688. G. Uribarri Bilbao, Monarquia y Trinidad. El concepto teológico "monarquia" en la controversia "monarquiana", Publicaciones de la Universidad Pontificia Comillas: Serie I Estudios 62 (Madrid 1996).

The author studies the concept of $\mu$ ov $\alpha \rho \chi i \alpha$ in the political sense from Aristotle until its application in the theology in the first five centuries CE. A central theme of this dissertation is the analysis of the term during the controversy between Praxeas and Tertullian, in the 2nd and 3rd century, when the concepts of unius principium and unicum principium were opposed. 
Philo is mentioned as testimony for the movement from the political to the theological sense; cf. esp. Fug. 11 and Decal. 51, 155, where monarchia is related to the first commandment of the Decalogue. This view is incorporated into Christian thought by authors like Justin, Tatian and Theophilus. (JPM)

9689. W. Verburg, Endzeit und Entschlafene. Syntaktisch-sigmatische, semantische und pragmatische Analyse von 1 Kor 15, Forschung zur Bibel 78 (Würzburg 1996), esp. 207-14.

Investigating the 'religionsgeschichtliche' background of 1 Cor 15:45-50 on pp. 199ff. the author searches for the origin of the concept of a vivifying pneuma. Already in Wisdom there is a difference between psyche and pneuma (against Sellin). Philo, moreover, has in common with Paul the idea of two 'Urmenschen' derived from Gen 2,7; they are qualified by 'earthly' and 'heavenly' respectively, and represent classes of men. In contrast to Philo, Paul reverses their order and has a positive estimation of the body. Psychikos, however, is not Philonic. (DZ)

9690. G. M. Vian, 'Purità e culto nell'esegesi giudaico-ellenistica', Annali di Storia dell'Esegesi 13 (1996) 67-84.

In Hellenistic Judaism the difficulties concerning the purity norms, and in particular those relating to food, contained in the Pentateuch, come under consideration at the beginning of the 1st cent. BCE in the Letter of Aristeas. Its author goes beyond the literal interpretation, seeing the injunctions as a moral teaching instead. Nearly two centuries later, this tendency was accentuated by Philo, who develops a highly allegorical interpretation of these and other purity norms. Philo's attempt can be seen as the highest expression of Jewish-Hellenistic thought. It was fundamental for Christianity, but was not pursued in later Judaism. (DTR, based on author's summary)

9691. G. M. Vian, 'Tra pagani e Cristiani: il problema del Giudaismo ellenistico', in A. FoA and L. Scaraffia (edd.), Conversioni nel Mediterraneo: Atti del convegno, Roma, 25-27 marzo 1996, Dimensioni e Problemi della Ricerca Storica. Rivista del Dipartimento di studi storici dal medioevo all'età contemporanea 2 (Rome 1996) 47-56.

In the context of a conference dedicated to the subject of conversion in the Mediterranean world (for the most part in modern times), the contribution briefly illustrates the role and significance of Hellenistic Judaism, making reference to a few central texts (Letter of Aristeas 128-129; Philo, Migr. 88-93). At first defined by the frontier of Judaism and Hellenism, after the birth of Christianity it becomes transformed with reference to the boundaries between paganism, Judaism and Christianity, as is shown by the fate of the Septuagint and the ancient reports on the Greek translations of Jewish scripture. (RR) 
9692. J. Whittaker, 'The Terminology of the Rational Soul in the Writings of Philo of Alexandria', The Studia Philonica Annual 8 (1996) 1-20.

Philo sometimes identifies the rational element in the soul by means of

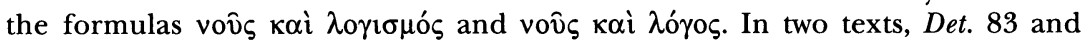
Praem. 26, he appears to draw attention to these formulations by saying that

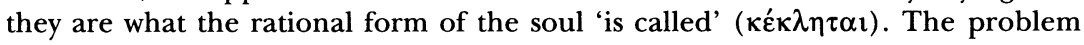
is, however, that such designations are not usually found as fixed terms in Middle Platonist texts, so that it is likely that both passages are corrupt and that we should read $\kappa \varepsilon \kappa \lambda \eta ் \omega \tau \alpha$ ('is possessed') instead. In an astonishing display of learning the author then proceeds to show the philosophical background of these two couplets. In the case of the former Middle Platonist usage clearly reveals Stoic influence. In the case of the latter a theological context is postulated. In both Stoic and Middle Platonist documents man's relation to God can be effected through 'nous and logos'. It is also noted that

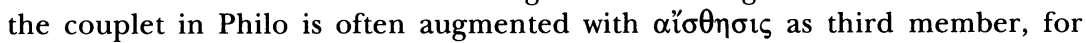
which parallels can be found in Cicero and Plutarch. (DTR)

9693. D. Winston, 'Hellenistic Jewish Philosophy', in D. H. Frank and O. Leaman (edd.), History of Jewish Philosophy, Routledge History of World Philosophies 2 (London-New York 1996) 38-61, esp. 50ff.

Brief treatment of Philo in the context of a broader survey of Hellenistic Jewish philosophy (including Wisdom literature and Qohelet), concentrating on his views on the relation between soul and God and the possibility of mystical ascent. (DTR)

\section{D. Winston, 'Philo's Mysticism', The Studia Philonica Annual 8 (1996) 74-82.}

Winston commences his article by stating what in his view mysticism is and stating his thesis that 'Philo indeed can lay claim to being a mystic, albeit within certain restricted parameters' (74). He then proceeds to give six key elements of mysticism, to all of which correspondences can be found in Philo's writings. What is not found, however, is the language of ecstatic possession or direct experience of God. For Philo the vision of God appears to culminate in a state of tranquillity. Through an analysis of Praem. 36-46 Winston concludes that the vision of God must take place at the level of God as the Intelligible world, or God qua Logos. (DTR)

9695. E. R. Wolfson, 'Traces of Philonic Doctrine in Medieval Jewish Mysticism: A Preliminary Note', The Studia Philonica Annual 8 (1996) 99-106. 
Wolfson reviews all the available evidence that connects Philo with medieval Jewish authors, and esp. those with mystical tendencies. He concludes that two sorts of argument have been used to support the claim that Philo played an instrumental role in the shaping of medieval Jewish mysticism. The textual-historical approach has not yielded definite positive results and has to be pursued further. The phenomenological-typological approach focuses on striking resemblances in thought, e.g. between Philo and the later kabbalists. Wolfson does not reach definite conclusions on this approach, but ends his article by arguing that the centrality of the doctrine of the Logos in a variety of mystical trends in the Jewish Middle Ages lends support to those who posit that the influence of Philo was significant. (DTR)

9696. Wen XIN, 'Comments on Philo Judaeus' Concept of God (Chinese)', Hang-chou ta hsueh hsueh pao. Che hsueh she hui 26.3 (1996) 30 .

We have not gained access to this article. See further the note on Philo studies in the Far East, in SPhA 9 (1997) 371. (DTR) 


\title{
PART THREE
}

\author{
1937-1986 \\ Additional Titles \\ AdDitional Reviews \\ Corrigenda AND AdDenda
}


Douwe (David) Runia - 978-90-04-31323-1 Downloaded from Brill.com๑4/26/2023 05:35:25AM via free access 


\section{A. ADDITIONAL TITLES \\ 1937-1986}

For an explanation of the rationale of this section of the Bibliography see $\$ 3$ of the Introduction

\section{Part One}

See above (Part One), nos. a2701, a3014 and a3015.

Part Two: Critical Studies

\section{7}

a3718. F. R. Montgomery HitchCock, 'Loofs' Theory of Theophilus of Antioch as a Source of Irenaeus', Journal of Theological Studies 38 (1937) 130-139, 255-266, esp. 131-134.

In this paper the author disproves the theory of $\mathrm{F}$. Loofs (Theophilus von Antiochien adversus Marcionem, 1930) that Irenaeus in his Adversus Haereses (notably 4.20.1-6) incorporated without acknowledgement the lost work of Theophilus against Marcion. Following two clues, viz. the triad of God, Logos and Sophia, and the 'Hands' of God, Loofs assembled twenty-nine passages from Irenaeus which he imputed to Theophilus. Montgomery Hitchcock argues, listing many Philonic passages, that Irenaeus and Theophilus independently of each other could have found the 'hands of God' in the LXX and in Philo (with whom both were familiar). Also the triad 'God, Logos and Sophia' (about which Irenaeus and Theophilus do not speak in exactly the same way) is identified as Philonic. (HMK)

a3719. A. Marmorstein, The Old Rabbinic Doctrine of God. vol. 2, Essays in Anthropomorphism (New York 1937, 19682), esp. 1-22, 150157

A chapter on 'Philo and the Haggadah' and a section entitled 'Philonic and Rabbinic Allegory' compare and confront Philonic interpretations (notably of biblical anthropomorphic speaking about God, e.g. 'God's repentance') with those found in the Haggadah. The author concludes that there were many different religious groups and schools practising allegorical and 
literal exegesis both in Alexandrian and in Palestinian Judaism in Philo's days, and suggests that Philo and his sources may have used more of the earlier Palestinian wisdom and scholarship than they are usually credited with. (HMK)

\section{8}

a3818. V. F. Hopper, Medieval Number Symbolism: its Sources, Meaning and Influence on Thought and Expression, Columbia University Studies in English and Comparative Literature 132 (New York 1938, 19692), esp. 46-49.

The final pages of a chapter on Pythagorean Number Theory are devoted to a thumbnail sketch of Philo's thought, with a quotation in translation from Leg. 1.2-4, illustrating Philo's interpretation of the numbers of the days of creation. (HMK)

\section{2}

a4208. L. Dujovne, Spinoza II: La época de Baruj Spinoza, Ensayos fiolosóficos 2 (Buenos Aires 1942).

In the second volume of an extensive study on Spinoza the author mentions Philo several times to compare the thought of both. The chief conclusion is: 'Philo recognizes a dualism of God and world, but he affirms such relationship among them that could serve as starting point for their ultimate identification' (69). For this reason the author includes Philo: in the development of Jewish philosophy Philo prepares Spinoza's monism. (JPM)

\section{4}

a4408. J. Laplace and J. Daniélou, Grégoire de Nysse, La création de l'homme, SC 6 (Paris 1944).

In the Introduction to this volume, as well as in a few notes to the Greek text, some references are made to Philo. Together with Cicero and Posidonius, Philo is among Gregory's philosophical sources, or at least he is part of the Stoic and Platonist environment which exerted influence on Gregory. While pointing at the similarities in thought between Gregory and Philo, notably where the 'double creation' of man is concerned, the introduction and notes to this volume place more emphasis on the differences between the two thinkers. (HMK) 


\title{
1946
}

\author{
a4608. W. C. Young, 'The Logos Doctrine of Philo Judaeus', The \\ Philosophical Forum 4 (1946) 14-22.
}

In Philo's thought the Logos and lesser powers serve to mediate between 'the completely transcendent God and his material universe'. Sometimes Philo speaks of the Logos as God's Reason, at other times as the instrument of God's will. In a Platonizing interpretation of the creation of man, Philo understands the Logos to be the Idea after which earthly man was fashioned. Important influences upon Philo include the Septuagint, the Book of Wisdom, and various Greek philosophers, but these sources provide no conclusive evidence for the doctrine of mediation. Philo in turn had an influence upon later sources: perhaps, but not certainly, some New Testament writers (Paul and the authors of Hebrews and the Fourth Gospel); Church Fathers, especially Origen; Plotinus and the Neoplatonists; and the Gnostics. (EB)

\section{7}

a4709. S. Stenger, Das Frömmigkeitsbild des hl. Ambrosius nach seinen Schriften De Abraham, De Isaac und De bono mortis (unpubl. diss. Tübingen 1947), esp. 43-61 ('Exkurs: Textvergleiche mit Philon').

It is argued that Ambrose's De Abraham is directly dependent on Philo's $Q G$, whereas similarities between this work of Ambrose and other writings of Philo (Migr., Her., Congr., Fug., Mut.) are only of a general nature. The author makes a detailed comparison between Ambrose's and Philo's work, putting the relevant sections of each (either summarized, or quoted) in two parallel columns. Ambrose at times follows Philo verbally, but just as often he changes or omits Philonic elements, or makes his own additions. For all that, Ambrose has his own independent theological stance, in which there is no place for Philo's doctrines of the divine powers (dunameis) and of the Logos' subordinate position, nor for certain features of Philo's anthropology or for the docetic traits in his Bible interpetations. While Philo, according to Stenger, sometimes shows himself more of a Hellenistic philosopher than of a Jewish teacher, Ambrose leaves no room for doubt about his Christian convictions. (HMK)

\section{8}

a4817. B. Kominiak, The Theophanies of the Old Testament in the Writings of St. Justin, The Catholic University of America, Studies in Sacred Theology 2.14 (Washington 1948), esp. 11-14, 30.

Justin is our first source for the identification of Jesus Christ, the Logos, with the Angel of Jahweh in the Old Testament. Could the writings of Philo, 
in which the Logos is identified with the Angel of Jahweh, have been Justin's source at this point? Whereas Goodenough and Heinisch answered this question affirmatively, Kominiak joins Lebreton, Harnack and Feder in minimizing Philo's influence on Justin. Justin's exegesis of the Old Testament theophanic texts is very different from that of Philo: between them is the infinite distance which separates the undetermined personality of the Philonian Logos from the real and historical person of the Logos of Justin. (HMK)

\section{0}

a5022. H. DE LUBAC, Histoire et Esprit: L'intelligence de l'Écriture d'après Origène, Théologie 16 (Paris 1950), esp. 159-164.

In a section entitled La part de Philon, De Lubac discusses and minimizes the contribution of Philo to Origen's exegetical practice, as far as the anthropological trichotomy (body, soul, spirit), the three senses of Scipture (historic, moral, mystic), and the correspondence in Origen between the two trichotomies are concerned. De Lubac argues that both trichotomies are primarily biblical, if not essentially Christian (the second one). Origen's exegesis has elements in common with Philonic and Rabbinic exegesis, such as criticism of anthropomorphisms and symbolic interpretation of numbers and names. The resemblances, however, are only external. Philo distinguishes no more than two senses of Scripture: the third, 'spiritual' kind of exegesis is lacking, i.e. the exegesis informed by the coming of Christ. 'Entre Philon et Origène, il y a tout le mystère chrétien. (p. 164)' (HMK)

\section{3}

a5316. D. DAuBE, 'Alexandrian Methods of Interpretation and the Rabbis', Festschrift Hans Lewald (Basel 1953) 27-44; reprinted in H. A. Fischer (ed.), Essays in Greco-Roman and Related Talmudic Literature (New York 1977), and in C. M. Carmichael (ed.), Collected Works of David Daube I, Talmudic Law (Berkely 1992) 357-376.

Two examples are brought from Philo (on last page, nn. 90, 91) in illustration of the thesis that some Hebrew technical locutions reflect Greek terminology. (NGC)

\section{5}

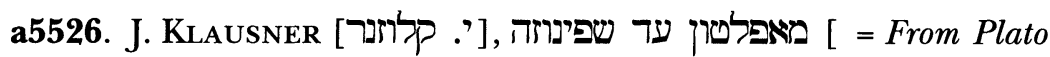
to Spinoza] (Jerusalem 1955), esp. 77-120. 
The book is a collection of five essays, one each devoted to Plato, Philo Judaeus, Solomon ibn Gabirol, Don Judah Abarbanel, and Spinoza. The essay on Philo (pp. 77-120) is a revised version of a chapter which originally appeared in פילוסופים והוגי דעות [Philosophim ve' Hogei De'ot = Philosophers and Thinkers], vol. 1 (Jerusalem 1934). Although it clearly reflects the scholarly trends and prejudices revailing at the time of its composition, it remains a concise and readable introduction in Hebrew to Philo's life and major patterns of thought. (NGG)

a5527. A. OrBe, En los albores de la exégesis iohannea (Joh.1,3), Estudios Valentinianos II, Analecta Gregoriana 65 (Roma 1955).

In this book more than 50 Philonic texts are cited to describe the context of the early exegesis of the Valentinian Gnostics. Among them, we note Opif. 89, important for the study of Gnostic cosmology, in which the hexad is a constant presence. The passage of Cher. 125 also occupies a central place in the discussion on the antecedents of the pattern of three causes. This pattern is used by Valentinians to explain the relationship between the divine principles and the formation of the world, that is to say, the sequence ex quo, per quod, in quo (cf. 191, 236). According to the author, it is here that the history of the Christian trinitarian exegesis begins. (JPM)

a5528. E. Przywara, 'Philon und Origenes', in IDEM, In und Gegen: Stellungnahmen zur Zeit (Nürnberg 1955) 281-294.

The essay on Philon und Origen in this collection of essays and broadcast talks confronts the claim that Hegel's philosophy is the climax of occidental (abendländisch) thought with the fact that Hegel's basic opposition between the material and the spiritual world is derived precisely from the orient (Asia), more concretely from the two great thinkers of Alexandria, Philo and Origen. The author describes the diverse ways in which the two thinkers dealt with this opposition, which for them was sharpened by the biblical revelation of the Old Covenant (for Philo), according to which the material world and a physical nation is God's, and of the New (for Origen), according to which the Logos has become Flesh. Philo's solution is that of allegory, characterized by Przywara as Verfälschung (falsification). (HMK)

\section{8}

a5824. G. Aєвy, Les missions divines de saint Justin à Origène, Paradosis 12 (Freiburg 1958).

Brief scattered observations on the possible indebtedness of Justin and the Alexandrian theologians Clement and Origen to Philo on the subject of theophanies or, as the author describes them, 'divine missions' of God or his Logos to humankind. See the list of references in the index on p. 194. We 
note the view of the author that it is impossible to demonstrate a direct dependence on Philo in the writings of Justin (p. 13). (DTR)

a5825. R. Holte, 'Logos Spermatikos: Christianity and Ancient Philosophy according to St. Justin's Apologies', Studia Theologica 12 (1958) 109-168, esp. 119-128, 146-148.

In section 2, on 'Justin's position within the History of Ideas', Holte discusses the Logos theory of Philo. In Philo, the term Logos has completely displaced Nous as an appellation of the Divine Intellect, and ideas are often termed as Logoi: in the (Stoic) Logos-conception, Philo felt a point of contact with the OT conceptions of the Word of God. Philo's Logos speculation is the most far-reaching attempt at hypostatization within the Hebrew tradition. The Logos is called 'power' ( $\delta v v^{\prime} \alpha \mu \iota \varsigma$ ) but also described with more personal epithets, such as 'Second God', 'Son of God', 'Angel'; likewise the ideas are 'powers' as well as 'angels'. This tendency to personify ideas indicates a transformation of the Middle Platonic system and bears witness to the Hebraic elements in Philo's thinking. The Logos conception in St. John's Prologue shows a clear affinity with Philo's, but what they share is common property, so that Philo cannot be taken as the exclusive source. There can scarcely be any doubt that it is under influence of Philo that Justin interprets both the Angel and God speaking to Moses in Exod. 3:14-15 as Logos. It also seems likely that the term Logos Spermatikos in Justin emanates from Philo. In Philo the term Logos Spermatikos is used to describe the transcendent and immaterial Logos as a principle of man's life, but in Justin it is used as a principle for natural revelation. (HMK)

a5826. G. B. LADNER, 'The Philosophical Anthropology of Saint Gregory of Nyssa', Dumbarton Oaks Papers 12 (1958) 59-94, esp. 72$73,80-83$.

In the context of a thorough examination of Gregory of Nyssa's anthropology as it is presented principally and systematically in the treatise $D e$ hominis opificio, a discourse in the vein of Philo's De opificio mundi, the author points at differences between Gregory and Philo (Philo often being Gregory's immediate source). Like Philo, Gregory has a conception of the six-day-work of creation as simultaneous and timeless creation, but, unlike Philo. he nonetheless takes the six days as indicating not only a logical but also a temporal order. Also with regard to a doctrine of double creation Gregory both follows and modifies Philo. Philo's ideal and generic creation of man (for which see Gen.1:26 and 2:7b, contrasted by Philo with 1:27b and 2:7a, the creation of male and female) is transformed by Gregory into a virtual creation of all mankind (for which see Gen.1:26-27, including the creation of the two sexes). Foresight of man's transgression and ensuing mortality necessitated man's constitution as a bisexual being and his sexual propagation: mankind must achieve the fulness of a God-like human race through a long chain of generations, while in a sinless state this fulness could have been accomplished without temporal delay. (HMK) 
a5827. A. Orbe, Hacia la primera teología de la procesión del Verbo, Estudios Valentinianos I, 1-2, Analecta Gregoriana 99-100 (Roma 1958).

This book offers a detailed and well documented study of the main streams of Christianity in the 2nd century, in order to explain theologically the ways in which the Logos proceeds from God. It mentions Philo more than 60 times. According to the author, the Valentinian Gnostics introduced into Christian theology the idea of an eternal and personal generation of the Logos. On the other hand, the ecclesiastical writers of the 2nd century, especially the apologists, thought the procession of Logos took place in two stages, in the first of which the personality of the Logos is not implied. On this matter, the apologists are closer to Philo, in the sense of Abr. 82-83 and Mut. 66-69. (JPM)

a5828. C. SpICQ, 'La Philanthropie hellénistique, vertu divine et royale (à propos de Tit. III,4)', Studia Theologica 12 (1958) 169-191, esp. 174-181.

A study of the meaning of $\varphi \imath \lambda \alpha \nu \theta \rho \omega \pi i \alpha$ from the classical period to the first century of the common era, with ample attention for the use of the term by Philo. As a divine attribute, $\varphi \imath \lambda \alpha v \theta \rho \omega \pi i \alpha$ according to Philo accounts for all providential interventions, and is the ground for God's condescension and help towards man. In turn, $\varphi \imath \lambda \alpha v \theta \rho \omega \pi i \alpha$ belongs to the first of the moral virtues to be shown by man himself towards others. Both Moses himself and

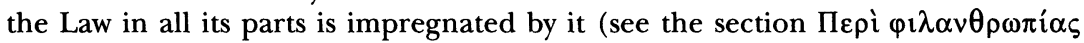
in Philo's Virt.). (HMK)

\section{9}

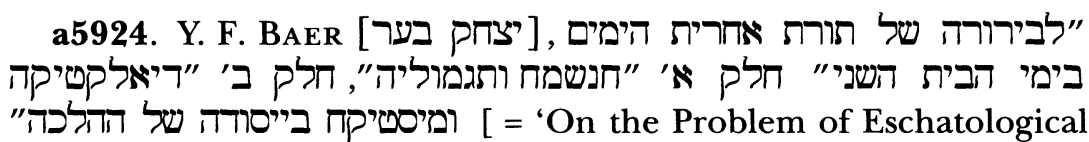
Doctrine During the Period of the Second Temple'], Part I: Zion 23 (1958) 1-34, Part II: Zion 24 (1959) 141-165 (the latter includes two appendices); reprinted in $\mathbf{a} 8550$ a.

The author proposes a new approach to the investigation of eschatological doctrine during the period of the Second Temple. Focusing upon the beliefs and doctrines of the Sages as expressed in Halacha and Haggadah, Baer argues that the foundations for these doctrines were laid down several generations prior to the destruction of the Second Temple and the advent of Christianity. He sees them as an amalgam of Biblical tradition influenced by contact with Platonic philosophy. Extensive discussion of Philonic passages in the context of parallel rabbinic material serves to underpin the author's 
thesis. The first instalment of the article (pp. 1-34) discusses the soul, its essence and its rewards, as well and the interrelation between the transcendental and temporal worlds. This includes a discussion of the similarities and differences between Philonic and rabbinic midrashic use of the image of 'mounted warrior' and of the locution 'place' (מקום, זó $\pi \circ$ ) for God. The second instalment of the article (pp. 141-165) addresses the dialectics and mysticism implicit in the halachic discourse. Advancing beyond the studies of Saul Lieberman and David Daube, Baer argues that many of its basic terms and frames of reference must be studied upon the backdrop of Platonic conceptual frames of reference and terminology - albeit transmuted in the process of their translation (e.g. Torah $=$ Logos $=$ heavenly Paradeigma). Baer makes extensive use of Philo's auvre, suggesting that its Hellenistic-Jewish amalgam was already present in his sources. The two appendices entitled, 'Remarks on the Doctrine of Creation', and 'The Illuminating and Opaque mirror', focus extensively upon Philo's relation to these topics against the backdrop of rabbinic thought. (NGC)

\section{0}

a6022. J. DaniÉlou, Art. 'Origène', Dictionnaire de la Bible Suppl. 6 (Paris 1960) 884-908, esp. 898-902.

In a section entitled 'L'influence de Philon', remarkable parallels are noted between Philo and Origen. Both of them are to be considered theologians, exegetes, and also mystics, and both interpret the Scriptures in terms of Greek philosophy. Philo's allegorical exegesis exerted great influence on Origen. Daniélou considers this influence fertile in those cases where the 'literal', or 'proper' sense of a text may be a 'figurative' one, but less fertile where it concerns the Philonic idea that all passages from the Scriptures have a figurative sense (which leads to strained or strange elements in the exegesis). Examples are given from exegesis of the creation account and of the lives of the patriarchs and Moses. (HMK)

a6023. G. Grigorian, 'The Armenian Commentaries on the Work of Philo of Alexandria' [in Armenian], Banber Matenadarani 5 (1960) 95-115.

The works of Philo were translated into Armenian during the intermediate five to six centuries and continued to influence Armenian authors throughout the Middle Ages. Many Armenian authors in the latter period wrote commentaries on the works of Philo. As a result of this, several of Philo's works are extant only in Armenian and the Armenian corpus of Philonic works antidates those extant in other versions. The Armenian commentaries are divided into three categories in this first attempt to identify certain anonymous commentators. (based on the abstract by A. Terian published in SPh 2 (1973) 57) 
a6024. D. G. MAeso, Manual de historia de la literatura hebrea (Madrid 1960), esp. 371-373.

In an extensive general presentation of Jewish literature from the biblical books until the modern writings, the author devotes attention to Philo in chapter 3, on Hellenistic-Jewish literature, dwelling upon Philo's life, his writings, the characteristics of his thought and his significance in the history of culture. In the same chapter, the author considers the New Testament as part of Hellenistic-Jewish literature. (JPM)

\section{1}

a6122. S. BeLKin, In His Image: The Jewish Philosophy of Man as Expressed in Rabbinic Tradition (New York n.d. [1961]).

Judaism has never successfully presented a systematic theology, because it is primarily interested in the practice of living as a Jew, so that articles of faith and religious theories cannot be divorced from particular practices. Philo is introduced on the first page as "probably the first Jew to present a Jewish theology', but it is claimed that 'even he was more concerned with a philosophy of Judaism, or better still, a philosophy of Jewish practice, than with mere theological dogma'. In accordance with Belkin's general views (see R$R$ 4002, RRS 8904), Philo is regarded as part and parcel of the Rabbinic tradition, and so plays a prominent role in this synthetic study, which presents a philosophical anthropology of Judaism that takes its starting point in the biblical claim that man is created in God's image. Separate chapters are dedicated to Man and the World, Man and Sin, The Equality of Man, Man and his Trustworthiness, The Sacredness of Human Life, The Community, Man and Public Consciousness, Man and his Family, Man: his Intention, Word and Action, Man and the Higher Law. For the individual references to Philo see the general index on p. 276. Unfortunately there is no index of passages cited. (DTR)

a6123. J. Daniélou, 'La notion des confins (methorios) chez Grégoire de Nysse', Recherches de Science Religieuse 49 (1961) 161187 , esp. 173, 180-184.

In this study of the term $\mu \varepsilon \theta$ ópios ('bordering') in the works of Gregory of Nyssa (cf. also R-R 7014), where it occurs some twenty times, the author concludes that in a technical sense the term is used to describe the cosmological role of the elements air and water, which at the same time unite and separate two opposites (fire and earth). The word is applied also to the human soul, to indicate not its cosmological but its existential condition: the soul finds itself between good and evil and has to choose between the life of the spirit and the life of the body. The same can be found in Philo, who of all ancient authors is the one we find using the word $\mu \varepsilon \theta$ óptos the most often, but also in Maximus of Tyre. This use of the term $\mu \varepsilon \theta$ ópıs for the position of the 
human soul belonged probably to the philosophic, Platonic language dating back to the first century BCE. (HMK)

a6124. H. DE LuBAC, Exégèse médiévale: les quatre sens de l'Ecriture, 2 vols. in 4, Theologie 41-42 (Paris 1959-1961), esp. 1.203-207, 376380 .

In this extensive study on medieval biblical exegesis and its patristic origins, Philo's allegorical exegesis is a recurring point of reference. The author underlines the fundamental difference between Philo's and Origen's exegesis, notwithstanding the resemblances (cf. above, a5022). (HMK)

a6125. A. Orbe, La unción del Verbo, Estudios Valentinianos III, Analecta Gregoriana 113 (Roma 1961).

The author's aim is to examine the relationship of Spirit and Logos in the theology of the 2nd century, and to understand in this context the theology of the Valentinian Gnostics. He gives special attention to the anointing of the Logos by the Spirit, through which the Logos is constituted christos. It is common to Gnostics and orthodox thinkers to refer to a double anointing of the Logos, the first prior to the incarnation and directed towards sanctification of the cosmos, the second after the incarnation and directed towards the health of mankind. Philo is frequently mentioned as antecedent for the former, which is the cause of the Logos' eternal priesthood. (JPM)

\section{2}

a6228a Y.F. BAER היסודות ההיסטוריים של ההלכה - פרקים [י. בער] [The Historical foundations of the halakha] Zion 27 (1962) 117-155.

In continuation of his previous research (see: R-R 5201 "Historical Foundations"), the author tries to verify the beginnings of the halakha by a comparison of the development of the law of the Greek polis. On pp. 126-128 Baer discusses Spec. 4.137-149. He credits Philo with being the first to explicitly

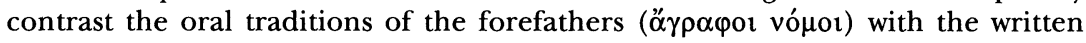
Torah. Philo's treatment of the Sabbatical year in Spec. 2.104 is quoted on p. 142. (Reprinted in a8550a) (NGC)

a6229. M. Harris, 'Marriage as Metaphysics: a Study of the 'Iggereth Hakodesh', Hebrew Union College Annual 33 (1962) 197-220, esp. 209-217.

The Iggereth Hakodesh is the first treatise in the history of Jewish thought that is devoted completely to the mystical understanding of marriage. 
Originating in the thirteenth century Spanish Jewish community, the work is usually attributed to Moses Nachmanides. It is written on two levels, an exoteric and an esoteric. On the exoteric level the work consists of five sections dealing with various aspects of sexual intercourse (such as the time of intercourse, man's intent during it, and techniques). But the text bristles with kabbalistic secrets and hints, and the controlling idea on the esoteric level is that the two joined cherubim of the Merkavah (1 Kings 7:33, 37; Ezek. $1: 8-9)$ are the paradigm and symbol of the great secret of intercourse. Harris argues that throughout the work there is a strong presence of Philonic thought, which was mediated by Gnosticism (which was certainly present in Spain at that period, as Gershom Scholem has shown). Especially Philo's $O n$ the Cherubim seems to be continuously echoed in the $I H$, but other Philonic works also offer many parallel thoughts. Both Philo and the $I H$ relate intercourse to a higher type of 'knowledge', i.e., metaphysical knowledge. (HMK)

\section{3}

a6327. R. Gögler, Zur Theologie des biblischen Wortes bei Origenes (Düsseldorf 1963), esp. 77-78., 95-96, 128-133.

Brief remarks on Philo's allegorical method and his doctrine of the Logos as background to an examination of Origen's theology of the personified Word of God. Philo's doctrine of the Logos takes its starting point in exegesis of the biblical text. In this process of interpretation the influence of philosophical ideas is strongly felt. At the same time, however, biblical thought is significantly present, above all in the personification of the Logos figure. (DTR)

a6328. P. Merlan, 'Religion and Philosophy from Plato's Phaedo to the Chaldean Oracles', Journal of the History of Philosophy 1 (1963) 163-176, esp. 169-176; reprinted in: IDEM, Kleine Philosophische Schriften, herausgegeben von F. MERLAN (Hildesheim - New York 1976) 358-371, esp. 364-371.

Starting from the claim made in the Phaedo that philosophy is the true (mystery) religion, the author discusses the opposite claim, i.e., that religion is the true philosophy, as made by Egyptians with regard to the Egyptian and by Philo with regard to the Jewish religion. For Philo, just as the enkyklia are in a subservient position (as a handmaid) to philosophia, so is philosophia to sophia-sophia here being religious wisdom. In the second century CE, Greek 'religionists' bring to expression that religion is true philosophy in the Chaldean Oracles. Philo's position strongly influenced Christian thinkers. (HMK) 


\section{5}

6531. W. Theiler, 'Philo von Alexandria und der Beginn des kaiserzeitlichen Platonismus', in K. Flasch (ed.), Parusia: Studien zur Philosophie Platons und zur Problemgeschichte des Platonismus; Festgabe für J. Hirschberger (Frankfurt 1965) 199-218; reprinted in IDEM, Untersuchungen zur antiken Literatur (Berlin 1970) 484-501.

6532. L. Thunberg, Microcosm and Mediator: the Theological Anthropology of Maximus the Confessor, ASNU 25 (Lund 1965), esp. 155-157, 195-199; revised version Chicago-La Salle 1995.

a6536. J. Theodor and C. Albeck, [י. טהעאדאר וחנוך אלבעק]], [=Einleitung und Register zum Bereschit Rabba] (Berlin 1931, reprinted Jerusalem 1965²), esp. 84-89.

In the context of the discussion of the parallels and possible sources for the material found in $B R$, Albeck introduces an appendix devoted to Philo and Josephus (pp. 84-89). Albeck states categorically that it is almost certain that Philo did not know Hebrew, suggesting that sometimes the parallels between Philonic and Rabbinic haggadic traditions reflect mutual fructification between the Palestinian and the Alexandrian centres (in both directions), while at other times independent development seems most likely. (NGC)

a6537. J. González, Historia del pensamiento cristiano (Buenos Aires 1965), esp. 37-41.

In a general survey of the Christian thought of the first centuries the author frequently mentions Philo, although on the basis of secondary literature only. In the section specially devoted to Philo he underlines the incompatible differences between the theological vision of the Alexandrian Jew and the basic concepts of the original Christian creeds. When Philo combines Plato's idea of Beauty with the God of the patriarchs and prophets, this is seen as representing 'danger' for Christian theology ( $p$ 41). The theological weaknesses of Philo are inherited by the Christian Alexandrian schools of the 2nd and 3th centuries. Philo's main objective is thought to be that of transforming the Bible into a logos that is pleasing to the Greeks. (JPM)

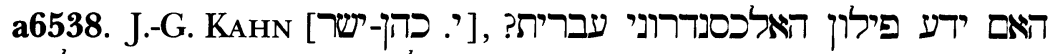
"['Did Philo Know Hebrew? The Testimony of the "Etymologies"'] Tarbiz 34 (1965) 337-345. 
The article argues that a careful study of the form and content of the often fanciful etymologies of Hebrew words in Philo's writings indicates that he must have used lists of etymologies written in Greek, but arranged according to the order of the Hebrew alphabet, of a type similar to those which have been found from a later time. (NGC)

a6539. D. Lührmann, Das Offenbarungsverständnis bei Paulus und in paulinischen Gemeinden, WMANT 16 (Neukirchen-Vluyn 1965), esp. 22-23, 32-34, 51-54.

Brief references to Philo's views on God's self-revelation and human knowledge of God, with somewhat more extensive attention paid to Moses' role as the great mystagoge and hierophant. (HMK)

\section{6}

a6639. M. Aubineau, Grégoire de Nysse Traité de la Virginité, SC 119 (Paris 1966), esp. 105-116.

In Aubineau's extensive introduction to Gregory of Nyssa's treatise on virginity, ten pages are devoted to Philo as one of the philosophical sources (among Platonism, Aristotle, Stoicism and Plotinus) for the treatise. A brief characterization of Philo's position in the history of philosophy and patristics in general is followed by an exposition of his influence on Gregory of Nyssa's biblical exegesis in $D e$ virginitate in particular. This influence is considerable, e.g. in Gregory's hypothesis of a 'double creation' and in his use of allegory. Then Aubineau points out the numerous traits which De virginitate has in common with Philo's De vita contemplativa. The spiritual doctrine of the Therapeutae as described by Philo shows resemblance with that proposed by Gregory (e.g. the ideas of spiritual marriage, and immortal seed or offspring conceived in the soul). Considered separately, the elements in common might seem to be coincidental, but a view of the whole makes it impossible to deny Philonic influence in Gregory's work. (HMK)

a6640. F. Daumas, 'L'activité de l'Institut français d'archéologie orientale durant l'année 1965-1966', Comptes Rendus de l'Académie des Inscriptions et Belles Lettres (1966) 298-309, esp. 299-300.

Brief report of excavations at Dikhela, in search of the place where the Therapeutae of Philo's De vita contemplativa may have lived: houses from the fifth to seventh centuries were discovered, and probably a church. (HMK)

a6641. F. Dvornik, Early Christian and Byzantine Political philosophy: Origins and Background, 2 vols., DOS 9 (Washington 1966), esp. 559-569 (=vol. 2). 
In the In Flaccum, as well as in many other treatises, Philo deals with the subject of Roman rule versus Jewish law. This question concerned Jews and Christians alike and thus sheds light also on the genesis of early Christian political thought. Dvornik builds on the research done by E. Bréhier (1925) and E. R. Goodenough (1938 = R-R 3805). Philo entertained the Hellenistic ideal of a king, viz. the king as soter and euergetes, and he also invested the ideal king with priestly functions. Thus he absorbed into his political scheme all the elements of the Hellenistic doctrine on kings, except their actual deification, but even there he framed a compromise that did justice to the Jewish faith and was at the same time acceptable to pagan intellectuals. There is a striking similarity between Philo's position and the words of Paul in Romans 13:1 ('powers that be are ordained by God'). Philo's speculation appealed to the Christian writers of the first centuries. (HMK)

a6642. A. Q. Morton and J. McLeman, Paul, The Man and The Myth: a Study in the Authorship of Greek Prose (New York 1966), esp. 57-59 and Table 6.

The thesis of this book is that by statistical analysis it can be demonstrated that no more than five of the fourteen Epistles attributed to Paul can safely be regarded as his. Table 6 shows sentence length distributions in the work of Philo, who like Paul was a Jew writing Greek. The latter fact appears not to have a detectable influence on sentence length distributions, whereas the nature of the text, i.e. whether it is a commentary or a free composition, clearly does make difference on this point. (HMK)

a6643. A. Orbe, La teología del Espiritu Santo, Estudios Valentinianos IV, Analecta Gregoriana 158 (Roma 1966).

Philo's writings are quoted extensively in order to show their outstanding place in the cultural and literary context in which Christian thought was born, be it orthodox or heterodox. In the case of the Gnostics in general, Philo is seen as an antecedent of symbolic interpretations of the cosmogonic account in the Bible. The author argues on the base of direct knowledge of Philonic texts and also of analyses given by authors such as F. N. Klein (R-R 6212) and others. Among the numerous topics on which Philo is mentioned, the following ones stand out: the arithmological interpretation of Genesis as antecedent of the Valentinian exegesis (cf. pp. 175-179 and passim), the topic of the brotherhood of Logos and Sophia (cf. p. 93f., 107), the original myth of the androgynous human being (cf. p. 505f.), the relationship of oikos-topos with Logos (cf. 52), the narrow relationship of Ebr. 30 and Fug. 108 with the symbology of a female principle next to God (p. 478f.), the distinction between anamnêsis and mnêmê (cf. pp. 628-631). In his conclusion the author points out the importance of Philo for the understanding of the development of Christian thought: to the Valentinians he offered terminology and exegesis, although Philo was more sober with regard to the number of cosmological and soteriological intermediaries (cf. p. 124). In this sobriety Philo stands closer to orthodox ecclesiastical writers (cf. p. 545). (JPM) 
a6644. L. Thunberg, 'Early Christian Interpretations of the Three Angels in Gen. 18', Studia Patristica 7 [Papers presented to the Fourth International Conference on Patristic Studies held at Oxford 1963] $=$ TU 92 (Berlin 1966) 560-570, esp. 565-567.

Among the Fathers there are three different interpretations of Abraham's visitors at Mamre (Gen. 18). The Trinitarian interpretation, represented within the Alexandrian tradition, may well in the author's view have been inspired by Philo. (HMK)

\section{7}

6753. M. Simon, 'Éléments gnostiques chez Philon', in Le origini dello Gnosticismo (cf. 6714) 359-376; reprinted in IDEM, Le christianisme antique, WUNT 23 (Tübingen 1981), 1.331ff.

a6761. P. Kaufmann, L'expérience émotionelle de l'espace (Paris 1967), esp. 180-185.

On the basis of a number of significant passages from Philo, the author describes the existential condition of man in relation to God. At the same time God is both very near to and infinitely remote from us: very near, since he has created us; infinitely remote, since he, as the Creator, is completely different from his creation (p. 185). This otherness, according to the author, could be conceived of only in a creationist environment, which Philo was the first to define in suitable philosophical terms. (RR)

a6762. А. Nomaсні, 'Aristobulus and Philo, with special reference to $\dot{\varepsilon} \beta \delta o \mu \alpha \varsigma^{\prime}$, Journal of Classical Studies (The Journal of the Classical Society of Japan) 15 (1967) 86-97 (with English summary).

In Leg. 1.2-16 Philo presents an allegorical interpretation of Gen. 2:2 which is far more developed than that of Aristobulus (in Eusebius, PE 13.12.916 ), who considers the seventh day simply as a symbol of the cosmic order. The conclusion is that Aristobulus cannot have been posterior to Philo. (HMK, based on APh 1967)

\section{8}

6832. S. SANDMEL, 'The Confrontation of Greek and Jewish Ethics: Philo, De Decalogo', CCARJ 15 (1968) 54-63, 96; reprinted in IDEM, Two Living Traditions (Detroit 1972) 279-290. 
a6841. F. Szaвó, Le Christ créateur chez saint Ambroise, Studia Ephemeridis «Augustinianum» 2 (Rome 1968), esp. 64-67, 120135.

Ambrose's writings show parallels with passages in Philo in particular on the themes of the omnipresence of the Logos in the world (cf. Ambrose, De Cain et Abel 1.8.32 with Philo, Sacr. 64-68) and the cosmic function of Christ (cf. Ambrose, De fuga saec. 3.13 and 3.16 with Philo, Fug. 108-112). The author concludes that Ambrose underwent the influence of both Philo and Origen, and that especially Philo could have led him towards a conception in which Christ as creator was no more than an instrument in a cosmological genesis instead of God-man and universal mediator. But Ambrose's originality resides precisely in his faithfulness to the Pauline and Johannine soteriology, while integrating aspects of the Philonic and Origenian Logos in it. (HMK)

1970

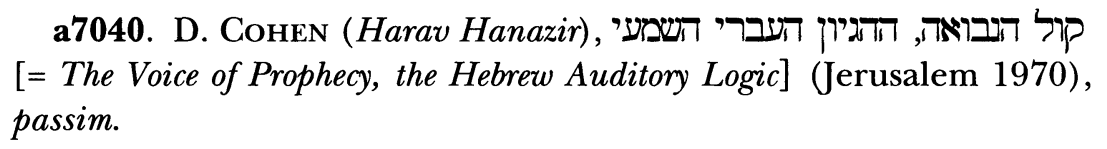

The central thesis of this book, written by a revered Torah Scholar and Mystic, is that while Greek Philosophy is a Weltanschauung (=View of the World), Hebrew Thought in the fields of Biblical interpretation, Kabbalah and 'authentic' Jewish Philosophy belongs to the dimension of inner hearing : 'Hear O Israel' - for the prophet first and foremost 'hears' the word of G-d. While others 'see' their god, the Hebrew 'hears' His voice. In contrast to almost all of his colleagues, the Rav Hanazir accepts Philo as an integral part of the Jewish philosophical tradition, and mentions him en passant (see p. 14, $15,20,33,34,41,42,50 \mathrm{ff} ., 54,67,75,167,232$ ) in support of his running arguments. A detailed chapter devoted specifically to Philo is found in Nazir Echav (see below a7749). See also the article of A. Neher listed at R-R 8643. (NGC)

a7041. C. W. Macleod, 'ANA $\Lambda \mathrm{Y} \Sigma \mathrm{I} \Sigma$ : a Study in Ancient Mysticism', Journal of Theological Studies 21 (1970) 43-55; reprinted in IDEM, Collected Essays (Oxford 1983) 292-304.

This study illustrates some forms of the mystic's search for the timeless and some of the reasoning which underlies this search, notably in the work of Gregory of Nyssa, Corpus Hermeticum XI and Plotinus. Valuable remarks are made on the meaning of the word $\alpha i \omega v$ in Philo (and elsewhere), and on Philo's views concerning the 'timelessness' of the intellect, negative theology, the limitations of the intellect and the fundamental division between God and his creation. (HMK) 


\section{1}

a7132. S. C. Motт, The Greek Benefactor and Deliverance from Moral Distress (Ph.D. diss. Harvard University, 1971).

Recognizing the importance of the term $\sigma \omega \tau \eta \dot{\eta} \rho$ (savior, deliverer) and related concepts in early Christian thought, Mott seeks the sources of these notions in Hellenistic writers. Soter should be understood as a benefactor who delivers from internal, moral distress rather than from external, material danger, and the term is part of a larger vocabulary of this kind of benefaction. After dismissing mystery religions, the ruler cult, and the Septuagint as possible sources, Mott identifies Hellenistic moralist writers as using the terminology of benefaction in a way most similar to that of the early Church. Of these Hellenistic writers, Philo-for whom the benefactor is always Goduses the terminology most extensively and shows the strongest parallels to early Christian usage, especially to that of Titus. While Titus is probably dependent upon the ideas expressed by Philo, other NT parallels to Philo may be independent. (EB)

a7133. E. NARDI, Procurato aborto nel mondo greco romano (Milan 1971), esp. 248-255.

With regard to abortion and the nature of the foetus Philo disagreed with the Stoics, who considered the foetus simply as a portio viscerum. The Alexandrian appears to hold that the formed foetus is in substance a human being, and that its formation takes place in the first forty days after the conception. (RR)

a7134. L. Robert, 'Les colombes d'Anastase et autres volatiles', Journal des Savants (1971) 81-105, esp. 91-97 (= § 2: 'Les colombes d'Aphrodisias et d'Ascalon').

A passage in Philo's Prov. 2.107 (transmitted by Eusebius PE 8.14 in the

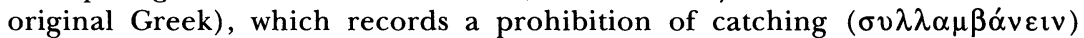
doves in Ascalon, sheds light on a first century CE inscription from Aphrodisias, first published by W. M. Calder in 1935. (HMK)

a7135. J. T. SANDERs, The New Testament Christological Hymns: their Historical Religious Background (Cambridge 1971).

Brief remarks on Philo, all in Part 2, 'The current status of the investigation' (pp. 29-98), which presents the conclusions of various scholars regarding the historico-religious background of the several New Testament Christological Hymns. This background is in all probability to be sought in preChristian Judaism. (HMK) 
a7136. W. C. van UNNIK, 'A $\Phi \Theta O N \Omega \Sigma$ META $\Delta \mathrm{I} \Delta \Omega \mathrm{MI}$ ', Mededelingen van de Koninklijke Vlaamse Academie voor Wetenschappen, Letteren en Schone Kunsten van België: Klasse der Letteren 33.4 (1971), esp. 24-31.

A thorough study, written in the Dutch language, of the terms $\dot{\alpha} \varphi \theta$ óv $\omega \varsigma$, $\varphi \theta$ óvo $\varsigma$ and related words as used in Christian, Jewish, and also pagan texts of the Imperial period, against the background of earlier classical and Hellenistic usage. Point of departure is a passage in Justin Martyr, where he liberally or unstintingly ( $\alpha \dot{\varphi} \theta$ ó $\omega \omega \varsigma$ ) summons everyone to receive God's grace. The use of the terms in Philo is extensively discussed: for Philo, Wisdom is

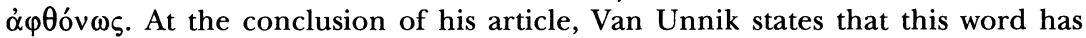
a two-sided meaning, referring not only (negatively) to the absence of envy but also (positively) to abundance. It applies to the attitude of non-possessors toward possessors as well as to that of those possessing toward those not possessing (in particular possessing special knowledge of mysteries). Cf. also a7352. (HMK)

\section{2}

a7243. D. Daube, 'Ecstasy in a Statement by R. Joshua b. Hananiah', Niv Hamidrasha (Tel Aviv 1972), 60-62; reprinted in C. M. Carmichael (ed.), Collected Works of David Daube, vol. 1 Talmudic Law (Berkeley 1992) 455-458.

It is suggested that Joshua b. Hananiah's use of the word bahus (בחוץ) [= 'outside'] to refer to Ben-Zoma's ecstatic state, reflects a very early rabbinic source which used Hellenistic terminology for lack of an appropriate Hebrew locution. Daube also explains why in his opinion it is far more likely that Philo's similar use of the term ekstasis (= 'ecstasy')-which is the word used in the Septuagint for MT החוצה in Gen. 15:5-depends on this early rabbinic source, rather than the other way around. (NGC)

a7244. J. M. Ford, 'The Ray, the Root and the River: a Note on the Jewish Origin of Trinitarian Images', Studia Patristica 11 [Papers presented to the Fifth International Conference on Patristic Studies held at Oxford 1967] = TU 108 (Berlin 1972) 158-165.

In De unitate ecclesiae Cyprian applies the images of the Sun, the Tree and the Stream to the Trinity (and to the Church). The author puts forward the hypothesis that these images have originated from the Jewish symbolism of the menorah, as suggested by Philo's allegorical interpretations of the candlestick in Her. 216-217, QE 2.73-81, Congr. 8. (HMK) 
a7245. P.-M. Guillaume, Art. 'Jacob. 4. Le judaisme', Dictionnaire de Spiritualité, Ascétique et Mystique, Doctrine et Histoire 8 (1972) 5-7.

Overview of the allegorical (moral and spiritual) meaning of Jacob in Philo's interpretation (with many references to Philonic passages), divided in a section on 'Jacob's personality' and on 'Jacob's journey'. (HMK)

a7245a. W. D. Hauschild, Gottes Geist und der Mensch. Studien zur frühchristlichen Pneumatologie, BEvTh 63 (München 1972) passim.

In determining the role of the doctrine of the spirit in the development of Christian theology, the author focuses frequently on the exegesis of Gen. 2:7, for which the Philonic background is indispensable. See the list of passages on p. 309. (DTR)

a7246. W. Warnach, Art. 'Freiheit', Historisches Wörterbuch der Philosophie 2 (Basel 1972) 1075-1076.

In the case of the important concept of freedom, the first confrontation of philosophical and biblical thought is found in Philo. Philo's thought on the theme of freedom appears to evolve from a juvenile, predominantly Stoic phase to a mature view which is more directly connected to the biblical content. In Philo's thought, only God can be free in the true sense, and only He can be considered liberator of man. On this context, mankind is divided in two parts; those who allow themselves to be liberated by God, and those who, rejecting this liberation, remain enslaved to vice. (HMK)

\section{3}

a7349. P. Geoltrain, 'Quelques lectures juives et chrétiennes des premiers versets de la Genèse de Qoumrân au Nouveau Testament', in In Principio: Interprétations des premiers versets de la Genèse, Études Augustiniennes 38 (Paris 1973) 47-60, esp. 51-55.

In a survey of interpretations of Genesis 1:1ff., the author sketches first Philo's interpretation as given in the De Opificio Mundi, focussing on the distinction and relation established by Philo between (the creation of) a corporeal and an intelligible world. He then briefly describes Philo's position in the De Aeternitate Mundi with regard to the world's createdness and corruptibility. According to Philo the world has been created (for which compare Plato) but at the same time is indestructible (for which compare Aristotle). (HMK)

a7350. G. M. LEE, 'Hellenistica', Studii Clasice (Bucarest) 15 (1973) 137. 
Very brief critical note on In Flaccum 36, in which the author suggests that

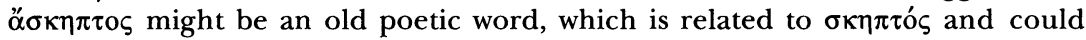
mean 'catastrophic'. (HMK)

a7351. P. Nautin, 'Genèse 1, 1-2, de Justin à Origène, in In Principio: Interprétations des premiers versets de la Genèse, Études Augustiniennes 38 (Paris 1973) 61-94, esp. 87-92.

In an article which follows that of P. Geoltrain (see above, a7349), various remarks are made on the dependence of Clement of Alexandria and Origen on Philo's interpretation of the first verses of Genesis 1 (notably his views on the creation of the intelligible and the corporeal world). (HMK)

a7352. W. C. VAN UNNIK, De $\dot{\alpha} \varphi \theta$ oví $\alpha$ van God in de oudchristelijke literatuur, Mededelingen KNAW, Afd. Letterkunde Nieuwe Reeks 36, no. 2 (Amsterdam-London 1973), esp. 40-45.

In this study of the conception of God's liberality ( $\dot{\alpha} \varphi \theta$ oví $\alpha$ ) in the earliest Christian literature, ample attention is also paid to Philo, for whom the concept refers to God's beneficence towards his creation. Cf. a7136. (HMK)

\section{4}

a7439. P. Courcelle, 'Ambroise de Milan dévot de la monade', Revue des Études Grecques 87 (1974) 144-154, esp. 150-152.

Philo's conception of the monad (Her. 190), itself derived from Pythagoras and Zeno of Citium, influenced Ambrose through the intermediation of Macrobius (on whose identity and date Courcelle has his own particular views) and Seneca. (HMK)

a7440. W. D. Davies, The Gospel and the Land: Early Christianity and Jewish Territorial Doctrine (Berkeley-Los Angeles-London 1974), esp. 121-124.

The concept of the 'land' is often used, both by Palestinian and Alexandrian sources, as a symbol for a transcendent order. This transcendence can be either radical or limited. The latter is the case of Philo, who, though not completely abolishing its material and geographical meaning, interprets the term 'with a moral and transcendental connotation' (p. 121). (RR)

a7442. S. SAGOT, 'La triple sagesse dans le De Isaac vel anima: Essai sur les procédés de composition de saint Ambroise', in Y.-M. Duval (ed.), Ambroise de Milan: XVI Centenaire de son élection 
épiscopale, Études Augustiniennes 39 (Paris 1974) 67-114, esp. 83-85 and 91-94.

Brief references to (and quotations from) Philo as an important influence on Origen, who in his turn was a source (when translated in Latin) for Ambrose's interpretation of Genesis 26:18-25. (HMK)

a7443. G. Segalla, Volontà di Dio e dell'uomo in Giovanni (Vangelo e Lettere), Supplementi alla Rivista Biblica 6 (Brescia 1974), esp. 4552.

The author discusses Philo in the third chapter in an exposition of the concept of will as related to God and to man. As far as the human will is concerned, the emphasis is on the doctrine of the free, ethical will, at the expense of the eschatological aspect which 'as motivation of good will' is typical of the Old Testament. For Philo, moral freedom finds its full realization in the observance of the divine Law and in the ensuing wellbeing. (RR)

a7444. E. Voegelin, Order and History, vol IV: The Ecumenic Age (Baton Rouge 1974), esp. 29-36.

In the introductory part of this volume of Voegelin's grand project Order and History (five volumes), seven pages are devoted to Philo. As formulated in terms of the typical vocabulary of Voegelin, the work of Philo represents a critical episode in the struggle for finding a new balance of consciousness in the ecumenic (i.e., multicivilizational) society of his days (p. 29). Whereas Gnosticism is characterized by Voegelin as 'the balance lost' and a 'dead end', in Philo's case the balance is 'regained'. Wolfson stressed that Philo has laid the foundations for seventeen centuries of religious philosophy until Spinoza, but according to Voegelin the influence of Philo's Allegoresis continued, among other things in the creation of the ideological systems as new types of Scripture. 'The Philonic symbolism is still a major obstacle to the life of reason in the twentieth century A.D.', largely because it has become an unconscious structure in Western thought (p. 30). Voegelin discerns in Philo's analysis of the ('pneumatic') cosmogony in the book of Genesis an inadequacy which is a 'millenial constant that must be dissolved by raising it into consciousness' (p. 31). 'The Philonic Allegoresis is (...) the great encounter of Hellenic philosophy with the Israelite-Judaic Torah in Alexandria; it is an attempt at cultural integration in an ecumenic-imperial society' (p. 35). In Voegelin's view, on the Greek side philosophy had to be deformed before it could become a suitable instrument of allegorical interpretation, while on the Israelite side the immediate pneumatic experiences were deformed by Scriptural mediation before they became the object of allegorical interpretation (p. 36). (HMK) 
a7557a. Y. F. BAER [בודת הקרבנות בימי הבית השני, ]י בער] ['The Liturgy of the Sacrifices in the days of the Second Temple'], Zion 40 (1975) 95-153; reprinted in a8550a.

Baer's major thesis is that the reading of Philo's lengthy homily on the 'Covenant between the Pieces' (Gen. 15) in Her., which he claims to be based upon a midrash (parts of which are still extant (with changes) in tannaitic and amoraic sources), as well as other material concerning sacrifices elsewhere in his auvre, against the backdrop of Mishnaic halakha provides the key to the understanding of the original mystical significance of the sacrificial service in the Second Temple. This original significance, he avers, was passed secretly to succeeding generations, to be rediscovered or restated explicitly and openly in the Kabbalah. (NGC)

a7558. V. V. Bychкov, 'The Aesthetics of Philo Alexandrinus' [Russian], Vestnik Dreonej Istorii [Journal of Ancient History] 133 (1975 nr. 3) 58-79 .

The article in Russian is followed by an English summary (on p. 79), which is given here in full: 'The author begins by pointing out that Philonian aesthetics are a synthesis of Greek and Hebrew philosophical, religious and aesthetic concepts, and reviews the basic categories of the aesthetic systems of the Old Testament and of Graeco-Roman antiquity. Bent on synthesising Greek philosophy and Hebrew theosophy and wishing to avoid the impasses of ancient rationalism, Philo hit upon an original philosophic method: a play of virtually free association on Old Testament themes. His gnosiology attains the level of the unconscious in the sphere of the emotionalaesthetic. Answers to many hotly debated questions of Hellenistic philosophy are implicit in the system of metaphors, images, symbols and associative connexions of his allegorical commentary. Philo's aesthetics are inseparable from his gnosiology and ethics, hence his basic aesthetic categories are meaningful also in his gnosiology and ethics. Among the fundamental problems posed by Philonian aesthetics are: pleasure ( $\left.\dot{\eta} \delta 0^{\prime} \eta^{\prime}\right)$ as a moral evil and as a most important aesthetico-gnosiological principle; beauty and the 'limits of the beautiful'; beauty in art as something higher than the beauty of the human body; beauty of content as more important than beauty of form; one's attitude to art; the category of 'light'-forerunner of the early Christian and mediaeval 'aesthetics of light'; the 'symbolical (allegorical) image' as the basis of a literary text; bearers of special non-literal information in a text.'

a7559. A.-H. Chroust, 'Lucretius, De Rerum Natura V. 110 ff.: a Possible Reference to Aristotle's On Philosophy', Acta Classica 18 (1975) 141-143.

Lucretius in DRN 5.110ff. seems to confirm what Philo in his De Aeternitate Mundi has reported about the views of Aristotle concerning the uncreatedness 
and indestructibility of the orderly universe, and thus lends support to the authenticity and correctness of Philo's account, which has been interpreted as containing fragments of Aristotle's On Philosophy. (HMK)

a7560. G. Schrceder and E. Des Places, Eusèbe de Césarée La Préparation Évangélique livre VII: Introduction, traduction et annotation; texte grec, SC 215 (Paris 1975).

The book of Eusebius' $P E$ presented in this volume could be entitled 'The theology of the Hebrews'. The extensive French Introduction points out how much Eusebius is indebted to Philo in this book, not only in the sections where Philo is literally quoted (§13: on the Logos; §18: on Man; §21: on Matter) but also where Eusebius speaks of the Patriarchs and Moses, interpreting their names and lives in the Philonic manner. (HMK)

a7561. J. P. Schultz, 'Two Views of the Patriarchs: Noahides and Pre-Sinai Israelites', in M. A. Fishbane and P. R. Flohr (edd.), Texts and Responses: Studies Presented to Nahum N. Glatzer on the Occasion of his Seventieth Birthday by his Students (Leiden 1975) 4359, esp. 48-52 and 59.

In post-biblical literature, the Patriarchs are pictured either as observing the Noahide commandments as well as other specific laws commanded by God, or already observing the entire law, written and oral. Schultz finds the former view in Philo, the latter e.g. in the Book of Jubilees and the Testaments of the Twelve Patriarchs. Philo differentiates between pre-Sinai and Sinaitic laws and identifies the Patriarchs' observance of the Noahide laws with the Greek concept of natural law. (HMK)

\section{6}

a7649. M. Dragona-Monachou, 'The Problem of Evil in Philo of Alexandria, with Special Reference to the De providentia' [in

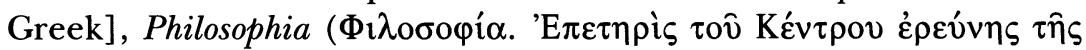

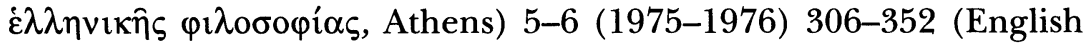
summary on pp. 351-352).

It has been argued that Philo's theodicy is Stoic. The author of this paper argues that this is only partly true in Prov. and only with regard to natural evil, but that it is not true for Philo's work as a whole or with respect to metaphysical and moral evil. From Opif. and some other exegetical treatises it appears that Philo is closer to Plato and the Pythagoreans than to the Stoics in considering metaphysical evil as due to the imperfection inherent in the status of creatures and perhaps to matter and its resistance to the divine purposes, and in attributing moral evil to human freedom and, allegorically 
speaking, to 'divine powers' and Logos, but not to the 'first God' Himself. A similar position concerning metaphysical and moral evil is taken even in Prov. Regarding natural evil, Philo is certainly close to the Stoic attitudes: some passages of Prov. should have been placed by Von Arnim among the Stoic fragments. Most of these attitudes, however, are not alien to Plato. Philo was eclectic in his theodicy as in so many other aspects of his philosophical theology. The author disagrees with the theory that Posidonius is Philo's main source in Prov. (Wendland), but she agrees to some extent with Boyancé's approximation of Philo to Antiochus. She believes that Philo's attack on astrology was not directed against orthodox Stoicism but rather against the astrological determinism of the Chaldeans. Because of the personal character of his attack, some working hypotheses are brought forward concerning the identification of Philo's target (the emperor Tiberius, or Manilius, or the astrologer calling himself Nechepso-Petosiris, or, more likely, the Egyptian Stoic Chaeremon). Philo's theodicy, for all its debts to Platonic, Stoic, and Judaic views, has also a personal character, which renders it both historically and philosophically important. (HMK, based on the English summary)

a7650. N. R. M. DE LANGE, Origen and the Jews: Studies in JewishChristian Relations in Third-Century Palestine, University of Cambridge Oriental Publications 25 (Cambridge 1976), esp. 108-30 and passim.

Briefly discusses the Philonic background which is part of Origen's debt to Jewish biblical interpretation. Origen made use of Philo's allegorical interpretations of proper names, but appears to be aware of their shortcomings and often accompanies them by alternative interpretations. Brief indications are also given of exegetical material drawn from Philo in Origen's interpretations of Genesis and Exodus. (DTR)

a7651. J. PÉPIN, 'Exégèse de 'In principio' et théorie des principes dans 1'"Exameron" (I 4,12-16)', in G. LAzzati (ed.), Ambrosius Episcopus: Atti del Congresso internazionale di studi ambrosiani nel XVI centenario della elevazione di sant'Ambrogio alla cattedra episcopale, Milano 2-7 dicembre 1974, Studia Patristica Mediolanensia 6 (Milan 1976) $1.427-482$.

Throughout the article remarks are made on the influence of Philo or 'philonism' on Ambrose's interpretations of both the many meanings of principium ( $\alpha \rho \chi \eta$, Gen. 1:1) and the spiritual meaning of Easter and the Exodus (as principium conversionis et depravationis). (HMK)

a7652. O. Schoenberger, 'Spiegelung eines alten Verses?', Rheinisches Museum N.F. 119 (1976) 95-96.

In this brief note the author suggests that Longus (2.4 and 2.5.2), Clement of Alexandria (Strom. 2.5.3) and Philo (Post. 18) all may show traces of an old 
poetical verse which spoke of a 'hunt' for Eros or some other elusive

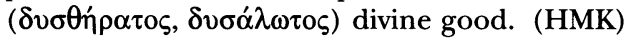

a7653. C. H. TAlBERT, 'The Myth of a Descending-Ascending Redeemer in Mediterranean Antiquity', New Testament Studies 22 (1976) 418-440, esp. 426-428.

The author argues that Philo shows a merging of angel and wisdom traditions with one another as well as with the concepts of the Logos and the first-born Son (among others). The result is that we meet in Philo's work a heavenly and divine figure, who is Son-Word-Angel-Wisdom-High PriestMan, the many-named one. (HMK)

a7654. D. C. Trakatellis, The Pre-existence of Christ in the Writings of Justin Martyr, Harvard Dissertations in Religion 6 (Missoula 1976).

The author argues that on many terminological as well as conceptual points Justin's thought on the pre-existence of Christ can be compared with passages in Philo (e.g. Philo's use of the verb $\pi \rho 0 \ddot{\pi} \pi \alpha$ $\rho \chi \varepsilon ı v$, the concepts of viós,

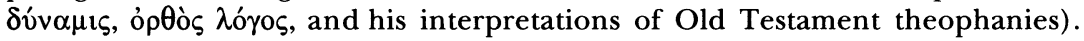
(HMK)

a7655. A. DE Vivo, 'Nota ad Ambriogio, "De Abraham" I 2, 4', in G. Lazzati (ed.), Ambrosius Episcopus: Atti del Congresso internazionale di studi ambrosiani nel XVI centenario della elevazione di sant'Ambrogio alla cattedra episcopale, Milano 2-7 dicembre 1974, Studia Patristica Mediolanensia 7 (Milan 1976) 2.233-242.

The author notes that Ambrose in his De Abraham made intensive use of Philo's De migratione Abrahami, even to the point of putting together a 'mosaic' of Philonic phrases and sentences. In so doing, however, Ambrose modified and adapted them to the new Christian context and purpose of his work. (HMK)

1977

a7747. A. Arazy, The Appellations of the Jews (Ioudaios, Hebraios, Israel) in the Literature from Alexander to Justinian (diss. New York 1977), esp. 141-158.

In this study of the usages and distinctive meanings and connotations of

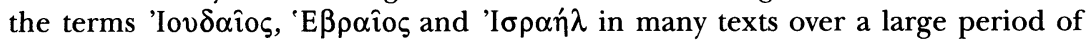
time, due attention is paid to Philo's usage, as illustrated by quotations from 
his works. Hebraios is for Philo only a term of the past, used to designate the progenitors of the Jewish nation; Ioudaios is the social and geo-political appellation used by speakers of Greek of Philo's own time, including himself; Israel, finally, is an appellation of another order: implying holiness, spiritual elevation, union with God and union with the members of the Jewish communities all over the world. (HMK)

a7748. A.-H. Chroust, 'Aristotle's On Philosophy and Plutarch's De Facie in Orbe Lunae', Wiener Studien N.F. 11 (1977) 69-75.

The article starts with the quotation of Philo, Aet. 28-34, in an English translation. This passage is considered to be a fragment of Aristotle's lost dialogue On Philosophy. Chroust then sets out to demonstrate that Plutarch in his De Facie takes issue, at least indirectly, with what is stated in this fragment about 'the proper location' of the component parts within the universe. Chroust argues that Philo quite faithfully reports what Aristotle originally said, and that Aet. 28-34 may therefore properly be called an authentic fragment of Aristotle's On Philosophy, as might also, with some reservations, be said of certain passages from Plutarch's De Facie. (HMK)

\footnotetext{
a7749. D. Cohen (Harav Hanazir), נזיר אחיו, דברי תורדה, הגות ומחקר)

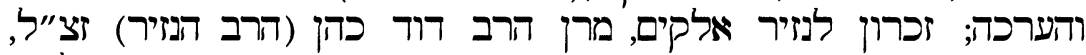
(= Nazir Echav. Essays and Articles by and in Memory of Rabbi David Cohen, The Nazir], 3 vols. (Jerusalem 1977) 2.289-404, esp. 322-404.
}

Volume 2 contains material from Cohen's hitherto unpublished literary legacy. The major portion of the chapter on Jewish Philosophy, pp. 289-404, is devoted to Alexandrian Jewish Philosophy and to Philo in particular, pp. 322-404. Harav Hanazir first introduces Philo to the novice, and then proceeds to engage the relevant scholarly literature in a running dialogue, quoting extensively from Philo to illustrate his arguments. He is unique among his colleagues in seeing Philo as representing the 'authentic' Jewish approach, which he finds reflected elsewhere in Jewish thought primarily in the Kabbalah, taking them to be connected by an invisible subterranean current. (NGC)

a7750. R. J. Daly, 'The Soteriological Significance of the Sacrifice of Isaac', Catholic Biblical Quarterly 39 (1977) 45-75, esp. 55-56.

Philo's interest in the sacrifice of Isaac lies in what it tells us of the progress of the mind or soul towards God. Abstracting from these allegorical developments, one can uncover a Philonic theology of Isaac's sacrifice which resembles that of the Palestinian targums and Josephus. The author lists the major points of this Philonic theology. (HMK) 
a7751. R. B. Motzo, 'Studi Filoniani' in IDEM, Ricerche sulla letteratura e la storia giudaico-ellenistica, edited by F. PARENTE (Roma 1977; reprint of Saggi di storia e letteratura guideo-ellenistica, Firenze 1924, and other essays published in various periodicals) 503606.

The section on Philo in this reprint collection of studies of the Italian scholar Raimondo Bacchisio Motzo (1883-1970) contains three articles, all of them originally published in 1911, concerning ПЕPI BIOY ПРАКTIKOY $\mathrm{H}$

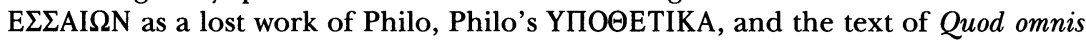
probus liber respectively. (HMK)

a7752. A. Strobel, Ursprung und Geschichte des frühchristlichen Osterkalenders, TU 121 (Berlin 1977), esp. 438-439.

Scattered references to remarks of Philo regarding the Passover festival, and a brief section on Philo's evidence concerning some precise calendaric and astronomical issues. (HMK)

\section{8}

a7854. A. Kenny, The Aristotelian Ethics: A Study of the Relationship between the Eudemian and Nicomachean Ethics of Aristotle (Oxford 1978), esp. 24-25.

In this work it is argued that 'ancient authors up to the second century A.D. do not regard the Nicomachean Ethics as having that primacy over the Eudemian Ethics which has been taken for granted during the last millenium and more' (p. 5). 'The way in which Philo applies the doctrine of the mean to particular virtues makes it more likely, if he is drawing on Aristotle directly, that he was acquainted with the Eudemian than the Nicomachean version of the doctrine; but the freedom with which he applies it (...) leaves it open that he is improvising upon a theme known to him at second hand. (24-25)' (HMK)

a7855. H.-J. Klauck, Allegorie und Allegorese in synoptischen Gleichnistexten, NTA NF 13 (Münster 1978, 1986²), esp. 96-104.

A section on Philo describes his position with regard to exegesis and allegory as situated in between the extremes of literalists and (too radical) allegorists. It analyzes Philo's allegorical method, and reaches the conclusion that Philo's approach to the Old Testament is dominated by the Platonizing character of his thought. (HMK) 
a7856. A. B. Kovelman, 'Philo Judaeus on the Labor of Free Man and Slaves in Roman Egypt' [in Russian], Vestnik Drevnej Istorii [Journal of Ancient History] 145 (1978 nr. 3) 150-157 (English summary on p. 157).

Philo thought the farmer ( $\gamma \varepsilon \omega \rho \gamma o ́ \varsigma)$ to do the best and most productive kind of labour, in contrast to the hired worker (who thinks only of his wages, not of the quality of his work) and the slave. For Philo, work should ideally be unselfish, free, pleasurable and its own reward: such is the work of the philosopher. Such is also the work of the Therapeutae and the Essenes who have no slaves. The papyri show that similar views were held among slave-owners in Egypt in the 1st century CE. (HMK, based on the English summary)

a7857. A. J. Malherbe and E. Ferguson, Gregory of Nyssa The Life of Moses, The Classics of Western Spirituality (New York 1978).

Succinct comparison with Philo's Life of Moses in the Introduction (p. 6) and frequent references to the same work and other Philonic treatises in the notes. (HMK)

a7858. A. Michel, 'A propos du bonheur: pensée latine et tradition philosophique', Revue des Études Latines 56 (1978) 349-368, esp. 365-367.

The author confronts the views of Seneca, Cicero and Augustine on happiness or well-being both with the doxography on this subject and with the philosophers Philo and Plotinus. What emerges is the unity of antique philosophy: one cannot talk of Cicero without thinking of Plotinus, nor of Augustine without referring to Seneca and Philo. In Philo we find a combination of the main currents of ancient thought (Academic and Stoic) on the subject of happiness and joy. Cicero's Hortensius, various texts of Philo, and Augustine's De beata vita show a tradition in which happiness is considered to reside in seeking rather than in possessing it. (HMK)

\section{a7859. N. Roth, 'The "Theft of Philosophy" by the Greeks from the Jews', Classical Folia 32 (1978) 53-67.}

The theme that the Greeks stole philosophy from the Jews, originally found in fragmentary Hellenistic Jewish sources, has a history in Jewish thought that reaches as far as late medieval Jewish works. Initially this was an apologetic argument conferring legitimacy upon the study of philosophy for hellenized Jews in Palestine challenged by pious co-religionists. Josephus, who preserves some of these fragmentary sources, does not emphasize the origins of philosophy for his later, Roman audience. Instead he notes Abraham's role as father of the practical disciplines astronomy and arithmetic. Philo acknowledges that Moses learned from Egyptian and Greek sages; Moses surpassed these sages, however, and some of his teachings were 
then borrowed by the Greeks. Generally, for Philo Moses represents the ideal 'philosopher king' of Plato, and his excellent laws were rightfully copied by the Greeks. Because Philo thought the Torah should 'be made to conform with Greek philosophy' and not that philosophy should be made to conform to the Torah, he was not accepted by the rabbis and remained unknown in Jewish circles until the Renaissance. The theft of philosophy from the Jews re-emerges as a theme in medieval Jewish writers under attack by fellows Jews for studying philosophy. At best, however, these writers had only an indirect knowledge of their predecessors. (EB)

a7860. E. \& F. STAGG, Woman in the World of Jesus (Philadelphia 1978), esp. $41-45$.

This book examines the status and role of women both in the world Jesus entered and in the world he came to create. In a chapter entitled 'The Jewish World', Philo is discussed as a devout Jew of wide influence, infatuated with Greek philosophy, whose perspectives must be considered as a significant part of the world into which Jesus came. Philo saw woman in a role strictly secondary to man, inferior and subordinate, which did not prevent him from showing some concern for humaneness to women. The description of Philo's views is illustrated by quotations from his works. It is concluded that 'Philo cannot be faulted for having been born into a world that was male-oriented, but his extensive writings indicate that he did little to redress any iniquities and much to further them. He tried to make nature, logic, and religion serve to validate male domination.' (HMK)

a7861. R. W. Thomson, Moses Khorenats'i: History of the Armenians. Translation and Commentary on the Literary Sources, Harvard Armenian Texts and Studies 4 (Cambridge Mass.-London 1978, $1980^{2}$ ), esp. 31-32.

The father of Armenian history did not live and work in the fifth century, as he claims, but probably wrote his work in the 8th century. The Armenian Philo was one of his more important non-Christian sources. On pp. 31-32 the author lists about 10 passages in which Moses makes direct use of Philo's work, borrowing either an expressive phrase or quoting a longer passage directly. (DTR)

\section{9}

a7949. D. Hill, New Testament Prophecy, New Foundations Theological Library (Atlanta 1979), esp. 31-33.

In the context of a description of prophecy in the Hebrew-Jewish tradition as background for New Testament prophecy, a succinct section is devoted to Philo. For Philo, the prophetic experience is a state of divine possession, 
which he describes in terms almost entirely derived from non-biblical Greek culture. Philo is at odds with known Jewish views in affirming that the gift of prophecy is available to his contemporaries, and in localizing the experience of hearing a prophetic 'voice' within the individual, whereas Rabbinic usage thinks of the 'voice' coming to the recipient from the heavenly sphere. (HMK)

a7950. J. P. Martín, El Espíritu Santo en los origenes del cristianismo; Estudio sobre I Clemente, Innacio, II Clemente y Justino mártir (Zürich 1971), esp. 286-291.

The author mentions Philo in connection with the term pneuma in the use of the Christian writers of the 2nd century. Especially he analyzes an argument of H. A. Wolfson, The Philosophy of the Church Fathers, 232-234 (R-R 5618) who tries to show the decisive influence of Philo in the formation of the trinitarian Christian doctrine with the following syllogism: (a) the apologists introduce the distinction of the two stages of generation of the Logos; (b) Justin is the first Christian writer that distinguishes the preexistent Logos-Sophia from the pre-existent Pneuma, (c) both suppositions belong to Philo and under their influence they are assimilated by Justin; therefore the Christian apologist opens a way for the development of the trinitarian theology. The author analyzes this argument and concludes that: as to (a), it has not been shown that this happens through influence of Philo; as to (b), the analysis of Justin's texts (cf. pp. 291-304) does not allow Wolfson's claim, because the distinction of Logos and Pneuma before the creation is more a conceptual element characteristic of common formulations than the result of Justin's own language and theology; as to (c) it is not proven with texts of Justin, but rather it is a deduction of Wolfson through use of his deductive hypothetical method. (JPM)

a7951. C. Mercier, 'L'École hellénistique dans la littérature arménienne', Revue des Etudes Armeniennes 13 (1978-79) 59-75.

Philo is mentioned only three times, but the background information provided in this article will be valuable for those studying his works preserved in Armenian. (DTR)

\section{0}

a8045. C. BASEvi, San Agustin: la interpretación del Nuevo Testamento (Pamplona 1977), esp. 88-90.

The author considers that Augustine had contact with the exegesis of Philo through Origen and Ambrose, although it is probable that he had direct knowledge of the text of Quaestiones in Genesim according to his testimony in Contra Faustum 12.39. (JPM) 
a8046. L. Cracco Ruggini, 'Nuclei immigrati e forze indigene in tre grandi centri commerciali dell'Impero', in J. H. D'ARMS and E. C. KopfF (edd.), The Seaborne Commerce of Ancient Rome: Studies in Archaeology and History, Memoirs of the American Academy in Rome 36 (1980) 55-76, esp. 56-60.

The anti-Jewish riots in Alexandria of $38 \mathrm{CE}$, for which Philo's Legatio ad Gaium and In Flaccum are the most important sources, are interpreted as having been above all politically motivated. This means that the violence on the part of the Greek population was directed against the Jews not for their being Jews but for their being a 'bourgeois' class which was trying to secure additional privileges. Cf. 9054. (HMK)

a8047. D. DAube, 'Jewish Law in the Hellenistic World', Jewish Law Annual, Suppl. 2: Jewish Law in Legal History and the Modern World (1980) 45-60; reprinted in C. M. Carmichael (ed.), Collected Works of David Daube I, Talmudic Law (Berkeley 1992) 213-230.

The article contains a series of examples of apparent interrelationships between Jewish and Roman Law. The first six pages argue in favor of the possibility that Philo did know Hebrew. (NGC)

a8048. J. D. G. DunN, Christology in the Making: A New Testament Inquiry into the Origins of the Doctrine of the Incarnation (London 1980).

Dunn's aim is to investigate as thoroughly as the available evidence allows the beginnings of early Christian theology and particularly the doctrine of incarnation which is central to early Christian christology. Philo is regarded as a valuable witness for the contemporary Jewish background and is referred to frequently, notably in discussions on the Epistle to the Hebrews (p. 53ff.), the hymn in Col. 1 (p. 165ff.), Pauline christology in 1 Cor. 10 (p. 183f.) and the background of Wisdom theology (p. 206f.). The most extensive passage, however, discusses Philo's Logos doctrine as background to the Prologue of John's Gospel (pp. 220-230). Dunn concentrates on the question whether the Philonic Logos should be regarded as an intermediary being between God and man. On the basis of a review of a large number of texts he concludes that this is not the case. 'In the end of the day the Logos seems to be nothing more for Philo than God himself in his approach to man, God himself insofar as he may be known by man' (p. 228). This conclusion was contested in a subsequent article by F. G. Downing (see 9017). (DTR)

a8049. R. M. GRANT, Eusebius as a Church historian (Oxford 1980), esp. 72-76.

A brief analysis of those passages in Eusebius' Ecclesiastical History in which Philonic material is used to explain the origins of the Church at Alexandria. Grant also notes that the principal motifs of the description of 
the Therapeutae which Eusebius draws from Philo reappear in his account of the early life of Origen. (DTR)

\section{1}

a8135. D. L. BALCH, Let Wives be Submissive: The Domestic Code in 1 Peter, SBLMS 26 (Chico 1981), esp. 52-55.

Apart from being adduced many times in the notes, Philo is also discussed in a separate section of this study. He represents a Hellenistic Jew who interprets the Decalogue in the light of Platonic and Aristotelian ethics, more precisely, in the light of the topos 'concerning household management' (and the topos 'concerning the constitution'). (HMK)

a8136. A. Broadie, A Samaritan Philosophy: A Study of the Hellenistic Cultural Ethos of the Memar Marqah, Studia Post-Biblica 31 (Leiden 1981), passim.

The aim of this book is to argue that the work of the fourth century Samaritan philosopher Marqah, totally ignored by subsequent generations of philosophers, contains a far-reaching philosophical system deserving close attention, and that this system is unmistakably Hellenistic, in particular bearing a striking resemblance to that of Philo. Discussing in successive chapters the topics of the Existence, the Oneness, the Unknowability, the Powers, the Personhood and the Creativity of God, as well as 'a Samaritan De Anima' and Ethics, Broadie compares Marqah's arguments with those of Plato, Aristotle, the Stoics and Philo, and concludes that 'Marqah's position is, indeed, so close to Philo's it would not tax the imagination to suppose that Marqah had studied Philo's writings' (p. 233). (HMK)

a8137. A. Butterweck, Jakobs Ringkampf am Jabbok: Gen 32,4 ff. in der jüdischen Tradition bis zum Frühmittelalter (Frankfurt am MainBern 1981), esp. 62-71.

This study investigates the history of interpretation of Jacob's wrestling with the Angel at the Jabbok (Gen. 32). A chapter devoted to the understanding of this theme in Hellenistic Judaism deals with Josephus (who gives the story a political maning), the book of Wisdom (spiritualizing it) and Philo (pp. 62-71: 'Die allegorisierende Interpretation des Ringkampfthemas bei Philo von Alexandrien'). Philo's interpretation synthesizes concepts from Wisdom, Platonism and the Stoa. Jacob/Israel is the prototype of the man who along the path of practice and struggle ultimately arrives at 'seeing' God. The angel according to Philo does not fight against Jacob, but as Logos/Sophia lends him support and guidance. (HMK) 
a8138. A. B. Kovelman, 'The Concept $\pi \rho 0 \theta v \mu i \alpha$ in the Official Ideology of Graeco-Roman Egypt' [in Russian], Vestnik Drevnej Istorii 155 (1981) 178-185 (English summary on p. 185).

The author's English summary is reproduced here in full: 'The concept $\pi \rho 0 \theta 0 \mu i \alpha$ (zeal) held an important place in the ethics of obedience in GraecoRoman Egypt. Unlike $\pi$ póvora (prudence), it applied not so much to polis citizens as, for example, to workers on the land. Prothumia was a quality required of persons liable to state service obligations. The inspiration to prothumia came

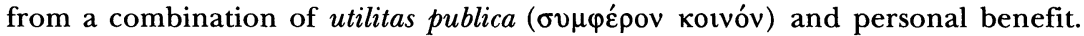
By the former was understood the prosperity of Egypt and of the empire as a whole and in particular the efficiency of irrigation. The concepts prothumia and euthumia (cheerfulness) are closely connected, to which a parallel may be found in the reflections of Philo Judaeus upon joyful service. The concept prothumia was of polis origin. In the Hellenistic monarchy it lost its original meaning.'

a8139. A. PolačEk, 'Holocaust, Two Millenia Ago', Proceedings of the XVI International Congress of Papyrology (Chico, California 1981) 699-706.

Description of the events of the progrom in Alexandria in $38 \mathrm{CE}$, on the basis of Philo's In Flaccum and Legatio ad Gaium, and illustrated by some papyri. The author concludes that, while it is possible to regard these events as a mere episode in the past, a more attentive reading of the source material shows that many a modern phenomenon has its counterpart in events of the past. Cf. 9054. (HMK)

a8140. H. D. Saffrey and L. G. Westerink (edd.), Proclus Théologie Platonicienne, vol. 4, Collection Budé (Paris 1981), esp. xii-xv.

Brief discussion of Philo's use and interpretation of Plato's Phaedrus myth, including a translation with comments of Opif. 69-71. (DTR)

a8141. M. Szymański, 'On Authenticity of Philolaus' Fr. B 20', Archiv der Geschichte der Philosophie 63 (1981) 115-117.

Defends Philo's presentation of Philolaus in Opif. 100 by noting that the quotation attributed to the latter has exactly seven attributes for the ruler of the Universe. (DTR)

\section{2}

a8253. H. Koester, Introduction to the New Testament, vol. 1: History, Culture and Religion of the Hellenistic Age (New YorkBerlin 1982), esp. 273-280.

English translation of R-R $\mathbf{8 0 2 3}$. 
a8254. R. BRague, Du temps chez Platon et Aristote: Quatre études, Épiméthée (Paris 1982), esp. 13-19.

In this collection of four studies, the first has the aim of putting an end once and for all to the idea of 'time ( $\chi \rho$ óvo $_{\text {) }}$ ) as the moving image of eternity ( $\alpha i \omega ́ v$ )'. Brague argues that Plato in Timaeus 37d does not, as is now the common interpretation, say that the 'image of $\alpha i \omega$ ' is time, but that it is heaven (ovjpavós). The traditional interpretation is found for the first time only several centuries after Plato, at the earliest maybe in Philo, then perhaps in Plutarch, but for certain not earlier than Albinus, Aëtius and Diogenes Laertius. In a close reading of the three passages in which Philo

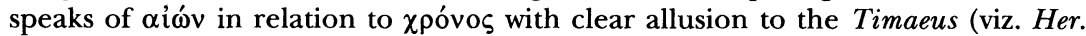
165, Mut. 267, and Deus 32) it emerges that these passages are by no means unambiguous as far as an interpretation of 'time as the image of $\alpha i \omega v$ ' is concerned. (HMK)

a8255. W. Theiler, Poseidonios: die Fragmente, 2 vols., Texte und Kommentare 10.1 (Texte) \& 10.2 (Erläuterungen) (Berlin-New York 1982).

This important collection of testimonies and fragments, the result of a life-time of research, includes a number of passages from Philo because they are thought to contain Posidonian material in the field of physics. Volume 1 contains under the sub-heading Theory of nature $(\Phi v \sigma i k o ̀ \varsigma ~ \lambda o ́ \gamma o \varsigma)$ Aet. $79=$ fr.

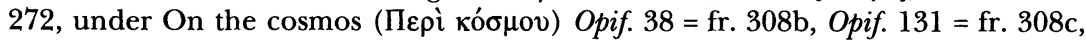

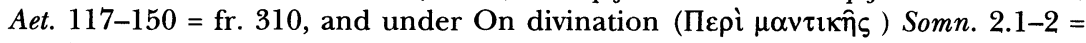
fr. 373b. Volume 2 offers commentary on these passages as well as numerous other references to Philo, for which see the index. (HMK)

\section{a8256. J. W. Thompson, The Beginnings of Christian Philosophy:} The Epistle to the Hebrews, CBQ.MS 13 (Washington DC 1982) passim.

Whereas previous research was primarily limited to a comparison of Hebrews with Philo, Qumran and other apocalyptic literature, Thompson's monograph attempts to examine the metaphysical assumptions of Hebrews within the context of Middle Platonism (which was the intellectual climate in which Philo lived). Philo still plays a major role in the monograph. It is concluded that the differences between Hebrews and Philo are probably great enough to exclude a literary dependence of the former on the latter. What the two writers share is a common set of categories and a metaphysic that is similar. An important theme in both is the motif of stability (of the heavenly world, as opposed to the unstable creation). The author concludes that 'Hebrews' less extensive use of Platonic categories may indicate that the author is more comfortable with the models offered by Aristobulos and other Alexandrian Jews than with the more extensive Platonism of Philo' (p. 158). (HMK) 


\section{3}

a8380. S. E. Dowd, 'The Theological Function of Petitionary Prayer in the Thought of Philo', Perspectives in Religious Studies 10 (1983) 241-254.

The first part of this article surveys Philo's vocabulary for petitionary prayer, which encompasses eight word families. Included among the word meanings are the asking for forgiveness and the vow, which combines a request with a promise as thanksgiving. Although Philo shared with other philosophers a higher regard for the spiritual realm than the material, he nonetheless speaks of external goods in addition to spiritual benefits as being among the things prayed for. The second part of the article addresses the function of petitionary prayer, which is closely related to Philo's belief in providence. The pious, who recognize the utter dependence of creation upon divine providence, demonstrate this recognition through prayers supplicating God 'to avert the evil and gain the good'. In contrast are the arrogant, who wrongly believe themselves or secondary sources, rather than God, to be the cause of all things and who call upon God, if at all, only as a last resort. (EB)

a8381. D. Wyrwa, Die christliche Platonaneignung in den Stromateis des Clemens von Alexandrien, AKG 53 (Berlin-New York 1983), passim.

As is only to be expected, Philo is referred to on numerous occasions in this definitive study on Clement's appropriation of Platonism in his Stromateis. The most extensive discussion is found at pp. 272-279, where the author deals with the theme of divine transcendence and argues that Clement's treatment reveals 'Schulplatonismus' linked up with Philo. See further the extensive list of references to Philonic texts given on pp. 351-353. (DTR)

\section{4}

a8463. B. Chiesa, 'Ya'qub al-Qirqisani come fonte storiografica', in B. ChiesA and W. Lockwood (edd.), Ya'qub al Qirqisani on Jewish Sects and Christianity, Judentum und Umwelt 10 (Frankfurt 1984) 1547, esp. 28-29.

Ya'qub al-Qirqisani, the great Karaite scholar of the first half of the tenth century, gave in his Book of Lights and Watchtowers a survey of the developments of Jewish religious history from ancient times to the author's own day. Chiesa argues that the work parallels in its heresiographic part both patristic writings such as John of Damascus' De fide orthodoxa and contemporary Muslim writings. In its doctrinal part, however, it is organized in an original way, viz. following the order of the Decalogue. This presentation according to 
Chiesa is inspired most probably by Philo, in particular his De Decalogo and De Specialibus Legibus. (HMK)

a8464. S. L. Davies, 'Ascetic Madness', in R. C. Smith and J. Lounibos (edd.), Pagan and Christian Anxiety: A Response to E. $R$. Dodds (Lanham - New York - London 1984) 13-26, esp. 17-19.

Davies contrasts three modes of life, all of which Dodds called 'ascetic', viz. that of the Essenes, of the Therapeutae, and of the Desert Fathers. For the (ideal) life of the Therapeutae, Philo's On the Contemplative Life is the source. It is concluded that the Therapeutae did not form a religious community: they 'strike one as being something of a retirement village for upper class Alexandrians'. (HMK)

a8465. J. N. Lightstone, The Commerce of the Sacred: Mediation of the Divine among Jews in the Graeco-Roman Diaspora, BJS 50 (Chico 1984), esp. 171-185: Appendix 'Philo and Philosophic Mysticism'.

Using a social-anthropological approach, this study undertakes to interpret Graeco-Roman Judaism by seeing it in terms of other comparable phenomena and of other religious and cultural systems. In an appendix the author criticizes the reduction of 'Hellenistic Judaism' to 'Philonism', a reduction very commonly made by most 'historians' of early Christianity and Late Antique Judaism (who are usually theologians and exegetes). 'That Philo represents much more than himself, for example, has resulted in such curiosities as the hypothesis of a Philonic 'school' so pervasive in the Diaspora that ultimately a Christian in Asia Minor writes the Epistle to the Hebrews under Philo's influence (p. 172).' Analyzing and criticizing the views of E. R. Goodenough on Philo as the proponent of a Jewish Mystery, Lightstone argues that Philo furnishes no evidence for a Jewish Mystery in the cultic sense of the word at all, but presents a Hellenistic philosophic mysticism in a Jewish mode. Philo's predilection for Graeco-Egyptian Platonic mysticism in fact undermines Torah-ritual (ritual occupying the senses and the body). Philo represents a particular type of Jewish holy man in the Graeco-Roman world, different from other types of Jewish holy men in the Hellenistic milieu. (HMK)

a8466. G. Lloyd, The Man of Reason: 'Male' and Female' in Western Philosophy, Ideas (London 1984), esp. 22-28.

The aim of this book is to bring to the surface the implicit maleness of our ideals of Reason. It thus deals with the conceptual reasons for the conflicts women may experience between Reason and femininity. The first chapter argues that from the beginnings of philosophical thought, femaleness was associated with what reason supposedly left behind: women's capacity to conceive connects them with the fertility of Nature. The second chapter elaborates the 'divided soul'-model, i.e. the soul seen as divided between Reason and the senses or passions. In Plato's Symposium the old conflicts between Reason and 
the fertility mysteries are subsumed in a treatment of Reason as itself being a passionate as well as creative and productive faculty. But later the divided-soul model is brought into conjunction with male-female symbolism. Lloyd describes three versions of this, presented by Philo, Augustine and Aquinas: their use of male-female symbolism occurs in the context of interpretation of the Genesis stories concerning Adam and Eve. For Philo, woman, symbolizing sense-perception, is the source of the Fall for man, who symbolizes Mind. Moral progress in his view means the giving up of the female gender by changing into that of the male. The ideas and ideals articulated through Philo's allegories became deeply ingrained in the developing structures of thought about Reason and gender. (HMK)

a8467. K. A. D. Smelik and E. A. Hemelrijk, "Who knows not what Monster demented Egypt Worships?": Opinions on Egyptian Animal Worship in Antiquity as Part of the Ancient Conception of Egypt', in W. HaAse (ed.), Aufstieg und Niedergang der römischen Welt II 17.4 (New York-Berlin 1984) 1852-2000, esp. 1915-1918.

Philo's negative attitude to Egyptian animal worship is consistent with his generally negative attitude to Egypt itself. In Legat. 139 and 163 accusation of animal worship is used for polemical purposes. Remarkably, however, in Mos. 1.23 the symbolic interpretation of animal worship that learned Egyptians taught Moses is not adversely commented on. (DTR)

a8468. A. Wasserstein, 'Greek (and Christian?) Sources in Ibn Ezra's Commentary on Psalms', Scripta Classica Israelica 7 (1983-84) 101-112.

Abraham Ibn Ezra (12th century) interprets Psalm 19 in a manner reminiscent of Plato's simile of the sun (Rep. VI 508a $4 \mathrm{ff}$.). It is likely that the analogy between the sun and the Torah came to Ibn Ezra not directly from a reading of Plato, but through different channels. In the works of Philo the sun is equated with a very similar complex of concepts, and comments of Ibn Ezra remind us of a good number of Philonic passages. Wasserstein argues that it is not absurd to admit the possibility that Ibn Ezra was acquainted with Philo either directly or indirectly through Christian literature; he might also have been acquainted with such material through traces of it in other Jewish writers of the Middle Ages, e.g. Ibn Gabirol. It would be most interesting to see whether the conjecture that some Jewish writers in the Middle Ages may have known something of Philo and possibly of Christian writers can be substantiated. (HMK)

\section{5}

a8549. J. Annas and J. BARnes, The Modes of Scepticism (Cambridge 1985). 
Philo's De ebrietate 169-205 is one of the chief sources of the tropes of the neopyrrhonist Aenesidemus. The two authors give a translation of and philosophical commentary on the three main sources, Sextus Empiricus, Diogenes Laertius and Philo. In the main text his version of the tropes is cut up and presented in the sequence of the chief source Sextus. In an Appendix (pp. 175180) the translation of Philo's text is reprinted in its correct sequence. (DTR)

a8550. R. BADENAS, Christ the End of the Law: Romans 10.4 in Pauline Perspective, JSNT.MS 10 (Sheffield 1985), esp. 65-69.

Crucial for the understanding of Romans 10:4 is the meaning of the word

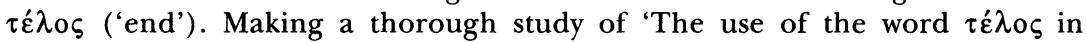
Biblical and cognate literature' (= chapter 2), Badenas also gives a complete survey of the use of the word in Philo (204 occurences in Mayer's Index

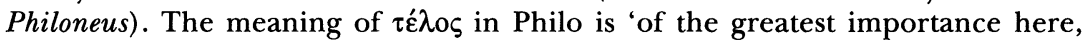
because of the many points of comparison between Philo and Paul' (p. 65). In

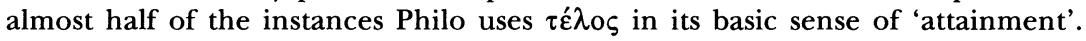
In most of the occurrences the word is used as a terminus technicus for the ethical concept of man's summum bonum as used in Greek philosophy. In connection with $\dot{\alpha} \rho \chi \eta \dot{~(43 ~ t i m e s) ~ i t ~ f o r m s ~ a n ~ e x p r e s s i o n ~ o f ~ t o t a l i t y . ~ F o r ~ P h i l o ~}$ the word $\tau \dot{\varepsilon} \lambda \varsigma_{\varsigma}$ did not carry any particular terminal connotations: 'In no

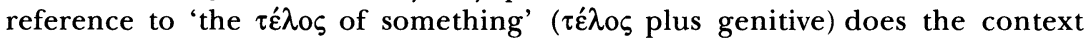
allow translation of the phrase in the sense of 'cessation', 'abrogation', 'supercession', etc. (p. 68)' (HMK)

\section{a8550a. Y. F. BAER, [בער [י. Studies in the History of the Jewish People [מחקרים ומסות בתולדות עם ישראר], 2 vols. (Jerusalem 1985).}

This is a collection, made posthumously, of some of Baer's articles. Most of the first volume contains studies on Judaism in the Second Temple period, and particularly the historical roots of the Halakha. In many of the articles in the first volume Philo is an important source for our knowledge of the subject under consideration. The original format of the articles is in most instances retained, including the original pagination at the top of the page, and there is a listing of where they first appeared at the end of the volume which greatly enhances the book's use for the scholar. Although volume 2 is devoted almost completely to Baer's scholarship on the Jews in Europe in the Middle Ages it also contains two references to Philo. A complete list of Baer's ספר זכרון ליצחק[ [בער = Zion 44 (1979), edited by H. BEINART, Y. ETTINGER and M. STERN, 321$329=$ R-R 8004. With regard to Philo see also R-R 5201, 5303, 5502, RRS a6228a, a7557a.

a8550b. F. Beatrice, 'Le tuniche di pelle. Antiche letture di Gen. 3:21', in U. BIANCHI (ed.), La tradizione dell'Enkrateia (Rome 1985) 433-484, esp. 463-467. 
Philo is an important witness in the tradition of exegesis of Gen. 3:21 because he is the first to identify the 'tunics' of skin with the human body. (DTR)

a8551. T. Callan, 'Prophecy and Ecstasy in Greco-Roman Religion and in 1 Corinthians', Novum Testamentum 27 (1985) 125140, esp. 133-136.

Callan argues that prophecy as Paul sees it is not ecstatic, i.e., not accompanied by trance. To this end he compares Paul's argument in 1 Cor. 14 with discussions about prophecy and trance among Greeks (notably Plato, Plutarch and Pindar) and Hellenistic Jews (notably the Septuagint and Philo), focusing on the meaning of the word $\pi \rho \circ \varphi \eta \tau \eta \zeta$. Callan concludes that, though Philo knows of prophecy as a trance phenomenon, he sees Moses mainly as a prophet whose prophecy does not involve trance. (HMK)

\section{a8552. H. Feld, Der Hebräerbrief, Erträge der Forschung 228 (Darmstadt 1985)}

This monograph sets out the main literary-historical and theological problems connected with the Letter to the Hebrews, and presents the solutions proposed by various currents of scholars. Describing the divergent views on the dependence of Hebrews on Philo of notably Spicq (see R-R 5019: dependence yes) and Williamson (see R-R 7037: dependence no), Feld concludes that the controversy between these two demonstrates how scholars may miss the mark due to preconceived opinions. (HMK)

a8553. H. Guevara, Ambiente político del pueblo judio en tiempos de Jesús, Academia Christiana 30 (Madrid 1985), esp. 147-154.

The author's thesis is that during the time of Jesus the relationships between Jews and Romans were peaceful, and that therefore his doctrine should not be framed in a context of armed struggle or social protest. As part of his arguments, the author engages in a detailed reading of Legatio ad Gaium, especially of Agrippa's letter to Gaius, Legat. 276-329, on the basis of which he concludes that the conflicts among Romans and Jews did not imply belligerency and certainly not armed rebellion. (JPM)

a8554. C. Kraus Reggiani, "Enkyklios Paideia» e filosofia come possibili fasi dell'itinerario a Dio nell'allegoresi biblica di Filone Alessandrino', Archivio di Filosofia 53 (1985) 187-197.

The 'exemplary lack of clarity' which C. Siegfried (Philo von Alexandria als Ausleger des Alten Testaments, Jena 1875, p. 223) describes as characteristic of Philo is a result of the fact that his way of writing closely resembles the musical technique of 'variations on a theme' (p. 187). But despite the 'repetitions, digressions, and incongruencies' (p. 193) of Philo's mode of composition, there is always a guiding idea behind his work. In the broadest sense this 
idea can be summed up in the expression 'God is everything and man is nothing', but more specifically, in relation to man's moral progress, it centres on the 'triad of perfection', that is to say on the three figures of Abraham, Isaac, and Jacob and their allegorical significance, and on the 'triad of perfectibility' (Enosh, Enoch, Noah). With regard to the figure of Abraham, Congr. should be read and interpreted as a concrete illustration of man's relationship with God according to the mathesis didaskalia relationship. In analyzing the themes of the treatise, Kraus Reggiani also exemplifies the formal and general characteristics of Philo's allegorical interpretation. (RR)

a8555. J. VANDer LeEst, 'Lucian in Egypt', Greek, Roman and Byzantine Studies 26 (1985) 75-82.

The author argues that Lucian's function (as described by himself in Apolo-

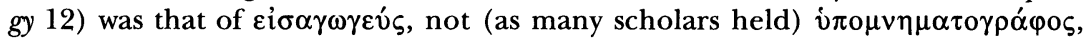
nor (another view) archistator. This was already the proposal of P. Meyer, which was strengthened by an emendation in a text of Philo by H. Box (1935). The text concerned is Flacc. 131, where Philo speaks about an Alexandrian Greek named Lampo. The emendation is adopted by Pelletier in the French edition. In a note, however, Pelletier maintains Pflaum's misconception that the function in reality was that of archistator. Vander Leest concludes from the texts of Lucian and Philo that the posts of Lampo and Lucian must have been the same, and that if Box's emendation of Philo's text is accepted,

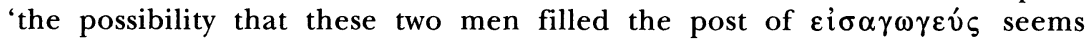
enhanced'. (HMK)

a8556. B. Mondin, 'Filone Alessandrino tra Ellenismo e Cristianesimo', Archivio di Filosofia 53 (1985) 199-208.

Sketch of Philo's views on the relation between revelational and rational knowledge (scripture and philosophy). Among the three available solutions -i.e. absolute independence of the two kinds of knowledge, total antithesis, or a harmony between them-Philo represents the third. According to Mondin, Philo's approach entails not only a Hellenization of Judaism, but also a Judaization of Hellenism in that he furnishes Greek words such as

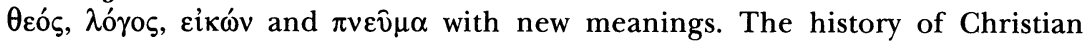
philosophy begins with Philo. (HMK)

a8557. C. Rowland, Christian Origins: an Account of the Setting and Character of the most Important Messianic Sect of Judaism (London 1985, reprinted Minneapolis 1988), esp. 81-87.

In order to test his hypothesis that it was the Jewish world which gave Christianity its essential outlines, the author first describes 'Jewish Life and Thought at the Beginning of the Christian Era', followed by a second part entitled 'The Emergence of a Messianic Sect'. Under the heading of 'Diaspora Judaism' Philo is described as our main source for Alexandrian Jewish theology. A brief sketch of his work and thought leads to a conclusion that 
Philo's own religion already had the seeds within it of some of the main features of gnostic religion. (HMK)

\section{6}

a8669. M. Aghiorgoussis, 'The Word of God in Orthodox Christianity', Greek Orthodox Theological Review 31 (1986) 79-103, esp. $85 \mathrm{ff}$.

The concept of the Logos expressed in the Prologue of the Gospel of John plays a fundamental role in the history of Christian dogma. One of its most important precedents is undoubtedly the Philonic Logos, which goes beyond the traditional Stoic conception, mainly in attributing to the Logos an intermediary function between God and the world. (RR)

a8670. B. H. Amaru, 'Land Theology in Philo and Josephus', in L. Hoffman (ed.), The Land of Israel: Jewish Perspectives, University of Notre Dame Center for the Study in Judaism and Christanity in Antiquity 6 (Notre Dame 1986) 65-93.

The author examines the manner in which Philo and Josephus, as 'the two intellectual giants of Hellenistic Judaism' (p. 65) deal with classical biblical Land theology. Four aspects are discussed: (1) the role of the Land in the Patriarchal covenant; (2) the unique properties ascribed to the Land; (3) the place of the Land in Torah legislation; (4) messianism linked to the Land in the early and later prophets. She concludes (p. 85): 'Neither Philo nor Josephus presents Land theology in a manner which can be described as true to their biblical source. Through allegory Philo turns biblical history into religious philosophy... Intellectually they share a love of certain aspects of the Hellenistic world view which taints their interpretations of Hebrew Scriptures. Both read into the text an element of universalism which does not fit well with the explicit particularism of biblical Land theology.' The article also contains interesting observations on Moses' personal relation to the Land which Philo blatantly distorts (p. 77) and on the nature of Philo's messianism in Praem. (p. 82ff.). (DTR)

a8671. J. Barton, Oracles of God: Perceptions of Ancient Prophecy in Israel after the Exile (London 1986), esp. 247-250.

In this study four modes are distinguished in which the Old Testament prophets have been read in Judaism and early Christianity. They were read as providing ethical instruction (this mode was central in most branches of Judaism), or foreknowledge of the present day (the 'eschatological' mode), or as revealing the divine plan for history, or as presenting theological and mystical knowledge. Philo represents the fourth mode in its most characteristic form. Although Philo's quotations from books outside the Pentateuch are 
comparatively few, such as do occur are treated (just as the Pentateuchal texts) as windows onto eternal philosophical or theological truth. The prophets are mystagogues and their texts, read in Philo's allegorical way, may speak of 'a Platonist heaven'. (HMK)

a8672. B. Belletti, 'Alcune precisazioni sulla teologia di Filone Alesandrino', Studia Patavina 33 (1986) 385-393.

The article focuses on the central themes of Philo's theology (God as absolute model; God and the Ideas; God-Logos) in order to deal with the following fundamental problem: is God, according to Philo, an Idea? Obviously, this hypothesis would contradict Philo's creationism, which presupposes a personalistic theology. By analyzing significant texts, Belletti shows that God should be conceived of as the Intellect of the world, while the Ideas, as God's thoughts, are images of this Intellect. (RR)

a8673. G. Bolognesi, 'Problèmes d'interprétation de la traduction arménienne du «De Providentia» de Philon le Juif', in D. Kouymjian (ed.) Armenian Studies: Etudes arméniennes in memoriam Haïg Berbérian (Lisbon 1986) 67-74.

Notes errors in J. B. Aucher's interpretation of the Armenian translation of $D e$ Providentia and some inaccurate remarks by G. Leopardi on the same translation. (RR)

a8674. F. E. BRENK, 'In the Light of the Moon: Demonology in the Early Imperial Period', in W. HaAse (ed.), Aufstieg und Niedergang der römischen Welt II 16.3 (Berlin-New York 1986) 2068-2145, esp. 2098-2107.

Philo's demonology is 'both similar in some respects and in others totally different from what we find in other Greek Middle Platonists (p. 2098)'. Brenk perceives three different interpretations of angels: (a) as $\delta \alpha i ́ \mu \nu v \varepsilon \varsigma-\psi v \chi \alpha i$ who are essentially incorporeal human souls; (b) as $\delta \alpha i \mu o v \varepsilon \varsigma-\psi v \chi \alpha i$ who are

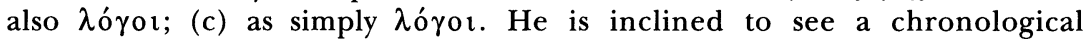
development in these views. It is noteworthy how Philo, influenced by the basically optimistic spirit of later Platonism, avoids the fallen angels of the Bible or evil demons of the Greek religious tradition. (DTR)

\footnotetext{
a8675. R. EchuARI, 'Dios y el ser', Annuario Filosófico (Universidad de Navarra) 19.1 (1986) 9-24.

Philo's interpretation of Exod. 3:14 is very important in that by identifying God's nature with his being (Mut. 21, 11, Somn. 1.230-232, Mos. 1.75) it proclaims God's eminence on the one hand and his unknowability on the other. Only God's existence, not his nature, can be demonstrated, precisely because he has no other determination apart from his being. This conception
} 
opens 'a new road which will be deeply explored by other illustrious philosophers' (p. 10), in particular by Avicenna, Maimonides, and Aquinas (p. 17). By contrast, Heidegger adopts an opposite position in that he distinguishes God's nature from his being (p. 19 ff.). (RR)

a8676. J. M. FAULDS, The Son and Satan in Paradise Lost: an Inquiry into the Poetic Theodicy of John Milton in the Western Tradition (diss. University of Dallas 1986), esp. Chap. 1.

The dissertation examines the relation between Milton's anti-Trinitarian christology and the problem of evil in Paradise Lost. Chapter 1 examines the beginning of Satan's heavenly rebellion in reaction to the birth and exaltation of the anti-Trinitarian Son. The Son's role in the angelic creation is a crucial point of argument between Satan and Abdiel. The seeming sequential contradiction of the Son's birth after the angelic creation is examined through the analogy of the stages in creation of Philo's Logos. (DTR, based on DA 47 p. 909)

a8677. G. Firpo, 'Antioco IV di Commagene e la $\mu$ oî $\rho \alpha$ dell'imperatore Gaio (Caligola), Annali della Scuola Normale Superiore di Pisa (Cl. di Lett. e Fil.) 16 (1986) 679-689.

According to Philo in Legat., Gaius was convinced that he possessed a superior moira to that of all other men. This conviction may have been influenced by Iranian conceptions, and in particular by the idea of being King of kings, with complete power over all other men. Many episodes during his reign might be explained in this way. (RR)

a8678. M. Gilbert, Art. 'Sagesse de Salomon (ou Livre de la Sagesse)', Supplément au Dictionnaire de la Bible 11, fasc. 60 (Paris 1986) 58-119, passim.

Philo is often quoted in relation to the subject, though he is never discussed separately. Three references in particular are to be noted: (1) p. $83 \mathrm{f}$. on the definition of the literary genre of Wisdom (a comparison with Prob.); (2) p. 92 on the problem of dating; (3) p. 97 showing some analogies of form and content. (RR)

a8679. P. Hofrichter, Im Anfang war der "Johannes-Prolog": Das urchristliche Logosbekenntnis - die Basis neutestamentlicher und gnostischer Theologie, Biblische Untersuchungen 17 (Regensburg 1986), esp. 337-363.

It is argued in this study that the prologue of John shows the formal characteristics of the text of a creed or symbol: a Logosbekenntnis. The literary background of this 'Logos confession' in John's prologue is the work of Philo, although the Philonic Logos has been modified and adapted. Five passages in 
Philo are identified as immediate Grundlage for the prologue's text. Hofrichter then goes on to argue that Christian and Gnostic interpretations of the prologue have again made use of Philo. Thus Jesus' baptism as narrated in the gospels-a dove as image of the Spirit descending on Jesus-is considered by Hofrichter to be a paraphrase of the 'Logos confession' and a reinterpretation on the basis of its Philonic background, since the same dove image is found in Philo; a similar argumentation is given with regard to the virgin birth. Gnostic themes such as the four divine hypostases, the valentinian Sophia myth, and the representation of all mankind by one man, are likewise considered as reinterpretations of Philonic motives. (HMK)

a8680. J. Lightstone, 'Christian Anti-Judaism in its Judaic Mirror: the Judaic context of Early Christianity Revised', in S. Wilson (ed.), Anti-Judaism in Early Christianity, vol. 2 Separation and Polemic, Studies in Christianity and Judaism 2 (Waterloo 1986) 103-132, esp. 112-115.

For the Judaic context of early Christianity it is better to look at Hellenistic than Rabbinic Judaism. The importance of Philo is that he represents a particular type of Jewish holy man in the Greco-Roman world. (DTR)

a8682. W. A. Meexs, The Moral World of the First Christians, Library of Early Christianity 6 (Philadelphia 1986), esp. 81-85.

In this study which tries 'to understand some particular dimensions of the social process by which the character of the Christian communities of the first two centuries took form' (p. 12), Philo is briefly invoked as a witness to the 'Great tradition' of Israel. It is argued that he found in the Bible a program of moral psychology. His ethic is not assimilationist, but rather sees a splendid harmony between the Greek pedagogical and philosophical tradition and the scripture of Israel. 'Israel' may be in Philo's universalizing moral allegories any virtuous soul who progresses toward the vision of God, but at the same time it is 'the most God-loved nation'. (DTR)

a8683. J. Ménard, Art, 'Philon d'Alexandrie', in G. Mathon et al. (edd.), Catholicisme, hier, aujourd'hui, demain: Encyclopédie publiée sous le patronage de l'Institut catholique de Lille, vol. 11, fasc. 49 (Paris 1986) 202-208.

A survey of Philo's thought, starting from the concept of the Logos and the themes of asceticism and mysticism. In particular the latter is dealt with extensively in a series of points which discuss from various angles the single theme of contemplation. Contemplation is related in this way to the vision of God, the imitation of God, enlightenment, the active life, and virginity. (RR) 
a8684. A. Meredith, 'Philo', in C. P. M. Jones, P. M. WainWRIGHT, E. YARNOLD (edd.), The Study of Spirituality (New YorkLondon 1986) 94-96.

Philo is given a brief space in the section on the 'philosophical roots' of Christian spirituality. (DTR)

a8685. J. Murphy-O'Connor, 'Pneumatikoi and Judaizers in 2 Cor 2:14-4:6', Australian Biblical Review 43 (1986) 42-58.

Paul is not trying to inculcate Philonic doctrine. 'It is nonetheless significant that, in a section where he is dealing with those who through Apollos were influenced by the teaching of the Alexandrian sage, we find so many elements that have parallels in Philo.' (DTR)

a8686. J. Pépin, 'Cosmic Piety', in A. H. Armstrong (ed.), Classical Mediterranean Spirituality: Egyptian, Greek, Roman, World Spirituality 15 (New York 1986) 408-435, esp. 422ff.

Philo furnishes valuable evidence on the notions of the temple as image for the cosmos, the cosmos itself as temple, and the idea that 'every day is a feast day'. (DTR)

a8687. A. Piñero-Sáenz, 'Concepciones de la inspiración en Filón de Alejandría', in D. MuÑoz León (ed.), Salvación en la Palabra: Targum-Derash-Berith: en memoria del profesor Alejandro Diez Macho (Madrid 1986) 223-233.

The article analyzes the various kinds of inspiration according to Philo. The author's purpose is to contribute to solving the problem whether Philo's doctrine of inspiration belongs to the Jewish-biblical tradition, or rather to that of Platonic Hellenism. The answer reached is: Philo maintains Greek elements, ignored by the vision of the LXX, such as those related with the

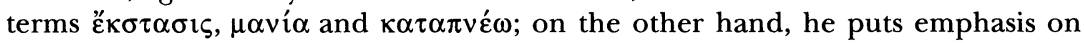
an idea characteristic of the Bible which is ignored by the Greek tradition,

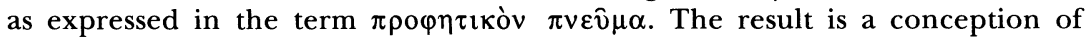
inspiration which consists of incompatible elements. (JPM)

a8688. J. I. Porter, 'Philo's Confusion of Tongues: Some Methodological Observations', Quaderni Urbinati di Cultura Classica 53 (1986) 55-74.

A lively, stimulating, if somewhat opaque, discussion of Philo's allegorical method and structural composition in the light of modern hermeneutical theory, with special reference to the treatise Conf. as an example. Two interrelated points are particularly stressed. (1) Philo's radical associative approach 
is based on the premise of the internal coherence of scripture, which is the paradigm for all meaning. This fundamental 'anaphoricity' allows Philo to liberally employ metaphorical and metonymical transfers to advance his argument (p. 58). (2) The coherence of scripture is founded on the grammaticality of the universe as a whole (via the Logos), and ultimately grounded in God himself. Such faith is entirely alien to modern Saussuran man (p. 73). (DTR)

a8689. C. J. Roetzel, 'Theodidaktoi and Handwork in Philo and 1 Thessalonians', in A. Vanhoye (ed.), L'âpotre Paul: Personnalité, style et conception du ministère, BEThL 73 (Leuven 1986) 324-331.

The author argues that Philo's usage of the terms $\alpha \dot{\tau} \tau \delta \delta 1 \delta \alpha \kappa \tau$ ó ('selftaught') and $\eta \sigma v \chi i \alpha$ ('calmness') may better explain the unusual combination

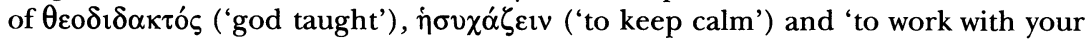
hands' in 1 Thessalonians 4:9-11 than Hellenistic philosophy does. Paul's coinage and use of the term $\theta \varepsilon \circ \delta i \delta \alpha \kappa \tau$ '́ $\varsigma$ would appear to be not a mild polemic against Epicurean views, but an attempt to make explicit what was already implicit in the term $\alpha$ v่ $\sigma_{0} \delta \delta \alpha \kappa \tau$ ó $\varsigma$ known in Hellenistic Jewish circles. (HMK)

a8690. J. SÁnchez Bosch, 'La figura de Abrahán en Pablo y en Filón de Alejandría', in D. Muñoz León (ed.), Salvación en la Palabra: Targum - Derash - Berith; en memoria del profesor Alejandro Diez Macho (Madrid 1986) 677-688.

The article compares the role of the figure of Abraham in Philo's writings and in Paul's epistles. The author points out numerous similarities in the topic of Abraham's relationship to faith and in his paternity of the nation of faith. But some important differences are also indicated: (1) Paul considers that a real novelty is possible in history, i.e. the Gospel; (2) Paul considers Abraham as Father of all those that have faith, i.e. extending beyond the Jewish nation. (JPM)

a8691. K. G. SANDElin, 'Vishetens måltid' [In Swedish: 'The Banquet of Wisdom'], in S. Hidal, K.-J. Illman, T. Kronholm, M. MÜller and O. SKarsaune (edd.), Judendom och kristendom under de första århundradena: nordiskt patristikerprojekt 1982-1985. Volym I [In Swedish: Judaism and Christianity During the First Centuries: Nordic Project on Patristics 1982-1985. Volume I] (Stavanger-Oslo-BergenTromsø 1986) 268-283, esp. 271-277.

The article starts by describing how the theme of the banquet of Wisdom is developed in Biblical and Jewish wisdom texts, esp. Prov. 8 and Sir. 14 and 24. In Philo one finds both direct descriptions of Wisdom as a figure offering her teaching to those who thirst for instruction (Prob. 13) and allegorical interpretations in which for instance the rock in the desert (Exod. 17:6 etc.) 
is understood as Wisdom giving her nourishment, i.e. her teaching (Det. 115f.). The question whether there is a connection between the Passover meal and the banquet of Wisdom is answered in the affirmative. The teaching of Wisdom is a reality at the Passover meal and the 'bread of affliction' may be seen as a symbol for that teaching (Congr. 161-174). The article ends with a discussion of the theme of the banquet of Wisdom in the New Testament. (KGS)

a8692. S. Schroer, 'Der Geist, Die Weisheit und die Taube: feministisch-kritische Exegese eines neutestamentlichen Symbols auf dem Hintergrund seiner altorientalischen und hellenistischfrühjüdischen Traditionsgeschichte', Freiburger Zeitschrift für Philosophie und Theologie 33 (1986) 197-225, esp. 208-211.

The image of the dove is used in Her. 126-128 as a symbol of Sophia. Schroer attempts to reconstruct the historical tradition of this symbol. Incorporating the findings of previous research, she concludes that the allegory can be understood as a 'reflective mythology' in which 'the personified Sophia has been presented with the mythological element of the dove associated with (ancient oriental) female divinities' (p. 211). (RR)

a8693. A. Segal, 'Judaism, Christanity, and Gnosticism', in S. Wilson (ed.), Anti-Judaism in Early Christianity, vol. 2 Separation and Polemic, Studies in Christianity and Judaism 2 (Waterloo 1986) 133-161, esp. 138-140.

Summary of material more fully presented in R-R 7741. Segal attempts 'to show that some valuable information about Gnosticism can be gained when rabbinic exegetical issues are placed in their appropriate contexts by comparison with Hellenistic writers like Philo and the Church fathers (p. 161)'. (DTR)

a8694. G. Sellin, Der Streit um die Auferstehung der Toten: eine religionsgeschichtliche und exegetische Untersuchung von 1. Korinther 15, FRLANT 138 (Göttingen 1986), esp. 90-185.

The theme of the two men in 1 Cor. 15:21f. and 45ff. can be explained by referring to Philonic precedents. On the basis of this conviction Sellin analyzes the basic texts in Philo which deal with the two prototypes of man. The perspectives taken are anthropological (p. 101ff., based on Leg. 1-3), ontological (p. 114ff.), and finally soteriological, with reference to man's fundamental dualistic structure (p. 127ff.), the themes of death (p. 137ff.), progress (p. 139ff.), inspiration and ecstasy (p. 143ff.). The author concludes that almost all of Philo's basic themes play an important role in 1 Corinthians, particularly in chapter 15. Sellin draws the following connections: (1) a Platonic ontological dualism is present, which is differently applied in the two contexts, but which carries the same meaning; (2) a new, above all spiritual, 
conception of life; (3) a group of themes and metaphors - in particular that of the two men - which establishes beyond any doubt a relationship between the two contexts. Hence Sellin's conclusion 'that the Christ-Adam typology in 1 Cor. 15:45 ultimately goes back to the Hellenistic-Judaic speculation known to us through Philo's work' (p. 174). (RR)

a8695. W. B. TAтum, 'The LXX Version of the Second Commandment (Ex. 20,3-6 = Deut. 5,7-10): a Polemic against Idols, not Images', Journal for the Study of Judaism 17 (1986) 177-195, esp. 187193.

It is argued that the formulation of the Second commandment in the LXX is not anti-iconic, but polemically anti-idolic. This is seen especially in the use of the term $\varepsilon$ $\delta \omega \lambda$ ov. Philo places the same anti-idolic emphasis in his interpretation, although in his polemic against idolatry he does show a clear anti-iconic tendency in his repeated condemnation of painting and sculpture. He probably does not use the term $\varepsilon i \delta \omega \lambda$ ov because of his apologetic agenda, which exploits Platonic ideas, so that he can point beyond the sensible to the invisible, i.e. the one God that IS. (DTR)

a8696. P. J. Tomson, 'The Names Israel and Jew in Ancient Judaism and in the New Testament', Bijdragen 47 (1986) 120-140, 266-289, esp. 136f.

The brief remarks on Philo are of interest because they are placed in a much wider framework. For Philo 'Iov $\delta \alpha \hat{\imath} o r$ is the 'outside name', while

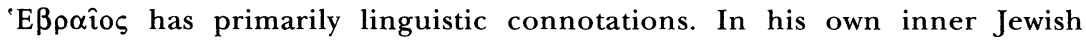

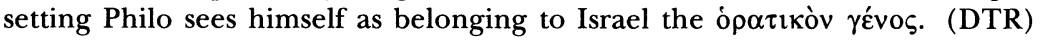

a8697. G. Veltri, 'L'ispirazione della LXX tra leggenda e teologia: dal racconto di Aristea alla veritas hebraica di Girolamo', Laurentianum 27 (1986) 3-71, esp. 18-21.

The inspired character of the translation of the LXX is most clearly formulated in Philo. The event of the translation is conceived by Philo as 'an irruption of the divine in the human' which concerns all men and not just the Jews. (RR)

a8698. H. Villadsen, 'Philon og den oldkirkelige skriftfortolkning' [In Danish: 'Philo and the Interpretation of Scripture in the Ancient Church'] in S. Hidal, K.-J. Illman, T. Kronholm, M. Müller and O. Skarsaune (edd.), Judendom och kristendom under de första århundradena: nordiskt patristikerprojekt 1982-1985. Volym II [In Swedish: Judaism and Christianity During the First Centuries: Nordic Project on Patristics 1982-1985. Volume II] (Stavanger-Oslo-BergenTromsø 1986) 93-112. 
Having given a general description of Philo on the borderline between Judaism and Hellenism, the author discusses the influence of Philo upon Christianity during the first eight centuries and especially his interpretation of the Old Testament. Several studies pertaining to the latter theme have emerged from 1875 onwards, but no general monograph after the study by C. Siegfried, Philo von Alexandria als Ausleger des Alten Testaments (Jena 1875). The concluding and main part of the article discusses how Gen. 3:21 is understood by Philo and Gnostic and Christian authors during the first five centuries. Philo presents two different interpretations: a literal or moral, and an allegorical understanding. The latter explains the garments of skin given to Adam and Eve as their physical bodies. No direct or certain influence of Philo's exegesis upon authors in the centuries following Philo's time can be detected. During the first two centuries similarities with Philo's understanding may be seen among Gnostics, whereas there exists no such equivalence among Christian authors until Origen. Certain Gnostics and apparently Origen as well come close to Philo's allegorical interpretation of Gen 3:21. (KGS)

\section{B. ADDITIONAL REVIEWS OF WORKS PUBLISHED IN 1937-1986}

In this section we list reviews of books contained in $\mathrm{R}-\mathrm{R}$ which appeared to late to be included or were overlooked. Reviews already listed in R-R are not repeated.

\section{Part One}

1820. Philon d'Alexandrie: Questions sur la Genèse II 1-7: texte grec, versions arménienne, parallèles latins, ed. J. PARAmelle avec la collaboration de E. LucCHESI; interpretation arithmologique par J. Sesiano, Cahiers d'Orientalisme 3 (Geneva 1984).

Reviews: J.-P. Mahé, REArm n.s. 19 (1985) 463-465; M.-H. Congourdeau, REByz 44 (1986) 298-299; A. Hilhorst, JSJ 17 (1986) 113-115; X. Jacques, NRTh 108 (1986) 425-426; J. A. Munitiz, HeyJ 27 (1986) 63-65; B. Coulie, Muséon 100 (1987) 430-433; J.-C. Haelewijck, Script 41 (1987) 168*; R. Joly, AC 56(1987) 345-346; J. R. Royse, SPhA 1 (1989) 134-144; M. E. Stone, JAOS 109 (1989) 119120.

2233. Les Euvres de Philon d'Alexandrie, Vol. 34A, Quaestiones et solutiones in Genesim I et II e versione armeniaca, introduction, traduction et notes par C. Mercier (Paris 1979); French title Questions et réponses de Philon sur la Genèse. 
2234. Vol. 34B, Quaestiones et Solutiones in Genesim III-IV-V-VI e versione armeniaca, introduction, traduction et notes par C. MERCIER, Complément de l'ancienne version latine, texte et apparat critique, traduction et notes par F. Petrt (Paris 1984); French title Questions et réponses de Philon sur la Genèse.

Reviews: J. Doignon, RHR 204 (1987) 300-301; J. Schamp, RBPh 65 (1987) $158-160$.

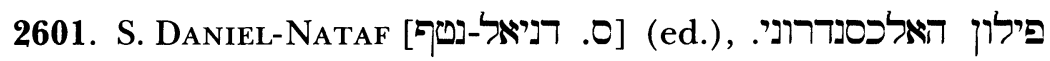
[Philo of Alexandria: Writings]: vol. 1, Historical writings, Apologetical writings (Jerusalem 1986).

Reviews: D. Satran, SPhA 2 (1990) 182-4; M. Hadas-Lebel, REJ 150 (1991) 184-186.

3101. D. Winston and J. Dillon, Two Treatises of Philo of Alexandria: a Commentary on De Gigantibus and Quod Deus Sit Immutabilis, BJS 25 (Chico 1983).

Reviews: T. H. Tobin, JBL 105 (1986) 352-354; M. Hadas-Lebel, REJ 150 (1991) 183.

3209. Biblia Patristica. Supplément: Philon d'Alexandrie, Centre d'analyse et de documentation patristiques: équipe de recherche associée au Centre National de la Recherche Scientifique: J. Allenbach, A. Benoît, D. A. Bertrand, A. Hanriot-Coustet, E. Junod, P. Maraval, A. Pautler, P. Prigent (Paris 1982).

Review: A. Hilhorst, JSJ 14 (1983) 52; W. A. Bienert, ZKG 96 (1985) 424425; P. Nautin, RHR 203 (1986) 212-213.

Part Two

6731. C. Kraus, Filone Alessandrino e un'ora tragica della storia ebraica, with preface by A. FERRABINo (Naples 1967).

Review: F. Càssola, Labeo 17 (1971) 87-90.

6916. B. Mondin, Filone e Clemente: saggio sulle origini della filosofia religiosa (Turin 1969, Vatican City 1984²).

Review: A. V. Nazzaro, Vich 6 (1969) 424-427. 
7611. G. D. Farandos, Kosmos und Logos nach Philon von Alexandria, Elementa. Schriften zur Philosophie und ihrer Problemgeschichte 4 (Amsterdam 1976) 150-306.

AdditionaL Review: R. Goulet, JHPh 17 (1979) 462-465.

7722. E. Lucchesi, L'usage de Philon dans l'oeuvre exégétique de Saint Ambroise: une 'Quellenforschung' relative aux Commentaires d'Ambroise sur la Genèse, ALGHJ 9 (Leiden 1977).

Reviews: F. Petit, BTh 12 (1978) 265; V. Roisel, NRTh 100 (1978) 290; J. C. M. van Winden, VChr 32 (1978) 302-303; Y.-M. Duval, Lat 38 (1979) 728-729; P. Maraval, RHPhR 59 (1979) 217; F. Bergamelli, Salesianum 43 (1981) 188.

7739. H. Savon, Saint Ambroise devant l'exégèse de Philon le Juif, 2 vols., Études Augustiniennes (Paris 1977).

Additional Reviews: C. Kannengiesser, RecSR 66 (1978) 280-285; F. Petit, BTh 12 (1978) 265; Y.-M. Duval, REAug 25 (1979) 196-200; G. Haendler, ThLZ 104 (1979) 667-669; C. Aziza, Lat 39 (1980) 241-242; G. M. de Durand, RSPh 64 (1980) 431-433; P. Nautin, RHR (1980) 467; L. F. Pizzolato, RSLR 16 (1980) 288291.

7929. L. A. Montes Peral, Akataleptos theos: eine Untersuchung über die Transzendenz und Immanenz im Gottesbegriff bei Philo von Alexandrien (diss. München 1979); republished as (8764) Akataleptos Theos: der unfassbare Gott, ALGHJ 16 (Leiden 1987).

Review: D. Zeller, SPhA 2 (1990) 201-204.

7939. S. SANDmel, Philo of Alexandria: an Introduction (New YorkOxford 1979).

Review: E. Hilgert, JR 65 (1985) 276-278.

8235. A. Mendelson, Secular Education in Philo of Alexandria, Monographs of the Hebrew Union College 7 (Cincinnati 1982).

Reviews: H. W. Attridge, RelStR 10 (1984) 405; A. Hilhorst, JSJ 16 (1985) 277-279.

8301. Y. Amir, Die hellenistische Gestalt des Judentums bei Philon von Alexandrien, Forschungen zum jüdisch-christlichen Dialog 5 (Neukirchen 1983).

Review: D T. Runia, SPhA 1 (1989) 144-148. 
8319. J. Cazeaux, Philon d'Alexandrie: de la grammaire à la mystique, Supplément au Cahier Évangile 44 (Paris 1983); Spanish translation by A. Ortiz Garci:A (Estella 1984).

Review (of the Sp. transl.): F. de Sola, EsEc 61 (1986) 100.

8320. J. CAZEAUX, La trame et la chaîne: structures littéraires et exégèse dans cinq traités de Philon d'Alexandrie, ALGHJ 15 (Leiden 1983).

Review: B. Coulie, $E t C l 57$ (1989) 177-178.

8321. J. Cazeaux, L'épée du Logos et le soleil de midi, Collection de la Maison de l'Orient Méditerranéen 13, Série Littéraire et Philosophique 2 (Lyon 1983).

Review: S. E. Robinson, RelStR 12 (1986) 80.

8373. T. Н. ТовIN, The creation of man: Philo and the history of Interpretation, CBQ.MS 14 (Washington 1983).

Reviews: G. Rinaldi, BibbiaOr 26 (1984) 64; G. Delling, ThLZ 110 (1985) 183-184; D. M. Hay, JQR 79 (1988) 73-75.

8408. R. M. Berchmann, From Philo to Origen: Middle Platonism in Transition, BJS 69 (Chico California1984) esp. 23-53.

Reviews: E. V. Gallagher, JAAR 54 (1986) 764; J. P. Kenney, JR 66 (1986) 480; T. H. Tobin, SCent 6 (19,88) 253-254.

8423. F. E. Greenspahn, E. Hilgert, B. L. Mack (edd.), Nourished with peace: studies in Hellenistic Judaism in memory of Samuel Sandmel, Scholars Press Homage Series 9 (Chico, California 1984).

Review: A. Hilhorst, JSJ 17 (1986) 104-106.

8424. W. HaAse (ed.), Hellenistisches Judentum in römischer zeit: Philon und Josephus, Aufstieg und Niedergang der römischen Welt, II Principat vol. 21 (Berlin-New York 1984).

Reviews: T. H., ThLZ 109 (1984) 807; H. W. Attridge, RelSt 11 (1985) 307; H.-W. Neudorfer, ZKG 96 (1985) 222-224; M. Petit, REJ 147 (1988) 189-195.

8540. H. Tarrant, Scepticism or Platonism?: the Philosophy of the Fourth Academy, Cambridge Classical Studies (Cambridge 1985). 
Review: J. Barnes, CR 36 (1986) 75-77.

8548. D. Winston, Logos and Mystical Theology in Philo of Alexandria (Cincinatti 1985).

Reviews: A. H. Armstrong, JThS 38 (1987) 293; J. Dillon, Herma 142 (1987) 67-69; W. Adler, JSP 5 (1989) 118.

8620. M. HARL, La Bible d'Alexandrie. La Genèse: traduction du texte grec de la Septante, introduction et notes (Paris 1986) passim.

Review: A. Hilhorst, JSJ 18 (1987) 235-237.

8636. J. P. Martín, Filón de Alejandría y la génesis de la cultura occidental (Buenos Aires 1986).

Reviews: A. Reix, RPhilos 157 (1987) 240-241; J.A. Soggin, ZAW 99 (1987) 293; R. Trevijano, Salm 34 (1987) 403-405; A. M. Artola, EstE 63 (1988) 508-509; A García y García, ZKG 99 (1988) 407; W. Wiefel, ThLZ 113 (1988) 24-25; J. M. B??, RevBib 51 (1989) 57-59; G. J. Brooke, JSS 34 (1989) 398; A. Hilhorst, JSJ 20 (1989) 100; A. Orbe, Gr 70 (1989) 592-593.

8638. A. MÉAsson, Du char ailé de Zeus à l'Arche d'Alliance: images et mythes platoniciens chez Philon d'Alexandrie (Paris 1986).

Reviews: D. T. Runia, VChr 42 (1988) 290-295; R. Ferwerda, Mnem 42 (1989) 203-204; D. T. Runia, SPhA 1 (1989) 153-155.

8656. D. T. Runia, Philo of Alexandria and the Timaeus of Plato, PhilAnt 44 (Leiden 1986).

Reviews: N. E. Emerton, VT 37 (1987) 498-500; J. Moulder, SAfrJPh 6 (1987) 68-69; J. M. Dillon, JHPh 26 (1988) 658-660; A. Hilhorst, JSJ 19 (1988) 258-259; R. Joly, AC 57 (1988) 364-365; E. N. Lee, CPhRev 8 (1988) 417-422; A. Paul, RSR 76 (1988) 73-74; T. H. Tobin, CrRBR 1 (1989) 378-381; J. den Boeft, $V C h r 44$ (1990) 83-85; D. M. Hay, Mnem 43 (1990) 490-493; B. Rosenstock, SPhA 2 (1990) 195-201; J. P. Martín, Meth 5 (1992) 135-143 = 9257; D. Winston, AncPhil 12 (1992) 222-7.

8660. K.-G. SANDElin, Wisdom as nourisher: a Study of an Old Testament Theme, its Development within Early Judaism and its Impact on Early Christianity, AAAbo.H 64.3 (Abo 1986).

Review: P. Borgen, SPhA 2 (1990) 220-223. 


\section{CORRIGENDA \& ADDENDA \\ 1937-1986}

The following list of corrections for R-R builds on the list already included in the Preface to the 2nd Edition (with thanks to the reviews by A. Hilhorst and E. Hilgert \& J. R. Royse, for details of which see above 1201, and also to personal communications of M. Hadas-Lebel and N. G. Cohen).

p. ix, line 11: 'University of Berkeley (California)' should be 'University of California, Berkeley'.

p. ix, 14 lines from bottom: 'Metafysica' should be 'Metafisica'.

p. xiv, 2 lines from bottom: add 'is' after 'this'.

p. xxxi and 421: Change ist in Quod Deus ist immutabilis to sit. p. xxxix, line 12: add 'years' after 'fifty'.

1802, 1. 4: 'of' should be 'to'; the title of the Grenfell and Hunt collection is The Oxyrhynchus Papyri.

1803: '5ff' should be '5f.'

1807: Also included are fragments drawn from Staehle and Lewy (see at 1800).

2112: Aucher's 1826 edition also includes (on pp. 629-30) a subject index to the Quaestiones. Naturally, Marcus's index is much fuller, and much more easily available.

2652: All publications by J.-G. Kahn are entered under that name although his Hebrew works are published under the name

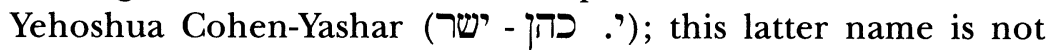
listed in the Index of Authors and no cross reference between these names is given; cf. 6729, 7110 , etc.

2653: Instead of the Hebrew name of N. G. Cohen the name of J. G. Kahn has been repeated from the previous entry; the correct name is found at 8513 .

4601: The initial word of the title in Hebrew (לשאלת) has been omitted.

5201: The cross-references at the end of the summary should be $5303,5502$.

5502: The cross-references in the summary should be 5303,5502 . 
5602: 'archtype' should be 'archetype', 'Palestininian' should be 'Palestinian' and 'that' should be 'than'.

5604: '663ff' should be '563ff'.

7122: It is important to know that the study of Revel is a reprint of a 1913 dissertation!

7306: After Papisci should be a comma, not a colon.

7554: The date of J. C. M. VAN Winden ... in W. DeN Boer et al. (edd.), Romanitas et Christianitas: studia J.H. Waszink ... oblata: should be 1973 and not 1975 . Because of the correction of the publication date, this item should actually be renumbered $(=7347 a)$.

8110: 'Horsely' should be 'Horsley' and ' $8: 1-16$ ' should be ' $8.1-6$ '.

8118: 'Horsely' should be 'Horsley'.

8130: the surname should be STroumsa.

8306: 'Subsequently published in Hebrew; cf. 8604' should be 'Previously published in Hebrew; cf. 7003'.

8515: delete quotation mark at end of title of book.

8548: 'Cincinatti' should be 'Cincinnati'.

8624: 'South Western' should be 'Southwestern'.

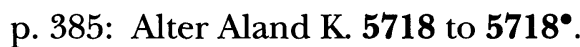

p. 386: Alter Belkin S. 7404 to 7402.

p. 387: Alter Bruns J. E. 7305 to 7306.

p. 389 and 399: There has been a sorry confusion between the two scholars M. Hadas and M. Hadas-Lebel: 2111, 5813, 6528 should be ascribed to the former, who has inadvertently been entirely omitted from both indices.

p. 415: Under Clement of Alexandria, parable, alter $\mathbf{4 7 0 4}$ to 4705.

p. 420: Under De vita contemplativa, French, alter 2224 to 2253.

p. 432: Under Gregory of Nyssa, and Paradise, alter 7304 to 7305.

p. 449: Under Paul, Areopagus speech, alter 7625 to 7626.

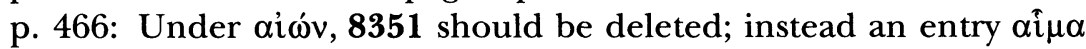
should be inserted, with the number $\mathbf{8 3 5 1}$. 
Douwe (David) Runia - 978-90-04-31323-1 Downloaded from Brill.com๑4/26/2023 05:35:25AM via free access 


\title{
INDICES
}

\author{
1. Index of authors \\ 2. Index of reviewers \\ 3. Index of biblical passages \\ 4. Index of Philonic passages \\ 5. Index of subjects \\ 6. Index of Greek terms \\ 7. Index of contributors
}

Before using the indices, the reader is advised to consult section 3 (e) of the Introduction.

\section{INDEX OF AUTHORS}

A bullet sign indicates that the scholar concerned was not the author of the item of scholarship on Philo which has been listed and summarized, but editor or co-editor of the book in which that item was published.

Ade, A. 9601

Aeby, G. a5824

Aghiorgoussis, M. a8669

Albeck, C. a6536

Alexandre jr., Manuel 8801, 9001, 9002, 9101, 9102, 9301

Alexandre, Monique 8802

Algra, K. A. $9648^{\bullet}$

Allen, P. 8701

Allison, M. E. 9302

Altenburger, M. 1301

Alter, R. $8717^{\circ}$

Amaru, B. H. a8670

Amir, Y. 8702, 8703, 8803, 8829, 9003, 9303, 9501

Amphoux, C.-B. 9624

Andia, Y. de 9304, 9602

Annas, J. a8549

Arazy, A. a7747

Arieti, J. 9201

Armstrong, A. H. a8686
Armstrong, K. 9305

Aspegren, K. 9004

Assaf, D. $9008^{\bullet}$

Attridge, H. W. 8901, 9037

Aubineau, M. a6639

Aucher, J. B. 2236

Aune, D. C. 9401

Autenrieth, J. $8839^{\circ}$

Avemarie, F. $9679^{\circ}$

Azkoul, M. 9502

Baarda, T. $8846^{\bullet}$

Badenas, R. a8550

Baer, Y. a5924, a6228a, a7557a, a8004, a8550a

Bailey, J. N. 9103, 9306

Baker, W. R. 9503

Balch, D. L. a8135

Baldassarri, M. 9307

Balderman, I. 8702

Baltes, M. 9015, 9603, 9628 
Barclay, J. M. G. 9203, 9604

Barker, M. 9104, 9202

Barnes, J. a8549

Barr, D. L. $9616^{\circ}$

Barrett, A. A. 8902

Bartelink, G. J. M. 8704, 9411

Barton, J. a8671

Basevi, C. a8045

Bastiaensen, A. A. R. $8928^{\circ}$

Baudry, G. H. 9308, 9402, 9606, 9605

Bayer, H. 8903, 9204

Bazeley, J. A. 8705

Beatrice, P. F. a8550b

Becker, J. 8706

Beckwith, R. T. 8804

Begg, C. 8707

Beierwaltes, W. 8724a

Beikircher, H. 8805

Beinart, H. a8004 ${ }^{\bullet}, \mathrm{a}^{8550 \mathrm{a}^{\bullet}}$

Bekken, P. J. 8806, 9504

Belkin, S. 8904, a6122

Bell, R. H. 9607

Belletti, B. 8708, 8709, 9005, a8672

Belleville, L. L. 9105

Ben Zwi, E. 8807

Berchmann, R. M. 8710, 8808, 8905, 9505, 9506

Berg, R. M. van den 1208, 1209

Bergmeier, R. 9309

Berk, L. 9310

Betz, O. 8809

Bhattacharyya, S. 9507

Bianchi, U. a8550b

Bickerman, E. J. 8810

Bilde, P. 9212 ${ }^{\circ}, 9533^{\circ}$

Birnbaum, E. 9205, 9311, 9508, 9608

Bitter, R. A. 1201, 1205, 9206

Black, C. A. $9612^{\circ}$

Blackburn, B. L. 9106

Blanchetierre, F. 8906

Blanquart, F. $8718^{\circ}$

Blomquist, J. $9512^{\circ}$

Blönnigen, C. 9207

Boccaccini, G. 1407, 9107, 9509, 8711

Bockmuehl, M. N. A. 9510, 8907

Boeft, J. den $8704^{\bullet}$

Bollack, J. 9639

Bolognesi, G. 8712, a8673

Bonato, A. 8713, 8908
Boorstin, D. J. 9208

Booth, A. P. 9403

Borgen, P. 8714, 9108, 9209, 9210, 9211, 9212, 9312, 9404, 9405, $9504^{\bullet}, 9511,9512,9513,9609$, $9610,9611,9612,9613,9614,9615$, 9616, 9617

Bos, A. P. 9109, 9618, 9628

Bosman, P. R. 9619

Bostock, G. 8715

Bowman, S. B. 9110

Boyarin, D. 9213, 9214

Bradshaw, D. H. 9620

Brague, R. a8254

Brashear, W. 1825

Bregman, J. 9261 ${ }^{\bullet}$

Brenk, F. E. 9215, a8674

Brewer, D. I. 9216

Brixhe, C. $9193^{\circ}$

Broadie, A. a8136

Brock, S. P. 9217

Broek, R. van den $8846^{\circ}, 9621$

Brooke, G. 9217 ${ }^{\bullet}$

Brottier, L. 8909

Bruce, F. F. 8716

Bruns, G. L. 8717, 9218

Brunschwig, J. 9251 ${ }^{\bullet}$

Bülow-Jacobsen, A. $1825^{\circ}$

Burkhardt, H. 8811, 9111

Butterweck, A. a8137

Bychkov, V. V. a7558

Cairus, A. E. 8910

Calabi, F. 9515

Callan, T. a8551

Callaway, P. R. 8812

Calleja, J. 8813

Calvert, N. L. 9313, 9406

Cancik, H. $9611^{\bullet}, 9635^{\bullet}$

Carabine, D. 9516

Carlier, C. 9112, 9622

Carmichael, C. M. 9517, 9623, a5316 ${ }^{\bullet}, \mathrm{a}^{2} 243^{\circ}, \mathrm{a} 8047^{\bullet}$

Carny, P. 8814

Carras, G. 9006, 9314

Carroll, R. $9203^{\bullet}$

Carson, D. A. $8818^{\circ}$

Cartlidge, D. R. a3014 ${ }^{\bullet}$

Casadio, G. 9315

Castelli, E. $9644^{\circ}$ 
Catan, J. R. $9056^{\bullet}$

Cathey, D. 1204

Cazeaux, J. 8718, 8719, 8815, 8816, $8911,8912,9153,9518,9624$

Ceauescu, G. 8720

Ceresa-Gastaldo, A. 8817

Charlesworth, J. H. 9211 ${ }^{\bullet}, 9312^{\bullet}$

Cheon, S. 9407

Chester, A. 9113

Chevallier, M.-A. 8721

Chiesa, B. a8463

Chilton, B. D. 8818

Christie, Y. $8944^{\bullet}$

Chroust, A.-H. a7559, a7748

Ciccarelli, M. 9316

Clark Kroeger, R. \& C. 9219

Clifford, R. J. 9285

Coggins, R. J. $9072^{\circ}$

Cohen, D. a7040, a7749

Cohen, J. 8913, 9317

Cohen, N. G. 1201, 1205, 8722, 9007, 9008, 9220, 9318, 9319, 9408, 9519, 9520, 9625

Cohen, S. J. D. 9367 ${ }^{\bullet}$

Cohen-Yashar, Y. see corrigenda

Collins, J. J. 9037, 9285

Colpe, C. 9009

Conick, A. D. de 9114

Conley, T. M. 8723

Copan, P. 9626

Corbett, J. H. 9409

Corrington, G. Paterson 2155

Couliano, I. P. 9221

Courcelle, P. a7439

Cracco Ruggini, L. a8046

Crepaldi, M. G. 8724, 8914

Criscuolo, L. $8956^{\bullet}$

Crossan, J. D. 9115

Cukrowski, K. L. 9410

Culpepper, R. A. $9612^{\circ}$

D'Arms, J. H. a8046

Daley, B. E. 9627

Daly, R. J. $9273^{\circ}$, a7750

Daniel-Nataf, S. $2602^{\circ}$

Daniélou, J. a4408, a6022, a6123

Darrach, L. A. 8915

Dassmann, E. $8818 \mathrm{a}, 8818 \mathrm{a}^{\circ}, 9116^{\circ}$, $9411^{\circ}, 9628^{\circ}$

Daube, D. 9412, a5316, a7243, a8047
Daubercies, P. M. 8725, 9521

Daumas, F. a6640

Dautzenberg, G. 8819

Davies, J. 9517

Davies, S. L. a8464

Davies, W.D. a7440

Dawson, D. 8820, 9222

De Rynck, P. 1303

Decharneux, B. 8916, 9010, 9011 , 9117, 9118, 9413, 9414, 9522

Dehandschutter, B. A. G. M. 8917

Deiana, G. 8726

Del Verme, M. 8727

Delling, G. 8728, 8729

Delorme, J. 8911 ${ }^{\bullet}$

Derousseaux, L. $8718^{\circ}$

Desjardins, M. 9629

Desprez, V. 9012

Deutsch, C. 8730

Deutsch, F. 9523

Dewey, A. J. 9013, 9415

Dexinger, F. 9223

Diego Sanchez, M. 9224

Dierkens, A. $9117^{\bullet}$

Dihle, A. 8724a, 9630

Dillon, J. M. $8847^{\circ}, 8918,8919$, 9014, 9320, 9416, 9524, 9631, 9632

Dimant, D. $9265^{\circ}$

Dionisio, F. 8821

Dogniez, C. 1304, 9225

Dohmen, C. 9633

Donaldson, T. L. 9016

Dorival, G. $9417,9564^{\circ}$

Dörrie, H. 8731, 9015

Dowd, S. E. a8380

Downing, F. G. 9017, a3015

Dragona-Monachou, M. a7649

Driscoll, J. 9439॰

Droge, A. J. 8920

Dujovne, L. a4208

Dumoulin, P. 9418

Dungan, D. L. a3014

Dunn, J. D. G. 8822, a8048

Dupuy, E. $8815^{\circ}$

Duval, Y.-M. a7442

Dvornik, F. a6641

Echuari, R. a8675

Eilberg-Schwarz, H. 9018

Eisenberger, H. $9039^{\circ}$ 
Elder, L. B. $9616^{\bullet}$

Ellens, J. H. 8732

Ellingworth, P. 9321

Ellis, E. E. 9322

Eloy Ponferrada, G 8733

Elsas, C. 9019

Engberg-Pedersen, T. $9212^{\bullet}, 9405^{\circ}$, $9533^{\circ}$

Ettinger, S. a8004 ${ }^{\bullet}$ a8550a ${ }^{\bullet}$

Evans, C. A. $9226,9312^{\circ}, 9323$

Evans, K. G. 9525

Evans, N. A. 9419

Fander, M. 8921

Farias, D. 9324

Faulds, J. M. a8676

Fauth, W. 9635

Fearghail, F. ó 9526

Feld, H. 8734, a8552

Feldman, L. H. 3019, 8736, 8737, $8796^{\circ}, 8823,8824,9119,9227$, 9325, 9326, 9634

Feldmeier, R. 9228, 9463•

Fendler, F. 9120

Ferguson, E. a7857

Ferguson, G. 8738

Ferguson, J. 9020

Fernandez Lago, J. 9328

Fernandez Sangrador, J. J. 9420

Fernandez-Galiano, D. 9327

Finan, T. $9526^{\circ}$

Finn, S. M. 8735

Firpo, G. 8825, a8677

Fischer, A. a5316 ${ }^{\bullet}$

Fishbane, M. A. a7561 ${ }^{\bullet}$

Fleischer, E. 9021

Flohr, P. R. a7561

Foa, A. $9691^{\bullet}$

Ford, J. M. a7244

Fornberg, T. $9511^{\bullet}$

Fortenbaugh, W. W. 2157

Fossum, J. 8739, 9114

Foster, R. A. 8922

Fowl, S. 9527

Fraade, S. D. 8826, 9121, 9329

Frank, D. H. 9693

Frankel, Y. 9122

Freedman, D. $9229^{\circ}, 9595^{\bullet}$

Frerichs, E. S. $8750^{\circ}$

Frohnhofen, H. 8740
Gaca, K. L. 9636, 9637

Gafni, I. $9337^{\circ}, 9647^{\bullet}$

Gagnon, R. A. J. 9330

Gallo, I. $9057^{\circ}$

Gammie, J. G. 9074

García Bazan, F. 9331

García Cordero, M. 9332

Gargano, G. I. 9528

Garnsey, P. 9421, 9638

Geerlings, W. 9548

Geljon, A. C. 1210, 3216, 9333

Gemünden, P. von 9529

Geoltrain, P. a7349

Georgi, D. 8827

Geraci, G. $8956^{\circ}$

Gersh, S. $9215^{\circ}$

Gianoulis, G. C. 8741

Gilabert i Barberà, P. 9022

Gilat, Y. D. 9230, 9334

Gilbert, G. 9123, 9231

Gilbert, M. a8678

Girardet, K. M. 9530

Giversen, S. 9504 ${ }^{\bullet}$

Glucker, J. 9023, 9232, 9335, 9421a, $9639^{\circ}$

Gobry, I. 9124

Gögler, R. a6327

Gombocz, W. L. 8742

González, J. a6537

Gonzalez Fernandez, M. 9422, 9531

Goodenough, E. R. 8828

Goodman, H. 9464 ${ }^{\bullet}$

Goodman, L. E. $9246^{\circ}$

Goodman, M. D. 3017, 9233

Goranson, S. 9423

Görg, M. 8809

Goudriaan, K. 9234

Goukowsky, P. 9193

Goulder, M. 9532

Goulet, R. 8743

Grabbe, L. 8829, 9235

Grabbe, L. L. 9125

Grabe, P. J. 9024

Græsholt, G. 9236, 9336, 9533

Graffigna, P. 2452, 3105, 9126, 9237, 9424,9640

Granata, G. 9534

Grant, R. M. 8830 , a8049

Green, A. $8826^{\circ}, 9238$

Green, J. B. $9404^{\bullet}$ 
Green, W. S. $8750^{\circ}$

Greene, J. T. 8923, 9025, 9239

Griffiths, J. G. 8744

Griggs, C. W. 9026

Grigorian, G. a6023

Grondin, J. 9127

Gruenwald, I. 9337

Guerra, A. J. 9027, 9535

Guevara, H. a8553

Guignard, V. 9338

Guillaume, P.-M. 8745, a7245

Guinot, J.-N. 8924

Gutas, D. 2157

Haase, W. $8716^{\bullet}, 9020^{\circ}, 9253^{\circ}$, $\mathrm{a} 8467^{\circ}, \mathrm{a} 8674^{\bullet}$

Hadas-Lebel, M. 8747, 9028

Hager, F.-P. 8745a

Hahn, F. 9339

Hallman, J. M. 9128

Hamerton-Kelly, R. G. 9129

Hamman, A. G. 8746

Hammerstaedt, J. 1824, 9411

Hanegraaf, J. 8925

Hannestad, L. 9212, 9533

Hanson, A. T. 8831

Harl, M. 8832, 9225, 9340

Harlé, P. 8833

Harris, M. a6229

Harrison, N. V. 9425

Harrison, V. E. F. 9536

Harrisville III, R. A. 9029

Hartmann, L. 8782

Harvey, G. A. P. 9642

Hauschild, W.-D. a7245a

Hata, G. $8796^{\circ}$

Hay, D. M. 8748, 8749, 8926, 9101 ${ }^{\circ}$, $9130^{\circ}, 9131,9132,9241,9426$

Hayward, C. T. R. 9537

Hayward, R. 8927

Hecht, R. D. 8750

Heckel, T. K. 9341

Heckel, U. $9113^{\circ}, 9463^{\circ}$

Heil, C. 9427

Heil, M. 9538

Heininger, B. 9643

Helleman, W. E. 9030, 9428

Hellholm, D. 9511

Hemelrijk, E. A. a8467

Hengel, M. $9113^{\circ}, 9189^{\circ}$
Henten, J. W. van $8917^{\bullet}$

Hertog, G. C. den 9539

Heuchan, V. 9673

Hidal, S. a8691 ${ }^{\bullet}$

Hiebert, R. J. V. 9429

Hilgert, E. 1401, 1406, 1409, 9133, 9644

Hilhorst, A. 8928, 9242

Hill, D. a7949

Himmelfarb, M. 9342

Hoek, A. van den 8751, 8834, 8929, 9031, 9430

Hoffman, L. a8670

Hofrichter, P. 9243, a8679

Hogan, L. P. 9244

Hoheisel, K. 9411

Holladay, C. R. 9540

Hollander, H. W. 9343

Holleman, J. W. 9343

Holte, R. a5825

Holum, K. G. $9675^{\bullet}$

Hoogewoud, F. J. 9372

Hopper, V. F. a3818

Horbury, W. $9104^{\circ}, 9431$

Hornung, E. $9315^{\circ}$

Horowitz, M. J. 8835

Horst, P. W. van der 9032, 9071, 9245, 9344, 9345, 9432, 9648

Hossfeld, F.-L. $9339^{\circ}, 9411$

Houlden, J. L. $9072^{\bullet}$

Huby, P. M. 2157, $8965^{\circ}$

Hülser, K. 8836

Hurley, D. W. 9134

Hurst, L. D. 9033

Hurtado, L. W. 8837

Hurvitz, A. $9595^{\bullet}$

Hyldahl, N. 9541

Idel, M. 8838

Illman, K.J. a8691

Isser, S. 9034

Jacobson, H. 9645

Jaitner-Hahner, U. 8839, 9346

Janowitz, N. 9135

Jaspert, B. $8858^{\circ}$

Jastram, D. N. 8930, 9136, 9433

Jay, P. 9628

Jervis, L. A. 9542

Joachimowicz, L. a2701 
Jones, C. P. M. a8684

Jong, Ab de $9344^{\bullet}$

Jong, Aleid de $9344^{\circ}$

Jónsson, G. A. $9687^{\bullet}$

Jorissen, H. $9339^{\bullet}$

Kahn, J.-G. 9035, 9434, 9646, a6537 (and see corrigenda)

Kalinkowski, S. 2751

Kamesar, A. 9347, 9435, 9543, 9544

Kampen, J. 9435

Kannengiesser, C. $8843^{\circ}, 9215^{\circ}$

Kasher, A. 8752

Katz, S. 9246

Katzoff, R. $9625^{\circ}, 9647$

Kaufmann, P. a6761

Kazdhan, A. P. $9110^{\circ}$

Keeney, D. E. 8753

Kenney, J. P. 9545

Kenny, A. a7854

Kerkhoff, M. 9036

Kermode, F. $8717^{\circ}$

Kidd, I. G. 9648

Kieffer, R. $9004^{\bullet}$

Kilaniotis, A. L. 3104

King, K. L. 9546

Kingsley, P. 9348, 9547

Kinneavy, J. L. 8754

Kippenberg, H. G. $9019^{\bullet}$

Klauck, H.-J. 8931, $9247^{\circ}$

Klausner, J. a5526

Klein, R. 8724a

Klopferstein, M. $8703^{\circ}$

Kloppenborg, J. S. $9672^{\bullet}$

Kneepkens, C. H. $8928^{\circ}$

Knight, T. E. 9349

Koch, D.-A. $9303^{\circ}$

Koester, C. R. 8932

Koester, H. a8253

Kollmann, B. 9649

Kominiak, B. a4817

König, H. 9548

Kopff, E. C. a8046 ${ }^{\bullet}$

Kouymjian, D. a8673

Kovelman, A. B. a7856, a8138

Kraemer, R. S. 8840, 8933, 9248, 9437

Kraft, R. A. 9037, 9137

Kraftchick, S. $9557^{\circ}$

Kraus, M. A. 9438
Kraus Reggiani, C. 2405, 2407, $3102,9038,9350,9439$, a8554

Kreitzer, L. 9351

Kreuzer, S. $9223^{\circ}$

Krieger, K.-S. 9549

Kronholm, T. a8691 ${ }^{\bullet}$

Kügler, J. 9650

Kuhn, P. 8934

Kushelevsky, R. 9550

Kuyt, A. $9032^{\circ}$

Kweta, G. 8841, 9651

Ladner, G. B. a5826

Laks, A. $9631^{\bullet}$

Lamirande, E. 8935

Lange, N. R. M. de a7650

Laplace, J. a4408

Laporte, J. 8842, 8843, 8936, 9138, 9551

Lattke, M. 9139

Lazzati, G. a7651 ${ }^{\bullet}$

Leaman, O. 9552, $9693^{\circ}$

Lease, G. 8755

Le Boulluec, A. 8937

Lee, G. M. a7350

Leest, J. vander a8555

Legarth, P. V. 9249

Leifer, J. 9440

Leloup, J.-Y. 2254, 2453, 2851

Lemche, N. P. $9472^{\bullet}$

Levarie, S. 9140

Levi, G. $9003^{\bullet}$

Levine, A.J. $9190^{\circ}$

Levine, D. B. 9352

Levison, J. R. 8844, 9441, 9553, 9554, 9555

Lévy, B. 8845

Lévy, C. 9250, 9251

Lewy, H. 2156

Lichtenberger, H. $9303^{\circ}, 9611^{\bullet}$, $9635^{\circ}$

Lies, L. $8715^{\circ}$

Lieu, J. $9233^{\circ}$

Lightstone, J. N. a8465, a8680

Lilla, S. R. C. $8756,9039,9040$

Limet, H. $8916^{\circ}$

Lindars, B. $9217^{\circ}$

Lindsay, D. 9353

Link-Salinger, R. $8919^{\circ}, 9230^{\circ}$

Livingstone, E. A. $8929^{\circ}$ 
Lloyd, G. a8466

Loader, J. A. 9041

Lockwood, W. a8463

Löfstedt, B. 9141

Löhr, H. 9354

Löhrer, M. $9576^{\circ}$

Lona, H. E. 9355

Long, A. A. $3016,8757,8847^{\circ}$

Longo, O. $9515^{\circ}$

Lorenzi, L. de $8943^{\circ}$

Lounibos, J. a8464 ${ }^{\circ}$

Lovering jr., E. H. $9103^{\circ}, 9241^{\bullet}$, $9311^{\bullet}, 9^{\circ} 06^{\bullet}, 9508^{\bullet}$

Lubac, H. de a5022, a6124

Ludwig, M. 9442

Lührmann, D. 9142, a6538

Lull, D. J. $8808^{\circ}, 8905^{\circ}, 9006^{\circ}$, $9013^{\circ}, 9025^{\bullet}, 9027^{\circ}, 9068^{\circ}$

Lüthi, K. $9223^{\circ}$

Mach, M. 1201, 1205

Macleod, C. W. a7041

McGing, B. C. 9151

McGinn, B. 9152

McIver, R. K. 8850

Mack, B. L. 9143,9556

McKay, H. A. 9252

McKnight, S. 8941, 9144

McLean, B. $9369^{\circ}$

McLeman, J. a6642

MacLennan, R. S. $9268^{\circ}$

McNeil, W. B. 9360

McVey, K. E. 9557

Maeso, D. G. a6024

Mahé, J.-P. 8846

Maier, J. 9042, 9652

Malbon, E. S. $9616^{\bullet}$

Malherbe, A. J. a7857

Mann, F. 1301

Mann, W. E. 8758

Manns, F. 9043

Mansfeld, J. $8846^{\circ}, 8847,8938$, 9044, 9254, 9653

Marchadour, A. $9663^{\circ}$

Margain, J. 9624 ${ }^{\circ}$

Margolin, R. $9646^{\circ}$

Markschies, C. 9255

Marmorstein, A. a3719

Martens, J. A. 9145
Martens, J. W. 9146, 9147, 9256, 9443

Martin, L. H. 8760

Martín, J. P. 1209, 1210, 1402, 8759, 8939, 8940, 9045, 9046, 9047, 9149, 9150, 9257, 9258, 9259, 9356, 9357, 9444, 9445, 9446, 9654, a7950

Martin Morales, E. 9148

Marx, J. 9011

Masi, G. 9558

Mathon, G. a8683

Mattei, J. F. $9036^{\circ}$

Mattila, S. L. 9655

Mayer, G. 9358

Mazzanti, A. M. $8761,8848,8849$, 9048, 9359

Mazzarelli, CR. 2407

Mazzetti, E. 9656

Méasson, A. 9153

Meeks, W. A. 9361, a8682

Meijer, P. A. 9260

Mélèze Modrzejewski, J. 9154, 9559

Ménard, J. 8762, a8683

Mendelson, A. 8851, 9155, 9447

Menken, M. J. J. 8852

Mercier, C. a7951

Meredith, A. a8684

Merino Rodriguez, M. 9448, 9657

Merklein, H. $8959^{\circ}, 9350^{\circ}$

Merlan, Ph. a6328

Messadié, G. 9657a

Meyer, B. F. 8851

Michel, A. 8763,8853 , a7858

Mills, M. 9049

Moehring, H. 9560

Mondin, B. a8556

Montes-Peral, L. A. 8764

Montgomery Hitchcock, F. R. a3718

Montserrat i Torrents dels Prats, J. 8765

Mor, M. $9227^{\bullet}$

Morland, K. A. 9156, 9449

Morris, J. 8766

Mortley, R. 9261

Morton, A. Q. a6642

Mott, S. C. a7132

Motte, A. $9010^{\circ}$

Motzo, R. B. a7751 
Mulder, M. J. $8803^{\bullet}$

Müller, K. $9350^{\circ}$

Müller, M. $9382^{\circ}, 9450,9472^{\circ}$, a8691 ${ }^{\bullet}$

Munk, R. $9372^{\bullet}$

Munnich, O. $9564^{\bullet}$

Muñoz León, D. a8687

Murdoch jr., J. M. 8942

Murphy-O’Connor, J. 8854, 8943, a8685

Nardi, E. a7133

Nash, R. 9262, 9362

Nautin, P. a7351

Navia, L. E. 1302

Neal, G. $8965^{\circ}$

Neary, M. 8855

Neeb, J. H. C. 9157

Nelson, A. B. 9561

Neudecker, R. 9451

Neudorfer, H. W. 9050

Neusner, J. $8750^{\circ}, 8828^{\circ}$

Neuwirth, A. 9339

Niebuhr, K.-W. 8767

Niehoff, M. R. 9263,9562

Nielsen, D. A. 9658

Nikiprowetzky, V. 8944, 8945, 9659

Nomachi, A. a6762

North, J. L. 8768, 9233

Nussbaum, M. $9251^{\bullet}$

Ochs, P. 9329

Oegema, G. S. 9452

Olivieri, M. 1826

Olsson, B. $8782^{\circ}$

Oort, J. van $8704^{\circ}, 9158$

Oppenheimer, A. $9337^{\circ}, 9647^{\circ}$

Orbe, A. 9660, a5527, a5827, a6125, a6643

Orrieux, C. 9290

Osborn, E. F. 8769

Overman, J. A. 8856, 9268

Owens, J. D. 9661

Paget, J. C. 9662

Panagopoulos, J. 9159

Parente, F. 8857

Pätzold, D. $9170^{\circ}$

Paul, A. 9663

Pawlaczyk, A. 9453, 9663a
Pearson, B. A. 9051, 9137

Pépin, J. 8770, 8771, 8772, 8724a, a7651, a8686

Pérez Ruiz, F. 8773

Perrot, C. 9564

Petersen, W. $8843^{\circ}$

Petit, F. 9264, 9363, 9563, 9664

Petit, M. 8774, 8946, 9265

Pétrement, S. 9052

Pétursson, P. 9687

Philonenko, M. 8775

Pilhofer, P. 9053

Piñero- Sáenz, A. 9665, a8687

Pinnick, A. K. 9666

Places, E. des a7560

Plese, Z. 9667

Pogoloff, S. M. 9266

Poirier, P.-H. 9454

Polaček, A. a8139

Porter, J. I. a8688

Pouderon, B. 8947, 9668

Pralon, D. 8833, 9565

Prato, G. L. $9455^{\circ}$

Pretagostini, R. 9375

Pricoco, S. 8858

Pritz, R. A. 8859

Przywara, E. a5527

Pucci Ben Zeev, M. 9054

Purdue, L. G. 9074

Pye, M. $87106^{\circ}$

Quinones, R. J. 9160

Quispel, G. 9206, 9669

Raban, A. $9675^{\circ}$

Rackman, J. 9364

Radice, R. 1201-1210, 2405, 2406, 2407, 2454, 3102, 8776, 8948, 9161, $9365,9455,9456$

Rajak, T. 9233॰

Rapoport-Albert, A. $8870^{\bullet}$

Rappaport, U. 9265

Rask, P. J. 9055

Reale, G. 2405, 2407, 2454, 3102, 8776, 9056

Rebolle Barrera, J. 9366

Redondo, E. 9448

Reeves, J. C. $9435^{\circ}$

Reinhartz, A. 9267, 9367, 9368

Reinhold, M. 3019 
Remus, H. 9670

Rescigno, A. 9057

Reventlow, H. Graf $8814^{\bullet}, 9058$

Reydams-Schils, G. J. 9457, 9458, 9566

Riaud, J. 8778, 9162, 9163, 9659, 9671

Richards, K. H. $8710^{\bullet}$

Richardson, G. P. 9369

Richardson, P. 9672, 9673

Richardson, W. 8949

Ricken, F. $9676^{\bullet}$

Riedweg, C. 8779, 9370, 9459

Ries, J. $8916^{\bullet}$

Rizzerio, L. 9674

Robert, L. a7134

Robertson, G. E. 8860

Robertson, S. D. 9164

Roetzel, C. J. 9268, a8689

Romano, F. 9421a

Rondeau, M.-J. 8780

Rose, J. J. 8861

Rösel, G. 9460

Rosso Ubigli, L. 8950

Roth, N. a7859

Rowland, C. a8557

Royse, J. R. 1823, 1827, 3214, 8951, 9165, 9166

Rubenstein, J. L. 9269, 9567

Ruiz-Montero, C. 9167

Runia, A. P. 1201, 1205

Runia, D. T. 1201-1210, 1403, 3211, 3212 , 3213, 3215, 3216, 3307$3314^{\bullet}, 8781,8862,8863,8952$, 8953, 8954, 8955, 9059, 9060, 9168 , 9169, 9170, 9171, 9172, 9270, 9271, 9272, 9273, 9274, 9275, 9276, 9371, 9372, 9373, 9374, 9461, 9462, 9568, $9569,9570,9648^{\bullet}, 9653,9675$, 9676

Rutherford, I. 9677

Saebø, M. 9682

Saffrey, H. D. a8140

Sagot, S. a7442

Salmon, J. $8752^{\bullet}$

Salvaterra, C. 8956

Sánchez Bosch, J. a8690

Sandelin, K. G. 8957, 9173, a8691, $1208,1209,1210,8782,9571$
Sanders, E. P. 9061, 9277

Sanders, J. T. a7135

Sandevoir, P. 8937

Sandmel, S. a6832

Sapp, D. A. 9062

Sartre, M. $8944^{\circ}$

Satran, D. 1201, 1202, 1203, 1205, $1206,1208,1210$

Scaraffia, L. $9691^{\bullet}$

Scarpat, G. 8783, 9174

Scarpi, P. 9515

Schabert, T. $9315^{\circ}$

Schaefer, P. $9611^{\bullet}, 9635^{\circ}$

Schaller, B. 1408

Schamps, J. 8784

Schenke, L. $8819^{\circ}$

Schimanowski, G. 9463

Schmidt, F. 8864, 9464

Schmidt, T. E. 8785

Schmitt, R. 8786

Schneider, S. 9678

Schoedel, W. R. 8958

Schoenberger, O. a7652

Scholer, J. M. 8865, 9175

Schöllgen, G. 9411, 9630

Scholten, C. $9630^{\circ}$

Schrage, W. 8959

Schrijver, E. G. L. 9032

Schrœder, G. a7560

Schroer, S. a8692

Schultz, J. P. a7561

Schur, C. $2602^{\bullet}, 9176$

Schürer, E. $8766^{\circ}, 8787$

Schutter, W. L. 8960

Schwankl, O. 8788

Schwartz, D. R. 1201, 1205, 8789, $8961,8962,9278,9647^{\bullet}$

Schwartz, S. 9063

Schweizer, E. 8866

Schwemer, A. M. $9189^{\circ}, 9679$

Scott, A. B. 8963,9177

Scott, J. M. 9572

Scullion, J. P. 9178

Sedley, D. N. 3016,8757

Segal, A. F. 8790, 9064, a8693

Segal, B. Z. $9003^{\bullet}$

Segalla, G. a7443

Seland, T. 3401, 9179, 9573, 9574, 9680

Sellin, G. 9279, 9681, a8694 
Septimus, B. $8791,8791^{\bullet}$

Sgarbi, R. 8964, 9280

Shanks, H. $9326^{\bullet}$

Sharma, A. $9684^{\circ}$

Sharples, R. W. 2157, 8965

Sheridan, M. $9439^{\circ}, 9576$

Shuler, P. 9065

Siegele-Wenschkewitz, L. $8827^{\circ}$

Siegert, F. 1404, 3103, 9281, 9465 , 9682

Sierra, S. J. $9501^{\bullet}$

Sigal, P. 8867

Sigurbjörnsson, E. 9687

Sijpestein, P. J. 8792

Silberstein., L. $9437^{\circ}$

Sills, D. 9282

Sim, U. 9683

Simon, M. a6732, 8793

Simonetti, M. 9375, 9466

Skarsaune, O. 8794, a8691 ${ }^{\bullet}$

Skarsten, R. 8795, 9180

Sly, D. I. 9066, 9181, 9182, 9183, 9467, 9577, 9684

Smallwood, E. M. 8796

Smelik, K. A. D. a8467

Smith, J. Z. 9067

Smith, R. C. a8464

Smith-Christopher, D. 9591

Söding, Th. 9685

Sorabji, R. 9376

Spicq, C. 8797, a5828

Spierenburg, H. J. 9468

Srigley, R. 9578

Stagg, E. \& F. a7860

Starobinski-Safran, E. 8798

Stead, C. 9469

Stegerhoff, R. $87106^{\bullet}$

Stern, M. a8004, a8550a ${ }^{\bullet}$

Stemberger, G. $9350^{\circ}, 9633$

Stenger, S. a4409

Sterling, G. E. 3106, 9068, 9184, $9283,9377,9579,9580,9581$

Stern, M. $8752^{\circ}, 9337^{\circ}$

Strange, J. $9382^{\bullet}$

Strickert, F. 9686

Strobel, A. a7752

Sysling, H. 8803

Szabó, F. a6841

Szymaski, M. a8141
Talbert, C. H. a7653

Taormina, D. P. $9421 \mathrm{a}^{\bullet}$

Tardieu, M. 9261

Tarrant, H. 9378

Tatum, W. B. a8695

Telesca, L. 9185

Temporini, H. 9253॰

Terian, A. 1305, 2235, 2236, 9186, 9187, 9379, 9470, 9471,9582

Thatcher, T. 9583

Theiler, W. a6531, a8255

Theobald, M. 9284

Thomas, C. 8799

Thompson, B. P. $8768^{\circ}$

Thompson, J. W. a8256

Thomson, R. W. 1306, a7861

Thorne, G. W. A. 8966

Thraede, K. 9411

Thunberg, L. a6532, a6644

Thyen, H. 9628

Timm, S. 8868

Tobin, T. H. $9037^{\bullet}, 9069,9188$, 9229, 9285,9380

Tollet, D. $8946^{\bullet}$

Tomson, P. J. 9070, 9381, a8696

Toorn, K. van der 9071

Torrallas Tovar, S. 9584

Touati, C. 8967

Trakatellis, D. C. a7654

Trebilco, P. R. 8968

Trevijano Etcheverría, R. 9585

Tronier, H. 9286, 9382, 9472, 9473, 9687

Turner, M. $9404^{\circ}$

Twersky, I. $8791^{\bullet}$

Twomey, V. $9526^{\bullet}$

Uchelen, N. A. van $9032^{\circ}$

Uffenheimer, B. $8814^{\bullet}$

Ullmann, D. W. 9586

Umemoto, N. 9189, 9474

Uña Juarez, A. 1405, 8969

Unnik, W. C. van 9383, a7136, a7352

Urbach, E. E. 9639

Uribarri Bilbao, G. 9688

Urio, B. $8944^{\circ}$

Urio, I. $8944^{\circ}$

Valantasis, R. $9536^{\circ}$ 
Vandergriff, K. L. 8869

Vanderjagt, A. $9170^{\circ}$

VanderKam, J. C. 9587

Vattioni, F. $8726^{\bullet}, 9316^{\bullet}$

Veltri, G. 8970, 9588, a8697

Verburg, W. 9689

Vermes, G. $3017,8766^{\circ}, 8918^{\circ}$

Vian, G. M. 8971, 9287, 9690, 9691

Villadsen, H. a8698

Vivo, A. de a7655

Voegelin, E. a7444

Vries, H. de 87100

Wainwright, P. M. a8684

Wallis, R. 9261 ${ }^{\bullet}$

Walter, N. 9589

Wan, S. K. 9590, 9591, 9288, 9384, 9475

Warnach, W. a7246

Warne, G. J. 9592

Wasserstein, A. a8468

Wedderburn, A. J. M. 87101

Wegner, J. R. 9190

Weinberg, J. 8870

Weinberger-Thomas, C. $9464^{\bullet}$

Weiss, H. D. 8972, 9191

Weiss, H. F. 9192

Weitzman, S. 9476

Welkenhuysen, A. 1303

Wen Xin, 9696

Wendel, G. $8793^{\bullet}$

Westerink, L. G. a8140

Whitman, J. 87102, 9289, 9692

Wilckens, U. 8724a

Wilken, R. L. 9477

Wilkins, M. J. 8871

Will, E. 9193, 9290
Willert, N. 8973

Williams, R. D. 87103

Williamson, H. G. M. $8818^{\bullet}$

Williamson, R. 3018, 9072

Wilson, N. G. 9478

Wilson, R. McL. 9385, 87104

Wilson, S. a8680

Wilson, S. G. $9672^{\circ}$

Wimbush, V. L. $2155^{\circ}, 9536^{\circ}$

Winden, J. C. M. van $8724 \mathrm{a}$

Winston, D. 87105, 8872, 8873, 8974, 9073, 9074, 9101, , 9194, 9291, 9386, 9479, 9593, 9594, 9595, 9693, 9694

Winter, B. W. 8874

Wire, A. 9415

Wolfe, B. P. 9075

Wolfson, E. R. 9695

Wolters, A. 9480

Wong, C. K. 9292

Wright, D. P. $9595^{\bullet}$

Wyrwa, D. 9195, a8381

Xavier, A. 9196

Yarnold, E. a8684

Yonge, C. D. 2113

Young, W. C. a4608

Zahle, J. 9212॰, 9533॰

Zandee, J. 9197

Zeller, D. 1210, 87106, 8875, 9076, 9387, 9596

Zimmerman, M. $8752^{\circ}$

Zipperstein, S. J. $8870^{\bullet}$

Zoumpos, A. 9077

Zuber, B. 9597

\section{INDEX OF REVIEWERS}

Adler, W. R-R8548

Alexandre jr., M. 8912

Alston, R. 9577

Amata, B. 8714

Anderson, G. A. 9373

Armstrong, A. H. R-R8548

Artola, A. M. R-R8636
Attridge, H. W. R-R8235, R-R8424, 9373

Aune, D. C. 9592

Auwers, J. M. 9659

Aziza, C. R-R7739

B., J. M. R-R8636 
Barker, M. 3018, 3018

Barnes, J. R-R8540

Barry, C. 9659

Bekken, P. J. 9608

Berchmann, R. M. 8912, 9059

Bergamelli, F R-R7722

Bernas, C. 9659

Bertrand, D. A. $1823,2236,8714$

Bienert, W. A. R-R3209

Birnbaum, E. 9520

Bitter, R. A. 9059, 9373

Bodeus, R. 8714

Boeft, J. den R-R8656, 1201

Borgen, P. 9608

Brooke, G. J. R-R8636, 3312, 3314, 9592

Brottier, L. 9413

Brown, C. A. 9066

Burkhardt, H. 9570

Calabi, F. 9216

Càssola, F. R-R6731

Cavadini, J. C. 9570

Chadwick, H. 8714

Chiesa, B. 8714

Cohen, N. G. 8851, 8904

Congourdeau, M.-H. R-R1820

Coulie, B. R-R8320, R-R1820, 3103

Crouzel, H. 1201, 2236, 8948, 9551, 9659

Degorski, B. O. 2236

Delling, G. R-R8373

Devos, P. 9281

Dillon, J. M. R-R8548, R-R8656, 2235, 2405, 8714, 8912, 9066

Doignon, J. R-R2233-2234

Downing, E. G. 8874

Driscoll, M. S. 9551

Druet, F.-X. 2236

Dugdale, A. 9222

Dupuy, B. 8723

Durand, G. M. de R-R7739, 8723

Duval, Y.-M. R-R7722, R-R7739

Edwards, M. J. 9059, 9373, 9551, 9570

Ehrman, B. 9570

Ellingworth, P. 3018

Ellis, E. E. 8743
Ellul, D. 8743

Emerton, N.E. R-R8656

Estébanez, E. G. 9570

Fédou, M. 9551

Feldman, L. H. 3312, 8851, 9574

Ferguson, E. 9570

Ferwerda, R. R-R8638

Fiedler, P. 9076

Fisk, B. N. 9222

Flint, P. W. 9373

Frickel, J. 8743

Füglseth, K. S. 9520

Gallagher, E. V. R-R8408

García y García, A R-R8636

Geljon, A. C. 9608

Gessel, W. 2236, 2405, 8743

Gigliucci, R. 8743

Goulet, R. R-R7611, 8829

Grabbe, L. L. 9373

Grant, R. M. 9373

Grilli, A. 2452

Gy, P.-M. 9551

H., T. R-R8424

Hadas Lebel, M. 3312, R-R2601, RR3101, 2405, 8743

Haelewijck, J. C. R-R1820

Haendler, G. R-R7739

Haquin, A. 9551

Hay, D. M. R-R8373, R-R8656, 3018, $8828,9076,9353,9373,9592,9659$

Hilgert, E. R-R7939, 1201, 3103

Hilhorst, A. R-R1820, R-R3209, RR8235, R-R8423, R-R8620, RR8636, R-R8656, 1201, 9373

Hoek, A. van den 9417

Holder, A. G. 9281

Holladay, C. R. 9235

Horbury, W. 2405, 8811

Horst, P. W. van der 1201, 3018, 9281,9520

Hoven, R. 9413

Igartua, J. M. 2405

Imhoof, S. 2235

Isser, S. 8743

Jacques, X. R-R1820, 2235, 2405 
Jastram, D. N. 9608

Johnson, L. T. 8763

Johnson, M. E. 9551

Jolivet, J. 8763

Joly, R. R-R1820, R-R8656

Jucci, E. 2452

Kaiser, O. 8763

Kamesar, A. 8829

Kannengiesser, C. R-R7739

Keizer, H. M. 9428

Kenney, J. P. R-R8408

Kerkeslager, A. 9373

Kerschensteiner, J. 8763

Klauck, H.-J. 8763, 8763

Kraemer, R. S. 9066

Kraus-Reggiani, C. 3018

Krentz, E. 9373

Kruse, T. 9577

Lange, N. R. M. de 9373

Lee, E. N. R-R8656

Leonard, J. M. 9659

Limburg, K. 8811

Loader, J. A. 3018

Lothar, L. 8834

Luisier, P. 9659

Lust, J. 9659

McCant, J. W. 9623

McKechnie, P. 9373

Mahé, J.-P. R-R1820

Maier, J. 8811

Manning, E. 1823

Maraval, P. R-R7722

Martin, M. J. 3312, 3314

Martín, J. P. R-R8656, 2405, 2406, 8763, 9001, 8948

Martinez, G. L. 8948

Mazzanti, A. M. 9608

Méasson, A. 8834

Mendelson, A. 8829, 8874, 9277, 9623

Messier, M. 8765

Meunier, B. 9570

Mitchell, A. C. 8874

Moore, A. 3314

Morani, M. 8964

Moulder, J. R-R8656

Munitiz, J. A. R-R1820
Murphy, F. J. 9608

Murphy-O'Connor, J. 2113

Nash, R. H. 8874

Nautin, P. R-R3209, R-R7739, 1201, 2405,9570

Nazzaro, A. V. R-R6916

Neudorfer, H.-W. R-R8424

Niebuhr, K.-W. 9452

Nobile, M. 9281

Nodet, E. 9373, 9608

Orbe, A. R-R8636

Osborn, E. 8834, 8851

Paul, A. R-R8656, 1201, 3018

Pearce, S. 9659

Pelland, G. 2235, 2405, 8772, 8948, 9659

Pervo, R. I. 9574

Petit, F. R-R7739, R-R7722

Petit, M. R-R8424, 1201, 8829

Pfeifer, G. 9608

Pierre, M. J. 8772, 8743, 8763

Pizzolato, L. F. R-R7739

Places, E. des 2405, 8772

Poirier, P. H. 1823, 2235, 2236

Porter, S. E. 2113

Pouilloux, J. 2236

Radice, R. 1823, 9076, 9373

Reedijk, W. M. 3018

Reeves, J. C. 8916, 9413

Reinhartz, A. 9608

Reix, A. R-R8636

Riaud, J. 2254, 2452, 8772

Riedweg, C. 9373

Rinaldi, G. R-R8373

Rizzerio, L. 8948

Robinson, S. E. R-R8321

Roisel, V. R-R7722, 2236

Rosenstock, B. R-R8656

Royse, J. R. R-R1820, 1201, 2236, 3103,8776

Runia, D. T. R-R8301, R-R8638, 1304, 1823, 2113, 2113, 2155, 2235, 2236, 2405, 2407, 2454, 3103, 8779, $8779,9222,9250,9264,9413,9428$, 9514, 9563, 9577, 9623 
Sandelin, K. G. 8779, 9076

Sandt, H. van de 9574

Satran, D. R-R2601

Schamp, J. R-R2233-2234, 2235, 2236

Schenke, H. M. 8811

Schmitt, H. C. 8811

Schofield, M. 9059

Sesbo, B. 8779

Siegert, F. 8811, 9076, 9383, 9659

Silverman, S. 3310, 3311

Smith, D. M. 8779

Soggin, J. A. R-R8636

Sola, F. de R-R8319

Solignac, A. 8779

Sterling, G. E. 1823, 3017, 3308, 3309, 8811, 8851, 8912, 9051, 9317, 9325, 9436, 9574, 9577, 9608

Stone, M. E. R-R1820, 3103

Strauss, J.A. 1823

Szram, M. 9551

Tanenzapf, S. 8851

Tenant, P. 2235, 2236

Terian, A. 8964, 9280, 9608

Thoma, C. 9281

Tobin, T. H. R-R3101, R-R8408, RR8656

Tomson, P. J. 9574, 9608

Trevijano, R. R-R8636
Trigg, J. W. 9373

VanderKam, J. C. 2113, 8829

Veloso, M. 2113

Vermes, G. 1201

Verniere, Y. 8779

Vicent, R. 9281, 9520

Viciano, A. 9059

Walter, N. 9370, 9456

Wan, S.-K. 9130, 9545

Wankenn, J. 9413

Ward, A. 9551

Whitman, J. 8779

Wiefel, W. R-R8636, 2236

Williams, C. H. 9623

Williamson, R. 1201, 1201, 1823, 3103,8779

Winden, J. C. M. van R-R7722, 2235, 2236, 3308, 3309, 3311

Winston, D. R-R8656, 1201, 3018, 8829, 8904, 8948, 9076, 9107, 9130, 9456, 9520, 9540

Wurzburger, W. S. 9520

Wüstemey, M. 8811, 8779

Wyrwa, D. 8779

Zeller, D. R-R7929, 8779, 8787, 9189, 9247, 9341

\section{INDEX OF BIBLICAL PASSAGES}

$\begin{array}{llll}\text { Genesis } & & 2: 2 & \text { a6762 } \\ 1 & 8709,9214 & 2: 2-3 & 9108 \\ 1-2 & 8846 & 2: 7 & 8721,9315,9355, \\ 1-3 & 8844 & & 9454,9541,9581, \\ 1-5 & 8801 & & 9689, \mathrm{a} 5826, \\ 1-11 & 9460 & 3 & \mathrm{a} 7245 \mathrm{a} \\ 1: 1 & 8795, \mathrm{a} 7651 & 3: 21 & 9156 \\ 1: 1-2 & \mathrm{a} 7349, \mathrm{a} 7351 & 6: 1-4 & \mathrm{a} 8550 \mathrm{~b}, \mathrm{a} 8698 \\ 1: 2 & 8721 & 7: 7 & 9223 \\ 1: 26 & 9030,9201,9541 & 12: 3 & 9408 \\ 1: 26-27 & 8813,9581, \mathrm{a} 5826 & 14: 22 & 9156,9449 \\ 1: 26-28 & 9511,9512 & 15 & 9476 \\ 1: 27 & 9323 & 15: 1-6 & \mathrm{a} 7557 \mathrm{a} \\ 1: 28 & 8913 & 15: 5 & 8910 \\ 2-3 & 9536 & & \mathrm{a} 7243\end{array}$


INDEX OF BIBLICAL PASSAGES

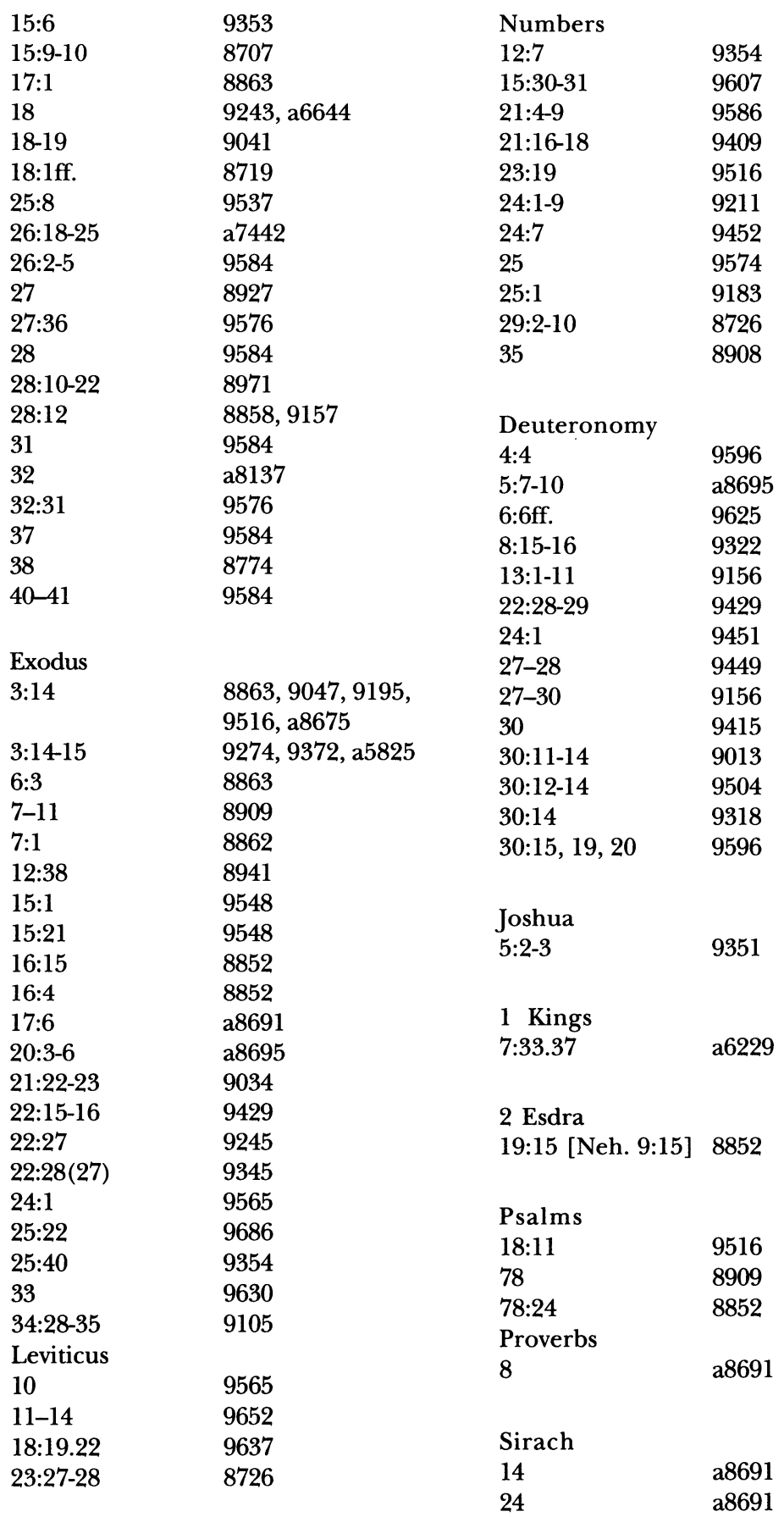




\begin{tabular}{|c|c|c|c|}
\hline \multicolumn{2}{|c|}{ Sapientia Salomonis } & \multirow{2}{*}{$\begin{array}{l}10: 1-15 \\
10: 4\end{array}$} & 9013 \\
\hline $10: 5$ & 9174 & & 9188, a 8550 \\
\hline $11-19$ & 9407 & $10: 6-8$ & 9504 \\
\hline $11: 20$ & 9658 & $10: 20$ & 8960 \\
\hline $16: 20-21$ & 9544 & $13: 1$ & $\mathrm{a} 6641$ \\
\hline \multicolumn{2}{|l|}{ Ezekiel } & \multicolumn{2}{|l|}{1 Corinthians } \\
\hline $1: 8-9$ & a6229 & $1-4$ & 9266 \\
\hline & & $1: 24$ & 9258 \\
\hline \multicolumn{2}{|l|}{ Habakuk } & $2: 6-3: 4$ & 9581 \\
\hline \multirow[t]{2}{*}{$3: 2$} & \multirow{3}{*}{9686} & 10 & a8048 \\
\hline & & 10:1-14 & 9571 \\
\hline Zechariah & & $10: 4-9$ & 9322 \\
\hline \multirow{2}{*}{$6: 12$} & \multirow{3}{*}{9249} & $10: 4 c$ & 9351 \\
\hline & & $11: 30$ & 9678 \\
\hline \multirow{2}{*}{\multicolumn{2}{|c|}{ Matthew }} & $11: 7-12$ & 9581 \\
\hline $\begin{array}{l}\text { Matthew } \\
5-7\end{array}$ & & $14: 34-35$ & 9542 \\
\hline $\begin{array}{l}5-7 \\
5: 33-37\end{array}$ & 8875 & 15 & 87101 \\
\hline $\begin{array}{l}5: 33-37 \\
5: 43 c\end{array}$ & 9649 & $15: 21-22$ & a8694 \\
\hline $\begin{array}{l}5: 43 c \\
6: 34\end{array}$ & 8819 & $15: 44-49$ & 9581 \\
\hline $\begin{array}{l}6: 34 \\
7: 12\end{array}$ & 9381 & $15: 45-49$ & a8694 \\
\hline & 9530 & $15: 45-50$ & 9689 \\
\hline $11: 25-30$ & 8730 & $15: 56$ & 9343 \\
\hline 13 & 8911 & & \\
\hline 21:1-7 & 9548 & 2 Corinthians & \\
\hline \multirow[t]{2}{*}{$22: 36-40$} & 9530 & 2:14-4:6 & a8685 \\
\hline & & $3: 1-4: 6$ & 9475 \\
\hline \multicolumn{2}{|l|}{ Mark } & 3:1-18 & 9047 \\
\hline \multirow{2}{*}{$8-16$} & \multirow{2}{*}{9644} & $4: 16$ & 9341 \\
\hline & & $6: 14-7: 1$ & 8854,8943 \\
\hline \multicolumn{4}{|l|}{ John } \\
\hline $1: 1-14$ & 9258 & $1: 6-12$ & 9156 \\
\hline $1: 1-18$ & 9323 & $1: 8-9$ & 9449 \\
\hline $5: 1-18$ & 9108 & $3-4$ & 8741,8860 \\
\hline \multirow[t]{2}{*}{$6: 31$} & \multirow[t]{2}{*}{8852} & $3: 8-14$ & 9156 \\
\hline & & $3: 10-13$ & 9449 \\
\hline Acts & & $4: 3,9$ & 8866 \\
\hline $6-7$ & 9589 & $4: 21-31$ & 9513 \\
\hline $16: 17 \mathrm{~b}$ & 8968 & & \\
\hline $20: 17-38$ & 9410 & & \\
\hline $27: 9$ & 8726 & $\begin{array}{l}\text { Uolossians } \\
1: 15-20\end{array}$ & a8048 \\
\hline \multicolumn{2}{|l|}{ Romans } & $2: 8.18 .20$ & 8866 \\
\hline $1: 20$ & 9024 & & \\
\hline $2: 14 f$ & 9530 & 1 Thessalonians & \\
\hline 4 & 8860 & $4: 9$ & 9196 \\
\hline 6 & 87101 & $4: 9-11$ & a8689 \\
\hline $6: 17 b$ & 9330 & 4:11f. & 9463 \\
\hline $10: 1-5$ & 9415 & & \\
\hline
\end{tabular}


1 Timothy

2:11-15

Titus

$3: 4$

Hebrews

3:5

5:11-6:20

8:5

James

$1: 17-25$
$5: 12$

9219

a5828

9354

8797

9354

9442
1 Peter

2:5.9

3

$3: 6 b$

a8135

2 Peter

1:19-21

2:15-16

Revelation

2:10-11
9573

9181

8809

8809

9649

8783

\section{INDEX OF PHILONIC PASSAGES}

See also general references to Philo's treatises under the heading Corpus Philonicum in the Subject index.

$\begin{array}{llll}\text { Opif. } & & 151-152 & 9206,9312 \mathrm{a} \\ 1-3 & 8966 & 151-166 & 9022 \\ 1-25 & 9618 & 170-172 & 8851,9045 \\ 4-6 & 8966 & & \\ 15-35 & 9285 & \text { Leg. } & \\ 17-18 & 8952,8955 & 1.2-4 & \mathrm{a} 3818 \\ 24-25 & 8844 & 1.2-16 & \mathrm{a} 6762 \\ 38 & \mathrm{a} 8255 & 1.31-32 & 9454 \\ 54 & 8731 & 1.31-42 & 8844 \\ 64-88 & 8844 & 1.37-38 & 9454 \\ 69 & 8862 & 1.42 & 9454 \\ 69-71 & \mathrm{a} 8140 & 2.4 & 8844 \\ 70 & 9627 & 2.57-58 & 9565 \\ 73-75 & 9402 & 2.86 & 9351 \\ 83-84 & 9511,9512 & 3 & 9156 \\ 89 & \mathrm{a} 5527 & 3.7 & 9446 \\ 100 & \mathrm{a} 8141 & 3.65-199 & 9449 \\ 104 & 9303 & 3.75-104 & 9153 \\ 129-130 & 9285 & 3.100 & 8779 \\ 131 & \mathrm{a} 8255 & 3.102 & 9354 \\ 134-135 & 9454 & 3.107-8 & 9449 \\ 134-169 & 8844 & 3.128-132 & 9529 \\ 136-138 & 9022 & 3.174 & 8726 \\ 140-142 & 9022 & 3.207 & 9476 \\ 143-135 & 9402 & 3.236-244 & 9528\end{array}$


Cher.

1-10

9528

21-50

23-24

27

$27-28$

40-50

125

125-127

9419

9686

9686

9475

8779

a5527

9603

Sacr.

8-9

$35-41$

64-68

8852

8801

102

a6841

123

9023

9023

Det.

38-40

54-56

83

96ff.

115-116

123-125

135

138

161-162

168

9102

9335

9692

9449

a8691

9543

9023

9023

8862

9521

Post.

13-16

18

28

42-43

84

110-111

9124

a7652

8852

9587

9449

9102

Gig.

6-18

49

$54-57$

60-61

65-66

9659

8852

8779

8919

9071

Deus

32

151

154-155

a8254

1825

1825

Agr.

$20-25 \quad 9449$

$25 \quad 9023$

67-88 9548

$97 \quad 9023$

Plant.

$27 \quad 9354$

$89 \quad 9654$

127-131 9271

Ebr.

20-26 9680

$30 \quad$ a6643

30-31 9557

105-107 9476

$150 \quad 9303$

157-159 9101

169-205 a8549

170-205 9531

171-205 9422

$199 \quad 8847$

Sobr.

$30-51 \quad 9449$

Conf.

62f. $\quad 9249$

$145 \quad 9261$

Migr.

$20 \quad 9665$

34-35 9475

47-52 8934

86-93 9070

$88-93 \quad 9691$

89-93 9123,9278

$93 \quad 8929$

$109 \quad 9449$

118-126 9156

$169 \quad 9565$

Her.

45-46 9232

45-48 9453

68-85 9508

$93 \quad 8854$

$98 \quad 9647$

126-128 a8692 


\begin{tabular}{|c|c|c|c|}
\hline 153 & 8731 & Somn. & \\
\hline 165 & a8254 & 1.1 & 9643 \\
\hline 166 & 9686 & $1.2-188$ & 8971 \\
\hline 190 & a7439 & $1.21-32$ & $9044,9253,9653$ \\
\hline 203-204 & 9571 & $1.21-34$ & 9531 \\
\hline $216-217$ & a7244 & 1.80 & 9678 \\
\hline 241 & 9521 & $1.137-141$ & 8866 \\
\hline $246-248$ & 8847 & $1.138-140$ & 8715 \\
\hline $280-283$ & 8866 & $1.164-165$ & 8779 \\
\hline \multirow[t]{2}{*}{309} & 9565 & 1.206 & 9354 \\
\hline & & $1.213-214$ & 8903 \\
\hline Congr. & & $1.228-230$ & 8903 \\
\hline $1-18$ & 9618 & $1.230-232$ & a8675 \\
\hline 8 & a7244 & $2.1-2$ & a8255 \\
\hline $71-89$ & 9618 & 2.67 & 9565 \\
\hline 79 & 8836 & $2.120-121$ & 9142 \\
\hline $140-141$ & 8836 & $2.123-132$ & $8961,9037,9137$ \\
\hline $161-174$ & a8691 & 2.160 & 9678 \\
\hline \multirow[t]{2}{*}{171} & 8951 & 2.189 & 8852 \\
\hline & & $2.250-254$ & 9475 \\
\hline \multicolumn{4}{|l|}{ Fug. } \\
\hline 11 & 9688 & $A b r$ & \\
\hline $50-51$ & 9557 & $17-19$ & 9587 \\
\hline 53-118 & 8703 & $50-52$ & 9372 \\
\hline 59 & 9565 & $82-83$ & a5827 \\
\hline 63 & 9521 & $107-132$ & 8719 \\
\hline $69-70$ & 9402 & $110 \mathrm{ff}$. & 9243 \\
\hline 82 & 9521 & $135 f$. & 8706 \\
\hline 100 & 9316 & $247-253$ & 9513 \\
\hline $100-101$ & 9686 & 269 & 8854 \\
\hline 108 & a6643 & 275 & 8854 \\
\hline $108-112$ & a6841 & & \\
\hline 117-201 & 8911 & Ios. & \\
\hline 151 & 9232 & 125 & 8946 \\
\hline $157-160$ & 9185 & $125-147$ & 9422, 9531 \\
\hline 179 & 9446 & & \\
\hline \multirow[t]{2}{*}{ 211f. } & 9436 & Mos. & \\
\hline & & 1.23 & a8467 \\
\hline Mut. & & $1.74-76$ & 9372 \\
\hline $1-33$ & 8863 & 1.75 & a8675 \\
\hline $7-14$ & 9372 & 1.147 & 8941 \\
\hline $11-26$ & 8862 & $1.148-162$ & 8862 \\
\hline 21 & a8675 & $1.150-162$ & 9518 \\
\hline $33-34$ & 9587 & $1.155-158$ & 8852 \\
\hline $66-69$ & a5827 & 1.158 & 9615 \\
\hline $175-187$ & 8863 & $1.158 \mathrm{f}$. & 9612 \\
\hline $218-232$ & 8863 & $1.201-202$ & 8852 \\
\hline \multirow[t]{2}{*}{267} & a8254 & 1.263 & 9554 \\
\hline & & $1.263-300$ & 8809 \\
\hline
\end{tabular}




\begin{tabular}{|c|c|c|c|}
\hline $1.273-284$ & 9554 & 2.104 & a6228a \\
\hline $1.289-291$ & 9211 & $2.193-196$ & 8726 \\
\hline 1.290 & 9452 & $2.252-254$ & 9574 \\
\hline 1.291 & 9449 & $3.1-6$ & 9475,9609 \\
\hline 1.313 & 8792 & 3.6 & 8730 \\
\hline $2.17-31$ & 9193 & $3.30 \mathrm{f}$. & 9451 \\
\hline $2.25-44$ & 8832 & $3.65-71$ & 9429 \\
\hline $2.26-44$ & 9450 & 3.72 & 9647 \\
\hline $2.37-40$ & 9564 & $3.169-175$ & 8840 \\
\hline 2.39 & 9259 & 3.189 & 9442 \\
\hline $2.43-44$ & 9016 & 4.49 & 9111,9564 \\
\hline $2.59-65$ & 8844 & $4.55-78$ & 9625 \\
\hline 2.67 & 9163 & $4.132-150$ & 8722 \\
\hline $2.97-100$ & 9686 & $4.133-135$ & 9318 \\
\hline 2.114 & 9166 & $4.133-150$ & 9520 \\
\hline 2.132 & 9166 & $4.137-138$ & 9625 \\
\hline $2.161,167$ & 9571 & $4.137-149$ & $\mathrm{a} 6228 \mathrm{a}$ \\
\hline $2.187-287$ & 9441 & $4.151-159$ & 9007,9008 \\
\hline $2.188 \mathrm{ff}$. & 8873 & $4.160-169$ & 9415 \\
\hline 2.195 & 9060 & 4.179 & 8851 \\
\hline $2.203 \mathrm{ff}$. & 9345 & 4 fin. & 8966 \\
\hline 2.251 & 8786 & & \\
\hline $2.253-255$ & 9101 & Virt. & \\
\hline 2.265 & 9441 & $51-168$ & 8819 \\
\hline 2.267 & 8852 & $51-174$ & 9301 \\
\hline \multirow[t]{2}{*}{$2.270-271$} & 9571 & 95 & 8727 \\
\hline & & $102-103$ & 8856 \\
\hline Decal. & & $102-108$ & 8941 \\
\hline $32-35$ & 8934 & $180-185$ & 9415 \\
\hline $46-49$ & 8934 & 183 & 9504 \\
\hline 51 & 9688 & $199-205$ & 8844 \\
\hline $82-91$ & 9436 & $212-219$ & 9404 \\
\hline \multirow[t]{2}{*}{155} & 9688 & & \\
\hline & & Praem. & \\
\hline Spec. & & 1 & 9057 \\
\hline 1.2 & 87106 & $16-17$ & 9587 \\
\hline 1.52 & 9027 & 26 & 9692 \\
\hline 1.53 & 9345 & $36-46$ & 9694 \\
\hline $1.54-57$ & 9574 & $62-63$ & 9402 \\
\hline 1.65 & 9111 & 79 & 9211 \\
\hline 1.65 & 9564 & $79-172$ & 9156,9449 \\
\hline 1.88 & 8731 & 80 & 9504 \\
\hline $1.131-155$ & 8727 & $93-97$ & 9211 \\
\hline $1.186-188$ & 8726 & 95 & 9452 \\
\hline $1.226-238$ & 9607 & $163-172$ & 9211 \\
\hline $1.285-345$ & 8964 & 163ff. & 9452 \\
\hline $1.315-318$ & 9156,9574 & $164-172$ & 9016 \\
\hline $1.319-323$ & 8779 & 167 & 9679 \\
\hline $2.36-43$ & 8706 & 172 & 9521 \\
\hline 2.62 & 9227 & & \\
\hline
\end{tabular}




\begin{tabular}{|c|c|c|c|}
\hline Prob. & & 281 & 9112 \\
\hline 13 & a8691 & $298-305$ & 8973 \\
\hline 19 & 9303 & 299-305 & 9583 \\
\hline $21-30$ & 8917 & $299-306$ & 9549 \\
\hline 43 & 8960 & $306-307$ & 8726 \\
\hline $62-73$ & 9415 & & \\
\hline $73-75$ & 9464 & Hypoth. & \\
\hline 75 & 9635 & $6.10-7.20$ & 9314 \\
\hline $75-91$ & 3017,9309 & $11.1-18$ & 9309 \\
\hline 84 & 9649 & & \\
\hline 93-96 & 9464 & Prov. & \\
\hline 116 & 9303 & 1.22 & 9653 \\
\hline 195-199 & 9638 & $2.34-41$ & 9674 \\
\hline & & 2.60 & 9348,9547 \\
\hline Contempl. & & 2.80 & 9677 \\
\hline 12 & 8840 & 2.107 & a7134 \\
\hline 25 & 8970 & & \\
\hline $32-33$ & 8840 & Alex./Anim. & \\
\hline $40-47$ & 9680 & 2 & 9525 \\
\hline $57,59-63$ & 9015 & 27 & 9538 \\
\hline $64 \mathrm{ff}$. & 9140 & 72 & 9525 \\
\hline $68-69$ & 8840 & & \\
\hline 78 & 8929 & $Q G$ & \\
\hline $83-88$ & 8840 & 1 & 9153 \\
\hline & & 1.27 & 9379 \\
\hline Aet. & & 1.32 & 8844 \\
\hline $28-34$ & a7748 & $1.47-48$ & 9153 \\
\hline 79 & a8255 & 1.51 & 8844 \\
\hline $117-149$ & 2157 & $1.57-99$ & 9153 \\
\hline $117-150$ & 9648, a 8255 & 1.79 & 9023 \\
\hline & & 1.81 & 8844 \\
\hline Flacc. & & $1.82-86$ & 9587 \\
\hline 36 & a7350 & $2-3$ & 9153 \\
\hline $121 \mathrm{f}$. & 9659 & 2.49 & 9408 \\
\hline $123-124$ & 9101 & $2.81-82$ & 9071 \\
\hline 131 & a8555 & 3.3 & 8965 \\
\hline $169-171$ & 9438 & 4 & 9153 \\
\hline 176 & 9680 & 4.1 & 9446 \\
\hline & & 4.2 & 9508 \\
\hline Legat. & & 4.56 & 9660 \\
\hline $53-56$ & 9109 & 4.145 & 9248 \\
\hline 54 & 9650 & $4.195,6$ & 8805 \\
\hline 118 & 9017 & $5-6$ & 9153 \\
\hline 139 & a8467 & & \\
\hline $143-147$ & 8720 & $Q E$ & \\
\hline $159-160$ & 9549 & 1.1 & 9379 \\
\hline 163 & a8467 & $1.1-2.52$ & 8966 \\
\hline $210-211$ & 8838 & 1.6 & 9165 \\
\hline 239 & 9612 & 1.23 & 9402 \\
\hline $276-329$ & a8553 & 2.2 & 8856,9123 \\
\hline
\end{tabular}




$\begin{array}{llll}2.5 & 9245,9345 & 2.46 & 9612 \\ 2.27 & 9565 & 2.51-123 & 8966 \\ 2.29 & 8852 & 2.62-68 & 2236,9686 \\ 2.29-47 & 9556 & 2.66 & 8838 \\ 2.39 & 9643 & 2.68 & 8934 \\ 2.40 & 8852 & 2.73-81 & \mathrm{a} 7244\end{array}$

\section{INDEX OF SUBJECTS}

Aaron, interpretation of 9102, 9529

Abelard and Heloise, Letters of 8903

abortion a7133

Abraham

and Messiah 8869

and Sarah, episode of 9011

and Spirit 9404

as 'great name' 9535

as man of politics 9518

as mystic 9590

as sage 9189

interpretation of 9029,9339 ,

9439, 9527, 9584, a8554, a8690

seed of, and sin 8842

Abraham traditions 9313, 9406

Abraham, song of 9476

Academy - see Platonism

Academy, New, and doxa 9251

Acts of Apostles

and temple and sabbath 8806

establishment violence in 9574

God-fearers in 8856

parrêsia in 9302

Paul's opponents in 8753

repentance in 9306

Adam

and language 8841

and semiotic perfection 9259

and $\sin 8842$

interpretation of 8844,9062 , 9502, 9606

Aenesidemus, tropes of a8549

aesthetics a7558

Aëtius 9653

agency 9612

Agrippa I 9007, 9008, 9583

Agrippa, Marcus Vipsanius 9423 aiôn, relation to time a8254

Albinus 9251

Alcinous 9365

Alexandria

Christian community, origins of 9026,9420

clubs and associations of 9680

founding of, and Opif. 8955

Jewish community of 8798,9235

Jewish society in 9066

Jews and non-Jews in 9212

Philo's 9577

riots $38 \mathrm{AD}$ at $9054,9292,9414$, $9559,9604, a 8046, a 8140$

Sitz im Leben in (scholarship on) 1409

society of 9684

Alexandria(n) - see also Egypt, Judaism

Alexandrian

library, influence on Philo of 8732

school of exegesis 9477

theology 9197

tradition $8935,9373,9430$

alien resident, theme of 8906

Allegorical Commentary

and Quaestiones 9288, 9384

Italian translation 2407

structure of 8966

allegorical commentary on

Pentateuch, source for Philo 8743

allegorical exegesis

and other Jewish exegesis 8818

bridge between Scripture and philosophy 9377 
character, form and purpose of 9350

general account of 8776,9633

levels of meaning in 9185

principle and codes of 9624

reasons for 9526

strained character of a6022

structure of 9631

allegorical interpretation

Alexandrian, of Scripture 8820

and dualism 9213

and Greek mythology 8814

and inspiration 9553

and literal interpretation 9121,

9350

and philosophical

hermeneutics 9127

and reinterpretation of the world 8820

and universal meaning 9129

as 'radical interpretation' 9218

characteristics of a8554

complexity of 8719

function of 9222

general account of 8803

influence of, in 20th cent. a7444

structure of 8815,9136

tradition of 9528

allegorical method

analysis of a7855, a8688

and halakha 9042

and Hellenistic philosophy 9286

and hermeneutic theories 8717

and midrashic interpretation 8717

compared with Confucian allegory 9591

criticism of Philo's 8870

essence of defined 8717

general account of 87100,87102 , $8772,9058,9216,9584$

new kinds of meaning in 9185

origin of 9274

origins and reception of 9207

sources of 9416,9501

transformation of 9439

- see also exegesis

allegorical treatises, structure of 8781, 8911, 8912, 9153 allegorists

pre-Philonic Jewish 9426

radical, Philo's battle against 8743

allegory

and analogy 9558

and dualism a5528

and metaphor 9357

and phusis 9640

and typology 9502

as method of knowledge 9357

evolution of the term 9375

nature of defined 9356

physical 9557

political 8748

Rabbinic a3719

al-Qirqisani, Ya'qub a8463

Ambrose

allegorical method of 9185

De Abraham and Philo's $Q G$ a4709

De Abraham, influence on a7655 influence on 9373, 9526, a7439, a7442, a7651

on Cain and Abel 9160

on the cities of refuge 8908

on heresy 9272

on the Levites 8713

on the Logos a6841

on slavery 9638

analogy and allegory 9558

androcentrism 9536

androgyny 9206, 9214, 9331, 9532,

9536, 9606, a6643

angel traditions a7653

angelic spirit and prophecy 9554, 9555

angelology $8916,9413,9659$

angel(s)

and demons 8947

and heavenly ascent 9312

and Logos/Sophia 9104, 9202, a8137

and miracles 9117

and salvific intervention 9359

and Sons of God 9202

as daimones-psuchai a8674

as logoi 9413, a8674

interpretation of, in Gen. 6 9223 
interpretation of three, in Gen.

18 a6644

worship of 8866

angelus interpres and Logos 9472

anger of God 9344

animal worship a8467

animals

man's sovereignty over 9511, 9512

status of 9376

Ankum, H. 9647

anthropology 8862, 9307, 9308,

9541, 9579, 9581, 9651

importance in Philo's thought 8850

Jewish-Hellenistic and Philonic 8759

Philo's, and Gnosticism 9315

philosophical, Jewish a6122

- see also man

anthropomorphism 9344, a3719, a5022

Antiochene school of exegesis 9045, 9477

Antiochus of Ascalon 8773, 9039, 9506, 9530, a7649

apatheia 9401, 9529, 9546

- see also God, impassibility of

Aphrodisias a7134

Apion 9068

Apocalypse of Abraham 9476

apocalyptic, Philo not 9143

Apocryphon of John 9532, 9546, 9667

Apollos 8854, 9541, 9581, a8685

apologetic intent 9345

apologetic motifs in Paul and

Philo 9535

apologetics 9352, 9534

and theft of philosophy a7859

centrality of in Philo 8835

early Christian 8742, 8830, 8920, 8958, 9373

Jewish 8794

Philo's 8851, 8855, 8962, 9053, 9068, 9144, 9193, 9290, 9406, 9549, a 8695

apologists, early Christian 9557, a5827

apostasy 9290,9574

Apuleius 9251
Aquinas a8675

Arcesilaus 9251

architect and king, image of 8952

Arianism 9261, 9272

and Logos 87103, 9440

Aristeas - see Letter of Aristeas

Aristobulus 8835, 8934, 9053, 9135, 9257, 9303, 9370, 9540, 9569, 9589, 9593, a6762, a 8256 comparison with Philo 9456

Aristotle

and immutability of God 8758

and male and female 9190

and memory 9107

and philosophy, concept of 8733

and self-love 9523

and slavery 9421

and slavery 9638

and soul 9596

and unmoved Mover 9654

and woman 8701

De philosophia a7559, a7748

Ethica Eud. and Nicom. a7854

arithmology 8909, 9011, 9560, 9569, 9658, a3818, a6643

Arius - see Arianism

Ark

and cherubim 9413

cover of 9316

Armenian commentaries a6023

Armenian Philo as historical

source a7861

Armenian translation 9348, 9379,

9677, a7951, a8673

and Contempl. 9280

and G. Leopardi 8712

bibliography 1305, 1306

scholarship on 1404

technique of 8964

value of 9470

Armenian transmission of Philo's work 9270

Arnaldez, R. 9290

Arnim, H. von a7649

Artapanus 8920, 8934

Ascalon a7134

Ascension of Isaiah 9555

ascent, heavenly or mystical 9040 , 9312, 9342, 9602, 9609, 9612, 9613, $9615,9643,9644,9693$ 
ascent, psychic 8872

ascetic life 9584, a8464

asceticism 2155, 8826, 8903, 8935, 9224, 9401, a8683

Asclepiadean system of grammatike 9435

Asclepius 8849, 9048

assimilation to God 9030

astrology 9292

Athenagoras 8947, 9276, 9668

Aucher, J. B. a8673

audience, Philo's 9132, 9193, 9288, 9406

Augustine 9373, a7858

contact with Philo's work a8045

De civitate Dei, relation to Philo 9150,9158

De doctrina christiana and Fug. 9148

Ideas as thoughts of God 8773

interpretation of Exod. 3:14-15 9372

knowledge of Philo 8704

on Cain and Abel 9160

on eternal law and law of nature 9530

on Exod. 3:14-15 9274

on Ideas 8969

on literary quality of the Bible 9543

on Nimrod 9071

Augustus, encomium on 8720

Aune, D. 9475

authority, non-Jewish, attitude towards 8857

Avicenna a8675

Babel, Tower of, interpretation of 9174

Baebius 9538

Baer, Y. F. a8550a

Baer, R. A. 9066

Balaam

as antithesis of Moses 8905

interpretation of 8809,8923 , 9010, 9025, 9239, 9413, 9554, 9555, 9643, 9670

balance, metaphor of 9232

Bamberger, B. J. 9125

baptism 8842
Barbelo 9532

Baruch, third 9579

Basil

and Jewish exegete 9275

and oral Jewish tradition 9544

influence on 9373

on ascent of the soul 9040

on Exod. 3:14-15 9274

beauty a7558

Being, Great Chain of 9684

Belkin, S. 9220, 9647

Benedictine rule 8858

benefaction, terminology of a7132

beneficence of God a7352

Berenice 9577

Bernays, J. 9639

Bible

and canon 9682

distribution of quotations

from 9597

literary quality of 9543

reception of, in Diaspora 9366

- see also Septuagint

Billings, T. H., index to 3216

biography

allegorical and political 9263

encomiastic 9065

of Moses 9670

birth imagery 9557

Blavatsky, H. P. 9468

body

and problem of evil $8745 a$

and tunics of skin a8550b

devaluation of 8746

evaluation of $9214,9312 a$

negative attitude towards 9581

relative denunciation of 8826

body and soul of Scripture 8929

Borgen, P. 8781, 9143, 9572

Borgen, P. and R. Skarsten, KWIC concordance 9060,9180

Box, H. a8555

Boyancé, P. a7649

bread, allegorical meanings of 9515

Bréhier, E.

brotherhood 9324

Bultmann, R. 9129

Byzantine period, fate of Philo in 9110 
Caecilius of Calacte 9579

Caesarea Maritima 9675

Cain and Abel, interpretation of 9150, 9160

Cain, and Paradise 8951

Caligula 8825, 8902, 8956, 9134, 9522,9613, a 8677

Camus, A. 9578

Canaan, interpretation of 9421 , 9638

candlestick a7244

canon 9050

canon, Muratorian 9431

captives 9412

Carabas 9115

Casel, O. 9651

Cassian, John 9576

categories of being 9506

Catena in Genesim and Quaestiones in Genesim 9264, 9363, 9563, 9664

Cathars 8903, 9204, 9221

Cazeaux, J. 8723, 8781, 8966

Celsus 9257, 9375

Chaeremon 9068, 9374, 9377, 9386, a7649

Chaldean Oracles a6328

Chaldeanism 9413

Chaldeans 9456, a7649 use of the term 9292

Chariton of Aphrodisias 9167

charity 8835

cherubim, interpretation of 8838 , 9686

childbearing, spiritual 9425, 9536

child-parent relationship 9367

Christ and Logos 9681

as charioteer of the soul 9548

as instrument in creation a6841 pre-existence of a7654

Christ - Adam typology a8694

Christian exegesis, influence on early 9682

Christian literature, early, Philo in 9373,9570

Christian thought, early and divine agency 8837 and Greek philosophy 8916 influence on $1402,9274,9568$, 9618, a6643 negative influence on a6537

Christian tradition, early, influence on 9432

Christianity, early

Alexandrian 9621

and Hellenistic Judaism 9610

and passions 9401

Hellenization of 9428

Jewish background of 9278

context of a 8682

Judaic context of a8680

relation to Philo 8738,8868 , 9402, 9539, a8557

christianization of Philo 8870

Christological hymns a7135

Christology 9017, 9258, 9279, 9322, a8048

Chronicles, use of 8807

chronology of writings 9137

Church Fathers

and allegorical

interpretation 9213

and woman 9022

influence on $8746,8835,8845$, $8918,8954,9039,9471,9526$

on body and sexuality 9214

on conscience 9436

references to Philo 3215

- see also Christian literature, early, and under individual names

Cicero 9232, 9436, 9692, a7858

and eternal law 9530

and scepticism 9250

as apologist 9053

philosophy of 8853

circumcision, interpretation of 9011,9535

citizenship, of (Augustine's) two cities 9150,9158

city

building and organisation 9683

founding of, image of 8955

of ideas 9656

Claudius 8973, 9577

Clement of Alexandria

and allegorical method 9207, 9222

and body and soul of Scripture 8929 
and Philo 'the Pythagorean' 9569

and synkatabasis

(anthropomorphism) 9344

and teleological ideals 8942

citation of Philo 9430, 9657

influence on $8769,8858,8949$, 9124, 9197, 9373, 9526

library of 9031

on androgyny 9206

on categories of being 9506

on forgiveness of sins 9551

on Gen. 1 a7351

on Moses 8868

on nomos empsychos 9443

on phusiologia 9674

on prophecy 8905

on sexual conduct 9636,9637

on spiritual struggle 9576

on the Logos 9440

on theophanies a5824

Paedagogus 9448

use of Philo 8834, 9657

use of Plato and Philo a8381

Clement of Rome 9444, 9445

Cleodemus Malchas 9579

Cleopatra 9577

clubs and associations 9680

Cohn, L. 8964, 9057

Cohen, N. G. 9256

Cohen, R. David 9593

Cohn-Wendland 9171

Cohn-Wendland, index to 3213

Coleridge 8915

Colson, F. H. 9057, 9171, 9453

commandments, Ten

see Decalogue

commentaries, Latin 9346

commentary tradition 9631

composition

periodic 9002,9101

- see also structure

compositional techniques and politics 8748

computer searches 9060,9180

concord 9411

concordances and computer 9060

Confucian allegory 9591

conscience 9436,9619

contemplation 9040 , a8683 contemplative life 8872,9584

conversion 8763, 9103, 9193, 9290, 9361

Conybeare, F. C. 3017

Coptic monastic literature 9576

Corinthians and Alexandrian Judaism 9581

Corpus Philonicum

classification of 9682

general account of 8766

manuscripts 8839,9584

organization of writings in 9511,9512

pseudonymous writings, see Pseudo-Philo

transmission and fragments of 1823

transmission of $9373,9471,9675$

De Abrahamo

Hebrew translation 2602

De aeternitate mundi

aim of the treatise 8718

and Aristotle, De philosophia

a7559, a7748

authorship 8795

pseudo-Philonic 9180, 9639

De agricultura

English commentary 3104

Italian translation and

commentary 2406

Polish translation 2751

De animalibus

French translation and

commentary 2235

De cherubim

and 'Iggereth Hakodesh a6229

De confusione linguarum

methodological observations a8688

Italian translation and commentary 2406

De congressu eruditionis gratia analysis 87100 , a8554

De decalogo

Hebrew translation 2602

Polish translation a2701

De Deo

Armenian text, Greek retroversion, German translation and commentary 3103 
De ebrietate

Italian translation and com mentary 2406

Polish translation 2751

De fuga et inventione methodological function 9148

De gigantibus Polish translation 2751

De gigantibus - Quod Deus sit immutablilis compositional structure 8781

De Iosepho

Hebrew translation 2602 analysis 9518

De migrationi Abrahami Italian translation and commentary 2406

De opificio mundi Hebrew translation 2602 Italian commentary 3102 Italian translation and commentary 2405 Polish translation a2701 - see also creation, Gen. 1

De plantatione Italian translation and commentary 2406

Polish translation 2751

De providentia and (Stoic) theodicy a7649

Armenian translation a8673 text constitution 1826

De sobrietate

Italian translation and commentary 2406

Polish translation 2751

De somniis analysis 9584 and Hellenistic dream theory 8710 scholarship on 1401

De specialibus legibus Hebrew translation 2602 survey 9518

De virtutibus

Polish translation a2701 rhetorical analysis 9301 scholarship on 1406 text tradition 9171
De vita contemplativa

analysis 9659

English translation 2155, 2156

extract in English 3017

French translation 2254

Italian commentary 3105

Italian translation 2453

Italian translation and commentary,

bibliography 2452

Latin translation 9622

Portugese translation 2851

summary in Spanish 9327

text reconstruction 9280

De vita Moysis

analysis 9120,9534

and Gregory of Nyssa's Life of

Moses a7857

extracts in English a3014

genre 9065

in Pseudo-Justin 9459

prophecy and divination in 8808

Hypothetica a7751

and Josephus' Contra Apionem 8767, 9006, 9314

extract in English transla tion 3017

reconstruction 9068

In Flaccum

philosophical reading of 9438

Legatio ad Gaium genre 8958

historical credibility 8796

hortatory epistle in 9583

Legum allegoriae

Italian translation and

commentary 2405

Polish translation a2701

PERI BIOU PRAKTIKOU $\mathrm{H}$ ESSAIÔN a7751

Quaestiones

and midrash 9220

and other exegetes 9131

and Rabbinic midrash 8904

chronology 9186

collection of studies on 9130

general introduction to 9287 
genre 9288, 9384

purpose of 9131

relation to Allegorical Com mentary $9153,9184,9384$ structure of 8966,9168 structure and genre of 9153 various traditions of 9133

Quaestiones in Exodum

French translation and commentary 2236 interpolations 9187

Quaestiones in Genesim

and Catena in Genesim 9263, 9363, 9563

and Jerome 9347

Quis rerum divinarum heres sit central theme 9663a Italian translation and commentary 2454

Quod Deus sit immutablilis compositional structure 8781 Polish translation 2751

Quod omnis probus liber sit analysis 9601 text a7751

cosmogony - see creation cosmology 9307, 9502, 9579, 9661

and Gnosticism a5527

key to Philo's thought 8850 cosmos

and God's activity 8764

as a power 8866

as polis 9683

as temple a8686

createdness and indestructibility of a7349

eternity of 9118

four principles of 9603

grammaticality of a 8688

origin of 9118

principles of 9458,9566

covenant 9608,9679

new 9351

createdness of the cosmos 9524, a7349

creatio ex nihilo - see creation, ex nihilo creation

and evil 8848

and manna 9418

and ontology 9047 and retribution 9658

as creatio aeterna 9283

as gift (grace) 9324

concept of $8762,8855,9004,9048$, 9283,9558

doctrine of $8948,9057,9456$, 9651, a5924

double nature of 8742,9109

dynamic conception of 8718

ex nihilo 9046, 9208, 9480, 9558, 9626

God's care for his 8705

man's domination over 9511, 9512

paradigms (ideas) of the 8708

creation acount

interpretation of $8709,8724 a$, $9214,9285,9623,9659$, a 5826 , a7349, a7351, a7444

interpretation of, and gnosti cism 9532

interpretation of the seventh day a6762

interpretation of the third day 9517

creationism, philosophical a6761

Critolaus 9232

crucifixion 9115

cultural life of 1st cent. CE a3015

culture

Hellenistic, attitude towards 9533

history of 8920

non-Jewish, attitude towards 8857

curse 9156,9449

Cyprian a7244

Daniélou, J. 9521

Daube, D. a5924

David, and Messiah 8869

Davidson, D. 8717

Dawson, D. 9426, 9527

day, and feast a8686

Dead Sea scrolls - see Qumran

death, twofold (physical and moral) 8783

Decalogue 9003, 9530

as framework for Jewish Law 9520 
interpretation of 9136 , a8135

deductive method 9382

defilement 8842

deification of man 9030

Demetrius the Chronographer 9435

democracy 9683

Democritus 9594

demonology a8674

demons 8916

desert, interpretation of 8944

Deuteronomy, Sifre to 9121, 9329

devil 8842

diaeretical method 9472, 9473, 9687

diairesis 9382

dialectic, Stoic 8836

Diaspora 8950, 9567, 9585, 9604

and Jerusalem 9112

use and meaning of the term 9383

view on 9572

- see also Judaism

Diaspora synagogue 9143

Didymus the Blind/ of Alexandria 8813, 8935, 9425, 9561, 9605, 9606

Diels, H. 9044

Dillon, J. 8965

Dio Chrysostom 8874

Dionysius of Halicarnassus 9677

Dionysius the Areopagite 9602

disciple, concept of 8871

divination $8710,8808,8809,8905$, 9010,9413

- see also prophecy

divine agent figures 8836

divine nourishment 9418

divine spirit 9554, 9555

divine spirit and inspiration 9553

divine voice 8934

division, central theme in $\mathrm{Her}$. 9453, 9663a

divorce 9451

Dodds, E. R. a8464

dogmatism, origins of 9274

Douglas, M. 9419

dove image a8679, a8692

doves a7134

doxa 9251

doxography 9044,9653

dreams 8946, 9584 and divination 9010

Greek theory of 9643

theory of 8710

tripartition of 8971

dualism 8939, 9213, 9251, 9635, a4208, a5528

anthropological 9315, 8746, 8788, 9045, 9359

central in Philo's thought 8841

cosmological 9045

of first and second God 8790 ontological a8694

Dunn, J. D. G. 9017

dynameis - see Powers

Ebionites 8804

eclecticism 8847, 9374, 9524, 9617

Academic, influence on Philo 8763

ecstasy 9441, 9529, 9643, a7243, a8551

and Plotinus 9260

poetic, and inspiration 9553

ecstatic prophecy 8873,8974

education 9684

Egypt 9518, 9604

and Alexandrian Jews 9068

and animal worship a8467

history of Jews in 9559

influences on Philo's thought 8744

Jews in 9154

prothumia in ideology of a8138

social relations in 9673

- see also Alexandria

Egyptian civilisation

attitude towards 87106

Egyptians

attitude towards 8851,9234 , 9236, 9263, 9282

Einstein, A. 9381

elements, four, not 'elemental spirits' 8866

Elias, N. 9529

Empedocles 9348, 9547

emperor worship 9611

encomiastic biography 9065

encomium 8801

encratism 9114, 9308

energeia 9620 
enkyklia and philosophy a6328

enkyklios paideia a8554

Enoch

heavenly ascent of 9312

interpretation of 9587

Enoch, second 9579

Epicureanism 9403

Philo's knowledge of 9020

epideictic literature 8958

epiphanies, Old Testament 9643

Epiphanius 8859

epistemology a7558

and language 8841

and phusiologia 9674

and politics 9438

not Stoic 8965

- see also knowledge

equality 9601, 9663a

erotic terminology 9434

Esau, interpretation of 9421, 9638

eschatological perspective 9504, 9511, 9512

eschatology 8831, 9038, 9143, 9212, 9452, 9572

absent from Philo 9502

and righteous gentiles 9016

political 8750

Essaioi 8859, a7751

Essenes 3017, 8812, 9235, 9423, 9601, 9622, 9635, 9649, a7856

and Essaioi 8859

and Essaioi 9309

and gymnosophists 9464

and H. P. Blavatsky 9468

and Magharians 8739

and the desert 8944

as readers of Philo 8739

influence on Philo 8919

Philo belonging to 8870

Philo's knowledge of 9265

reconstruction 8821

wisdom of 8903

- see also Therapeutae

Essenism

and Paul 8854

establishment violence 9574

eternity - see aiôn

ethical allegory 9207

ethical behaviour and providential

care 9438 ethical theory 9136

ethics 8762, 8948, 8959, 8972, 9041, $9250,9307,9358$, a7558, a8682

importance in Philo's thought 8850

personal speech- 9503

social, and creation 9324

ethnical strategies 9234

etymologies a6538

general account of Philo's use of 8829

Hebrew 8743

use of 9176

etymology

and exegesis 8774

eudaimonia 9371, a7858

Eudorus 8742, 9506

Eunomius 9272

Eupolemus 8920, 9579

Eusebius 1824, 8954, 9373, 9622,

$9675, a 7560, a 8049$

on Therapeutae 9369

Eve, interpretation of 9066, 9312a, 9606

evil 9308, 9403, 9552, a7649

origin of $8745 \mathrm{a}, 8848$

concord of 9174

exegesis

and inspiration 9553

and spiritual itinerary 9528

biblical, general account of 9072

biblical, influence on tradition

of biblical 9664

central role of 8966, 9059, 9076, 9439, 9508

charismatic 9475

early Christian, influence on a8698

Jewish, place in 9216

literal and allegorical 8946, 9043, 9213, 9287, 9526

medieval and patristic,

influence on a6124

metaphors for 9409

modes of, terms for 8771

principles of 9135,9659

scientific, genre of 9435

- see also allegorical exegesis/

interpretation/method 
exegete

Philo's view of himself as 9132

exegetes

earlier Alexandrian 9526

references to other 9131

exegetical method 9107, 9368

and 'secondary texts' 9168

and politics 8748

backgrounds of (scholarship on) 1409

general account of 9682

exegetical paraphrase 9504

exegetical strategies 8847, 8912

exegetical tradition

Hellenistic Jewish 8835, 9285

Jewish 8774

place in 9159

Exodus, Book of 8937

exodus, interpretation of the 9382, 9407, a7651

Exposition of the Law structure of 8966 system of 9617

Ezekiel 8724a

Ezekiel tragicus 8852, 8862, 9589, 9679

faith

and pistis 8926

concept of 8754,9353

psychology of 8749

relation to knowledge 8793

virtue of 8725

fall

and female 9455

interpretation of 9004, 9308, 9502

- see also sin, original

family, Philo's 9154, 9525

family values 9367,9368

farmers a7856

fasting 8726

fear of God 8703, 8928

fearers of God - see God-fearers

female gender, relation to Sophia denied 8827

female personifications 9655

female principle next to God a6643

feminine qualities - see woman

feminine virtues of the soul 9536 feministic exegesis a8692

Flaccus 8825, 9657a

Flavius Mithridates. 9479

flesh 8842

foetus a7133

food

fields of reference of terms for 9515

- see also bread

forgiveness 8936

of sins 9551

freedom a7246

as central theme in Philo 8945

Friedländer, M. 9051

Früchtel, L. 9165

Gadamer, H.-G. 87100, 8717

Gaius - see Caligula

Galen 9257

Ganymede, allegorical interpretation of 9014

Geerebaert, A. 1303

gender 9437, 9467, 9655, a8466

allegorization of 9536

Genesis, interpretation of, and gnosticism 9221

gentiles

and Jews 9474

differences from Jews 9406

righteous 9016

genus and species 8930,9136

geography

allegorizing of 9522

- see also topographical terms

geometry

as language pattern 9259

Germans, Philo's account of 9142

Girard, R. 9129

glory 9105

Gnostic synthesis 9578

Gnosticism 8938, 8939, 9019, 9221, 9255, a6229, a7444, a8557, a8679, a8693

and androgyny 9331

and Arian debate 9261

and H. P. Blavatsky 9468

and Philo in the Middle Ages 9204

and Philo's dualistic anthropology 9315 
and tripartition of men 8919

antecedent of a6643

Christian origin of 9052

comparison with Philo 9221

parallels with 9532

Philo's context near to 9665

relation to $9051,9219,9385$

similarities with Philo a8698

Valentinian a5527, a5827, a6125

- see also Valentinus

God

access to 9415

activity of 8764

and creation a7041

and kairos 9036

and Logos and Sophia. a3718

and nous 9654

and sexuality 8922

anger of 9344

as Being 9195

as benefactor a7132

as geometer 9259

as Giver 9324

as king 9189, 9358

as pilot of the cosmos 9668

as sôtêr 9359

attributes (masculine and

feminine) of 8838

concept of 9696

different from Plato's 9271

essence and existence of 9195 , 9305, 9421a

hands of a3718

imagery for 8922

immanence of 8764,9189

immutability of $8740,8758,9128$

impassibility of $8740,9128,9291$

in Platonism and Judaism 9377

ineffability of $9246,9279,9516$

interpretation of Exod. 3:14-15 9274, 9372

knowledge of as object $8863,9076,9189$, 9215

as subject a6539

love of (as subject) 9685

man's relation to 8862,9030 , a6761

Most High 8968

namelessness of 8841 naming of 8863,9651

nature of $8762,8764,9073,9440$ and being of a8675

One, topos of 9027

philanthropia of 9616, a5828

relation to ideas 9374 , a8672

relation to Jews 9608

self-revelation of a6539

transcendence of 8764,9014 ,

9189, 9307

union with 9304

unknowability of 8724,9017 , 9201, 9291

vision of 9508,9694

God-fearers 8856, 9123, 9231

- see also proselytizing

godlessness 9142

gods, pagan 9245,9345

Goodenough, E. R. 9248, 9312, 9337, 9574, 9647, a4817, a6641, a8465

and cherubim 8838

and Justin Martyr 8794

and mystery 8755

and Politics of Philo Judaeus 8748

on Philo's messianism 8750

Goodman, M. 9662

goods, doctrine of 8743

Gospel of Matthew, Mark, Luke, John - see under the individual names

Gospel of Truth 9261

Gottmann, J. 9656

Goulet, R. 9320, 9426

grace, concept of 9076,9387

Grail Legend 8903

Greek transmission of Philo's work 9270

Greeks, attitude towards 8851

Green, R. Arthur 9593

Gregory of Nazianze, influence on 9373

Gregory of Nyssa anthropology of a5826

attack on Philo's Logos conception 9502

De vita Moysis 9124

influence on 9373, 9526, a4408, a6639

on Exod. 3:14-15 9274

on heresy 9272 
on methorios a6123

on Moses in Midian 9630

on mystical union 9602, 9627

on the Egyptian plagues 8909

on union with God 9304

influence on 8746

relation to Philo (bibliography) 1301

Gulak, A. 9647

gymnasium 9405

gymnosophists 9464

Hagar, interpretation of 9618

Hagar and Ishmael, interpretation of 9513

haggadah a3719, a5924, a6536

relation to $9125,9319,9435$

haggadic elements 9071

in Moses nativity story 9317

hairesis 9569

halacha 1409, a5924, a6228a,

a7557a, a8550a

acquaintance with 9216

and Philo's allegorical method 9042

and Platonic concepts a5924

and sabbath 9230

on rulers 9007,9008

on slavery 9601

on violation of betrothal 9647

relation to 9319

halachic outlook, Philo's 9334

Hamerton-Kelly, R. G. 8781, 9406

hands of God a3718

handwork a8689

happiness - see eudaimonia, life (good)

Harl, M. 9047

harlots 9066

Harnack, A. 9428, a4817

healing, concept of 9244

hearing 9116

inner a7040

heaven 9116

division of 8912

heavenly bodies - see stars

heavenly realm, entering into 9312

heavens

and the sage 9228 unknowability of 9044

hebdomad 9011, 9560

Hebrew and Greek scripture, equality of 9564

Hebrew elements in thinking a5825

Hebrew language, knowledge of 8829, 8870, 9176, 9216, 9501, 9646, a6536, a6538, a8047

Hebrews

and Chaldeans 9292

use of the name 9608,9642 , a7747, a8696

Hebrews, Letter to the and Alexandria 8716

Logos concept in 9262

and Philo 87104, 8716, 8734, $8754,8797,8831,8901,9033$, 9192,9321

and Rome 8716

interpretation of Exod. 25:40 9354

relation to Middle Platonism a8256

relation to Philo 8865, a8048, a8465, a8552

Hegel, G. W. F. a5528

Heidegger, M. a8675

Heinemann, I. 9122, 9647

Heliodorus 9060, 9242

Hellenism

Judaization of a8556

- see also at Judaism

Hellenistic culture acculturation in 8953

Hellenistic Judaism - see Judaism

Hellenistic philosophy anthology of 3016

Hellenistic popular philosophy, agreements with 8767

Hellenists and Hellenistic Diaspora Jews 9589

Hellenization 9604, 9618, a8556 of the barbarian world 8720 of Christianity 9428

Hemsterhuys, T. 9060

Henoch, First (Ethiopian) 9472

Heraclitus the Presocratic 8915, 9446, 9596

Heraclitus the Stoic 9416 
heresy, Christian 9254, 9272

hermeneutical method 9382

hermeneutics 8724a, 9218, 9222, 9473,9682

diaeretical 9286

homiletic 9519

Hermetica 8846

and androgyny 9206

Poimandres 8775

Hesiod 9022

Hesychius, Epitome of 8784

hierarchy 9116

high priest 9138, 9411, 9413, 9573

vestments of 9625

- see also priesthood

Hilgert, E. 9172

Hillel 9647

Hippolytus 9254

Hirzel, R. 9649

historical events, biblical 9597

historical source, Philo as 8789 , 8796, 8902, 8962, 9235, 9325, 9326

historical writings, Philo's 8752

history

and allegorical method 8789

and haggadah 9435

and philosophy 8789

attitude towards 9338

Jewish, Philo as source for 8810

history of philosophy, Philo's place in 9046,9251

holy 8724 a

holy man, Jewish a8465, a8680

Homer 8751, 9360, 9411

homilies, Hellenistic-Jewish 9281

homosexuality 9411

negative attitude to 8706

hope 8725,9116

hortatory epistle 9583

hubris 9352

human kinship 9601

human life 9507

human rights 9412

hymns 9139

hypocrisy $8724 \mathrm{a}$

hypostasis 9411

'I am' sayings 9628

Ibn Ezra 9515, a8468

Ibn Gabirol a8468
Idea, meanings of the term 8708

Ideas

and personification a5825

as paradigms of the creation 8708

as Powers 8708

as thoughts of God 8708, 8969, 8773, 8948, 9039, 9047, 9161, 9365, a8672

relation to God 9374

ideas, theory of 8814,9628

and genus-species hierarchy 9136

and H. A. Wolfson 9047

transformation of 9439

ideological criticism 9527

idolatry 9173, a8695

'Iggereth Hakodesh a6229

illness 9244

image

metaphysics of the 8709

theory of 9126

immanence 9628,9655

immortality 9315,9418

as reward for the soul 9038

imprint, imagery of 9330

incarnation 9663, a8048

inclination, bad 9402

India 9464

Indian sages 8864

indices and computer 9060

infanticide 9267

inner human, metaphor of the 9341

inspiration 9441, 9553, 9582

Greek views on 8811

incongruous conception of a8687

of Scripture 8811, 9111, 9216

of the Torah 9135

Philo's 9132

prophetic, mechanical concep tion of 9050

theory of 9682

- see also prophecy, prophet(ic),

Septuagint

intellect - see nous

intelligible cosmos and man 8966

Internet, Philo on 3401, 3402

intuition 9651

invective 8958 
Irenaeus 9660, a3718

Isaac

interpretation of 9584,9595

sacrifice of, interpretation of a7750

Isaiah 9628

Isidore of Pelusium 9169, 9275

Israel

and 'seeing God' 9508, 9608

as chosen people 9338

concept of 8950

concept of, and 'Jews' 9311

interpretation of 9576 , a 8682

list of tribes of 9055

restoration of 9572

use of the name 9608, 9642,

a7747, a8696

Jacob

dream of, interpretation of 8858,8971

interpretation of 9576 , a7245

list of sons of 9055

wrestling with Angel, interpre tation of a8137

Jacob and Esau, interpretation of 9411

Jacob Qirqisani 9479

James, Letter of 9503

Jauss, H.-R. 9282

Jeremiah 9628

Jerome 9576, 9622, 9675

and Philo 9373

Hebrew Questions on Genesis 9347, 9537

on Philo 8817

Jerusalem 8931, 9572

and Diaspora 9112

Jesus

and Moses 8799, 9615

as lawgiver 8875

Matthew's, and Philo's Moses 9065

on oaths and vows 9145

Jewish

authenticity, Philo's a7749

elements in Philo (scholarship on) 1409

identity

in the Diaspora 9604
Philo's 8851, 8870, 9155,

9169, 9236, 9319, 9336, 9533

nation, as Philo's life-

setting 9572

traditions and Philo 9373

Jews

and gentiles 9474

and Greeks 9234

concept of, and 'Israel' 9311

Gentile descriptions of 8753

in Egypt 9154

use of the name 9608,9642 , a7747, a8696

Joel, M. 9053

John, Gospel of and Moses 8799, 8852

and sabbath 8806

and sabbath 9108

and seven days of creation 9623

and temple 8806

on divine spirit 9555

Prologue of

and Jewish-Alexandrian

culture 9284

and Logos a8048, a8669,

a8679

and Logos as $a$ God 9310

and Wisdom speculation

9069

differences from Philo 9502

relation to Philo 9262, 9323, 9333, a5825

relation to Philo 8782,9108 , 9612

wedding at Cana, and creation account 9517

John, Revelation to 9609,9611 , 9613, 9615, 9683

Joseph

and Potiphar's wife 9011

and prophetic spirit 9554

as diviner 9413

as man of politics 9518

interpretation of 9137, 9251, 9263, 9584

Joseph and Aseneth 8711

Josephus

and anti-Jewish account of Moses 9282

and charismatic exegesis 9475 
and history of culture 8920

and Legat. 9115

and natural law 9510

and Roman rule 8747

and universalism 8711

Antiquitates, relation to Philo 9119

Contra Apionem 8767

and Philo's Hypothetica 9006

credibility of 8796,9326

on 'worship of angels' 8866

on a God-fearer 9123

on Bible 9633

on Caligula 8956

on diathêkê 9679

on Essenes 8812, 9309, 9423, 9635,9649

on faith 9353

on hubris 9352

on Jews in the early Empire 8753

on misanthropy 8819

on Noah 8823

on pagan gods 9245

on Pilate 8973, 9151, 9278

on sacrifice of Isaac a7750

on Sarah 9181

on tabernacle 8932,9164

on the Land a8669

on Tiberius Julius Alexander 9037

on violation of virgin 9429

parrêsia in 9302

Philo's influence limited 9063

references to Philo 3215

relation to Philo 8824,8934 , 9579

summary of the Law in 9314

use of diaspora 9383

use of Philo 9634

views on Judaism 8702,8760

vocabulary of 9167

Joshua b. Hananiah, R. a7243

Judah Halevi 9372

Judaism

and Christianity 9585

and Hellenism 8864

in Philo 9073, 9433

scholarship on 1409
- see also synthesis; Judaism,

Hellenistic

and Hellenistic religions 8760

and philosophical religion 9522

and Platonism, basic orienta-

tions of 9562

anthropological interpretation

of 9018

as missionary religion 9227

contrast with Hellenistic

philosophy 9027

contribution to 9238

convergence with Platonism 9381

Hellenization of a8556

older than Greek culture 9053

pagan reaction to 8702

Philo's Nachleben in 9479

Philo's place in 9593, a7040

Philo's views on 9608

- see also Judaism, Philo's

Judaism, 'common'

and Philo's 9447

Philonic evidence for 9277

Judaism, Alexandrian 9325, 9621,

9647

and gnosticism 9051

and oikoumene 9268

self-identity of 9580

Judaism, Diaspora 9228, 9277, 9325, 9589

and Jewish Law 9061

and Palestinian, relation

between 9326

beyond Alexandria, relation to 9579

Philo as representative of 9336

unity of 8729

Judaism, Hellenistic

and early Christianity 9610, a8680

and Philonism a8465

anthology on 3019

scholarship on 1408

significance of 9691

tradition and innovation in 9038

and Palestinian, relation to 14 , $8728,8967,9070,9220,9519$, 9520, a3719, a6536 
and Rabbinic, opposition to 8737, 9312a

Judaism, Middle instrument of research on 1407

Judaism, normative, Alexandrian version of 9519

Judaism, Philo's 9205, 9539 and Rabbinic 9556

Jewish dimension of 8722,9073 , 9070

Judaism, pre-Christian, not monotheistic 9202

Judea 9634

justice, principle of 9182

Justin Martyr 9688

influence on 8794, 9243

on Abraham 9527

on Gen. 2:7 and immortality of the soul 9355

on Logos a4817, a5825

on Logos and Pneuma a7950

on theophanies a5824

on pre-existence of Christ a7654

Justus of Tiberias 9579

Kabbalah 8838, 9386, 9562, 9695, a7557a, a7749

kairos, twofold interpretation of 9036

Karaites 8739, a8463

Kasher, A. 8789

kashrut, and rulership 9007, 9008

Kellia, monasteries at 9369

Khorenats'i, Moses a7861

king

and architect, image of 8952

Hellenistic ideology of 9650 , a6641

kingdom of God, sapiential interpretation of 9115

Kingsley, Charles 9155

Klein, F. N. a6643

knowledge

desire for 9434

human, and divine revelation 8735

of self, and anthropology 8759

relation to faith 8793

theory of 9651

- see also epistemology
Koester, H. 9510

Kraabel, A. T. 8856

labourers 9601

Lampo a8555

land theology, biblical a 8669

land, interpretation of the term a7440

language

and geometry 9259

and the sexes 9066

concept of 9035

general account of views on 8841

mystical philosophy of 9562

philosophy of 8841,9651

theory of $9194,9213,9222$

Latin translations 9141, 9346

law

and creation 9658

and halakhah a6228a

living as opposed to written 9443

natural 9324, 9510, 9530

of the cosmos 9414

unwritten 9256

unwritten and (Rabbinic) Oral

Law 9520, a7557a

unwritten, and law of nature 9520

written and 'higher' 9146, 9147

written and unwritten 9510 , 9530

- see also nomos

Law, Mosaic (or Jewish)

adherence to $8722,9103,9146$

allegorical approach to 8703

and angelology 9659

and Diaspora Judaism 9061, 9070

and 'higher' law 9146, 9147

and natural law 9238, 9510

and Nature 9640

and oral law 8722

and Roman law a8047

and the Patriarchs 9339

attitude towards 8834, 9533, 9647

establishment violence against

non-conformity to 9574

Greek version of 9450

interiorized 9535 
observance of 9526, 9580

observed by Patriarchs a7561

on purity 9652,9690

summations of 8767,9314

universal meaning of 9414,9589

vs. Plato 9341

Law, Oral, ignorance of 8870

laws, dietary 9427

Leah

allegorical meaning of 8745

legal status of Jews in Alexandria 9604

Leisegang, H. 8961

index 9060

Leone Ebreo 8701

Leontopolis 9673

Leopardi, G. a8673

and Armenian translation 8712

letter

and 'soul' of the text 8815,8929

and logos (reason) 8845

Letter of Aristeas 9135, 9450, 9501, 9593, 9690, 9691

Levites interpretation of 8713

Leviticus 8833

Libelli, Lilio Egidio 8839

liberty 9601

Lieberman, S. a5924

life

ages of 8842

good 9676

taking human life 9507

light

and cognition and

knowledge 8841

and silence 9651

metaphor of 9562, 9643, a7558

theme of 8945

Lilius Tifernas 9346

literal meaning

and Rabbinic peshat 9408

- see also exegesis, literal and

allegorical

literary quality of the Bible 9543

liturgical songs 9139

logos

and nous a5825

as equivalent to nomos 9442

logos spermatikos a5825 logos tomeus 9011, 9663a

Logos

as Name of God 9261

key concept to Philo 8969

Logos, logoi - see also angel(s)

Logos (as hypostasis)

and Angel of Jahweh a4817

and angels 8916

and Christian Logos 9262

and division $9663 \mathrm{a}$

and epistemology 9472

and gnosticism 9221

and God 9005

and God's activity 8764

and hypostatization a5825

and language 9651

and Letter to the Hebrews 9362

and Milton's Paradise Lost a8676

and miracles 9117

and monotheism 8836, 9663

and Prologue of John 9069, 9284, 9310, 9323, 9332, 9362,

9502

and Sophia a6643

and the contemplative life 8872

and Theophilus of Antioch 9258

and world-soul 8765

anointed by the Spirit a6125

as bridge but not independent entity 9333

as creator 9195

as heavenly figure a7653

as instrument in creation 9658 , a6841

as intermediary 9113, 9201, a4608, a 8669

as place 9681 , a6643

as second god 9202, 9310

between God and creation 9017

concept of 8762

doctrine of 8862

generation of a7950

in Gregory of Nyssa and

Philo 9502

in Justin and Philo a4817, 9243

man's assimilation to 9030

nature of 9440

not as intermediary a8048

procession of $\mathrm{a} 5827$ 
Logos doctrine 9279, 9524, 9557, a4608

and Arius 87103

and biblical thought a6327

and high priest 9138, 9175, 9413

and image, concept of 9009 and philosophy of language 9562

general account 9229, 8770

Platonist background of 8918

secular origins of 9378

in medieval Jewish mysticism 9695

Logos tradition 8915

Loisy, A. 9332

Loofs, F. a3718

Lot, daughters of, interpretation of 9660

love

God's 9685

of God, as mystical experience 8703

of self 9523

of self and of God 9047

Lovejoy, A. 9684

Lucan 8972

Lucian a8555

Lucretius a7559

Luke, Gospel of establishment violence in 9574 repentance in 9306

Luzzatto, Simone 8791

Lysimachus 9068

Lysimachus, uncle/nephew of Philo 9525

\section{Maccabees}

Second Book of 8752

Third Book of 8857

Fourth Book of 8825, 9579, 9593 and eschatology 9038 and passions 9401,9529 image of contest in 8917

Mack, B. L. 8781,8966

Macrobius a7439

macrocosm microcosm 8912

Magharians 8739

magic 8809, 8905

Maimonides a8675 male and female 9004, 9048, 9066, 9190, 9206, 9367, 9437, 9467, 9655, 9684, a8466 in five semantic areas 9455 man

and intelligible realm 8966 and reason 8921 as image of God 9005, 9201 as intermediate figure 8761 , $8762,8844,8849$

as intermediate figure (methorios) 9048, a6123 as the 'double' of God 9424 classes of men 8919 concept of 8762,8862 creation of $8746,8813,8855$, 9541, 9581

creative power of 9208 destination of 9109 double creation of 8846,8935 , $9109,9605, \mathrm{a} 4408$, a5826 dual nature of $9689,9308,9546$ dualistic conception of 8759 , 8761

earthly and heavenly a8694 pneumatic and earthly 9541 relation to God, man, and nature 9182

relation to sense-perceptible world 9523

relation to woman 8935

sovereignty over animal and nature 9511, 9512

Stoic-synthetic conception of 8759

- see also anthropology

Mangey, T. 1827

Manicheans 9204

Manilius a7649

manna 9381, 9418, 9544

mantic, terminology of 9111

Marcellus of Ancyra 9459

Marcionites 8939

Mark, Gospel of and De vita Moysis 9120

Marqah a8136

marriage 8921, 8935, 9004, 9048 mystical or spiritual a6229, a6639

Martens, J. W. 9319 
mathematics

and music 8736

matter

and problem of evil $8745 a$

created and pre-existent 9057

eternity of 8870

pre-existent 9480

Matthew, Gospel of 8911

'disciple' in 8871

and De vita Moysis 9065

Maximus of Tyre a6123

May, G. 9626

Mayer, G., index 9060

measure, number and weight, concept of 9658

mediatorial figure: see Logos

mediators of God's providence 9244

medicine in Alexandria 9577

megalopolis 9656

Megasthenes 9464

memory 9107

Mesopotamia 9518

Messiah 8869, 9249

messianic expectations 9452, 9572, 9601

messianism

no interest in 9338

Philo's 8835, 9211, a8670, 8750

metaphor

and allegory 9356

metaphysical realm

novelty of 9456

metaphysics apophatic-kataphatic 9506

Methodius of Olympus 9425

methodology, how to approach Philo 8945

metonymy and allegory 9356

Meyer, P. a8555

Middle Ages, knowledge of Philo in 9204 , a8468

Middle Platonism and creation 9283

and interpretation of Scripture 8830

and Letter to the Hebrews a8256

and prophecy 8905

and Stoicism 9692

and transcendence 9291

history of 9047 influence on Philo a8674

on categories of being 9506

psychology of 9251

Philo's relation to, scholarship on 1405

relation to $8731,8742,8765$, $8907,8918,9161,9215,9257$, 9320, 9341, 9374, 9377, 9380, 9386, 9632

transformation of a5825

midrash 9381, 9408

and allegorical method 8717 , 9043

joint Palestinian/Diaspora 9625

of Philo 8904, 8910, 9220, 9520

on Moses nativity story 9317

on Noah 8823

on virtue 9318

relation to $8781,8814,8818$, 9519,9520

- see also Rabbinic interpre tation

migration, as central theme 2406, 8703, 8906, 8916, 8945, 8972, 9047, 9439, 9456, 9591

migration of Abraham, interpretation of 9382

Milton, J. a8676

mind - see nous

miracles 9117

misanthropy 8819,8851

missionary activities 9233

- see also proselytizing

missionary consciousness in

Judaism 9662

missionary religion, Judaism as 9227

monad a7439

monarchia 9688

monarchy 9019, 9189

monasticism 9224

and Therapeutae 9369

monism a 4208

monotheism 8702, 8836, 8863, 9010, 9019, 9027, 9202, 9247, 9608, 9614, 9663

monotheistic corrections of texts 9303

Montaigne, M. de 9422

Moore, G. F. 9193 
mortality and sin 9343

Moses

and apatheia 9401

and heavenly ascent 9644

and Jesus 8799, 8875

and prophetic spirit 9554

anti-Jewish account of 9282

as 'great name', testimonial use of 9535

as divine agent 8836,9106

as god and nous 8862, 9030

as legislator, sage, prophet 8937

as man of politics 9518

as Middle Platonist 9377

as mystagoge and hierophant a6539

as philosopher $8847,9259,9410$, 9501

as philosopher king a7859

as prophet $8873,8974,9073$, 9501, 9643

as sage $9073,9189,9529,9595$

as thaumaturge and more 9670

as wonder-worker 9049

authority of 8803

birth of, tradition concerning 9666

central role of 9556

death of 9550

figure of, manipulation of 9203

heavenly ascent of 9312

in early Christianity 8868

in Midian, interpretation of 9630

in Philo and other Jewish sources 9534

interpretation of 9615

nativity story 9317

older than the Greeks 9053

Philo's, and Matthew's Jesus 9065

relation to the land a8670

Moses-doxa tradition 9105

Muratorian canon 9431

music, Philo's views on 8736,9140

mysteries and revelation 8907

terminology 87101, 8779, 9331,

9419, 9643

mystery cults

and Judaism 8755 influence of 8811

mystic, as sage 9074

mystic, Philo as 9624

mystical expressions 9681

mystical knowledge 8907

mystical union 9438

mysticism 8835, 8872, 9073, 9107, 9590, 9593, 9602, 9627, 9694, a5924, a7041, a8683

and exegesis 9475

and Law 9640

and Logos theology 9279

and Plotinus 9260

and prophecy 8873,8974

Hellenistic philosophic, Philo's a8465

in Philo's thought 87100, 8719

influence on Middle Ages 8903

medieval Jewish 9695

Philo's, as foundation of

Christian 9152

Rabbinic, as distinct from

Philo's 9337

myths, attitude towards 9288

Nachmanides a6229

Nadab and Abihu, disappearance of, interpretation of 9565

Nag Hammadi 9470, 9665

nationalism 9572

Nature

and Law 9640

personification of 9655

Nechepso-Petosiris a7649

negative theology 9516, a7041

and catachresis 9289

attributes of God in 8756

Philo's contribution to 9279 , 8742

principles of 8724

survey of representatives 8756

Neoplatonism

and ineffability of God 9246

and literal meaning 8845

and prophecy 8905

and Trinity 8918

influence on 9170

Neopythagoreanism 9291

and problem of evil $8745 \mathrm{a}$ 
New Testament

and Hellenistic culture 9262

contrast with pagan philosophy 9362

relation to $8738,8806,9373,9470$

New Testament studies

Philo's value for 9226

Nicholas of Damascus 9265

Nikiprowetzky, V. 8781, 8912, 8936, 8966, 9047, 9290, 9671

Nimrod, interpretation of 9071

Nitschke, A. 9529

Noah, interpretation of 8823,8846

Noahide laws a7561

nomenclature used to describe

Philo 9461

nomistic paradigms 8860

nomos

as equivalent to logos 9442

- see also law, Law (Mosaic)

nous

and feminine qualities 9425

and logos a5825

and logos and aisthêsis 9692

and pneuma 9681

and sense-perception 9655

as charioteer 9548

as name of God 9654

divine nature of 9030

doxography on 9044

in movement and repose 9331

limitations of a7041

timelessness of a7041

vs. sophia 9439

- see also soul, reason

novel, Philo in 9657a

number - see arithmology

Numenius 9170, 9257, 9260, 9377, 9386

oath 9649

oaths and vows 9145

obedience, ethic of 8972

offerings, priestly 8727

oikoumene 9268

old and new, attitude towards 9053

One God topos 9535

One, the $8724 \mathrm{a}, 8845$

onomastica 8829

ontology, and interpretation Exod.

\section{3:14 9047}

Origen

and allegorical method 9207

and exegesis of Gen. 3:21 a8698

and Philo's De somniis 9157

and synkatabasis (anthropo morphism) 9344

citation of Philo 9430

difference with Philo a5022, a6124

exegesis of topographical terms 9328

influence on 9373, 9526, a6022, a7442, a7650

library of 9675

on 'feminine man' 9425

on allegory 9375

on androgyny 9206

on body and soul of Scripture 8929

on categories of being 9506

on creation of man 8813

on Egyptian plagues 8909

on forgiveness of sins 9551

on Gen. 1 a7351

on literary quality of the Bible 9543

on Logos a6327, a6841

on man as methorios 9048

on material and spiritual world a5528

on mystical union 9627

on original $\sin 8842,9605,9606$

on pre-existence of the soul 8715

on prophecy 8905

on sacrifice 8843

on spiritual struggle 9576

on stars 8963,9177

on teleological ideals 8942

on theophanies a5824

on virtue, grades of 9014

references to Philo 9273

relation to Philo 8858, 9197

spirituality of 9551

originality 9582

Orpheus, Testament of 9370

Orthodoxy, and Logos 9440, a8669

orthodoxy, Philo's 8851

Otte, K. 8841, 9651

Otzen, B. 9336 
pagan cults, attitude towards 8957 , 9405

Panaetius 9558

papyri 1825 , a7856, a8139

Paradise, rivers of, interpretation of 9136

paraphrase, exegetical 9504

parent-child relationship 9367

participium $=$ participatio 8805

Pascal, B. 9372

Pascher, J 8779

passions 9529,9584 mastery of 9401

Passover

date of a7752

interpretation of a7651

Patriarchs

allegorical meaning of a8554

and Law a7561

and politics 9518

and the Torah of Moses 9339

as propaedeutic types 9148

interpretation of 8949

patristic hermeneutics 8814

Paul

and Abrahamic Tradition 8860

and Alexandrian sophists 8874

and allegory 9213,9528

and charismatic exegesis 9475

and dunamis 9024

and homosexuality 8706

and Mosaic Law 9146

and Philonism 8854

as ideal philosopher 9410

Colossians, and answer to gnosticism 9532

comparison with Philo 9076

context of, comparison with

Philo's 9592

1 Corinthians

and hermeneutics 9473

and spirit 9687

relation to Philo 9571, 9592, a8694

cosmological statements in 9661

difference with Philo on dietary laws 9427

differences with Philo 9415

doctrine of Scripture 9075

Galatians and Abraham 9404, 9590

and curse 9156,9449

and interpretation of Hagar

and Ishmael 9513

hermeneutical method 9382

mysticism of 9064

on 'in Christ' 9681

on Abraham 9527, a8690

on Adam and Christ 9062

on body and sexualtity 9214

on conscience 9436,9619

on grace 9076

on passions 9529

on prophecy a 8551

on silence of women 9542

on slavery 9601

on telos a8550

on the goal of the Law 9188

parallels with Philo a8685

Romans

and apologetic tradition 9535

10 , and exegetical method

9504

and Philo 8822

sentence length distributions in a6642

Pelletier, A a8555

Pentateuch

and Old Testament 9050

centrality of 9350

quoted percentage 9597

special status of 9564

- see also Torah

perfection 9630

Pergamene school 9416

periodic composition

- see composition

Peripatetic doctrine of goods 8743

peristasis catalogue 8786

perjury 9574

persecution 9611

peshat 9408

pesher, pesharim 8818, 9121

Peter, Second Letter of, doctrine of

Scripture in 9075

Petit, F. 9133, 9165

Pharisees 8845

on oaths and vows 9145

philanthropia 9616

philanthropy 9182, 9601 
Philo

general account of, in

English 87105, 8766

short introduction to

in Dutch 8925, 8953

in English 8855, 9210, 9235, 9364, 9469, 9682, a8253

in French 9624, a8683

in German 9042

in Hebrew a5526

in Norwegian 9209

in Spanish 9585, a6024

introduction to, from Jewish perspective 8867

philosophical thought of, introduction to

in English 9056, 9693

in French 8835

in German 9676

in Hebrew a7749

in Italian 8776, 9307

in Spanish 8733

religious thought of, intro duction to, in English 8872

research in, instrument of 9659

thought of, introduction to, in

English 3018

historical novel on 9657a

historical role and meaning of a7444

Philo Alexandrinus, Judaeus and other names 9461

Philo Christianus 9373

Philo the Epic Poet 9589

Philo, other men with this name 9461

Philo studies in the Far East 9696

Philolaus a8141

Philonism 9274, a8465

philosophia ancilla theologiae 9439

philosophical goal, Philo's 8850

philosophy

Alexandrian Jewish a7749

and Christian faith 9618

and Hebrew thought 9201

and moral progress a8554

and phusiologia 9674

and religion a6328

and revelation 8733

and Scripture a8556 and theology 9438

and wonder 8914

Greek

and Hebrew a7040

and Philo (scholarship on)

1409

influence of 8847

relation to 9524

Hellenistic Jewish 9693

Hellenistic, anthology of 3016

Jewish a6122

meaning of the term 9318

Philo's systematic 9617

Philo's, and mysticism 8872

tension with religion 9594

theft of a7859

Phineas and the Midianite women, interpretation of 9183

Photius 8784, 9478

phusiologia 9674

physics 9250

piety, and virtues 9318

Pilate 8825, 8973, 9151, 9278, 9549, 9583, 8768, 9677

Pinehas 9574

plagues, Egyptian, interpretation of 8909

Plato

and androgyny 9536

and concept of truth 9349

and concept of woman 8701

and condemnation of homo sexuality 8706

and 'feminine man' 9425

and male and female 9536

and music 8736

and Philo, proverb about 9067

and prophecy 8873,8974

and self-love 9523

and soul 9596

and spiritual childbearing

9536

influence on Philo 8746

vs. Torah 9341

works

Epinomis, and angels 9413

Euthyphro 12e-15a 9335

Phaedo

on philosophy as religion a6328 


\section{Phaedrus}

and angels 9413

and the charioteer of the soul 9548

myth a 8140

Sophist 9149

Symposium

erotic terminology in 9434 mystery language in 9419

Timaeus

and Apocryphon of John 9667

and creation 9285

and excellence of the cosmos 9271

and LXX Genesis 9460

and Sophist 9149

encomium of light in 9644

history of interpretation of 9457

interpretation of, and Justin on Gen. 2:7 9355

influence of 9674

on heavenly spheres 9686

on time and aiôn a8254

Philo's Stoicized interpretation of 9458,9566

Platonism

and allegory 9416

and concept of creation 9480

and concept of God 9189, 9274, 9377

and cosmos, four principles of 9603

and evil 8745a, a7649

and exegesis of Genesis 9045

and Judaism,

basic orientations of 9562

convergence with 9381

and negative theology 9516

and prophecy 9505

and silent prayer 9432

and soul, division of 9401

and vision of God 9508

and woman 9022

as Philo's main source 8853 , 9307

called Pythagoreanism 9569

ethics a8135

influence on Christian thought 9618 influence on halakha a5924

Jewish Alexandrian 9161

mystical, Philo's 9073

Philo's 9558

scholarship on 1405

Philo's contributions to 8948, 9365

- see also Middle Platonism

Platonism, history of Philo's

place in 9149

pleasure $8935,9403,9637$, a7558

Plotinus 8773, 9152, 9684, a7858

and concept of God 9246

and divine transcendence 9331

and excellence of the cosmos 9271

and ho hestôs 9170

and tripartition of men 8919

and unification with the One 9260

and virtue, grades of 9014

polemic against biblical philosophy 9331

pluralism, Philo's 9320, 9377

Plutarch 8726, 9377, 9554, 9692, a7748

on angels and miracles 9117

on excellence of the cosmos 9271

on man as methorios 9048

on prophecy 8873,8974

on virtue 8861

vocabulary of 9167

pneuma a7950

and early Christian

theology a7245a

and nous 9681

vivifying 9689

- see also spirit

pneumatikoi a8685

pneumatological reading of Gen. 2:7 9454

Pohlenz, M. 8961

political allegory 8748

political commentary 9007, 9008

politics

and the Patriarchs 9518

criticism of 9518

Philo's 9438, 9452, 9546

politics, man of, nature and role of 8946, 9263 
Porphyry 8781, 8918, 9327, 9378

Posidonius 8783, 9039, 9423, 9558, a7649, a8255

possession, divine 9643, 9694

power 9024, 9415

Powers

and cherubim 9686

and creation 9048, 9456

and God's activity 8764,9189 , 9305

and God's kingship 9358

and ideas 8708

and mercy 9316

and salvific intervention 9359

praeparatio evangelica motif 9433

prayer $8872,9175,9418$

communal, fixed 9021

petitonary a8380

silent 9432

pre-existence 8842

pride 9116

priesthood 8865, 9175, 9249, 9573

- see also high priest

prisoners of war 9601

Proclus 8845, 9152, a8140

procreation 8913, 8935, 9018, 9190, 9637

progress, and telos 8762

propaganda techniques 9144

propagandistic motives 9194

prophecy $8808,8809,8905,8907$,

a7949, a8551

'hyparic' 9505

and hearing a7040

and inspiration 9111

and politics 9518

ecstatic 9441

ecstatic and noetic 9073

false 9574

Greek theory of 9564

in De vita Moysis 9505

kinds of 8873,8974

prophet

as instrument of God 9050

conception of 9413

prophetic inspiration 8960

prophetic spirit 9554, 9555

Prophets, Old Testament, Philo's

view of a8671

proselytes $8941,9016,9027,9103$,
9311, 9404, 9513, 9608

proselytism 9326, 9614, 9662

proselytizing 9144, 9193, 9227, 9233, 9290

- see also God-fearers

protological perspective 9511, 9512

protreptic apologetics 9535

protreptic elements 9371

Providence, in Flacc. 9438

Pseudo-Archytas 9506

Pseudo-Aristotle 8795

Pseudo-Justin 9459

Pseudo-Justin 9370

Pseudo-Longinus 9579

Pseudo-Okellos 8795

Pseudo-Philo 1305, 9645

Biblical Antiquities, on Noah 8823

De Jona 9281

De Sampsone 9281

homilies 9281, 9465

in the Middle Ages 9204

Pseudo-Phocylides 8767

Pseudo-Plutarch 9416, 9653

psuchê and pneuma 9689

psychology

Hellenistic Jewish 8749

moral a8682

of opinion (doxa) 9251

Philonic 9251

purification, ritual 8936

purity and impurity 9652,9690

Pyrrhonism 9422, 9531

Pythagoras 1302, a7439

on male and female 9190

Pythagorean

Philo as 8903, 9569

schema of three types of life 8919

Pythagorean monastery 9327

Pythagorean number theory a3818

Pythagoreanism 9649 and music 8736

Pythagoreans and Essenes 9309

Pythogarean procreationism 9636, 9637

Qohelet 9593

Quine, W. v. O. 8717, 9218

Qumran 9470, 9635, 9673 
and charismatic exegesis 9475 and Essenes 9265

and Letter to the Hebrews 8831

community of 9228 and repentance 9306

Damascus Rule and Thanksgiving hymn 9409

on oaths and vows 9145

scrolls 8739, 9121

Temple Scroll 9429

- see also Essenes

Rabbinic allegory a3719

Rabbinic evidence on Gnosticism a8693

Rabbinic interpretation and Greek terminology a5316 comparison with Philo's 9122, 9213, 9214, 9412

influence on 8955

of body and sexuality 9312 a

of divorce 9451

of proselytes 8941

of spiritual food 9381

of the song of Abraham 9476

of Yom Kippur 8726

- see also midrash, haggadah, halakha

Rabbinic Judaism

and attack on Philo 8737

and Philonic exegesis a5924

and rejection of Philo a7859

Rabbinic thought

Moses in 8852

pre-existence of Torah in 9509 relation to a5924

Rabbinic tradition 8951, 9408

and Greek terminology a7243

parallels with 8934

Philo part of a6122

views on prophecy a7949

Rachel, allegorical meaning of 8745

Radice, R. 8781, 9046, 9047

Ramban 9515

Rashi 9515

rationality 8959,9307

and reality 9382

as a problem for Judaism 8791

Reale, G. 9047 reason

and Logos 9005

authority of 9068

maleness of a8466

two types of 8965

- see also nous

Rebecca

interpretation of 9066, 9659

reception, Philo's 9682

in later European thought 9588

in modern Judaism 9593

refuge, cities of, interpretation of 8703, 8908

Reiter, S. 9438

religion

and philosophy a6328

Jewish and philosophical 9522

religious thought and psychology 8749

Renaissance

Philo's reception in 9588

repentance 9073, 9103, 9306, 9594

reproductive fertility - see procreation

resurrection of the body and mysteries 87101

no room for 8788

retribution 9038, 9658

revelation

and human knowledge 8735

and rationality 8959

concept of 8907

divine voice of 8934

rhetoric 9670

Alexandrian 9266

and allegory 9357

and pragmatologeîn 8780

encomium 8801

general account of Philo's 8723, 9001

grammatical and stylistic

features 8723

Greek, and concept of faith

8754

role of $8723,9101,9102$

- see also structure, rhetorical

Ricoeur, P. 9357

Rijk, L. M. de 87100

rock, divine wisdom as 9322, 9351

Roman citizenship, Philo's 9525 
Roman law 9647

and Jewish law a8047

Roman rule and royalty of God 9189

attitude towards, Philo's 8747, 9028, 9338, 9533, 9611, a6641 attitude towards, Josephus's 8747,9028

\section{Romans}

and Jews a8553

Rossi, A. de' 8870, 8967, 9588, 9593

Runia, D. T. $1405,9257,9289,9320$, 9430, 9471, 9477, 9479, 9618, 9668

Saadia ben Joseph 8735,9479

sabbath 9108, 9230, 9463

and Alexandrian Judaism

8806

centrality of 9334

conception of 9191

Philonicevidence on 9252

sabbath crisis 9137

Sacra Parallela 9165

sacrifice $8707,8726,8843,8872$, 8936, 9175, 9316, 9359, 9659

and halakhah a7557a

sage

and healing 9138

as mystic 9074

as stranger 9228

Stoic, and Moses 9595

superiority of 9189

Sages

and Philonic exegesis a5924

salvation 9114,8705

and male and female 9004

through asceticism 8903

Samaranch, F. de P. 8940

Samaritan interpretation of Moses 8799

Samaritan philosophy a8136

Samaritans 8852

Sanders, E. P. 9447

Sapientia Salomonis 8937, 9593, a8678

and eschatology 9038

and Muratorian canon 9431

and pneumatological reading of

Gen. 2:7 9454 on creation and retribution 9658

on Divine spirit 8721

on the exodus 9407

on manna 9418

on pagan cults 8957

on psuchê and pneuma 9689

on the sage as mystic 9074

on the tabernacle 8932

Philonic authorship of 9544

relation to 8835,9658

Sarah, interpretation of 8827,9066 , 9181, 9136

Sarah and Hagar, interpretation of 9150,9618

Saussure, F.de a8688

scepticism 9629, a8549

Schlatter, A. 9353

Scholem, G. a6229

school of Philo (alleged) 9556, a8465

Scripture

authority of 8803,9068

canon of 8970,9050

coherence of a8688

doctrine of 9075

Philo's attitude to 8803,8814

senses of a5022, a6124

use of 9350

seal, metaphor of 9562

Seianus 9549

semiotics 9259

Seneca 8773, 9436, 9506, a7439, a7858

sense-perception, personification of 9655

sentence length distributions a6642

Septuagint 9633

and allegorical exegesis 8832

and law on injury to pregnant woman 9034

and Masoretic text 8802

and other Greek translations 8802

and Philo's philosophy 8835

and Philonic exegesis 9340

attitude to biblical translation 9217

authority of 8803 
bibliography on 1304

inspiration of $9450,9501,9564$, a8697

legend of origin of 9450,9501

origins of 8832, 9460

praise of 9194

text of 9350

translation of Pentateuch 9135

use of alêtheia 9349

Genesis 9460

Deuteronomy 9225

Numbers 9417

- see also Bible

serpent 9403,9586

serving God 8928

sex-polarity, in Aristotle and Philo 8701

sexual conduct 9636,9637

sexual impropriety 9352

sexual intercourse, and meta-

physical knowledge a6229

sexuality $8921,8922,9011,9022$, $9107,9214,9312 a$, a5826

Shema 9520, 9625

Shepherd of Hermas 9555

shepherd, interpretation of 9116

Shih Ching 9591

Sibylline Oracles 9579, 9589

on One God 9027

Sichard, J. 9622

Siegfried, C. a8554

Sifre to Deuteronomy 9121, 9329

silence 8841, 9651

expressive value of 8724

requisite for the spiritul journey 9542

Silvanus, Teachings of 9197

sin

and mortality 9343

intentional and

unintentional 9607

original $8842,9308,9402,9605$, 9606

Sirach, Wisdom of Jesus (ben) 8937, 9562

Skarsten, R. 8781

slave and free 9684

slavery $9421,9601,9638,9659$

slaves 9412 , a7856

sleep, metaphor of 9678
Smallwood, E. M. 8789

social life 9680

social life of 1st cent. CE a3015

social order, attitude towards 9415

social relations, and creation 9324

society 9684

Socrates, Hist. Eccl. 9242

Sodom and Gomorrah, interpretation of 9041

Son, and Logos a7653

sonship, to God and to Abraham 8741

sophia (as concept)

and apocalyptic eschatology 9143

as distinct from philosophia 9439

as religious wisdom a6328

desire for 9434

general account of 8816

through revelation 8730

Sophia (as hypostasis)

and divine spirit 87101

and Gnosticism 9221

and monotheism 9663

and Prologue of John 9069

and Theophilus of Antioch 9258

and Yahweh and Christ 9322

as mother and as daughter 9557

as nourisher 8782

female nature of 8760,8827

general account 8816

male and female personification of 9655

Sophia (as personification)

and dove image a8692

banquet of a8691

sophia theology a8048

sophia traditions a7653

sophists, Alexandrian 8874

Sophronius 8784

Souda 8784

soul

and heavenly bodies 8963

and Middle Platonist cento 9254

and mind, differentation of 9596

and virtue 9521

divided a 8466

doctrine of 9458

doctrine of 9566

doctrine of 9592 
doxography on 9044

journey of 9109

life and death of 9596

masculine and feminine virtues of 9536

'mixed' 9251

nature and parts of 9044

pre-existence of the, origins in

Philo 8715

rational 9692

relation to God 9693

structure of 9524

tripartite division of 9401

- see also ascent (heavenly) and nous

Sowers, S. G. 87104

speech

spiritual 9542

speech-ethics 9503

Spicq, C. 87104, a8552

Spinoza a4208

spirit

and early Christian theology a7245a

Divine, in the cosmos and man 8721

double, in man 8775

reception of 9404

- see also pneuma

spiritual growth 9004

spiritual quest 9425

spirituality $8872,9551,9558$

Christian, influence on 9224,

a8684

Levitic 9413

spoliatio motif 9433

sport 9405

in Alexandria 9577

stars

and souls 8963

attitude to 9177

statistical analysis a6642

Sterling, G. 9320

Stobaeus 9443

Stoicism

and allegory 8751,9528

and death, twofold 8783

and eupatheia 9291

and evil 8745a, a7649

and foetus a7133 and goal of literature 9543

and conception of God 9189

and ideas, theory of 9039

and logic 9068

and natural law 9510

and nature 9655

and passion 9401, 9529

and Philo's ethics 9041

and physical allegory 9557

and Platonism in Philo 9307

and prophecy 9505

and sage 9595

and sexual conduct 9636

and slavery 9421,9638

and Timaeus, interpretation of

9457, 9458, 9566

and woman 8921

in Clement of Rome 9445

psychology of 9251

Strabo 9142, 9423

stranger, metaphor of 9228

structuralist analysis 8723

structure

compositional a8554, a8688

of exegetical treatises 8966

rhetorical 8723, 9001, 9101, 9301

- see also allegorical treatises, structure of

style 9301

- see also rhetoric, stylistic

features

Suetonius 9134, 8956

suicide 9412

Sukkot, festival of 9269, 9567

sun metaphor 9635, a7244, a8468

sun worship 9635

suppliants 9659

symbolism 8828,8829

synagogue

Alexandrian 9281

synagogue

as collegium 9672

contrast with club 9680

design of 9369

evidence on in Philo 9021

origins in Egypt 8744

synagogue prayers,

Hellenistic 9579

synkatabasis (anthropomorphism) 
synthesis of Judaism and

Hellenism

8855, 8969, 9353, 9439, 9480, 9520,

9578, 9592, 9604, a5924, a7558,

a7859, a8682

- see also Judaism

synthetical thinking, Philo representative of? 9428

Syrian writers, pagan 9579

Tabernacle 8932, 9164, 9522

Tamar, interpretation of 8774

Targum 8723, 8927, 8941, a7750

Tatian 9688

teacher, figure of 8730

teaching 9418

teleological perfection 8942

Temple 9522, 9573

and Alexandrian Judaism 8806

as image of cosmos a8686

cult 9249

imagery 9104

Terian, A. 9538

Tertullian 9688

Testaments of the Twelve Patriarchs 9579

Tetragrammaton 9166

textual notes on Philo. 9077

thanksgiving 8730, 8872

Theaetetus Commentary, Anonymous 8781

theodicy a7649

theological concern, Philo's 9592

theology

Alexandrian Jewish a8557

and philosophy 8733,8862 , 9208

as praeparatio evangelica 8903

Jewish a6122

Jewish monotheistic 9247

Philo's 9195, 9258, 9279, 9305,

9516, a7750, a8672

and katachrêsis 8863

and Platonic 8765, 8948

incompatible with Christian a6537

theophanies 8794, a4817, a5824, a7654

Theophilus of Antioch 9047, 9258, a3718 dependence on and criticism of Philo 9045

influence on 8939

Theophrastus 2157, 9648

Therapeutae 9235, 9437, 9577, 9585, $9601,9673,9680$, a7856, a8464

general account of 9162

and Christian monasticism

9012

and desert 8944

and Essaioi 8859

and Essenes 9309

and first Christians 8954

and H. P. Blavatsky 9468

and monasticism 9369

and music 8736

and Origen's early life a8049

and Pythagorean monastery 9327

and sabbath 9252

and sun worship 9635

attitude towards 9241

contemplative life of 9163

identity of, survey of research on 8778

in novel $9657 \mathrm{a}$

influence on Philo 8919

liturgy of 9139

place of living of a6640

spiritual doctrine of, and

Gregory of Nyssa a6639

spirituality of 8903

vegetarianism of 8804

Therapeutrides 8933, 9248, 9673

Thomas, Gospel of 9114

thought world of 1st cent. CE a3015

Thrasyllus 9378

Tiberius Julius Alexander 8961, 9037, 9137, 9525

Tiberius, emperor 8973, a7649

Timaeus Locrus 9053

time

conception of 9118

relation to aiôn a8254

tithe 8727

Titus, Letter to a7132

TLG database 9060

Tobin, T. H. 9406, 9426

topographical terms

exegesis of 9328 
- see also geography

Torah, pre-existence of 9509

tradition 9520, 9681

transcendence $9472,9473,9628$

transcendental concepts, and

deductive method 9382

tree, metaphor of a7244

Tregelles 9431

trinitarian

doctrine a7950

exegesis, Christian a5527

images a7244

interpretation of Gen. 18 a6644

trinity 8918

and pre-Christian Judaism 9202

Triviño, J. M. 8940

truth 9349

and speech 9503

Turnebus, A. 9422

tunics of skin a8550b

typology 9129

Philonic as opposed to Christian 8814

typos imagery 9330

universalism 8950, 9234, 9236, 9312a, 9474, 9522, 9589, a8669

and particularism 9311

in the N.T. 8721

of late Judaism 8711

urim, interpretation of 8924

utopean perspective 9013

Valentinus 9222, 9255, 9669

- see also Gnosticism, Valen-

tinian

vegetarianism 8804

verba philonica 9668

vigilantism 9574

violence 9414

- see also establishment violence

virgin birth a8679

virgin, law on violation of 9429

virginity $9011,9066,9224,9425$, 9467,9107

virtue

and doctrine of the mean a7854

and Jewish observance of the

law 9520

concept of $8725,8861,8872,9521$

\section{contest of 8917}

generic and specific 8930, 9136

philosophical and Mosaic 9318

vision 9643

vocabulary, Philo's 9276, 9520, 9668

Völker, W., index to 3211

vows 9145

Warner, F. 9155

water

metaphor of 9562 , a7244

muddy, metaphor of 9409

wealth, Philo's attitude to 8785

Wendland, P. 9004, a7649

will, concept of a7443

Williamson, R. 87104, a8552

Windisch, H. 8809

Winston, D. 9337, 9441, 9480

wisdom - see sophia, Sophia

Wisdom of Solomon - see Sapientia

Salomonis

wise man - see sage

Wittgenstein, L. 9259

Wolfson, H. A. 87103, 8733, 8750, 9047, 9480, 9618, a7444, a7950

woman

as misfortune $9312 \mathrm{a}$

as not intellectual 9684

as source of Fall a8466

attitude to 9182,9190

domestic role of a8135

concept of 8701, 9004, 9022, 9606

feminine qualities

negatively valued 9467

spiritualized 9425

negative valuation of 8921

perception of 9066,9467

relation to man 8935

role of 8933,9219

and status of a7860

in Egypt 9673

women

important Alexandrian 9577

observances, rituals and festivals of 8840

- see also Therapeutrides

women in the Bible, interpretation of 8751,9066

wonder, concept of 8914 
world

attitude towards 8906

- see also cosmos

worship 8872

writings - see Corpus Philonicum
Yom Kippur 8726, 9178

Yonge, C. D. 1827, 9462

Zealots 9475

Zeno of Citium a7439

\section{INDEX OF GREEK TERMS}

$\not \alpha \gamma \alpha \lambda \mu \alpha \quad 9126$

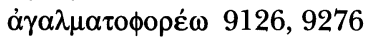

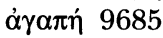

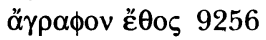

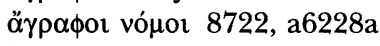

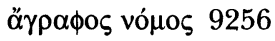

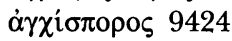

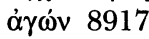

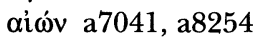

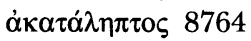

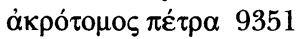

$\dot{\alpha} \lambda \dot{\eta} \theta \varepsilon \iota \alpha \quad 9349$

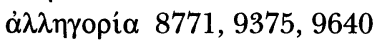

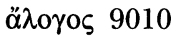

ỏvó $\mu v \eta \sigma 1 \varsigma$ a6643

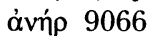

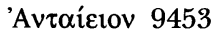

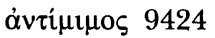

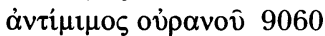

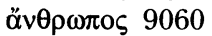

$\dot{\alpha} \pi \alpha \dot{\theta} \theta \varepsilon \iota \alpha \quad 8740$

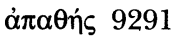

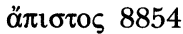

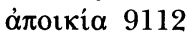

$\dot{\alpha} \pi 0 \tau 0 \lambda \mu \alpha \dot{\alpha} \omega 8960$

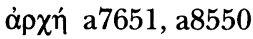

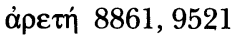

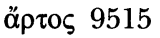

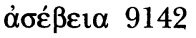

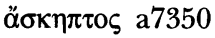

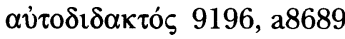

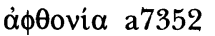

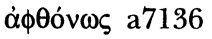

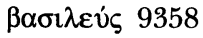

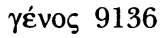

$\gamma \rho \alpha \mu \mu \alpha \tau \iota \kappa \dot{~} 9435$

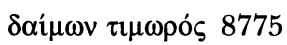

$\delta \varepsilon ı \sigma เ \delta \alpha \iota$ ovía 8702

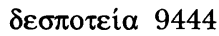

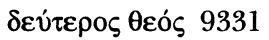

$\delta \bar{\eta} \lambda$ os 8924

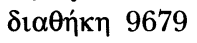

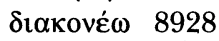

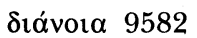

$\delta 1 \alpha \sigma \pi \mathrm{o \rho \alpha ́} 9383$

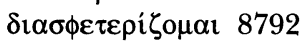

$\delta 1 \alpha \phi \omega v i \alpha \quad 8847$

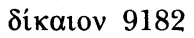

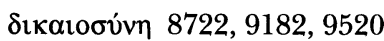

$\delta o ́ \xi \alpha 9251$

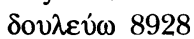

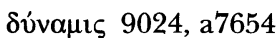

$\delta v \sigma \alpha ́ \lambda \omega \tau o \varsigma$ a7652

$\delta v \sigma \theta \dot{n} \rho \alpha \tau$ a 7652

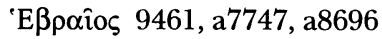

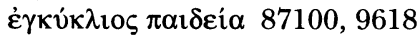

ह̌ $\theta \eta$ 9256, 9319

है $\theta$ vท 9474

हैं vos 9572

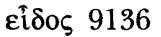

$\varepsilon$ हॉ $\delta \omega \lambda$ ov a8695

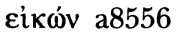

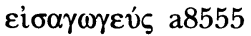

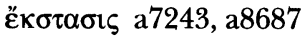

है $\lambda \varepsilon \gamma \chi 0 \varsigma 9436$

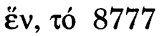

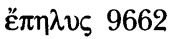

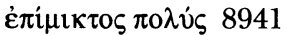

$\dot{\varepsilon} \pi \mathrm{i} \sigma \tau \dot{\eta} \mu \eta \mathbf{8 8 4 1}$

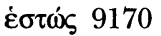

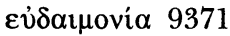

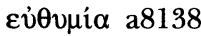

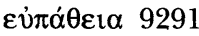


$\varepsilon v ่ \pi \alpha ́ \theta \varepsilon ı \iota \imath 9014$

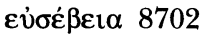

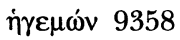

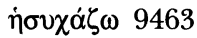

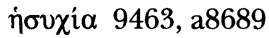

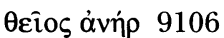

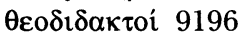

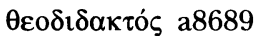

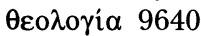

Өعós 9030, 9166, 9358, 9665, a8556

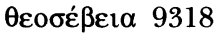

$\theta \varepsilon o \phi ı \lambda \dot{n}$ s 9685

$\theta \varepsilon \circ \phi i \lambda i \alpha a 685$

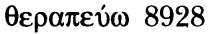

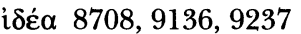

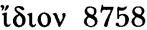

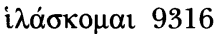

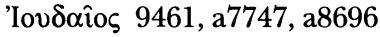

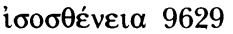

iøótns 9518

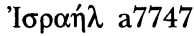

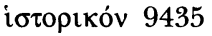

каıрóৎ 9036

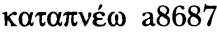

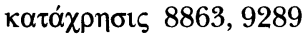

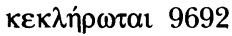

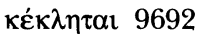

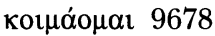

кúpı̣s 9166, 9358, 9665

$\lambda \alpha \tau \rho \varepsilon v ́ \omega 8928$

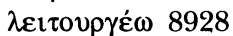

$\lambda$ ó $1 \alpha 9442$

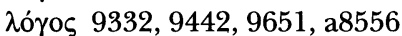

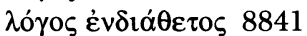

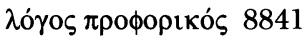

$\mu \alpha \theta \eta \tau \dot{\prime} \varsigma 8871$

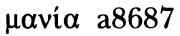

$\mu \varepsilon \theta$ óplos 8761, 8849, 9048, a6123

$\mu \varepsilon \tau \alpha v \alpha \dot{\sigma \tau \alpha \sigma \iota \varsigma} 9651$

$\mu \varepsilon \tau \alpha \dot{v o t \alpha} 8763,9103$

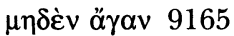

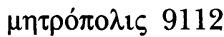

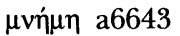

$\mu o v \alpha \rho \chi i ́ \alpha 9688$

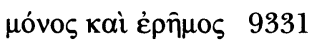

vónos 9442

vó $\mu$ os ع̈ $\mu \psi v \chi 0 \varsigma 9443$

vouิs 8959, 9581

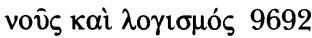

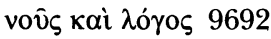

vovิs $\pi v \lambda \omega \rho$ ós 8775

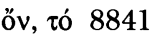

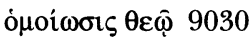

ómóvora 9411, 9444

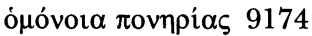

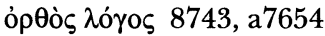

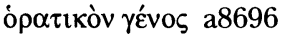

$\pi \alpha \rho \alpha ́ \delta \varepsilon \imath \gamma \mu \alpha$ a5924

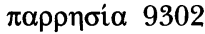

$\pi \alpha \dot{\tau} \tau \imath \varsigma 9112$

$\pi \varepsilon \rho \alpha \tau \dot{\prime} \varsigma 9665$

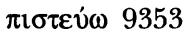

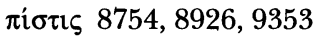

$\pi v \varepsilon \hat{\mu} \alpha$ 9581, 9689, a8556

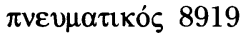

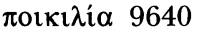

$\pi \circ \lambda i \tau \varepsilon \cup \mu \alpha 8857$

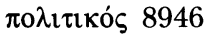

$\pi \circ \lambda \lambda \eta^{\prime} 9659$

$\pi \rho \alpha \gamma \mu \alpha \tau$ นо

$\pi \rho \circ \theta u \mu i \alpha$ a8138

лрофиंтs a8551

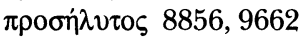

$\pi \rho \circ \ddot{\sim} \pi \alpha \dot{\rho} \chi \omega$ a7654

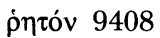

баркıко́s 8919

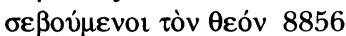

$\sigma \varepsilon \mu \mathrm{i} \delta \alpha \lambda \iota \varsigma 9515$

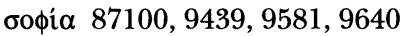

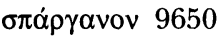

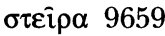

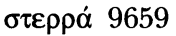

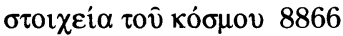

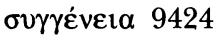

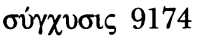

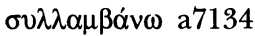

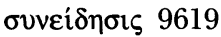

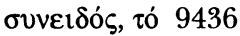

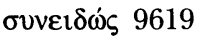




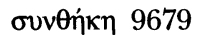

бúvoเ $\delta \alpha 9619$

$\sigma \hat{\omega} \mu \alpha \tau \hat{\omega} v$ $\gamma \rho \alpha \phi \hat{\omega} v 8929$

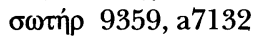

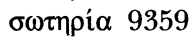

$\tau \varepsilon \lambda \varepsilon \tau \dot{~} 8779$

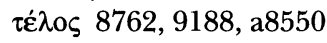

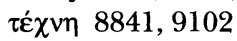

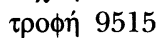

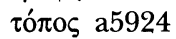

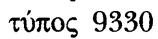

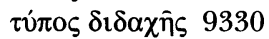

üßpıৎ 9352

viós a7654

نे $\mu v \varepsilon ́ \omega 9139$

ข̌ $\mu$ vo 9139

vँ $\pi \alpha \rho \xi_{1 \varsigma} 9421 \mathrm{a}$

نंสó $\chi \omega$ 9421a

نં

ن่

ن்óvola 8771

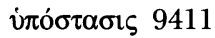

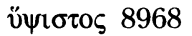

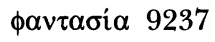

фóvos a7136

$\phi 1 \lambda \alpha v \theta \rho \omega \pi i \alpha$ 9182, 9616, 9685, a5828

$\phi 1 \lambda \alpha v \tau i \alpha 9523$

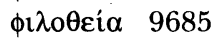

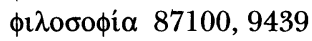

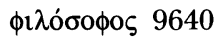

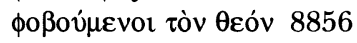

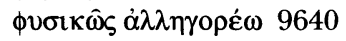

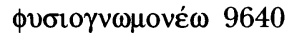

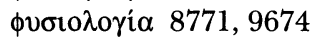

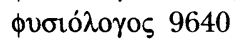

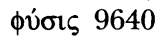

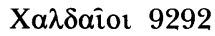

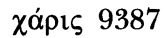

Xpıбтós 9322

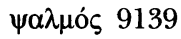

$\psi \alpha \dot{\lambda} \lambda \omega \omega 9139$

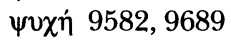

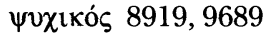

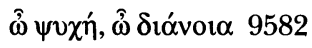

őv, ò 8863, 9195

\section{INDEX OF CONTRIBUTORS}

Berg, R. M. van den (= RMB)

2156, 8944, 9016, 9036, 9055, 9062, 9075, 9103, 9105, 9106, 9107, 9109, 9113, 9114, 9119, 9121, 9127, 9134, 9135, 9137, 9140, 9144, 9145, 9146, 9147, 9151, 9157, 9158, 9164, 9175, 9181, 9182, 9193, 9196, 9202, 9204, 9208, 9213, 9218, 9235, 9236, 9239, 9244, 9246, 9256, 9260, 9263, 9265, 9267, 9268, 9282, 9285, 9289, 9291, $9292(55)$

Birnbaum, E. (= EB)

9262, 9362, 9364, 9412, 9425, 9576, 9583, 9607, a4608, a7132, a7859, a8380 (12)

Cathey, P. A. (= PAC)

$8730,8804,8807,8814,8818,8831,8842,8843,8844,8850,8852,8854,8855$, $8856,8866,8867,8870(17)$

Cohen, N. G. (= NGC)

a5316, a5526, a5924, a6228a, a6536, a6537, a7040, a7243, a7441, a7557a, a7749, a8047 (12)

Geljon, A. C. (= ACG)

9104, 9206, 9266, 9305, 9310, 9311, 9317, 9320, 9322, 9323, 9330, 9333, 9344, 9349, 9351, 9361, 9367, 9377, 9379, 9401, 9403, 9409, 9415, 9421, 9423, 9426, 
9428, 9429, 9433, 9435, 9438, 9443, 9464, 9466, 9467, 9470, 9476, 9480, 9502, 9503, 9504, 9508, 9510, 9516, 9517, 9526, 9532, 9536, 9542, 9546, 9553, 9554, 9557, 9572, 9573, 9574, 9581, 9587, 9591, 9592, 9608, 9618, 9642, 9644, 9655, 9670, 9677, $9686(68)$

Keizer, H. M. (= HMK)

$1303,1304,1826,8721,8731,8747,87104,8838,8858,8872,8943,9004,9010$, 9221, 9223, 9319, 9341, 9352, 9408, 9439, 9527, 9535, 9549, 9555, 9559, 9567, 9597, 9606, 9621, 9635, 9649, 9652, 9662, 9663a, 9664, 9683, 9684, a3014, a3718, a3719, a3818, a4408, a4409, a4817, a5022, a5527, a5825, a5826, a5828, a6022, a6123, a6124, a6229, a6328, a6538, a6639, a6640, a6641, a6642, a6644, a6762, a6841, a7041, a7134, a7135, a7136, a7244, a7245, a7246, a7349, a7350, a7351, a7352, a7439, a7442, a7444, a7445, a7559, a7560, a7561, a7649, a7651, a7652, a7653, a7654, a7655, a7747, a7748, a7750, a7751, a7752, a7854, a7855, a7856, a7857, a7858, a7860, a7949, a8046, a8135, a8136, a8137, a8139, a8254, a8255, a8256, a8463, a8464, a8465, a8466, a8468, a8550, a8551, a8552, a8555, a8556, a8557, a8671, a8679, a8689 (120)

Martín, J. P. (= JPM)

2851, 9224, 9257, 9258, 9259, 9327, 9328, 9331, 9332, 9356, 9357, 9366, 9420, 9444, 9445, 9446, 9448, 9531, 9584, 9585, 9654, 9657, 9660, 9665, 9688, a4208, a5527, a5827, a6024, a6125, a6537, a6643, a7950, a8045, a8553, a8687, a8690 (37)

Pawlaczyk, A. (= AP)

2751, a2701 (2)

Radice, R. (= RR)

1402, 1404, 1405, 2254, 2405, 2406, 2452, 2454, 3102, 3105, 8701, 8702, 8703, $8704,8705,8706,8707,8708,8709,8710,8711,8712,8713,8714,8715,8716$, $8717,8718,8719,8722,8723,8724,8725,8727,8728,8729,8732,8734,8735$, $8736,8737,8738,8739,8740,8741,8742,8745,8746,8748,87106,8801,8802$, $8805,8809,8811,8813,8815,8816,8817,8819,8821,8825,8827,8832,8833$, $8835,8839,8845,8848,8849,8853,8864,8868,8875,8903,8906,8909,8911$, $8912,8914,8916,8916,8921,8928,8934,8937,8939,8946,8947,8948,8950$, 8956, 8964, 8967, 8969, 8970, 8971, 9005, 9010, 9011, 9022, 9028, 9038, 9042, 9045, 9046, 9047, 9048, 9050, 9057, 9076, 9111, 9118, 9120, 9124, 9126, 9148, 9149, 9162, 9174, 9185, 9189, 9195, 9228, 9237, 9243, 9247, 9279, 9280, 9284, 9290, 9307, 9308, 9316, 9324, 9350, 9359, 9365, 9375, 9424, 9455, 9456, 9501, 9515, 9528, 9544, 9558, 9656, 9674, 9691, a6761, a7133, a7440, a7443, a8554, a8669, a8672, a8673, a8675, a8677, a8678, a8683, a8692, a8694, a8697 (165)

Riaud, J. (= JR)

9402, 9414, 9422, 9454, 9518, 9521, 9522, 9523, 9529, 9564, 9565, 9605, 9624, 9657a, 9659, 9663, 9668, 9671 (17)

Runia, D. T. (= DTR) all numbers not listed in this index

Sandelin, K.-G. (= KGS) 8744, 8806, 8957, 8973, 9156, 9173, 9209, 9211, 9249, 9286, 9312, 9336, 9382, 9405, 9450, 9472, 9473, 9511, 9513, 9533, 9541, 9571, 9575, 9609, 9610, 9611, 9612, 9613, 9614, 9615, 9616, 9617, 9687, a8691, a8698 (35)

Satran, D. (= DS) 2602, 8720, 8743, 9021, 9035, 9122, 9176, 9334, 9337, 9434, 9625, 9646, 9647 (13) 
Zeller, D. (= DZ)

1408, 1824, 9303, 9309, 9315, 9339, 9346, 9354, 9355, 9358, 9370, 9383, 9387, 9427, 9436, 9442, 9451, 9452, 9460, 9463, 9465, 9474, 9530, 9538, 9548, 9589, 9596, 9601, 9630, 9633, 9643, 9650, 9651, 9679, 9681, 9685, 9689 (37) 
Douwe (David) Runia - 978-90-04-31323-1 Downloaded from Brill.com๑4/26/2023 05:35:25AM via free access 
Douwe (David) Runia - 978-90-04-31323-1 Downloaded from Brill.com๑4/26/2023 05:35:25AM via free access 


\section{SUPPLEMENTS TO VIGILIAE CHRISTIANAE}

1. Tertullianus. De idololatria. Critical Text, Translation and Commentary by J.H. Waszink and J.G.M. van Winden. Partly based on a Manuscript left behind by P.G. van der Nat. 1987. ISBN 9004081054

2. Springer, C.P.E. The Gospel as Epic in Late Antiquity. The Paschale Carmen of Sedulius. 1988. ISBN 9004086919

3. Hoek, A. van den. Clement of Alexandria and His Use of Philo in the Stromateis. An Early Christian Reshaping of a Jewish Model. 1988. ISBN 9004087567

4. Neymeyr, U. Die christlichen Lehrer im zweiten Fahrhundert. Ihre Lehrtätigkeit, ihr Selbstverständnis und ihre Geschichte. 1989.

ISBN 9004087737

5. Hellemo, G. Adventus Domini. Eschatological Thought in 4th-century Apses and Catecheses. 1989. ISBN 9004088369

6. Rufin von Aquileia. De ieiunio I, II. Zwei Predigten über das Fasten nach Basileios von Kaisareia. Ausgabe mit Einleitung, Übersetzung und Anmerkungen von H. Marti. 1989. ISBN 9004088970

7. Rouwhorst, G.A.M. Les hymnes pascales d'Éphrem de Nisibe. Analyse théologique et recherche sur l'évolution de la fête pascale chrétienne à Nisibe et à Edesse et dans quelques Églises voisines au quatrième siècle.

2 vols: I. Étude; II. Textes. 1989. ISBN 9004088393

8. Radice, R. and D.T. Runia. Philo of Alexandria. An Annotated Bibliography 1937-1986. In Collaboration with R.A. Bitter, N.G. Cohen, M. Mach, A.P. Runia, D. Satran and D.R. Schwartz. 1988. repr. 1992.

ISBN 9004089861

9. Gordon, B. The Economic Problem in Biblical and Patristic Thought. 1989. ISBN 9004090487

10. Prosper of Aquitaine. De Providentia Dei. Text, Translation and Commentary by M. Marcovich. 1989. ISBN 9004090908

11. Jefford, G.N. The Sayings of Jesus in the Teaching of the Tweelve Apostles. 1989. ISBN 9004091270

12. Drobner, H.R. and Klock, Ch. Studien zu Gregor von Nyssa und der christlichen Spätantike. 1990. ISBN 9004092226

13. Norris, F.W. Faith Gives Fullness to Reasoning. The Five Theological Orations of Gregory Nazianzen. Introduction and Commentary by F.W. Norris and Translation by Lionel Wickham and Frederick Williams. 1990. ISBN 9004092536

14. Oort, J. van. Ferusalem and Babylon. A Study into Augustine's City of God and the Sources of his Doctrine of the Two Cities. 1991.

ISBN 9004093230

15. Lardet, P. L'Apologie de Jérôme contre Rufin. Un Commentaire. 1993. ISBN 900409457 l

16. Risch, F.X. Pseudo-Basilius: Adversus Eunomium IV-V. Einleitung, Übersetzung und Kommentar. 1992. ISBN 9004095586 
17. Klijn, A.F.J. Fewish-Christian Gospel Tradition. 1992. ISBN 9004094539

18. Elanskaya, A.I. The Literary Coptic Manuscri pts in the A.S. Pushkin State Fine Arts Museum in Moscow. ISBN 9004095284

19. Wickham, L.R. and Bammel, C.P. (eds.). Christian Faith and Greek Philosophy in Late Antiquity. Essays in Tribute to George Christopher Stead. 1993. ISBN 9004096051

20. Asterius von Kappadokien. Die theologischen Fragmente. Einleitung, kritischer Text, Übersetzung und Kommentar von Markus Vinzent. 1993. ISBN 9004098410

21. Hennings, R. Der Briefwechsel zwischen Augustinus und Hieronymus und ihr Streit um den Kanon des Alten Testaments und die Auslegung von Gal. 2,11-14. 1994. ISBN 9004098402

22. Boeft, J. den \& Hilhorst, A. (eds.). Early Christian Poetry. A Collection of Essays. 1993. ISBN 9004099395

23. McGuckin, J.A. St. Cyril of Alexandria: The Christological Controversy. Its History, Theology, and Texts. 1994. ISBN 9004099905

24. Reynolds, Ph.L. Marriage in the Western Church. The Christianization of Marriage during the Patristic and Early Medieval Periods. 1994.

ISBN 9004100229

25. Petersen, W.L. Tatian's Diatessaron. Its Creation, Dissemination, Significance, and History in Scholarship. 1994. ISBN 9004094695

26. Grünbeck, E. Christologische Schriftargumentation und Bildersprache. Zum Konflikt zwischen Metapherninterpretation und dogmatischen Schriftbeweistraditionen in der patristischen Auslegung des 44. (45.) Psalms. 1994. ISBN 9004100210

27. Haykin, M.A.G. The Spirit of God. The Exegesis of 1 and 2 Corinthians in the Pneumatomachian Controversy of the Fourth Century. 1994. ISBN 9004099476

28. Benjamins, H.S. Eingeordnete Freiheit. Freiheit und Vorsehung bei Origenes. 1994. ISBN 9004101179

29. Smulders s.J., P. (tr. \& comm.). Hilary of Poitiers' Preface to his Opus historicum. 1995. ISBN 9004101918

30. Kees, R.J. Die Lehre von der Oikonomia Gottes in der Oratio catechetica Gregors von Nyssa. 1995. ISBN 9004102000

31. Brent, A. Hippolytus and the Roman Church in the Third Century. Communities in Tension before the Emergence of a Monarch-Bishop. 1995.

ISBN 9004102450

32. Runia, D.T. Philo and the Church Fathers. A Collection of Papers. 1995. ISBN 9004103554

33. De Coninck, A.D. Seek to See Him. Ascent and Vision Mysticism in the Gospel of Thomas. 1996. ISBN 9004104011

34. Clemens Alexandrinus. Protrepticus. Edidit M. Marcovich. 1995. ISBN 9004104496

35. Böhm, T. Theoria-Unendlichkeit-Aufstieg. Philosophische Implikationen zu De vita Moysis von Gregor von Nyssa. 1996. ISBN 9004105603 
36. Vinzent, M. Pseudo-Athanasius, Contra Arianos IV. Eine Schrift gegen Asterius von Kappadokien, Eusebius von Cäsarea, Markell von Ankyra und Photin von Sirmium. 1996. ISBN 9004106863

37. Knipp, P.D.E. 'Christus Medicus' in der frühchristlichen Sarkophagskulptur. Ikonographische Studien zur Sepulkralkunst des späten vierten Jahrhunderts. 1998. ISBN 9004108629

38. Lössl, J. Intellectus gratiae. Die erkenntnistheoretische und hermeneutische Dimension der Gnadenlehre Augustins von Hippo. 1997. ISBN 9004108491

39. Markell von Ankyra. Die Fragmente. Der Brief an Julius von Rom. Herausgegeben, eingeleitet und übersetzt von Markus Vinzent. 1997. ISBN 9004109072

40. Merkt, A. Maximus I. von Turin. Die Verkündigung eines Bischofs der frühen Reichskirche im zeitgeschichtlichen, gesellschaftlichen und liturgischen Kontext. 1997. ISBN 9004108645

41. Winden, J.C.M. van. Archè. A Collection of Patristic Studies by J.C.M. van Winden. Edited by J. den Boeft and D.T. Runia. 1997. ISBN 9004108343

42. Stewart-Sykes, A. The Lamb's High Feast. Melito, Peri Pascha and the Quartodeciman Paschal Liturgy at Sardis. 1998. ISBN 9004112367

43. Karavites, P. Evil, Freedom and the Road to Perfection in Clement of Alexandria. 1999. ISBN 9004112383

44. Boeft, J. den and M.L. van Poll-van de Lisdonk (eds.). The Impact of Scripture in Early Christianity. 1999. ISBN 9004111433

45. Brent, A. The Imperial Cult and the Development of Church Order. Concepts and Images of Authority in Paganism and Early Christianity before the Age of Cyprian. 1999. ISBN 9004114203

46. Zachhuber, J. Human Nature in Gregory of Nyssa. Philosophical Background and Theological Significance. 1999. ISBN 9004115307

47. Lechner, Th. Ignatius adversus Valentinianos? Chronologische und theologiegeschichtliche Studien zu den Briefen des Ignatius von Antiochien. 1999. ISBN 9004115056

48. Greschat, K. Apelles und Hermogenes. Zwei theologische Lehrer des zweiten Jahrhunderts. 1999. ISBN 9004115498

49. Drobner, H.R. Augustinus von Hippo: Sermones ad populum. Überlieferung und Bestand - Bibliographie - Indices. 1999. ISBN 9004114513

50. Hübner, R.M. Der paradox Eine. Antignostischer Monarchianismus im zweiten Jahrhundert. Mit einen Beitrag von Markus Vinzent. 1999. ISBN 9004115765

51. Gerber, S. Theodor von Mopsuestia und das Nicänum. Studien zu den katechetischen Homilien. 2000. ISBN 9004115218

52. Drobner, H.R. and A. Viciano (eds.). Gregory of Nyssa: Homilies on the Beatitudes. An English Version with Commentary and Supporting Studies. Proceedings of the Eighth International Colloquium on Gregory of Nyssa (Paderborn, 14-18 September 1998) 2000 ISBN 9004116214 
53. Marcovich, M. (ed.). Athenagorae qui fertur. De resurrectione mortuorum. 2000. ISBN 9004118969

54. Marcovich, M. Origines: Contra Celsum Libri VII. ISBN 9004119760 In preparation.

55. McKinion, S. Words, Imagery, and the Mystery of Christ. A Reconstruction of Cyril of Alexandria's Christology. 2001. ISBN 9004119876

56. Beatrice, P.F. Theosophia, An Attempt at Reconstruction. ISBN 9004117989 In preparation.

57. Runia, D.T. Philo of Alexandria: An Annotated Bibliography 1987-1996. 2001. ISBN 9004116826 